UNIVERSIDADE DE BRASÍLIA

FACULDADE DE TECNOLOGIA DEPARTAMENTO DE ENGENHARIA CIVIL E AMBIENTAL

ESTUDO DOS PARÂMETROS DE AUTOADENSABILIDADE E DE REOLOGIA DE ARGAMASSAS E DE CONCRETOS AUTOADENSÁVEIS

MARCUS VINÍCIUS ARAÚJO DA SILVA MENDES

ORIENTADOR: ELTON BAUER

TESE DE DOUTORADO EM ESTRUTURAS E CONSTRUÇÃO CIVIL

PUBLICAÇÃO: E.TD - 9A/16

BRASÍLIA/DF: 07 DE DEZEMBRO DE 2016 
UNIVERSIDADE DE BRASÍLIA

FACULDADE DE TECNOLOGIA

DEPARTAMENTO DE ENGENHARIA CIVIL E AMBIENTAL

\section{ESTUDO DOS PARÂMETROS DE AUTOADENSABILIDADE E DE REOLOGIA DE ARGAMASSAS E DE CONCRETOS AUTOADENSÁVEIS}

\section{MARCUS VINÍCIUS ARAÚJO DA SILVA MENDES}

TESE SUBMETIDA AO DEPARTAMENTO DE ENGENHARIA CIVIL E AMBIENTAL DA FACULDADE DE TECNOLOGIA DA UNIVERSIDADE DE BRASÍLIA COMO PARTE DOS REQUISITOS NECESSÁRIOS PARA A OBTENÇÃO DO GRAU DE DOUTOR EM CONSTRUÇÃO CIVIL.

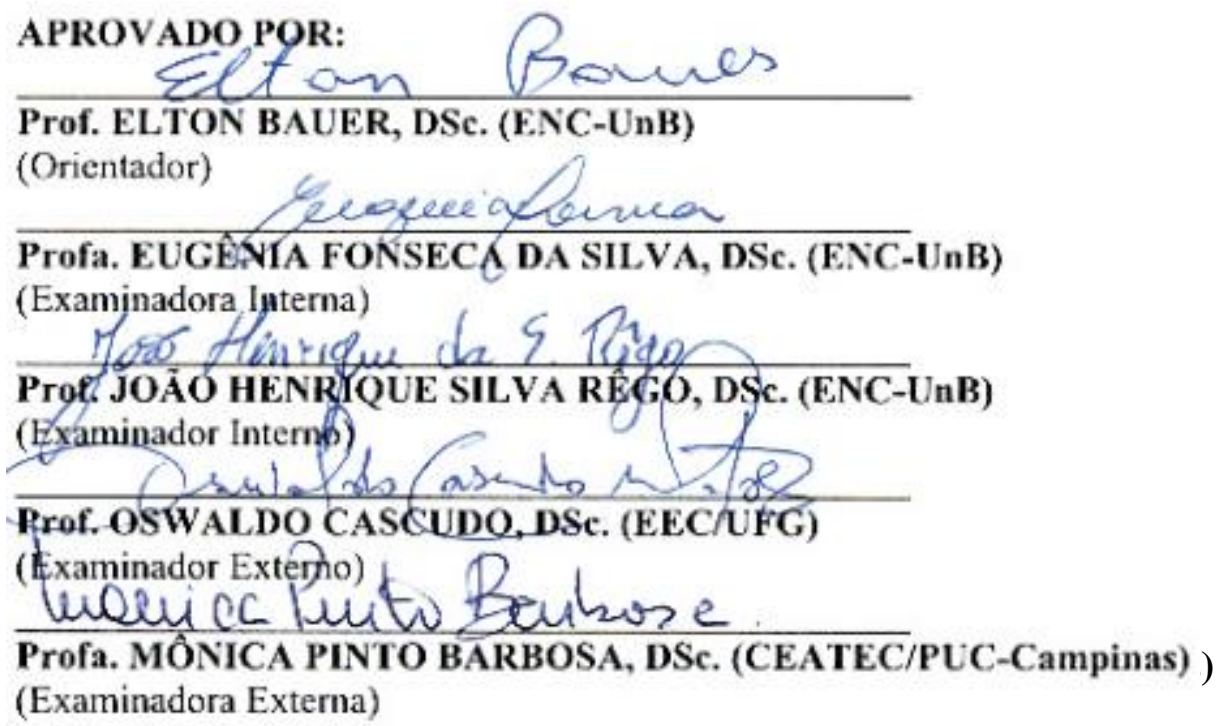

BRASÍLIA/DF: 07 DE DEZEMBRO DE 2016 


\section{FICHA CATALOGRÁFICA}

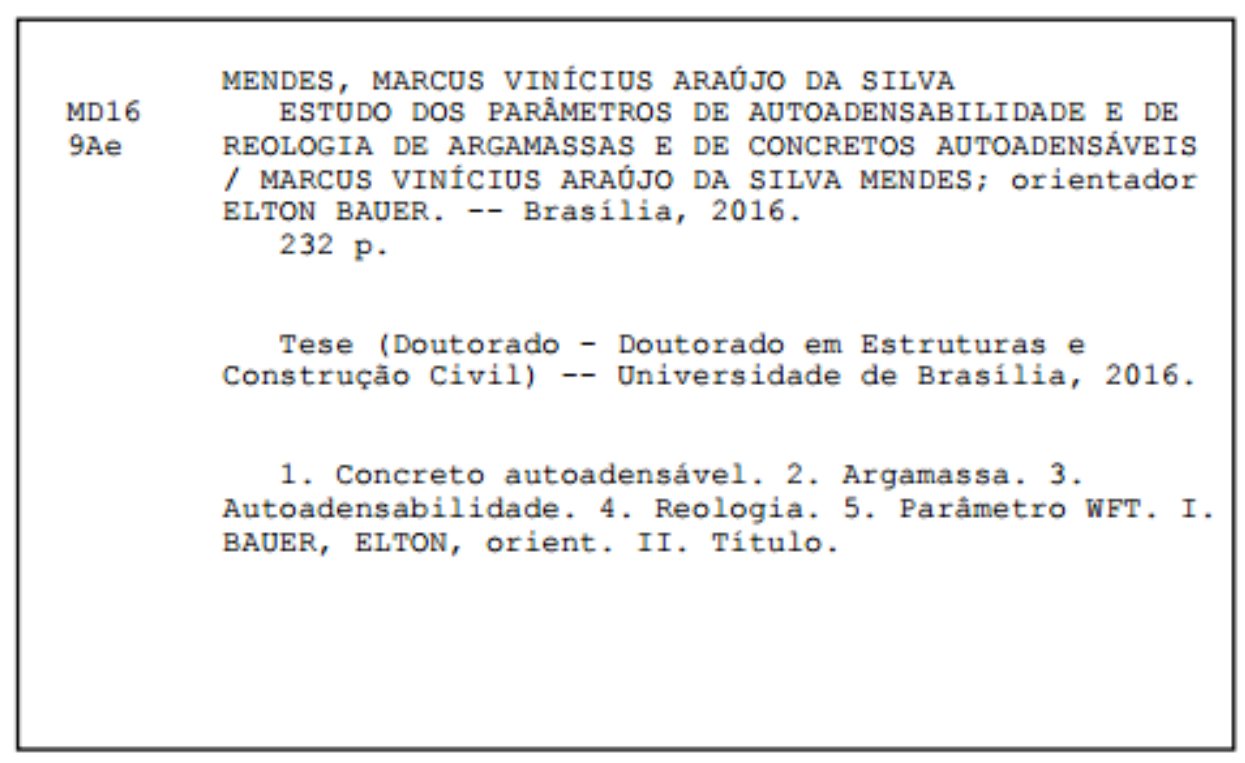

\section{REFERÊNCIA BIBLIOGRÁFICA}

MENDES, M. V. A. S. (2016). Estudo dos parâmetros de autoadensabilidade e de reologia de argamassas e de concretos autoadensáveis. Tese de Doutorado em Estruturas e Construção Civil, Publicação E.TD - 9A/16, Departamento de Engenharia Civil e Ambiental, Universidade de Brasília, Brasília, DF, 232 p.

\section{CESSÃO DE DIREITOS}

AUTOR: Marcus Vinícius Araújo da Silva Mendes.

TÍTULO: Estudo dos parâmetros de autoadensabilidade e de reologia de argamassas e de concretos autoadensáveis.

\section{GRAU: Doutor ANO: 2016}

É concedida à Universidade de Brasília permissão para reproduzir cópias desta tese de doutorado e para emprestar ou vender tais cópias somente para propósitos acadêmicos e científicos. O autor reserva outros direitos de publicação e nenhuma parte dessa tese de doutorado pode ser reproduzida sem autorização por escrito do autor.

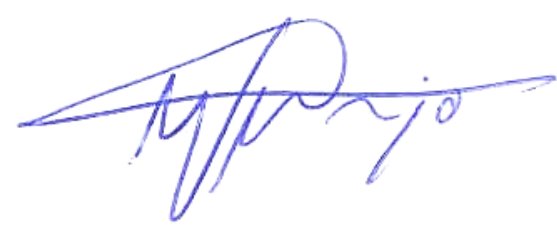

Marcus Vinícius Araújo da Silva Mendes

Av. Rio Branco, n³050, Ed. Saint Martin I, bloco E-3 ap. 302, Setor Urias Magalhães, CEP: 74565-070. Goiânia - GO - Brasil. 
A Deus.

A minha mãe.

Ao meu pai (em memória).

Aos meus avós (em memória). Aos meus tios e tias, primos e primas.

A toda minha família e amigos. 


\section{AGRADECIMENTOS}

A DEUS, que sempre guia meus passos me protegendo, iluminando e concedendo oportunidades.

Às mulheres da minha vida, mãe, tias Nadi e Eneida, as quais sempre me apoiaram no cumprimento dos meus objetivos. À minha namorada, Núbia, pelo apoio, compreensão e carinho.

Ao meu orientador Elton Bauer, pelo apoio, incentivo, sugestões e contribuições ao longo desta pesquisa.

À Universidade de Brasília, pela oportunidade de estudar numa universidade pública, gratuita e de qualidade.

Ao Instituto Federal de Goiás, pela licença concedida para eu cursar o doutorado e a confiança depositada em mim.

À Universidade Federal da Bahia (UFBA), pelo suporte dado na caracterização reológica das argamassas do meu estudo. Em especial as pessoas que ajudaram de forma efetiva nesta caracterização reológica, tais como: João (aluno), Jacó (aluno), José (aluno), Paulo (técnico do laboratório), Prof. Francisco Gabriel, Prof. Vanessa (coordenadora do laboratório).

Ao Laboratório de Materiais (LEM/UnB) e todo o pessoal envolvido, em especial, aos técnicos Washington, Severino e Patrícia, pelo compromisso e disposição em auxiliar nos ensaios deste trabalho.

Aos professores do Programa de Pós-Graduação em Estruturas e Construção Civil pela dedicação no exercício da profissão, buscando transmitir conhecimento com qualidade.

À professora Valdirene Capuzzo, pelo apoio na caracterização dos concretos, no estado endurecido, e também pelas sugestões apresentadas na minha qualificação de doutorado.

Ao Ricardo, secretário do PECC pelo apoio diário e disponibilidade.

Aos amigos e colegas que tive oportunidade de conhecer durante os 5 anos no PECC-UnB, em especial: Carlos Mariano, Maria Claúdia, João Uchoa, Gilson, Jéssica, Gelson, Marília, Alejandro e Vitor. 
"Consagre ao Senhor tudo o que você faz, e os seus planos serão bem-sucedidos.” Provérbios 16:3 


\title{
RESUMO
}

\author{
Autor: Marcus Vinícius Araújo da Silva Mendes \\ Orientador: Elton Bauer \\ Programa de Pós-Graduação em Estruturas e Construção Civil \\ Brasília, 2016
} Estudo dos parâmetros de autoadensabilidade e de reologia de argamassas e de concretos
autoadensáveis

O concreto autoadensável é um tipo de material que exige um estudo prévio e minucioso da sua mistura em função do comportamento solicitado no seu estado fresco, que o torna ainda pouco empregado em obras usuais de concreto armado. Diante disso, buscou-se, no presente trabalho, explorar a relação existente entre os parâmetros de autoadensabilidade e de reologia para argamassas e concretos e, além disso, agregar constatações obtidas por meio dos resultados do parâmetro WFT das argamassas, que envolve conceitos de densidade de empacotamento e área especifica total do sistema granular de materiais cimentícios. Esses aspectos citados, tiveram a finalidade de propor valores de referências provindos das interações entre esses parâmetros, no sentido de tornar o processo de obtenção de argamassas e de concretos autoadensáveis menos complexo. Para isso, decidiu-se obter parâmetros de autoadensabilidade e de reologia por meio de estudos em argamassas e, posteriormente, estudos em concretos. Os parâmetros decorrentes da avaliação das argamassas foram obtidos por meio dos seguintes ensaios: mini-slump, minifunil e caracterização reológica por meio do reômetro da marca Rheotest N4.1. Os parâmetros provenientes da avaliação dos concretos foram obtidos por meio dos ensaios e modelos matemáticos: slump flow, T500, funil V, anel J, caixa L, caixa U, tubo de segregação. Os parâmetros reológicos estimados por meio de equações matemáticas propostas por Sedran e De Larrard(1999). Com esses parâmetros, foi possível propor referências de argamassas e de concretos autoadensáveis com vista na norma NBR 15823-1 (2010) que prescreve os requisitos de autoadensabilidade exigidos para o concreto no Brasil. Também foi feita uma avaliação dos ensaios prescritos nesta norma para avaliação do concreto autoadensável. Nesse sentido, constatou-se que o ensaio T500 não apresentou resultados consistentes de viscosidade plástica aparente quando comparados com os resultados de viscosidade plástica aparente obtidos pelo ensaio de Funil V. Verificou-se que os ensaios que avaliam habilidade passante, tais como, caixa $\mathrm{L}$ e anel $\mathrm{J}$, não demonstraram uma boa sintonia entre seus resultados. $\mathrm{O}$ ensaio de espalhamento demonstrou-se eficiente para estimar a habilidade passante do concreto por meio dos ensaios de caixa L e caixa U. Ademais, constatou-se que o parâmetro WFT não foi capaz de governar as propriedades de autoadensabilidade e de reologia de argamassas e de concretos autoadensáveis contrariando afirmações de outros pesquisadores, os quais afirmam, com convicção, que esse parâmetro governa as propriedades no estado fresco dos materiais cimentícios. Por fim, foi possível sugerir classes de autoadensabilidade às argamassas autoadensáveis, bem como se definiu suas curvas de fluxo de reologia mais comuns apresentadas nesta tese.

Palavras-chave: Concreto autoadensável. Argamassa, Autoadensabilidade, Reologia, Parâmetro WFT. 


\begin{abstract}
Author: Marcus Vinícius Araújo da Silva Mendes

First Advisor: Elton Bauer

Programa de Pós-Graduação em Estruturas e Construção Civil

Brasília, 2016
Evaluation of the workability and rheology parameters of self-compacting mortar concrete

The self-compacting concrete is a type of material that requires a previous and detailed study of its mixture in function of the requested behavior in its fresh state, which makes it still little used in usual works of reinforced concrete. In the present work, the aim of this work was to explore the relationship between workability and rheology parameters of mortars and concretes and, in addition, to add knowledge acquired through the WFT parameter results of mortars, whose parameter involves concepts of packing density and total specific area the granular system of cementitious materials. These cited aspects had the purpose of proposing reference values from the interactions between these parameters in order to make the process of obtaining mortar and self-compacting concrete less complex. For this, it was decided to obtain parameters of self-absorption and rheology by means of studies on mortars and, later, studies on concretes. The parameters resulting from the evaluation of the mortars were obtained by means of the following tests: mini-slump, mini funnel and rheological characterization using the rheometer of Rheotest N4.1 brand. The parameters resulting from the evaluation of concrete were obtained through the tests and mathematical models: slump flow, T500, V funnel, J ring, L box, U box, segregation tube, rheological parameters estimated by mathematical equations proposed by Sedran and De Larrard. From these parameters, it was possible to propose references of mortar and self-compacting concrete according with NBR 15823-1 (2010), which prescribes the selfcompacting requisites for concrete in Brazil. An evaluation of the tests prescribed in this standard was also made to evaluate the self-compacting concrete. It was found, for example, that the T500 test results showed no apparent consistent plastic viscosity compared to plastic apparent viscosity results obtained by testing funnel $\mathrm{V}$. Tests that assess pass ability, such as Lbox and J-ring, did not show a good match between their results. The scattering test proved to be efficient in estimating the concrete's ability to pass through the L-box and U-box tests. In addition, it was found in this study that the WFT parameter was not able to govern the selfmortars and self-compacting concretes, in opposing to statements of other researchers, who affirm with conviction that this parameter governs the properties in the fresh state of cementitious materials. Finally, it was possible to suggest classes of workability to selfcompacting mortars, as well as defining their most common rheology flow curves presented in this thesis.
\end{abstract}

Keywords: Self-compacting concrete. Mortar. Workability. Rheology. WFT Parameter. 


\section{SUMÁRIO}

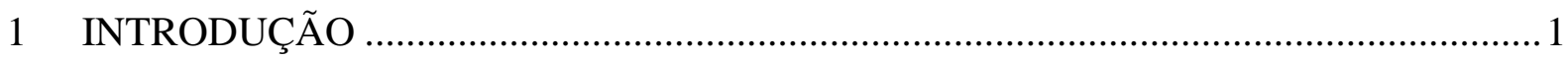

1.1 IMPORTÂNCIA DO TEMA E JUSTIFICATIVA ….........................................

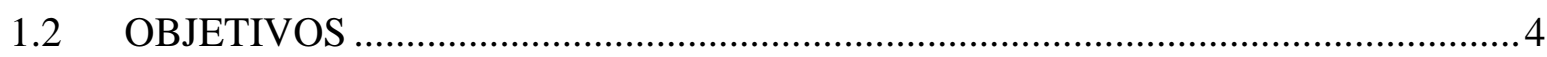

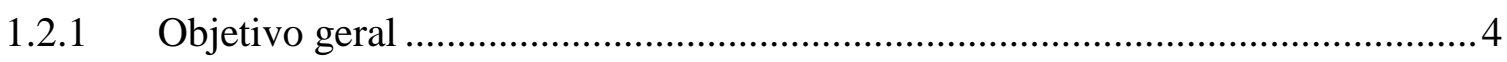

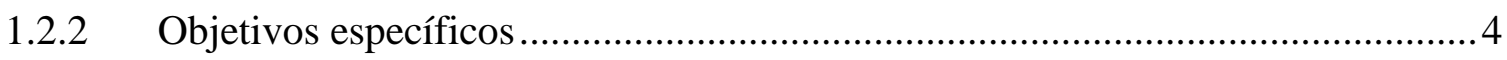

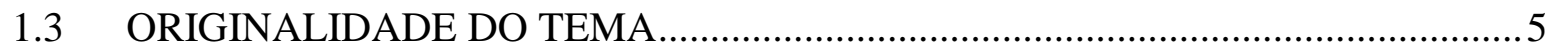

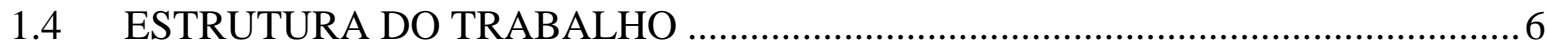

2 Capítulo II - AUTOADENSABILIDADE E REOLOGIA DE MATERIAS

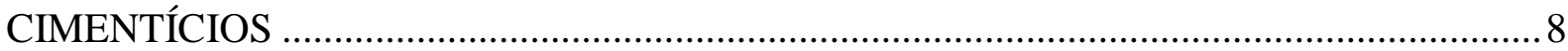

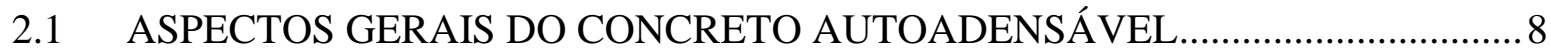

2.2 PROPRIEDADES DO CONCRETO AUTOADENSÁVEL NO ESTADO FRESCO 9

2.2.1 Requisitos para o alcance da autoadensabilidade ..........................................

2.2.2 Parâmetros físicos que influenciam a trabalhabilidade .................................... 10

2.3 PARÂMETRO WFT (WATER FILM THICKNESS) ......................................... 12

2.3.1 Medida da densidade de empacotamento ......................................................... 13

2.3.2 Determinação do parâmetro WFT …............................................................. 16

2.3.3 Resultados da aplicação do método WFT ..................................................... 18

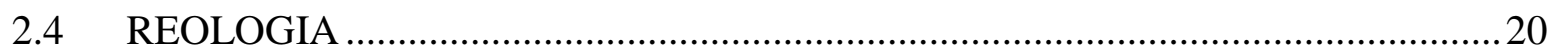

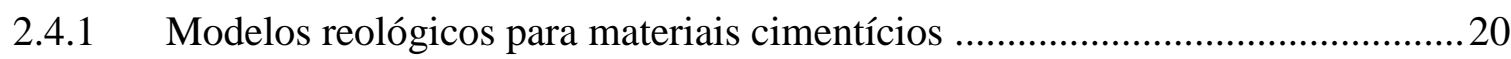

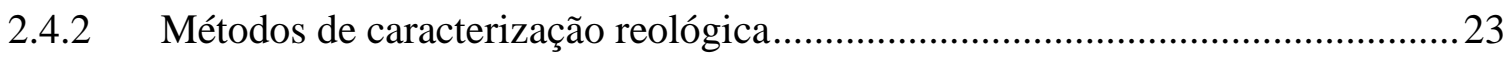

2.4.3 Características reológicas dos concretos autoadensáveis .................................225

2.5 SUGESTÕES DE PROPORÇÕES DE MATERIAIS PARA PRODUÇÃO DO

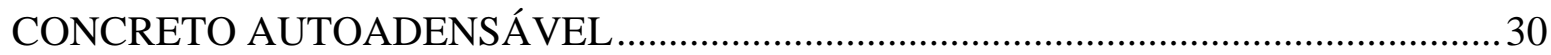

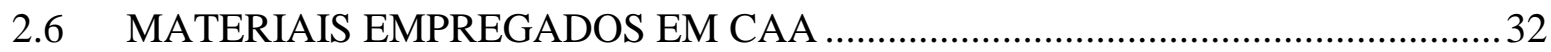




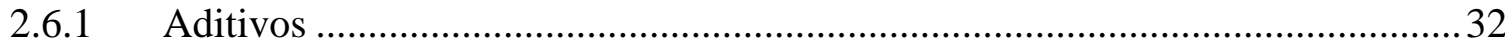

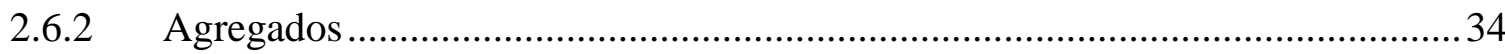

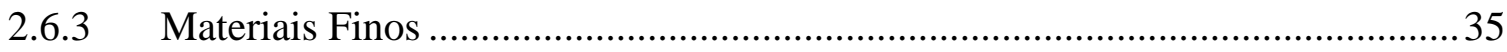

2.7 PRINCIPAIS MÉTODOS DE AVALIAÇÃO DA AUTOADENSABILIDADE DE

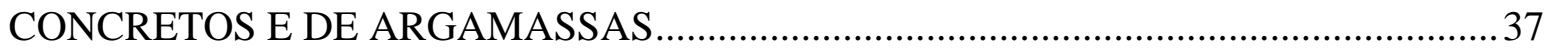

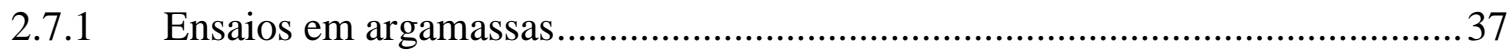

2.7.2 Ensaios de autoadensabilidade voltados para o concreto autoadensável ............39

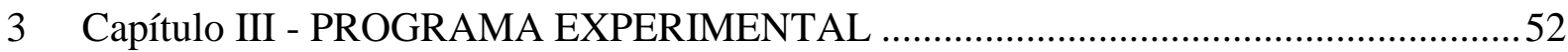

3.1 CARACTERIZAÇÃO DOS MATERIAIS EMPREGADOS …............................52

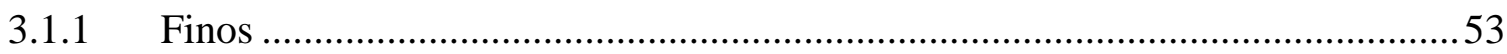

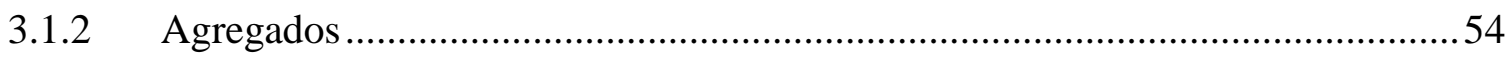

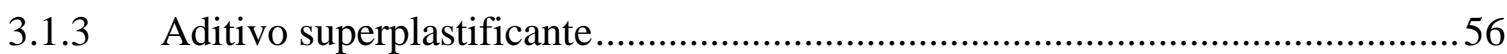

3.2 ETAPAS DO PROGRAMA EXPERIMENTAL …..................................................57

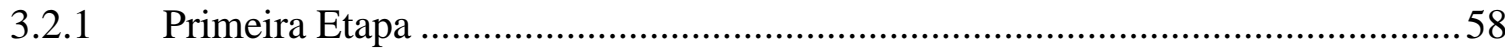

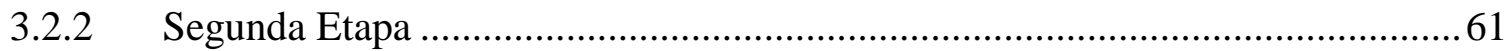

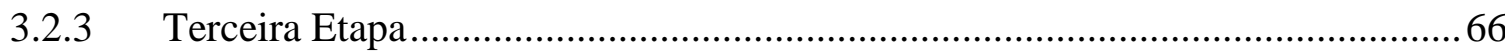

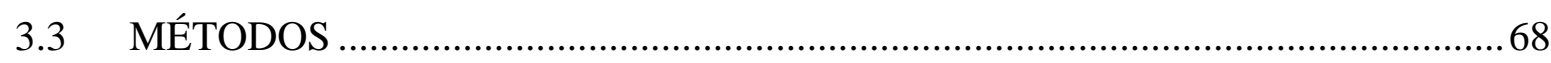

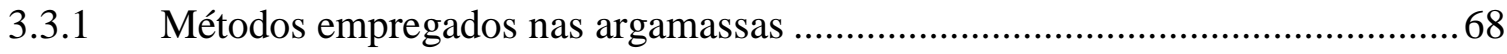

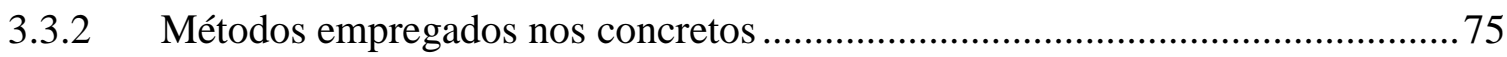

3.4 TRATAMENTOS OS DADOS E PLANEJAMENTO ESTATÍSTICO ..................82

4 Capítulo IV - RESULTADOS DO PROGRAMA EXPERIMENTAL .............................. 84

4.1 ESTUDO DA TRABALHABILIDADE DAS ARGAMASSAS COM ÊNFASE NA

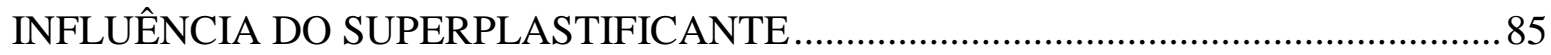

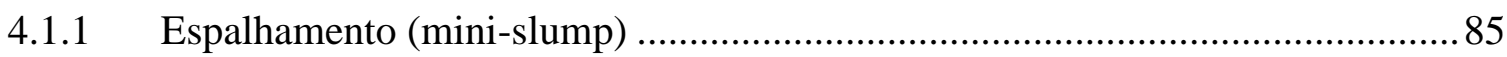

4.1.2 Avaliação da viscosidade (mini-funil) ............................................................ 93

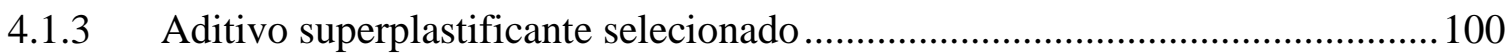


4.2 ARGAMASSAS PARA PRODUÇÃO DE CONCRETOS AUTOADENSÁVEIS 101

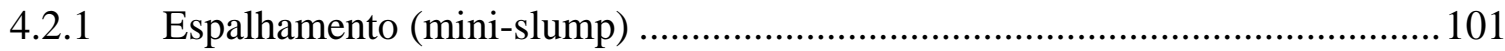

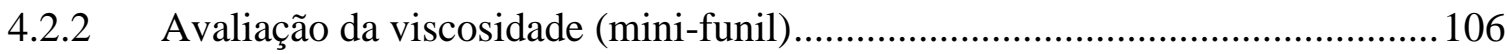

4.3 AUTOADENSABILIDADE DE CONCRETOS …........................................... 111

4.4 AUTOADENSABILIDADE DAS ARGAMASSAS REFERÊNCIAS ................. 112

4.5 REOLOGIA TEÓRICA DOS CONCRETOS AUTOADENSÁVEIS ..................... 113

4.6 REOLOGIA DAS ARGAMASSAS REFERÊNCIAS ....................................... 114

4.6.1 Curvas de fluxo reológico das argamassas ................................................. 114

4.6.2 Resultados dos parâmetros reológicos das argamassas ................................... 118

4.7 RESULTADOS DO PARÂMETRO WFT ........................................................... 119

4.8 RESULTADOS DAS PROPRIEDADES MECÂNICAS DOS CONCRETOS .....120

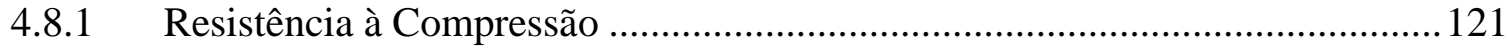

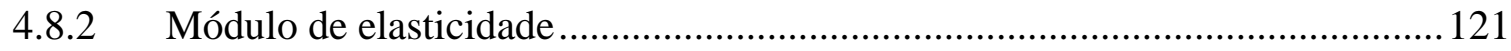

5 Capítulo V - DISCUSSÃO DOS RESULTADOS ................................................. 123

5.1 ANÁLISE DA AUTOADENSABILIDADE DOS CONCRETOS........................ 124

5.2 ANÁLISE DA AUTOADENSABILIDADE DAS ARGAMASSAS REFERÊNCIAS 129

5.3 ASSOCIAÇÃO DO COMPORTAMENTO DE AUTOADENSABILIDADE DAS

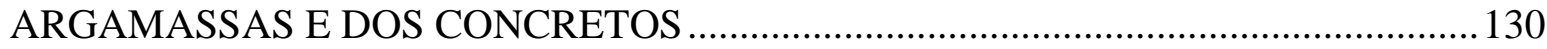

5.4 REOLOGIA TEÓRICA DOS CONCRETOS AUTOADENSÁVEIS ..................... 132

5.5 AVALIAÇÃO DA REOLOGIA DAS ARGAMASSAS REFERÊNCIAS ............ 133

5.6 COMPORTAMENTO REOLÓGICO DE ARGAMASSAS E DE CONCRETOS 139

5.7 AVALIAÇÃO DO PARÂMETRO WFT .......................................................... 140

5.8 AVALIAÇÃO DAS PROPRIEDADES MECÂNICAS DOS CONCRETOS........ 149

5.8.1 Resistência à Compressão ...................................................................... 149

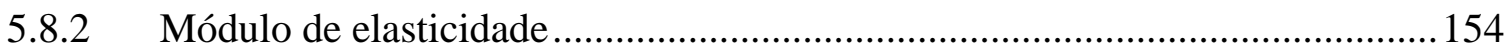


6.1 CONCLUSÕES

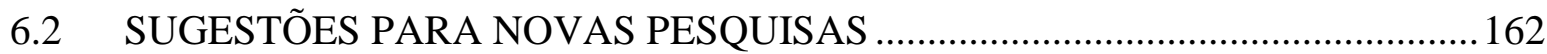

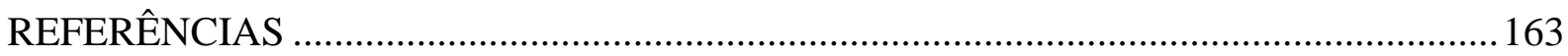

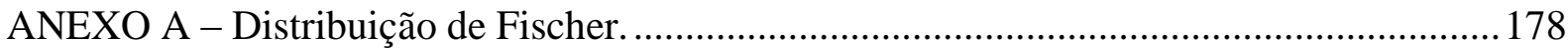

APÊNDICE A - ESTUDO PILOTO_....................................................................... 180

A1 Estudo preliminar em concretos ............................................................... 180

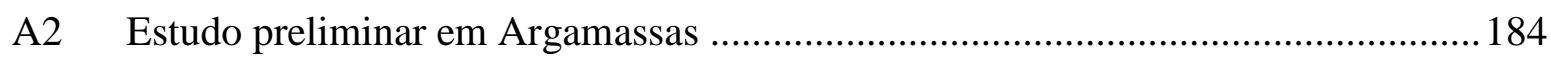

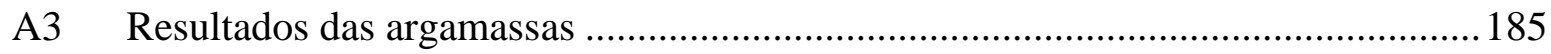

A4 Resultados de autoadensabilidade dos concretos obtidos a partir de argamassas referências

A5 Considerações gerais sobre o estudo piloto ............................................................ 190

APÊNDICE B - ANOVA - ESPALHAMENTO DA ARGAMASSA (1 ${ }^{\mathrm{a} E T A P A) \ldots . . . . . . . ~} 192$

B1 ANÁLISE DE VARIÂNCIA REFERENTE O ESTUDO DA TRABALHABILIDADE DAS ARGAMASSAS COM ÊNFASE NA INFLUÊNCIA DO SUPERPLASTIFICANTE192

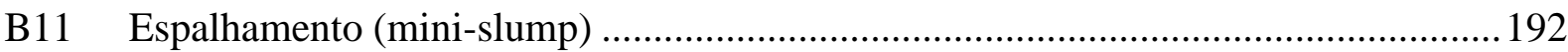

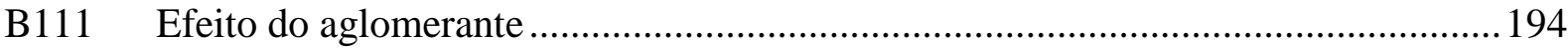

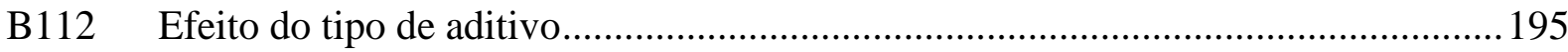

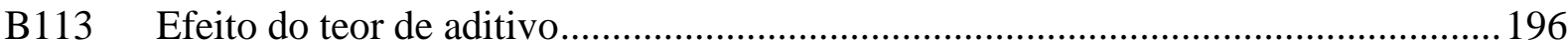

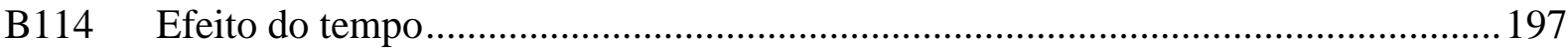

APÊNDICE C - ANOVA: FLUIDEZ DA ARGAMASSA (1 ${ }^{\mathrm{a} E T A P A) ~ . . . . . . . . . . . . . . . . . . . . . . . . . . ~} 199$

C1 AVALIAÇÃO DA VISCOSIDADE (MINI-FUNIL) ............................................ 199

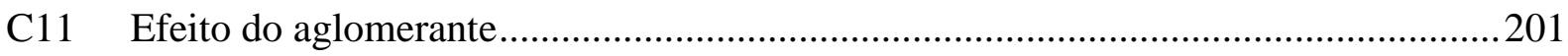

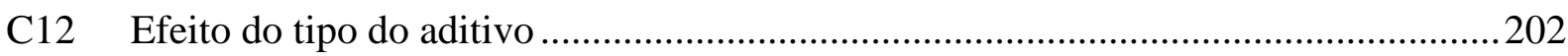

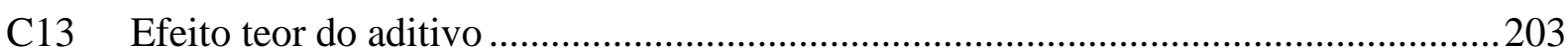

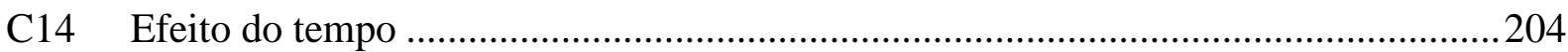


APÊNDICE D - ANOVA: ESPALHAMENTO DA ARGAMASSA (2aETAPA) ..........206

D1 ANÁLISE DE VARIÂNCIA REFERENTE O ESTUDO DAS ARGAMASSAS PARA PRODUÇÃO DE CONCRETOS AUTOADENSÁVEIS ......................................................206

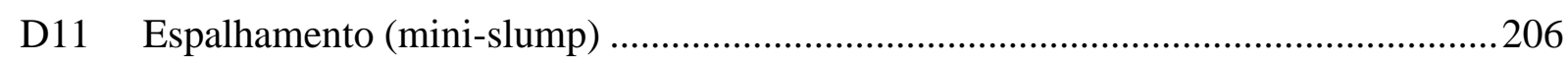

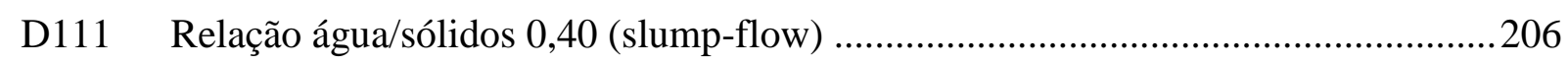

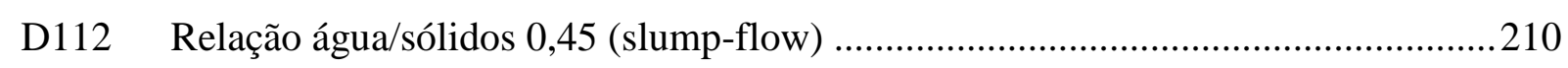

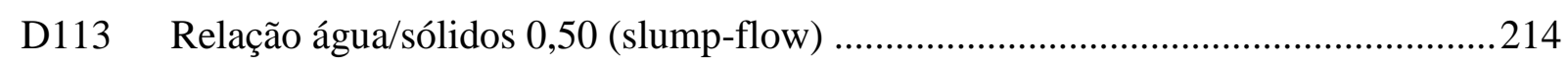

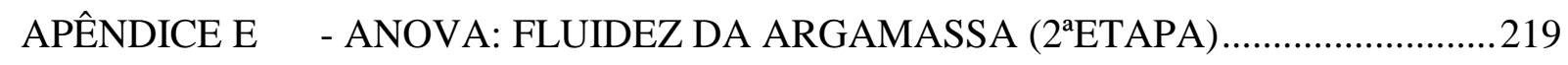

E1 AVALIAÇÃO DA VISCOSIDADE (MINI-FUNIL) ..........................................2 219

E11 Relação água/sólidos 0,40 (mini-funil) …..........................................................219

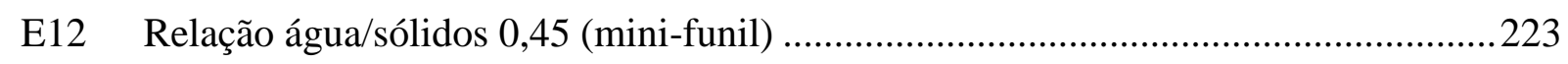

E13 Relação água/sólidos 0,50 (mini-funil) …..........................................................227

APÊNDICEF - Resultados individuais de Resistência à Compressão e Módulo de Elasticidade $\quad 232$ 


\section{LISTA DE FIGURAS}

Figura 1 - Significado físico da espessura de água. ........................................................... 12

Figura 2 - Correlação entre resultados de WFT e de trabalhabilidade das argamassas (FUNG, 2010).

Figura 3 - Correlação entre resultados de WFT e de reologia das argamassas (FUNG, 2010).

Figura 4 - Comportamento reológico dos fluidos: (1) newtoniano; (2) de Bingham; (3) pseudoplástico; (4) pseudoplástico com tensão de escoamento; (5) dilatante; (6) dilatante com

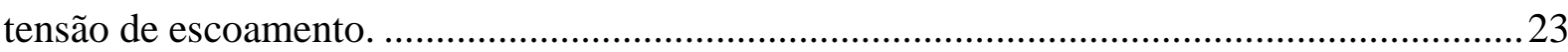

Figura 5 - Curva de fluxo com histerese de um material cimentício. 25

Figura 6 - Reografia dos efeitos de diferentes composições da mistura cimentícia de referência.

Figura 7 - Reografia dos efeitos de diferentes composições da mistura cimentícia de referência.

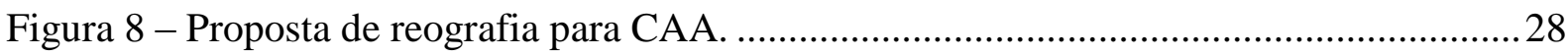

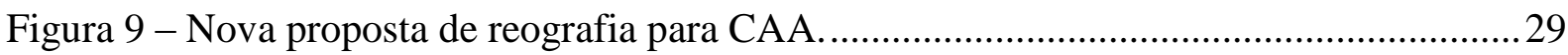

Figura 10 -Reografia referente aos concretos autoadensáveis de diferentes países.................29

Figura 11 - Ilustração esquemática da (a) repulsão eletrostática e (b) efeito estérico. 33

Figura 12 - Aparatos para avaliação da trabalhabilidade e autoadensabilidade da argamassa: (a) mini-slump; (b) mini-funil. 39

Figura 13 - Aparatos para espalhamento e T500, cone de Abrams. ...................................... 40

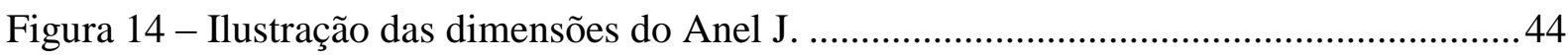

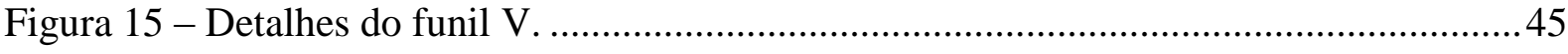

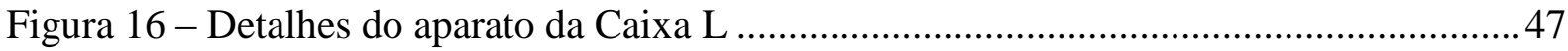

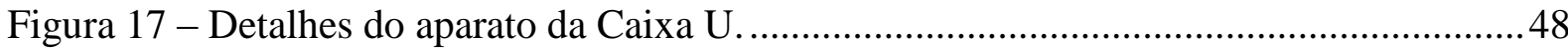

Figura 18 - Ilustração do aparato de coluna de segregação referente ao ensaio que avalia resistência à segregação do concreto.

Figura 19 - Fluxograma de apresentação geral das partes integrantes do desenvolvimento da

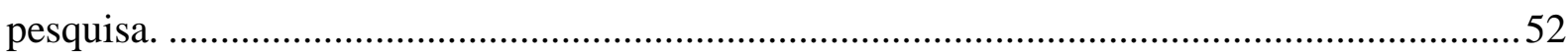

Figura 20 - Distribuição granulométrica a laser dos finos: (a) cimento, (b) fíler calcário. .....54 
Figura 21 - Distribuição granulométrica dos agregados miúdos conforme a NBR NM 248 (2003): (a) areia quartzosa (rosa), (b) combinção das areias (30\% de areia rosa e 70\% de areia artificial), (c) areia artificial calcária.

Figura 22 - Distribuição granulométrica do agregado graúdo (brita calcária) conforme a NBR NM 248 (2003).

Figura 23 - Fluxograma do Programa Experimental para o estudo das argamassas e dos concretos. 58

Figura 24 - Apresentação das variáveis independentes e dependentes para o estudo em argamassas com ênfase na influência do superplastificante - $1^{a}$ Etapa.

Figura 25 - Apresentação das variáveis independentes e dependentes para o estudo em argamassas, a fim de identificar as prováveis argamassas referências de concretos autoadensáveis $-2^{\mathrm{a}}$ etapa.

Figura 26 - Aparência superficial das argamassas no estado fresco: (a) argamassa coesa; (b) argamassa iminente para exsudar e segregar.

Figura 27 - Aparência superficial das argamassas no estado fresco: (a) argamassa muito consistente (forma de prato invertido); (b) exemplo de argamassa que sofreu segregação e exsudação.

Figura 28 - Esquema que apresenta as argamassas selecionadas para servirem como referências dos concretos autoadensáveis. 65

Figura 29 - Algumas partes do procedimento de mistura: (a) determinação das massas dos materiais; (b) homogeneização dos materiais; (c) mistura da argamassa. 70 Figura 30 - Determinação do espalhamento da argamassa: (a) preenchimento do tronco de cone com argamassa; (b) execução do ensaio de espalhamento; (c) medida do espalhamento da argamassa.

Figura 31 - Determinação da fluidez da argamassa: (a) mini-funil preenchido com argamassa; (b) . 71

Figura 32 - Memorial de cálculo para determinação do parâmetro WFT 73

Figura 33 - Determinação da massa unitária e densidade de empacotamento via úmida da argamassa.

Figura 34 - Ilustração da metodologia adotada para extração dos parâmetros reológicos. .....75 Figura 35 - Detalhes do reômetro de argamassa da marca Rheotest N4.1: (a) vista panorâmica do equipamento; (b) detalhe da haste; (c) vista do recipiente preenchido com argamassa...... 74 
Figura 36 - Misturador empregado para produção de concreto.

Figura 37 - Etapas da produção do concreto: (a) pesagem dos materiais; (b) mistura dos materiais no misturador de concreto; (c) determinação da massa específica...........................77

Figura 38 - Determinação do espalhamento do concreto..................................................... 77

Figura 39 - Determinação da habilidade passante do concreto por meio do Anel J............... 78

Figura 40 - Determinação da viscosidade plástica aparente por meio do ensaio de funilV ... 79

Figura 41 - Determinação da habilidade passante do concreto por meio do ensaio de caixa L.

Figura 42 - Determinação da habilidade passante do concreto por meio do ensaio de caixa U.

Figura 43 - Determinação da resistência à segregação do concreto por meio do ensaio de coluna de segregação: (a) coluna de segregação preenchida com concreto; (b) retirada da argamassa; (c) redução do excesso de água na superfície dos agregados; (d) pesagem dos agregados. ....80 Figura 44 - Determinação das propriedades mecânicas do concreto. (a) Resistência à Compressão; (b) Módulo de Elasticidade.

Figura 45 - Comportamento das argamassas frente ao ganho de espalhamento, tomando como ênfase a variável independente tipo de aglomerante. 88

Figura 46 - Comportamento das argamassas frente ao ganho de espalhamento, tomando como ênfase a variável independente tipo de aditivo.

Figura 47 - Comportamento das argamassas frente ao ganho de espalhamento, tomando como ênfase a variável independente tempo. 92

Figura 48 - Comportamento das argamassas frente ao ganho de fluidez, tomando como ênfase a variável independente tipo de aglomerante. 96

Figura 49 - Comportamento das argamassas frente ao ganho de fluidez, tomando como ênfase a variável independente tipo de aditivo. 98

Figura 50 - Comportamento das argamassas frente ao ganho de fluidez, tomando como ênfase a variável independente tempo. 99

Figura 51 - Comportamentos das argamassas sob a influência da variação do tipo de aglomerante, relação água/sólidos, teor de aditivo e variação do tempo frente ao espalhamento.

Figura 52 - Comportamentos das argamassas sob a influência da variação do tipo de aglomerante, relação água/sólidos, teor de aditivo e variação do tempo frente à fluidez. ..... 109 
Figura 53 - Curvas de fluxo obtidas com as argamassas referências de relação água/sólidos 0,40 . As setas indicam as velocidades ascendente e descendente.

Figura 54 - Curvas de fluxo obtidas com as argamassas referências de relação água/sólidos 0,45 . As setas indicam as velocidades ascendente e descendente.

Figura 55 - Curvas de fluxo obtidas com as argamassas referências de relação água/sólidos 0,50. As setas indicam a velocidade ascendente e descendente.

Figura 56 - Regressão tipo linear entre os resultados de viscosidade plástica aparente dos concretos obtidos tanto pelo ensaio de funil V como também pelo ensaio de T500. 126 Figura 57 - (a) Regressão tipo linear entre os resultados de espalhamento e do ensaio de caixa dos concretos (b) Regressão tipo linear entre os resultados de espalhamento e resultados do ensaio de caixa $U$ dos concretos 128

Figura 58 - Aparência superficial dos concretos. (a) concreto 16C; (b) concreto 18C. ........128 Figura 59 - Relação dos resultados de velocidade relativa de fluidez-Rm(mini-funil) e Área relativa de espalhamento-Gc das argamassas.

Figura 60 - (a) Regressão linear entre os resultados de espalhamento (slump-flow) dos concretos e os resultados de espalhamento (mini-slump) das argamassas. (b) Regressão tipo exponencial entre os resultados de viscosidade aparente dos concretos por meio do ensaio de funil V e das argamassas referências por meio do ensaio de mini-funil. 131

Figura 61 - Relação dos resultados dos parâmetros reológicos teórico dos concretos. 133 Figura 62 - Comportamento dos valores médio de tensão de escoamento de torque das argamassas referencias. 134

Figura 63 - Comportamento dos valores médio de tensão de escoamento de torque das argamassas referencias. 135

Figura 64 - Valores médios de histerese das argamassas referencias 136 Figura 65 - Regressão tipo exponencial entre os resultados de velocidade relativa de fluidez$\mathrm{Rm}$ e os resultados de viscosidade plástica de torque das argamassas. 139 Figura 66 - (a) Regressão tipo linear entre os resultados de viscosidade plástica aparente dos concretos por meio do ensaio de funil $\mathrm{V}$ e resultados de viscosidade plástica de torque das argamassas. (b) Regressão tipo linear entre os resultados de viscosidade plástica aparente dos concretos por meio do ensaio T500 e resultados de viscosidade plástica de torque das argamassas.

Figura 67 - Relação dos valores encontrados de WFT para as argamassas referências. 
Figura 68 - Relação dos resultados de WFTeq e de espalhamento das argamassas e dos concretos.

Figura 69 - Relação dos resultados de WFTeq e tensão de escoamento. (a) WFTeq e tensão de escoamento de torque (argamassas) (b) WFTeq e tensão de escoamento teórica. 146 Figura 70 - Relação dos resultados de WFTeq e viscosidade plástica. (a) WFTeq e viscosidade plástica aparente (mini-funil) (b) WFTeq e viscosidade plástica aparente (FunilV) (c) WFTeq e viscosidade plástica de torque (d) WFTeq e viscosidade plástica teórica. 148 Figura 71 - Resultados médios de resistência à compressão. 150 Figura 72 - Valores médios globais de resistência à compressão em função do tipo de aglomerante empregado nos concretos, com seus intervalos de confiança de $95 \%$ e seus desvios padrões. As linhas tracejadas verticais definem os grupos que diferem significamente 153 Figura 73 - Valores médios globais de resistência à compressão em função da relação água/sólidos empregado nos concretos, com seus intervalos de confiança de 95\% e seus desvios padrões. As linhas tracejadas verticais definem os grupos que diferem significamente. 154 Figura 74 - Resultados médios de módulo de elasticidade dos concretos. 155 Figura 75 - Valores médios globais de módulo de elasticidade em função do tipo de aglomerante empregado nos concretos, com seus intervalos de confiança de $95 \%$ e seus desvios padrões. As linhas tracejadas verticais definem os grupos que diferem significamente 157 Figura 76 - Valores médios globais de módulo de elaticidade em função da relação água/sólidos empregado nos concretos, com seus intervalos de confiança de $95 \%$ e seus desvios padrões. As linhas tracejadas verticais definem os grupos que diferem significamente. 158 Figura 77 - Aspecto visual do concreto após o espalhamento (estudo piloto). 183 Figura 78 - Planejamento experimental do estudo em argamassas de CAA (estudo piloto). 185 Figura 79 - Ilustração dos ensaios dos processos seguidos para avaliação das argamassas (estudo piloto) 185

Figura 80 - Correlação entre os resultados de espalhamento da argamassa versus os valores de WFT (estudo piloto). 187

Figura 81 - Relação da tensão de escoamento com parâmetro WFT, seguido com a ilustração do aspecto visual das argamassas estudadas (estudo piloto). 188 Figura 82 - Aspectos visuais dos concretos. (a) C0,50_20, (b) C0,55_2,0 (estudo piloto)...190 
Figura 83 - Valores médios globais de espalhamento em função do tipo de aglomerante empregado nas argamassas, com seus intervalos de confiança de $95 \%$ e seus desvios padrões. As linhas tracejadas verticais definem os grupos que diferem significamente. Figura 84 - Valores médios globais de espalhamento em função do tipo de aditivo empregado nas argamassas, com seus intervalos de confiança de $95 \%$ e seus desvios padrões. As linhas tracejadas verticais definem os grupos que diferem significamente. 196 Figura 85 - Valores médios globais de espalhamento em função dos teores de aditivo empregado nas argamassas, com seus intervalos de confiança de $95 \%$ e seus desvios padrões. As linhas tracejadas verticais definem os grupos que diferem significamente. Figura 86 - Valores médios globais de espalhamento em função dos tempos considerados para medir o espalhamento das argamassas, com seus intervalos de confiança de $95 \%$ e seus desvios padrões. As linhas tracejadas verticais definem os grupos que diferem significamente. 198 Figura 87 - Valores médios globais de fluidez em função do tipo de aglomerante, com seus intervalos de confiança de $95 \%$ e seus desvios padrões. As linhas tracejadas verticais definem os grupos que diferem significamente. 202 Figura 88 - Valores médios globais de fluidez em função do tipo de aditivo superplastificante, com seus intervalos de confiança de $95 \%$ e seus desvios padrões. As linhas tracejadas verticais definem os grupos que diferem significamente.

Figura 89 - Valores médios globais de fluidez em função do teor do aditivo superplastificante, com seus intervalos de confiança de $95 \%$ e seus desvios padrões. As linhas tracejadas verticais definem os grupos que diferem significativamente. 204 Figura 90 - Valores médios globais de fluidez em função da variável tempo, com seus intervalos de confiança de $95 \%$ e seus desvios padrões. As linhas tracejadas verticais definem os grupos que diferem significativamente.

Figura 91 - Valores médios globais de espalhamento em função do tipo de aglomerante referentes as argamassas de relação água/sólidos 0,40, com seus intervalos de confiança de $95 \%$ e seus desvios padrões. As linhas tracejadas verticais definem os grupos que diferem significativamente. 208

Figura 92 - Valores médios globais de espalhamento em função do teor do aditivo referentes as argamassas de relação água/sólidos 0,40, com seus intervalos de confiança de $95 \%$ e seus desvios padrões. As linhas tracejadas verticais definem os grupos que diferem significativamente. 209 
Figura 93 - Valores médios globais de espalhamento em função do tempo referentes as argamassas de relação água/sólidos 0,40, com seus intervalos de confiança de $95 \%$ e seus desvios padrões. As linhas tracejadas verticais definem os grupos que diferem significativamente.

Figura 94 - Valores médios globais de espalhamento em função do tipo de aglomerante referentes as argamassas de relação água/sólidos 0,45, com seus intervalos de confiança de $95 \%$ e seus desvios padrões. Os grupos estão discriminados na figura.

Figura 95 - Valores médios globais de espalhamento em função do teor do aditivo referentes as argamassas de relação água/sólidos 0,45, com seus intervalos de confiança de $95 \%$ e seus desvios padrões. As linhas tracejadas verticais definem os grupos que diferem significativamente.

Figura 96 - Valores médios globais de espalhamento em função do teor do aditivo referentes as argamassas de relação água/sólidos 0,45, com seus intervalos de confiança de $95 \%$ e seus desvios padrões. As linhas tracejadas verticais definem os grupos que diferem significativamente.

Figura 97 - Valores médios globais de espalhamento em função do tipo de aglomerante referentes as argamassas de relação água/sólidos 0,50, com seus intervalos de confiança de 95\% e seus desvios padrões. Os grupos estão discriminados de acordo com diagrama que consta na figura 216 Figura 98 - Valores médios globais de espalhamento em função do teor de aditivo referentes as argamassas de relação água/sólidos 0,50, com seus intervalos de confiança de $95 \%$ e seus desvios padrões. As linhas tracejadas verticais definem os grupos que diferem significativamente.

Figura 99 - Valores médios globais de espalhamento em função do tempo referentes as argamassas de relação água/sólidos 0,50, com seus intervalos de confiança de $95 \%$ e seus desvios padrões. As linhas tracejadas verticais definem os grupos que diferem significativamente. 218

Figura 100 - Valores médios globais de fluidez em função do tipo de aglomerante referentes as argamassas de relação água/sólidos 0,40, com seus intervalos de confiança de $95 \%$ e seus desvios padrões. As linhas tracejadas verticais definem os grupos que diferem significativamente. 
Figura 101 - Valores médios globais de fluidez em função do teor do aditivo referentes as argamassas de relação água/sólidos 0,40, com seus intervalos de confiança de $95 \%$ e seus desvios padrões. As linhas tracejadas verticais definem os grupos que diferem significativamente.

Figura 102 - Valores médios globais de fluidez em função do tempo referentes as argamassas de relação água/sólidos 0,40, com seus intervalos de confiança de 95\% e seus desvios padrões. As linhas tracejadas verticais definem os grupos que diferem significativamente. 223 Figura 103 - Valores médios globais de fluidez em função do tipo de aglomerante referentes as argamassas de relação água/sólidos 0,45, com seus intervalos de confiança de 95\% e seus desvios padrões. As linhas tracejadas verticais definem os grupos que diferem significativamente. 225

Figura 104 - Valores médios globais de fluidez em função do teor de aditivo referentes as argamassas de relação água/sólidos 0,45, com seus intervalos de confiança de $95 \%$ e seus desvios padrões. As linhas tracejadas verticais definem os grupos que diferem significativamente. .226 Figura 105 - Valores médios globais de fluidez em função do tempo referentes as argamassas de relação água/sólidos 0,45, com seus intervalos de confiança de $95 \%$ e seus desvios padrões. As linhas tracejadas verticais definem os grupos que diferem significativamente.

Figura 106 - Valores médios globais de fluidez em função do tipo de aglomerante referentes as argamassas de relação água/sólidos 0,50 , com seus intervalos de confiança de $95 \%$ e seus desvios padrões. As linhas tracejadas verticais definem os grupos que diferem significativamente.

Figura 107 - Valores médios globais de fluidez em função do teor de aditivo referentes as argamassas de relação água/sólidos 0,50, com seus intervalos de confiança de $95 \%$ e seus desvios padrões. As linhas tracejadas verticais definem os grupos que diferem significativamente.

Figura 108 - Valores médios globais de fluidez em função do tempo referentes as argamassas de relação água/sólidos 0,50, com seus intervalos de confiança de $95 \%$ e seus desvios padrões. As linhas tracejadas verticais definem os grupos que diferem significativamente. 


\section{LISTA DE TABELAS}

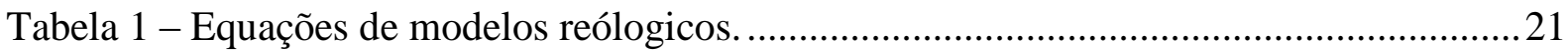

Tabela 2 - Proporções de materiais recomendados pelo ACI237R-07 (2007)....................... 30

Tabela 3 - Resumo dos melhores traçõs de CAA. .................................................................... 31

Tabela 4 - Quantidade de finos em função do espalhamento do CAA..................................... 35

Tabela 5 - Quantidade de finos em função do espalhamento do CAA..................................... 41

Tabela 6 - Classes de viscosidade plástica aparente do T500 ...............................................42

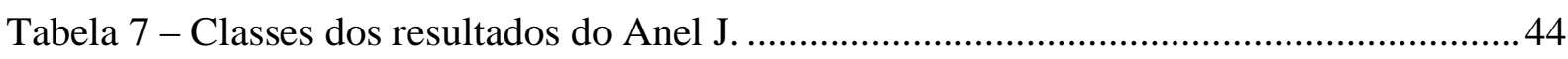

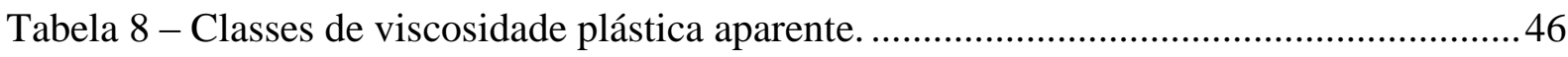

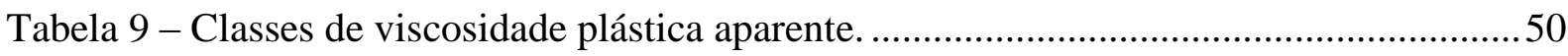

Tabela 10 - Citação das normas brasileiras, americanas e europeias que prescrevem os ensaios

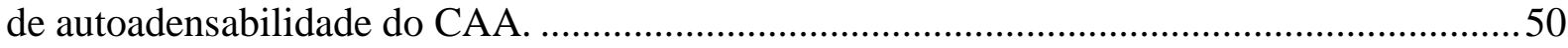

Tabela 11 - Resultados de várias pesquisas relativas à autoadensabilidade do CAA..............51

Tabela 12 - Caracterização química e física dos finos: cimento CPV ARI RS, fíler calcário. 53 Tabela 13 - Principais características dos aditivos a base de policarboxilato de sódio

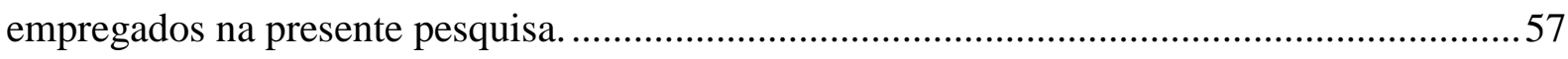

Tabela 15 - Quantitativo de materiais das argamassas produzidas com emprego de um superplastificante.

Tabela 16-Quantitativo de materiais das argamassas produzidas na segunda etapa do Programa Experimental.

Tabela 17 - Quantitativo dos materiais empregados nos concretos de acordo com as argamassas referências.

Tabela 18 - Descrição das classes e das tolerâncias dos resultados dos ensaios de

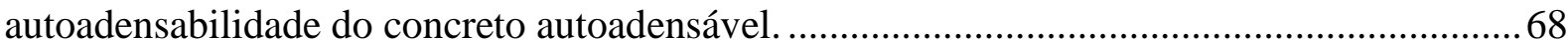

Tabela 19 - Resultados médios de espalhamento das argamassas........................................ 86

Tabela 20 - Resultados médios de fluidez das argamassas.................................................... 94

Tabela 21 - Resultados médios de espalhamento das argamassas com emprego somente do aditivo SP3.

Tabela 22 - Resultados médios de fluidez das argamassas com emprego somente do aditivo SP3. 107

Tabela 23 - Resultados e classificações de autoadensabilidade dos concretos 112 
Tabela 24 - Resultados médios e classificação de autoadensabilidade das argamassas referências.

Tabela 25 - Resultados dos parâmetros reológicos teórico dos concretos.

Tabela 26 - Resultados dos parâmetros reológicos das argamassas referencias

Tabela 27 - Resultados médios do parâmetro WFT das argamassas referências.

Tabela 28 - Resultados médios de resistência à compressão dos concretos.

Tabela 29 - Resultados médios de modulo de elasticidade dos concretos.

Tabela 30 -Associação dos resultados de autoadensabilidade e as características das misturas dos concretos.

Tabela 31 - Sugestões de classes de autoadensabilidade para argamassas.

Tabela 32 - Resultados e classificações de autoadensabilidade das argamassas referências. 144 Tabela 33 - Resultados da análise de variância (ANOVA) realizada com os dados de resistência à compressão, para as variáveis consideradas no modelo estatístico.

Tabela 34 - Resultados da análise de variância (ANOVA) realizada com os dados de módulo de elasticidade para as variáveis consideradas no modelo estatístico. 156

Tabela 35 - Distribuição de Fischer - valores tabelados de Ftab, para $\alpha=0,05$. 178 Tabela 41 - Resultados da análise de variância (ANOVA) realizada com os dados de espalhamento (espalhamento-100), para as variáveis consideradas no modelo estatístico....193 Tabela 42 - Resultados da análise de variância (ANOVA) realizada com os dados de fluidez, para as variáveis consideradas no modelo estatístico. 200

Tabela 43 - Resultados da análise de variância (ANOVA) realizada com os dados de espalhamento das argamassas de relação água/sólidos 0,40, para as variáveis consideradas no modelo estatístico.

Tabela 44 - Resultados da análise de variância (ANOVA) realizada com os dados de espalhamento das argamassas de relação água/sólidos 0,45 , para as variáveis consideradas no modelo estatístico. 210

Tabela 45 - Resultados da análise de variância (ANOVA) realizada com os dados de espalhamento das argamassas de relação água/sólidos 0,50, para as variáveis consideradas no modelo estatístico.

Tabela 46 - Resultados da análise de variância (ANOVA) realizada com os dados de fluidez das argamassas de relação água/sólidos 0,40 , para as variáveis consideradas no modelo estatístico. 
Tabela 47 - Resultados da análise de variância (ANOVA) realizada com os dados de fluidez das argamassas de relação água/sólidos 0,45, para as variáveis consideradas no modelo estatístico.

Tabela 48 - Resultados da análise de variância (ANOVA) realizada com os dados de fluidez das argamassas de relação água/sólidos 0,50, para as variáveis consideradas no modelo estatístico. 228 


\section{LISTA DE SÍMBOLOS, NOMENCLATURA E ABREVIAÇÕES}

$\phi$

$\rho_{w}$

$\rho_{c}$

$\rho_{f}$

$R_{c}$

A

ABNT:

ACI:

ASTM:

$A_{\alpha}, A_{\beta}$ e $A_{\gamma}$

BAC

$\mathrm{CCV}$

CAA

$\mathrm{C}_{3} \mathrm{~A}$

$\mathrm{C}_{4} \mathrm{AF}$

$D=$

$\mathrm{Db}=$

Dm concentração de sólidos (adimensional)

densidade da água $\left(\mathrm{g} / \mathrm{cm}^{3}\right)$

densidade do cimento $\left(\mathrm{g} / \mathrm{cm}^{3}\right)$

densidade do agregado $\left(\mathrm{g} / \mathrm{cm}^{3}\right)$

relação volumétrica das partículas sólidas do cimento pelo volume total de sólidos

área superficial total dos sólidos da mistura $\left(\mathrm{m}^{2} / \mathrm{m}^{3}\right)$

Associação Brasileira de Normas

Técnicas

American Concrete Institute

American Society for Testing and Materials

são as áreas superficiais dos sólidos $\alpha, \beta$ e $\gamma\left(\mathrm{m}^{2} / \mathrm{m}^{3}\right)$

Congresso Ibero-americano sobre Betão auto-compactável

concreto convencional ou referência de concreto convencional

concreto autoadensável ou referência de concreto autoadensável

Aluminato tricálcico

Ferro aluminato tetracálcico

ganho de espalhamento ( $\mathrm{mm}$ )

diâmetro da base do cone ( $\mathrm{mm}$ )

resultado médio dos espalhamentos

perpendiculars $(\mathrm{mm})$ 
The European Federation of Specialist Construction Chemicals and Concrete Systems

$\mathrm{Gc}=$

LN

$M$

PC

RILEM

$R_{f}$

$R_{\alpha}, R_{\beta}, R_{\gamma}$

SMF

SNF

$u$

$u_{\mathrm{w}}^{\prime}$

$u_{a}$

$u_{\min }$

$u_{\mathrm{w}}$

V

V

$V_{s}$

$\varepsilon_{\mathrm{a}}$ área relativa de espalhamento

(adimensional)

lignosulfonatos modificados

massa do material cimentício (g)

éteres polycarboxilato

Réunion Internationale des Laboratoires et Experts des Matériaux

relação volumétrica dos agregados pelo volume total de sólidos (adimensional)

são as razões volumétricas dos sólidos $\alpha$, $\beta$ e $\gamma$ (adimensional)

formaldeído melanina sulfonato condensado

formaldeído naftaleno sulfonato condensado

índice de vazios (adimensional)

relação entre o volume de água excedente e volume total de sólidos (adimensional)

relação entre o volume de ar e volume total de sólidos (adimensional).

índice de vazios mínimo (adimensional)

relação entre o volume de água e volume total de sólidos (adimensional)

volume do material cimentício acondicionado no recipiente $\left(\mathrm{cm}^{3}\right)$

volume total do material granular $\left(\mathrm{cm}^{3}\right)$

volume total dos sólidos $\left(\mathrm{cm}^{3}\right)$

teor de ar (adimensional) 
$\varepsilon_{\mathrm{W}}$

$\varepsilon$

WFT teor de água (adimensional)

porosidade (adimensional)

water film thickness 


\section{INTRODUÇÃO}

A presente tese está inserida na linha de pesquisa "Tecnologia, Processos, Componentes e Materiais de Construção", área de concentração em Construção Civil, do Programa de PósGraduação em Estruturas e Construção Civil da Universidade de Brasília (PECC/UnB), abordando especificamente o estudo da autoadensabilidade e da reologia de argamassas e de concretos.

No Programa de Pós-Graduação em Estruturas e Construção Civil, já foram concluídas dissertações e teses, com ênfase em concreto, que envolveram temas relacionados com propriedades mecânicas e de durabilidade e propriedades no estado fresco. No âmbito do estado endurecido, cabe destacar os seguintes trabalhos: Rodrigues (2010) com trabalho intitulado Contribuição Ao Estudo da Retração e da Fluência e Seus Mecanismos de Atuação a Baixas Idades em Concretos Estruturais; Feijão (2000) com trabalho intitulado Contribuição Ao Estudo dos Sensores de Corrosão para Estruturas de Concreto Armado; Pozzan (2001) com trabalho intitulado Interação Entre Os Mecanismos de Transporte de Cloretos e a Estrutura Interna do Concreto em Diferentes ondições de Carbonatação; Pereira (2008) com trabalho intitulado Controle da Resistência do Concreto: Paradigmas e Variabilidades - Estudo de Caso; Joffly (2010) com trabalho intitulado Avaliação do Ensaio de Penetração de Pino para Mensuração Indireta de Resistência à Compressão do Concreto; Palacios (2012) com trabalho intitulado Emprego de Ensaios Não Destrutivos e de Extração de Testemunhos na Avaliação da Resistência à Compressão do Concreto; Leal (2012) com trabalho intitulado Investigação Experimental do Módulo de Elasticidade nos Concretos Produzidos em Brasília; Ramos (2005) com trabalho intitulado Avaliação da Influência das Elevadas Temperaturas em Concretos Empregados em Revestimentos de Túneis; Samaniego (2014) com trabalho intitulado Ensaios Não Destrutivos para Avaliação da Resistência do Concreto: Estudo de Aplicação em Obras.

Dentre os principais trabalhos com foco no estado fresco do concreto, têm-se: Santos (2008) com trabalho intitulado A Influência das Características da Areia Artificialmente Britada Nas Propriedades do Estado Fresco do Concreto; Coelho (2012) com trabalho intitulado Um Estudo Numérico do Efeito Térmico em Concreto Massa; Ordónez (2013) com trabalho intitulado Mitigação da Retração Autógena em Microconcretos de Alta Resistência com Adição de Polímeros Superabsorventes e Aditivo Redutor de Retração; Rodolpho (2007) com trabalho 
intitulado Estudo do Comportamento do Concreto no Estado Fresco contendo Areia Britada; Suarez (2015) com trabalho intitulado Polímeros Superabsorventes (Psa) Como Agente de Cura Interna para Prevenir Fissuração em Concretos de Alta Resistência. Além desses trabalhos, recentemente, foi defendida uma tese intitulada Estudo Experimental de Materiais Cimentícios de Alta Resistência Modificados com Polímeros Superabsorventes (Psas) Como Agentes de Cura Interna por Manzano (2016), o qual focou seu estudo em microconcretos, tendo abordado análises de reologia e trabalhabilidade desses materiais.

Por fim, cabe enfatizar que a presente tese é o primeiro trabalho do PECC/UnB que trata sobre concreto autoadensável, portanto iniciando-se com estudo de suas características de autoadensabilidade e de reologia e, também, da argamassa que o compõe.

\subsection{IMPORTÂNCIA DO TEMA E JUSTIFICATIVA}

É de conhecimento do meio científico que os primeiros estudos sobre concreto autoadensável (CAA) foram coordenados por Hajime Okamura, por volta de 1983, no Japão (OKAMURA, OUCHI, 2003). Esse concreto possui vantagens exclusivas, destacando-se alguns exemplos como: redução da mão-de-obra e de equipamentos necessários para o lançamento do concreto, adensamento mais eficiente, redução do prazo de execução devido à alta produtividade e melhor acabamento superficial das peças de concreto. Diante dessas vantagens, cada dia esse concreto tem despertado interesse dos concreteiros e de pesquisadores. Congressos e conferências para tratar do assunto são cada vez mais frequentes como o First North American (ATTIOGBE et al., 2002), Five RILEM conference (WALLEVIK et al., 2007) e o BAC (NUNES et al., 2015). Entretanto, o CAA é de difícil obtenção por demandar um estudo complexo na composição e nas proporções de seus materiais, tais como: teor de finos, fração de argamassa, fração de agregados graúdos e teor de superplastificante. Esse estudo é necessário para a contribuição ao atendimento dos requisitos de autoadensabilidade (habilidade passante, capacidade de preenchimento e resistência de segregação), tornando sua obtenção mais simples e viável. Além disso, ainda não há um consenso geral sobre os métodos de ensaio que avaliam a autoadensabilidade do concreto no que se refere a sua confiabilidade e eficácia, sendo, portanto, uma questão para ser explorada (EL-CHABIB, NEHDI, 2006).

Para a produção de concreto autoadensável, o tecnologista do concreto ou pesquisador adota um método de dosagem que mais convém. Dessa forma, pode-se buscar um método que seja 
capaz de alcançar os requisitos de autoadensabilidade do concreto de maneira mais rápida e fácil e outros adotam um método que não se preocupa somente com requisitos de autoadensabilidade, mas também com requisitos de propriedades mecânicas, durabilidade e custo benefício. Por meio de parâmetros de autoadensabilidade, de reologia, de propriedades mecânicas e estatísticos é possível construir um método de dosagem (SHI et al., 2015). Nesse sentido, Shi et al. (2015) definiram que os métodos de dosagem voltados para o concreto autoadensável estão inseridos em cinco grupos: métodos de dosagem empírico; métodos que levam em consideração a resistência à compressão; métodos que levam em consideração a densidade de empacotamento dos agregados; métodos que consideram o planejamento fatorial; métodos que consideram a reologia da pasta. No geral, esses métodos de dosagem partem de estudos em argamassas.

Estudos em argamassas são importantes para prever o comportamento do concreto autoadensável frente às suas caraterísticas de reologia e de autoadensabilidade, bem como a possibilidade de efetuar várias combinações com maior número de variáveis, assim contribuindo para o entendimento mais consistente das propriedades estudadas com menor gasto de materiais e de recurso humano (SHI et al., 2015). Isso é possível pelo fato desses materiais cimentícios possuírem comportamentos semelhantes no estado fresco (JIN, 2002).

Quanto aos métodos de ensaio, vários métodos têm sido propostos e boa parte deles já são normalizados. A maioria desses métodos é usada para avaliar a habilidade passante do CAA. Dentre os ensaios comumente utilizados para esta finalidade são Anel J (J-ring), Caixa L e Caixa U. Libre et al. (2012) afirmam que o ensaio de Caixa U é mais sensível para indentificar mudanças na mistura, no entanto não é normalizado. Com relação à resistência à segregação, Cussigh (2003) afirma que o ensaio de coluna de segregação é o mais adequado para se notar quantitativamente diferenças entre misturas de CAA, o que é corroborado por Libre et al. (2012). O método da sonda tem sido usado para quantificar a segregação, sendo inclusive classificado como ágil e mais eficaz (LIBRE et al., 2012). A avaliação qualitativa da segregação é exigida pela ASTM C1611 (2010), entretanto a norma brasileira ABNT NBR 15823 (2010) não exige essa avaliação.

Há outros estudos que consideram também outros parâmetros para melhor entender o comportamento do concreto autoadensável. Estudos que consideram referências de parâmetros 
reológicos apresentadas em reografias para avaliação e definição da autoadensabilidade do concreto (WALLEVIK; WALLEVIK, 2011). Outros estudos consideram parâmetros reólogicos estimados por meio de equações de Sedran e De Larrard (1999), por exemplo. Existem, também, estudos que agregam parâmetros físicos, tais como: densidade de empacotamento, área superficial dos sólidos do sistema de partículas e relação água/sólidos ( FUNG, 2010; KWAN et al., 2010; OLIVEIRA, 2013; NEPOMUCENO et al., 2014).

Por fim, nota-se que há uma preocupação em tornar mais simples a obtenção do concreto autoadensável por meio de estudos em argamassas, por variados tipos de métodos de dosagem e relações de parâmetros. Com esse viés, almeja-se confrontar os parâmetros obtidos de autoadensabilidade e de reologia das argamassas e dos concretos, bem como discutir os critérios de autoadensabilidade associada à avaliação da adequabilidade dos ensaios correntemente empregados.

\subsection{OBJETIVOS}

A seguir, são apresentados os objetivos traçados para o alcance dos resultados deste trabalho, divididos em objetivo geral e objetivos específicos.

\subsubsection{Objetivo geral}

O presente trabalho visa explorar a relação existente entre os parâmetros de autoadensabilidade e de reologia de argamassas e concretos, a fim de propor valores de referências gerados a partir da interação desses parâmetros, assim contribuindo para tornar a obtenção do concreto autoadensável menos complexa.

\subsubsection{Objetivos específicos}

Os objetivos específicos são listados a seguir:

- validar a capacidade dos estudos de trabalhabilidade em argamassas de concreto para identificar as prováveis argamassas referências para produção de concreto autoadensável;

- avaliar a influência de diferentes aditivos superplastificantes, de mesma base química, sobre a autoadensabilidade de argamassas; 
- avaliar a influência da substituição de cimento por fíler calcário sobre autoadensabilidade de argamassas e concretos;

- discutir os critérios de autoadensabilidade associada à avaliação da adequabilidade dos ensaios correntemente empregados pela norma brasileira NBR 15823 (2010); .

- verificar a sintonia existente dos parâmetros reológicos medidos nas argamassas de referência com os parâmetros reológicos teórico dos concretos autoadensáveis;

- analisar as curvas de fluxo reológico das argamassas referências de concretos autoadensáveis;

- verificar a sintonia existente dos parâmetros de autoadensabilidade de argamassas e de concretos;

- avaliar a capacidade do parâmetro WFT (water film thickness) de referenciar e governar os parâmetros reológicos e de autoadensabilidade de argamassas ou concretos autoadensáveis;

- caracterizar e efetuar uma sucinta análise sobre as propriedades mecânicas dos concretos, tais como: resistência à compressão e módulo de elasticidade, principalmente sob a influência da substituição do cimento por fíler calcário.

\subsection{ORIGINALIDADE DO TEMA}

A tese tem como contribuição principal apresentar valores de referência dos parâmetros de autoadensabilidade e de reologia de argamassas e concretos, com ênfase nos estudos em argamassas. Para isso, foi adotado um procedimento original de estudo que se diferenciou nos seguintes aspectos principais:

- as classes de autoadensabilidade do concreto serviram como norteadores do processo de obtenção de argamassas referências de concretos autoadensáveis. Isso significa que quando os concretos foram classificados como autoadensáveis, também foram classificadas como autodensáveis as argamassas de referência;

- estudo da capacidade do parâmetro WFT (water thickness film), que envolve conceitos de densidade de empacotamento e área superficial total das partículas sólidas, de governar as propriedades de autoadensabilidade e de reologia de argamassas e de concretos;

- avaliação quanto a capacidade dos ensaios de avaliarem a autoadensabilidade do concreto. 
É importante frisar que no Brasil ainda existe uma carência de estudos voltados à atribuição de valores de referência de autoadensabilidade e de reologia de concretos autoadensáveis, ao contrário dos países europeus e dos Estados Unidos, os quais possuem parâmetros reológicos e de autoadensabilidade bem definidos e registrados dos seus concretos autoadensáveis.

\subsection{ESTRUTURA DO TRABALHO}

Esta tese encontra-se estruturada em seis capítulos. No primeiro capítulo tem-se a introdução da tese, onde são apresentadas a justificativa e a importância do tema, bem como os objetivos da pesquisa e originalidade do tema.

No capítulo 2 é apresentada uma revisão de literatura sobre as principais características dos concretos autoadensáveis no estado fresco, relatando os requisitos para o alcance da autoadensabilidade e os parâmetros físicos que a influenciam. Em seguida, é apresentado o parâmetro WFT que consiste em uma medida de espessura de água envolta dos grãos de um sistema granular cimentício, o qual é defendido pelo meio científico como capaz para governar as propriedades de autoadensabilidade e de reologia de argamassas e de concretos, levando em consideração conceitos de densidade de empacotamento e área superficial total dos grãos. Além disso, é feita uma abordagem sobre os comportamentos mais comuns de autoadensabilidade e de reologia das argamassas e dos concretos autoadensáveis. Por fim, são relatadas as sugestões de proporções de materiais para produção do concreto autoadensável e os materiais mais empregados, bem como os principais métodos de avaliação da autoadensabilidade de argamassas e de concretos.

No capítulo 3 tem-se apresentada a metodologia do programa experimental, destacando-se as variáveis do experimento, os materiais utilizados e os métodos utilizados para a obtenção dos resultados, visando atingir os objetivos propostos.

Prosseguindo, no capítulo 4, são descritos os resultados do programa experimental. Primeiramente, decidiu-se apresentar os resultados da $1^{\text {a }}$ etapa referente o estudo do superplastificante, na qual obteve-se resultados dos ensaios de mini-slump, mini-funil e inspeção visual das argamassas. Em seguida, são apresentados os resultados da $2^{\text {a }}$ etapa referente ao estudo para identificar as prováveis argamassas referências de concretos autoadensáveis, na qual obteve-se resultados dos ensaios de mini-slump, mini-funil e inspeção 
visual das argamassas. Além disso, são apresentados os resultados da $3^{\mathrm{a}}$ etapa referente o estudo de autoadensabilidade dos concretos de acordo com a norma ABNT NBR 15823-1 (2010) e os valores estimados dos parâmetros reológicos dos concretos. Por último, são apresentados resultados de reologia e de WFT das argamassas referências, assim como os resultados de resistência à compressão e módulo de elasticidade dos concretos.

No capítulo 5, são discutidos os resultados de autoadensabilidade das argamassas e dos concretos, bem como é feita uma associação dos seus comportamentos. Em seguida, são avaliados os resultados de reologia das argamassas e dos concretos relacionando-os, sempre que possível, com resultados de outros pesquisadores. Além disso, é apresentada a discussão dos resultados de WFT das argamassas referências e a relação desses resultados com valores de autoadensabilidade e de reologia das argamassas e dos concretos autoadensáveis. Por fim, são discutidos os resultados de resistência à compressão e módulo de elasticidade dos concretos de maneira bem sucinta.

No capítulo 6, são apresentadas as conclusões e sugestões para futuras pesquisas extraídas do trabalho realizado. 


\section{Capítulo II - AUTOADENSABILIDADE E REOLOGIA DE MATERIAS CIMENTÍCIOS}

\subsection{ASPECTOS GERAIS DO CONCRETO AUTOADENSÁVEL}

A autoadensabilidade do concreto no estado fresco é descrita como a habilidade do material preencher espaços e envolver as barras de aço e outros obstáculos por meio exclusivamente da ação da força de gravidade, de forma que sua composição se mantenha homogênea e estável no estado fresco (BOSILJKOV, 2003). De acordo com ABNT NBR 15823-1 (2010), o concreto autoadensável é capaz de fluir, autoadensar, preencher a forma e passar por embutidos, enquanto mantém sua homogeneidade nas etapas de mistura, transporte, lançamento e acabamento.

Dessa forma, o concreto autoadensável propicia vantagens como, por exemplo, redução da mão de obra e de equipamentos necessários para o lançamento do concreto, redução de ruído devida a eliminação do vibrador mecânico, redução do prazo de execução devida à alta produtividade, redução dos acidentes de trabalho resultante da diminuição de recurso humano para a etapa de lançamento do concreto, mais recomendado para estruturas densamente armadas e, também, por conferir um acabamento superficial adequado às peças pré-moldadas (OUCHI, 1999; EFNARC, 2005; BOSILJKOV, 2003; TUTIKIAN, 2004; NÚÑEZ, 2009).

Entretanto o emprego do CAA exige um maior controle e estudo de sua composição para que cumpra com as vantagens supracitadas. Este concreto é mais susceptível a sofrer alterações em suas propriedades no estado fresco quando se aumenta o teor de finos e aditivos (WALRAVEN, 2005; IAM et al., 2016). Kim et al.(2012) frisam que o aumento de finos no CAA contribuem para uma maior manutenção da autoadensabilidade, no entanto pode ser um efeito negativo no sentido de aumentar a pressão sobre as fôrmas a ponto de comprometer a segurança e economia da obra. Nehdi e Rahman (2004) afirmam que o custo do CAA pode ser de $20 \%$ a $60 \%$ superior ao concreto convencional (CCV) com características similares no estado endurecido. 


\subsection{PROPRIEDADES DO CONCRETO AUTOADENSÁVEL NO ESTADO FRESCO}

\subsubsection{Requisitos para o alcance da autoadensabilidade}

De acordo com a EFNARC (2005), o concreto é classificado como autoadensável se cumprir com os seguintes requisitos (propriedades) no estado fresco: habilidade de preenchimento; habilidade passante; resistência à segregação.

A habilidade de preenchimento consiste na capacidade do concreto autoadensável de fluir dentro da fôrma e preencher todos os espaços passando por entre as armaduras sem obstrução do fluxo ou segregação (DOMONE, 2009; LIU, 2009; GOMES; BARROS, 2009).

A habilidade de passante consiste na capacidade do CAA de passar por entre as armaduras e seções estreitas sem que haja obstrução do fluxo. Os mecanismos que governam essa propriedade são: viscosidade da pasta e da argamassa e as características dos agregados. Havendo presença de segregação essa propriedade dificilmente será atendida (GOMES; BARROS, 2010).

A resistência à segregação é a propriedade que caracteriza a capacidade do CAA de se manter homogêneo durante as etapas de mistura, transporte e lançamento, sem que ocorra segregação por afundamento dos agregados ou ascensão da água de mistura (exsudação) no concreto colocado nas fôrmas (REPETTE, 2011).

Outras propriedades têm sido tomadas como importantes no estado fresco do CAA, tais como: robustez e retenção da trabalhabilidade. Robustez se refere à capacidade do CAA manter suas propriedades no estado fresco em função da qualidade e quantidade dos materiais constituintes e, também, das condições climáticas. Retenção de trabalhabilidade refere-se ao período de duração das propriedades frescas (LIU, 2009; FEYS, SCHUTTER; 2016).

Kasemchaisiri e Tangermsirikul (2008) afirmam que a manutenção da autoadensabilidade do CAA deve durar entre 60 a 90 minutos, sendo esse tempo necessário para o transporte e lançamento do concreto. A perda da autoadensabilidade ou trabalhabilidade pode ser devida à interação do aglomerante com aditivo superplastificante, por isso se faz necessário avaliar a compatibilidade desses materiais (KHAYAT, 1999). Concretos com altos teores de $\mathrm{C}_{3} \mathrm{~A}$ (maior que $9 \%$ ) tendem a perder a trabalhabilidade mais rapidamente. Com relação à temperatura, 
quanto mais alta ela for, mais rápida será a perda de trabalhabilidade. $\mathrm{O}$ aumento da temperatura pode promover o deslocamento da água livre na mistura para hidratação das partículas de cimento, assim contribuindo para reduzir a fluidez da mistura cimentícia (MALHOTRA, 1981; RONCERO, GETTU, 1998; KLEIN, 2008; GOLASZEWSKI et al., 2016).

\subsubsection{Parâmetros físicos que influenciam a trabalhabilidade}

Normalmente, a trabalhabilidade do concreto é ajustada por meio da variação de parâmetros como teor de água, teor de cimento, proporção de agregados, teor de finos no total de agregados, adição mineral, adição de superplasticante e assim por diante.

Diferentes combinações desses parâmetros poderiam resultar em diferentes níveis de trabalhabilidade do concreto por meio de tentativas e erros a ponto de chegar no nível de trabalhabilidade desejado. No entanto, essa forma empírica de alcançar a trabalhabilidade, torna-se inviável quando se trata de um concreto mais complexo como, por exemplo, os concretos de alto desempenho e autoadensável. Estes concretos possuem uma maior quantidade de materiais envolvidos, tais como, as adições minerais e os aditivos químicos que levam a aumentar as combinações entre os parâmetros supracitados. Esses parâmetros influenciam a trabalhabilidade do concreto de forma ainda não tão clara (FUNG, 2010).

Diante disso, um grupo de pesquisadores chineses tem defendido investigar os mecanismos básicos que regem a trabalhabilidade do concreto, a fim de desvendar o significado físico subjacente de cada parâmetro. Esse grupo defende que a densidade de empacotamento e a área superficial dos sólidos do sistema de partículas são as duas características físicas de maior relevância no controle da trabalhabilidade ou da autoadensabilidade de diferentes materiais cimentícios (KWAN, WONG, 2008; KWAN, FUNG, 2009; FUNG, 2010; KWAN, LI, 2012; KWAN, MCKINLEY, 2014).

A densidade de empacotamento do sistema de partículas sólidas é a razão do volume absoluto pelo volume aparente das partículas. Em outras palavras, é o volume total de partículas sólidas que pode ser preenchida em um volume unitário. Defende-se que a densidade de empacotamento dos sólidos constituintes do concreto pode impor um efeito significativo no desempenho do concreto e, por isso, deve ser considerado na dosagem do concreto. O papel da densidade de empacotamento no desempenho do concreto pode ser exemplificado em dois 
níveis. O nível macroscópico, que no concreto seria a composição de agregados e a pasta de cimento. Os agregados possuem dimensões que podem variar $75 \mu \mathrm{m}$ e alcançar valores maiores que $10 \mathrm{~mm}, 20 \mathrm{~mm}$ ou 40mm. As partículas de dimensão média preenchem os vazios entre as partículas de maior dimensão, enquanto as partículas menores preenchem os vazios das partículas médias. O preenchimento sucessivo dos vazios por partículas de menor tamanho pode reduzir o volume de vazios e aumentar a densidade de empacotamento dos agregados. Com relação à pasta de cimento, pode-se afirmar que a pasta preenche primeiramente os vazios entre os agregados e o seu excesso lubrifica todo o concreto, contribuindo para aumentar a densidade de empacotamento da mistura, além de melhorar a trabalhabilidade que, por sua vez, conduz para um melhor adensamento da peça concretada. Esta teoria sobre pasta excedente foi desenvolvida por Powers (1968). Nesse sentido, recentes trabalhos sobre tecnologia do concreto enfatizam a importância da distribuição granulométrica dos agregados, a ponto de influenciar na densidade de empacotamento dos agregados (CASTRO, PANDOLFELLI, 2009; OLIVEIRA, 2013).

No nível microscópico, tem-se a pasta de cimento que pode ser considerada como uma composição de grãos de aglomerantes (cimento Portland, escória de alto forno, cinza volante etc) e água. Nesse caso, as dimensões das partículas variam entre $1 \mu \mathrm{m}$ a $75 \mu \mathrm{m}$ e o mecanismo de preenchimento dos vazios é semelhante ao preenchimento sucessivo no nível macroscópico. Inicialmente a água preenche os vazios do volume total de material aglomerante e a água excedente lubrifica a pasta de cimento. Com uma determinada quantidade de água pode-se chegar a uma elevada densidade de empacotamento que, por sua vez, pode refletir na melhora da trabalhabilidade e até mesmo na resistência mecânica e durabilidade do concreto. Isso pode ser considerado como uma extensão da teoria da pasta excedente em nível microscópico (KWAN, WONG, 2008; KWAN, FUNG, 2009; FUNG, 2010; KWAN, LI, 2012).

O estudo da influência da densidade de empacotamento de partículas sólidas sobre a trabalhabilidade do material cimentício ainda carece de entendimento (KWAN, FUNG, 2009; ISAIA 2011). A principal razão para isso se deve às dificuldades encontradas na determinação da densidade de empacotamento de materiais aglomerantes (KWAN, WONG, 2008).

A área superficial total do sistema de partículas sólidas também é um parâmetro físico que influencia de forma significativa a trabalhabilidade do concreto (GALLIAS et al.,2000). A 
explicação para isso vem sendo defendida pela influência do teor de finos na mistura cimentícia, o qual pode ser o grande responsável de controlar a demanda de água envolta das superfícies dos agregados a ponto de manter a trabalhabilidade a um nível considerável (MINDESS et al., 2003). Não é possível estudar o efeito da área especifica dos sólidos sem considerar o efeito simultâneo da densidade de empacotamento ou vice-versa (KWAN, FUNG, 2009; FUNG, 2010).

O efeito combinado da densidade de empacotamento e da área específica dos sólidos pode ser expresso em termos da espessura do filme de água que reveste as partículas sólidas. Esta película de água é conhecida como WFT (water film thickness), que promove a dispersão das partículas sólidas dos materiais componentes do concreto e a redução de atrito entre elas, conforme está apresentado na Figura 1. Esse parâmetro é defendido como sendo capaz de governar as propriedades no estado fresco de diferentes materiais cimentícios (KWAN, WONG, 2008; KWAN, FUNG, 2009; FUNG, 2010; KWAN, LI, 2012; KWAN, MCKINLEY, 2014)

Figura 1 - Significado físico da espessura de água.

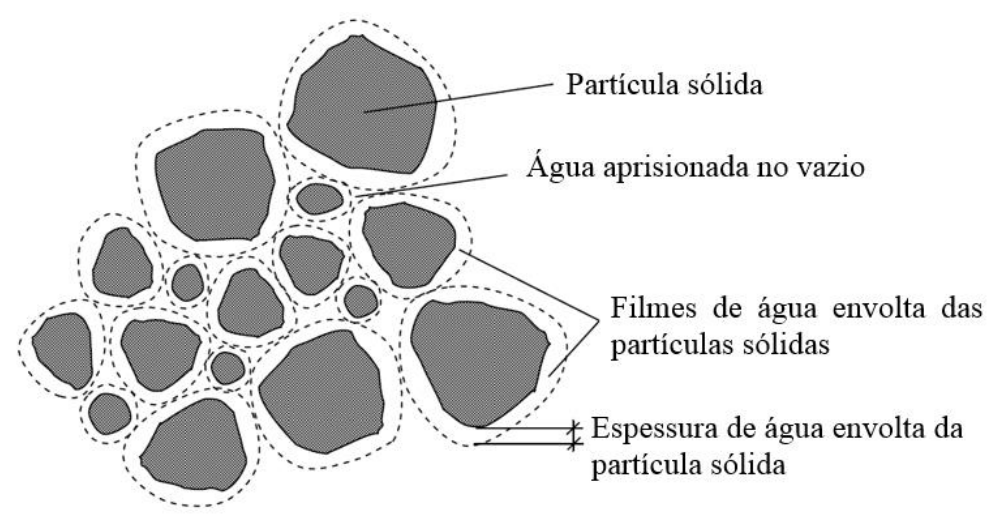

FONTE: Fung (2010).

\subsection{PARÂMETRO WFT (WATER FILM THICKNESS)}

Diante da capacidade do parâmetro WFT governar as propriedades no estado fresco de materiais cimentícios, pesquisadores têm relacionado-o com parâmetros de trabalhabilidade e de reologia de pastas, argamassas e concretos (KWAN et al., 2010; KWAN, WONG, 2008; FUNG, 2010; KWAN, MCKINLEY, 2014). No Brasil, Mendes e Bauer (2015) têm aplicado para argamassas autoadensáveis. 
A seguir, está descrito o memorial de cálculo para determinação do parâmetro WFT. Para tanto, inicialmente é necessário a determinação da densidade de empacotamento, área total superficial dos sólidos e água excedente da mistura cimentícia. Além disso, constam neste item exemplos de resultados com esse parâmetro.

\subsubsection{Medida da densidade de empacotamento}

De modo geral, os métodos existentes para medir a densidade de empacotamento de partículas sólidas podem ser classificados como: (1) o método de empacotamento seco e, (2) o método de empacotamento úmido. O método de empacotamento seco é geralmente utilizado para medir a densidade de empacotamento de agregado. $\mathrm{O}$ empacotamento úmido tem sido aplicado para medir a densidade de empacotamento da pasta de cimento (WONG, 2007).

Quando o método de empacotamento seco é empregado em partículas muito finas (cimento e finos), identificou-se que a densidade de empacotamento medido é bastante sensível para a compactação aplicada (SVAROVSKY, 1987). Além disso, a presença de forças eletrostáticas sob condições seca, não é muito adequado para nenhum sistema de partículas muito finas. Quanto ao emprego do método de empacotamento úmido, a massa real e a densidade são diretamente medidas, no entanto, o teor de ar na mistura pode ser significativo e nem sempre é identificado (FUNG, 2010).

Para determinação do parâmetro WFT, foi criado um novo método de empacotamento úmido para medir a densidade de empacotamento de materiais cimentícios (WONG, 2007; WONG, KWAN, 2008; FUNG, 2010). Este novo método de medida de densidade possui a vantagem de ser medido em condição úmida, que engloba os efeitos da água e das adições incorporadas na matriz cimentícia, bem como a presença de ar na mistura. Ademais, esse método não é dependente da avaliação da consistência.

Esse método de empacotamento úmido, de acordo com Wong e Kwan (2008), consiste primeiramente em determinar a massa unitária úmida. Sendo assim, determina-se a massa (M) e o volume (V) da argamassa no molde (o molde usado é cilíndrico e possui $62 \mathrm{~mm}$ de diâmetro e $60 \mathrm{~mm}$ de altura, mas outros moldes de mesma proporção podem ser utilizados). A massa unitária úmida é igual a M/V. A concentração de sólidos (densidade de empacotamento) é determinada por meio da Equação 1, a seguir: 


$$
\phi=\frac{M / V}{\rho_{w} u_{w}+\rho_{c} R_{c}+\rho_{f} R_{f}}
$$

Em que:

$\phi=$ concentração de sólidos (adimensional);

$M=$ massa do material cimentício $(\mathrm{g})$;

$V=$ volume do material cimentício acondicionado no recipiente $\left(\mathrm{cm}^{3}\right)$;

$u_{\mathrm{w}}=$ relação entre o volume de água e volume total de sólidos (adimensional);

$\rho_{w}=$ densidade da água $\left(\mathrm{g} / \mathrm{cm}^{3}\right) ;$

$\rho_{c}=$ densidade do cimento $\left(\mathrm{g} / \mathrm{cm}^{3}\right)$;

$\rho_{f}=$ densidade do agregado $\left(\mathrm{g} / \mathrm{cm}^{3}\right)$;

$R_{c}=$ relação volumétrica das partículas sólidas do cimento pelo volume total de sólidos (adimensional); $R_{f}=$ relação volumétrica dos agregados pelo volume total de sólidos (adimensional);

É importante enfatizar, que a densidade de empacotamento pode ser definida por outros termos. Primeiramente, tem-se a porosidade (denotada por $\varepsilon$ ) do sistema granular que é definida como a relação do volume dos vazios pelo volume total do material granular, enquanto o índice de vazios (denotado por $u$ ) é definido como a relação do volume de vazios pelo volume sólido das partículas, conforme a Equação 2, a seguir:

$$
\varepsilon=\frac{u}{1+u}
$$

Em que:

$\varepsilon=$ porosidade (adimensional);

$u=$ índice de vazios (adimensional).

Os vazios podem ser preenchidos com água ou ar, ou ambos. O teor de água (denotado por $\varepsilon_{\mathrm{W}}$ ) é definido como a relação entre o volume de água e volume total do material granular, conforme a Equação 3. E o termo $u_{\mathrm{w}}$ é definida como a relação entre o volume de água e volume total de sólidos. Enquanto o teor de ar (denotado por $\varepsilon_{\mathrm{a}}$ ) é definido como a relação entre o volume de ar 
e volume total do material granular, conforme a Equação 4 . O termo $u_{a}$ é definida como a relação entre o volume de ar e volume total dos sólidos.

$$
\varepsilon_{w}=\frac{u_{w}}{1+u_{w}+u_{a}}
$$

Em que:

$\varepsilon_{\mathrm{w}}=$ teor de água (adimensional);

$u_{\mathrm{w}}=$ relação entre o volume de água e volume total de sólidos (adimensional);

$u_{a}=$ relação entre o volume de ar e volume total de sólidos (adimensional).

$$
\varepsilon_{a}=\frac{u_{a}}{1+u_{w}+u_{a}}
$$

Em que:

$\varepsilon_{\mathrm{a}}=$ teor de ar (adimensional);

$u_{\mathrm{w}}=$ relação entre o volume de água e volume total de sólidos (adimensional);

$u_{a}=$ relação entre o volume de ar e volume total de sólidos (adimensional).

A concentração de sólidos da matriz pode ser obtida, também, de forma direta como a relação entre o volume de sólidos e volume total do material granular, conforme a Equação 5.

$$
\emptyset=\frac{V_{s}}{V}
$$

Em que:

$\emptyset=$ concentração de sólidos (adimensional);

$V=$ volume total do material granular $\left(\mathrm{cm}^{3}\right)$;

$V_{s}=$ volume total dos sólidos $\left(\mathrm{cm}^{3}\right)$;

Na Equação 6, tem-se a concentração de sólidos em função da porosidade.

$$
\varnothing=1-\varepsilon=\frac{1}{1+u}
$$


Em que:

$\varepsilon=$ porosidade (adimensional);

$u=$ índice de vazios (adimensional).

Por fim, têm-se os parâmetros $u$ e $u_{a}$ apresentados em função de grandezas em volume, conforme as Equações 7 e 8, respectivamente.

$$
u=\frac{\left(V-V_{s}\right)}{V_{s}}
$$

Em que:

$u=$ índice de vazios (adimensional);

$V=$ volume total do material granular $\left(\mathrm{cm}^{3}\right)$;

$V_{s}=$ volume total dos sólidos $\left(\mathrm{cm}^{3}\right)$;

$$
u_{a}=\frac{\left(V-V_{s}-V_{w}\right)}{V_{s}}
$$

Em que:

$u_{a}=$ relação entre o volume de ar e volume total de sólidos (adimensional).

$V=$ volume total do material granular $\left(\mathrm{cm}^{3}\right)$;

$V_{s}=$ volume total dos sólidos $\left(\mathrm{cm}^{3}\right)$;

$V_{w}=$ volume total de água $\left(\mathrm{cm}^{3}\right)$;

\subsubsection{Determinação do parâmetro WFT}

De posse do parâmetro concentração de sólidos $(\varnothing)$, que é simplesmente a densidade de empacotamento úmido representado pelo parâmetro $\tau$, a seguir (Equação 9), é possível determinar o parâmetro WFT conforme orientações dos trabalhos de Wong (2007), Wong e Kwan (2008), Fung (2010), Kwan et al. (2010), Kwan e Mckinley (2014).

Primeiramente, deve-se determinar o índice de vazios mínimo (definido como a relação entre o volume mínimo de vazios e volume de partículas sólidas, que nada mais é do que o índice de vazios), conforme está apresentada na Equação 9. 


$$
u_{\min }=\frac{1-\tau}{\tau}
$$

Em que:

$u_{\min }=$ índice de vazios mínimo (adimensional);

$\boldsymbol{\tau}=$ densidade de empacotamento úmido, que equivale à concentração de sólidos (adimensional).

Em seguida, obtém-se o volume excedente de água conforme apresentado pela Equação 10.

$$
u_{w}^{\prime}=u_{w}-u_{\min }
$$

Em que:

$u_{\min }=$ índice de vazios mínimo (adimensional);

$u_{\mathrm{w}}^{\prime}=$ relação entre o volume de água excedente e volume total de sólidos (adimensional);

$u_{\mathrm{w}}=$ relação entre o volume de água e volume total de sólidos (adimensional);

Para determinação da área superficial total dos sólidos da mistura, representada pelo parâmetro A, antes é preciso conhecer as áreas específicas das diferentes partículas sólidas no sistema granular de uma matriz cimentícia, bem como o volume ocupado de cada tipo de partícula sólida. Define-se a área superficial total dos sólidos como a relação entre a área específica dos sólidos e o volume desses sólidos. A razão volumétrica de um tipo de partícula sólido, consiste na relação entre o volume desse sólido e o volume total de todos os tipos de sólidos de um sistema granular. Para essas partículas sólidas são atribuídos índices de referência, tais como, $\alpha, \beta, \gamma$ e assim por diante. Portanto o valor de A é determinado pela Equação 11.

$$
A=A_{\alpha} x R_{\alpha}+A_{\beta} x R_{\beta}+A_{\gamma} x R_{\gamma}
$$


Em que:

$A$ = área superficial total dos sólidos da mistura $\left(\mathrm{m}^{2} / \mathrm{m}^{3}\right)$;

$A_{\alpha}, A_{\beta}$ e $A_{\gamma}=$ são as áreas superficiais dos sólidos $\alpha, \beta$ e $\gamma\left(\mathrm{m}^{2} / \mathrm{m}^{3}\right)$;

$R_{\alpha}, R_{\beta}, R_{\gamma}=$ são as razões volumétricas dos sólidos $\alpha, \beta$ e $\gamma$ (adimensional).

Por fim, obtém-se a relação entre a água excedente de um sistema granular e a área superficial total dos sólidos, que resulta na determinação do parâmetro $u_{w}^{\prime \prime}$, conhecido também como parâmetro WFT, conforme está apresentado por meio da Equação 12.

$$
u_{w}^{\prime \prime}=W F T=\frac{u_{w}^{\prime}}{A}
$$

$u_{w}{ }^{\prime}=$ espessura de água envolta dos grãos, conhecido como parâmetro WFT $(\mu \mathrm{m})$;

$u_{\mathrm{w}}=$ relação entre o volume de água excedente e volume total de sólidos (adimensional);

$A$ = área superficial total dos sólidos da mistura $\left(\mathrm{m}^{2} / \mathrm{m}^{3}\right)$;

\subsubsection{Resultados da aplicação do método WFT}

De acordo com trabalho de Fung (2010), estão apresentadas as relações entre o parâmetro WFT e parâmetros de trabalhabilidade e de reologia. Quanto ao estudo do WFT com os parâmetros de trabalhabilidade, observa-se, na Figura 2, as regressões de WFT com espalhamento e fluidez da argamassa, respectivamente. Nota-se que o coeficiente de determinação da regressão de WFT com o espalhamento da argamassa foi de $\mathrm{R}^{2}$ igual a 0,89 e o coeficiente de determinação da WFT com a fluidez da argamassa foi de $\mathrm{R}^{2}$ igual a 0,93 , ambos os coeficientes comprovam uma importante relação entre os parâmetros envolvidos. 

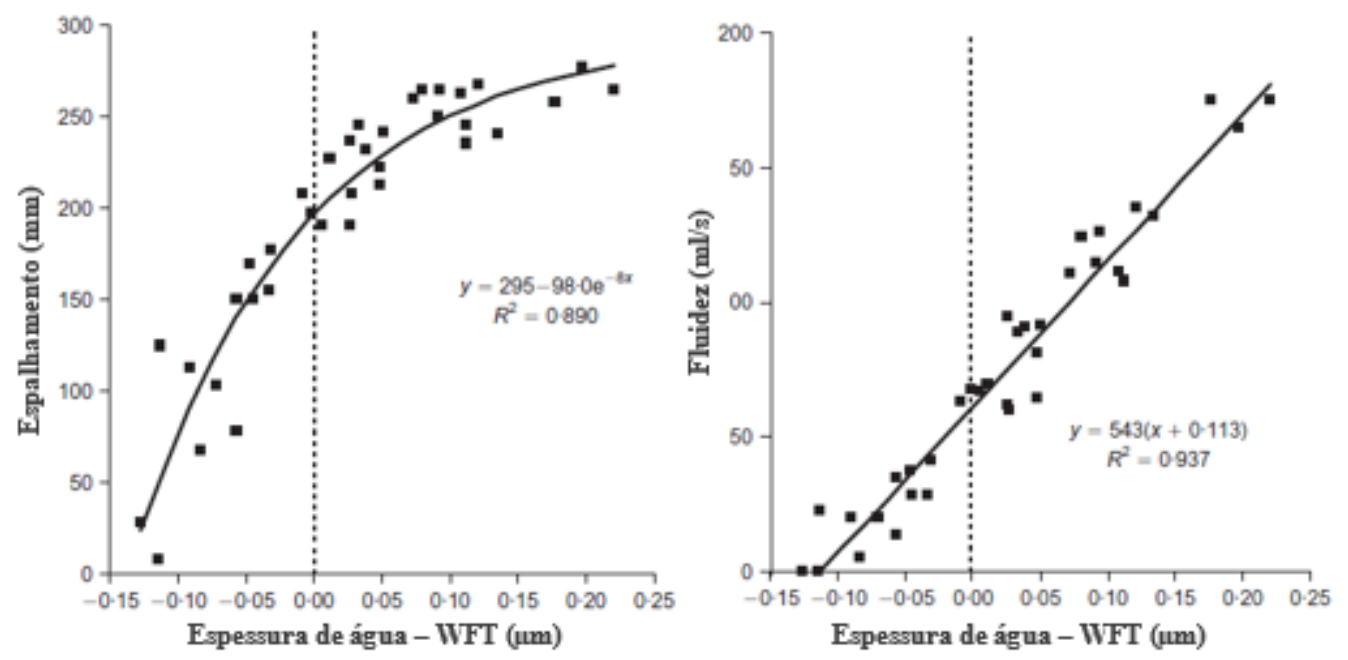

FONTE: Fung (2010).

Em relação à comparação do parâmetro WFT com os parâmetros reológicos, nota-se, também, que foram obtidas boas correlações tanto para tensão de escoamento quanto para viscosidade aparente, sendo que para o primeiro o coeficiente de determinação foi de 0,893 e para o segundo o coeficiente de determinação foi de 0,821 , conforme consta na Figura 3. Isso significa, segundo Kwan et al. (2010), que o WFT é um parâmetro importante e exclusivo, capaz de governar a trabalhabilidade e as propriedades reológicas da argamassa. 
Figura 3 - Correlação entre resultados de WFT e de reologia das argamassas (FUNG, 2010).
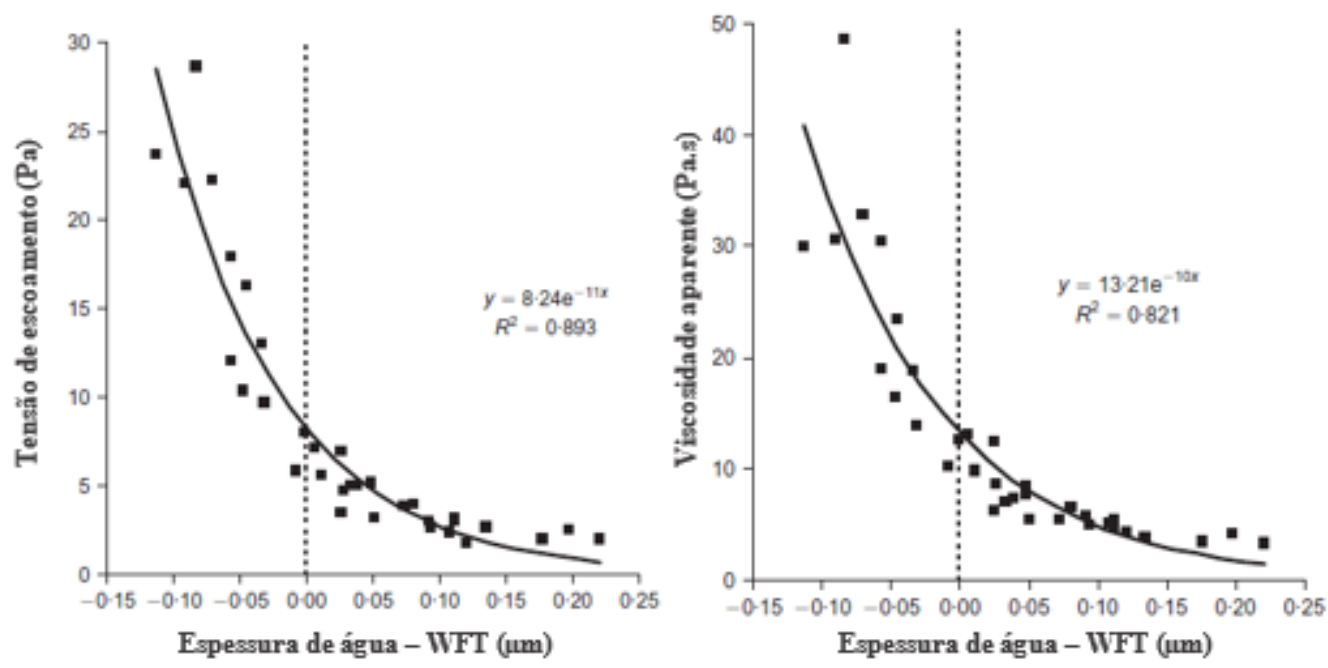

FONTE: Fung (2010).

Verifica-se, por fim, que os valores de WFT ficaram entre $-0,15 \mu \mathrm{m}$ e $0,25 \mu \mathrm{m}$. Para as argamassas que tiveram valores negativos de WFT, significa que elas não possuem água suficiente para propiciar bons resultados nas propriedades relacionadas no estado fresco, portanto o parâmetro é um indicativo. Por outro lado, no caso das argamassas que tiveram valores positivos de WFT, o valor positivo tem significado físico e consiste na medida da espessura de água envolta dos grãos do sistema granular da mistura (KWAN et al., 2010; KWAN, WONG, 2008; FUNG, 2010; KWAN; MCKINLEY, 2014).

\subsection{REOLOGIA}

Os concretos e as argamassas são compostos por agregados, cimento e água, principalmente. $\mathrm{O}$ concreto é uma suspensão concentrada de partículas sólidas (agregados) em um líquido viscoso (pasta de cimento). A pasta de cimento não é um líquido homogêneo, sendo composta de partículas (grãos de cimento) em um líquido (água). A nível macroscópico, o concreto fresco flui como um líquido (FERRARIS, 1999).

\subsubsection{Modelos reológicos para materiais cimentícios}

O comportamento reológico dos fluidos divide-se em Newtonianos e não-Newtonianos. Esta divisão ocorre pela diferença do comportamento dos fluidos diante da tensão cisalhante e a taxa de cisalhamento podendo ser relacionados com a dependência ou independência do tempo de 
aplicação da tensão sobre eles (BANFILL, 1994; FERRARIS, 1999; PANDOLFELLI et al., 2000; COUTO, 2016). Nos fluidos newtonianos, o comportamento possui uma relação linear entre a aplicação da tensão de cisalhamento $\tau$ e taxa de cisalhamento $\dot{\gamma}$ como mostra a Equação 13, conhecida como equação de Newton. Nesse caso, o fluido não necessita de uma tensão de escoamento maior que zero para iniciar seu fluxo, por isso que a curva que representa esse comportamento passa pela origem do gráfico.

$$
\tau=\eta \dot{\gamma}
$$

O concreto no estado fresco, necessita-se de uma tensão maior que zero para fluir, portanto o seu comportamento reológico não é representado pelo modelo newtoniano (FERRARIS, 1999). $\mathrm{Na}$ Tabela 1, estão descritas equações para o comportamento reológico de materiais com partículas em suspensão, como os concretos e as argamassas (FERRARIS, 1999).

Tabela 1 - Equações de modelos reólogicos.

\begin{tabular}{l|c}
\hline \multicolumn{1}{c}{ Modelo } & Equação \\
\hline Bingham & $\tau=\tau_{0}+\kappa \dot{\gamma}$ \\
\hline Herschel-Bulkley & $\tau=\tau_{0}+\kappa \dot{\gamma}^{\eta}$ \\
\hline Lei das Potencias & $\tau=A \dot{\gamma}^{\eta}$ \\
\hline Vom Berg & $\tau=\tau_{0}+\operatorname{Bsin}^{-1}(\dot{\gamma} / C)$ \\
Oswald-de-Waele & $\left.\tau=a \dot{\gamma}+B \sin ^{-1}(\dot{\gamma} / C)\right)$ \\
\hline Eyring & $\tau=a(\dot{\gamma}+C)^{b}$ \\
\hline Robertson-Stiff & $\dot{\gamma}=\alpha \tau^{2}+\beta \tau+\delta$ \\
\hline Atzeni et al. & \\
\hline Definição das variáveis: & \\
$\tau=$ tensão de cisalhamento & \\
$\tau_{0}=$ tensão de escoamento & \\
A, a, B, b, C,K, $\alpha, \beta, \delta=$ constantes & \\
$\dot{\gamma}=$ taxa de cisalhamento & \\
$\eta=$ viscosidade & \\
\hline
\end{tabular}

Fonte: Ferraris (1999)

Dentre as equações apresentadas na Tabela 1, cabe destacar as equações de Bingham e de Hershel-Bulkley que descrevem comportamento de fluidos não-Newtoniano independentes do tempo, as quais são consideradas por vários pesquisadores as mais adequadas para descreverem o comportamento reológico dos materiais cimentícios (WALLEVIK, 2006). Fluidos independentes do tempo são caracterizados pela necessidade da aplicação de uma tensão mínima (tensão de escoamento) para promover seu escoamento, bem como a taxa de 
cisalhamento em qualquer ponto do fluido é função somente da tensão de cisalhamento PANDOLFELLI et al., 2000).

Estudos afirmam que o melhor modelo que descreve o comportamento do concreto ao longo de sua fase no estado fresco é o de Bingham (TATTERSALL, 1991; FERRARIS, 1999; WALLEVIK, 2006). Quanto às argamassas, Banfill (1994) afirma que o modelo de Binghan é suficiente para descrever o comportamento reológico e identificar os parâmetros de tensão de escoamento e viscosidade plástica.

Mais especificamente, considerando o concreto autoadensável, o modelo que vem sendo usado com maior frequência e considerado o mais adequado para descrevê-lo quanto ao seu comportamento reológico, é o modelo de Herschel - Bulkley (JIN, 2002; WALLEVIK, WALLEVIK, 2011). Uma das razões para uso desse modelo, deve-se principalmente o fato dos valores de tensão de escoamento dificilmente serem negativos, ao contrario, quando se aplica o modelo de Binghan (WALLEVIK; WALLEVIK, 2011). Por outro lado, Lu et al.(2008) ressaltam que o modelo de Herschel - Bulkley não é capaz de identificar os efeitos dos materiais e de diferentes misturas sobre o comportamento reológico do concreto.

Os fluidos bighamianos são caracterizados por uma relação linear entre a tensão e a deformação a partir de um determinado valor de tensão de cedência. Isto é, são materiais que resistem sem fluir a tensões de cisalhamento inferiores à tensão de escoamento, mas acima desta apresentam um comportamento linear entre a tensão de cisalhamento e a taxa de deformação, sendo caracterizados por uma viscosidade plástica $(\mu)$ (PAIVA, 2005).

O modelo de Herschel - Bulkley representa um fluido pseudoplástico com tensão de escoamento (PANDOLFELLI et al., 2000). Os fluidos pseudoplásticos, descritos por meio da equação da Lei das Potências, apresentada na Tabela 1, são fluidos que apresentam um comportamento linear com a aplicação da força. Quando o expoente dessa equação é $\mathrm{n}<1$, estes fluidos apresentam um comportamento fluidificante sob ação de uma ação cisalhante. Quando $\mathrm{n}>1$, apresentam um comportamento dilatante ou espessante perante uma ação cisalhante. Em ambos os casos, trata-se de um comportamento não linear, onde a viscosidade não é uma constante (BANFILL, 1994). Nesse contexto, nota-se na Tabela 1, que a equação do modelo de Herchel - Bulkley possui o termo da equação da Lei das Potências, mais o termo 
referente a tensão de escoamento. Para ilustrar os comportamentos reológicos (curvas de fluxo) citados, na Figura 4 estão apresentados esses comportamentos, a seguir.

Figura 4 - Comportamento reológico dos fluidos: (1) newtoniano; (2) de Bingham; (3) pseudoplástico; (4) pseudoplástico com tensão de escoamento; (5) dilatante; (6) dilatante com tensão de escoamento.

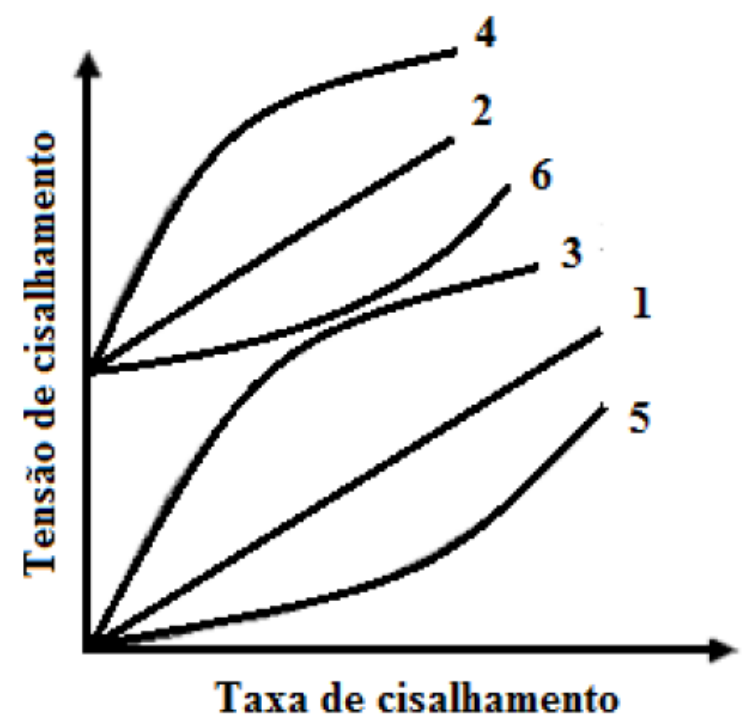

Fonte: Pandolfelli et al. (2000).

Verifica-se, na Figura 4, que as curvas 1 e 2 são comportamentos newtoniano e bighamiano, respectivamente. As curvas 3 e 4 são comportamentos pseudoplástico e pseudoplástico com tensão de escoamento, respectivamente. Por fim, as curvas 5 e 6 são definidas como dilatantes, sendo que a primeira sem tensão de escoamento e a segunda com tensão de escoamento.

\subsubsection{Métodos de caracterização reológica}

Ensaios de espalhamento e de fluidez avaliam os materiais cimentícios frente as propriedades no estado fresco como, por exemplo, a trabalhabilidade. Dessa forma, também têm sido usados para entender o comportamento reológico de pastas, argamassas e concretos por meio de um parâmetro ou constante determinada pelo ensaio. Segundo Tattersall e Banfill (1993), os ensaios onde somente uma constante é determinada não são capazes de classificar a trabalhabilidade do concreto, visto que podem classificar dois concretos como iguais sendo estes possuem comportamentos distintos, retratando um exemplo de avaliação subjetiva e imprecisa. Diante disso, recomenda-se ensaios que determinem dois parâmetros (dois pontos) que podem ser expressos em termos de grandezas físicas fundamentais, tais como, viscosidade plástica e tensão de escoamento (WALLEVIK, 2006). 
Os reômetros fornecem os dois parâmetros fundamentais para a descrição do comportamento reológico, a viscosidade e a tensão de escoamento (BANFILL, 1994). Nesse sentido, Banfill (1993) demonstrou que caracterizar uma argamassa por meio desses dois parâmetros fundamentais com um reômetro de cilindros coaxiais seria o ideal, pois as equações de fluxo podem ser expressas com precisão. Os reômetros fornecem muito mais informações do que os ensaios convencionais, as informações obtidas são mais objetivas, uma vez que o ensaio é totalmente automatizado e controlado por computador (De LARRARD et al., 1998).

Há uma grande variedade de reômetros rotacionais, sendo os mais comuns os reômetros do tipo cilindros coaxiais, cone e placa e placas paralelas.

O reômetro tipo cilindros coaxiais consiste em um equipamento formado por um cilindro interno (spindle) e outro externo (copo). Entre os cilindros possui um espaço reservado para o fluido que será avaliado quando submetido a um cisalhamento por tempo determinado. O fluido deve possuir partículas sólidas menor que 1/3 da distância entre os dois cilindros.

O reômetro tipo cone e placa consiste em um equipamento que possui uma placa plana horizontal e um cone invertido, cujo vértice encontra-se muito próximo à placa. Esse reômetro é recomendado para materiais com alta viscosidade e sem partículas granulares (SCHRAMM, 2006).

O reômetro tipo placas paralelas consiste em um equipamento composto por duas placas paralelas em forma de disco com uma determinada distância entre elas. Esse reômetro é indicado para materiais não homogêneos com partículas grandes (De LARRARD et al., 1998).

Cabe destacar, que os reômetros são capazes também de determinar a histerese, que significa a energia demandada para o material sofrer uma quebra estrutural sob ação de um cisalhamento (KHAYAT et al., 2002). Para isso, calcula-se a área formada pela curva ascendente e curva descendente resultantes do cisalhamento sobre o material a uma taxa de cisalhamento crescente e descrescente, respectivamente. A histerese permite efetuar uma análise qualitativa do cisalhamento que, por sua vez, possibilita tirar conclusões quanto à estabilidade da estrutura do material (SUHR, 1991). A seguir, na Figura 5, ilustra a histerese entre as curvas de fluxo. 
Figura 5 - Curva de fluxo com histerese de um material cimentício.

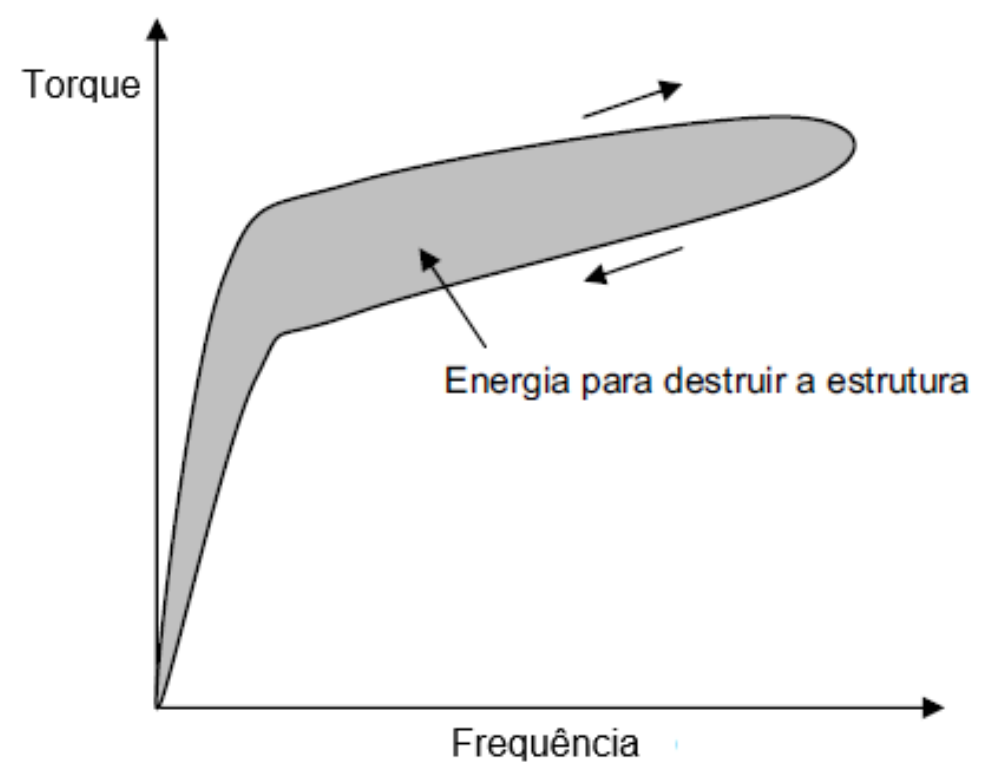

Fonte: Adaptado de Khayat et al. (2002).

Segundo Banfill (1994), tanto as argamassas como as pastas apresentam destruição estrutural irreversível e suas curvas de fluxo descendentes se comportam de acordo com o modelo de Binghan. A destruição estrutural desses materiais pode ser explicada pelo modelo proposto por Tattersal e Banfill (1983). Esse modelo defende que a membrana de minerais hidratados em volta dos grãos de cimento é uma estrutura resistente que se rompe sob ação de um cisalhamento separando as partículas. Essas partículas separadas não se ligam como antes da aplicação da tensão, portanto caracterizando uma destruição irreversível.

\subsubsection{Características reológicas dos concretos autoadensáveis}

O concreto autoadensável é composto por uma gama de materiais e, por isso, considerado um material complexo. Diferentes proporções desses materiais refletem nas características de autoadensabilidade e de reologia no estado fresco do concreto (SIEDLARZ, GOLASZEWSKI, 2016).

Com ênfase na reologia do material cimentício, Lu et al. (2008) constataram que diferentes diâmetros de agregado míudo numa proporção de $10 \%$ a $20 \%$ com relação o volume da argamassa, os valores dos parâmetros reológicos fundamentais (tensão de escoamento e viscosidade plástica) da argamassa não se diferem de forma significativa. No entanto, esses agregados numa proporção entre $30 \%$ e $40 \%$, os valores de tensão de escoamento e de 
viscosidade plástica variam de forma bem nítida e significativa. O aumento de agregados com diâmetros menores tende em aumentar a demanda de água na mistura, devido ao aumento da área especifica e, com isso, contribui para reduzir os valores dos parâmetros reológicos (METHA; MONTEIRO, 2014).

Wallevik (1983) mostra a influencia de diferentes composições na mistura do material cimentício sobre as características reológicas por meio de reografia, conforme está apresentado na Figura 6. A reografia é definida como uma impressão das variações dos parâmetros reológicos em função das propriedades dos materiais, diferentes materiais, diferentes concretos, etc. A par disso, na Figura 6, estão apresentados somente os efeitos da adição de água (water), ar incorporado (ar), superplastificante (SP) e sílica ativa (SA). É importante frisar, que esses resultados são válidos para argamassa e concreto, exceto para pasta devido a sua tixotropia ser mais intensa (WALLEVIK, WALLEVIK, 2011).

Figura 6 - Reografia dos efeitos de diferentes composições da mistura cimentícia de referência.

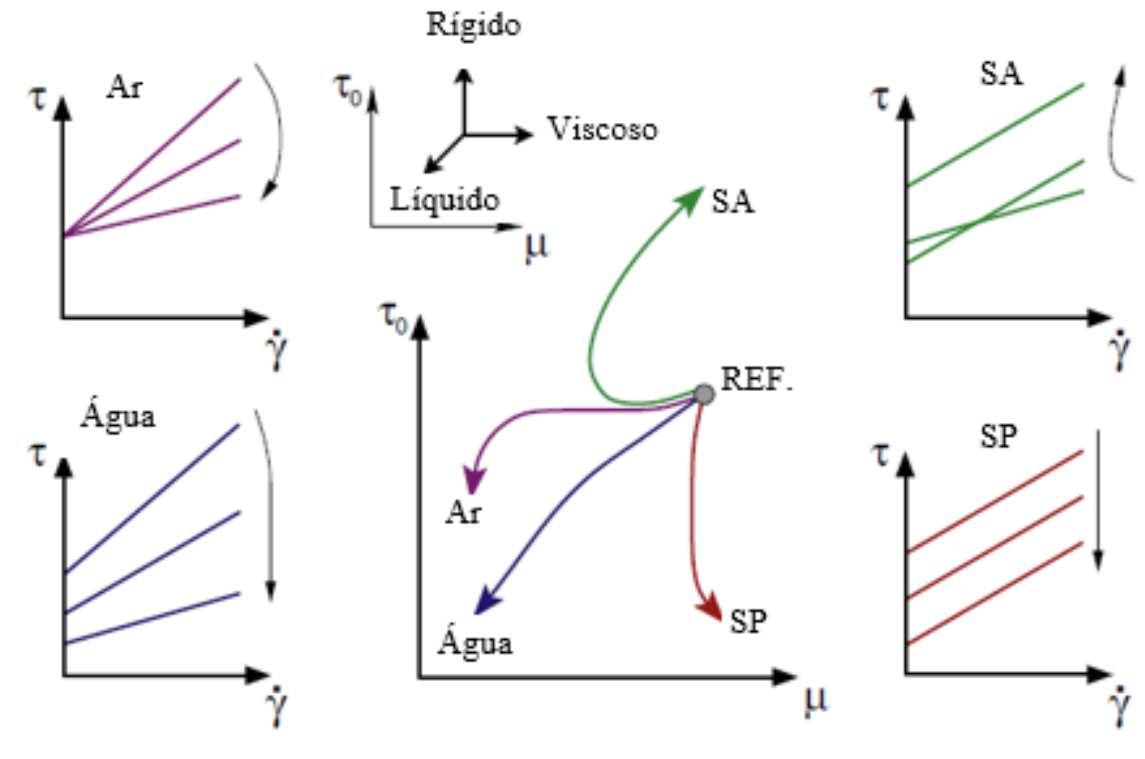

Fonte: Wallevik (1983); Wallevik e Wallevik (2011).

Observa-se, na Figura 6, que o aumento dos teores de ar e de superplastificante tende a reduzir a tensão de escoamento da mistura, ao contrário de quando se aumenta o teor de substituição do cimento por sílica ativa. Quanto à viscosidade plástica, nota-se que o aumento dos teores de ar e de água propicia a redução na viscosidade plástica, enquanto que o aumento de superplastificante não altera este parâmetro. Em particular, o efeito da sílica ativa atua de forma 
peculiar sobre a viscosidade plástica quando comparado com os outros efeitos. O aumento da adição de sílica ativa tende a diminuir a viscosidade plástica até certo limite, a partir daí há uma convergência tendendo a elevar a viscosidade plástica.

$\mathrm{Na}$ Figura 7, a seguir, tem-se uma reografia que reforça e demonstra o efeito do superplastificante sobre os parâmetros reológicos da água, da pasta, da argamassa e do concreto, conforme Wallevik e Wallevik (2011).

Figura 7 - Reografia dos efeitos de diferentes composições da mistura cimentícia de referência.

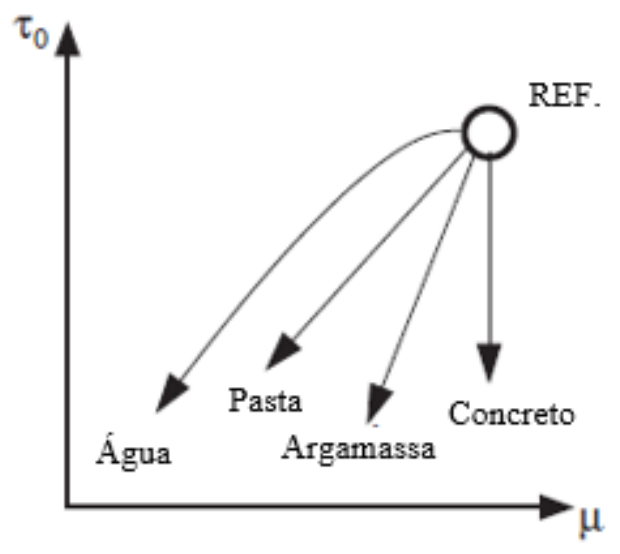

Fonte: Wallevik (1983); Wallevik e Wallevik (2011).

Verifica-se, na Figura 7, que o aumento do superplastificante reduz a tensão de escoamento e viscosidade plástica da água, da pasta e da argamassa, exceto o concreto que há somente redução na tensão de escoamento, conforme já foi visto na Figura 6.

A proposta de reografia para CAA foi primeiramente apresentada na conferência em Kochi, Japão, em 1998, na Figura 8, está apresentada a primeira proposta de reografia para concreto autoadensável (CAA) pelo Wallevik (2002). Nota-se, na Figura 8, que a pequena área em vermelho consta os valores dos parâmetros reológicos mais recomendados para CAA, enquanto que a área envolta da área vermelha consta os valores dos parâmetros reológicos normalmente encontrados para o CAA. Além disso, nessa proposta de reografia relaciona os parâmetros de reologia com os resultados de espalhamento do concreto. 
Figura 8 - Proposta de reografia para CAA.

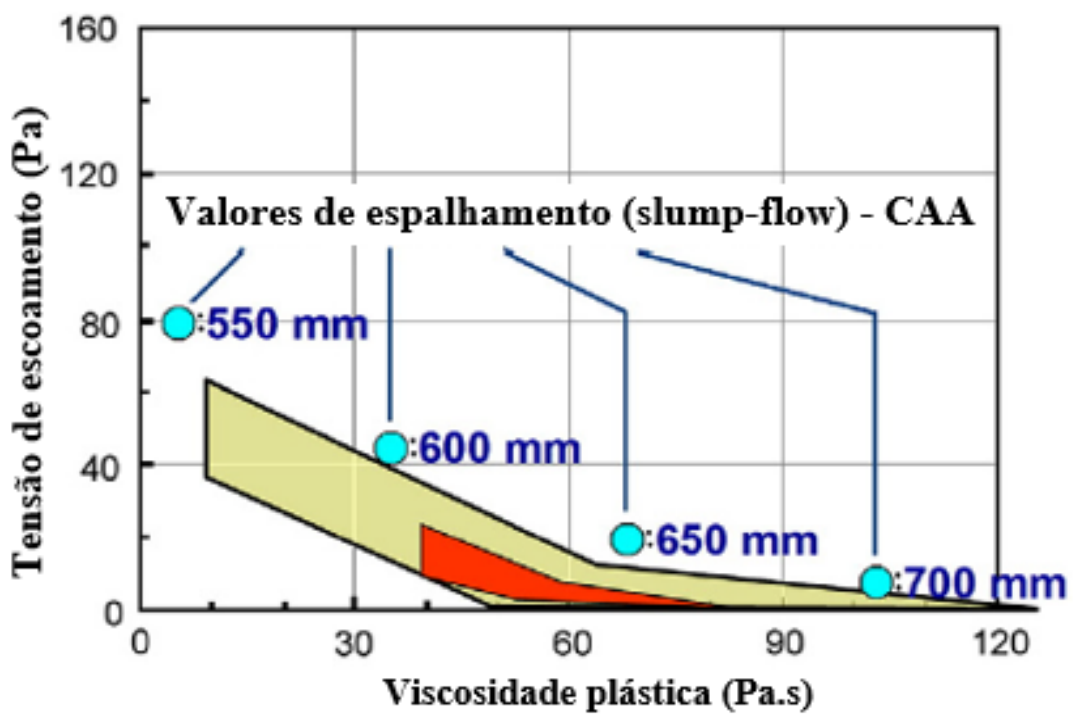

Fonte: Wallevik (2002)

Wallevik e Wallevik (2011) apresentaram uma nova proposta de reografia para CAA com base na reografia apresentada na Figura 8. Na nova proposta, eles classificaram os concretos autoadensáveis levando em consideração a magnitude dos valores das propriedades reológicas. Dessa forma, na Figura 9, nota-se que a reografia está dividida em diferentes áreas e cores, sendo que, a área especificada como "HY-SCC", se refere o CAA com alto valor de tensão de escoamento, a área nomeada como "LV-HY-SCC" se refere o CAA com baixa viscosidade plástica e alta tensão de escoamento e, a área definida como "LV-SCC", se refere o CAA com baixa viscosidade plástica. Os concretos autoadensáveis com parâmetros reológicos mais recomendados e mais usuais estão apresentados na reografia pelas áreas de cor verde e de cor azul claro (SCC), respectivamente.

Além dessas áreas que representam os valores dos parâmetros reológicos dos concretos autoadensáveis, nota-se uma área em azul escuro (Easy-CC) que representa os concretos de fácil adensamento, ou seja, equivalente ao concreto bombeável. 
Figura 9 - Nova proposta de reografia para CAA.

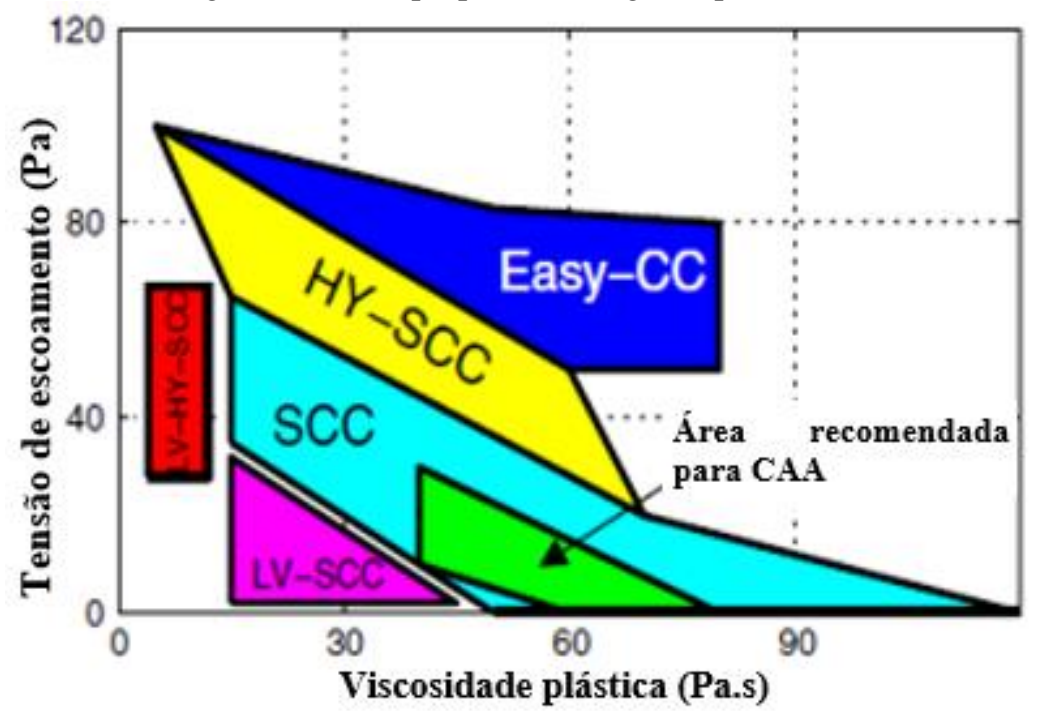

Fonte: Wallevik e Wallevik (2011)

Na Figura 10, está apresentada uma reografia adaptada da reografia apresentada na Figura 9, na qual consta os prováveis valores dos parâmetros reológicos dos concretos autoadensáveis de diferentes países. Verifica-se, que os Estados Unidos possuem concretos autoadensáveis na área recomendada por Wallevik, enquanto que os países Alemanha e Japão possuem concretos autoadensáveis na área classificada como mais usuais. No entanto, não consta os prováveis valores dos parâmetros reológicos dos concretos autoadensáveis no Brasil.

Figura 10 -Reografia referente aos concretos autoadensáveis de diferentes países.

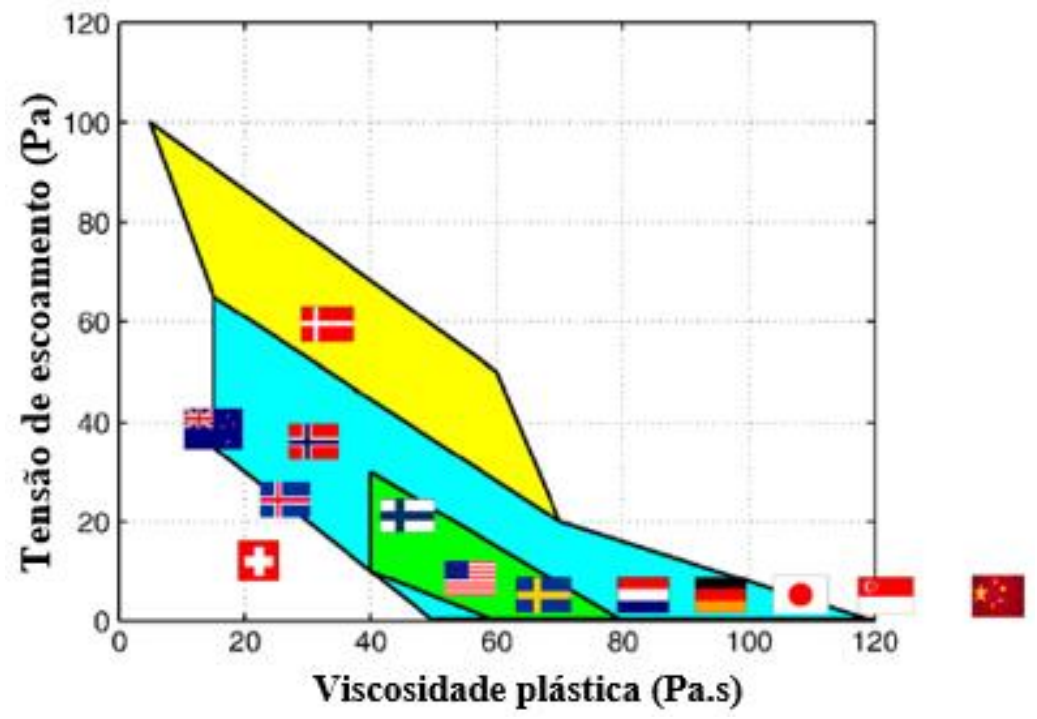

Fonte: Wallevik e Wallevik (2011) 


\subsection{SUGESTÕES DE PROPORÇÕES DE MATERIAIS PARA PRODUÇÃO DO CONCRETO AUTOADENSÁVEL}

É sabido que o concreto autoadensável possui teores de pasta e de argamassa maiores do que o concreto convencional. Esses teores mais elevados propiciam o CAA atender os requisitos de autoadensabilidade, tais como, habilidade passante, habilidade de preenchimento e resistência à segregação. Exemplos de referencias de proporções de materiais e materiais empregados têm sido propostos por pesquisadores e entidades relacionadas com CAA. Domone (2009) constatou-se que $50 \%$ de um total de 68 concretos autoadensáveis foram empregados o aditivo modificador de viscosidade. Além disso, notou-se que o fíler calcário é a adição mais empregada e a dimensão máxima do agregado está entre $16 \mathrm{~mm}$ e $20 \mathrm{~mm}$. BIBM et al. (2005) sugerem as seguintes faixas de composição do CAA: proporção de $27 \%$ a $36 \%$, em volume, de agregado graúdo; consumo de $380 \mathrm{~kg} / \mathrm{m}^{3}$ a $600 \mathrm{~kg} / \mathrm{m}^{3}$ de aglomerante; consumo de $150 \mathrm{~kg} / \mathrm{m}^{3}$ a $210 \mathrm{~kg} / \mathrm{m}^{3}$ de água e proporção de $48 \%$ a $55 \%$ de agregado miúdo em função do peso total de agregado.

Corroborando em parte com as faixas de proporções dos materiais já apresentadas, têm-se as recomendações do ACI 237R - 07 (2007) e, apresentadas na Tabela 2, orienta que os valores sugeridos de proporções dos materias, são recomendações iniciais para um estudo de dosagem de CAA, visto que há diferença nas características físicas e químicas dos materiais provenientes de locais distintos.

Tabela 2 - Proporções de materiais recomendados pelo ACI237R-07 (2007).

\begin{tabular}{l|l}
\hline Volume absoluto de agregado graúdo & $28 \%$ a $32 \%$ (>12 mm de diâmetro máximo) \\
\hline Fração de pasta (calculado sobre o volume) & $34 \%$ a $40 \%$ (referente ao volume total da mistura) \\
\hline Fração de argamassa (calculado sobre o volume) & $68 \%$ a $72 \%$ (referente ao volume total da mistura) \\
\hline Relação água/aglomerante & 0,32 a 0,45 \\
\hline Proporção de aglomerante & $386 \mathrm{~kg} / \mathrm{m}^{3}$ a $475 \mathrm{~kg} / \mathrm{m}^{3}$ \\
\hline
\end{tabular}

Fonte: ACI237R-07 (2007)

Nesse contexto, na Tabela 3, estão apresentados exemplos de traços de CAA sugeridos pelo ACI 237R-07 (2007), os quais demonstraram bons resultados no estado fresco em vários estudos. 
Tabela 3 - Resumo dos melhores traçõs de CAA.

\begin{tabular}{|c|c|c|c|c|c|c|}
\hline Slump flow & $660 \mathrm{~mm}$ & $660 \mathrm{~mm}$ & $660 \mathrm{~mm}$ & $838 \mathrm{~mm}$ & $686 \mathrm{~mm}$ & $660 \mathrm{~mm}$ \\
\hline SP policarboxilato & Sim & Sim & Sim & Sim & Sim & Sim \\
\hline Ar incorporado & Sim & Sim & Sim & Sim & Sim & Sim \\
\hline Redutor de água & Sim & ---- & $\begin{array}{ll}--- \\
\end{array}$ & Sim & $\begin{array}{ll}---- \\
\end{array}$ & $\begin{array}{ll}--- \\
\end{array}$ \\
\hline VMA & $\begin{array}{ll}--- \\
\end{array}$ & $\begin{array}{ll}--- \\
-\end{array}$ & $\begin{array}{ll}--- \\
-\end{array}$ & Sim & Sim & $\begin{array}{ll}--- \\
\end{array}$ \\
\hline $\begin{array}{l}\text { Material aglomerante total } \\
\left(\mathrm{kg} / \mathrm{m}^{3}\right)\end{array}$ & 445 & 403 & 463 & 473 & 415 & 415 \\
\hline Cimento & 356 & 403 & 368 & 205 & 415 & 356 \\
\hline Cinza volante & 89 & ---- & ---- & 83 & ---- & 59 \\
\hline Escória de alto-forno & $\begin{array}{ll}--- \\
\end{array}$ & $\begin{array}{ll}--- \\
\end{array}$ & 90 & 185 & $\begin{array}{ll}--- \\
\end{array}$ & ---- \\
\hline Relação água/aglomerante & 0,37 & 0,42 & 0,39 & 0,34 & 0,41 & 0,40 \\
\hline $\begin{array}{l}\text { Agregado miúdo/agregado } \\
\text { graúdo }\end{array}$ & 49 & 49 & 46 & 61 & 53 & 48,2 \\
\hline Fração de pasta & 37,1 & 36,5 & 38,1 & 36 & 34,7 & 35 \\
\hline Fração de argamassa & 64,6 & 68,3 & 63,4 & 64 & 59,5 & 65,6 \\
\hline Volume de agregado graúdo & 35,6 & 31,7 & 36,6 & 36 & 31 & 33,5 \\
\hline \multicolumn{7}{|l|}{$\begin{array}{l}\text { Distribuição granulométrica } \\
\text { (porcentagem retida) }\end{array}$} \\
\hline $25 \mathrm{~mm}$ & ---- & ---- & ---- & ---- & ---- & ---- \\
\hline $19 \mathrm{~mm}$ & 2,3 & $\begin{array}{ll}--- \\
\end{array}$ & 0,7 & 0,75 & 3 & 9 \\
\hline $12.5 \mathrm{~mm}$ & 9,2 & $\begin{array}{ll}--- \\
\end{array}$ & 11,3 & 5,6 & 15 & 19 \\
\hline $9.5 \mathrm{~mm}$ & 5,1 & $\begin{array}{ll}--- \\
\end{array}$ & 6,5 & 11,8 & 14 & 8 \\
\hline $4.75 \mathrm{~mm}$ & 25,4 & 26,6 & 23,6 & 26,2 & 15 & 14 \\
\hline $2.36 \mathrm{~mm}$ & 14,4 & 23,3 & 16,9 & 12,4 & 16 & 4 \\
\hline $1.18 \mathrm{~mm}$ & 9,5 & 10 & 5,7 & 12,5 & 14 & 12 \\
\hline $600 \mu \mathrm{m}$ & 11,1 & 12,5 & 8,2 & 20,1 & 10 & 13 \\
\hline $300 \mu \mathrm{m}$ & 12,2 & 14,5 & 18,4 & 8,5 & 8 & 14 \\
\hline $150 \mu \mathrm{m}$ & 7 & 11,2 & 7,1 & 1,5 & 3 & 6 \\
\hline Fundo & 3,9 & 2,3 & 1,4 & 0,24 & 1 & 1 \\
\hline
\end{tabular}

Pelo exposto nas Tabelas 2 e 3 sobre as proporções dos materiais referentes aos concretos autoadensáveis, a seguir, algumas observações relevantes:

- a fração de argamassa está em torno de $65 \%$ com relação ao volume total da mistura, isso significa que o CAA é muito argamassado;

- nota-se que a quantidade de aglomerante por metro cúbico de concreto varia de $386 \mathrm{~kg}$ a $475 \mathrm{~kg}$, portanto faixa inferior a sugerida por BIBM et al. (2005);

- verifica-se que todos os traços sugeridos de CAA constam o emprego do aditivo superplastificante, a base de policarboxilato, para reduzir o consumo de água e conferir autoadensabilidade ao concreto;

- observa-se que o aditivo modificador de viscosidade (VMA) não é muito utilizado para conferir estabilidade ao concreto, pois de um total de seis traços somente dois constam o emprego de VMA. 
- nota-se que em nenhum traço recomendado consta o incremento de aditivo redutor de água e retardador (polifuncional), o qual é utilizado pelas concreteiras com a principal finalidade de retardar a pega do concreto;

\subsection{MATERIAIS EMPREGADOS EM CAA}

A seguir, estão apresentados os principais materiais empregados em argamassas e concretos autoadensáveis.

\subsubsection{Aditivos}

De acordo com a ABNT NBR 11768 (2011), aditivos químicos são produtos que adicionados em pequena quantidade nos concretos de cimento Portland, modificam algumas de suas propriedades, no sentido de melhor adequá-los a determinadas condições. A norma européia EN 480 - 1 (1998), define que os aditivos são produtos que, adicionados em pequena quantidade (até 5\%), são capazes de modificar as propriedades tanto no estado fresco como no estado endurecido de concretos, argamassas, pastas e grautes.

\section{a) Superplastificante}

Uma variedade de aditivos superplastificantes foi desenvolvida e está disponível no mercado, podendo ser dividida em quatro grupos de acordo com a sua estrutura química, como os lignosulfonatos modificados (LN), formaldeído melanina sulfonato condensado (SMF), formaldeído naftaleno sulfonato condensado (SNF) e os éteres polycarboxilato (PC), também chamados pente-polímeros pelo fato da possibilidade de conter grupos sulfônicos e carboxílicos (CHANDRA; BJORNSTROM, 2002; DRANSFIELD, 2003; NUNES, 2008).

Os aditivos superplastificantes a base de policarboxilato são os mais utilizados para produção de concretos autoadensáveis e de auto-desempenho. Esses aditivos atuam de forma mais completa nas partículas de cimento por meio do efeito estérico provindo das longas cadeias laterais dos polímeros a base de policarboxilato. A repulsão estérica resulta da adsorção da cadeia do polímero na superfície do cimento e da extensão das cadeias laterais do polímero na superfície do cimento. Essas cadeias laterais aumentam o espaço físico entre as partículas de cimento, resultando em uma redução de água muito superior aos superplastificantes normais (acima de $40 \%$ ). Outra grande vantagem adicional desse tipo de aditivo se deve a sua 
capacidade de manter a trabalhabilidade ou adensabilidade do material cimentício por mais tempo (NUNES, 2008).

A seguir, na Figura 11, estão ilustrados os dois mais importantes mecanismos de dipersão das partículas de cimento, os quais são: repulsão eletrostática e o impedimento estérico (CHANDRA; BJÖRNSTRÖM, 2003; ESEN; ORHAN, 2016).

Figura 11 - Ilustração esquemática da (a) repulsão eletrostática e (b) efeito estérico.

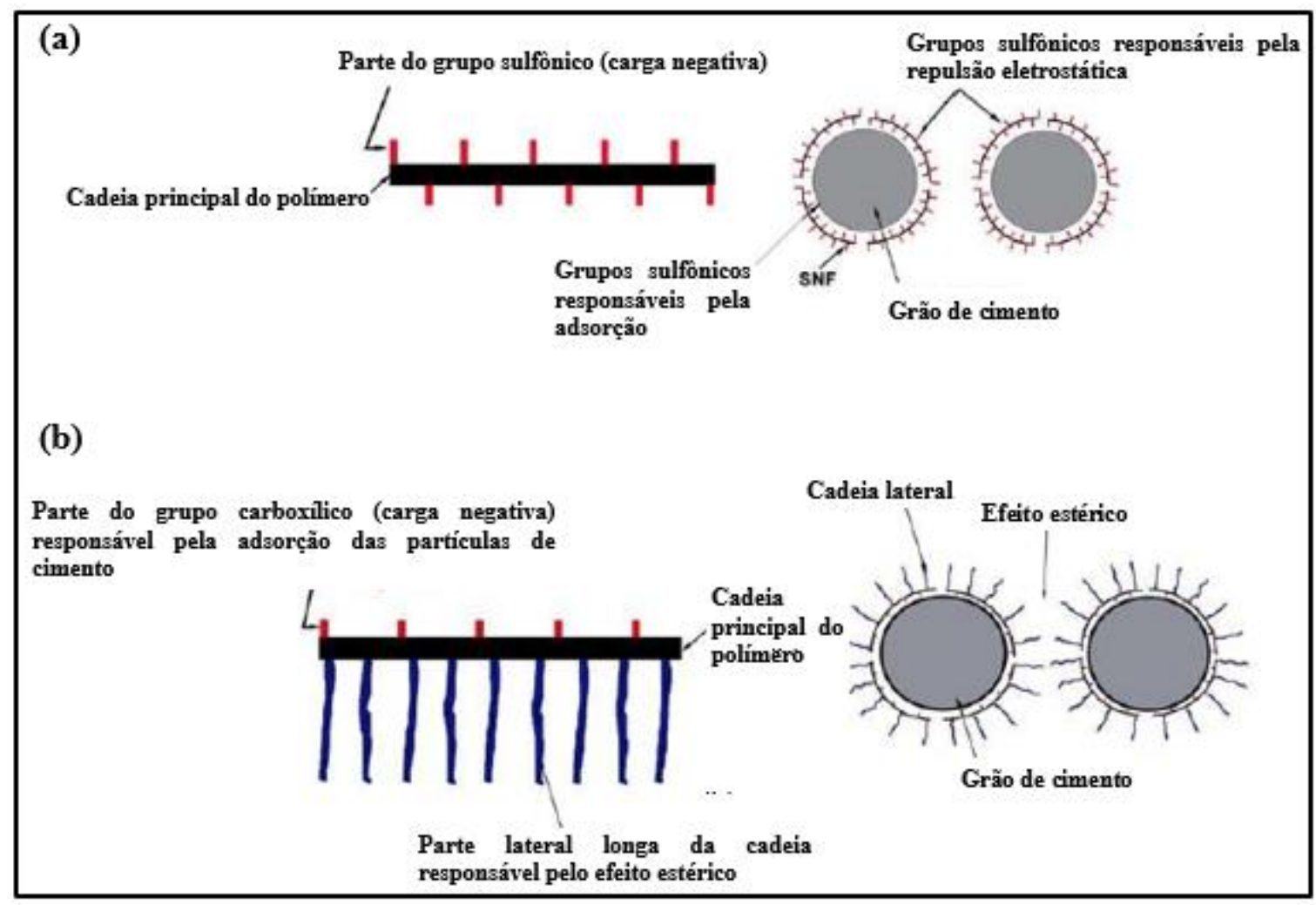

Fonte: Nunes (2008)

b) Modificadores de Viscosidade

Aditivos modificadores de viscosidade são polímeros solúveis em água adicionados nos concretos e nas argamassas para modificar suas propriedades reológicas. Esses aditivos normalmente possuem formulação a base de óxidos de polietileno, éteres de celulose e poliacrilamidas. Eles promovem uma redução na tendência a segregação e exsudação do material cimentício, assim como podem ser indicados para melhorar a aplicação e o bombeamento do concreto pelo fato de propiciarem o aumento da viscosidade e coesão da mistura cimentícia (HARTMANN et al., 2011; NAJI et al; 2011). 
Os aditivos modificadores de viscosidade têm sido empregados com maior frequência em grautes e concretos autoadensáveis devido a esses materiais cimentícios serem mais suscetíveis a segregação e exsudação no estado fresco. No caso de concretos autoadensáveis com baixo teor de finos, esses aditivos agem no sentido de evitar a segregação e exsudação da mistura (HARTMANN et al., 2011; NAJI et al.; 2011).

\subsubsection{Agregados}

A European Guidelines for Self-Compacting Concrete - EGSCC (2005) afirma que o tipo de agregado graúdo é relevante no sentido de exercer influência significativa no módulo de elasticidade estático, enquanto os agregados miúdos exercem mais influência nas propriedades no estado fresco do concreto.

Uysal (2012) constatou-se que boa parte dos concretos autoadensáveis produzidos com diferentes tipos de agregados graúdos alcançam bons resultados frente as propriedades do estado fresco. A distribuição granulométrica e a forma do agregado graúdo influenciam diretamente na fluidez do concreto autoadensável (EFNARC, 2005).

Türkel e Kandemir (2010) constataram que os concretos com emprego de agregado graúdo e fíller calcário apresentaram resultados melhores frente às propriedades no estado fresco quando comparados com misturas com emprego de agregado e fíller basáltico. Estes últimos se comportaram de maneira desvantajosa pelo fato do agregado e fíller basáltico possuírem morfologia angular e rugosa.

Os efeitos das adições minerais sobre as propriedades no estado fresco do concreto são mais dominantes do que os efeitos dos agregados graúdos. Isso reforça o fato da reologia do concreto sofrer alteração de forma mais sensível quando se altera os parâmetros de mistura da argamassa (TÜRKEL, KANDEMIR, 2010).

Nesse contexto, Benabed et al. (2012) recomendam a utilização de agregados rico em finos como mais uma alternativa para obter bons resultados de reologia e de autoadensabilidade do CCA. Dessa forma, acredita-se que o custo benefício para produção do CAA é melhorado. 


\subsubsection{Materiais Finos}

Sabe-se que uma das desvantagens do CAA é o seu custo elevado resultante do emprego aditivos químicos e alto consumo de cimento Portland (rico em clínquer).

Uma alternativa para reduzir o custo do CAA e torna-lo mais sustentável é o emprego de adições (finos) que propiciam redução de clínquer, bem como podem melhorar as propriedades do concreto no estado fresco. Para isso, empregam-se vários tipos de adições minerais ou finos, tais como, sílica ativa, metacaulim, cinza de casca de arroz, escória de alto-forno e pó de pedra de diferentes litologias. Segundo Sonebi et al.(2013), esses finos podem aumentar a fluidez do concreto e, também, podem reduzir o teor de superplastificante necessário para atender os requisitos de autoadensabilidade. Além disso, a incorporação de materiais finos pode melhorar a distribuição granulométrica dos grãos do sistema granular da mistura que, por sua vez, pode resultar numa melhor densidade de empacotamento dos grãos, assim garantindo uma maior coesão a mistura cimentícia (BOUKENDAKDJI et al.,2009).

A seguir, na Tabela 4, estão apresentadas as sugestões de quantidade de materiais finos por metro cúbico de concreto, a fim que o concreto autoadensável atenda no mínimo o espalhamento de 550 mm. Essas sugestões são recomendações do ACI-237R (2007).

Tabela 4 - Quantidade de finos em função do espalhamento do CAA

\begin{tabular}{l|c|c|c}
\hline & \multicolumn{3}{|c}{ Espalhamento (Slump flow) } \\
\hline & $<550 \mathrm{~mm}$ & $550 \mathrm{~mm}$ a $600 \mathrm{~mm}$ & $>650 \mathrm{~mm}$ \\
\hline Quantidade de finos $\left(\mathbf{k g} / \mathbf{m}^{\mathbf{3}}\right)$ & 355 a 385 & 385 a 445 & \multirow{2}{*}{$458>$} \\
\hline
\end{tabular}

Fonte: ACI 237R-07 (2007)

Em seguida, estão apresentados os principais efeitos dos finos sobre os parâmetros de trabalhabilidade (autoadensabilidade) e de reologia dos concretos e das argamassas.

a) Cimento

Pode ser utilizado diferentes tipos de cimento Portland que obedeça às condições normativas a eles referentes. A quantidade de cimento a ser adotada varia segundo as especificações de cada aplicação EFNARC (2005). 
Deve-se atentar a composição do cimento frente ao desempenho do concreto autoadensável no que tange, principalmente, a sua interação com os aditivos superplastificantes, sendo que estes são primeiramente adsorvidos pelo $\mathrm{C}_{3} \mathrm{~A}$ e $\mathrm{C}_{4} \mathrm{AF}$ do cimento após a mistura. Isso significa, que a eficiência da dispersão promovida pelo superplastificante depende dos teores de $\mathrm{C}_{3} \mathrm{~A}$ e $\mathrm{C}_{4} \mathrm{AF}$ (NAWA et al., 1998). Altos teores de $\mathrm{C}_{3} \mathrm{~A}$ e $\mathrm{C}_{4} \mathrm{AF}$ aceleram à pega do cimento, com isso comprometem a manutenção da trabalhabilidade de diferentes materiais cimentícios (pasta, argamassa e concreto) por um tempo mais longo (COLLEPARDI, 1998).

b) Outros finos

Os finos considerados neste item são: sílica ativa, metacaulim, escória de alto forno e fíler calcário.

Inicialmente, tem-se a sílica ativa conhecida por propiciar bons resultados nas propriedades mecânicas e de transporte de massa, no entanto tem seu uso limitado quando se busca bons resultados de autoadensabilidade do CAA (WALLEVIK, 2006).

Nesse sentido, Hassan et al. (2012) constataram que a adição de metacaulim nos teores de $8 \%$ e $11 \%$ em substituição do cimento do CAA propiciou um consumo de $16 \%$ a mais de superplastificante quando comparado com CAA de referência. A adição de sílica ativa nos mesmos teores supracitados propiciou um incremento de consumo de superplastificante de 24,5\% e 32,5\%, respectivamente, quando comparado também com CAA referência. Com relação a essas duas adições, estudos de Caldarone et al.(1994) e Ding e Li(2002) mostraram que a adição de metacaulim promove uma melhor trabalhabilidade as misturas cimentícias do que adição de sílica ativa.

Vejmelková et al.(2011) verificaram que para alcançar os requisitos necessários de um CAA no que se refere seus parâmetros reológicos e de autoadensabilidade, os concretos autoadensáveis com adição de metacaulim exigem maior quantidade de água e de superplastificante do que os concretos autoadensáveis com escória de alto-forno. Além disso, observou-se que a perda de autoadensabilidade do CAA com adição de metacaulim foi mais acentuada. Isto se deve a maior área específica superficial total resultante da mistura de cimento e metacaulim que, por sua vez, propiciou uma maior reatividade de hidratação. 
Quanto a adição de fíler calcário, Yahia et al.(2005) afirmaram que os variados tipos de fíler calcário podem reduzir o teor de superplastificante, sendo capazes de garantir uma boa fluidez ao concreto. Sahmaran et al. (2006) enfatizaram que a adição de fíler calcário melhorou de maneira significativa a autoadensabilidade das argamassas estudadas. Türkel e Kandemir (2010) utilizaram o filer calcário de morfologia angular, ainda assim, foi constatado bons resultados nas propriedades do estado fresco dos concretos autoadensáveis, como também esses resultados foram ligeiramente melhores com relação os resultados dos concretos que sofreram adição de cinza volante de morfologia esférica.

\subsection{PRINCIPAIS MÉTODOS DE AVALIAÇÃO DA AUTOADENSABILIDADE DE CONCRETOS E DE ARGAMASSAS}

\subsubsection{Ensaios em argamassas}

Ensaios com pastas e argamassas no estado fresco têm sido usados para selecionar materiais e identificar proporções adequadas de materiais para produção de concretos. A seguir, os principais métodos de ensaio para avaliação da trabalhabilidade de argamassas com aparatos de ensaio conforme Okamura e Ouchi (2003). Estes aparatos de ensaio estão apresentados na Figura 12.

a) Ensaios com mini-funil e mini-cone

Os ensaios de mini-slump e mini-cone têm sido usados para desenvolver traços de CAA, a fim de conhecer as interações entre cimento, aditivos químicos e adições minerais (JACOBS, 1999; GOMES, 2002; LACHEMI et al., 2007; LIU, 2009; FUNG, 2010; MADDURU et al., 2016). Liu (2009) lista as razões que estes ensaios são amplamente utilizados para avaliar a trabalhabilidade das argamassas:

- os dois tipos de ensaios têm uma boa sintonia com os principais parâmetros reológicos:

boas correlações têm sido encontradas entre os resultados de espalhamento e tensão de escoamento, e entre os resultados de funil V e viscosidade plástica de argamassas ensaiadas;

- as correlações supracitadas estão de acordo com os resultados obtidos por Jin e Domone (2002), Roy e Roussel (2005), Schwartzentruber et al. (2006) e Fung (2010); 
- os resultados de mini-slump e mini-funil também possuem boas correlações com resultados de ensaios que avaliam a capacidade de preenchimento do CAA. Isto pode ser visto no trabalho de Liu (2009);

- os ensaios em argamassas são simples e eficientes, de tal forma, que necessitam de menor número de pontos experimentais e são mais fáceis de serem operados quando comparados com ensaios em concretos.

Existem diferentes parâmetros que podem ser obtidos por meio de ensaios de mini-slump e mini-funil. Os parâmetros mais conhecidos são a área relativa de espalhamento (Gc) e a velocidade relativa de fluidez (Rc) propostas por Okamura e Ouchi (2003), os quais estão apresentados nas Equações 14 e 15, respecivamente.

$$
G c=\left(\frac{D m}{D_{0}}\right)^{2}+1
$$

Em que:

$\mathrm{Gc}=$ área relativa de espalhamento (adimensional);

$\mathrm{Dm}=$ resultado médio dos espalhamentos perpendiculars $(\mathrm{mm})$;

$\mathrm{Db}=$ diâmetro da base do cone $(\mathrm{mm})$.

$$
R c=\frac{10}{t}
$$

Em que:

$\mathrm{Rc}=$ velocidade relativa $\left(\mathrm{s}^{-1}\right)$;

$\mathrm{t}=$ tempo de a argamassa fluir completamente do orifício inferior do mini-funil V (s).

Fung (2010) e outros pesquisadores têm adotado outros parâmetros para avaliar a trabalhabilidade ou autoadensabilidade de argamassas. Dessa forma, têm-se o ganho de espalhamento D obtido pelo mini-slump e fluidez (V) em unidade de vazão, $\mathrm{ml} / \mathrm{s}$, obtido pelo funil V. Esses parâmetros são determinados pelas Equações 16 e 17, respectivamente.

$$
D=D_{m}-D_{b}
$$

Em que:

$D=$ ganho de espalhamento (mm); 
$D_{m}=$ resultado médio dos espalhamentos perpendiculares $(\mathrm{mm}) ;$

$D_{b}=$ diâmetro da base do cone (mm).

$$
V=\frac{V o l}{t}
$$

Em que:

$\mathrm{V}=$ fluidez $(\mathrm{ml} / \mathrm{s})$;

Vol = volume total de argamassa no mini-funil $(\mathrm{ml})$;

$\mathrm{t}=$ tempo de a argamassa fluir completamente do orifício inferior do mini-funil $\mathrm{V}(\mathrm{s})$.

Figura 12 - Aparatos para avaliação da trabalhabilidade e autoadensabilidade da argamassa: (a) mini-slump; (b) mini-funil.

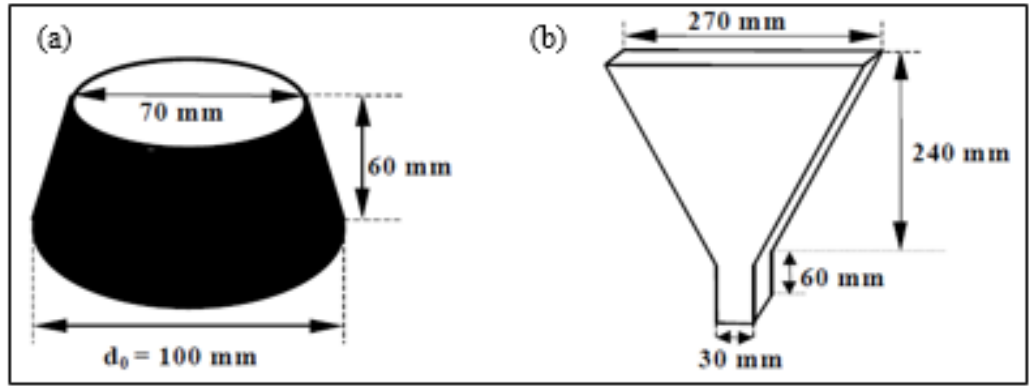

Fonte: Okamura e Ouchi (2003).

\subsubsection{Ensaios de autoadensabilidade voltados para o concreto autoadensável}

Vários métodos de ensaio têm sido propostos para avaliação da trabalhabilidade do CAA (EFNARC, 2005; CONCRETE SOCIETY, 2005). No entanto, ainda não há um consenso geral sobre estes métodos no que tange a sua confiabilidade e eficácia, sendo, portanto, uma questão para ser explorada (EL-CHABIB; NEHDI, 2006). A maioria dos métodos de ensaio foi usada, nesta última década, para avaliar a habilidade passante do CAA. Dentre os ensaios comumente utilizados para esta finalidade são Anel J, Caixa L e Caixa U (OZAWA et al., 1995; GROTH, NEMEGEER, 1999; PETERSSON et al., 1996). Outro ensaio comum é o ensaio de espalhamento (slump flow) que foi padronizado no Japão em 1990 (JSCE-F503, 1990), entretanto é aplicado para avaliar a habilidade de preenchimento do concreto, embora seja utilizado para avaliar a estabilidade do concreto por meio de inspeção visual. Neste caso, a inspeção visual consiste em verificar se há um anel de exsudação e agregado graúdo concentrado na região central do concreto espalhado.

Com relação os ensaios que avaliam a estabilidade do concreto autoadensável de forma quantitativa, pode-se citar os ensaios de coluna de segregação, settlement column, penetration 
apparatus, segregation probe, flow trough e sieve stability. Boa parte desses ensaios são propostas recentes e ainda não há uma padronização destes métodos (LIBRE et al., 2012).

De acordo com Cussigh (2003), dentre os ensaios que avaliam a estabilidade do concreto, o ensaio de coluna de segregação é o mais adequado para notar diferenças entre diferentes misturas de CAA. Este ensaio é o mais adotado pelas normas de classificação do concreto autoadensável em diferentes países.

A seguir, uma descrição sucinta dos principais ensaios que avaliam a autoadensabilidade do concreto autoadensável.

a) Método Cone de Abrams (Slump Flow Test) / T500 mm

Consiste em um método para avaliação da capacidade de preenchimento e fluidez do concreto autoadensável. Nesse método, são determinados dois parâmetros de avaliação: o espalhamento e o tempo de escoamento (T500). Para isso, são necessários os seguintes aparatos para determinação desses parâmetros conforme a ABNT NBR 15823-2 (2010):

- uma base metálica de no mínimo $900 \mathrm{~mm}$ de lado e 1,5 mm de espessura que não absorva água e nem reaja com componentes do concreto e pelo Cone de Abrams. Essa base metálica deve possuir três marcações circulares centradas com diâmetros de 100 mm, 200 mm e 500 mm, conforme está apresentado na Figura 13;

- são necessários também: régua metálica; recipiente para concreto de material não absorvente, complemento metálico tronco-cone, colher de pedreito com precisão mínima de 0,1 segundos.

Figura 13 - Aparatos para espalhamento e T500, cone de Abrams.

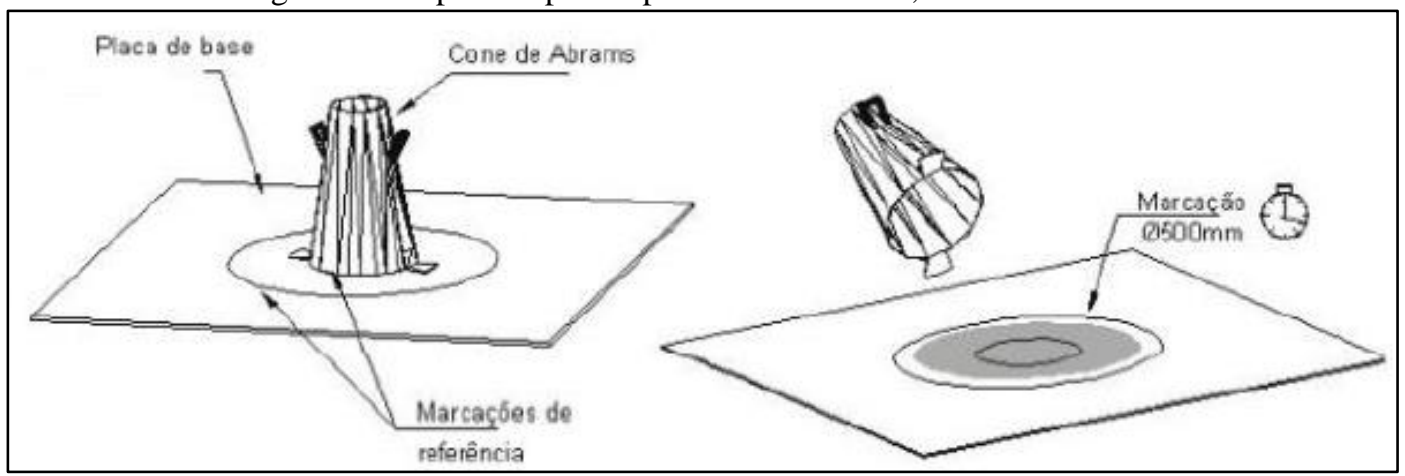

Fonte: ABNT NBR 15823-2 
Quanto a execução do ensaio, primeiramente, efetua-se o umedecimento da base e do molde e a colocação da base em superfície nivelada. Coloca-se o molde sobre a base centralizada namarcaç marcação de 200 mm. Em seguida, preenche-se o cone de Abrams com uma amostra de concreto com auxílio do complemento cônico, sem realizar nenhum tipo de adensamento. Após preenchido, retira-se o complemento de metal na parte superior do cone e remova-se o excesso de concreto com a colher de pedreiro. Por último, levanta-se verticalmente o cone com velocidade constante, deixando o concreto fluir livremente. No momento em que o cone é levantado deve ser disparado o cronômetro e coletar o tempo quando a massa de concreto alcançar a marca circular de $500 \mathrm{~mm}$. Esse tempo, em segundos, é o resultado de fluidez ou viscosidade aparente do concreto denominado de T500.

O espalhamento (slump flow - SF) é determinado pela média aritmética de duas medidas perpendiculares do diâmetro do espalhamento final em milímetros.

Os valores de espalhamento podem ser classificados nas seguintes classes apresentadas na Tabela 5. Essa classificação é adotada pela norma brasileira (ABNT NBR 15823-2, 2010), norma europeia (EN 12350-8, 2010) e americana (ASTM C1611, 2009).

Tabela 5 - Quantidade de finos em função do espalhamento do CAA.

\begin{tabular}{c|c}
\hline Classe & Espalhamento (mm) \\
\hline SF1 & 550 A 650 \\
\hline SF2 & 660 a 750 \\
\hline SF3 & 760 a 850 \\
\hline
\end{tabular}

Fonte: ABNT NBR 15823-1 (2010)

Para cada classe referente ao espalhamento do concreto, possui um significado do uso do concreto na obra ou na indústria de pré-moldados. Os concretos da classe SF1 são indicados para aplicações em estruturas com baixa taxa de armadura e para situações de bombeamento. Os concretos da classe SF2 são adequados para maioria das situações correntes em obra. Os concretos da classe SF3 são indicados para estruturas com elevada densidade de armadura e fôrmas mais complexas (ASTM C1611, 2009; EN 12350-8, 2010; ABNT NBR 15823-2, 2010). Quanto aos valores de T500 têm-se duas classes que definem a viscosidade aparente do concreto, conforme estão apresentadas na Tabela 6. Essa classificação é adotada pela norma brasileira (ABNT NBR 15823-2, 2010), norma europeia (EN 12350-8, 2010) e americana (ASTM C1611, 2009). 
Tabela 6 - Classes de viscosidade plástica aparente do T500.

\begin{tabular}{c|c}
\hline Classe & T500(s) \\
\hline VS1 & $\leq 2$ \\
\hline VS2 & $>2$ \\
\hline
\end{tabular}

Fonte: ABNT NBR 15823-2 (2010)

Os concretos da classe VS1 quando aplicados, são recomendados para estruturas com elevada densidade de armadura, enquanto os concretos da classe VS2 são adequados para a maioria das aplicações correntes (ASTM C1611, 2009; EN 12350-8, 2010; ABNT NBR 15823-2, 2010).

Dentre as normas citadas que prescrevem avaliação do espalhamento e da viscosidade plástica aparente do CAA, cabe destacar a norma americana ASTM C1611 (2009). Somente esta norma prescreve uma metodologia de avaliação da estabilidade (resistência à segregação) por meio de inspeção visual do concreto espalhado, assim classificando a estabilidade do CAA por índices que variam de 0 a 3 . O índice 3 significa um concreto exsudado e segregado e o índice 0 significa um concreto homogêneo e bem coeso. Esta metolodologia é conhecida como Visual Stability Index (VSI).

Por fim, parâmetros reológicos do CAA são possíveis de serem estimados pelas equações de Sedran e De Larrard (1999) por meio dos resultados de espalhamento e T500 (viscosidade plástica aparente) e a massa específica do concreto. A equação para estimar a viscosidade plástica teórica do CAA, é dada pela Equação 18, a seguir.

$$
\eta=\frac{\rho}{10000}\left(0,026 d_{F}-2,39\right) T_{500}
$$

Em que:

$\eta=$ viscosidade plástica (Pa.s);

$\rho=$ massa específica do concreto $\left(\mathrm{kg} / \mathrm{m}^{3}\right)$;

$\mathrm{dF}=$ diâmetro médio final do espalhamento, em $\mathrm{mm}$;

$\mathrm{T} 500=$ tempo para alcançar um espalhamento de $500 \mathrm{~mm}$.

A tensão de escoamento teórica é estimada por meio do resultado de espalhamento e da massa específica do concreto. Para isso, estima-se esse parâmetro reológico, conforme a Equação 19 proposta por Sedran e De Larrard (1999), a seguir. 


$$
\tau_{0}=\frac{\rho}{11740}\left(808-d_{F}\right)
$$

Em que:

$\tau 0=$ tensão de escoamento $(\mathrm{Pa})$

$\rho=$ massa específica do concreto $\left(\mathrm{kg} / \mathrm{m}^{3}\right)$;

$\mathrm{dF}=$ diâmetro médio final do espalhamento $(\mathrm{mm})$.

b) Anel J (J ring)

O ensaio de Anel - J avalia a habilidade passante do concreto autoadensável. Para isso, os seus aparatos de ensaio são semelhantes do ensaio de espalhamento (slump-flow), mais a inclusão do Anel J. De acordo com ABNT NBR 14823 - 3 (2010), o anel J consiste em um anel metálico com $300 \mathrm{~mm}$ de diâmetro e $120 \mathrm{~mm}$ de altura, com barras verticais de $10 \mathrm{~mm}$ de diâmetro, distribuídas a cada $(58 \pm 2)$ mm, conforme apresentado na Figura 14.

Outras normas prescrevem esse ensaio, tais como, a norma europeia EN 12350-12 (2010) e a norma americana ASTM C1621 (2009), porém empregam diâmetros maiores da barra do anel J com dimensões iguais $(18 \pm 0,5) \mathrm{mm}$ e $(16 \pm 3,3) \mathrm{mm}$, respectivamente. Isso significa, que os espaço entre as barras são menores com relação ao Anel J do ensaio brasileiro, portanto os ensaios da norma europeia e americana são mais rigorosos para avaliação da habilidade passante do concreto do que o ensaio do Anel J brasileiro. 
Figura 14 - Ilustração das dimensões do Anel J.

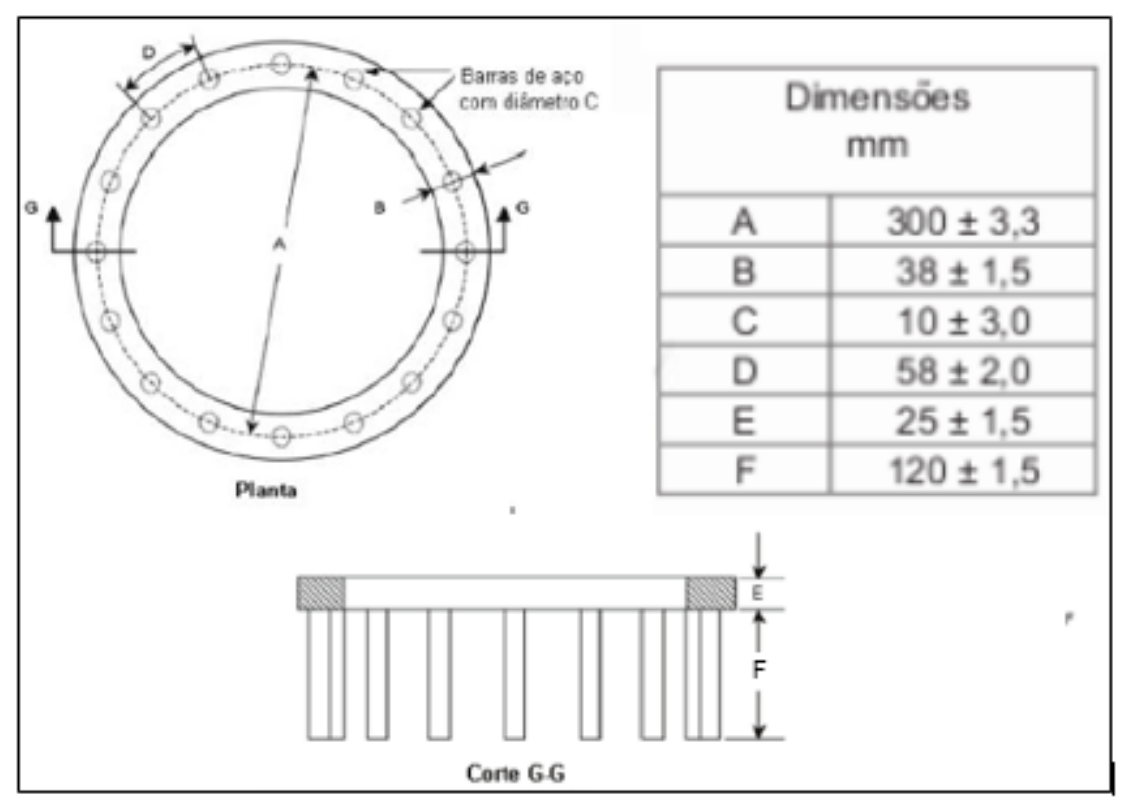

Fonte: ABNT NBR 15823-2 (2010)

O procedimento de execução do ensaio do Anel $\mathbf{J}$ se assemelha do ensaio de espalhamento. A diferença consiste em um acréscimo do anel - $\mathbf{J}$ sobre a base metálica, em torno do molde. $\mathrm{O}$ resultado do ensaio é a diferença do espalhamento médio do concreto sem o anel e com anel, sendo dado em milímetros (ABNT NBR 14823-3, 2010).

De acordo com a NBR 15823:2010, os concretos autoadensáveis podem ser divididos nas seguintes classes, conforme estão apresentados na Tabela 7, a seguir.

Tabela 7 - Classes dos resultados do Anel J.

\begin{tabular}{c|c}
\hline Classe & Anel-J $(\mathbf{m m})$ \\
\hline PJ1 & 0 a 25 com 16 barras de aço \\
\hline PJ2 & 25 a 50 com 16 barras de aço \\
\hline
\end{tabular}

Fonte: ABNT NBR 15823-2 (2010)

Os concretos da classe PJ1 são indicados para aplicações em estruturas com espaçamentos de armadura de $80 \mathrm{~mm}$ a $100 \mathrm{~mm}$, enquanto a classe PJ2 é adequada para a maior parte das utilizações correntes e elementos com espaçamentos de armaduras de $60 \mathrm{~mm}$ a $80 \mathrm{~mm}$ NBR 15823 (2010). Estas classes, bem como as recomendações de uso do CAA, também, são consideradas pelas normas EN 12350-12 (2010) e ASTM C1621 (2009). 
c) Funil em V (V-Funnel Test)

O ensaio do Funil-V avalia a habilidade passante e viscosidade plástica aparente do CAA por meio do estreitamento de uma seção, apenas sob a ação de seu próprio peso. Além disso, é possível verificar a segregação do concreto por inspeção visual, quando se nota o impedimento do concreto fluir pelo orifício inferior do funil (GOMES; BARROS, 2009). Este método se mostra adequado para concretos com agregados graúdos com dimensão máxima de $20 \mathrm{~mm}$ (ABNT NBR 15823 -5, 2010). Gomes e Barros (2009) afirmam que depois do ensaio de espalhamento com o cone de Abrams, o ensaio de Funil-V é o mais utilizado para verificar a fluidez do concreto.

$\mathrm{O}$ funil $\mathrm{V}$ é um equipamento confeccionado em chapa metálica com as dimensões mostradas na Figura 15. Outros aparatos são necessários para efetivação do ensaio: recipiente metálico, colher de pedreiro, concha metálica e cronômetro (ABNT NBR 15823-5, 2010).

Figura 15 - Detalhes do funil V.

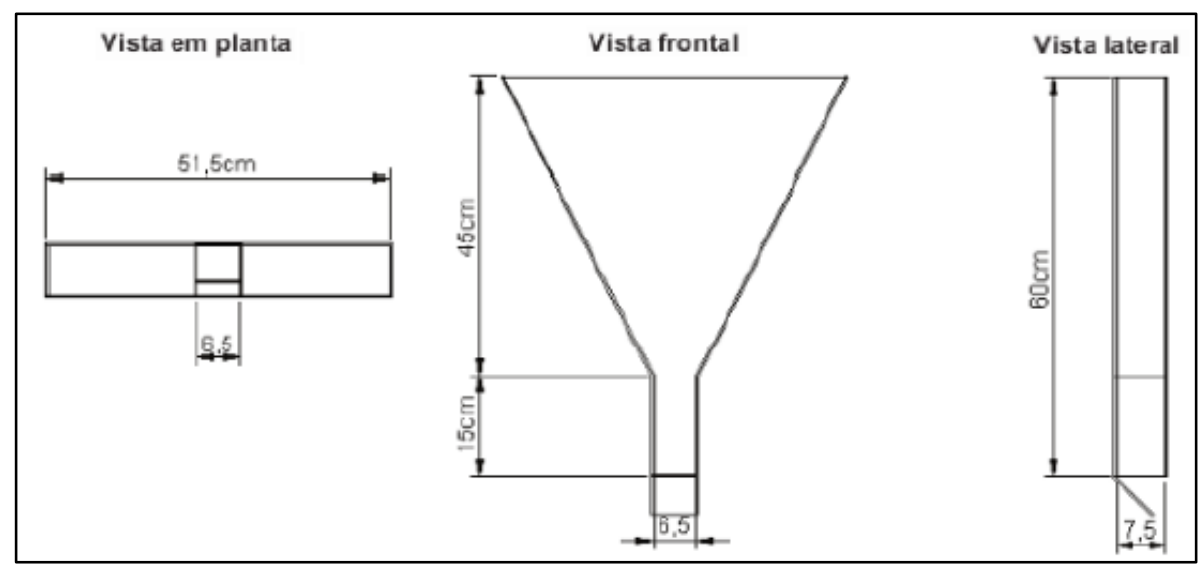

Fonte: ABNT NBR 15823-2 (2010)

O procedimento inicia-se com umedecimento da parte interna do funil V. Deve-se então preencher todo o funil com concreto sem realizar nenhum tipo de adensamento. Após preenchido, retirar todo o excesso que sobressai na parte superior do funil com a colher de pedreiro. Em seguida, abre-se a comporta em um tempo menor que 30 segundos e, no mesmo instante, aciona-se o cronômetro e pare de marcar o tempo quando avistar a claridade do ambiente de execução do ensaio pela parte superior do funil, assim garantindo que todo 
concreto fluiu pelo do funil. O tempo de fluidez neste caso é denominado de T30seg (EFNARC, 2005; ABNT NBR 15823-5, 2010; EN 12350-9, 2010).

Para determinação do escoamento no tempo 5 min (T5min), que não é uma medida obrigatória, mede-se o tempo de escoamento do CAA após 5 minutos do preenchimento do funil $\mathrm{V}$ da primeira determinação de fluidez, T30seg. Para isso, após a coleta de T30seg, deve-se preencher o funil imediatamente com o material coletado pelo recipiente. Espera-se 5 minutos, em seguida, abre-se a comporta do funil e no mesmo instante acione cronômetro e determine o tempo de fluidez coletado conforme o procedimento supracitado para determinar o T30seg (EFNARC, 2005; ABNT NBR 15823-5, 2010; EN 12350-9, 2010).

De acordo a NBR 15823 - 5 (2010), existem duas classes de viscosidade aparente, conforme a Tabela 8. A norma europeia EN 12350-9 (2010) e EFNARC (2005) também adotam esta classificação. No entanto, a norma americana ASTM não emprega este tipo de ensaio para avaliar a fluidez do concreto.

Tabela 8 - Classes de viscosidade plástica aparente - Funil V.

\begin{tabular}{c|c}
\hline Classe & Funil V (s) \\
\hline VF1 & $<9$ \\
\hline VF2 & 9 a 25 \\
\hline
\end{tabular}

Fonte: ABNT NBR 15823-5 (2010)

Os concretos de classe VF1 são recomendados para estruturas com elevada taxa de armadura. Enquanto os concretos da classe VF2 se mostram adequados para a maioria das aplicações correntes (ABNT NBR 15823, 2010; EN 12350-9, 2010, EFNARC, 2005).

\section{d) Caixa em L (L-Box Test)}

O ensaio de Caixa L consiste em verificar se o concreto sob a força de seu peso tem a capacidade de ultrapassar as armaduras sem que ocorra bloqueio e separação dos seus materiais constituintes.

Para realização do ensaio, inicialmente a Caixa-L é colocada em uma posição estável e horizontalmente nivelada. Em seguida, o trecho vertical é preenchido com a amostra de concreto de aproximadamente 12 litros. Espera-se em torno de 30 segundos para levantar a comporta. Levanta-se a comporta e deixe o concreto fluir do trecho vertical para o trecho horizontal da Caixa-L. Depois de cessado o movimento do concreto, coleta-se a altura do 
concreto no final do trecho horizontal $\left(\mathrm{H}_{2}\right)$ e a altura do concreto remanescente do trecho vertical $\left(\mathrm{H}_{1}\right)$ da Caixa-L. Com esses parâmetros de altura, obtém-se um parâmetro de habilidade de preenchimento (HP), conforme a Equação 20. A HP para o CAA é $\geq 0,8$ (GOMES, 2002; EFNARC, 2005; ABNT NBR 15823-4, 2010; EN 12350-10, 2010).

$$
H P=\frac{H_{2}}{H_{1}}
$$

A seguir, na Figura 16, detalhes da Caixa-L conforme ilustrado por Gomes (2002).

Figura 16 - Detalhes do aparato da Caixa L

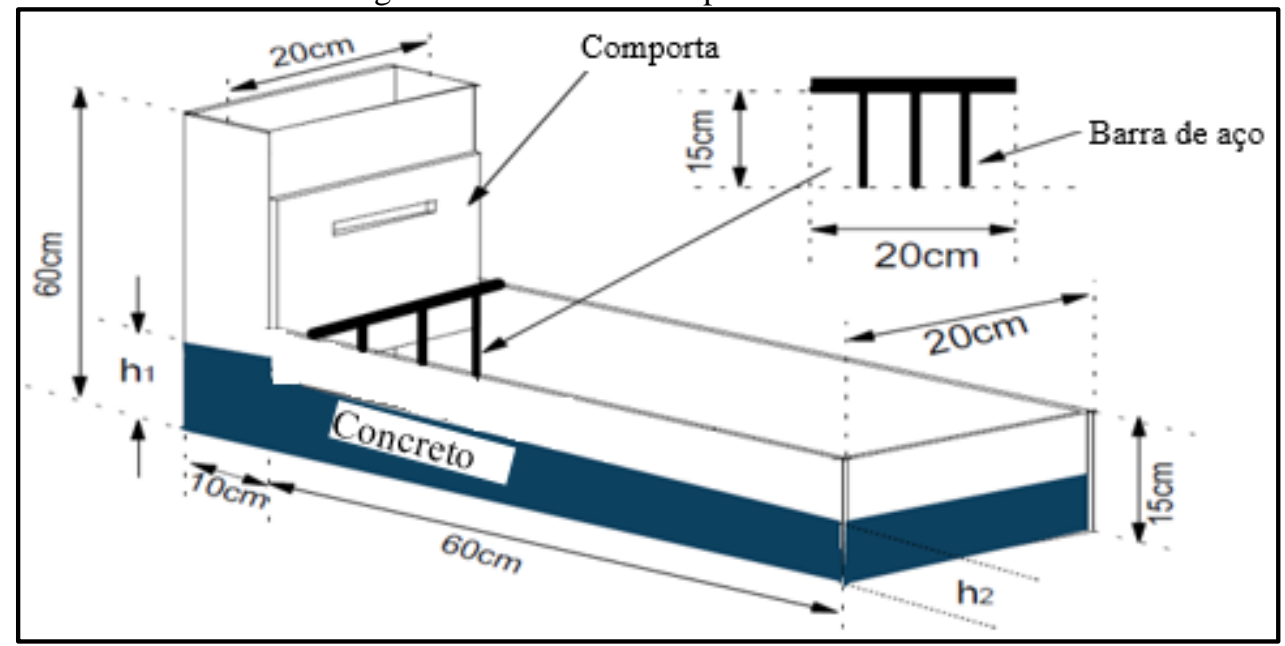

Fonte: Gomes (2002).

\section{e) Caixa em U (U-Box)}

O ensaio da Caixa-U serve para avaliar a habilidade passante. Neste ensaio, o grau de adensabilidade pode ser indicado pela altura que o concreto alcança após fluir através de obstáculos.

Após preparar a Caixa-U para o ensaio, esta é preenchida com uma amostra de CAA, no estado fresco no compartimento da esquerda do aparato, com a comporta fechada. Passa-se um minuto, a comporta é então aberta e, em seguida, inicia-se o escoamento do concreto entre as armaduras alcançando outro compartimento da Caixa U. Assim que o movimento se cessa, medem-se as alturas R1 e R2, respectivamente. A altura R1 se refere ao material concreto que ficou alojado no compartimento da esquerda e a altura R2 se refere ao material que ficou alojado no compartimento da direita. A partir daí, calcula-se a diferença entre R2 e R1, conforme a 
Equação 21, obtendo-se o parâmetro $\mathrm{R}_{\mathrm{U}}$, o qual indica se o concreto possui autoadensabilidade adequada (EFNARC, 2005). Segundo Gomes e Barros (2009), o RU para o CAA deve estar entre 0 e $30 \mathrm{~mm}$. Quanto maior a capacidade de preenchimento do CAA, mais próximo de zero será o $\mathrm{R}_{\mathrm{U}}$. Na Figura 17 está apresentado detalhes do aparato de ensaio da Caixa U.

$$
R_{u}=R_{2}+R_{1}
$$

Figura 17 - Detalhes do aparato da Caixa U.

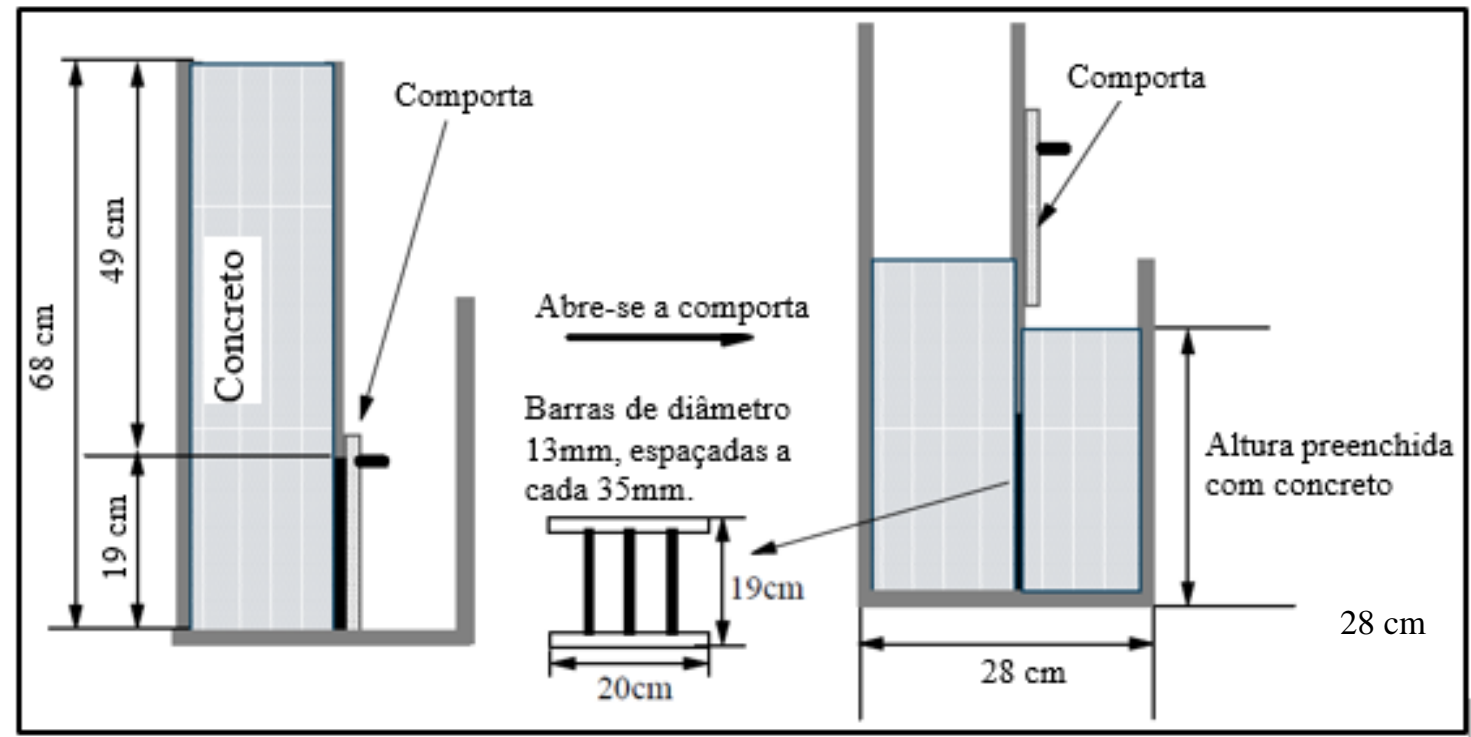

Fonte: Gomes (2002).

O ensaio de Caixa $U$ foi considerado mais sensível para identificar mudanças na mistura do CAA do que o ensaio de Caixa L, no entanto ainda não foi normalizado (LIBRE et al., 2012).

f) Coluna de Segregação

Dentre os ensaios que quantificam a segregação do concreto, pode-se citar o ensaio de coluna de segregação, visto que este ensaio é prescrito no Brasil pela norma ABNT NBR 15823 - (2010) e, também, nos Estados Unidos pela norma ASTM C1610 (2010), conforme está apresentado na Tabela 9. Na Europa para avaliar a segregação adota-se o ensaio da peneira (EN 12350-11, 2010).

No Brasil, adota-se o aparato de ensaio conforme está apresentado na Figura 18. O aparato de ensaio consiste em um tubo de PVC de $20 \mathrm{~cm}$ de diâmetro com $66 \mathrm{~cm}$ de altura, o qual está dividido em três partes: região superior (topo), região central e base. $\mathrm{O}$ topo e a base possuem 
uma altura de $16,5 \mathrm{~cm}$ e a parte central possui uma altura de $33 \mathrm{~cm}$. As seções são unidas por fitas e grampos (ALENCAR, 2008; GOMES; BARROS, 2009; ABNT NBR 15823, 2010).

Quanto à execução do ensaio, depois de decorrido 20 min do lançamento do concreto, coletamse amostras de concreto no topo e na base do tubo. Em seguida, estas amostras são lavadas em uma peneira de $4,8 \mathrm{~mm}$, a fim de extrair o agregado graúdo. A seguir, o agregado graúdo retido referente a cada amostra é pesado.

Figura 18 - Ilustração do aparato de coluna de segregação referente ao ensaio que avalia resistência à segregação do concreto.

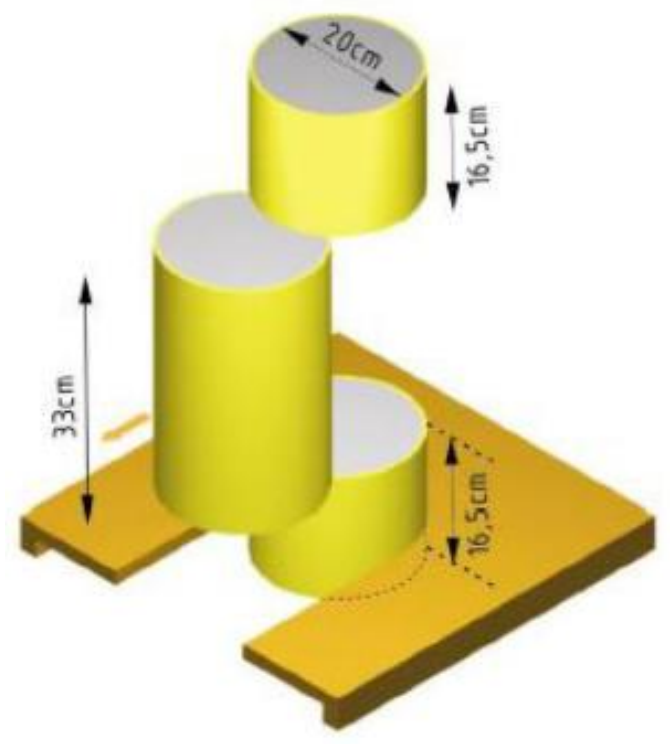

Fonte: Alencar (2008).

De acordo com ABNT NBR 15823-6 (2010) a resistência à segregação é definida pela diferença percentual entre a quantidade de agregado graúdo retida na base e no topo da coluna de segregação, conforme Equação 22, a seguir.

$$
S R=\frac{2 \cdot\left(m_{B}-m_{T}\right)}{\left(m_{B}+m_{T}\right)} \cdot 100
$$

Em que:

$\mathrm{SR}=$ resistência à segregação do concreto $(\%)$;

$\mathrm{m}_{\mathrm{B}}=$ massa do agregado graúdo obtida na porção retida na base da coluna $(\mathrm{g})$; 
$\mathrm{m}_{\mathrm{T}}=$ massa do agregado graúdo obtida na porção retida no topo da coluna $(\mathrm{g})$.

A norma destaca que se o valor de $\mathrm{mT}$ for maior ou igual que o de $\mathrm{mB}$, a segregação é nula. A seguir, duas classes de resistência à segregação apresentadas na Tabela 9.

Tabela 9 - Classes de resistência à segregação.

\begin{tabular}{c|c}
\hline Classe & Coluna de Segregação (\%) \\
\hline SR1 & $\leq 20$ \\
\hline SR2 & $\leq 15$ \\
\hline
\end{tabular}

Fonte: ABNT 15823-6 (2010).

É recomendada a utilização de CAAs da classe SR1 para lajes pouco espessas e estruturas com reduzida complexidade. Por outro lado, os concretos da classe SR2 são indicados para fundações profundas, elementos pré-moldados e estruturas mais complexas (ASTM C1610, 2010; ABNT NBR 15823, 2010).

g) Considerações finais sobre os ensaios que avaliam autoadensabilidade do concreto

Pelo exposto, na Tabela 10, são apresentadas às normas que prescrevem os ensaios de autoadensabilidade em consonância com a norma brasileira. Para isso, considerou-se as normas da Europa e dos Estados Unidos. Além dessas, cita-se o ensaio de caixa U que não é prescrita por nenhuma norma.

Tabela 10 - Citação das normas brasileiras, americanas e europeias que prescrevem os ensaios de autoadensabilidade do CAA.

\begin{tabular}{|c|c|c|c|}
\hline ENSAIOS & $\begin{array}{l}\text { PROPRIEDADE } \\
\text { AVALIADA }\end{array}$ & NORMAS & \\
\hline \multirow[t]{3}{*}{ Slump flow } & \multirow{3}{*}{\begin{tabular}{l}
\multicolumn{3}{l}{$\begin{array}{l}\text { Habilidade de Preenchimento } \\
\text { Resistência a } \\
\text { inspeção visual }\end{array}$} & Segregação & por \\
inspalo
\end{tabular}} & BRASIL & ABNT NBR 15823-2 (2010) \\
\hline & & EUROPA & EN 12350-8 (2010) \\
\hline & & E.U.A & ASTM C1611 (2009) \\
\hline \multirow[t]{3}{*}{ Slump flow T50 } & \multirow{3}{*}{$\begin{array}{l}\text { Habilidade de Preenchimento } \\
\text { Viscosidade aparente (fluidez) }\end{array}$} & BRASIL & ABNT NBR 15823-2 (2010) \\
\hline & & EUROPA & EN $12350-8(2010)$ \\
\hline & & E.U.A & ASTM C1611 (2009) \\
\hline \multirow[t]{3}{*}{ Funil V } & \multirow{3}{*}{$\begin{array}{l}\text { Habilidade passante } \\
\text { Viscosidade aparente (fluidez) }\end{array}$} & BRASIL & ABNT NBR 15823-5 (2010) \\
\hline & & EUROPA & EN 12350-9 (2010) \\
\hline & & E.U.A & ------ \\
\hline \multirow[t]{3}{*}{ Caixa L } & \multirow{3}{*}{$\begin{array}{l}\text { Habilidade de Preenchimento } \\
\text { Habilidade Passante }\end{array}$} & BRASIL & ABNT NBR 15823-4 (2010) \\
\hline & & EUROPA & EN 12350-10 (2010) \\
\hline & & E.U.A & ----- \\
\hline \multirow[t]{3}{*}{ Caixa U } & \multirow{3}{*}{$\begin{array}{l}\text { Habilidade de Preenchimento } \\
\text { Habilidade passante }\end{array}$} & BRASIL & ------- \\
\hline & & EUROPA & $-\overline{----}$ \\
\hline & & E.U.A & 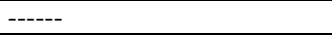 \\
\hline \multirow{3}{*}{ J-Ring } & \multirow{3}{*}{ Habilidade Passante } & BRASIL & ABNT NBR 15823-3 (2010) \\
\hline & & EUROPA & EN 12350-12 (2010) \\
\hline & & E.U.A & ASTM C1621 (2009) \\
\hline \multirow[t]{3}{*}{ Coluna Segregação } & \multirow{3}{*}{$\begin{array}{l}\text { Resistência a Segregação } \\
\text { (mensurável) }\end{array}$} & BRASIL & ABNT NBR 15823-5 (2010) \\
\hline & & EUROPA & ------ \\
\hline & & E.U.A & ASTM C1610 (2010) \\
\hline
\end{tabular}

Fonte: Próprio autor. 
Na Tabela 11, estão apresentados os resultados de diferentes pesquisas e valores de referência da EFNARC (2005), com intuito de propor valores de referência médios de autoadensabilidade para futuros trabalhos com CAA.

Tabela 11 - Resultados de várias pesquisas relativas à autoadensabilidade do CAA.

\begin{tabular}{|c|c|c|c|c|c|c|c|c|c|c|c|c|c|c|}
\hline \multirow{2}{*}{ Ensaios } & \multicolumn{2}{|c|}{$\begin{array}{c}\text { EFNARC } \\
(2005)\end{array}$} & \multicolumn{2}{|c|}{$\begin{array}{l}\text { Gomes } \\
(2002)\end{array}$} & \multicolumn{2}{|c|}{$\begin{array}{l}\text { Silva } \\
(2007)\end{array}$} & \multicolumn{2}{|c|}{$\begin{array}{c}\text { Liu } \\
(2009)\end{array}$} & \multicolumn{2}{|c|}{ Nuruddin et al.(2012) } & \multicolumn{2}{|c|}{ Khaleel e Razak (2014) } & \multicolumn{2}{|c|}{ Intervalos médios } \\
\hline & $\min$ & $\max$ & $\min$ & $\max$ & $\min$ & $\max$ & $\min$ & $\max$ & $\min$ & $\max$ & $\min$. & $\max$ & $\min$. & $\max$ \\
\hline $\begin{array}{l}\text { slump } \\
\text { flow }(\mathbf{m m})\end{array}$ & 650 & 800 & 660 & 680 & 642 & 698 & 580 & 730 & 630 & 820 & 630 & 680 & 632 & 735 \\
\hline T500 (s) & 2,0 & 5,0 & 4,0 & 10,0 & 3,2 & 6,2 & ---- & ---- & 2,5 & 6,5 & 2,0 & 3,5 & 2,7 & 6,2 \\
\hline Funil V(s) & 0 & 30,0 & 10,8 & 10,8 & 9,3 & 14,1 & 5,7 & 9,1 & 7,0 & 12,5 & 7,0 & 13,0 & 6,6 & 14,9 \\
\hline $\begin{array}{l}\text { Caixa L } \\
(\text { H2/H1) } \\
\end{array}$ & 0,80 & 1,00 & 0,83 & 0,83 & 0,81 & 0,86 & ----- & ----- & 0,82 & 1,00 & 0,78 & 0,87 & 0,81 & 0,91 \\
\hline Caixa U (mm) & 0 & 30 & ----- & ----- & ----- & ----- & ----- & ----- & ----- & ----- & ---- & ---- & 0 & 30 \\
\hline J-ring (mm) & 0 & 10 & ----- & ----- & ----- & ----- & 11 & 30 & 0 & 12 & ---- & ---- & 4 & 17 \\
\hline $\begin{array}{l}\text { Coluna de } \\
\text { Segregação(\%) }\end{array}$ & 0 & 15 & ---- & ----- & ----- & ----- & 5 & 13 & ----- & ---- & 7 & 14 & 6 & 14 \\
\hline
\end{tabular}

Fonte: Próprio autor.

Por último, para avaliar de forma efetiva autoadensabilidade do concreto, sugere-se: (i) o uso dos ensaios slump flow e J-ring para avaliar a fluidez; (ii) o uso dos ensaios de coluna de segregação, segregation probe e surface bleending, para avaliar a estabilidade e (iii) para avaliar habilidade passante do CAA entre seções estreitas, recomenda-se os ensaios de CaixaL e Caixa-U (LIBRE et al., 2012). 


\section{Capítulo III - PROGRAMA EXPERIMENTAL}

Neste capítulo são detalhadas as partes integrantes do programa experimental e apresentados os materiais empregados e suas principais características, bem como os procedimentos experimentais adotados em cada ensaio. De forma simplificada, pode-se dividir este capítulo como mostra a Figura 19.

Figura 19 - Fluxograma de apresentação geral das partes integrantes do desenvolvimento da pesquisa.

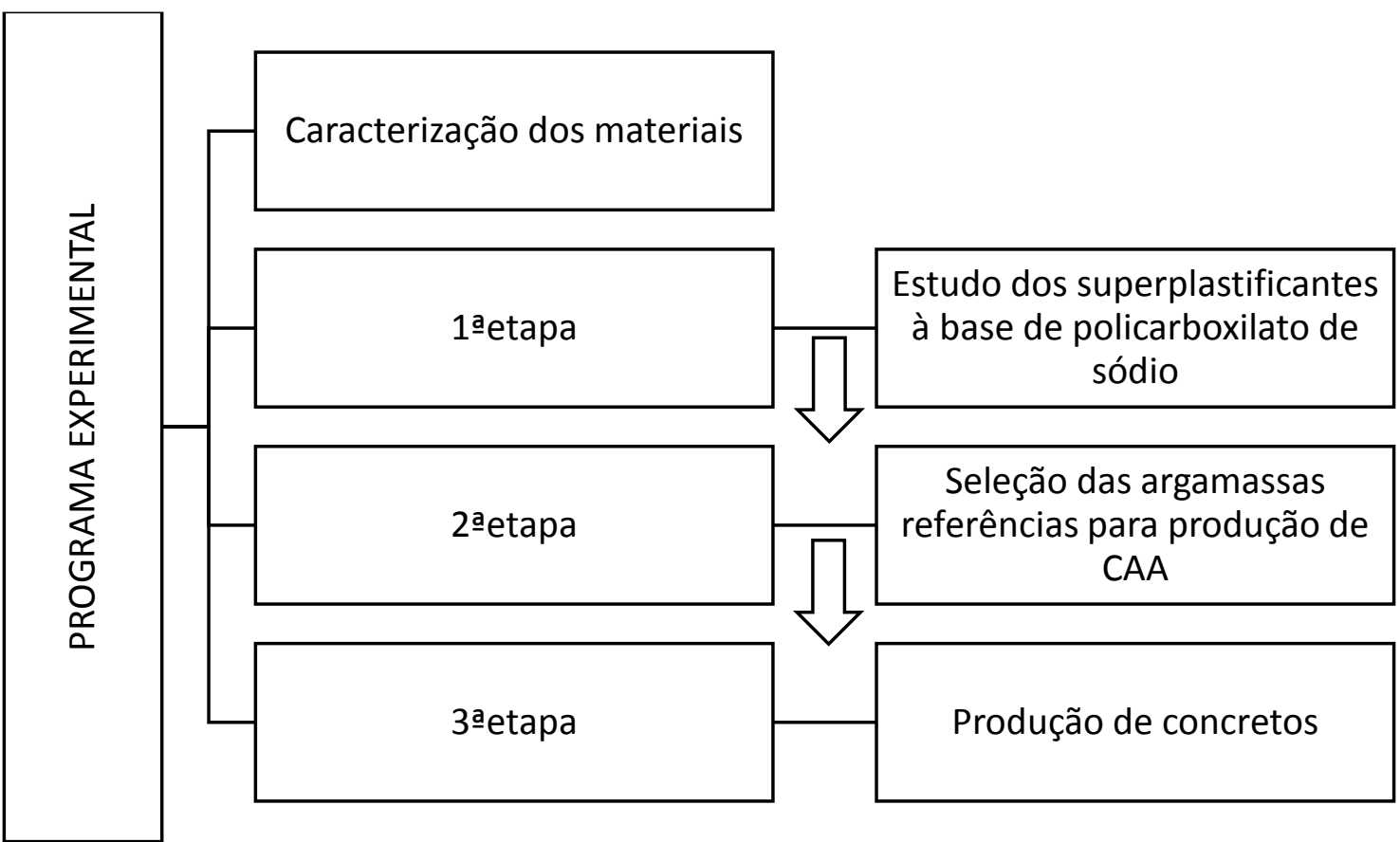

Fonte: Próprio autor.

Primeiramente, realizou-se a caracterização dos materiais que foram empregados nesta tese. Em seguida, desenvolveu-se o programa experimental, o qual envolveu estudos em argamassas e concretos no que tange às suas propriedades de autoadensabilidade e de reologia como, também, obtiveram-se resultados das propriedades mecânicas dos concretos. A seguir, estão detalhadas as partes integrantes do desenvolvimento da Pesquisa.

\subsection{CARACTERIZAÇÃO DOS MATERIAIS EMPREGADOS}

Os materiais empregados na pesquisa foram provenientes da região de Brasília-DF, exceto os aditivos superplastificantes, que foram doações de uma indústria química do estado de São 
Paulo. A seguir, estão descritas as características dos materiais empregados no programa experimental.

\subsubsection{Finos}

Para produção das argamassas e dos concretos foram empregados os finos: um cimento Portland de alta resistência inicial (CPV ARI-RS) e fíler calcário. O fíler calcário foi utilizado em substituição, em massa, do cimento até um teor de 30\%. A seguir, na Tabela 12, estão apresentadas as principais características físicas e químicas desses finos.

Tabela 12 - Caracterização química e física dos finos: cimento CPV ARI RS, fíler calcário.

\begin{tabular}{l|c|c|c}
\hline \multirow{2}{*}{ Elemento } & \multicolumn{2}{|c}{ Cimento } & Fíler calcário \\
& $\begin{array}{c}\text { Exigências } \\
\text { NBR 5737:1992 }\end{array}$ & Resultado & Resultado \\
\hline $\mathrm{SiO}_{2}(\%)$ & N.E* & 24,58 & 8,62 \\
\hline $\mathrm{CaO}(\%)$ & N.E. & 52,84 & 50,67 \\
\hline $\mathrm{MgO}(\%)$ & $\leq 6,5$ & 3,58 & 3,31 \\
\hline $\mathrm{Al}_{2} \mathrm{O}_{3}(\%)$ & ---- & 7,43 & 2,89 \\
\hline $\mathrm{Fe}_{2} \mathrm{O}_{3}(\%)$ & ---- & 3,13 & 1,04 \\
\hline $\mathrm{SO}_{3}(\%)$ & $\leq 3,5$ & 3,23 & --- \\
\hline $\mathrm{K}_{2} \mathrm{O}(\%)$ & ---- & 0,86 & 0,50 \\
\hline $\mathrm{Na}_{2} \mathrm{O}(\%)$ & ---- & 0,15 & 0,13 \\
\hline $\mathrm{Perda}$ ao fogo & $\leq 4,5$ & 2,08 & --- \\
\hline Resíduo insolúvel & N.E. & 8,87 & --- \\
\hline massa específica $\left(\mathrm{g} / \mathrm{cm}^{3}\right)$ & ---- & 3,11 & 2,70 \\
\hline Blaine $(\mathrm{cm}$ /g) & ---- & 5786 & 3289 \\
\hline$* N . E .=$ Não Especificado. & & & \\
\hline
\end{tabular}

Fonte: Próprio autor.

Observa-se, na Tabela 12, que o fíler calcário é calcítico. Com relação à finura por meio do ensaio de Blaine, nota-se que o cimento possui uma área específica maior, portanto mais fino que o fíler calcário.

Quanto às distribuições granulométricas dos finos, verifica-se na Figura 20, que a distribuição granulométrica do fíler calcário apresenta uma proporção levemente superior de grãos com dimensões entre $0,001 \mathrm{~mm}$ e $0,003 \mathrm{~mm}$ do que o cimento; entretanto a distribuição granulométrica do cimento apresenta maior proporção do que o fíler calcário, de forma bem acentuada, de grãos com dimensões acima de $0,003 \mathrm{~mm}$. Este fato pode contribuir para explicar a maior finura do cimento com relação ao fíler calcário. 
Figura 20 - Distribuição granulométrica a laser dos finos: (a) cimento, (b) fíler calcário.

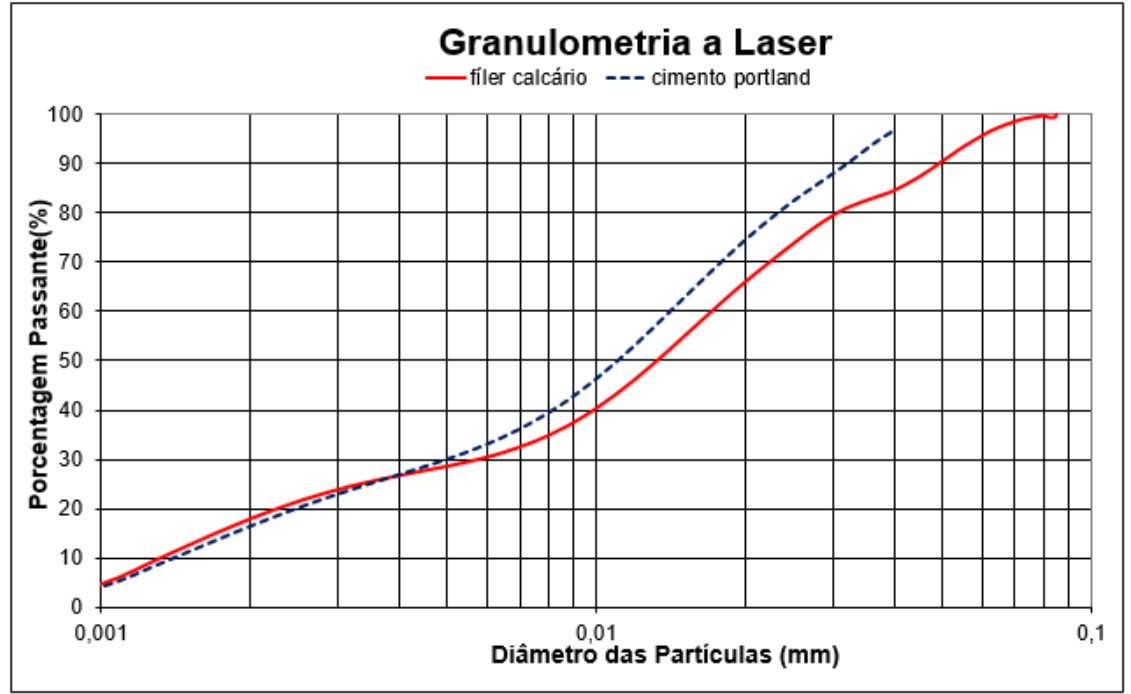

Fonte: Próprio autor.

\subsubsection{Agregados}

Adotou-se a norma NBR NM 248 (2003) para determinar a distribuição granulométrica dos agregados, com a inclusão da peneira de abertura $0,075 \mathrm{~mm}$, com intuito de verificar o teor de finos que é um parâmetro importante no alcance da estabilidade do concreto autoadensável no estado fresco.

a) Areia rosa: areia quartzosa, comum na região de Brasília. Possui uma massa específica de $2,66 \mathrm{~g} / \mathrm{cm}^{3}$, obtida pelo frasco de Chapman. A sua distribuição granulométrica não se enquadra na zona utilizável, sendo, portanto, uma areia com maior predominância de grãos de diâmetro inferior a $0,3 \mathrm{~mm}$, conforme mostra a linha tracejada vermelha na Figura 21 (a). Os finos equivalem a 4,3\% da fração total. O módulo de finura é igual a 1,09 e dimensão máxima de $0,6 \mathrm{~mm}$.

b) Areia artificial calcária: areia com massa específica igual a 2,73 g/ $/ \mathrm{cm}^{3}$. Quanto à sua distribuição granulométrica, observa-se que a linha alaranjada na Figura 21 (b) encontra-se na zona utilizável, bem próxima da tendência da zona ótima. O módulo de finura é igual a 2,91 e dimensão máxima de $4,75 \mathrm{~mm}$. Os finos correspondem a $0,9 \%$ da fração total.

c) Combinação das areias: buscou-se uma combinação das areias que pudesse reduzir os vazios e, consequentemente, o consumo de cimento, assim como uma composição de grãos com variadas dimensões que pudesse contribuir para uma melhor autoadensabilidade da matriz cimentícia. Para isso, determinou-se a maior massa unitária compactada seca da combinação da 
areia rosa (quartzosa) e da areia artificial, conforme a norma ABNT NBR NM 45 (2006). A maior massa unitária compactada seca da combinação das areias foi encontrada para uma composição de $30 \%$ de areia rosa e $70 \%$ de areia artificial. Essa composição foi empregada tanto nas argamassas como nos concretos. Nota-se, na Figura 21 (c), que a distribuição granulométrica da combinação das areias (linha verde) está mais ajustada na zona ótima do que a distribuição granulométrica de cada areia tomada de forma isolada. Esse melhor ajuste da distribuição granulométrica das areias combinadas pode ser explicado pelo maior empacotamento dessa combinação granular resultante de proporções adequadas de diferentes dimensões de grãos que, por sua vez, reduzem os vazios do sistema granular.

Figura 21 - Distribuição granulométrica dos agregados miúdos conforme a NBR NM 248 (2003): (a) areia quartzosa (rosa), (b) combinção das areias (30\% de areia rosa e 70\% de areia artificial), (c) areia artificial calcária.

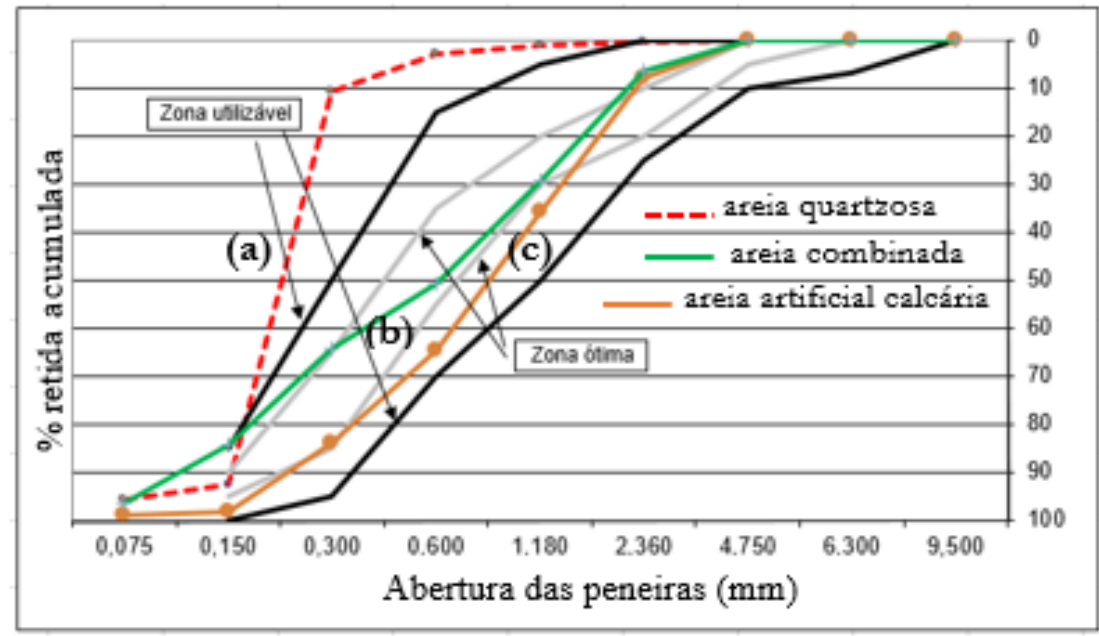

Fonte: Próprio autor.

d) Agregado graúdo: litologia calcária com massa específica igual a $2,73 \mathrm{~g} / \mathrm{cm}^{3}$. A sua distribuição granulométrica está boa parte enquadrada na zona 4,8/12,5, conforme apresenta a Figura 22. O módulo de finura é igual a 5,78 e o dimensão máxima igual a 12,5 mm. 
Figura 22 - Distribuição granulométrica do agregado graúdo (brita calcária) conforme a NBR NM 248 (2003).

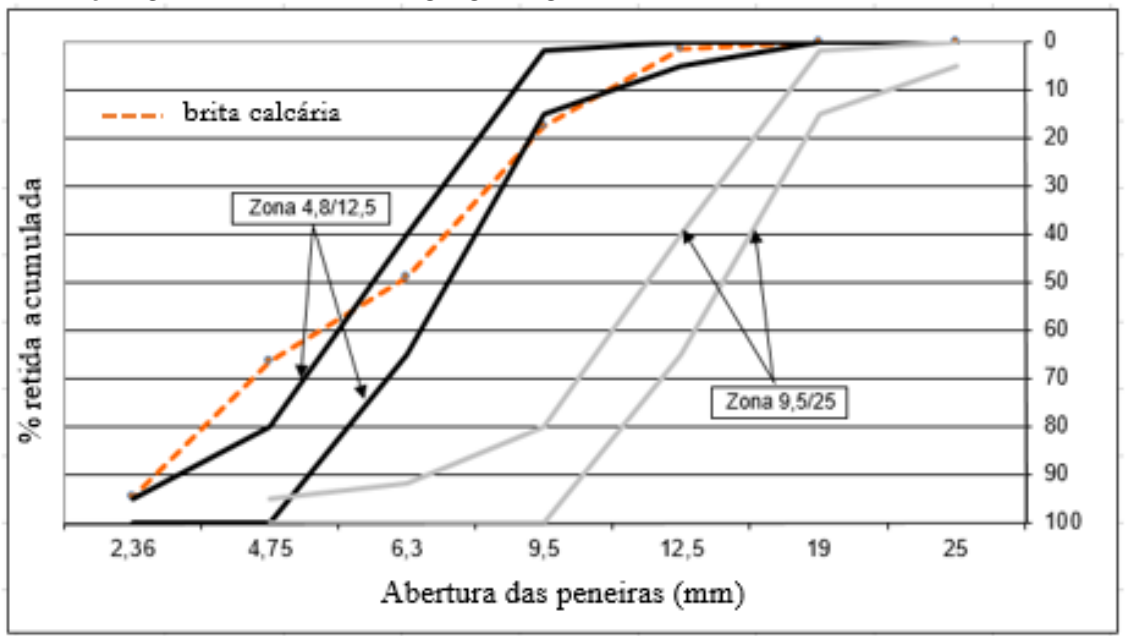

Fonte: Próprio autor.

\subsubsection{Aditivo superplastificante}

Foi selecionado, entre aditivos de mesmo fabricante, o aditivo superplastificante à base de policarboxilato de sódio que fosse capaz de conferir uma autoadensabilidade mais adequada e duradoura à argamassa, de acordo com os propósitos e limites adotados na presente pesquisa. Para isso, foi feito um estudo em argamassas de relação água/sólidos (em volume) igual a 0,45, considerado a primeira etapa do programa experimental desta tese. Nessa avaliação, considerou-se os resultados de espalhamento e de fluidez das argamassas diante da adoção das seguintes variáveis independentes: tempo (níveis: $30 \mathrm{~min}, 60 \mathrm{~min}$ e $90 \mathrm{~min}$ ); tipo de aglomerante (níveis: referência, $20 \%$ de substituição (em massa) de fíler calcário, $30 \%$ de substituição (em massa) de fíler calcário); superplastificante (níveis: SP1; SP2; SP3) e teor de aditivo em função do consumo de aglomerante (níveis: 0,6\%, 0,8\%, 1,0\%, 1,2\%, 1,4\%). Dessa forma, foi possível constatar que o aditivo superplastificante SP3, de maior teor de resíduo sólido (conforme está apresentado na Tabela 13), propiciou um melhor desempenho às argamassas no que tange à propriedade de autoadensabilidade. A partir daí, esse aditivo foi adotado para produção de argamassas e de concretos em outras etapas subsequentes do programa experimental desta tese. $\mathrm{Na}$ Tabela 13, encontram-se as principais características dos aditivos superplastificantes estudados. 
Tabela 13 - Principais características dos aditivos a base de policarboxilato de sódio empregados na presente

\begin{tabular}{|c|c|c|c|c|c|c|}
\hline \multirow[b]{2}{*}{$\begin{array}{l}\text { Tipo } \\
\text { SP }\end{array}$} & \multicolumn{2}{|c|}{$\begin{array}{c}\text { Teor de sólidos } \\
\text { NBR } 10908 \text { (1990) }\end{array}$} & \multirow[b]{2}{*}{ pH } & \multirow[b]{2}{*}{$\begin{array}{c}\text { Densidade } \\
\left(\mathrm{g} / \mathrm{cm}^{3}\right)\end{array}$} & \multirow[b]{2}{*}{$\begin{array}{l}\text { Recomendações } \\
\text { técnicas }\end{array}$} & \multirow{2}{*}{$\begin{array}{l}\text { Dosagem } \\
\text { recomendada } \\
\text { (\% sobre } \\
\text { aglomerante } \\
\text { - em massa) }\end{array}$} \\
\hline & $\begin{array}{c}\text { Referência } \\
\text { do } \\
\text { fabricante } \\
(\%) \\
\end{array}$ & $\begin{array}{c}\text { Determinado } \\
\text { experimentalmente } \\
(\%)\end{array}$ & & & & \\
\hline SP1 & 34,00 & 13,90 & 6,0 & 1,06 & $\begin{array}{l}\text { Concreto em geral, fluido } \\
\text { ou autoadensável. } \\
\text { Proporciona ótima } \\
\text { redução da demanda água, } \\
\text { ótimas resistências } \\
\text { iniciais e excelente } \\
\text { manutenção de } \\
\text { abatimento. }\end{array}$ & 0,4 a 1,2 \\
\hline SP2 & 20,00 & 9,07 & 6,0 & 1,06 & $\begin{array}{c}\text { Excelente poder } \\
\text { dispersante permitindo } \\
\text { grande redução da relação } \\
\text { água/cimento e aumento } \\
\text { de resistências iniciais e } \\
\text { finais. Menor } \\
\text { incorporação de ar. }\end{array}$ & 0,5 a 1,0 \\
\hline SP3 & 40,00 & 37,56 & 6,0 & 1,09 & $\begin{array}{c}\text { Concretos de alto } \\
\text { desempenho, } \\
\text { autoadensável, para pré- } \\
\text { moldados e para artefatos } \\
\text { de cimento - proporciona } \\
\text { manutenção da } \\
\text { trabalhabilidade por } \\
\text { elevados períodos e } \\
\text { obtenção de elevadas } \\
\text { resistências iniciais e } \\
\text { finais }\end{array}$ & 0,3 a 1,2 \\
\hline
\end{tabular}

Fonte: Próprio autor.

\subsection{ETAPAS DO PROGRAMA EXPERIMENTAL}

Inicialmente, cabe frisar que foram realizados estudos preliminares com o intuito de definir o procedimento laboratorial, definir parâmetros de mistura das argamassas e dos concretos e avaliar o emprego de alguns ensaios que estão apresentados no Apêndice A. Estes estudos, também, estão apresentados por meio dos seguintes trabalhos: Mendes e Bauer (2014) e Mendes e Bauer (2015).

Diante disso, foi possível definir as etapas do programa experimental deste trabalho com objetivo principal de produzir concretos autoadensáveis de acordo com norma ABNT NBR 15823 - 1 (2010), a partir de estudos em argamassas. Para tanto, na primeira etapa, estudou-se a influência de diferentes aditivos superplastificantes de mesma base química, policaborxilato de sódio, na trabalhabilidade das argamassas, a fim de identificar o aditivo superplastificante mais adequado para ser empregado nas etapas seguintes do programa experimental. Na segunda etapa, empregou-se o aditivo superplastificante selecionado na etapa anterior, em novas proporções de argamassas que também foram avaliadas quanto à sua trabalhabilidade e, por 
fim, selecionou-se as prováveis argamassas que poderiam servir como referência para produção de concretos autoadensáveis. Em seguida, na terceira etapa, os concretos foram produzidos com base nas proporções das argamassas tomadas como referências, os quais foram submetidos aos ensaios nos estados fresco e endurecido. Na Figura 23, está apresentado o fluxograma do programa experimental para o estudo no estado fresco de argamassas e de concretos, bem como a obtenção de características mecânicas dos concretos.

Figura 23 - Fluxograma do Programa Experimental para o estudo das argamassas e dos concretos.

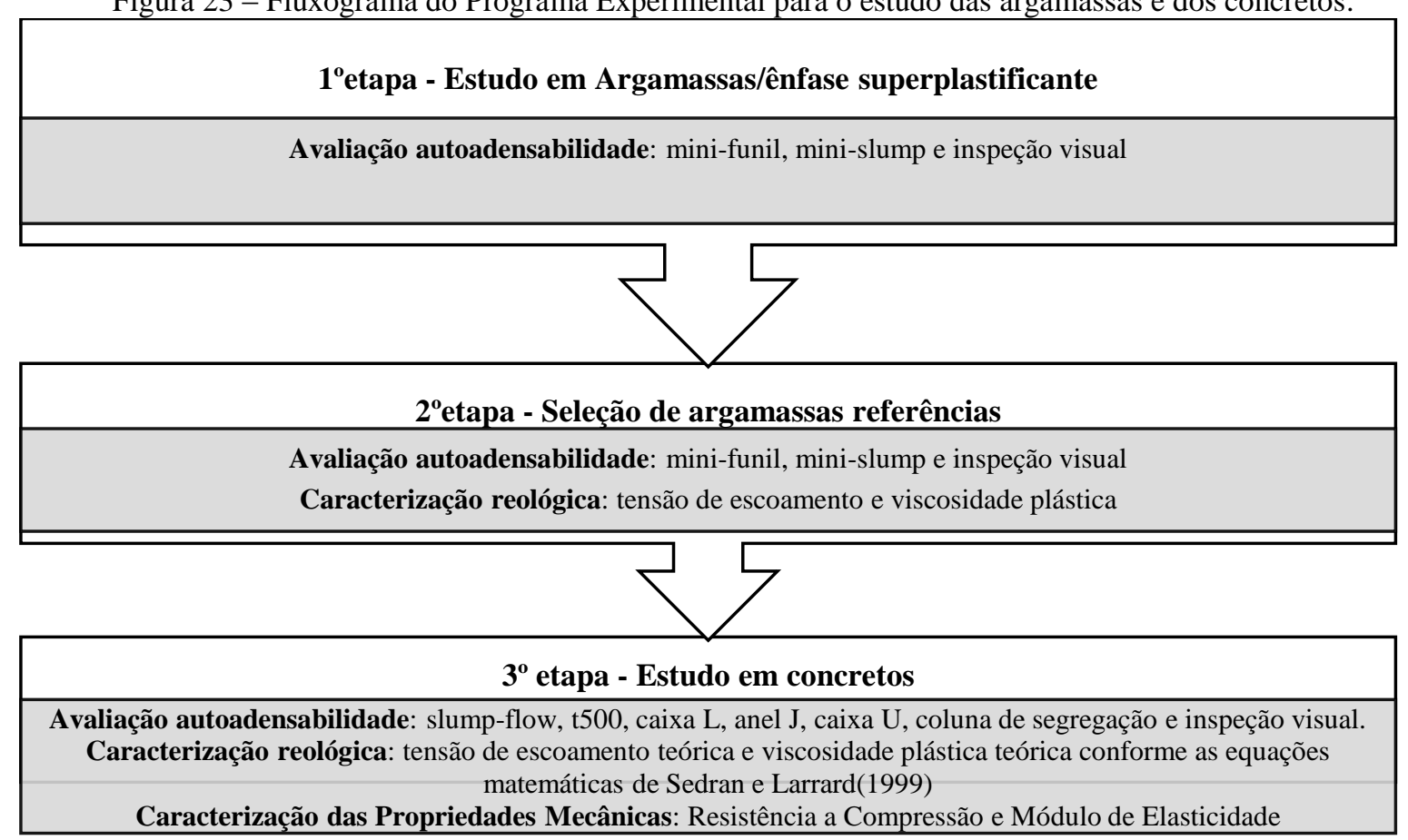

Fonte: Próprio autor.

\subsubsection{Primeira Etapa}

A primeira etapa consistiu em avaliar o desempenho de três aditivos superplastificante de base química de policarboxilato de sódio, provindos de mesmo fabricante, frente aos ensaios que avaliam trabalhabilidade, tais como: mini-slump (espalhamento) e mini-funil (fluidez). Para isso, produziram-se argamassas com relação água/sólidos igual a 0,45 , sendo esta uma condição fixa adotada de acordo com os valores de relação água/sólidos considerados por Mendes e Bauer (2014) e Mendes e Bauer (2015). Estas argamassas sofreram variação na mistura com as seguintes variáveis independentes: tipo de aglomerante, tipo de superplastificante e teor de superplatificante. Além disso, neste estudo considerou-se a variável tempo para coletar as medidas de espalhamento e fluidez. Na Figura 24, são apresentadas as variáveis independentes 
e seus níveis e as variáveis dependentes, bem como as combinações dessas variáveis para cumprir com o estudo referente à primeira etapa do programa experimental da tese.

Figura 24 - Apresentação das variáveis independentes e dependentes para o estudo em argamassas com ênfase na influência do superplastificante $-1^{\mathrm{a}}$ Etapa.

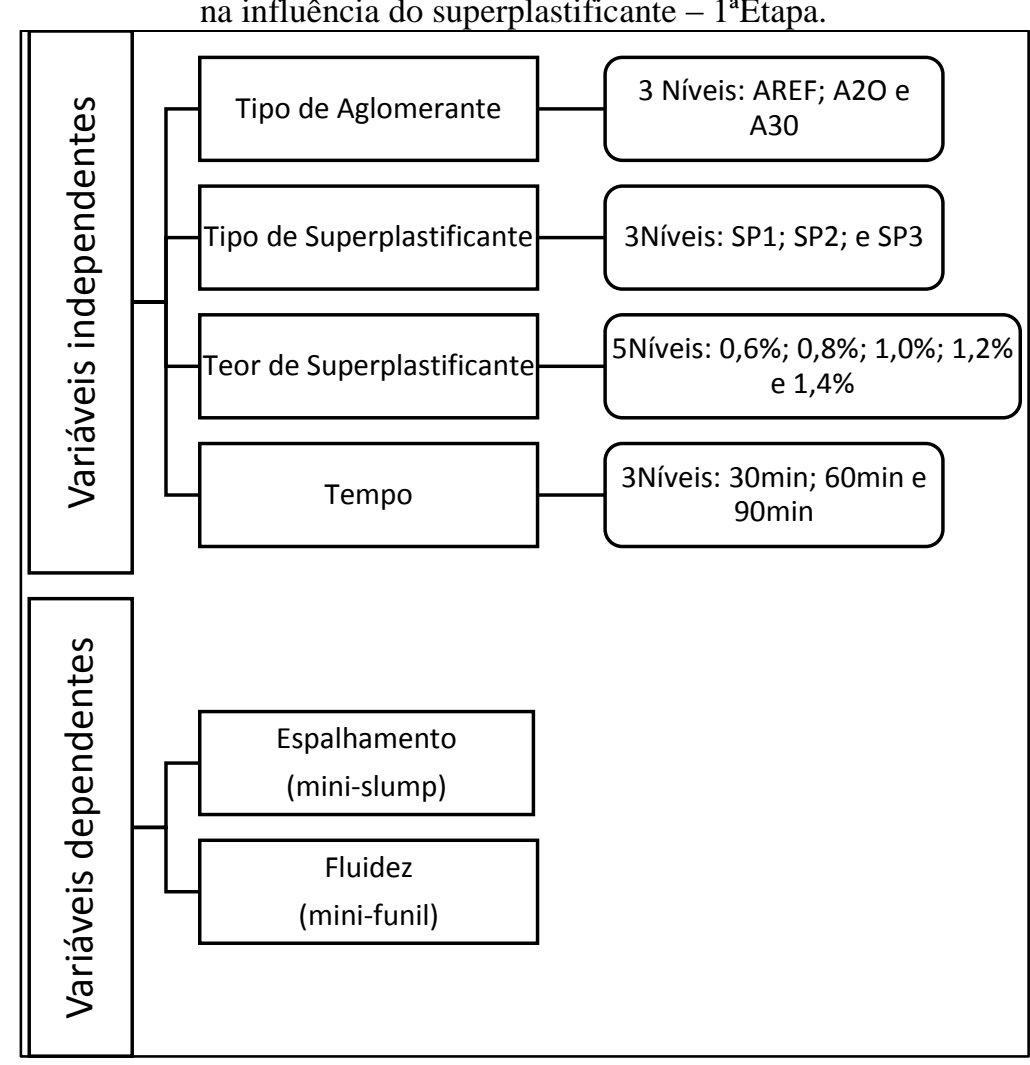

Fonte: Próprio autor.

Verifica-se, na Figura 24, que as variáveis tipo de aglomerante, tipo de superplastificante e tempo possuem três níveis de variação, enquanto que a variável teor de SP possui cinco níveis de variação. Esses níveis de variação foram adotados de acordo com as justificativas, a seguir:

- tipo de aglomerante (AREF, A20, A30): AREF significa um aglomerante com 100\% de cimento; A20 significa um aglomerante com substituição (em massa) de $20 \%$ do cimento por fíler calcário e A30 significa um aglomerante com substituição (em massa) de 30\% do cimento por fíler calcário. Considerou-se uma substituição do cimento (em massa) de até $30 \%$, com intuito de se obter concretos com consumo aproximado de cimento de $300 \mathrm{~kg} / \mathrm{m}^{3}$. Este consumo é comumente aplicado para produção de concretos convencionais e, decidiu-se, também, aplicar esse consumo para produção de concretos autoadensáveis com vistas na economia e sustentabilidade; 
- tipo de superplastificante (SP1, SP2, SP3): os três tipos de superplastificante são à base de policarboxilato de sódio provindos de mesmo fabricante. Neste caso, buscou-se identificar o aditivo que melhor conferiu trabalhabilidade às argamassas e, assim, adotá-lo para cumprimento das etapas subsequentes;

- teor de aditivo em função da massa do aglomerante $(0,6 \% ; 0,8 \% ; 1,0 \% ; 1,2 \% ; 1,4 \%)$ : os teores de aditivo considerados neste presente estudo, foram extraídos do intervalo de dosagem recomendado pelo fabricante, conforme está apresentado na Tabela 13, exceto o teor de $1,4 \%$ que está fora do intervalo. Considerou-se mais níveis de variação para essa variável independente, devido $\mathrm{o}$ fato da importância de visualizar o comportamento da autoadensabilidade da argamassa, possibilitando identificar o teor máximo de SP necessário para promover boas características de trabalhabilidade (autoadensabilidade);

- tempo (30 min; $60 \mathrm{~min} ; 90 \mathrm{~min}$ ): foi adotada esta variável, a fim de verificar a perda de trabalhabilidade da argamassa com decorrer do tempo.

Com relação às variáveis dependentes, as quais respondem às características de trabalhabilidade (autoadensabilidade) de cada argamassa, têm-se o espalhamento da argamassa, obtido por meio de um mini-slump, e a viscosidade (fluidez), obtida por meio de um mini-funil. As combinações dessas variáveis geraram 45 argamassas, levando-se o cumprimento de 135 situações de estudo. Isso significa que cada argamassa produzida gerou 3 situações de estudo. Por fim, na Tabela 14, está apresentado o quantitativo de materiais para produção de argamassas de relação água/sólidos igual a 0,45 e com emprego de um superplastificante. 
Tabela 14 - Quantitativo de materiais das argamassas produzidas com emprego de um tipo de superplastificante.

\begin{tabular}{|c|c|c|c|c|c|c|c|c|c|c|c|}
\hline \multirow{3}{*}{$\begin{array}{c}\text { ARGAMASSA } \\
\text { (3x) }\end{array}$} & \multirow{3}{*}{$\begin{array}{c}\text { Rel.a/s } \\
\text { (em } \\
\text { volume) }\end{array}$} & \multicolumn{3}{|c|}{ Aglomerante } & \multirow[t]{3}{*}{$\mathrm{Vs} / \mathrm{Vm}$} & \multirow[t]{3}{*}{$\mathbf{V p} / \mathbf{V s}$} & \multirow{3}{*}{$\begin{array}{c}\text { Areia } \\
\text { rosa } \\
\left(\mathbf{k g} / \mathbf{m}^{3}\right)\end{array}$} & \multirow{3}{*}{$\begin{array}{c}\text { Areia } \\
\text { art. } \\
\left(\mathrm{kg} / \mathrm{m}^{3}\right)\end{array}$} & \multirow{3}{*}{$\begin{array}{c}\text { Água } \\
\left(\mathbf{k g} / \mathbf{m}^{3}\right)\end{array}$} & \multicolumn{2}{|c|}{ Aditivo-SP } \\
\hline & & \multirow{2}{*}{$\begin{array}{c}\text { Cimento } \\
\left(\mathrm{kg} / \mathrm{m}^{3}\right)\end{array}$} & \multicolumn{2}{|c|}{ Fíler calcário } & & & & & & & $\left(1 / m^{3}\right)$ \\
\hline & & & Subst. & $\left(\mathrm{kg} / \mathrm{m}^{3}\right)$ & & & & & & $(\%)$ & \\
\hline \multirow{5}{*}{ AREF } & 0,45 & 606 & 0 & 0 & 0,49 & 0,41 & 382 & 891 & 303 & 0,6 & 4,0 \\
\hline & 0,45 & 606 & 0 & 0 & 0,49 & 0,41 & 382 & 891 & 303 & 0,8 & 5,3 \\
\hline & 0,45 & 606 & 0 & 0 & 0,49 & 0,41 & 382 & 891 & 303 & 1,0 & 6,6 \\
\hline & 0,45 & 606 & 0 & 0 & 0,49 & 0,41 & 382 & 891 & 303 & 1,2 & 7,9 \\
\hline & 0,45 & 606 & 0 & 0 & 0,49 & 0,41 & 382 & 891 & 303 & 1,4 & 9,2 \\
\hline \multirow{5}{*}{ A20 } & 0,45 & 485 & $20 \%$ & 121 & 0,48 & 0,43 & 382 & 891 & 303 & 0,6 & 4,0 \\
\hline & 0,45 & 485 & $20 \%$ & 121 & 0,48 & 0,43 & 382 & 891 & 303 & 0,8 & 5,3 \\
\hline & 0,45 & 485 & $20 \%$ & 121 & 0,48 & 0,43 & 382 & 891 & 303 & 1,0 & 6,6 \\
\hline & 0,45 & 485 & $20 \%$ & 121 & 0,48 & 0,43 & 382 & 891 & 303 & 1,2 & 7,9 \\
\hline & 0,45 & 485 & $20 \%$ & 121 & 0,48 & 0,43 & 382 & 891 & 303 & 1,4 & 9,2 \\
\hline \multirow{5}{*}{ A30 } & 0,45 & 424 & $30 \%$ & 182 & 0,48 & 0,43 & 382 & 891 & 303 & 0,6 & 4,0 \\
\hline & 0,45 & 424 & $30 \%$ & 182 & 0,48 & 0,43 & 382 & 891 & 303 & 0,8 & 5,3 \\
\hline & 0,45 & 424 & $30 \%$ & 182 & 0,48 & 0,43 & 382 & 891 & 303 & 1,0 & 6,6 \\
\hline & 0,45 & 424 & $30 \%$ & 182 & 0,48 & 0,43 & 382 & 891 & 303 & 1,2 & 7,9 \\
\hline & 0,45 & 424 & $30 \%$ & 182 & 0,48 & 0,43 & 382 & 891 & 303 & 1,4 & 9,2 \\
\hline Onde: & \multirow{4}{*}{\multicolumn{11}{|c|}{$\begin{array}{l}\text { relação água/sólidos } \\
\text { relação entre o volune de areia e volume de argamassa } \\
\text { Relação entre o volume de finos e volume de areia }\end{array}$}} \\
\hline Rel. a/s & & & & & & & & & & & \\
\hline $\mathrm{Vs} / \mathrm{Vm}$ & & & & & & & & & & & \\
\hline $\mathrm{Vp} / \mathrm{Vs}$ & & & & & & & & & & & \\
\hline
\end{tabular}
Fonte: Próprio autor.

\subsubsection{Segunda Etapa}

A segunda etapa do estudo consistiu na avaliação da trabalhabilidade das argamassas com emprego do aditivo selecionado na primeira etapa, a fim de identificar as prováveis argamassas referências de concretos autoadensáveis. Assim sendo, elas foram submetidas aos ensaios de mini-slump e mini-funil, assim como foram avaliadas quanto à estabilidade (resistência à segregação) por inspeção visual, conforme ilustra na Figura 26. Nesta etapa, foram consideradas as seguintes variáveis independentes com os respectivos níveis:

- relação água/sólidos - em volume (níveis: 0,40; 0,45 e 0,50): os níveis de variação adotados foram extraídos boa parte da faixa de valores considerada por Mendes e Bauer (2015), os quais afirmam que esses valores podem alcançar argamassas referêncas de CAA. Para tanto, nesta etapa, foram produzidas argamassas de relação água/sólidos iguais 0,40 e 0,50, enquanto as argamassas de relação água/sólido igual 0,45 , consideraram os seus resultados obtidos na $1^{\circ}$ etapa;

- tipo de aglomerante (AREF, A20 e A30): ver a justificativa do emprego desta variável apresentada no subitem 3.2.1;

- teor de aditivo em função da massa do aglomerante: vale ressaltar que os teores de aditivo adotados neste presente estudo, foram extraídos do intervalo de dosagem recomendado 
pelo fabricante, conforme está apresentado na Tabela 13, exceto o teor de 1,4\% que está fora do intervalo. Nesta etapa, para as argamassas de relação água/sólidos igual a 0,45, considerouse os resultados das argamassas em cinco níveis de teor de aditivo, os quais foram determinados na primeira etapa. As demais argamassas com relação água/sólidos 0,40 e 0,50 sofreram variação em três níveis, tendo em comum o teor de $1 \%$ (considerado como ponto de saturação na primeira etapa), outros teores foram definidos de acordo com avaliação da estabilidade da argamassa por inspeção visual;

- tempo (30 min; $60 \mathrm{~min} ; 90 \mathrm{~min}$ ): ver a justificativa do emprego desta variável apresentada no subitem 3.2.1.

A seguir, na Figura 25, estão apresentadas as variáveis independentes e dependentes consideradas nesta etapa. 
Figura 25 - Apresentação das variáveis independentes e dependentes para o estudo em argamassas, a fim de identificar as prováveis argamassas referências de concretos autoadensáveis - $2^{\mathrm{a}}$ etapa.

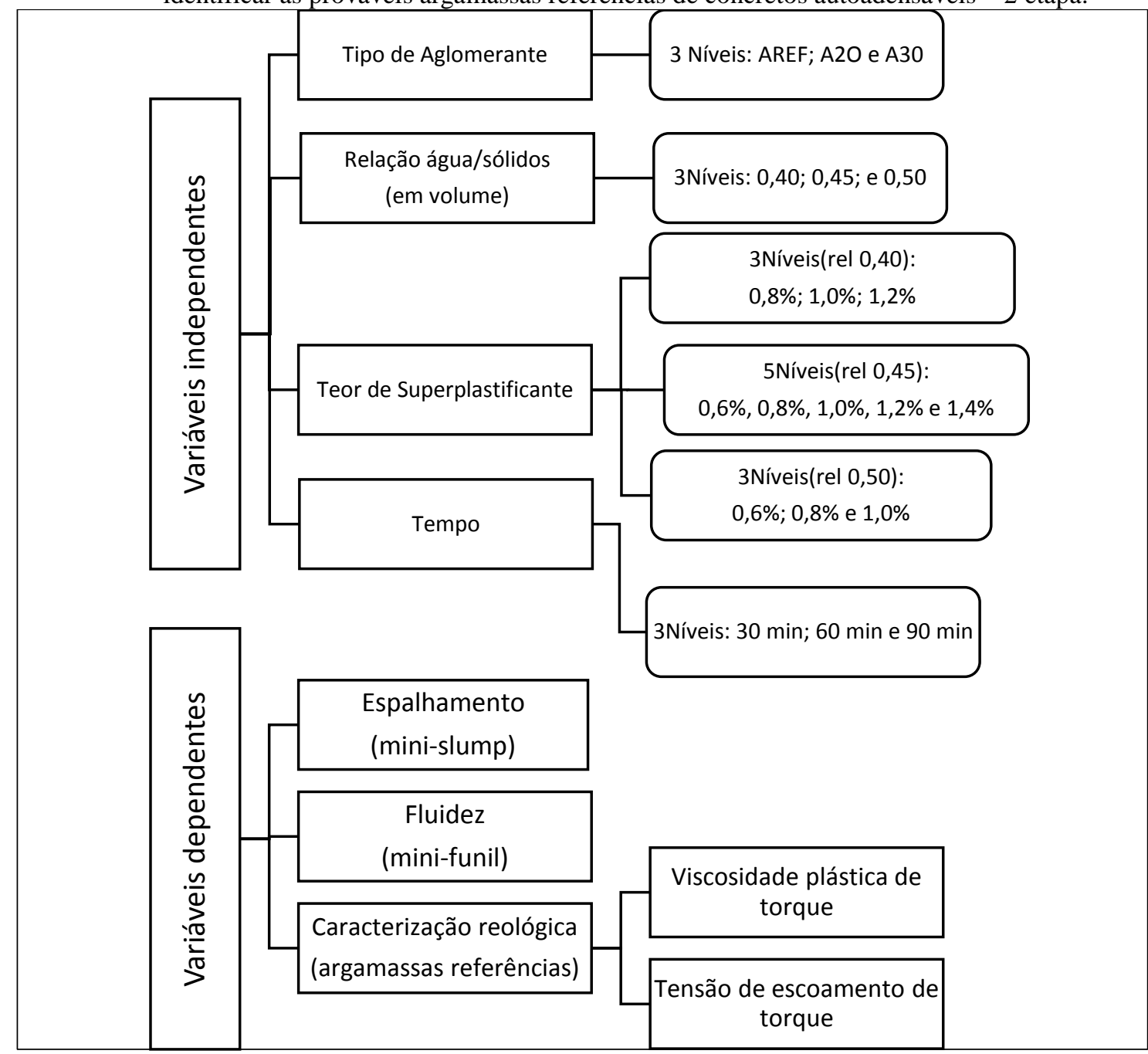

Fonte: Próprio autor.

No total foram avaliadas 33 argamassas, das quais 18 foram selecionadas para servirem como referência no alcance de concretos autoadensáveis. As argamassas foram selecionadas de acordo com seus resultados apresentados no tempo de ensaio igual a $30 \mathrm{~min}$, as quais cumpriram com os seguintes quesitos e tolerâncias:

- consideraram-se as argamassas com espalhamento próximo e superior a $230 \mathrm{~mm}$ e tempo de fluidez máximo de 10 segundos $(113 \mathrm{ml} / \mathrm{s})$, dentro dos valores recomendados por EFNARC (2005) e encontrados por Nepomuceno et al.(2014), Güneyisi et al. (2016);

- para misturas com proporções iguais de materiais secos e água, selecionou-se duas argamassas; 
- com relação à estabilidade no estado fresco, por inspeção visual, foram consideradas as argamassas coesas e as iminentes para exsudar e segregar, como ilustra a Figura 26.

- na Figura 27, têm-se exemplos de argamassas não selecionadas por inspeção visual. Primeiramente, na Figura 27(a), está exemplificada a argamassa que não atendeu as tolerâncias supracitadas dos ensaios de mini-slump e mini-funil, a qual apresentou no seu espalhamento, uma aparência muito consistente, a ponto de se ter um espalhamento com formato de um "prato invertido". Enquanto na Figura 27(b), está exemplificada a argamassa que sofreu exsudação e segregação.

Figura 26 - Aparência superficial das argamassas no estado fresco: (a) argamassa coesa; (b) argamassa iminente

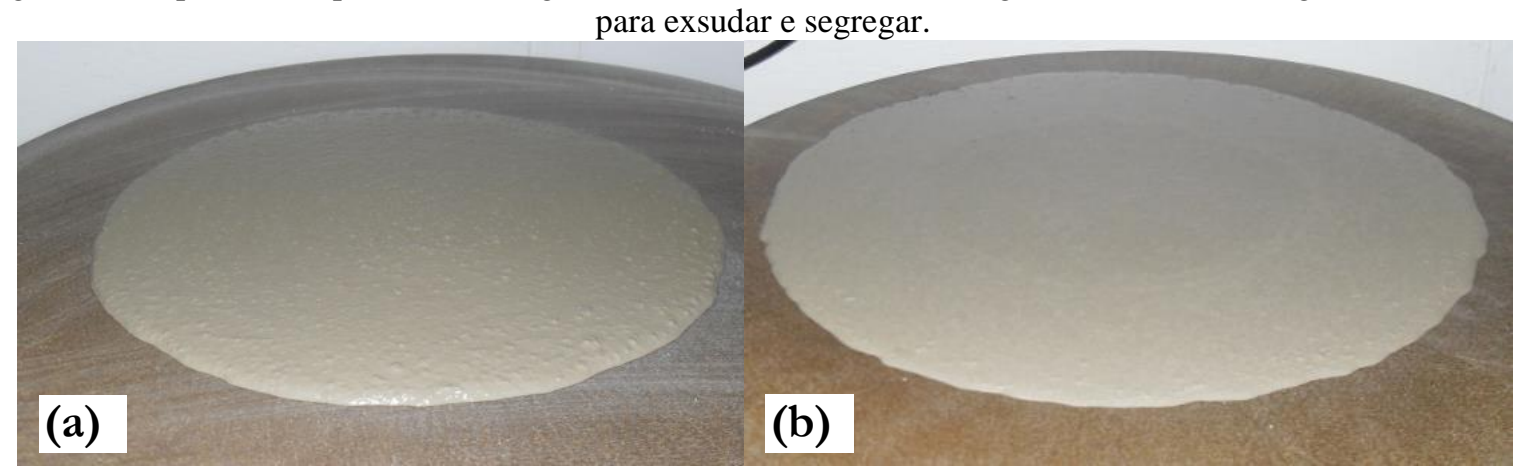

Fonte: Próprio autor.

Figura 27 - Aparência superficial das argamassas no estado fresco: (a) argamassa muito consistente (forma de prato invertido); (b) exemplo de argamassa que sofreu segregação e exsudação.

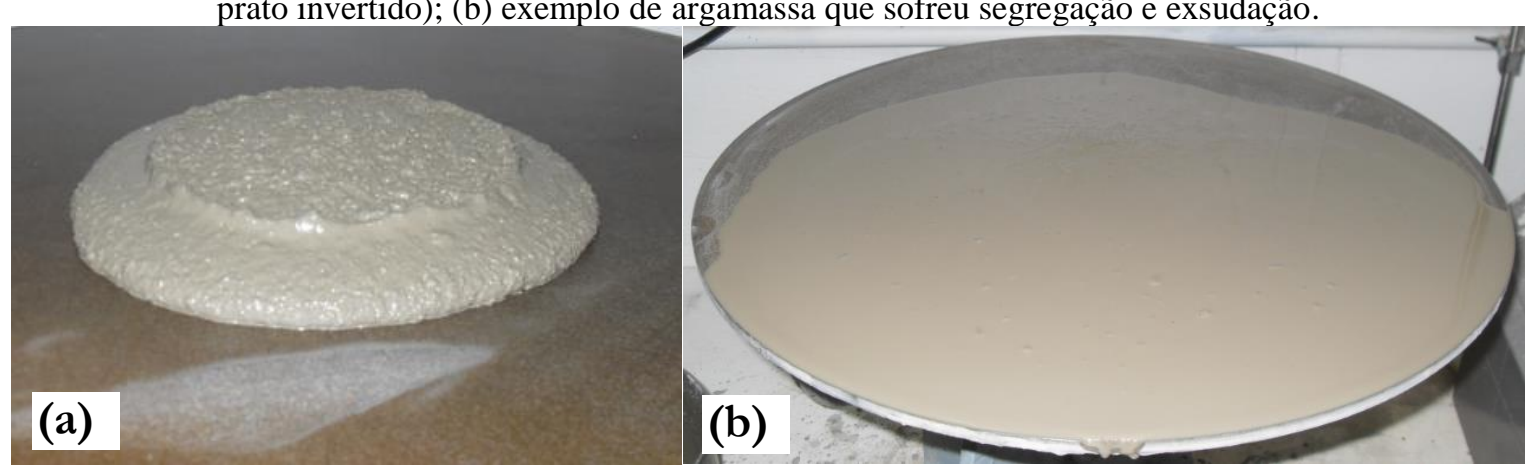

A seguir, na Figura 28, consta um esquema apresentando as argamassas selecionadas como referências de concretos autoadensáveis, as quais estão assinaladas em verde. As células de cor vermelha representam as argamassas que não atenderam aos requisitos de autoadensabilidade exigidos neste estudo. As células hachuradas de cor cinza representam as argamassas que não foram produzidas. Após a seleção, as argamassas selecionadas como referência foram submetidas à caracterização reológica em um reômetro coaxial da marca Rheotest RN 4.1, no 
qual foram obtidos os parâmetros de viscosidade plástica de torque e tensão de escoamento de torque.

Figura 28 - Esquema que apresenta as argamassas selecionadas para servirem como referências dos concretos autoadensáveis.

\begin{tabular}{|c|c|c|c|c|c|c|c|}
\hline \multirow{15}{*}{ 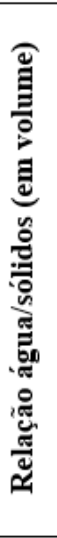 } & \multirow{5}{*}{$\stackrel{\text { fo }}{s}$} & Tipo de aglomerante & \multicolumn{5}{|c|}{ Teor de superplastificante(\%) } \\
\hline & & & 0,6 & 0,8 & 1,0 & 1,2 & 1,4 \\
\hline & & $\mathrm{AREF}-100 \%$ clínquer & $\overline{\mathrm{NP}}$ & NS & $\mathrm{S}$ & $\mathrm{S}$ & $\overline{\mathrm{NP}}$ \\
\hline & & A20 - $20 \%$ subst. por filer calcário & NP & NS & $\mathrm{S}$ & $\mathrm{S}$ & NP \\
\hline & & A $30-30 \%$ subst. por filer calcário & NP & NS & $\mathrm{S}$ & $\mathrm{S}$ & $\mathrm{NP}$ \\
\hline & & Tipo de aglomerante & \multicolumn{5}{|c|}{ Teor de superplastificante(\%) } \\
\hline & \multirow{4}{*}{$\stackrel{10}{6}$} & & 0,6 & 0,8 & 1,0 & 1,2 & 1,4 \\
\hline & & AREF & NS & $\mathrm{S}$ & $\mathrm{S}$ & NS & NS \\
\hline & & A20 - $20 \%$ subst. por filer calcário & NS & $\mathrm{S}$ & $\mathrm{S}$ & NS & NS \\
\hline & & A30 - $30 \%$ subst. por filer calcário & NS & $\mathrm{S}$ & $\mathrm{S}$ & NS & NS \\
\hline & & Tipo de aglomerante & \multicolumn{5}{|c|}{ Teor de superplastificante(\%) } \\
\hline & \multirow{4}{*}{ 占 } & & 0,6 & 0,8 & 1,0 & 1,2 & 1,4 \\
\hline & & AREF & $\mathrm{S}$ & $\mathrm{S}$ & NS & NP & NP \\
\hline & & A20 - $20 \%$ subst. por filer calcário & $\mathrm{S}$ & $\mathrm{S}$ & NS & NP & NP \\
\hline & & A30 - 30\% subst. por filer calcário & $\mathrm{S}$ & $\mathrm{S}$ & NS & NP & NP \\
\hline \multicolumn{8}{|c|}{ Legenda: } \\
\hline & & $\begin{array}{l}\text { gamassas não selecionadas (NS); } \\
\text { gamassas selecionadas (S); } \\
\text { uações de estudo que não foram }\end{array}$ & & & & & \\
\hline
\end{tabular}

Fonte: Próprio autor.

O quantitativo das argamassas de relação água/sólidos iguais a 0,40 e 0,50 está apresentado na Tabela 15. 
Tabela 15 - Quantitativo de materiais das argamassas produzidas na segunda etapa do Programa Experimental.

\begin{tabular}{|c|c|c|c|c|c|c|c|c|c|c|c|}
\hline \multirow{3}{*}{ ARGAMASSA } & \multirow{3}{*}{$\begin{array}{c}\text { Rel. a/s } \\
(\mathbf{e m} \\
\text { volume })\end{array}$} & \multicolumn{3}{|c|}{ Aglomerante } & \multirow[t]{3}{*}{$\mathbf{V s} / \mathbf{V m}$} & \multirow[t]{3}{*}{$\mathbf{V p} / \mathbf{V s}$} & \multirow{3}{*}{$\begin{array}{c}\text { Areia } \\
\text { rosa } \\
\left(\mathrm{kg} / \mathrm{m}^{3}\right)\end{array}$} & \multirow{3}{*}{$\begin{array}{l}\text { Areia } \\
\text { art. } \\
\left(\mathrm{kg} / \mathrm{m}^{3}\right)\end{array}$} & \multirow{3}{*}{$\begin{array}{c}\text { Água } \\
\left(\mathbf{k g} / \mathbf{m}^{3}\right)\end{array}$} & \multicolumn{2}{|c|}{ Aditivo-SP } \\
\hline & & \multirow{2}{*}{$\begin{array}{c}\text { Cimento } \\
\left(\mathrm{kg} / \mathbf{m}^{3}\right)\end{array}$} & \multicolumn{2}{|c|}{ Fíler calcário } & & & & & & & $\left(1 / \mathrm{m}^{3}\right)$ \\
\hline & & & Subst. & $\left(\mathrm{kg} / \mathrm{m}^{3}\right)$ & & & & & & (\%) & $\left(1 / \mathbf{m}^{*}\right)$ \\
\hline \multirow{3}{*}{ AREF } & 0,40 & 630 & 0 & 0 & 0,51 & 0,41 & 397 & 926 & 277 & 0,8 & 5,5 \\
\hline & 0,40 & 630 & 0 & 0 & 0,51 & 0,41 & 397 & 926 & 277 & 1,0 & 6,9 \\
\hline & 0,40 & 630 & 0 & 0 & 0,51 & 0,41 & 397 & 926 & 277 & 1,2 & 8,2 \\
\hline \multirow{3}{*}{ A20 } & 0,40 & 504 & $20 \%$ & 126 & 0,50 & 0,43 & 397 & 926 & 277 & 0,8 & 5,5 \\
\hline & 0,40 & 504 & $20 \%$ & 126 & 0,50 & 0,43 & 397 & 926 & 277 & 1,0 & 6,9 \\
\hline & 0,40 & 504 & $20 \%$ & 126 & 0,50 & 0,43 & 397 & 926 & 277 & 1,2 & 8,2 \\
\hline \multirow{3}{*}{ A30 } & 0,40 & 441 & $30 \%$ & 189 & 0,50 & 0,43 & 397 & 926 & 277 & 0,8 & 5,5 \\
\hline & 0,40 & 441 & $30 \%$ & 189 & 0,50 & 0,43 & 397 & 926 & 277 & 1,0 & 6,9 \\
\hline & 0,40 & 441 & $30 \%$ & 189 & 0,50 & 0,43 & 397 & 926 & 277 & 1,2 & 8,2 \\
\hline \multirow{3}{*}{ AREF } & 0,50 & 588 & 0 & 0 & 0,47 & 0,41 & 370 & 864 & 323 & 0,6 & 3,8 \\
\hline & 0,50 & 588 & 0 & 0 & 0,47 & 0,41 & 370 & 864 & 323 & 0,8 & 5,1 \\
\hline & 0,50 & 588 & 0 & 0 & 0,47 & 0,41 & 370 & 864 & 323 & 1,0 & 6,4 \\
\hline \multirow{3}{*}{ A20 } & 0,50 & 470 & $20 \%$ & 118 & 0,47 & 0,43 & 370 & 864 & 323 & 0,6 & 3,8 \\
\hline & 0,50 & 470 & $20 \%$ & 118 & 0,47 & 0,43 & 370 & 864 & 323 & 0,8 & 5,1 \\
\hline & 0,50 & 470 & $20 \%$ & 118 & 0,47 & 0,43 & 370 & 864 & 323 & 1,0 & 6,4 \\
\hline \multirow{3}{*}{ A30 } & 0,50 & 412 & $30 \%$ & 176 & 0,47 & 0,43 & 370 & 864 & 323 & 0,6 & 3,8 \\
\hline & 0,50 & 412 & $30 \%$ & 176 & 0,47 & 0,43 & 370 & 864 & 323 & 0,8 & 5,1 \\
\hline & 0,50 & 412 & $30 \%$ & 176 & 0,47 & 0,43 & 370 & 864 & 323 & 1,0 & 6,4 \\
\hline Onde: & \multirow{2}{*}{\multicolumn{11}{|c|}{$\begin{array}{l}\text { relação água/sólidos } \\
\text { relação entre o volune de areia e volume de argamassa } \\
\text { relação entre o volume de finos e volume de areia }\end{array}$}} \\
\hline $\begin{array}{l}\text { Rel. a/s } \\
\text { Vs/Vm } \\
\text { Vp/Vs }\end{array}$ & & & & & & & & & & & \\
\hline
\end{tabular}
Fonte: Próprio autor.

\subsubsection{Terceira Etapa}

Os concretos foram produzidos a partir das proporções das argamassas referências supracitadas e, também, com base nas proporções dos materiais recomendados pelo ACI 237R-07 (2007), conforme está apresentado na Tabela 2, capítulo 2.

Dessa forma, os concretos tiveram as seguintes proporções dos materiais, aproximadamente: consumo de aglomerante médio igual $430 \mathrm{~kg} / \mathrm{m}^{3}$, fração percentual de pasta igual 38\%, fração percentual de argamassa igual a $72 \%$ e percentual de agregado graúdo igual a $29 \%$. Na Tabela 16 está apresentado o quantitativo dos materiais empregados nos concretos de acordo com as argamassas referências. 
Tabela 16 - Quantitativo dos materiais empregados nos concretos de acordo com as argamassas referências.

\begin{tabular}{|c|c|c|c|c|c|c|c|c|c|}
\hline \multirow{3}{*}{ CONCRETO } & \multicolumn{3}{|c|}{ Aglomerante } & \multirow{3}{*}{$\begin{array}{c}\text { Areia rosa } \\
\left(\mathbf{k g} / \mathbf{m}^{3}\right)\end{array}$} & \multirow{3}{*}{$\begin{array}{c}\text { Areia art. } \\
\left(\mathbf{k g} / \mathbf{m}^{3}\right)\end{array}$} & \multirow{3}{*}{$\begin{array}{c}\text { Brita - } \\
12 \mathrm{~mm} \\
\left(\mathrm{~kg} / \mathrm{m}^{3}\right)\end{array}$} & \multirow{3}{*}{$\begin{array}{c}\text { Água } \\
\left(\mathbf{k g} / \mathbf{m}^{3}\right)\end{array}$} & \multicolumn{2}{|c|}{ Aditivo SP } \\
\hline & \multirow{2}{*}{$\begin{array}{c}\text { Cimento } \\
\left(\mathrm{kg} / \mathrm{m}^{3}\right)\end{array}$} & \multicolumn{2}{|c|}{$\begin{array}{c}\text { Fíler } \\
\left(\mathbf{k g} / \mathbf{m}^{3}\right)\end{array}$} & & & & & $(\%)$ & litro \\
\hline & & $\%$ & $\mathrm{~kg} / \mathrm{m}^{3}$ & & & & & & \\
\hline $1 \mathrm{C}$ & 441 & 0 & 0 & 278 & 648 & 794 & 194 & 1,0 & 4,0 \\
\hline $2 \mathrm{C}$ & 441 & 0 & 0 & 278 & 648 & 794 & 194 & 1,2 & 4,9 \\
\hline $3 \mathrm{C}$ & 353 & 20 & 88 & 278 & 648 & 794 & 194 & 1,0 & 4,0 \\
\hline $4 \mathrm{C}$ & 353 & 20 & 88 & 278 & 648 & 794 & 194 & 1,2 & 4,9 \\
\hline $5 \mathrm{C}$ & 309 & 30 & 132 & 278 & 648 & 794 & 194 & 1,0 & 4,0 \\
\hline $6 \mathrm{C}$ & 309 & 30 & 132 & 278 & 648 & 794 & 194 & 1,2 & 4,9 \\
\hline $7 \mathrm{C}$ & 429 & 0 & 0 & 270 & 631 & 773 & 215 & 0,8 & 3,1 \\
\hline $8 \mathrm{C}$ & 429 & 0 & 0 & 270 & 631 & 773 & 215 & 1,0 & 3,9 \\
\hline $9 \mathrm{C}$ & 343 & 20 & 86 & 270 & 631 & 773 & 215 & 0,8 & 3,1 \\
\hline $10 \mathrm{C}$ & 343 & 20 & 86 & 270 & 631 & 773 & 215 & 1,0 & 3,9 \\
\hline $11 \mathrm{C}$ & 300 & 30 & 129 & 270 & 631 & 773 & 215 & 0,8 & 3,1 \\
\hline $12 \mathrm{C}$ & 300 & 30 & 129 & 270 & 631 & 773 & 215 & 1,0 & 3,9 \\
\hline $13 \mathrm{C}$ & 420 & 0 & 0 & 265 & 617 & 756 & 231 & 0,6 & 2,3 \\
\hline $14 \mathrm{C}$ & 420 & 0 & 0 & 265 & 617 & 756 & 231 & 0,8 & 3,1 \\
\hline $15 \mathrm{C}$ & 336 & 20 & 84 & 265 & 617 & 756 & 231 & 0,6 & 2,3 \\
\hline $16 \mathrm{C}$ & 336 & 20 & 84 & 265 & 617 & 756 & 231 & 0,8 & 3,1 \\
\hline $17 \mathrm{C}$ & 294 & 30 & 126 & 265 & 617 & 756 & 231 & 0,6 & 2,3 \\
\hline $18 \mathrm{C}$ & 294 & 30 & 126 & 265 & 617 & 756 & 231 & 0,8 & 3,1 \\
\hline
\end{tabular}

Fonte: Próprio autor.

A terceira etapa consistiu em avaliar a autoadensabilidade dos concretos. Dessa forma, foram empregados os ensaios de slump flow, T500, anel J, caixa L, funil V, caixa U e Coluna de Segregação, conforme estão listados na Tabela 18. Estes ensaios seguiram as prescrições da norma ABNT 15823 -1 (2010), exceto o ensaio da caixa U, que seguiu as prescrições da EFNARC (2005). Efetuou-se somente uma leitura por ensaio para cada situação de estudo. Dessa forma, cada situação foi avaliada por um período aproximado de 50 min pelo fato de envolver vários ensaios. Isso justifica o fato de não considerar mais repetições por ensaio, visto que mais repetições levaria muito tempo, que, por sua vez, poderia comprometer a avaliação da autoadensabilidade dos concretos. A seguir, na Tabela 17, estão apresentadas as tolerâncias prescritas pela norma ABNT NBR15823(2010) e EFNARC (2005) para avaliar autoadensabilidade de concretos. 
Tabela 17 - Descrição das classes e das tolerâncias dos resultados dos ensaios de autoadensabilidade do concreto autoadensável.

\begin{tabular}{|c|c|c|c|}
\hline Ensaios & Referência & Classe & Tolerâncias \\
\hline \multirow{3}{*}{$\begin{array}{l}\text { slump-flow } \\
\text { (espalhamento) }\end{array}$} & \multirow[t]{3}{*}{ ABNT NBR 15823-1 (2010) } & SF1 & $550 \mathrm{~mm}$ a $650 \mathrm{~mm}$ \\
\hline & & SF2 & $660 \mathrm{~mm}$ a $750 \mathrm{~mm}$ \\
\hline & & SF3 & $760 \mathrm{~mm}$ a $850 \mathrm{~mm}$ \\
\hline \multirow{2}{*}{$\begin{array}{l}\text { T500 } \\
\text { (viscosidade plástica aparente) }\end{array}$} & \multirow[t]{2}{*}{ ABNT NBR 15823-1 (2010) } & VS1 & $\leq 2 \mathrm{~s}$ \\
\hline & & VS2 & $>2 s$ \\
\hline \multirow{2}{*}{$\begin{array}{l}\text { funil V } \\
\text { (viscosidade plástica aparente) }\end{array}$} & \multirow[t]{2}{*}{ ABNT NBR 15823-1 (2010) } & VF1 & $<9 s$ \\
\hline & & VF2 & $9 \mathrm{~s}$ a $25 \mathrm{~s}$ \\
\hline \multirow[t]{2}{*}{$\begin{array}{l}\text { anel J } \\
\text { (habilidade passante) }\end{array}$} & \multirow[t]{2}{*}{ ABNT NBR 15823-1 (2010) } & PJ1 & $\begin{array}{c}0 \mathrm{~mm} \text { a } 25 \mathrm{~mm} \text { com } 16 \\
\text { barras de aço }\end{array}$ \\
\hline & & $\mathrm{PJ} 2$ & $\begin{array}{c}25 \mathrm{~mm} \text { a } 50 \mathrm{~mm} \text { com } 16 \\
\text { barras de aço }\end{array}$ \\
\hline \multirow{2}{*}{$\begin{array}{l}\text { caixa L } \\
\text { (habilidade passante) }\end{array}$} & \multirow[t]{2}{*}{ ABNT NBR 15823-1 (2010) } & PL1 & $\begin{array}{c}\geq 0,80 \text {, com duas barras } \\
\text { de aço }\end{array}$ \\
\hline & & PL2 & $\begin{array}{c}\geq 0,80 \text {, com duas barras } \\
\text { de aco }\end{array}$ \\
\hline $\begin{array}{l}\text { caixa U } \\
\text { (habilidade passante) }\end{array}$ & EFNARC (2005) & ----- & $<30 \mathrm{~mm}$ \\
\hline \multirow[t]{2}{*}{ Coluna de segregação } & \multirow[t]{2}{*}{ ABNT NBR 15823-1 (2010) } & SR1 & $\leq 20 \%$ \\
\hline & & SR2 & $\leq 15 \%$ \\
\hline
\end{tabular}

Fonte: Próprio autor.

\subsection{MÉTODOS}

Neste item, são apresentados e discutidos os métodos empregados para avaliação das argamassas e dos concretos no estado fresco e para avaliação mecânica dos concretos no estado endurecido.

\subsubsection{Métodos empregados nas argamassas}

A seguir, são apresentados o procedimento de mistura dos materiais na produção das argamassas, métodos para avaliação da autoadensabilidade e da reologia das argamassas.

\subsubsection{Procedimento de mistura dos materiais na produção das argamassas}

As argamassas desta pesquisa foram produzidas com base nos procedimentos adotados por Fung (2010), não somente para obter o parâmetro WFT, mas, também, para submetê-las aos ensaios que avaliam a trabalhabilidade (autoadensabilidade) no estado fresco.

A mistura das argamassas foi realizada por meio de um misturador planetário de massas Hobart modelo N50, capacidade de 5 litros, com rotação em torno do eixo de 14 rpm e movimento de 
translação de $60 \mathrm{rpm}$ aproximadamente, na velocidade baixa. A seguir, está descrito o procedimento de mistura adotado nesta pesquisa para produção de argamassa:

- primeiramente, determinou-se a massa dos materiais a saber: massas de agregados, aditivos, cimento e água. Em seguida, realizou-se a homogeneização dos materiais sólidos (argamassa seca) em um recipiente durante 2 min;

- adicionou-se boa parte da água no recipiente do misturador, deixando uma pequena quantidade para remover o aditivo impregnado no béquer ;

- adicionou-se a metade da argamassa seca e a metade do aditivo no recipiente do misturador; em seguida, misturou-se por 3 min em velocidade lenta (rotação baixa);

- adicionou-se, então, a outra metade da argamassa seca e o restante do aditivo. Em seguida, misturou-se por mais 3 min;

- com misturador desligado, removeu-se com espátula a porção de argamassa impregnada no fundo do recipiente do misturador.

- misturou-se por mais 3 min a argamassa, totalizando 9 min de mistura;

- desligou-se o misturador e, em seguida, a argamassa foi submetida à determinação da densidade de empacotamento úmido, aguardando-se alcançar o tempo de 30 min (a partir da mistura com a água) para dar início avaliação de suas propriedades no estado fresco.

A seguir, na Figura 29, estão ilustradas algumas etapas do procedimento de mistura da argamassa. 
Figura 29 - Algumas partes do procedimento de mistura: (a) determinação das massas dos materiais; (b) homogeneização dos materiais; (c) mistura da argamassa.
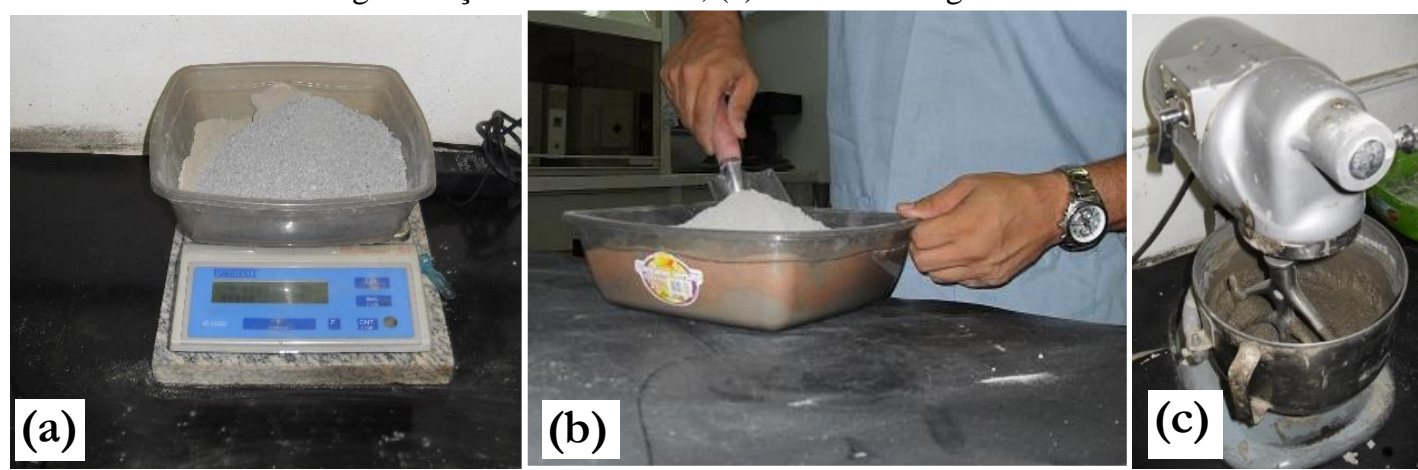

Fonte: Próprio autor.

\subsubsection{Avaliação da autoadensabilidade das argamassas}

A autoadensabilidade (trabalhabilidade) das argamassas foi avaliada por meio dos ensaios de mini-slump e mini-funil, conforme os aparatos de Okamura e Ouchi (2003). Por meio do ensaio de mini-slump se obteve o espalhamento da argamassa, com o qual foi possível obter outros parâmetros, tais como: área relativa de espalhamento e ganho de espalhamento por intermédio das Equações 14 e 16, respectivamente. Já no ensaio de mini-funil, obtém-se o tempo de fluidez, com o qual foi possível gerar mais parâmetros de viscosidade plástica aparente, tais como: velocidade relativa de fluidez e fluidez em unidade de vazão $(\mathrm{ml} / \mathrm{s})$ através das Equações 15 e 17. Para cada ensaio, foram coletadas três leituras por situação, ou seja, três repetições.

Os procedimentos para determinação do espalhamento e da fluidez das argamassas estão apresentados, a seguir. Inicialmente, tem-se o procedimento para determinação do espalhamento:

- primeiro, preencheu-se com argamassa o aparato com cavidade interna em formato de tronco de cone sobre uma mesa de espalhamento;

- em seguida, tirou-se o excesso da parte superior do aparato e levantou-se lentamente o aparato, deixando a argamassa se espalhar pelo seu próprio peso;

- após cessar o espalhamento, mediu-se o espalhamento da argamassa em três direções radiais e, em seguida, obteve-se a média do espalhamento;

- limpou a mesa e repetiu esse procedimento por mais duas vezes.

Na Figura 30 estão apresentadas as principais etapas na determinação do espalhamento da argamassa. 
Figura 30 - Determinação do espalhamento da argamassa: (a) preenchimento do tronco de cone com argamassa; (b) execução do ensaio de espalhamento; (c) medida do espalhamento da argamassa.
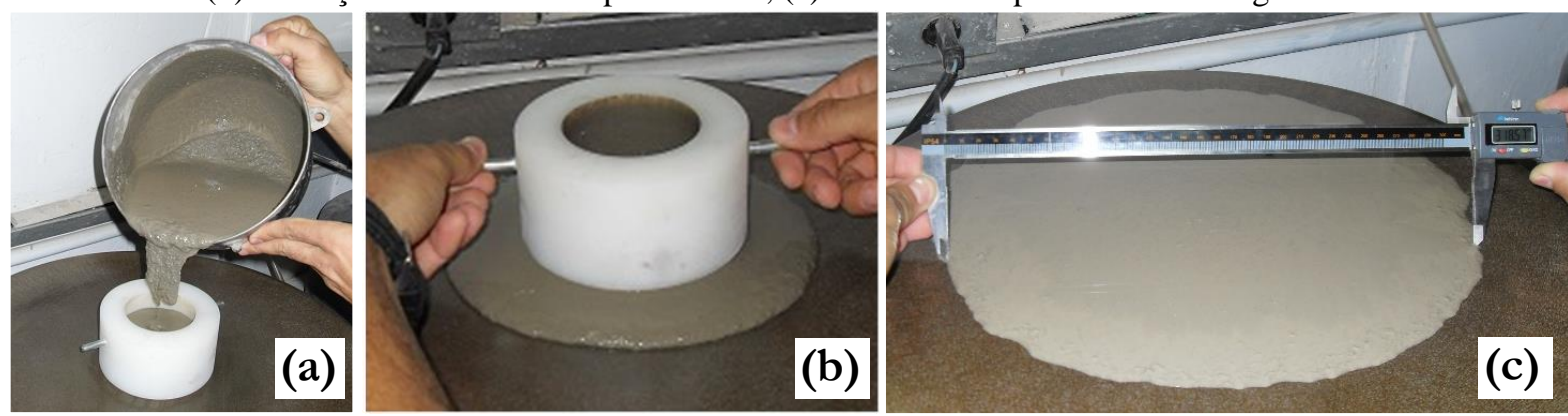

Fonte: Próprio autor.

A seguir, está apresentado o procedimento para determinação da fluidez da argamassa:

- $\quad$ primeiramente, vedou-se o orifício inferior do funil com fita adesiva;

- em seguida, preencheu-se com argamassa o funil;

- tirou-se o excesso de argamassa na parte inferior do funil;

- retirou-se a vedação inferior e, imediatamente, acionou-se o cronômetro para marcar o tempo;

- o tempo de fluidez foi medido até o momento em que se avistou a claridade do ambiente da sala pela parte superior do funil. Isso significa que toda argamassa fluiu;

- repetiu-se por mais duas vezes esse procedimento para uma mesma amostra de argamassa.

Por fim, na Figura 31, estão apresentadas algumas etapas na determinação da fluidez da argamassa.

Figura 31 - Determinação da fluidez da argamassa: (a) mini-funil preenchido com argamassa; (b) .

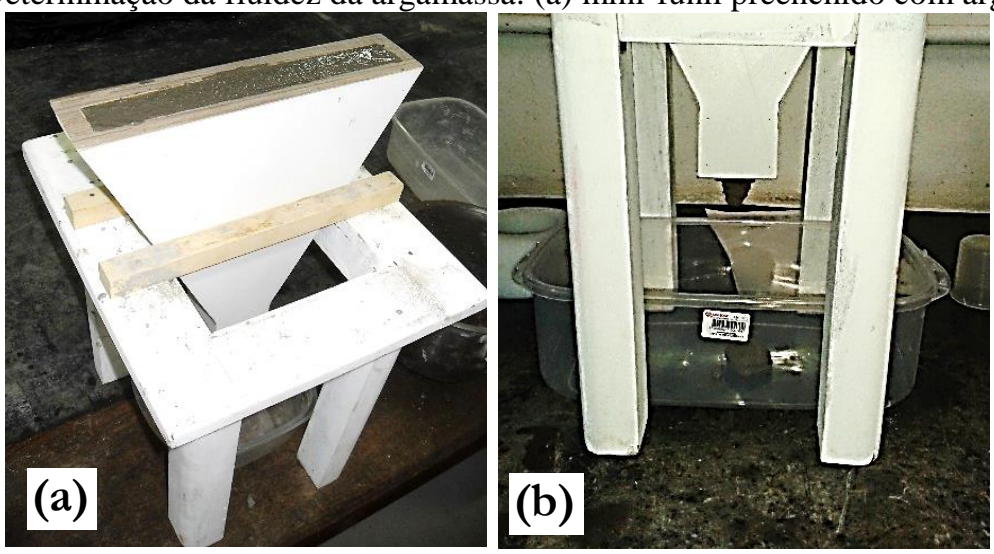

Fonte: Próprio autor. 


\subsubsection{Parâmetro WFT}

A seguir, na Figura 32, apresenta-se um memorial para calcular o parâmetro WFT, bem como os parâmetros necessários para o seu cálculo, tais como: densidade de empacotamento, índice de vazios mínimo, água excedente e área superficial total dos sólidos. Para o cálculo da área superficial total dos sólidos, considerou-se os valores de área específica dos finos obtidos pelo blaine e os valores de área específica das areias provindos de estimativas efetuadas por meio da Equação 23, de acordo com Allen (1990). Esta equação considera as informações apresentadas pela distribuição granulométrica do sólido considerando os grãos com morfologia esférica. Mais detalhes sobre os cálculos da densidade de empacotamento e do parâmetro WFT estão apresentados nos subitens 2.31 e 2.3 .2 do capítulo 2 .

$$
S w=\frac{6}{\rho} \sum \frac{x_{r}}{d r}
$$

Em que:

$\mathrm{Sw}=$ área específica do sólido $\left(\mathrm{cm}^{2} / \mathrm{g}\right)$;

$\rho=$ massa específica do sólido $\left(\mathrm{g} / \mathrm{cm}^{3}\right)$

$x_{\mathrm{r}}=$ percentual de grãos retidos em uma determinada peneira $(\mathrm{g})$;

$d r$ = diâmetro médio dos grãos retidos, o qual é a média entre a dimensão da abertura da peneira que retém os grãos e a dimensão da abertura da peneira imediatamente superior. 
Figura 32 - Memorial de cálculo para determinação do parâmetro WFT.

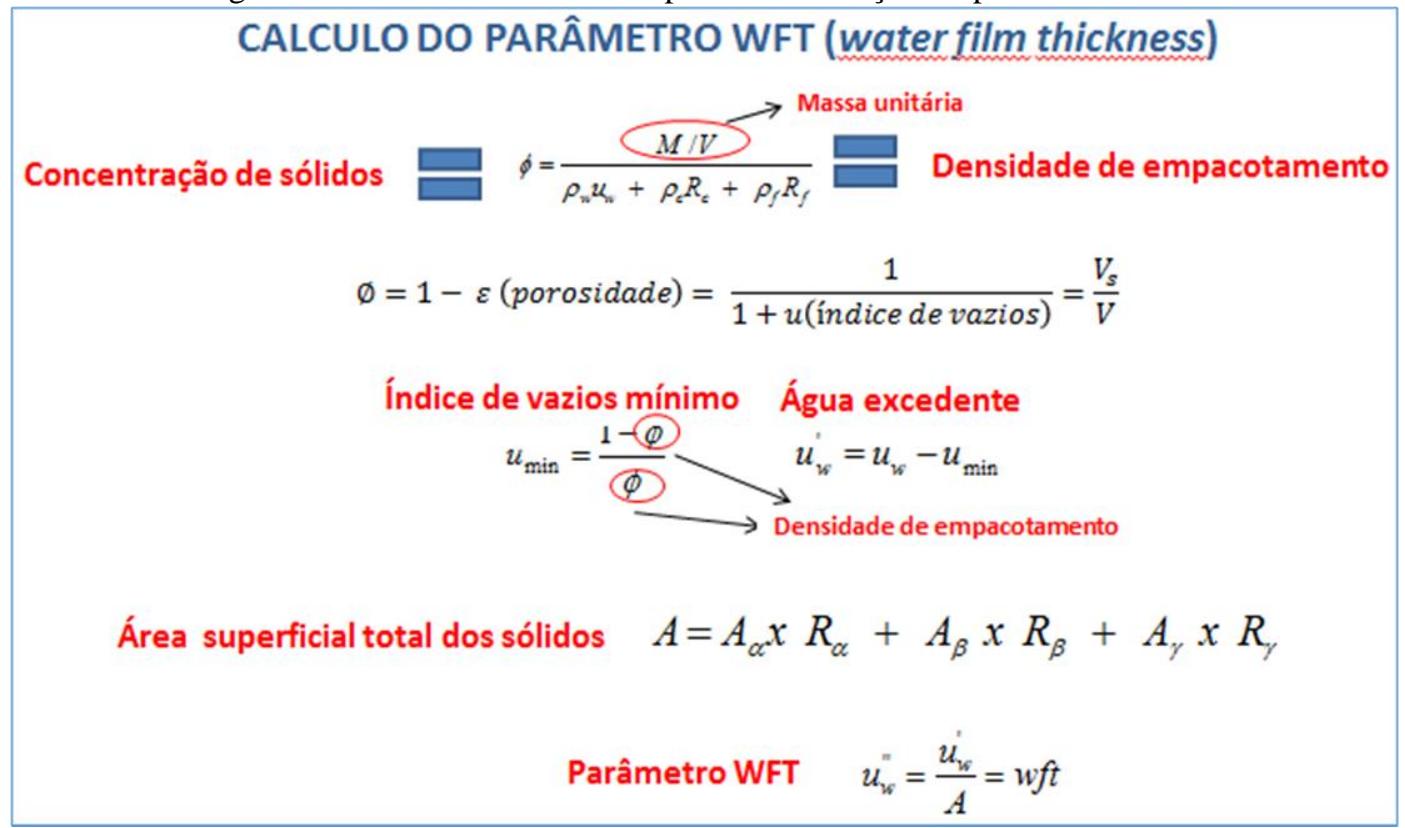

Fonte: Próprio autor.

A seguir, na Figura 33, está ilustrada a determinação da massa unitária úmida da argamassa para obtenção da densidade de empacotamento de acordo com Fung (2010). Nessa ocasião, foram efetuadas três leituras de cada argamassa, ou seja, três repetições por situação de estudo.

Figura 33 - Determinação da massa unitária e densidade de empacotamento via úmida da argamassa.

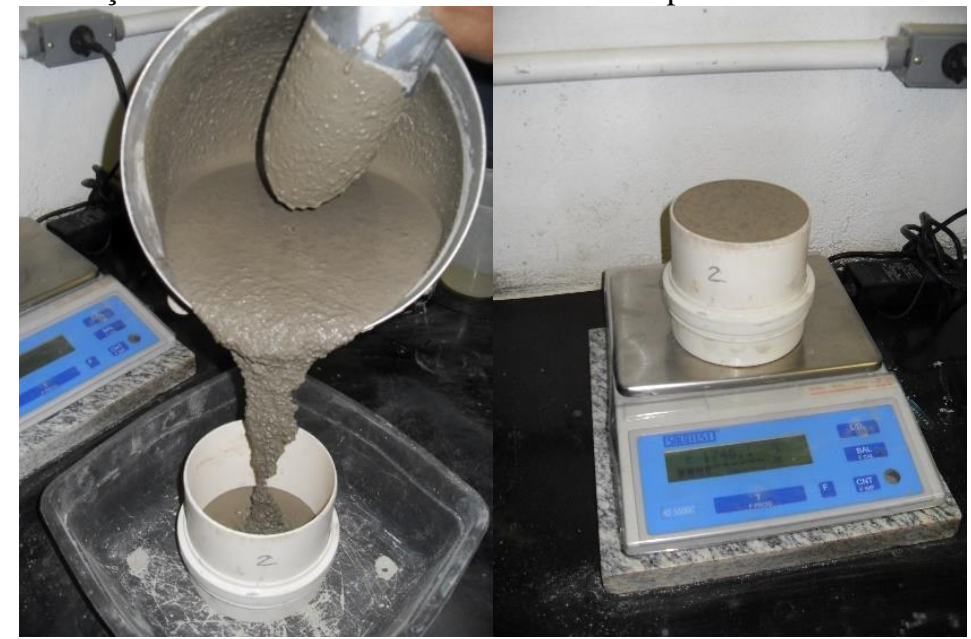

Fonte: Próprio autor.

\subsubsection{Ensaio de reometria rotacional}

O ensaio de reometria foi realizado no centro de tecnologia de argamassas (CETA) da UFBA, onde foi utilizado um reômetro coaxial da marca Rheotest RN 4.1, que consiste em um cilíndrico coaxial que armazena a argamassa, conforme ilustra a Figura 34(a). Foram 
determinados os parâmetros reológicos das argamassas referências, de acordo com a metodologia de Silva (2015) pelo fato de ainda não existir uma normativa nacional e internacional para utilização da reometria rotacional em materiais cimentícios.

Figura 34 - Detalhes do reômetro de argamassa da marca Rheotest N4.1: (a) vista panorâmica do equipamento; (b) detalhe da haste; (c) vista do recipiente preenchido com argamassa.
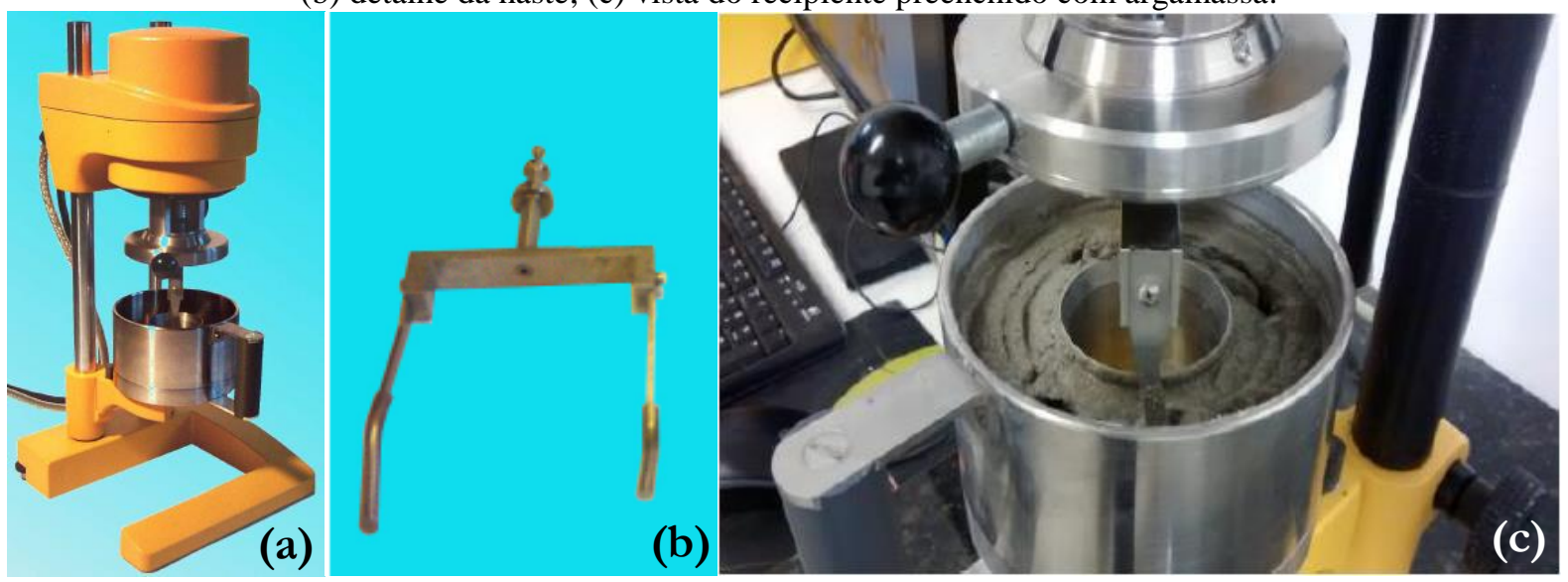

Fonte: Próprio autor.

Assim sendo, uma haste compatível ao recipiente cilíndrico coaxial é rotacionada imersa na argamassa até uma determinada frequência, conforme apresenta a Figura 34(b), assim, obtendose o torque necessário para vencer a resistência viscosa da argamassa. Neste estudo, determinou-se a avaliação reológica da argamassa de maneira pontual, no tempo 30min (considerada a partir da adição de água na mistura). Para tanto, adotou-se um aumento de frequência de 0 rpm a 150 rpm e, em seguida, um decréscimo de frequência de $150 \mathrm{rpm}$ a $1 \mathrm{rpm}$. As curvas de fluxo obtidas no ensaio de reometria são representações da variação do torque em função da velocidade de rotação, a partir das quais é possível determinar constantes proporcionais à viscosidade plástica $(\mathrm{h})$ e à tensão de escoamento $(\mathrm{g})$ por meio da inclinação da reta e da ordenada na origem, respectivamente, considerando o comportamento tipicamente Binghamiano das matrizes cimentícias, conforme Equação 24, que é utilizada somente na avaliação pontual da argamassa (PAIVA, 2005; JAU, YANG, 2010; HU, WANG, 2011 SILVA, 2015; VARHEN et al., 2016).

$$
\mathrm{T}=\mathrm{g}+\mathrm{h} . \mathrm{N}
$$

Em que:

$\mathrm{T}=$ torque $(\mathrm{mN} \cdot \mathrm{m})$;

$\mathrm{g}=$ tensão de escoamento de torque (mN.m); 
$\mathrm{h}=$ viscosidade plástica de torque (mN.m.min);

$\mathrm{N}=$ frequência $(\mathrm{rpm})$.

Dessa forma, os valores dos principais parâmetros reológicos das argamassas referencias como a tensão de escoamento de torque e a viscosidade plástica de torque, foram extraídos das curvas de fluxo reológico descendente de comportamento binghamiano, conforme recomendado por Ferraris (1999). É consensual entre vários pesquisadores que esses parâmetros obtidos em regime de velocidade descendente apresentam maior confiabilidade, uma vez que as curvas oriundas de velocidade ascendente refletem geralmente o fenômeno de reconstrução estrutural decorrente do repouso da suspensão (PAIVA, 2005). Nesse sentido, a viscosidade plástica de torque é o valor do coeficiente "a" e a tensão de escoamento de torque é o valor do coeficiente "b" da regressão linear, conforme está esquematizado na Figura 35.

Figura 35 - Ilustração da metodologia adotada para extração dos parâmetros reológicos.

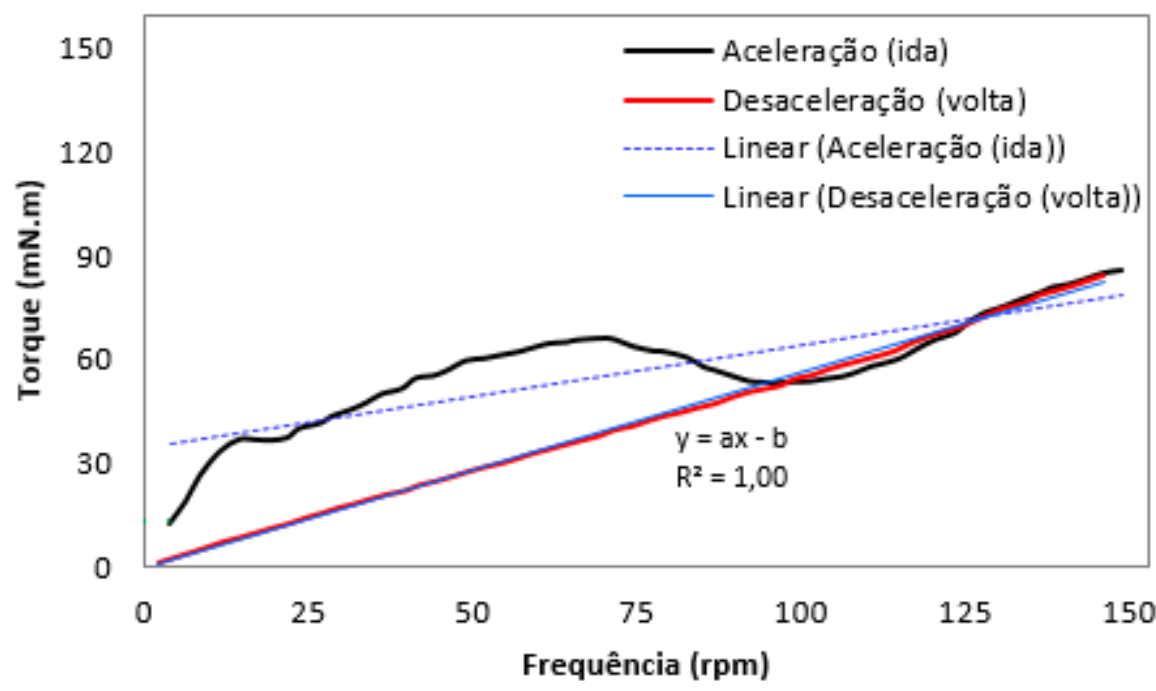

Fonte: Próprio autor.

\subsubsection{Métodos empregados nos concretos}

\subsubsection{Procedimento de mistura dos materiais na produção dos concretos}

A mistura do concreto foi realizada em um misturador de concreto tipo planetária orbital da marca CUMFLOW, com capacidade nominal de 280 litros, apresentada na Figura 36, em ambiente de laboratório. 
Figura 36 - Misturador empregado para produção de concreto.

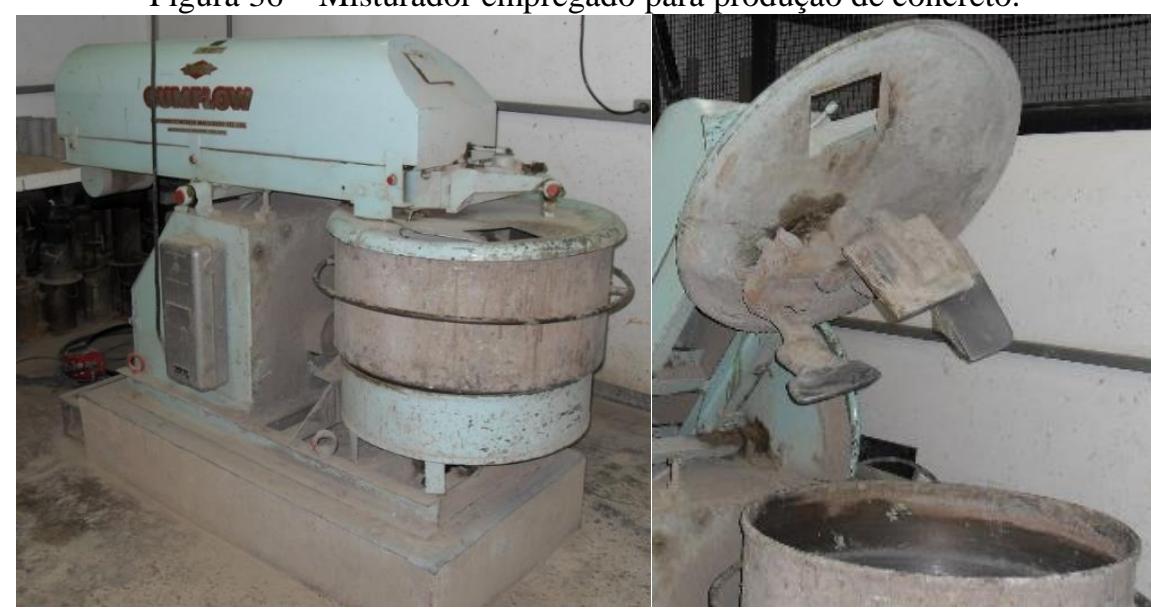

Fonte: Próprio autor.

A sequência de introdução dos materiais no misturador e o tempo de amassamento do concreto obedeceram à seguinte ordem:

- primeiramente, com o misturador parado e previamente umedecido foram adicionados os agregados graúdo e miúdo e parte da água;

- após um minuto de movimentação, seguida de parada do misturador, foi introduzido o cimento.

- após o misturador entrar em movimento, por três minutos, foi adicionado o restante da água, deixando somente uma pequena quantidade para retirar o aditivo adsorvido na superfície interna do Becker. $\mathrm{O}$ aditivo superplastificante foi adicionado diretamente no concreto, com o misturador em movimento, durante o início do segundo minuto de amassamento do concreto;

- foram efetuadas paradas intermediárias durante à mistura para retirar agregados e finos impregnados no fundo do misturador;

- a mistura do concreto teve duração de $12 \mathrm{~min}$. Após o término da mistura, foi verificado a autoadensabilidade do concreto por meio de ensaios que avaliam habilidade passante, preenchimento e estabilidade e, também, determinada a massa específica do concreto. Em seguida, foram preenchidas as fôrmas sem a necessidade de adensar o concreto com vibrador, a fim de obter corpos de prova para os ensaios de caracterização do concreto no estado endurecido. A seguir, têm-se algumas etapas da produção do concreto. 
Figura 37 - Etapas da produção do concreto: (a) pesagem dos materiais; (b) mistura dos materiais no misturador de concreto; (c) determinação da massa específica.
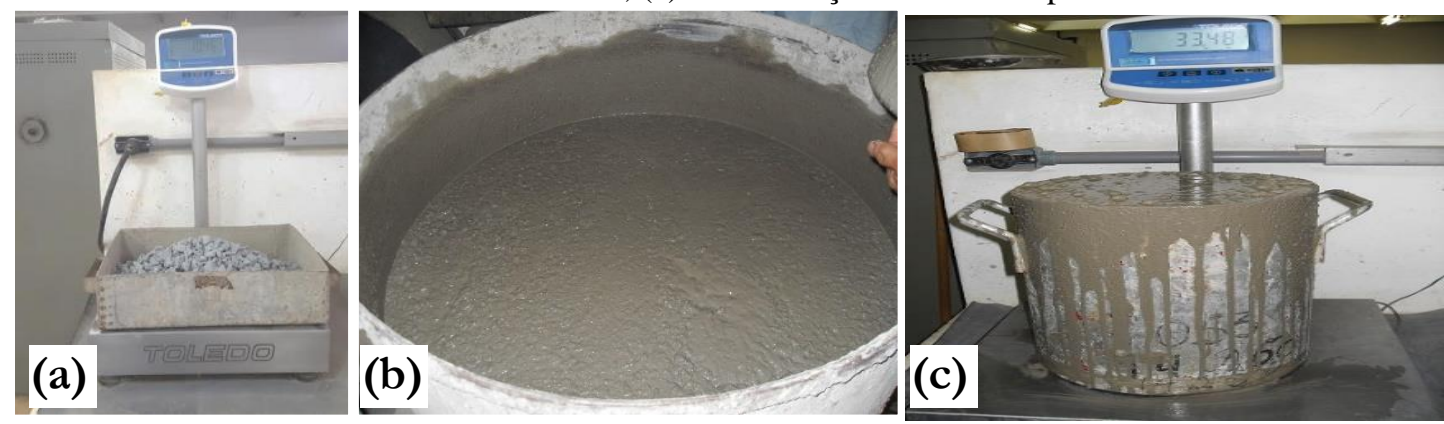

Fonte: Próprio autor.

\subsubsection{Avaliação da autoadensabilidade dos concretos}

Para avaliação da autoadensabilidade dos concretos autoadensáveis foram empregados os ensaios de espalhamento pelo cone de Abrams, T500, Anel J, funilV, caixa L, caixa U e coluna de segregação. Os procedimentos, bem como o cálculo dos parâmetros desses ensaios estão detalhadamente descritos no item 2.7.2 do capitulo 2 desta tese. A seguir, tem-se uma síntese dos ensaios empregados para avaliar a autoadensabilidade dos concretos.

\section{a) Espalhamento pelo Cone de Abrams (Slump Flow Test)}

Mediu-se o espalhamento do concreto, em duas direções perpendiculares conforme as prescrições da norma NBR 15823-2 (2010). Esse ensaio foi executado após 15 min da adição da água na mistura. A seguir, na Figura 38, ilustra-se a determinação do espalhamento do concreto.

Figura 38 - Determinação do espalhamento do concreto.

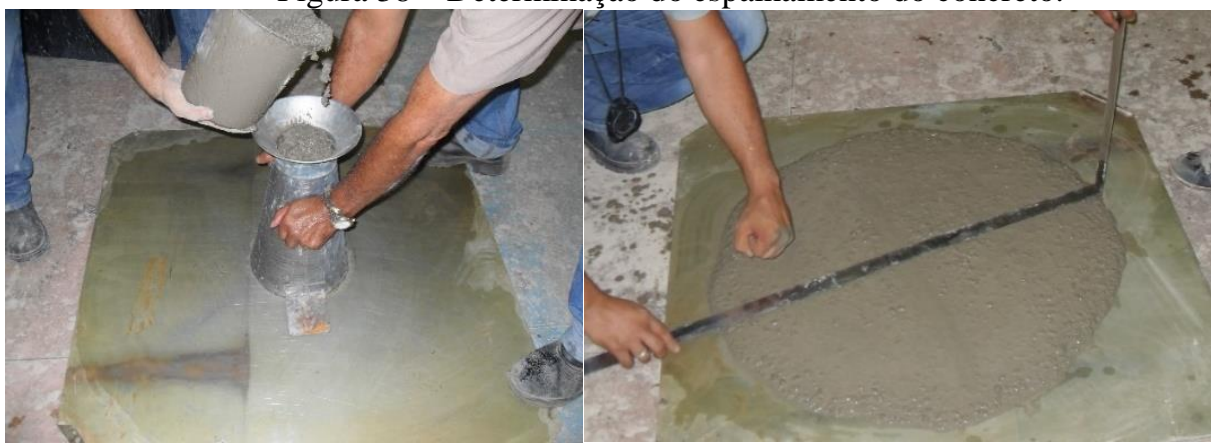

Fonte: Próprio autor. 
b) Espalhamento pelo T500 (T500 Slump Flow Test)

O ensaio de T500 é uma forma de avaliar a viscosidade plástica aparente do concreto. Medese, então, o tempo que a mistura leva para se espalhar $500 \mathrm{~mm}$ conforme as prescrições da norma NBR 15823-2 (2010). Esse ensaio foi executado após 20 min da adição da água na mistura

\section{c) Anel J}

O ensaio de Anel - J avalia a habilidade passante do concreto autoadensável. O seu aparato de ensaio é semelhante ao do ensaio de espalhamento (slump-flow), todavia com a inclusão do Anel J. De acordo com ABNT NBR 14823 - 3 (2010), o procedimento de execução do ensaio do Anel $\mathbf{J}$ se assemelha ao do ensaio de espalhamento, o qual consiste em obter a diferença do espalhamento médio do concreto sem o anel e com anel, sendo dado em milímetros. Esse ensaio foi executado após 25 min da adição da água na mistura. A seguir, na Figura 39, ilustra-se o ensaio de Anel J.

Figura 39 - Determinação da habilidade passante do concreto por meio do Anel J.

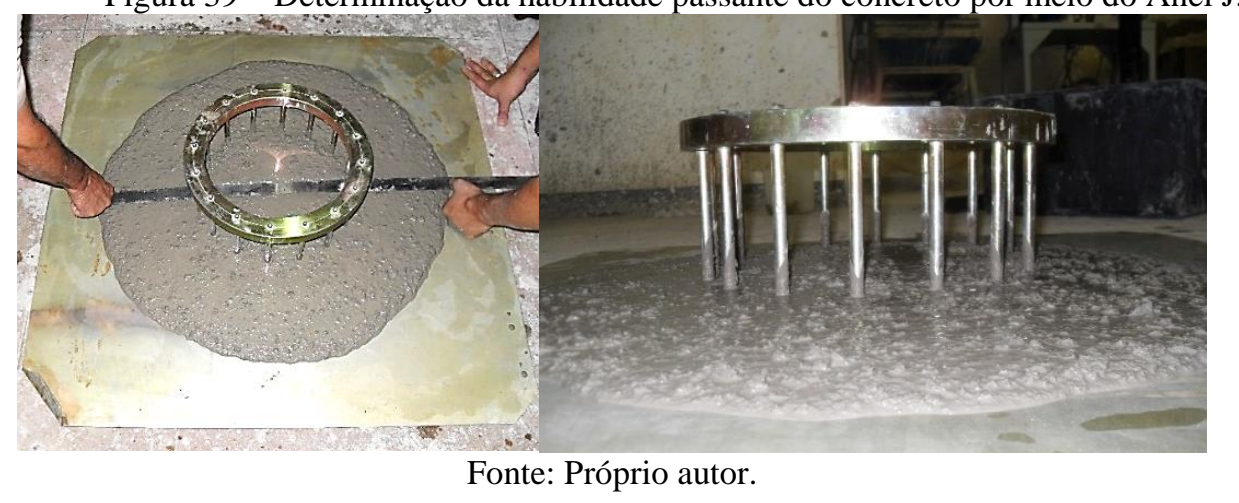

d) Funil V (V-Funnel Test)

O ensaio serve para medir a fluidez ou viscosidade plástica aparente do concreto. Portanto, mediu-se o tempo necessário para que 12 litros de material pudesse fluir através do funil, conforme as orientações da norma NBR 15823-5 (2010). Esse ensaio foi executado após 30 min da adição da água na mistura do concreto. A seguir, na Figura 40, está ilustrado a determinação da viscosidade plástica aparente pelo ensaio do funil V. 
Figura 40 - Determinação da viscosidade plástica aparente por meio do ensaio de funilV.

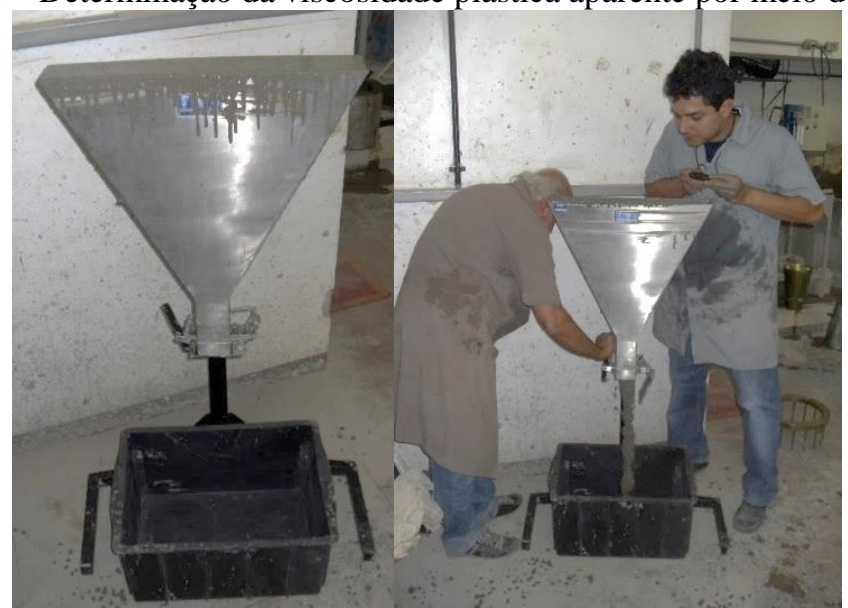

Fonte: Próprio autor.

\section{e) Caixa em L (L-Box Test)}

Este ensaio mede a habilidade de preenchimento do concreto simultaneamente com a sua habilidade de passar por obstáculos, permanecendo coeso. Mediu-se então as alturas $\mathrm{H}_{1}$ e $\mathrm{H}_{2}$ após o escoamento. $\mathrm{O}$ valor obtido foi a razão entre $\mathrm{H}_{2}$ e $\mathrm{H}_{1}$ que deve se situar entre 0,8 a 1,0. Este ensaio foi executado conforme NBR 15823-4 (2010), no instante 32 min após a adição da água na mistura do concreto. A seguir, na Figura 41, está apresentada a determinação da habilidade passante do concreto por meio do ensaio de caixa L.

Figura 41 - Determinação da habilidade passante do concreto por meio do ensaio de caixa L.

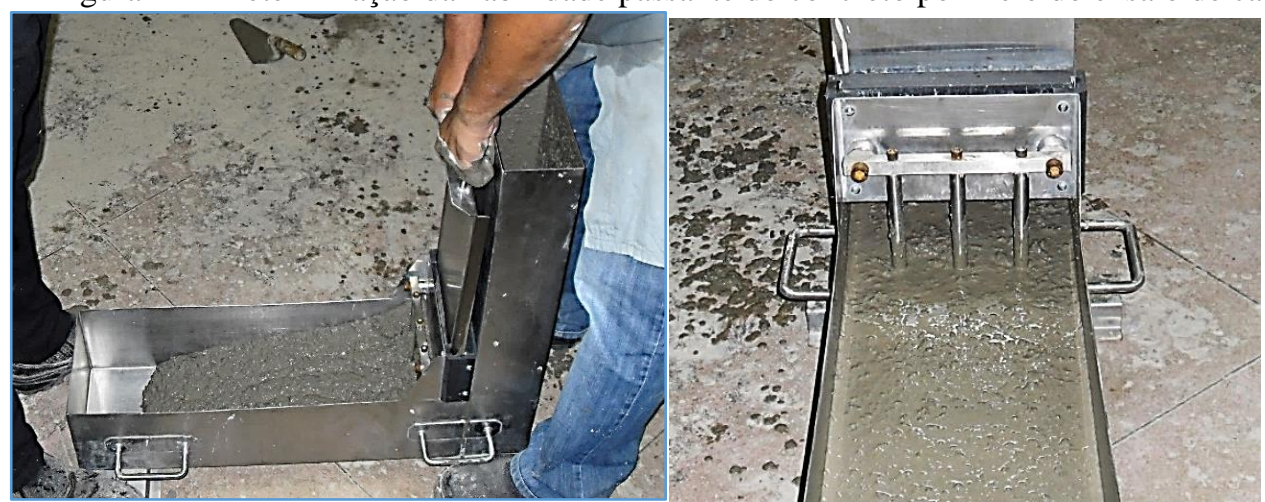

Fonte: Próprio autor.

\section{f) Caixa em U (U-Box)}

Este ensaio avalia a capacidade do CAA passar através da armadura por meio de uma simulação com barras da armadura, estreitamente espaçadas. O ensaio consiste em preencher com concreto de um lado do aparato em forma de U e, em seguida, após abertura da comporta verificar a 
habilidade passante desse concreto. Para isso, mede-se alturas $\mathrm{R}_{1}$ e $\mathrm{R}_{2}$ de cada coluna do aparato U e faz-se a diferença dessas alturas, que não deve ultrapassar $30 \mathrm{~mm}$. Esse ensaio foi executado conforme a recomendação da EFNARC (2005), no instante 34 min após a adição de água na mistura. A seguir, na Figura 42, está ilustrada a determinação da habilidade passante do concreto por meio do ensaio de caixa $U$.

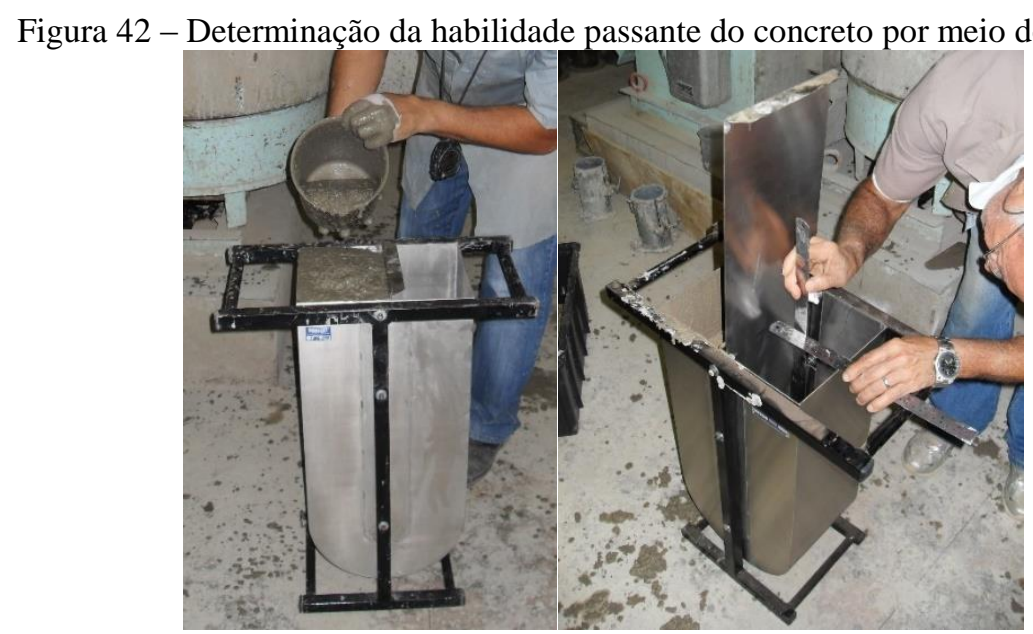

Fonte: Próprio autor.

g) Coluna de segregação

A resistência à segregação é definida pela diferença percentual entre a quantidade de agregado graúdo retida da base e do topo da coluna de segregação. Este ensaio foi executado conforme a prescrições da norma ABNT NBR 15823-6 (2010), no instante 40 min após a adição de água na mistura. Cabe destacar que a coluna de segregação foi preenchida com concreto no instante que se executava o ensaio de T500. Isto foi necessário, pelo fato do ensaio de coluna de segregação exigir o descanso de $20 \mathrm{~min}$ do concreto na coluna. A seguir, na Figura 43, está ilustrado o ensaio de resistência à segregação.

Figura 43 - Determinação da resistência à segregação do concreto por meio do ensaio de coluna de segregação: (a) coluna de segregação preenchida com concreto; (b) retirada da argamassa; (c) redução do excesso de água na superfície dos agregados; (d) pesagem dos agregados.

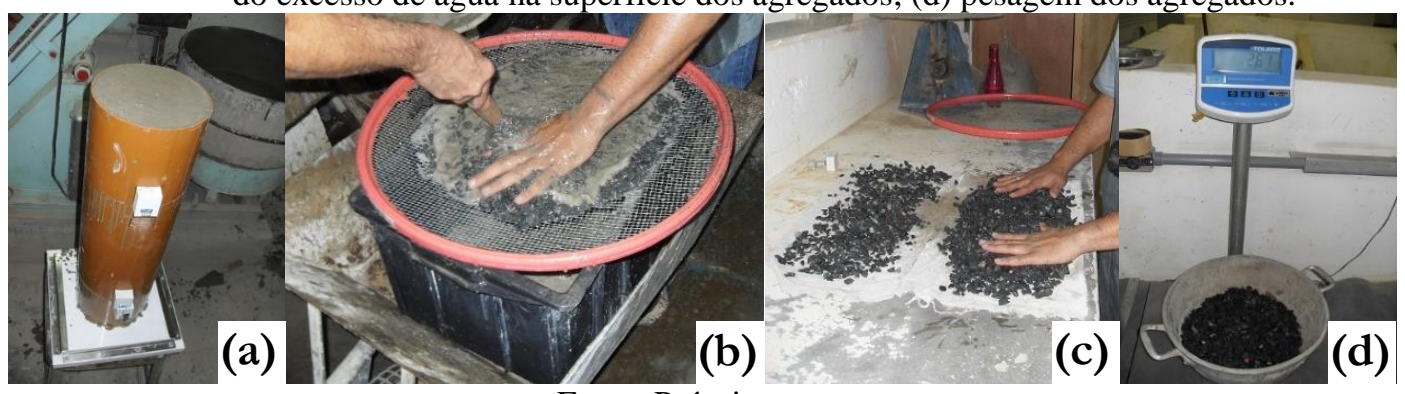

Fonte: Próprio autor. 


\subsubsection{Caracterização reológica dos concretos}

Quanto aos parâmetros reológicos dos concretos, foram obtidos os parâmetros de tensão de escoamento e viscosidade plástica por meio de equações matemáticas propostas por Sedran e De Larrard (1999), as quais estão apresentadas nas Equações 18 e 19. Estas equações foram adotadas por dois motivos principais: pela necessidade do emprego de parâmetros de autoadensabilidade do concreto e por se tratar de modelos matemáticos consolidados no meio científico.

\subsubsection{Caracterização no estado endurecido}

No estado endurecido, procedeu-se à caracterização mecânica somente dos concretos por meio de resultados de resistência à compressão e de módulo de elasticidade estático aos 28 dias de idade. O ensaio de resistência à compressão seguiu as orientações da ABNT NBR 5739 (1994), enquanto o ensaio de módulo de elasticidade seguiu as orientações da ABNT NBR 8522 (2008). Adotou-se corpos de prova cilíndricos de dimensões $10 \mathrm{cmx} 20 \mathrm{~cm}$, os quais foram submetidos à cura úmida até o dia do ensaio. Em seguida, as bases desses corpos de prova foram retificadas com disco diamantado, tornando as bases regulares, e, assim, os corpos de prova ficaram aptos para serem submetidos aos ensaios mecânicos.

Quanto à execução dos ensaios, foram destinados 3 corpos de provas para resistência à compressão e 3 corpos de prova para módulo de elasticidade. A seguir, na Figura 44, está ilustrada a determinação das propriedades mecânicas de resistência à compressão e módulo de elasticidade, por meio de uma prensa EMIC DL30000, no Laboratório de Ensaio de Materiais da Universidade de Brasília. 
Figura 44 - Determinação das propriedades mecânicas do concreto. (a) Resistência à Compressão; (b) Módulo de Elasticidade.

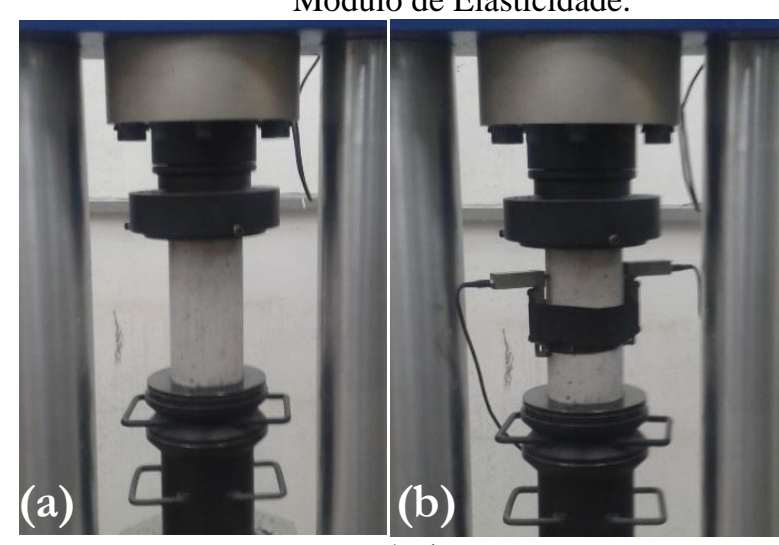

Fonte: Próprio autor.

\subsection{TRATAMENTOS OS DADOS E PLANEJAMENTO ESTATÍSTICO}

Os resultados dos ensaios que obtiveram mais de uma leitura por situação de estudo foram tratados quanto aos seus valores espúrios de acordo com método de Dixon, prescrito pela norma americana ASTM E178 (2008), considerando um nível de significância de 95\%. Após esse tratamento, foram analisados os dados restantes com geração de gráficos de tendência e análise de variância.

Dessa forma, para uma melhor interpretação dos resultados da pesquisa, os valores individuais obtidos nos ensaios de espalhamento e de fluidez das argamassas, bem como os valores individuais obtidos nos ensaios de resistência à compressão e módulo de elasticidade dos concretos foram submetidos à uma análise estatística.

Com o intuito de determinar as variáveis do estudo que exercem influência nas propriedades estudadas, adotou-se um planejamento fatorial completo para identificar as interações dos efeitos e a análise de variância dos efeitos principais (main effects), de modo a identificar a influência desses efeitos tomados isoladamente.

Com relação aos testes de significância deste planejamento experimental, estes foram realizados por análise de variância (ANOVA) utilizando-se o programa Statistica South América ${ }^{\circledR}$, adotando-se um intervalo de confiança igual a 95\% e, conseqüentemente, um nível de significância de 5\%. Tais análises são apresentadas em tabelas de ANOVA, onde podem ser observadas quais variáveis de estudo foram significativas nas propriedades relacionadas com as argamassas e os concretos e quais não apresentaram influência significativa. Também se 
obtém da ANOVA a intensidade da significância dos fatores de estudo e a análise das interações entre tais fatores. 


\section{Capítulo IV - RESULTADOS DO PROGRAMA EXPERIMENTAL}

No presente capítulo estão apresentados os resultados obtidos no programa experimental. Inicialmente, tem-se o item relativo ao estudo da autoadensabilidade das argamassas com ênfase na influência do superplastificante. Neste item, apresentam-se os resultados de autoadensabilidade das argamassas obtidos por meio de ensaios de mini-slump e mini-funil. Esses resultados foram importantes para selecionar o aditivo superplastificante à base de policarboxilato de sódio, que melhor conferiu autoadensabilidade às argamassas, o qual foi adotado em todo o estudo do programa experimental na produção de argamassas e concretos. Em seguida, tem-se o item que apresenta os resultados de autoadensabilidade das argamassas com diferentes relações água/sólidos e produzidas com emprego somente do superplastificante selecionado no estudo anterior. Com esses resultados, foi possível identificar referências de argamassas para produção de concretos autoadensáveis. A partir dessas argamassas referências de concreto autoadensável, foram produzidos concretos e avaliados sua autoadensabilidade por meio dos seguintes ensaios: slump-flow, T500, anel J, funil V, caixa L, caixa U e coluna de segregação. Os resultados desses ensaios estão apresentados no terceiro item, no qual consta também a classificação dos concretos com relação a propriedade de autoadensabilidade, conforme as prescrições da norma ABNT NBR 15823 - 1 (2010). Nos itens posteriores são apresentados resultados de parâmetros reológicos das argamassas e dos concretos. Os parâmetros reológicos das argamassas referências foram medidos por meio de um reômetro e dos concretos por meio de equações matemáticas que envolvem parâmetros de autoadensabilidade do concreto. Além disso, destinou-se um item para apresentar os resultados do parâmetro WFT das argamassas referências do concreto e outro item para apresentar os resultados das propriedades mecânicas dos concretos produzidos, tais como, resultados de resistência à compressão e módulo de elasticidade. Cabe salientar que os resultados individuais de diferentes propriedades avaliadas foram submetidos a uma análise estatística de variância, com a principal finalidade de dar um melhor respaldo às análises e discussões realizadas. 


\subsection{ESTUDO DA TRABALHABILIDADE DAS ARGAMASSAS COM ÊNFASE NA INFLUÊNCIA DO SUPERPLASTIFICANTE}

A seleção do aditivo superplastificante à base de policarboxilato de sódio que melhor conferiu características de autoadensabilidade às argamassas, envolveu a determinação de resultados de espalhamento e de fluidez (viscosidade) por meio de ensaios de mini-slump e de mini-funil, respectivamente.

\subsubsection{Espalhamento (mini-slump)}

Na Tabela 18 estão apresentados os resultados médios de espalhamento das argamassas por meio do ensaio de mini-slump. Essas argamassas sofreram variações em sua mistura com diferentes tipos de aglomerante, aditivos, teores de aditivo e foram submetidas ao ensaio nos tempos de $30 \mathrm{~min}, 60 \mathrm{~min}$ e $90 \mathrm{~min}$. Cabe ressaltar que, para identificar o aditivo superplastificante que melhor conferiu características de autoadensabilidade às argamassas, considerou-se os resultados de espalhamento subtraídos por 100 (base do cone). Dessa forma, facilitou visualizar o ganho de espalhamento de uma determinada argamassa com emprego de diferentes aditivos, por exemplo. 
Tabela 18 - Resultados médios de espalhamento das argamassas por tipo de SP.

\begin{tabular}{|c|c|c|c|c|c|c|c|c|}
\hline \multirow{3}{*}{ Argamassas } & \multirow{3}{*}{ Aditivo } & \multirow{3}{*}{$\begin{array}{c}\text { Teor de } \\
\text { aditivo } \\
(\%)\end{array}$} & \multicolumn{3}{|c|}{ Espalhamento (mm) } & \multicolumn{3}{|c|}{ Espalhamento $-100 \mathrm{~mm}(\mathrm{~mm})$} \\
\hline & & & & Tempo & & & Tempo & \\
\hline & & & $30 \mathrm{~min}$ & $60 \mathrm{~min}$ & $30 \mathrm{~min}$ & $30 \mathrm{~min}$ & $60 \mathrm{~min}$ & $90 \mathrm{~min}$ \\
\hline \multirow{5}{*}{ AREFSP1 } & \multirow{15}{*}{ SP1 } & 0,6 & 100 & 100 & 100 & 0 & 0 & 0 \\
\hline & & 0,8 & 200 & 198 & 136 & 100 & 98 & 36 \\
\hline & & 1,0 & 270 & 270 & 250 & 170 & 170 & 150 \\
\hline & & 1,2 & 301 & 302 & 302 & 201 & 202 & 202 \\
\hline & & 1,4 & 352 & 328 & 309 & 252 & 227 & 209 \\
\hline \multirow{5}{*}{ A20SP1 } & & 0,6 & 133 & 100 & 131 & 33 & 0,0 & 31 \\
\hline & & 0,8 & 211 & 196 & 225 & 111 & 96 & 125 \\
\hline & & 1,0 & 310 & 303 & 301 & 210 & 203 & 201 \\
\hline & & 1,2 & 348 & 318 & 309 & 248 & 218 & 209 \\
\hline & & 1,4 & 332 & 323 & 305 & 232 & 223 & 205 \\
\hline \multirow{5}{*}{ A30SP1 } & & 0,6 & 107 & 100 & 100 & 7 & 0 & 0 \\
\hline & & 0,8 & 245 & 197 & 200 & 145 & 97 & 100 \\
\hline & & 1,0 & 309 & 303 & 285 & 209 & 203 & 185 \\
\hline & & 1,2 & 330 & 310 & 300 & 230 & 210 & 200 \\
\hline & & 1,4 & 430 & 308 & 310 & 330 & 208 & 210 \\
\hline \multirow{5}{*}{ AREFSP2 } & \multirow{15}{*}{ SP2 } & 0,6 & 100 & 100 & 100 & 0 & 0 & 0 \\
\hline & & 0,8 & 100 & 100 & 100 & 0 & 0 & 0 \\
\hline & & 1,0 & 100 & 100 & 100 & 0 & 0 & 0 \\
\hline & & 1,2 & 124 & 104 & 103 & 24 & 4 & 3 \\
\hline & & 1,4 & 133 & 141 & 115 & 33 & 41 & 15 \\
\hline \multirow{5}{*}{ A20SP2 } & & 0,6 & 100 & 100 & 100 & 0 & 0 & 0 \\
\hline & & 0,8 & 100 & 100 & 100 & 0 & 0 & 0 \\
\hline & & 1,0 & 100 & 100 & 100 & 0 & 0 & 0 \\
\hline & & 1,2 & 124 & 111 & 100 & 24 & 11 & 0 \\
\hline & & 1,4 & 120 & 104 & 100 & 20 & 4 & 0 \\
\hline \multirow{5}{*}{ A 30 SP 2} & & 0,6 & 100 & 100 & 100 & 0 & 0 & 0 \\
\hline & & 0,8 & 100 & 100 & 100 & 0 & 0 & 0 \\
\hline & & 1,0 & 100 & 100 & 100 & 0 & 0 & 0 \\
\hline & & 1,2 & 143 & 145 & 100 & 43 & 45 & 0 \\
\hline & & 1,4 & 179 & 180 & 170 & 79 & 80 & 70 \\
\hline \multirow{5}{*}{ AREFSP3 } & \multirow{15}{*}{ SP3 } & 0,6 & 173 & 154 & 120 & 73 & 54 & 21 \\
\hline & & 0,8 & 273 & 259 & 253 & 173 & 159 & 153 \\
\hline & & 1,0 & 349 & 316 & 393 & 249 & 216 & 193 \\
\hline & & 1,2 & 342 & 320 & 308 & 242 & 220 & 208 \\
\hline & & 1,4 & 408 & 372 & 327 & 308 & 272 & 227 \\
\hline \multirow{5}{*}{ A20SP3 } & & 0,6 & 176 & 145 & 100 & 76 & 45 & 0 \\
\hline & & 0,8 & 258 & 236 & 222 & 158 & 136 & 122 \\
\hline & & 1,0 & 337 & 323 & 305 & 237 & 223 & 205 \\
\hline & & 1,2 & 340 & 330 & 302 & 240 & 220 & 202 \\
\hline & & 1,4 & 330 & 330 & 315 & 230 & 230 & 215 \\
\hline \multirow{5}{*}{ A30SP3 } & & 0,6 & 174 & 148 & 100 & 74 & 48 & 0 \\
\hline & & 0,8 & 283 & 270 & 228 & 183 & 170 & 128 \\
\hline & & 1,0 & 333 & 325 & 302 & 233 & 225 & 196 \\
\hline & & 1,2 & 336 & 330 & 310 & 221 & 230 & 210 \\
\hline & & 1,4 & 350 & 340 & 340 & 250 & 240 & 240 \\
\hline
\end{tabular}

Fonte: Próprio autor.

Nota-se, na Tabela 18, que o ganho de espalhamento das argamassas foi mais relevante para as argamassas produzidas com emprego dos aditivos SP1 e SP3. Os valores máximos de ganho de espalhamento em função desses aditivos foram $330 \mathrm{~mm}$ e $308 \mathrm{~mm}$, respectivamente, para o tempo de leitura de resultado de $30 \mathrm{~min}$. As argamassas com emprego do aditivo SP2 não 
tiveram resultados satisfatórios de ganho de espalhamento. $\mathrm{O}$ valor máximo de ganho de espalhamento com esse aditivo foi de $79 \mathrm{~mm}$ para o tempo $30 \mathrm{~min}$.

A seguir, na Figura 45, tem-se o comportamento das argamassas frente ao ganho de espalhamento, tomando como ênfase a variável independente tipo de aglomerante. Observa-se, na Figura 45, que as curvas das argamassas obtidas com o tipo de aglomerante A30 (30\% de substituição por fíler calcário), no geral, ficaram superior às curvas das argamassas AREF (sem substituição) e A20 de forma pouca acentuada. Isso significa que as argamassas com A30 tiveram um leve ganho de espalhamento corroborando o que foi obtido no gráfico dos valores médios globais na Figura 83 referente à ANOVA, que está apresentado no Apêndice B. 
Figura 45 - Comportamento das argamassas frente ao ganho de espalhamento, tomando como ênfase a variável independente tipo de aglomerante.
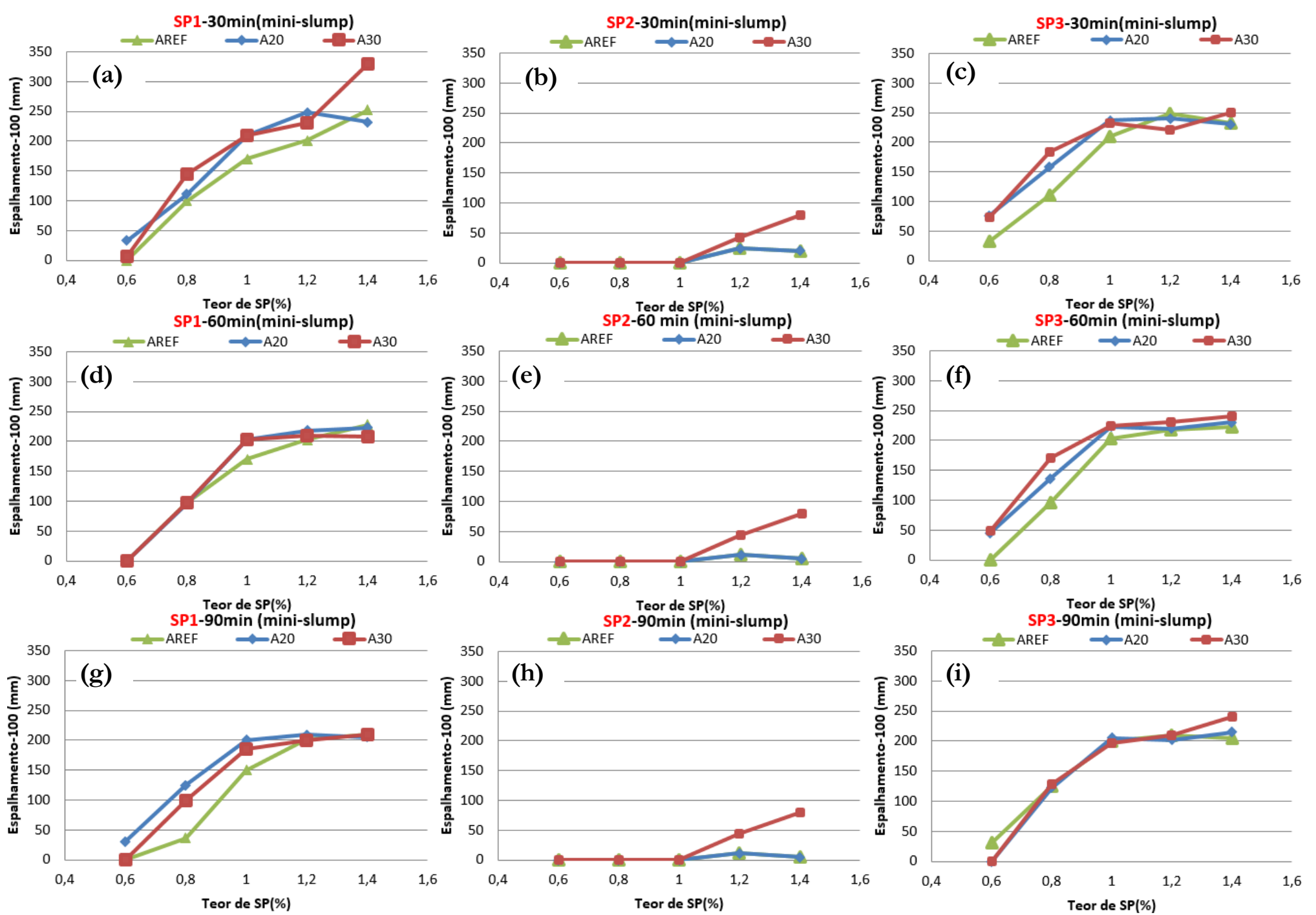

Fonte: Próprio autor. 
Na Figura 46, tem-se o comportamento das argamassas frente ao ganho de espalhamento, tomando como ênfase a variável independente tipo de aditivo. Observa-se, ainda, que as argamassas com tipo de aditivo superplastificante SP3 tiveram, no geral, melhor comportamento quando comparadas com as argamassas com aditivos SP1 e SP2. Isso se observa nas curvas de cor verde superior as curvas de cor azul (SP1) e cor vermelha (SP2). Verifica-se, também, que o tipo de aditivo SP3 demonstrou melhor comportamento com as argamassas de tipo de aglomerante REF. Isso se comprova, quando se nota as curvas de cor verde (SP3) superior e distantes de forma acentuada em relação as curvas de cor azul (SP1). Nesse sentido, para um teor de $1,0 \%$ de aditivo superplastificante, observa-se que a diferença de espalhamento entre AREF - SP3 (30 min) e AREF-SP1 (30 min) foi de 67mm, enquanto para as argamassas A20 e A30, considerando os mesmos aditivos, essa diferença foi de $27 \mathrm{~mm}$ e $24 \mathrm{~mm}$, respectivamente. 
Figura 46 - Comportamento das argamassas frente ao ganho de espalhamento, tomando como ênfase a variável independente tipo de aditivo.
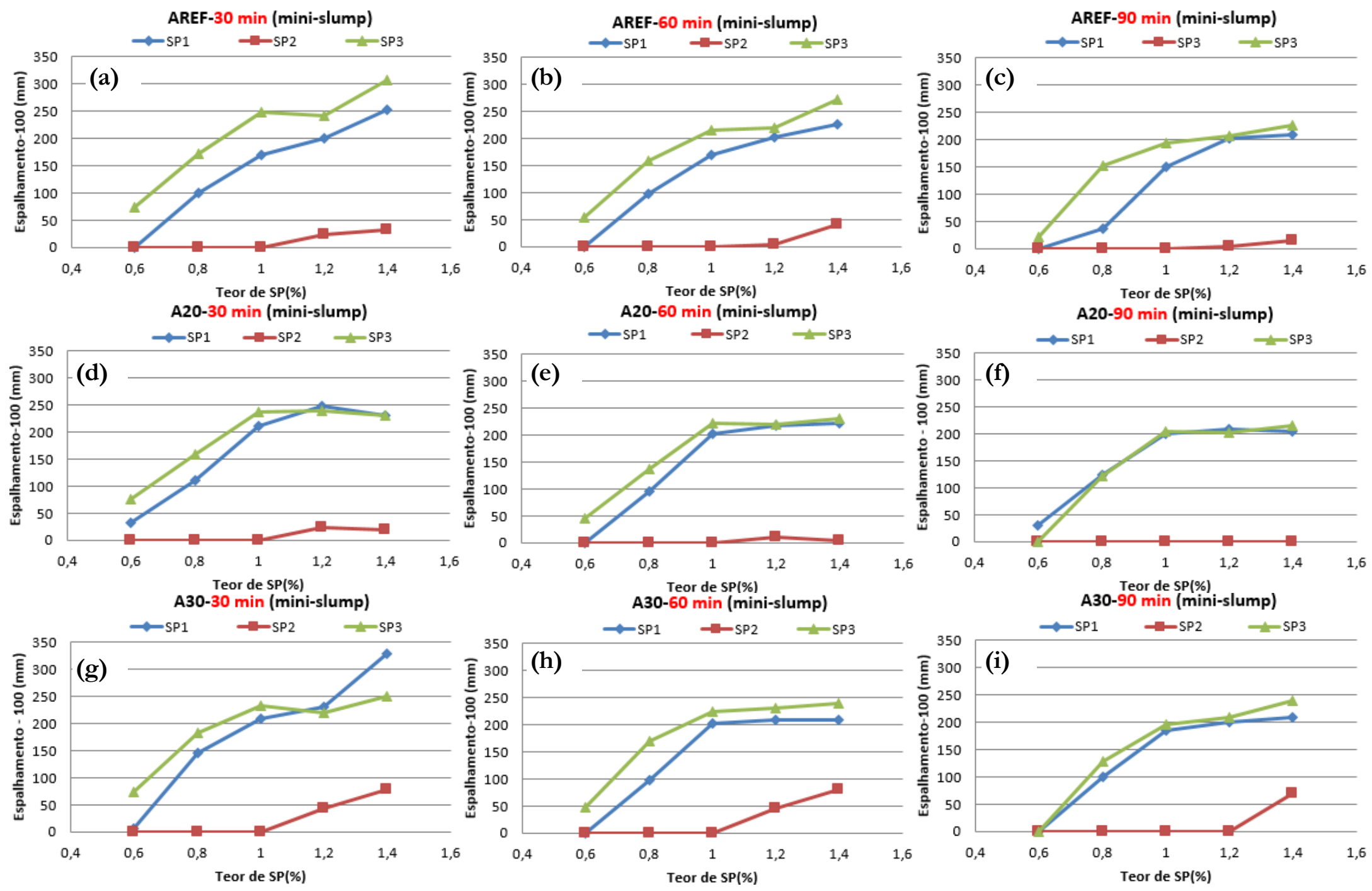

Fonte: Próprio autor. 
Na Figura 47, tem-se o comportamento das argamassas frente ao ganho de espalhamento, tomando como ênfase o tempo considerado para efetuar a medida de espalhamento. Verificase, nitidamente, uma perda de espalhamento com decorrer do tempo para as argamassas que tiveram o emprego do aditivo SP3. Em relação às argamassas que tiveram emprego dos aditivos SP1 e SP2, não se notou um comportamento definido de perda de espalhamento. Isso provavelmente pode explicar o fato do fator (variável independente) tempo ser menos influente sobre o espalhamento do que as variáveis independentes como tipo de aditivo e teor de aditivo, conforme está apresentado na tabela da ANOVA ( Tabela 40 - Apêndice B). 
Figura 47 - Comportamento das argamassas frente ao ganho de espalhamento, tomando como ênfase a variável independente tempo.
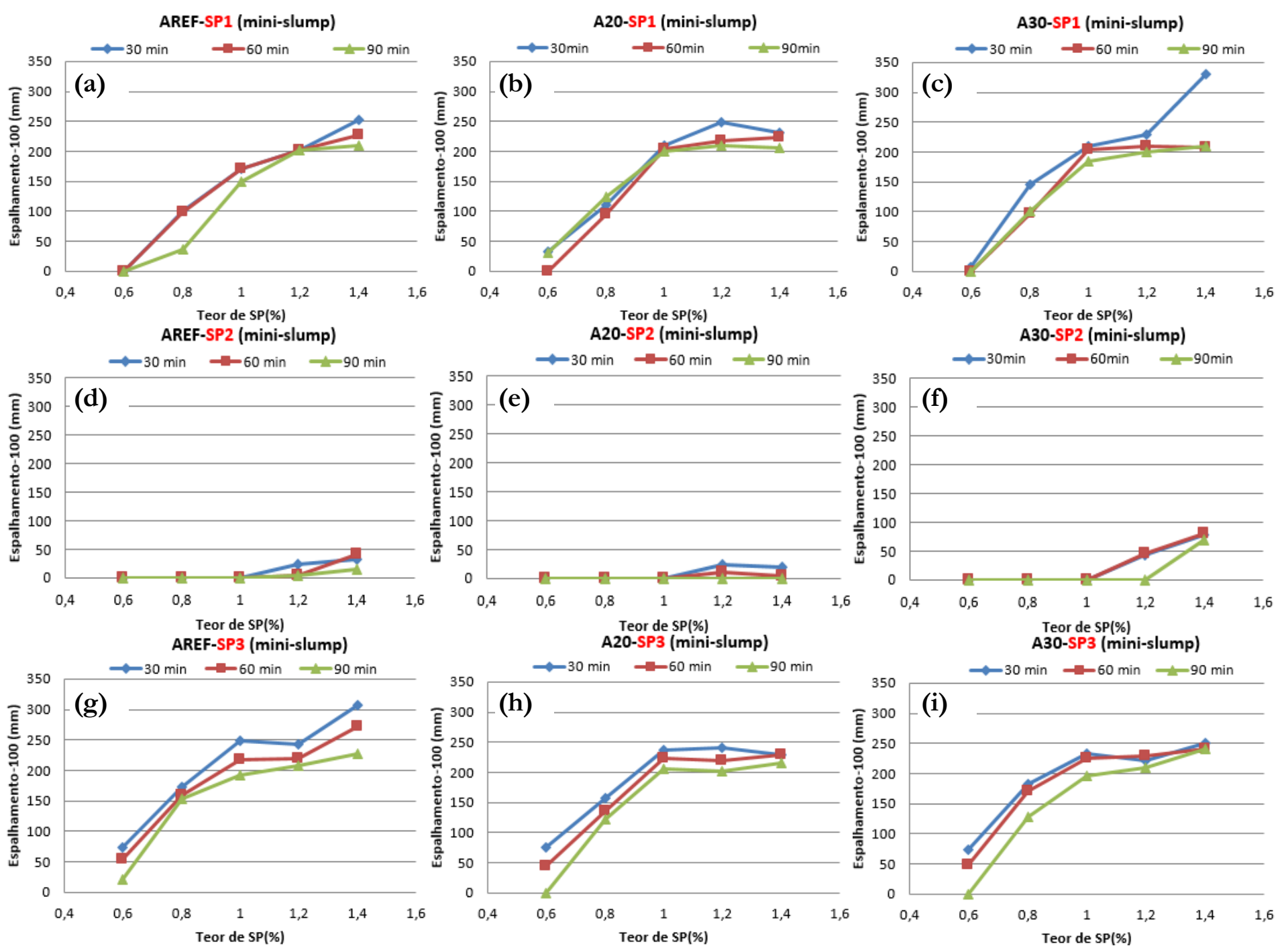

Fonte: Próprio autor. 
A análise de variância foi realizada para consolidar as observações dos comportamentos dos resultados sobre ganho de espalhamento apresentados anteriormente. Essa análise também foi feita para os resultados que envolvem fluidez das argamassas como, também, para os resultados mecânicos dos concretos autoadensáveis. A análise de variância para o ganho de espalhamento está apresentada na íntegra no Apêndice B. Esta análise mostrou que os efeitos individuais dos fatores principais analisados, ou seja, tipo de aglomerante, tipo de aditivo, teor de aditivo e tempo são estatisticamente significativos a um nível de confiança de 95\%. Isto confirma a influência de cada uma dessas variáveis independentes, quando tomadas isoladamente.

A variável mais influente no espalhamento foi o tipo de aditivo, em segundo lugar apresentouse a variável teor de aditivo, em terceiro lugar a variável tempo e a menor influência foi exercida pela variável tipo de aglomerante.

Quanto às interações duplas, triplas e quadrúplas, observa-se a sinergia dos fatores para esses tipos de interação, evidenciada pelo resultado estatisticamente significativo, demonstrando que o efeito que uma variável exerce sobre o espalhamento depende das outras variáveis associadas a ela. Cabe destacar a interação dupla entre os fatores tipo de aditivo e teor de aditivo, que demonstrou ser estatisticamente significativo numa intensidade bem superior quando comparada com outras interações. Isso se comprova, quando se compara o Fcal e Ftab e notase uma elevada diferença entre esses parâmetros.

Por fim, realizou-se comparação múltipla de médias pelo método de Duncan, em virtude da influência das variáveis: tipo de aglomerante, tipo de aditivo, teor de aditivo e tempo. Os resultados destas análises são apresentados no Apêndice B.

\subsubsection{Avaliação da viscosidade (mini-funil)}

Na Tabela 19 estão apresentados os resultados médios de fluidez (viscosidade) das argamassas, por meio do ensaio de mini-funil. Essas argamassas sofreram variações em sua mistura com diferentes tipos de aglomerante (AREF, A20, A30), aditivos (SP1, SP2, SP3), teores de aditivo $(0,8 ; 1,0 ; 1,2)$. Além disso, essas argamassas foram submetidas ao efeito do tempo (30 min, $60 \mathrm{~min}$ e $90 \mathrm{~min}$ ), que consistiu no momento em que foi coletada a medida de fluidez, tomando como referência o momento da adição de água na mistura. Cabe destacar que para identificar o aditivo superplastificante que melhor conferiu características de autoadensabilidade às 
argamassas, consideraram-se os resultados de fluidez em unidade de vazão (ml/s), conforme está apresentado no capítulo 2 subitem 2.7.1.

Tabela 19 - Resultados médios de fluidez das argamassas.

\begin{tabular}{|c|c|c|c|c|}
\hline \multirow{3}{*}{ Argamassas } & \multirow{3}{*}{$\begin{array}{c}\text { Teor de aditivo } \\
(\%)\end{array}$} & \multicolumn{3}{|c|}{ Fluidez $(\mathrm{ml} / \mathrm{s})$} \\
\hline & & & Tempo & \\
\hline & & $30 \mathrm{~min}$ & $60 \mathrm{~min}$ & $90 \mathrm{~min}$ \\
\hline \multirow{5}{*}{ AREFSP1 } & 0,6 & 100,62 & 0,00 & 0,00 \\
\hline & 0,8 & 247,87 & 202,68 & 133,96 \\
\hline & 1,0 & 314,13 & 243,61 & 161,88 \\
\hline & 1,2 & 342,60 & 267,45 & 176,22 \\
\hline & 1,4 & 474,48 & 357,17 & 267,77 \\
\hline \multirow{5}{*}{ A20SP1 } & 0,6 & 100,40 & 82,89 & 0,00 \\
\hline & 0,8 & 273,25 & 186,72 & 111,25 \\
\hline & 1,0 & 362,88 & 250,88 & 149,47 \\
\hline & 1,2 & 442,39 & 331,90 & 221,05 \\
\hline & 1,4 & 431,73 & 270,86 & 197,10 \\
\hline \multirow{5}{*}{ A30SP1 } & 0,6 & 168,50 & 0,00 & 0,00 \\
\hline & 0,8 & 378,00 & 263,93 & 166,93 \\
\hline & 1,0 & 426,32 & 327,75 & 238,24 \\
\hline & 1,2 & 516,24 & 359,62 & 264,13 \\
\hline & 1,4 & 575,63 & 507,00 & 376,74 \\
\hline \multirow{5}{*}{ AREFSP2 } & 0,6 & 0,00 & 0,00 & 0,00 \\
\hline & 0,8 & 0,00 & 0,00 & 0,00 \\
\hline & 1,0 & 0,00 & 0,00 & 0,00 \\
\hline & 1,2 & 164,43 & 130,75 & 88,25 \\
\hline & 1,4 & 227,41 & 197,10 & 112,76 \\
\hline \multirow{5}{*}{ A20SP2 } & 0,6 & 0,00 & 0,00 & 0,00 \\
\hline & 0,8 & 0,00 & 0,00 & 0,00 \\
\hline & 1,0 & 110,10 & 0,00 & 0,00 \\
\hline & 1,2 & 185,50 & 110,85 & 59,97 \\
\hline & 1,4 & 142,16 & 86,96 & 50,18 \\
\hline \multirow{5}{*}{ A30SP2 } & 0,6 & 0,00 & 0,00 & 0,00 \\
\hline & 0,8 & 0,00 & 0,00 & 0,00 \\
\hline & 1,0 & 137,45 & 0,00 & 0,00 \\
\hline & 1,2 & 229,71 & 131,96 & 66,29 \\
\hline & 1,4 & 348,92 & 247,24 & 149,54 \\
\hline \multirow{5}{*}{ AREFSP3 } & 0,6 & 230,49 & 147,37 & 62,69 \\
\hline & 0,8 & 357,73 & 275,24 & 197,22 \\
\hline & 1,0 & 437,84 & 294,16 & 218,29 \\
\hline & 1,2 & 584,54 & 411,62 & 340,54 \\
\hline & 1,4 & 550,49 & 474,48 & 401,42 \\
\hline \multirow{5}{*}{ A20SP3 } & 0,6 & 232,62 & 115,56 & 0,00 \\
\hline & 0,8 & 366,99 & 258,51 & 170,36 \\
\hline & 1,0 & 489,85 & 382,25 & 275,69 \\
\hline & 1,2 & 558,62 & 365,41 & 254,83 \\
\hline & 1,4 & 578,57 & 442,39 & 326,49 \\
\hline \multirow{5}{*}{ A30SP3 } & 0,6 & 235,03 & 0,00 & 0,00 \\
\hline & 0,8 & 425,52 & 278,40 & 166,76 \\
\hline & 1,0 & 560,00 & 423,66 & 276,36 \\
\hline & 1,2 & 576,61 & 508,52 & 413,87 \\
\hline & 1,4 & 725,37 & 668,37 & 526,63 \\
\hline
\end{tabular}

Fonte: Próprio autor.

Observa-se, na Tabela 19, que as argamassas A30 tiveram os maiores resultados de fluidez. Essas argamassas alcançaram maior fluidez com o emprego do aditivo superplastificante SP3, 
o qual propiciou obter um valor de fluidez de $725,37 \mathrm{ml} / \mathrm{s}$ para um teor de aditivo de $1,4 \%$ e tempo de 30 min. $\mathrm{O}$ segundo melhor desempenho frente à fluidez foi demonstrado pelas argamassas com emprego do aditivo SP2, com o qual foi possível obter uma fluidez de $575,63 \mathrm{ml} / \mathrm{s}$ para uma argamassa A30, teor de 1,4\% e tempo de $30 \mathrm{~min}$. Entretanto, as argamassas com emprego do aditivo SP2 tiveram os piores resultados de fluidez, a ponto de se obter fluidez $0 \mathrm{ml} / \mathrm{s}$ para os teores de aditivo $0,6 \%$ e $0,8 \%$ com os três diferentes tipos de aglomerante. As argamassas A30 com emprego deste aditivo tiveram um valor máximo de fluidez de $348,92 \mathrm{ml} / \mathrm{s}$ para um teor de aditivo de $1,4 \%$ e $30 \mathrm{~min}$. Este valor de fluidez corresponde $48 \%$ do valor obtido quando se emprega o aditivo SP3 com teor de 1,4\% para a argamassa A30. Por último, cabe enfatizar que é nítida a perda de fluidez das argamassas com decorrer do tempo, ao contrário do que foi observado para os resultados de espalhamento.

A seguir, na Figura 48, tem-se o comportamento das argamassas frente à fluidez, tomando como ênfase a variável independente tipo de aglomerante. Observa-se, na Figura 48, que as curvas das argamassas com tipo de aglomerante A30 (30\% de substituição por fíler calcário), no geral, ficaram superior às curvas das argamassas AREF (sem substituição) e A20. Isso significa que as argamassas A30 tiveram maior ganho de fluidez, corroborando o que foi constatado no gráfico dos valores médios globais na Figura 87, referente à ANOVA, apresentado no Apêndice C. 
Figura 48 - Comportamento das argamassas frente ao ganho de fluidez, tomando como ênfase a variável independente tipo de aglomerante.
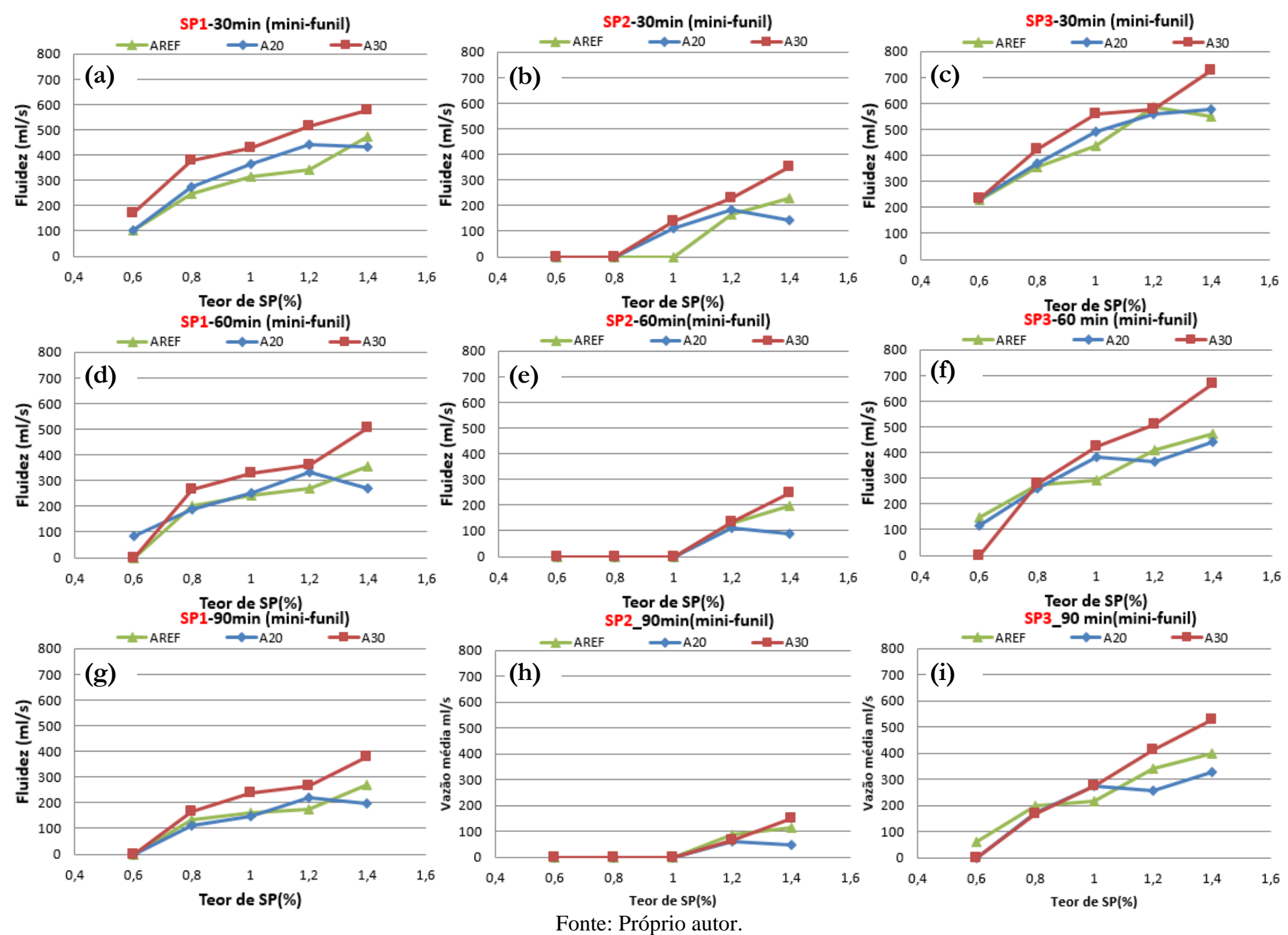
Na Figura 49, tem-se o comportamento das argamassas frente à fluidez, tomando como ênfase a variável independente tipo de aditivo. De maneira mais evidente do que foi apresentado no comportamento das argamassas frente ao espalhamento, as curvas referentes às argamassas com emprego do aditivo SP3 apresentaram curvas superiores às curvas referentes as argamassas com aditivos SP1 e SP2. Isso significa que as argamassas com emprego do aditivo SP3 tiveram melhor desempenho com relação à fluidez. Por outro lado, as argamassas com emprego do aditivo SP2, tiveram resultados não satisfatórios, ao ponto de conferir aproximadamente um terço da fluidez alcançada com emprego do aditivo SP3.

Na Figura 50, tem-se o comportamento das argamassas frente à fluidez, tomando como ênfase a variável tempo. No geral, observa-se claramente a perda de fluidez com decorrer do tempo para todas argamassas com diferentes tipos de aditivos. No entanto, para o espalhamento não se observa essa perda promovida pelo fator tempo de forma tão nítida, conforme notado na Figura 47. Isso ressalta a importância de se medir, também, a viscosidade (fluidez) do material cimentício antes de seu uso e não somente quanto à sua aplicabilidade no estado fresco por meio de único parâmetro de trabalhabilidade como, por exemplo, o espalhamento. 
Figura 49 - Comportamento das argamassas frente ao ganho de fluidez, tomando como ênfase a variável independente tipo de aditivo. AREF-30min (mini-funil) AREF-60min (mini-funil)
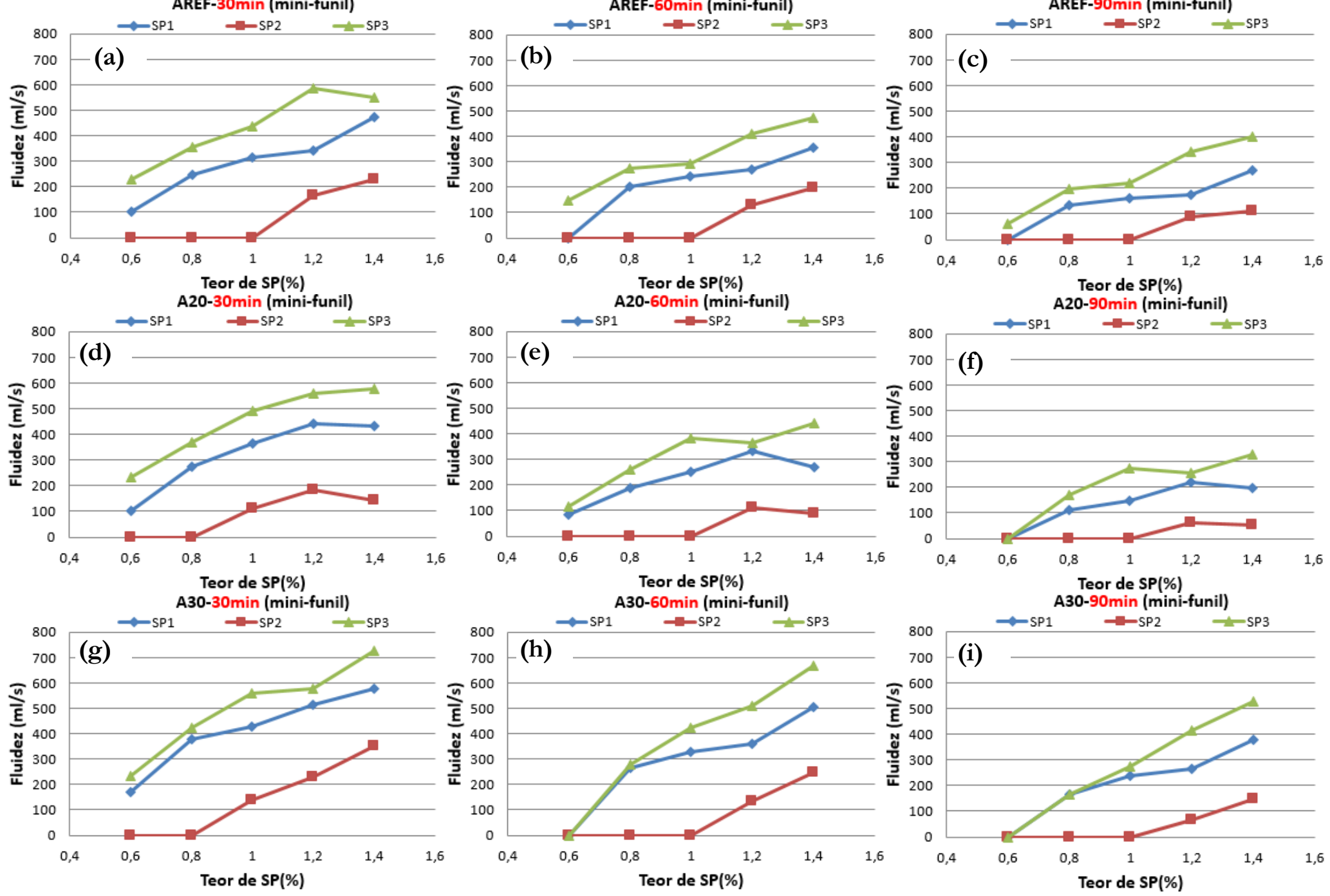

Fonte: Próprio autor. 
Figura 50 - Comportamento das argamassas frente ao ganho de fluidez, tomando como ênfase a variável independente tempo.

AREF-SP1 (mini-funil)

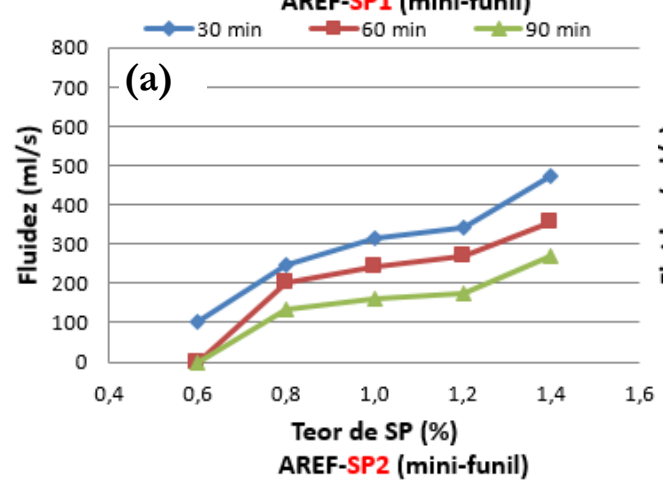

AREF-SP2 (mini-funil)

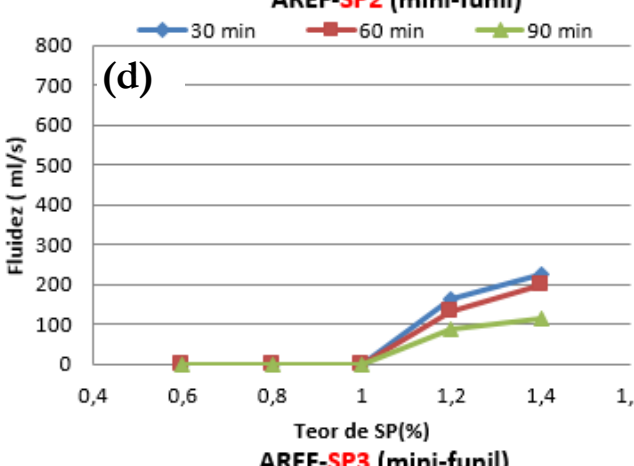

AREF-SP3 (mini-funil)

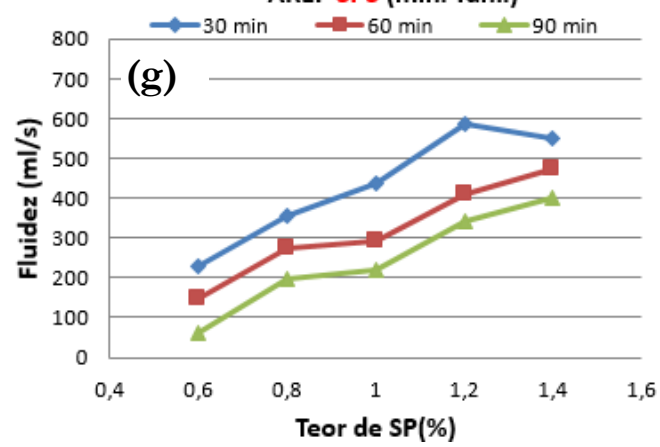

A20-SP1 (mini-funil)

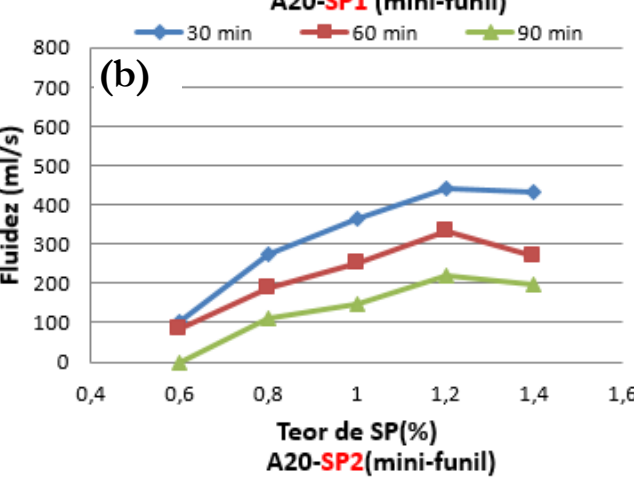

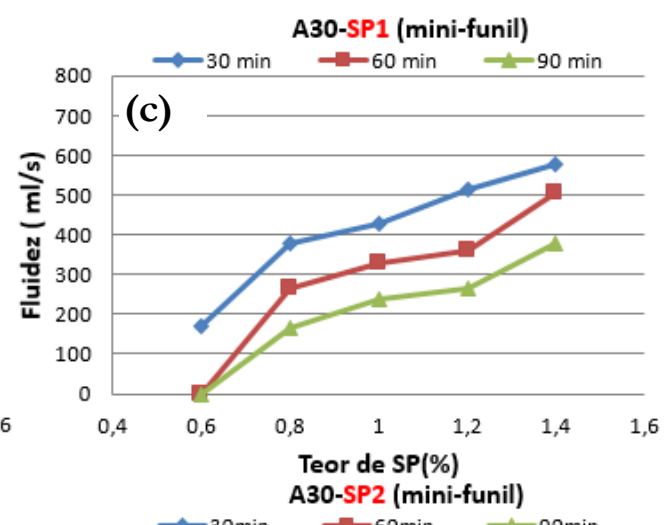
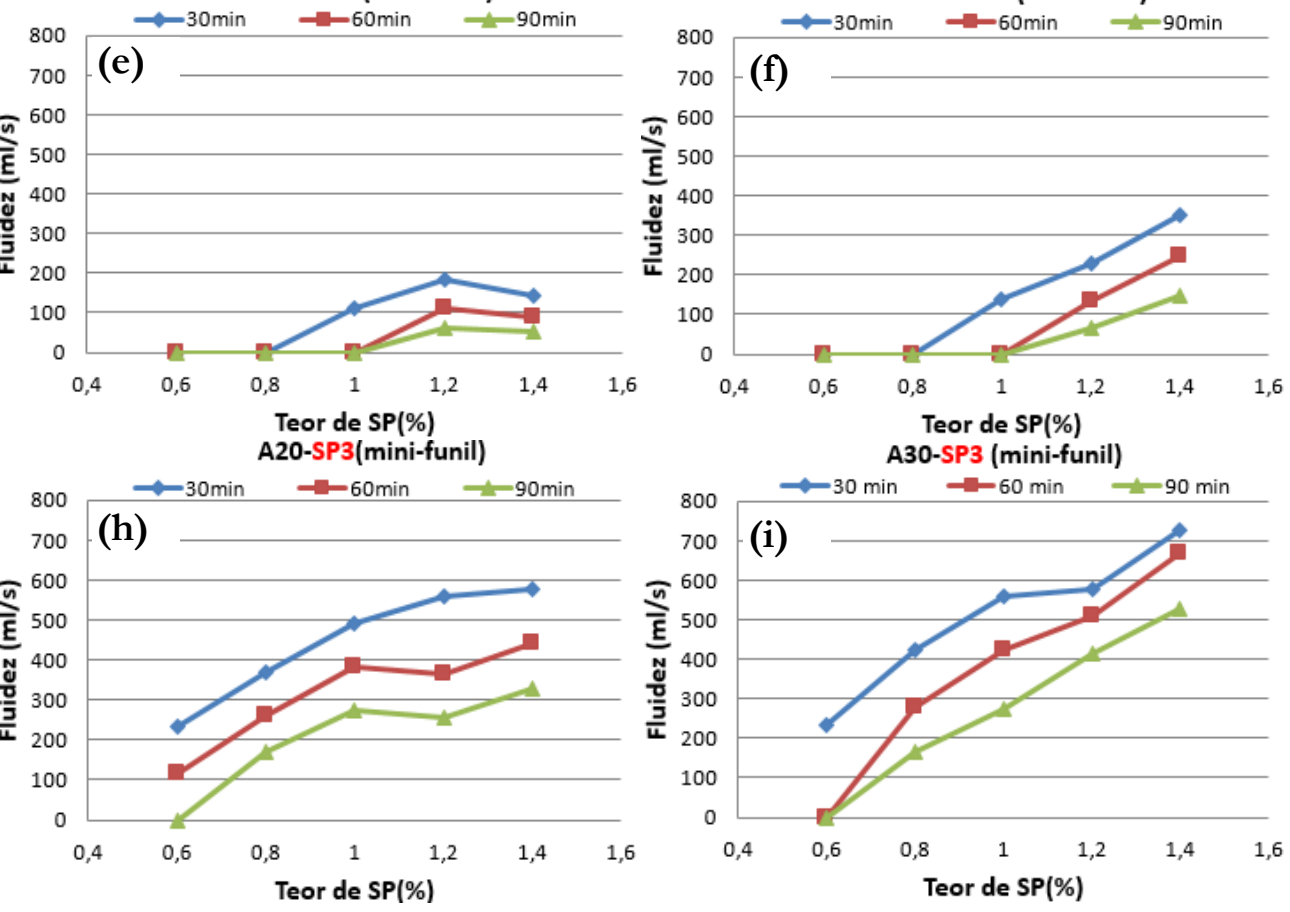

Fonte: Próprio autor. 
A análise de variância para os resultados de viscosidade supracitados também mostrou que os efeitos individuais dos fatores principais analisados, ou seja, tipo de aglomerante, tipo de aditivo, teor de aditivo e tempo são estatisticamente significativos a um nível de confiança de 95\%, conforme está apresentado na íntegra no Apêndice C. Isto confirma a influência de cada uma dessas variáveis independentes, quando tomadas isoladamente.

A variável mais influente na fluidez foi o tipo de aditivo, em segundo lugar apresentou-se a variável tempo, em terceiro lugar a variável teor de aditivo e a menor influência foi exercida pelo variável tipo de aglomerante.

Quanto às interações duplas, triplas e quadruplas, observa-se a sinergia dos fatores para esses tipos de interações, evidenciada pelo resultado estatisticamente significativo, demonstrando que o efeito que uma variável exerce sobre a fluidez depende das outras variáveis associadas a ela. Exceto a interação tripla TAg (tipo de aglomerante) x TAd\% (teor de aditivo) x tempo (t) que não se apresentou significativa. Dentre as interações que se apresentaram significativas, a interação TAd\% (teor de aditivo) x tempo (t) apresentou-se ser mais influente, a qual se confirma na maior diferença proporcional entre os parâmetros Fcal e Ftab. É importante frisar que a influência das interações sobre a variável dependente fluidez é menor na maioria dos casos ao se comparar com os efeitos individuais dos fatores. Mais uma vez, isso se comprova diante da maior diferença proporcional entre os parâmetros Fcal e Ftab.

Por último, realizou-se comparação múltipla de médias pelo método de Duncan, em virtude da influência das variáveis: tipo de aglomerante, tipo de aditivo, teor de aditivo e tempo. Os resultados destas análises estão apresentados no Apêndice C.

\subsubsection{Aditivo superplastificante selecionado}

Esta etapa teve como foco principal avaliar as argamassas no estado fresco com o emprego de diferentes aditivos superplastificantes, de mesma base química, e selecionar o aditivo que melhor conferiu trabalhabilidade às argamassas. Isso foi importante para empregar o aditivo de melhor desempenho nos estudos em argamassas e concretos nas etapas posteriores desta tese.

De posse dos resultados de espalhamento e de fluidez das argamassas. Constatou-se que o aditivo SP3 conferiu melhor desempenho às propriedades no estado fresco. Além disso, considerou-se o teor de aditivo de $1 \%$ para iniciar o estudo em argamassas de relações 
água/sólidos iguais a 0,40 e 0,50, visto que esse teor demonstrou ser o ponto de saturação do aditivo SP3.

Por fim, é importante destacar que o aditivo selecionado possui o maior teor de sólidos em sua composição quando comparado aos outros dois aditivos e, além disso, o seu teor de sólidos determinado experimentalmente no presente trabalho, está próximo do valor especificado pelo fabricante, conforme pode ser visto na Tabela 13. Isto desperta a importância de levar em consideração o teor de sólidos do aditivo nas dosagens de argamassas e concretos, bem como verificar a qualidade do aditivo empregado por meio de ensaios de caracterização.

\subsection{ARGAMASSAS PARA PRODUÇÃO DE CONCRETOS AUTOADENSÁVEIS}

No estudo anterior concluiu-se que o aditivo SP3 conferiu maior trabalhabilidade às argamassas. Diante disso, adotou-se o aditivo superplastificante SP3 neste estudo e, também, no estudo em concretos. A seguir, apresentam-se os resultados de espalhamento e de fluidez das argamassas com relações água/sólidos 0,40; 0,45 e 0,50, com emprego do aditivo SP3, com intuito de identificar as prováveis argamassas referências para produção de concretos autoadensáveis.

\subsubsection{Espalhamento (mini-slump)}

Na Tabela 20 estão apresentados os resultados médios de espalhamento das argamassas, por meio do ensaio de mini-slump e, também, está apresentada a classificação dessas argamassas quanto à sua estabilidade no estado fresco. Essas argamassas sofreram variações em sua mistura com diferentes tipos de aglomerante (AREF, A20, A30) e teores de aditivo. Para as argamassas de relação água/sólidos 0,40 e 0,50, definiu-se três níveis de teor de aditivo, tendo em comum o teor de aditivo de $1 \%$. Para as argamassas de relação água/sólidos igual a 0,45 , considerou-se os resultados do estudo anterior. Neste estudo, também, considerou-se o efeito do tempo (30 min, 60 min e $90 \mathrm{~min}$ ), que consistiu no momento da medida do espalhamento com relação ao instante da adição de água na mistura. Neste caso, adotou-se o espalhamento total, visto que não cabe neste item verificar o ganho de espalhamento promovido principalmente pelo emprego do aditivo. 
Tabela 20 - Resultados médios de espalhamento das argamassas com emprego somente do aditivo SP3.

\begin{tabular}{|c|c|c|c|c|c|c|c|c|}
\hline \multirow{4}{*}{ Argamassas } & \multirow{4}{*}{$\begin{array}{c}\text { Teor de } \\
\text { aditivo }(\%)\end{array}$} & \multirow{2}{*}{\multicolumn{3}{|c|}{ Espalhamento }} & \multicolumn{4}{|c|}{ Estabilidade } \\
\hline & & & & & \multicolumn{2}{|c|}{ Exsudação } & \multicolumn{2}{|c|}{ Segregação } \\
\hline & & \multicolumn{3}{|c|}{ Tempo } & SIM & $\mathrm{NÃO}$ & SIM & NÃO \\
\hline & & $30 \mathrm{~min}$ & $60 \mathrm{~min}$ & $90 \min$ & & & & \\
\hline \multirow{3}{*}{ AREF40 } & 0,8 & 166 & 169 & 143 & & $\mathrm{X}$ & & $\mathrm{X}$ \\
\hline & 1,0 & 235 & 231 & 206 & & $\mathrm{X}$ & & $\mathrm{X}$ \\
\hline & 1,2 & 308 & 293 & 270 & & $\mathrm{X}$ & & $\mathrm{X}$ \\
\hline \multirow{3}{*}{ A2040 } & 0,8 & 189 & 179 & 144 & & $X$ & & $X$ \\
\hline & 1,0 & 289 & 274 & 245 & & $\mathrm{X}$ & & $\mathrm{X}$ \\
\hline & 1,2 & 321 & 318 & 300 & & $\mathrm{X}$ & & $\mathrm{X}$ \\
\hline \multirow{3}{*}{ A 3040} & 0,8 & 181 & 149 & 122 & & $\mathrm{X}$ & & $\mathrm{X}$ \\
\hline & 1,0 & 306 & 296 & 267 & & $X$ & & $\mathrm{X}$ \\
\hline & 1,2 & 314 & 294 & 295 & & $\mathrm{X}$ & & $\mathrm{X}$ \\
\hline \multirow{5}{*}{ AREF45 } & 0,6 & 173 & 154 & 120 & & $X$ & & $\mathrm{X}$ \\
\hline & 0,8 & 273 & 259 & 253 & & $X$ & & $X$ \\
\hline & 1,0 & 349 & 316 & 393 & & $X$ & & $X$ \\
\hline & 1,2 & 342 & 320 & 308 & $X$ & & & $X$ \\
\hline & 1,4 & 408 & 372 & 327 & $X$ & & & $\mathrm{X}$ \\
\hline \multirow{5}{*}{ A2045 } & 0,6 & 176 & 145 & 100 & & $X$ & & $\mathrm{X}$ \\
\hline & 0,8 & 258 & 236 & 222 & & $\mathrm{X}$ & & $\mathrm{X}$ \\
\hline & 1,0 & 337 & 323 & 305 & $X$ & & & $X$ \\
\hline & 1,2 & 340 & 330 & 302 & $X$ & & & $\mathrm{X}$ \\
\hline & 1,4 & 330 & 330 & 315 & $X$ & & & $\mathrm{X}$ \\
\hline \multirow{5}{*}{ A3045 } & 0,6 & 174 & 148 & 100 & & $\mathrm{X}$ & & $X$ \\
\hline & 0,8 & 283 & 270 & 228 & & $X$ & & $X$ \\
\hline & 1,0 & 333 & 325 & 302 & & $\mathrm{X}$ & & $X$ \\
\hline & 1,2 & 336 & 330 & 310 & $\mathrm{X}$ & & & $X$ \\
\hline & 1,4 & 350 & 340 & 340 & $X$ & & & $\mathrm{X}$ \\
\hline \multirow{3}{*}{ AREF50 } & 0,6 & 237 & 220 & 211 & & $X$ & & $\mathrm{X}$ \\
\hline & 0,8 & 322 & 315 & 302 & & $\mathrm{X}$ & & $\mathrm{X}$ \\
\hline & $1,0^{*}$ & 470 & --- & --- & $\mathrm{X}$ & & $X$ & \\
\hline \multirow{3}{*}{ A2050 } & 0,6 & 248 & 239 & 218 & & $X$ & & $X$ \\
\hline & 0,8 & 331 & 308 & 286 & & $X$ & & $X$ \\
\hline & $1,0^{*}$ & 465 & --- & --- & $\mathrm{X}$ & & $X$ & \\
\hline \multirow{3}{*}{ A 3050} & 0,6 & 241 & 233 & 200 & & $X$ & & $\mathrm{X}$ \\
\hline & 0,8 & 325 & 314 & 279 & & $X$ & & $X$ \\
\hline & $1,0 *$ & 495 & --- & --- & $\mathrm{X}$ & & $\mathrm{X}$ & \\
\hline \multicolumn{5}{|c|}{$\begin{array}{l}\text { *o ensaio foi abortado pelo fato da argamassa aparentar instável (segregou e } \\
\text { exsudou intensamente) }\end{array}$} & \multicolumn{4}{|c|}{$\begin{array}{l}\text { Exsudação: NÃO e Segregação: NÃO = estáve } \\
\text { Exsudação: SIM e Segregação: NÃO = } \\
\text { iminente instabilidade } \\
\text { Exsudação: Sim e Segregação: SIM = instável }\end{array}$} \\
\hline
\end{tabular}

Fonte: Próprio autor.

Verifica-se, na Tabela 20, que o menor valor de espalhamento foi de $166 \mathrm{~mm}$ para argamassa AREF40, com teor de aditivo $0,8 \%$, referente ao tempo de $30 \mathrm{~min}$. O maior valor de espalhamento foi de $408 \mathrm{~mm}$ para argamassa AREF45, com teor de aditivo 1,4\%, referente ao tempo de $30 \mathrm{~min}$. Quanto à estabilidade das argamassas no estado fresco, dentre as 33 argamassas descritas na mesma Tabela 20, verifica-se que 23 argamassas se mostraram estáveis, 7 argamassas se mostraram iminentes instáveis e 3 argamassas se mostraram instáveis. Para o tempo de $30 \mathrm{~min}$, os maiores valores de espalhamento das argamassas estáveis e das argamassas iminentes instáveis foram 349 mm (AREF45-1,0\%SP) e 408 mm (AREF45- 
1,4\% SP), respectivamente. As argamassas instáveis não foram consideradas para serem avaliadas quanto à possibilidade de servirem como referências para produção de concretos autoadensáveis.

Na Figura 51 estão apresentados os comportamentos das argamassas sob a influência da variação do tipo de aglomerante, relação água/sólidos, teor de aditivo e variação do tempo frente ao espalhamento. Verifica-se que as argamassas sofreram uma leve perda de espalhamento com a variação do tempo. Isso se comprova com as curvas representadas por linha cheia (30 minutos), linha pontilhada (60 minutos) e linha tracejada (90 minutos) no sentido decrescente. 
Figura 51 - Comportamentos das argamassas sob a influência da variação do tipo de aglomerante, relação água/sólidos, teor de aditivo e variação do tempo frente ao espalhamento.
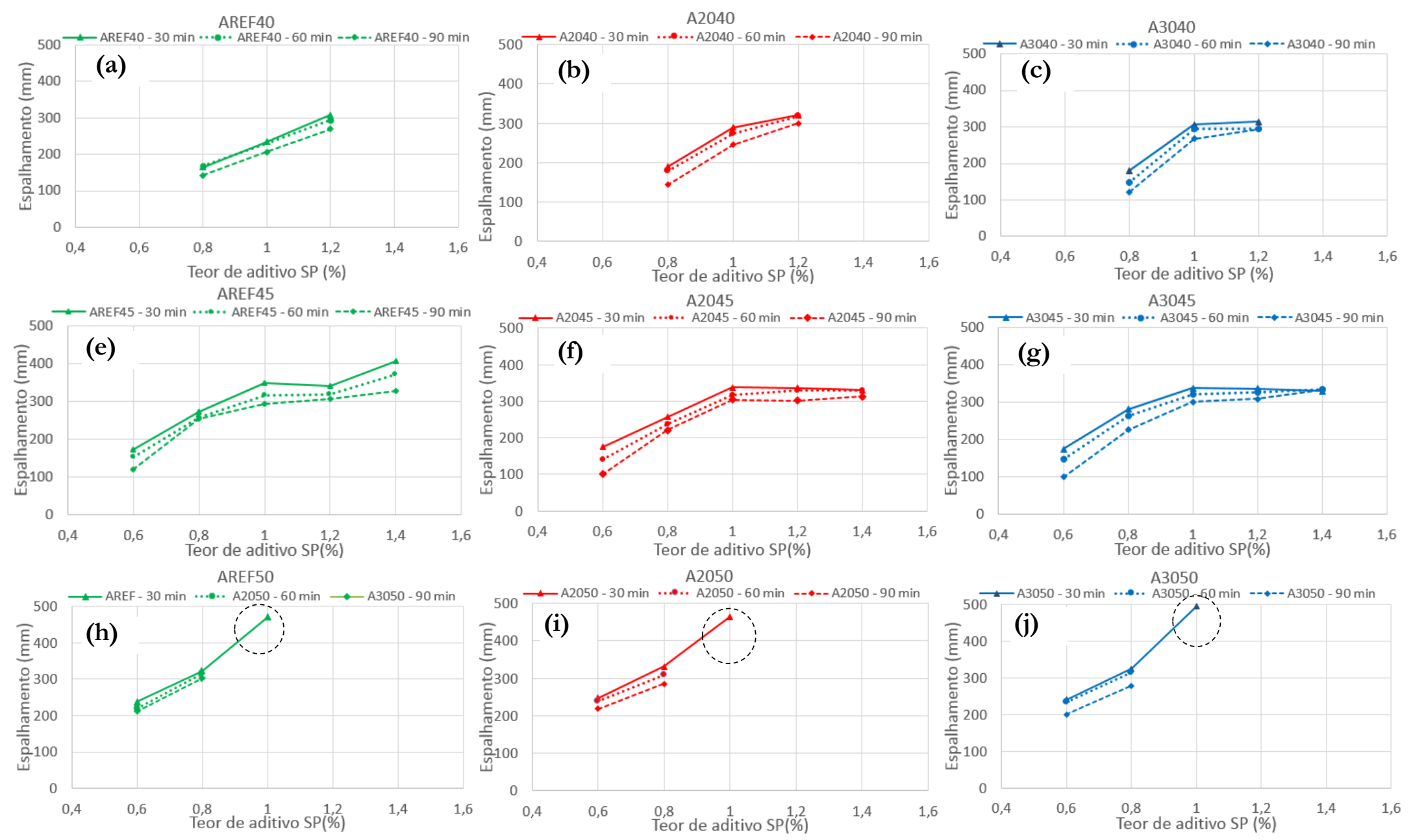

Fonte: Próprio autor. 
Nota-se, na Figura 51, que o teor de saturação do aditivo se define nitidamente em $1 \%$ para as argamassas A2040, A3040, AREF45, A2045 e A3045. No entanto, para as argamassas de relação água/sólidos 0,50 , não se tem apresentado o ponto de saturação. Nesta relação água/sólidos, tem-se apresentado de forma evidente o comportamento típico de uma argamassa instável. Esse comportamento é demonstrado pelo sobressalto da curva no seu extremo, conforme está circundado pela linha tracejada de cor preta.

Por último, foram realizadas as análises de variância das variáveis independentes sobre o espalhamento, com intuito de respaldar as análises de comportamento dos resultados apresentados anteriormente. Realizou-se, portanto, uma análise de variância dos resultados de espalhamento das argamassas para cada relação água/sólidos, bem como comparação múltipla de médias pelo método de Duncan dos fatores que apresentaram ser significativos, cujos resultados estão apresentados na íntegra no Apêndice D. A seguir, tem-se uma síntese dessa análise de variância, a qual apresenta os efeitos que se mostraram significativos sobre o espalhamento, para cada relação água/sólidos das argamassas. Dessa forma, dividiu-se as análises por relações água/sólidos: 0,40, 0,45 e 0,50, como se tem na sequência.

\section{- Relação água/sólidos 0,40}

A análise estatística dos resultados mostrou que o modelo fatorial adotado é significativo em um valor de $\mathrm{R}^{2}$ mod igual a 0,94. A análise mostrou, também, que os efeitos individuais dos fatores principais analisados: tipo de aglomerante, teor de aditivo e tempo são estatisticamente significativos a um nível de confiança de 95\%, evidenciando a influência que cada uma das variáveis independentes exerce no espalhamento, quando tomadas isoladamente.

Tomando-se como base a magnitude dos valores de Fcal, pode-se constatar que a variável mais influente no espalhamento foi teor de aditivo, seguida do tempo e tipo de aglomerante, nesta ordem.

- Relação água/sólidos 0,45

A análise estatística dos resultados mostrou que o modelo fatorial adotado é significativo em um valor de $\mathrm{R}^{2}$ mod igual a 0,97. A análise mostrou, também, que os efeitos individuais dos fatores principais analisados: teor de aditivo, tempo e tipo de aglomerante são estatisticamente 
significativos a um nível de confiança de 95\%, evidenciando a influência que cada uma das variáveis independentes exerce no espalhamento, quando tomadas isoladamente.

Em relação à magnitude dos valores de Fcal, pôde-se constatar que a variável mais influente no espalhamento foi o teor de aditivo, seguida do tempo e tipo de aglomerante, nesta ordem.

- Relação água/sólidos 0,50

A análise estatística dos resultados mostrou que o modelo fatorial adotado é significativo, resultando em um valor de $\mathrm{R}^{2}$ mod igual a 0,97 . A análise mostrou, também, que os efeitos individuais dos fatores principais analisados: tipo de aglomerante, teor de aditivo e tempo são estatisticamente significativos a um nível de confiança de 95\%, evidenciando a influência que cada uma das variáveis independentes exerce no espalhamento, quando tomadas isoladamente.

Com base na magnitude dos valores de Fcal, pode-se constatar que a variável mais influente no espalhamento foi teor de aditivo, seguida do tempo e tipo de aglomerante, nesta ordem.

Para concluir, observou-se que o teor de aditivo exerce maior influência sobre o espalhamento da argamassa e o tipo de aglomerante influencia com menor magnitude. Isto significa, por exemplo, que o aumento do teor de aditivo influenciou mais no aumento do espalhamento da argamassa do que influenciou o teor de substituição do cimento por fíler calcário.

\subsubsection{Avaliação da viscosidade (mini-funil)}

Na Tabela 21 estão apresentados os resultados médios de fluidez (viscosidade aparente) das argamassas por meio do ensaio de mini-funil e, também, consta a classificação dessas argamassas quanto à sua estabilidade no estado fresco. Essas argamassas sofreram variação em sua mistura com diferentes tipos de aglomerante e teores de aditivo. Além disso, elas foram submetidas ao efeito do tempo (30 $\mathrm{min}, 60 \mathrm{~min}$ e $90 \mathrm{~min}$ ), que consistiu no momento da leitura do resultado de fluidez, tomando como referência o instante da adição de água na mistura. 
Tabela 21 - Resultados médios de fluidez das argamassas com emprego somente do aditivo SP3.

\begin{tabular}{|c|c|c|c|c|c|c|c|c|}
\hline \multirow{4}{*}{ Argamassas } & \multirow{4}{*}{$\begin{array}{l}\text { Teor de } \\
\text { aditivo } \\
\qquad \%)\end{array}$} & \multicolumn{3}{|c|}{ Fluidez $(\mathrm{ml} / \mathrm{s})$} & \multicolumn{4}{|c|}{ Estabilidade } \\
\hline & & & & & \multicolumn{2}{|c|}{ Exsudação } & \multicolumn{2}{|c|}{ Segregação } \\
\hline & & \multicolumn{3}{|c|}{ Tempo } & SIM & NÃO & SIM & NÃO \\
\hline & & $30 \mathrm{~min}$ & $60 \mathrm{~min}$ & $90 \mathrm{~min}$ & & & & \\
\hline \multirow{3}{*}{ AREF40 } & 0,8 & 102,67 & 78,50 & 47,42 & & $\mathrm{X}$ & & $\mathrm{X}$ \\
\hline & 1,0 & 169,33 & 121,86 & 83,18 & & $\mathrm{X}$ & & $\mathrm{X}$ \\
\hline & 1,2 & 208,11 & 125,37 & 67,57 & & $\mathrm{X}$ & & $\mathrm{X}$ \\
\hline \multirow{3}{*}{ A2040 } & 0,8 & 136,51 & 85,44 & 30,95 & & $\mathrm{X}$ & & $\mathrm{X}$ \\
\hline & 1,0 & 213,59 & 152,64 & 95,28 & & $\mathrm{X}$ & & $\mathrm{X}$ \\
\hline & 1,2 & 329,17 & 237,24 & 178,90 & & $\mathrm{X}$ & & $\mathrm{X}$ \\
\hline \multirow{3}{*}{ A3040 } & 0,8 & 131,90 & 69,33 & 28,11 & & $\mathrm{X}$ & & $\mathrm{X}$ \\
\hline & 1,0 & 321,90 & 204,68 & 90,93 & & $X$ & & $X$ \\
\hline & 1,2 & 301,55 & 202,19 & 145,46 & & $\mathrm{X}$ & & $\mathrm{X}$ \\
\hline \multirow{5}{*}{ AREF45 } & 0,6 & 230,49 & 147,37 & 62,69 & & $\mathrm{X}$ & & $\mathrm{X}$ \\
\hline & 0,8 & 357,73 & 275,24 & 197,22 & & $X$ & & $X$ \\
\hline & 1,0 & 437,84 & 294,16 & 218,29 & & $X$ & & $\mathrm{X}$ \\
\hline & 1,2 & 584,54 & 411,62 & 340,54 & $\mathrm{X}$ & & & $\mathrm{X}$ \\
\hline & 1,4 & 550,49 & 474,48 & 401,42 & $X$ & & & $X$ \\
\hline \multirow{5}{*}{ A2045 } & 0,6 & 232,62 & 115,56 & 0,00 & & $X$ & & $X$ \\
\hline & 0,8 & 366,99 & 258,51 & 170,36 & & $X$ & & $X$ \\
\hline & 1,0 & 489,85 & 382,25 & 275,69 & $X$ & & & $\mathrm{X}$ \\
\hline & 1,2 & 558,62 & 365,41 & 254,83 & $\mathrm{X}$ & & & $\mathrm{X}$ \\
\hline & 1,4 & 578,57 & 442,39 & 326,49 & $X$ & & & $X$ \\
\hline \multirow{5}{*}{ A3045 } & 0,6 & 235,03 & 0,00 & 0,00 & & $X$ & & $X$ \\
\hline & 0,8 & 425,52 & 278,40 & 166,76 & & $X$ & & $X$ \\
\hline & 1,0 & 560,00 & 423,66 & 276,36 & & $\mathrm{X}$ & & $\mathrm{X}$ \\
\hline & 1,2 & 576,61 & 508,52 & 413,87 & $X$ & & & $\mathrm{X}$ \\
\hline & 1,4 & 725,37 & 668,37 & 526,63 & $X$ & & & $X$ \\
\hline \multirow{3}{*}{ AREF50 } & 0,6 & 451,77 & 315,08 & 234,10 & & $X$ & & $X$ \\
\hline & 0,8 & 580,94 & 455,48 & 337,73 & & $X$ & & $X$ \\
\hline & 1,0 & $*$ & $*$ & $*$ & $X$ & & $X$ & \\
\hline \multirow{3}{*}{ A2050 } & 0,6 & 556,64 & 390,78 & 248,22 & & $X$ & & $\mathrm{X}$ \\
\hline & 0,8 & 693,68 & 531,34 & 434,38 & & $\mathrm{X}$ & & $\mathrm{X}$ \\
\hline & 1,0 & $*$ & $*$ & $*$ & $X$ & & $X$ & \\
\hline \multirow{3}{*}{ A3050 } & 0,6 & 542,46 & 375,73 & 269,01 & & $X$ & & $\mathrm{X}$ \\
\hline & 0,8 & 770,68 & 539,88 & 422,23 & & $X$ & & $X$ \\
\hline & 1,0 & $*$ & $*$ & $*$ & $\mathrm{X}$ & & $\mathrm{X}$ & \\
\hline \multicolumn{5}{|c|}{$\begin{array}{c}\text { *o ensaio foi abortado pelo fato da argamassa aparentar instável }_{\text {(segregou e exsudou intensamente) }}\end{array}$} & \multicolumn{4}{|c|}{$\begin{array}{l}\text { Exsudação: NÃO e Segregação: NÃ̃ = estável } \\
\text { Exsudação: SIM e Segregação: NÃO = iminente } \\
\text { instabilidade } \\
\text { Exsudação: Sim e Segregação: SIM = instável }\end{array}$} \\
\hline
\end{tabular}

Fonte: Próprio autor.

Observa-se, na Tabela 21, que o menor valor de fluidez foi de 102,67 ml/s para argamassa AREF40, com teor de aditivo 0,8\% e referente ao tempo de $30 \mathrm{~min}$. O maior valor de fluidez é de $770,68 \mathrm{ml} / \mathrm{s}$ para argamassa A3050, com teor de aditivo $0,8 \%$ e referente ao tempo de $30 \mathrm{~min}$; em seguida, tem-se o valor de fluidez de 725,37 ml/s para argamassa A3045, com teor de $1,4 \%$ e referente ao tempo de $30 \mathrm{~min}$. Nota-se que os maiores valores de fluidez dizem respeito às argamassas com substituição de $30 \%$ de cimento por fíler calcário. No âmbito das argamassas classificadas como estáveis (sem exsudação e sem segregação) e de diferentes relações água/sólidos, os maiores valores de fluidez para o tempo de $30 \mathrm{~min}$ são 770,68 ml/s, 
$560 \mathrm{ml} / \mathrm{s}$ e $329 \mathrm{ml} / \mathrm{s}$, referentes às argamassas A3050-0,8\%, A3045-1,0\% e A2040-1,2\%, respectivamente.

Ressalta-se ainda, que a perda de trabalhabilidade da argamassa é notada de forma mais nítida e acentuada diante dos resultados de fluidez da argamassa. Tomando como exemplo a argamassa A3050-0,8\%, os seus valores de fluidez com relação ao tempo são $770,68 \mathrm{ml} / \mathrm{s}(30 \mathrm{~min}), 539,88 \mathrm{ml} / \mathrm{s}(60 \mathrm{~min})$ e $422,23 \mathrm{ml} / \mathrm{s}$ (90 $\mathrm{min})$. Isso equivale uma perda de fluidez em função do tempo de $30 \%$ entre 30 min e 60 min e de $22 \%$ entre 60 min e 90 min e, por fim, uma perda de $45 \%$ entre $30 \mathrm{~min}$ e $90 \mathrm{~min}$. Essa perda de fluidez se confirma na Figura 52, a seguir, demonstrada pelas curvas de linha cheia (referente à curva de $30 \mathrm{~min}$ ), linha pontilhada (referente à curva de $60 \mathrm{~min}$ ) e linha tracejada (referente à curva de $90 \mathrm{~min}$ ), distantes de forma bem evidente.

Por fim, é importante frisar que as argamassas AREF50-1,0\%, A2050-1,0\% e A3050-1,0\% não apresentaram valores de fluidez, pelo fato delas terem apresentado exsudação e segregação intensa; com isso, não foram consideradas para avaliação de fluidez. 
Figura 52 - Comportamentos das argamassas sob a influência da variação do tipo de aglomerante, relação água/sólidos, teor de aditivo e variação do tempo frente à fluidez. AREF40

A...AREF40 - 60 min --- -- AREF40 - 90 min

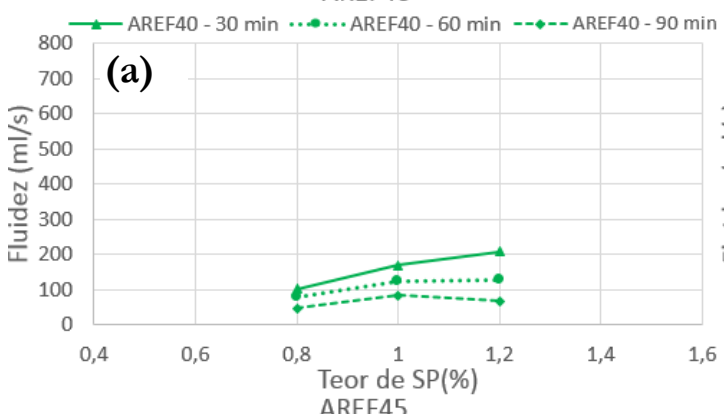

-AREF45 - 30 min …....AREF45 - 60 min --๑-- AREF45 - 90 min
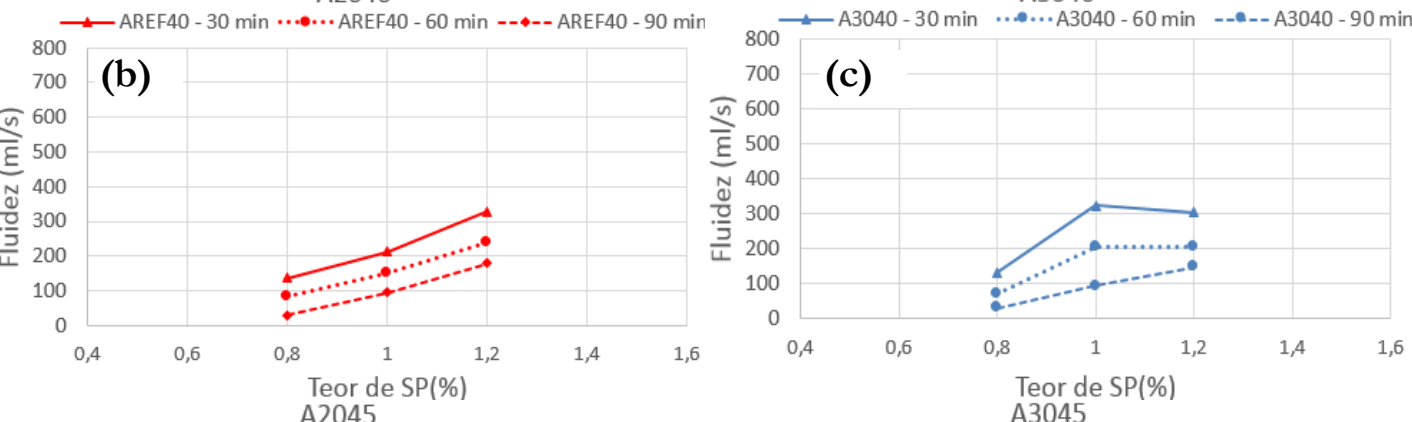

$$
700 \text { (d) }
$$
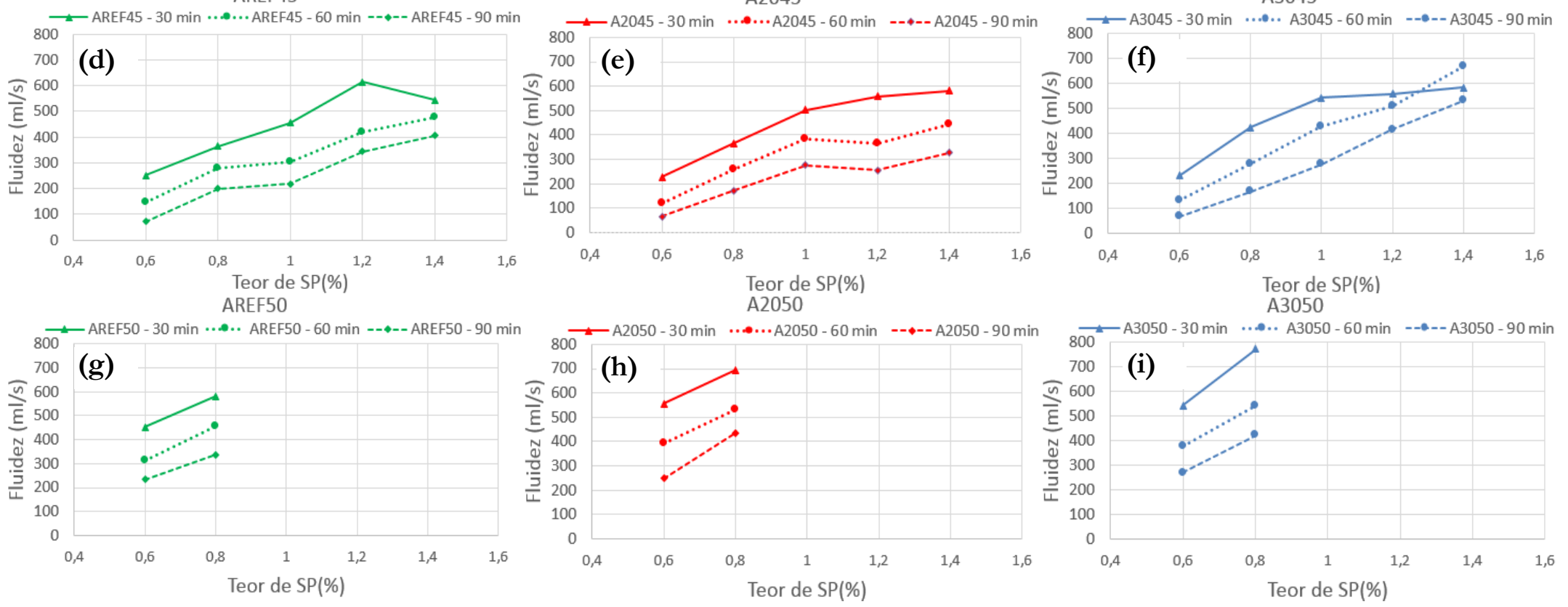

Fonte: Próprio autor. 
Além da influência da variável tempo sobre a fluidez, na Figura 52, também estão apresentados os comportamentos das argamassas sob a influência da variação do tipo de aglomerante, relação água/sólidos e teor de aditivo. Nota-se que as argamassas A2045, A3045, A3040 e AREF40 apresentam ponto de saturação do aditivo para o teor de $1 \%$.

Por fim, foram realizadas as análises de variância das variáveis independentes sobre a fluidez das argamassas, com intuito de respaldar as análises de comportamento dos resultados apresentadas acima. Realizou-se, portanto, uma análise de variância dos resultados de viscosidade (fluidez) das argamassas para cada relação água/sólidos, bem como comparação múltipla de médias pelo método de Duncan dos fatores que apresentaram ser significativas, que estão apresentadas na íntegra no Apêndice F. A seguir, tem-se uma síntese dessas análises de variância, a qual apresenta os efeitos que se mostraram significativos sobre a fluidez, para cada relação água/sólidos das argamassas. Dessa forma, dividiu-se as análises por relações água/sólidos 0,40, 0,45 e 0,50, como se tem a seguir.

- Relação água/sólidos 0,40

A análise estatística dos resultados mostrou que o modelo fatorial adotado é significativo, resultando em um valor de $\mathrm{R}^{2}$ mod igual a 0,84 . A análise mostrou, também, que os efeitos individuais dos fatores principais analisados: tipo de aglomerante, teor de aditivo e tempo, são estatisticamente significativos a um nível de confiança de $95 \%$, evidenciando a influência que cada uma das variáveis independentes exerce na fluidez (viscosidade plástica aparente), quando tomadas isoladamente.

Tomando-se como base a magnitude dos valores de Fcal, pode-se constatar que a variável mais influente na fluidez foi o tempo, seguida do teor de aditivo e tipo de aglomerante, nesta ordem.

\section{- Relação água/sólidos 0,45}

A análise estatística dos resultados mostrou que o modelo fatorial adotado é significativo para o valor de $\mathrm{R}^{2}$ mod igual a 0,89 . A análise mostrou, também, que os efeitos individuais dos fatores principais analisados: tipo aglomerante, teor de aditivo e tempo são estatisticamente significativos a um nível de confiança de 95\%, evidenciando a influência que cada uma das 
variáveis independentes exerce na fluidez (viscosidade plástica aparente), quando tomadas isoladamente.

Ao considerar como base a magnitude dos valores de Fcal, pode-se constatar que a variável mais influente na fluidez foi o tempo, seguida do teor de aditivo e do tipo de aglomerante, nesta ordem.

- Relação água/sólidos 0,50

A análise estatística dos resultados mostrou que o modelo fatorial adotado é significativo, resultando em um valor de $\mathrm{R}^{2} \bmod$ igual a 0,88 . A análise mostrou, também, que os efeitos individuais dos fatores principais analisados: tipo de aglomerante, teor de aditivo e tempo, são estatisticamente significativos a um nível de confiança de 95\%, evidenciando a influência que cada uma das variáveis independentes exerce na fluidez (viscosidade plástica aparente), quando tomadas isoladamente.

Quanto a magnitude dos valores de Fcal, pode-se constatar que a variável mais influente na fluidez foi teor de aditivo, seguida do tempo e do tipo de aglomerante, nesta ordem. Cabe destacar, que o Fcal $(109,93)$ referente à variável teor de aditivo é bem próxima do Fcal $(109,02)$ referente à variável tempo. Pode-se afirmar, neste caso, que essas duas variáveis influenciam a fluidez de forma muito similar.

Para concluir, observou-se que as variáveis teor de aditivo e tempo exercem influência sobre a fluidez quase na mesma magnitude e o tipo de aglomerante influencia com menor magnitude. O aumento dos valores do teor de aditivo e do teor de substituição do cimento por fíler calcário tende a aumentar a fluidez, no entanto o aumento do tempo tende a diminuir a fluidez.

\subsection{AUTOADENSABILIDADE DE CONCRETOS}

Na Tabela 22, estão apresentados os resultados dos ensaios que avaliam autoadensabilidade dos concretos, a saber: slump flow, T500, funil V, anel J, caixa L, caixa U e coluna de segregação, bem como estão classificados os resultados desses ensaios conforme a ABNT NBR 15823- (2010). De acordo com esta norma, o concreto para ser definido como autoadensável deve se enquadrar, no mínimo, na classificação prescrita para os ensaios de slump flow, T500 ou funil V, anel J ou caixa L. 
Tabela 22 - Resultados e classificações de autoadensabilidade dos concretos.

\begin{tabular}{|c|c|c|c|c|c|c|c|c|c|c|c|c|c|c|c|c|c|c|}
\hline \multirow[t]{2}{*}{ Ensaios } & \multicolumn{18}{|c|}{ CONCRETO } \\
\hline & $1 \mathrm{C}$ & $2 \mathrm{C}$ & $3 \mathrm{C}$ & $4 C$ & $5 \mathrm{C}$ & $6 \mathrm{C}$ & $7 \mathrm{C}$ & $8 \mathrm{C}$ & 9C & $10 \mathrm{C}$ & $11 \mathrm{C}$ & $12 \mathrm{C}$ & 13C & $14 C$ & $15 \mathrm{C}$ & $16 \mathrm{C}$ & $17 \mathrm{C}$ & $18 \mathrm{C}$ \\
\hline m) & 525 & 682 & 615 & 716 & 693 & 707 & 580 & 722 & 618 & 720 & 665 & 704 & 520 & 608 & 550 & 682 & 512 & 740 \\
\hline Class & $\mathrm{N}$ & SF2 & SF1 & SF2 & SF2 & SF2 & SF1 & SF2 & SF1 & SF2 & SF2 & SF2 & $\mathrm{N}$ & SF1 & SF1 & SF2 & $\mathrm{N}$ & SF2 \\
\hline $\mathrm{T}$ & 41 & 5,19 & 4,18 & 3,10 & 4,12 & 2,37 & 2,34 & 3,25 & 2,60 & 3,19 & 2,31 & 1,68 & 2,82 & 3,75 & 1,72 & 1,41 & 2,59 & 1,81 \\
\hline Class & S2 & VS2 & VS2 & VS2 & VS2 & VS2 & VS2 & VS2 & VS2 & VS2 & VS2 & VS1 & VS2 & VS2 & VS1 & VS1 & VS2 & VS1 \\
\hline & 10,78 & 9,25 & 11,47 & 12,34 & 12,16 & 8,04 & 5,91 & 5,25 & 5,91 & 4,40 & 5,56 & 4,69 & 4,09 & 4,53 & 3,66 & 3,31 & 2,88 & 2,84 \\
\hline Classe & VF2 & VF2 & VF2 & VF2 & VF2 & VF1 & VF1 & VF1 & VF1 & VF1 & VF1 & VF1 & VF1 & VF1 & VF1 & VF1 & VF1 & VF1 \\
\hline & 68 & 8 & 72 & 38 & 46 & 94 & 50 & 31 & 60 & 86 & 18 & 21 & 60 & 61 & 50 & 65 & 58 & 5 \\
\hline Classe & $\mathrm{N}$ & PJ1 & $\mathrm{N}$ & $\mathrm{PJ} 2$ & $\mathrm{PJ} 2$ & $\mathrm{~N}$ & PJ2 & PJ2 & $\mathrm{N}$ & $\mathrm{N}$ & PJ1 & PJ1 & $\mathrm{N}$ & $\mathrm{N}$ & PJ2 & $\mathrm{N}$ & $\mathrm{N}$ & PJ1 \\
\hline Caixa L & 0,45 & 0,91 & 0,54 & 0,85 & 0,66 & 0,90 & 0,60 & 0,81 & 0,68 & 0,91 & 0,75 & 0,85 & 0,37 & 0,80 & 0,62 & 0,80 & 0,44 & 1,00 \\
\hline Classe & $\mathrm{N}$ & PL2 & $\mathrm{N}$ & PL2 & $\mathrm{N}$ & PL2 & $\mathrm{N}$ & PL2 & $\mathrm{N}$ & PL2 & $\mathrm{N}$ & PL2 & $\mathrm{N}$ & PL2 & $\mathrm{N}$ & PL2 & $\mathrm{N}$ & PL2 \\
\hline Caixa U ( & 105 & 10 & 66 & 23 & 34 & 22 & 64 & 9 & 58 & 50 & 35 & 36 & 86 & 48 & 57 & 34 & 97 & 17 \\
\hline Classe & $\mathrm{N}$ & S & $\mathrm{N}$ & $S$ & $\mathrm{~N}$ & $S$ & $\mathrm{~N}$ & $S$ & $\mathrm{~N}$ & $\mathrm{~N}$ & $\mathrm{~N}$ & $\mathrm{~N}$ & $\mathrm{~N}$ & $\mathrm{~N}$ & $\mathrm{~N}$ & $\mathrm{~N}$ & $\mathrm{~N}$ & S \\
\hline Coluna (\%) & 8,17 & 1,84 & 17,80 & 12,10 & 2,82 & 14,60 & 10,25 & 12,63 & 5,86 & 3,56 & 12,36 & 4,08 & 5,53 & 0,40 & 8,27 & 21,71 & 14,34 & 34,2 \\
\hline Classe & SR2 & SR2 & SR1 & SR2 & SR2 & SR2 & SR2 & SR2 & SR2 & SR2 & SR2 & SR2 & SR2 & SR2 & SR2 & $\mathrm{N}$ & SR2 & $\mathrm{N}$ \\
\hline CAA & não & $\operatorname{sim}$ & não & $\operatorname{sim}$ & $\operatorname{sim}$ & $\operatorname{sim}$ & $\operatorname{sim}$ & $\operatorname{sim}$ & não & $\operatorname{sim}$ & $\operatorname{sim}$ & $\operatorname{sim}$ & não & $\operatorname{sim}$ & $\operatorname{sim}$ & $\operatorname{sim}$ & não & $\operatorname{sim}$ \\
\hline
\end{tabular}

Fonte: Próprio autor.

Observa-se, na Tabela 22, que treze concretos são classificados como autoadensáveis de um total de dezoito concretos. Isto prova que o estudo preliminar em argamassas foi importante para buscar referências de proporções de materiais capazes de alcançarem concretos autoadensáveis.

\subsection{AUTOADENSABILIDADE DAS ARGAMASSAS REFERENCIAS}

As argamassas foram classificadas como autoadensáveis, a partir da classificação da autoadensabilidade do concreto. Isso significa que o concreto classificado como autoadensável no item anterior correspondeu a uma argamassa de referência também classificada como autoadensável.

$\mathrm{Na}$ Tabela 23, estão apresentados os resultados de autoadensabilidade das argamassas referências submetidas aos ensaios de mini-slump e de mini-funil. 
Tabela 23 - Resultados médios e classificação de autoadensabilidade das argamassas referências.

\begin{tabular}{|c|c|c|c|c|c|c|c|c|}
\hline \multirow{3}{*}{$\begin{array}{l}\text { ARGAMASSA } \\
\text { Referência }\end{array}$} & \multirow[b]{3}{*}{$\begin{array}{l}\text { Rel. } \\
\text { a/s }\end{array}$} & \multirow{3}{*}{$\begin{array}{l}\text { Tipo } \\
\text { de } \\
\text { agl. }\end{array}$} & \multirow[b]{3}{*}{$\begin{array}{l}\text { Teor } \\
\text { Ad. }\end{array}$} & \multirow[b]{3}{*}{$\mathbf{A} \mathbf{A} \mathbf{A}^{*}$} & \multicolumn{4}{|c|}{ Avaliação da autoadensabilidade } \\
\hline & & & & & \multicolumn{2}{|c|}{ mini-slump $(\mathbf{m m})$} & \multicolumn{2}{|c|}{ (mini-funil) (s) } \\
\hline & & & & & $\begin{array}{c}\text { Espalhamento } \\
(\mathbf{m m})\end{array}$ & $\begin{array}{l}\text { Área relativa de } \\
\text { espalhamento } \\
(\text { Gc) }\end{array}$ & $\begin{array}{l}\text { Tempo } \\
\text { de } \\
\text { fluidez } \\
\text { (s) }\end{array}$ & $\begin{array}{c}\text { Velocidade } \\
\text { relativa de } \\
\text { fluidez }-\mathbf{R m} \\
\left(\mathrm{s}^{-1}\right)\end{array}$ \\
\hline $1 \mathrm{~A}$ & 0,40 & REF & 1,0 & & 235 & 4,52 & 6,71 & 1,49 \\
\hline $2 \mathrm{~A}$ & 0,40 & REF & 1,2 & $\mathrm{X}$ & 308 & 8,49 & 5,46 & 1,83 \\
\hline $3 \mathrm{~A}$ & 0,40 & 20 & 1,0 & & 289 & 7,37 & 5,31 & 1,88 \\
\hline $4 \mathrm{~A}$ & 0,40 & 20 & 1,2 & $\mathrm{X}$ & 321 & 9,28 & 3,45 & 2,90 \\
\hline $5 \mathrm{~A}$ & 0,40 & 30 & 1,0 & $\mathrm{X}$ & 306 & 8,36 & 3,53 & 2,83 \\
\hline $6 \mathrm{~A}$ & 0,40 & 30 & 1,2 & $X$ & 314 & 8,86 & 3,76 & 2,66 \\
\hline $7 \mathrm{~A}$ & 0,45 & REF & 0,8 & $\mathrm{X}$ & 273 & 6,45 & 3,17 & 3,15 \\
\hline $8 \mathrm{~A}$ & 0,45 & REF & 1,0 & $\mathrm{X}$ & 349 & 11,18 & 2,59 & 3,86 \\
\hline $9 \mathrm{~A}$ & 0,45 & 20 & 0,8 & & 257 & 5,60 & 3,10 & 3,23 \\
\hline $10 \mathrm{~A}$ & 0,45 & 20 & 1,0 & $X$ & 337 & 10,38 & 2,26 & 4,42 \\
\hline $11 \mathrm{~A}$ & 0,45 & 30 & 0,8 & $X$ & 280 & 6,84 & 2,68 & 3,73 \\
\hline $12 \mathrm{~A}$ & 0,45 & 30 & 1,0 & $\mathrm{X}$ & 337 & 10,38 & 2,10 & 4,76 \\
\hline $13 \mathrm{~A}$ & 0,50 & REF & 0,6 & & 237 & 4,63 & 2,51 & 3,98 \\
\hline $14 \mathrm{~A}$ & 0,50 & REF & 0,8 & $X$ & 322 & 9,39 & 1,99 & 5,03 \\
\hline $15 \mathrm{~A}$ & 0,50 & 20 & 0,6 & $X$ & 248 & 5,13 & 2,04 & 4,90 \\
\hline $16 \mathrm{~A}$ & 0,50 & 20 & 0,8 & $X$ & 331 & 9,98 & 1,65 & 6,07 \\
\hline $17 \mathrm{~A}$ & 0,50 & 30 & 0,6 & & 241 & 4,82 & 2,09 & 4,78 \\
\hline $18 \mathrm{~A}$ & 0,50 & 30 & 0,8 & $X$ & 325 & 9,54 & 1,51 & 6,62 \\
\hline
\end{tabular}

Fonte: Próprio autor.

Nota-se, na Tabela 23, que os valores de espalhamento das argamassas estão entre $235 \mathrm{~mm}$ e $349 \mathrm{~mm}$, ao passo que as argamassas autoadensáveis têm seus valores de espalhamento entre $248 \mathrm{~mm}$ e $349 \mathrm{~mm}$. Quanto à fluidez, as argamassas possuem resultados entre 1,51 s e 6,71 s, enquanto que as autoadensáveis os seus resultados estão compreendidos entre 1,51 e 5,46.

\subsection{REOLOGIA TEÓRICA DOS CONCRETOS AUTOADENSÁVEIS}

Decidiu-se adotar as equações matemáticas de Sedran e De Larrard (1999) para estimar os parâmetros reológicos fundamentais dos concretos, conforme está descrito no capítulo 3 desta tese. Portanto, os resultados estimados dos parâmetros reológicos estão apresentados na Tabela 24, a seguir. 
Tabela 24 - Resultados dos parâmetros reológicos teórico dos concretos.

\begin{tabular}{c|c|c|c|c|c|c}
\hline Referência & $\begin{array}{c}\text { Relação } \\
\text { água/sólidos } \\
(\mathbf{a} / \mathbf{s})\end{array}$ & $\begin{array}{c}\text { Tipo } \\
\mathbf{d e} \\
\text { aglomerante }\end{array}$ & $\begin{array}{c}\text { Teor } \\
\mathbf{d e} \\
\text { aditivo } \\
\mathbf{( \% )}\end{array}$ & CAA* & $\begin{array}{c}\text { Tensão de } \\
\text { escoamento } \\
\text { teórica (Pa) }\end{array}$ & $\begin{array}{c}\text { Viscosidade } \\
\text { plástica teórica } \\
\text { (Pa.s) }\end{array}$ \\
\hline 1C & 0,40 & REF & 1,0 & & 542,77 & 111,81 \\
\hline 2C & 0,40 & REF & 1,2 & $\mathrm{X}$ & 252,29 & 187,17 \\
\hline 3C & 0,40 & 20 & 1,0 & & 378,75 & 130,97 \\
\hline 4C & 0,40 & 20 & 1,2 & $\mathrm{X}$ & 181,95 & 116,79 \\
\hline 5C & 0,40 & 30 & 1,0 & $\mathrm{X}$ & 222,69 & 147,14 \\
\hline 6C & 0,40 & 30 & 1,2 & $\mathrm{X}$ & 196,37 & 86,51 \\
\hline 7C & 0,45 & REF & 0,8 & $\mathrm{X}$ & 440,22 & 67,31 \\
\hline 8C & 0,45 & REF & 1,0 & $\mathrm{X}$ & 167,74 & 122,72 \\
\hline 9C & 0,45 & 20 & 0,8 & & 269,55 & 81,50 \\
\hline 10C & 0,45 & 20 & 1,0 & $\mathrm{X}$ & 173,21 & 120,38 \\
\hline 11C & 0,45 & 30 & 0,8 & $\mathrm{X}$ & 280,04 & 79,13 \\
\hline 12C & 0,45 & 30 & 1,0 & $\mathrm{X}$ & 204,15 & 61,61 \\
\hline 13C & 0,50 & REF & 0,6 & & 549,32 & 70,28 \\
\hline 14C & 0,50 & REF & 0,8 & $\mathrm{X}$ & 388,18 & 114,26 \\
\hline 15C & 0,50 & 20 & 0,6 & $\mathrm{X}$ & 497,84 & 46,41 \\
\hline 16C & 0,50 & 20 & 0,8 & $\mathrm{X}$ & 244,45 & 49,51 \\
\hline 17C & 0,50 & 30 & 0,6 & & 580,07 & 65,27 \\
\hline 18C & 0,50 & 30 & 0,8 & $\mathrm{X}$ & 133,84 & 70,48 \\
\hline CAA*: concreto classificado como autoadensável & & & \\
\hline
\end{tabular}

Fonte: Próprio autor.

Nota-se, na Tabela 24, que os concretos apresentaram valores de tensão de escoamento teórica entre $133,84 \mathrm{~Pa}$ e 580,07 Pa e valores de viscosidade plástica teórica entre 46,41 Pa.s e 187,17 Pa.s.

\subsection{REOLOGIA DAS ARGAMASSAS REFERÊNCIAS}

Neste item, são apresentadas as curvas de fluxo obtidas das argamassas referências no instante 30 min após adição de água na mistura. Considerou-se esse tempo com o intuito de comparar com os resultados de viscosidade aparente (fluidez) das argamassas e dos concretos, os quais foram determinados por meio dos ensaios de mini-funil e funil V, respectivamente. Em seguida, têm-se os valores de viscosidade plástica de torque e de tensão de escoamento de torque, ambos determinados a partir das curvas de fluxo reológico das argamassas.

\subsubsection{Curvas de fluxo reológico das argamassas}

A seguir, nas Figuras 53, 54 e 55, estão apresentadas as curvas de fluxo das argamassas referências de relações água/sólidos $0,40,0,45$ e 0,50, respectivamente. Nessas curvas, é possível visualizar a energia demandada para quebrar a estrutura das partículas de um fluído (argamassa) quando submetido a uma ação de corte. Essa energia corresponde à área 
compreendida entre as curvas ascendentes e descendentes, sendo conhecida como área de histerese. Além disso, é possível também, por meio das curvas, coletar os valores dos principais parâmetros reológicos, como a tensão de escoamento de torque e a viscosidade plástica de torque.

Para cada argamassa consta uma curva ascendente e uma descendente referente ao seu fluxo reológico. As argamassas foram limitadas a sofrerem uma velocidade de cisalhamento (frequência) de $150 \mathrm{rpm}$ e um torque de $150 \mathrm{mN}$.m. Algumas delas atingiram um torque de 150 mN.m antes da frequência de 150 rpm. Estas argamassas tiveram o início de suas curvas de fluxo ascendente logo após a curva ascendente alcançar o torque máximo tolerado. É importante frisar que as argamassas identificadas com códigos de cor verde são aquelas que foram classificadas como autoadensáveis. Mais detalhes dessa identificação encontra-se na Tabela 26.

Na Figura 53 estão apresentadas as curvas de fluxo reológico das argamassas de relação água/sólidos igual a 0,40. Dentre elas, as argamassas 2A, 4A, 5A e 6A são classificadas como autoadensáveis. Aparentemente, não se observa uma diferença de comportamento de fluxo nítida entre as argamassas autoadensáveis e não autoadensáveis. No geral, verifica-se uma histerese relevante, a qual é a área compreendida pela curva ascendente de comportamento pseudoplástico e a curva descendente, que se ajusta a um modelo binghamiano.

Nota-se, na Figura 53, que as argamassas atingiram o torque de $150 \mathrm{mN} . \mathrm{m}$ antes de sofrerem uma velocidade de cisalhamento de $150 \mathrm{rpm}$, exceto a argamassa 5A. 
Figura 53 - Curvas de fluxo obtidas com as argamassas referências de relação água/sólidos 0,40. As setas indicam as velocidades ascendente e descendente.
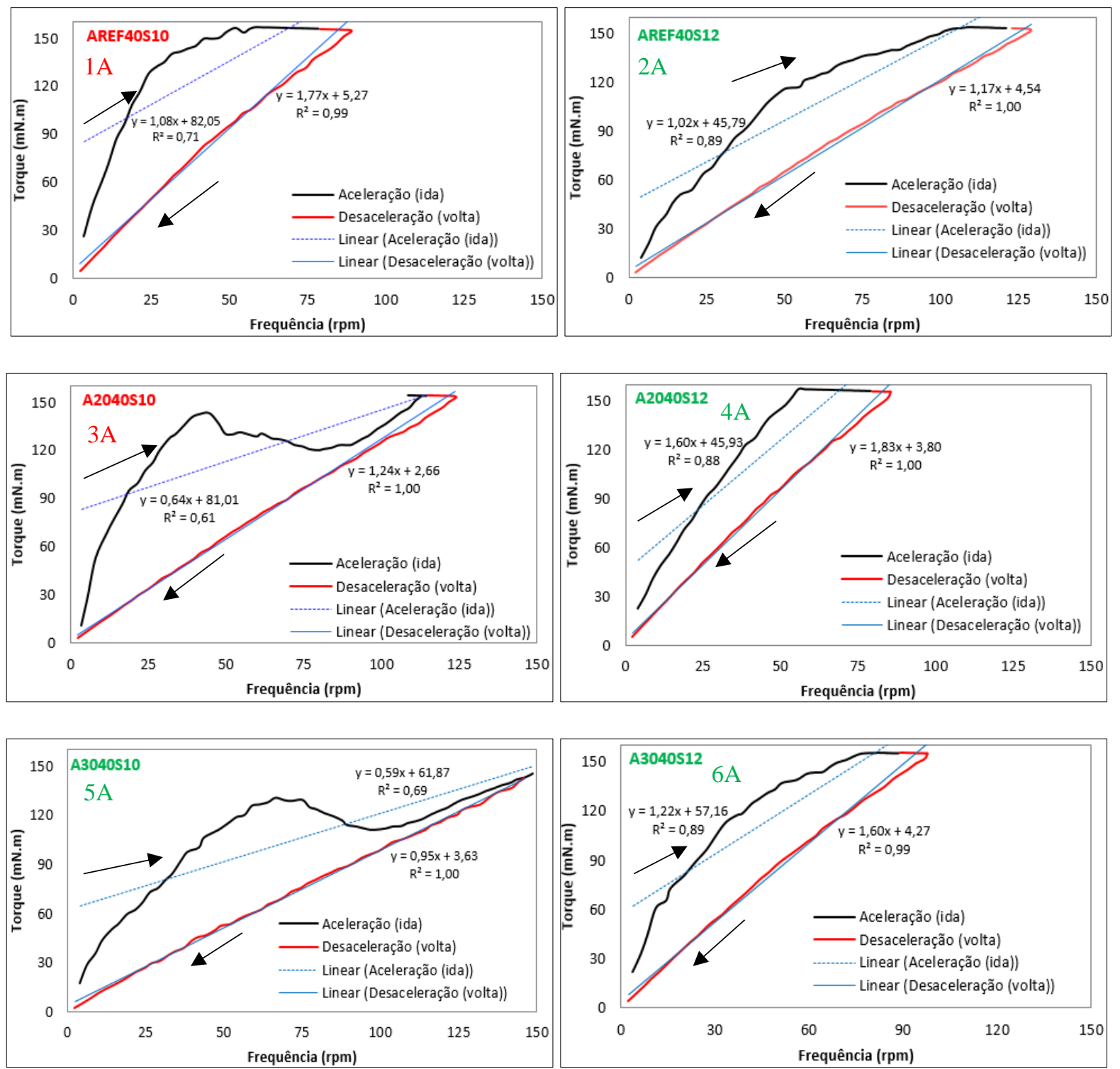

Fonte: Próprio autor.

Na Figura 54 estão apresentadas as curvas de fluxo reológico das argamassas de relação água/sólidos igual a 0,45. Dentre as argamassas, somente a 9A não foi classificada como autoadensável. No geral se observa um comportamento de fluxo semelhante para todas as argamassas. Dessa forma, nota-se uma curva de fluxo ascendente de comportamento pseudoplástico e uma curva descendente que se ajusta a um modelo binghamiano, as quais se interceptam em uma velocidade de cisalhamento (frequência) entre $80 \mathrm{rpm}$ e $100 \mathrm{rpm}$, aproximadamente. Somente as argamassas 7A e 11A não apresentaram interceptação das curvas nesse intervalo. Verifica-se, também, uma importante histerese entre as curvas. 
Figura 54 - Curvas de fluxo obtidas com as argamassas referências de relação água/sólidos 0,45. As setas indicam as velocidades ascendente e descendente.
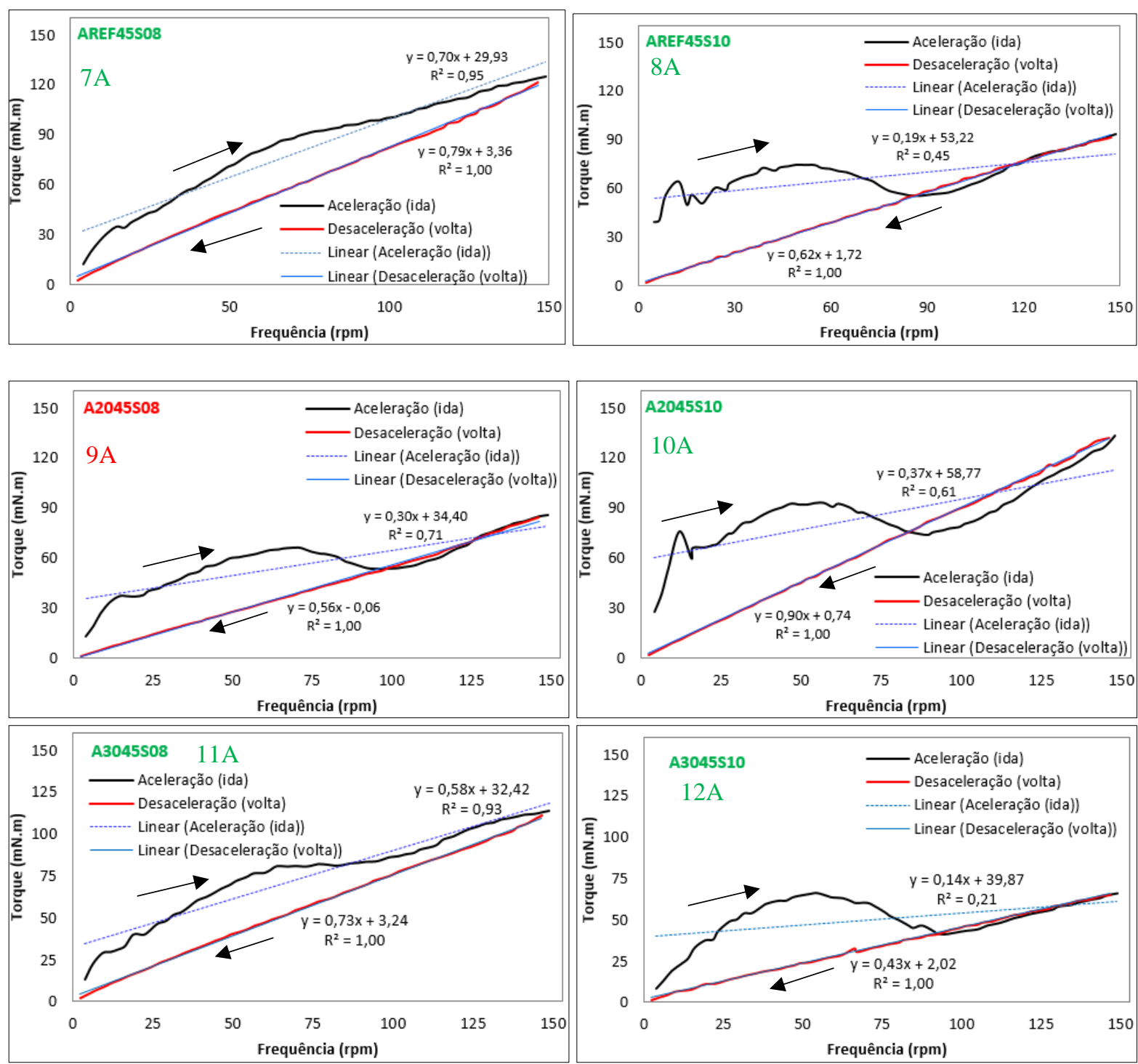

Fonte: Próprio autor.

Na Figura 55 estão apresentadas as curvas de fluxo reológico das argamassas de relação água/sólidos igual a 0,50. Dentre as argamassas, somente as argamassas 13A e 17A não foram classificadas como autoadensáveis.

Verifica-se que há diferença nas curvas de fluxo das argamassas de forma clara. Nota-se que as argamassas $(13 \mathrm{~A}, 15 \mathrm{~A}, 17 \mathrm{~A})$ de menores teores de aditivo apresentaram curvas de fluxo ascendente bem próximas do modelo binghamiano, resultando em uma pequena histerese, visto que as curvas descendentes seguem o modelo de bigham. Por outro lado, as argamassas com maiores teores de aditivo apresentaram uma maior histerese a ponto de se ter curvas ascendentes 
com vários picos de torque fugindo de um comportamento pseudoplástico. As argamassas que apresentaram estas curvas são classificadas como autoadensáveis e sofreram substituição de cimento por fíler calcário.

Figura 55 - Curvas de fluxo obtidas com as argamassas referências de relação água/sólidos 0,50. As setas indicam a velocidade ascendente e descendente.
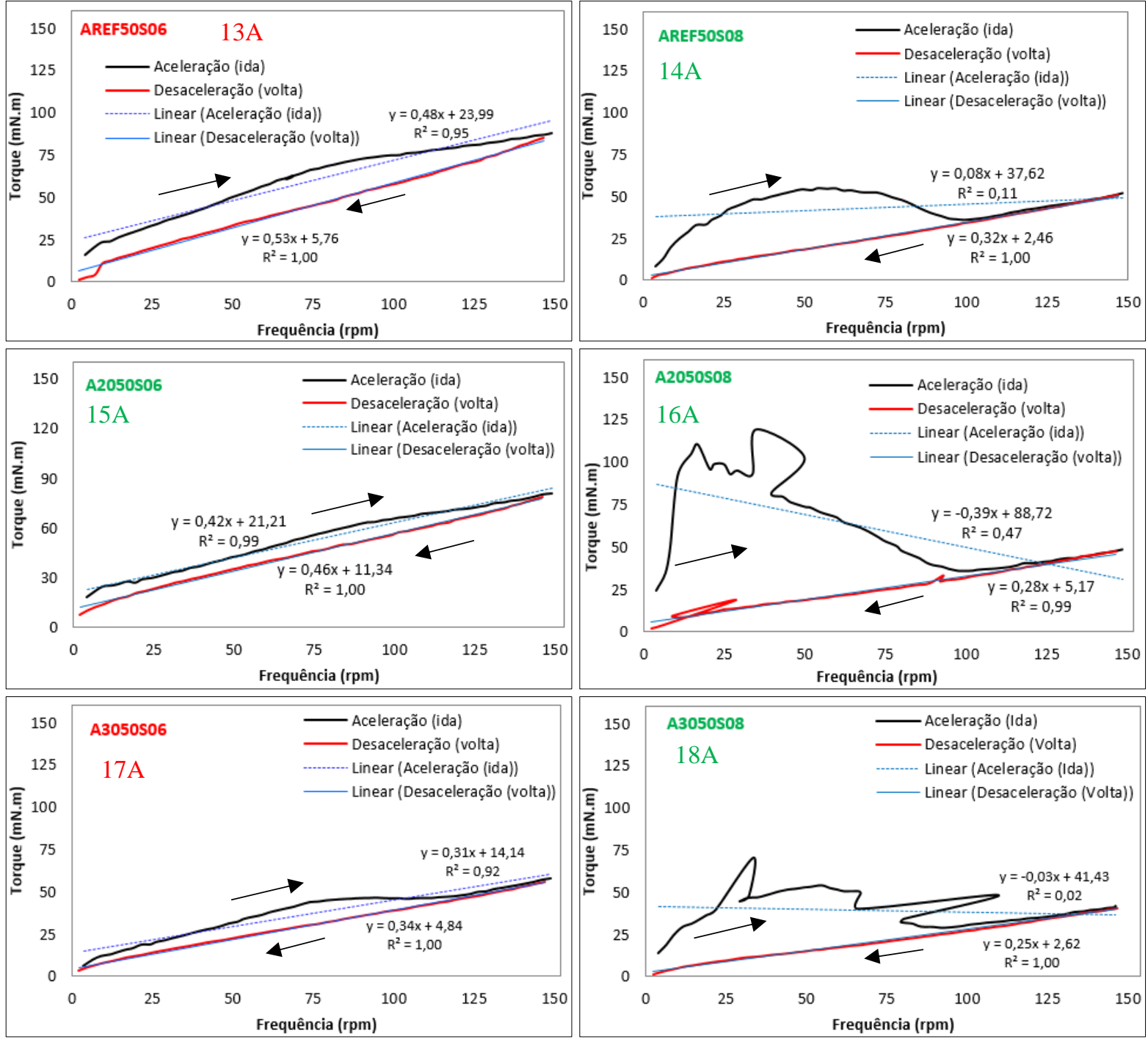

Fonte: Próprio autor.

\subsubsection{Resultados dos parâmetros reológicos das argamassas}

Na Tabela 25, estão apresentados os resultados de tensão de escoamento de torque, viscosidade plástica de torque e a histerese relacionadas as argamassas referências. Observa-se que os valores de tensão de escoamento de torque ficaram entre $0,74 \mathrm{mN} . \mathrm{m}$ e $11,34 \mathrm{mN} . \mathrm{m}$. Os valores de viscosidade de torque ficaram compreendidas entre $0,25 \mathrm{mN}$.m.min e 1,77 mN.m.min. Os valores de histerese ficaram entre 1013,23 mN.m.rpm e 5012,06 mN.m.rpm. 
É importante frisar, que para argamassa 9A, foi obtido um valor negativo de tensão de escoamento de torque igual a - 0,06 mNm, este valor é o coeficiente "b" (ver subitem 3.3.1.4) da regressão linear que representa o seu comportamento bighamiano no regime de velocidade descendente. Diante disso, para tornar coerente a interpretação do comportamento adotado, decidiu-se considerar o mesmo valor de tensão de escoamento de torque determinado para argamassa 10A, que foi igual a $0,74 \mathrm{mNm}$. Esta decisão se sustentou por duas razões, a saber:

- as argamassas 9A e 10A possuem proporções iguais dos materiais, exceto no teor de aditivo. O primeiro foi empregado um teor de aditivo igual $0,8 \%$ (em função da massa do aglomerante) e o segundo foi empregado um teor de 1,0\%;

- nota-se que os valores de tensão de escoamento de torque das argamassas que possuem proporções iguais dos materiais (exceto no teor de aditivo), no geral, são bem próximos entre as argamassas de relação água/sólidos iguais a 0,40 e 0,45.

Tabela 25 - Resultados dos parâmetros reológicos das argamassas referências.

\begin{tabular}{|c|c|c|c|c|c|c|c|c|}
\hline & ferências & $\begin{array}{l}\text { Rel. } \\
\text { a/s }\end{array}$ & $\begin{array}{l}\text { Tipo } \\
\text { de } \\
\text { agl. }\end{array}$ & $\begin{array}{l}\text { Teor de } \\
\text { aditivo } \\
(\%)\end{array}$ & $\mathbf{A} \mathbf{A} \mathbf{A}^{*}$ & \multirow{2}{*}{$\begin{array}{c}\text { Tensão de } \\
\text { Escoamento } \\
\text { de torque } \\
(\mathrm{mN} . \mathrm{m}) \\
\end{array}$} & \multirow{2}{*}{$\begin{array}{c}\begin{array}{c}\text { Viscosidade } \\
\text { Plástica de } \\
\text { torque }\end{array} \\
\text { (mN.m.min) }\end{array}$} & $\begin{array}{c}\text { Histerese } \\
\text { positiva }\end{array}$ \\
\hline $1 \mathrm{~A}$ & AREF40S10 & 0,40 & REF & 1,0 & --- & & & 4066,63 \\
\hline $2 \mathrm{~A}$ & AREF40S12 & 0,40 & REF & 1,2 & $\mathrm{X}$ & 4,54 & 1,17 & 4056,93 \\
\hline $3 \mathrm{~A}$ & A2040S10 & 0,40 & 20 & 1,0 & --- & 2,66 & 1,24 & 4944,71 \\
\hline $4 \mathrm{~A}$ & A2040S12 & 0,40 & 20 & 1,2 & $\mathrm{X}$ & 3,80 & 1,60 & 2671,10 \\
\hline $5 \mathrm{~A}$ & A3040S10 & 0,40 & 30 & 1,0 & $\mathrm{X}$ & 3,63 & 0,95 & 4523,38 \\
\hline $6 \mathrm{~A}$ & A3040S12 & 0,40 & 30 & 1,2 & $\mathrm{X}$ & 4,27 & 1,60 & 3366,82 \\
\hline $7 \mathrm{~A}$ & AREF45S08 & 0,45 & REF & 0,8 & $\mathrm{X}$ & 3,36 & 0,79 & 2801,79 \\
\hline $8 \mathrm{~A}$ & AREF45S10 & 0,45 & REF & 1,0 & $\mathrm{X}$ & 1,72 & 0,62 & 2799,58 \\
\hline $9 \mathrm{~A}$ & A2045S08 & 0,45 & 20 & 0,8 & --- & 0,74 & 0,56 & 2229,52 \\
\hline $10 \mathrm{~A}$ & A2045S10 & 0,45 & 20 & 1,0 & $\mathrm{X}$ & 0,74 & 0,90 & 3025,02 \\
\hline $11 \mathrm{~A}$ & A3045S08 & 0,45 & 30 & 0,8 & $\mathrm{X}$ & 3,24 & 0,72 & 1993,35 \\
\hline $12 \mathrm{~A}$ & A3045S10 & 0,45 & 30 & 1,0 & $\mathrm{X}$ & 2,02 & 0,43 & 2386,72 \\
\hline $13 \mathrm{~A}$ & AREF50S06 & 0,50 & REF & 0,6 & --- & 5,76 & 0,53 & 1993,35 \\
\hline $14 \mathrm{~A}$ & AREF50S08 & 0,50 & REF & 0,8 & $\mathrm{X}$ & 2,46 & 0,32 & 2410,17 \\
\hline $15 \mathrm{~A}$ & A2050S06 & 0,50 & 20 & 0,6 & $\mathrm{X}$ & 11,34 & 0,46 & 1013,23 \\
\hline $16 \mathrm{~A}$ & A2050S08 & 0,50 & 20 & 0,8 & $X$ & 5,17 & 0,28 & 5012,06 \\
\hline $17 \mathrm{~A}$ & A3050S06 & 0,50 & 30 & 0,6 & --- & 4,84 & 0,34 & 2153,35 \\
\hline $18 \mathrm{~A}$ & A3050S08 & 0,50 & 30 & 0,8 & $X$ & 2,62 & 0,25 & 2627,48 \\
\hline
\end{tabular}

Fonte: Próprio autor.

\subsection{RESULTADOS DO PARÂMETRO WFT}

Na Tabela 26 estão apresentados os valores da espessura de água envolta das partículas sólidas da argamassa, definido como parâmetro WFT. Vale ressaltar, segundo Fung (2010), que o valor negativo desse parâmetro significa que a quantidade de água foi insuficiente na mistura 
cimentícia para propiciar uma trabalhabilidade adequada. Entretanto, o valor positivo significa a espessura de água envolta dos grãos da mistura que pode ser capaz de propiciar uma redução do atrito interno entre as partículas sólidas, assim contribuindo para uma melhor trabalhabilidade da matriz cimentícia no seu estado fresco.

Tabela 26 - Resultados médios do parâmetro WFT das argamassas referências.

\begin{tabular}{|c|c|c|c|c|c|c|c|c|c|}
\hline Referência & $\begin{array}{c}\text { Tipo } \\
\text { Aglomerante } \\
\end{array}$ & $\mathbf{a} / \mathbf{s}$ & $\begin{array}{c}\text { Teor de aditivo } \\
(\%)\end{array}$ & $\mathbf{A A A} *$ & $(\Phi)$ & umin & u'w & $\mathbf{A}\left(\mathbf{m}^{2} / \mathbf{m}^{3}\right)$ & $\begin{array}{l}\text { WFT } \\
(\mu \mathrm{m})\end{array}$ \\
\hline $1 \mathrm{~A}$ & AREF & 0,40 & 1,0 & & 0,705 & & $-0,017$ & 173408 & $-0,1006$ \\
\hline $2 \mathrm{~A}$ & AREF & 0,40 & 1,2 & $X$ & 0,706 & & $-0,017$ & 173498 & $-0,0993$ \\
\hline $3 \mathrm{~A}$ & A20 & 0,40 & 1,0 & & 0,710 & & $-0,012$ & 160302 & $-0,0732$ \\
\hline $4 \mathrm{~A}$ & A20 & 0,40 & 1,2 & $\mathrm{X}$ & 0,708 & & $-0,016$ & 160302 & $-0,1027$ \\
\hline $5 \mathrm{~A}$ & A30 & 0,40 & 1,0 & $\mathrm{X}$ & 0,709 & & $-0,016$ & 153834 & $-0,1035$ \\
\hline $6 \mathrm{~A}$ & A30 & 0,40 & 1,2 & $\mathrm{X}$ & 0,708 & & $-0,018$ & 153834 & $-0,1155$ \\
\hline $7 \mathrm{~A}$ & REF & 0,45 & 0,8 & $\mathrm{X}$ & 0,701 & & 0,028 & 173408 & 0,1634 \\
\hline $8 \mathrm{~A}$ & REF & 0,45 & 1,0 & $\mathrm{X}$ & 0,684 & & $-0,007$ & 173498 & $-0,0425$ \\
\hline $9 \mathrm{~A}$ & A20 & 0,45 & 0,8 & & 0,685 & & $-0,009$ & 160302 & $-0,0536$ \\
\hline $10 \mathrm{~A}$ & A20 & 0,45 & 1,0 & $X$ & 0,679 & & $-0,022$ & 160302 & $-0,1357$ \\
\hline $11 \mathrm{~A}$ & A30 & 0,45 & 0,8 & $\mathrm{X}$ & 0,684 & & $-0,014$ & 153834 & $-0,0890$ \\
\hline $12 \mathrm{~A}$ & A30 & 0,45 & 1,0 & $\mathrm{X}$ & 0,680 & & $-0,022$ & 153834 & $-0,1433$ \\
\hline $13 \mathrm{~A}$ & AREF & 0,50 & 0,6 & & 0,672 & & 0,011 & 173408 & 0,0643 \\
\hline $14 \mathrm{~A}$ & AREF & 0,50 & 0,8 & $\mathrm{X}$ & 0,666 & & $-0,001$ & 173498 & $-0,0035$ \\
\hline $15 \mathrm{~A}$ & A20 & 0,50 & 0,6 & $\mathrm{X}$ & 0,674 & & 0,013 & 160302 & 0,0807 \\
\hline $16 \mathrm{~A}$ & A20 & 0,50 & 0,8 & $\mathrm{X}$ & 0,660 & & $-0,019$ & 160302 & $-0,1185$ \\
\hline $17 \mathrm{~A}$ & A30 & 0,50 & 0,6 & & 0,670 & & 0,001 & 153834 & 0,0095 \\
\hline $18 \mathrm{~A}$ & A30 & 0,50 & 0,8 & $X$ & 0,660 & & $-0,021$ & 153834 & $-0,1374$ \\
\hline
\end{tabular}

Onde:

a/s:relação água/sólidos

$\Phi:$ densidade de empacotamento

AAA*: argamassa classificada como autoadensável

Fonte: Próprio autor.

Observa-se, na Tabela 26, que as argamassas referências apresentaram valores de WFT no intervalo de $-0,1433 \mu \mathrm{m}$ e $0,1634 \mu \mathrm{m}$ para valores de densidade de empacotamento no intervalo de 0,710 e 0,660. Nota-se, no geral, que as argamassas apresentaram valores de WFT negativo. Isso significa, que essas argamassas não atingiram uma trabalhabilidade adequada de acordo com Fung (2010), portanto, essa afirmação não procede, pelo fato que boa parte das argamassas foram classificadas como autoadensável.

\subsection{RESULTADOS DAS PROPRIEDADES MECÂNICAS DOS CONCRETOS}

A seguir, estão apresentados os resultados médios de resistência à compressão e módulo de elasticidade como parte da caracterização, no estado endurecido, dos concretos. 


\subsubsection{Resistência à Compressão}

Na Tabela 27 estão apresentados os resultados médios de resistência à compressão dos concretos aos 28 dias de idade.

Tabela 27 - Resultados médios de resistência à compressão dos concretos.

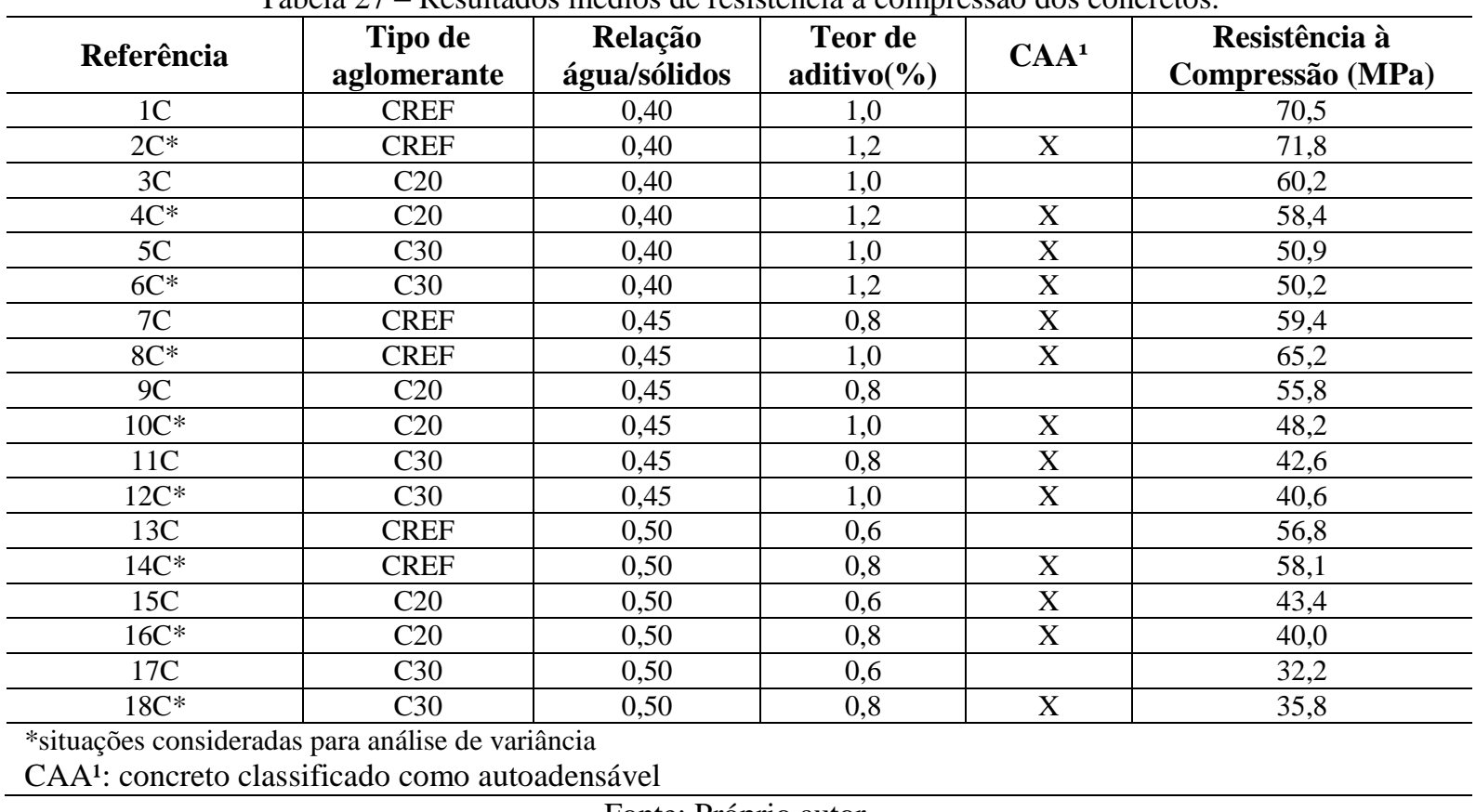

Fonte: Próprio autor.

Observa-se, na Tabela 27, que os resultados de resistência à compressão variaram de 71,8 MPa a 32,2 MPa sob a influência de diferentes relações água/sólidos, tipos de aglomerante e teores de aditivo.

\subsubsection{Módulo de elasticidade}

Na Tabela 28 estão apresentados os resultados médios de módulo de elasticidade dos concretos aos 28 dias de idade. 
Tabela 28 - Resultados médios de módulo de elasticidade dos concretos.

\begin{tabular}{|c|c|c|c|c|c|}
\hline Referência & $\begin{array}{c}\text { Tipo de } \\
\text { aglomerante }\end{array}$ & $\begin{array}{c}\text { Relação } \\
\text { água/sólidos }\end{array}$ & $\begin{array}{c}\text { Teor de } \\
\operatorname{aditivo}(\%)\end{array}$ & $\mathbf{C A A}^{1}$ & $\begin{array}{c}\text { Módulo de } \\
\text { Elasticidade (GPa) }\end{array}$ \\
\hline $1 \mathrm{C}$ & REF & 0,40 & 1,0 & & 33,1 \\
\hline $2 C^{*}$ & REF & 0,40 & 1,2 & $\mathrm{X}$ & 35,4 \\
\hline $3 \mathrm{C}$ & 20 & 0,40 & 1,0 & & 30,5 \\
\hline $4 C^{*}$ & 20 & 0,40 & 1,2 & $\mathrm{X}$ & 34,2 \\
\hline $5 \mathrm{C}$ & 30 & 0,40 & 1,0 & $\mathrm{X}$ & 31,3 \\
\hline $6 C^{*}$ & 30 & 0,40 & 1,2 & $\mathrm{X}$ & 31,5 \\
\hline $7 \mathrm{C}$ & REF & 0,45 & 0,8 & $\mathrm{X}$ & 31,9 \\
\hline $8 C^{*}$ & REF & 0,45 & 1,0 & $\mathrm{X}$ & 33,1 \\
\hline $9 \mathrm{C}$ & 20 & 0,45 & 0,8 & & 29,8 \\
\hline $10 \mathrm{C}^{*}$ & 20 & 0,45 & 1,0 & $\mathrm{X}$ & 31,2 \\
\hline $11 \mathrm{C}$ & 30 & 0,45 & 0,8 & $\mathrm{X}$ & 27,6 \\
\hline $12 \mathrm{C}^{*}$ & 30 & 0,45 & 1,0 & $\mathrm{X}$ & 28,0 \\
\hline $13 \mathrm{C}$ & REF & 0,50 & 0,6 & & 29,0 \\
\hline $14 C^{*}$ & REF & 0,50 & 0,8 & $\mathrm{X}$ & 28,6 \\
\hline $15 \mathrm{C}$ & 20 & 0,50 & 0,6 & $\mathrm{X}$ & 27,4 \\
\hline $16 C^{*}$ & 20 & 0,50 & 0,8 & $\mathrm{X}$ & 29,6 \\
\hline $17 \mathrm{C}$ & 30 & 0,50 & 0,6 & & 25,6 \\
\hline $18 C^{*}$ & 30 & 0,50 & 0,8 & $\mathrm{X}$ & 27,2 \\
\hline
\end{tabular}

*situações consideradas para análise de variância

$\mathrm{CAA}^{\mathbf{1}}$ : concreto classificado como autoadensável

Fonte: Próprio autor.

Observa-se, na Tabela 28, que os resultados de módulo de elasticidade variaram de 35,4 GPa a 25,6 GPa sob a influência de diferentes relações água/sólidos, tipos de aglomerante e teores de aditivo. 


\section{Capítulo V - DISCUSSÃO DOS RESULTADOS}

No presente capítulo estão discutidos os resultados obtidos no programa experimental. Inicialmente, tem-se o item relativo à discussão da autoadensabilidade do concreto. Em seguida, tem-se a discussão da autoadensabilidade das argamassas. Diante disso, são efetuadas relações dos parâmetros de autoadensabilidade de concretos e de argamassas. São propostas classes de das argamassas frente à propriedade de autoadensabilidade. Quanto à propriedade de reologia, primeiramente tem-se a discussão das curvas de fluxo reológico das argamassas referências e, por fim, são definidas as curvas de fluxo mais comuns das argamassas autoadensáveis. Para complementar o estudo de autoadensabilidade e de reologia de argamassas e de concretos, temse um item que trata sobre o parâmetro WFT no que tange à sua capacidade de governar as propriedades de autoadensabilidade e de reologia de materiais cimentícios autoadensáveis. Por fim, discute-se as propriedades mecânicas dos concretos, tais como, resistência à compressão e módulo de elasticidade. 


\subsection{ANÁLISE DA AUTOADENSABILIDADE DOS CONCRETOS}

Neste item, foram discutidos os aspectos mais relevantes apresentados pelos resultados dos ensaios que avaliaram a autoadensabilidade dos concretos empregados nesta tese. Inicialmente, de forma mais geral, seguem algumas observações importantes constatadas a partir desses resultados:

- observou-se que todos os concretos foram classificados frente aos ensaios que avaliaram viscosidade aparente, como o T500 e Funil V;

- com relação à avaliação da habilidade passante, notou-se que somente dez concretos foram classificados tanto pelo ensaio de anel J como, também, pelo ensaio de caixa L. Isso significa que não há uma relação importante entre os ensaios que avaliam habilidade passante;

- O ensaio de caixa U classificou cinco concretos no que se refere ao quesito de habilidade passante. Esse ensaio não é prescrito pela norma ABNT NBR 15823-1 (2010), portanto necessita-se de mais estudos para propor tolerâncias e classificações de acordo com os concretos brasileiros, a fim de adotá-lo para avaliar habilidade passante. É importante ressaltar que esse ensaio foi considerado importante por Libre et al. (2012) para identificar alterações na mistura do concreto;

- Notou-se que a norma ABNT NBR 15823-1 (2010) permite classificar um concreto como autoadensável, sem mesmo cumprir com o quesito de resistência à segregação. Isso se comprovou na classificação dos concretos $16 \mathrm{C}$ e $18 \mathrm{C}$;

- Observou-se que o quesito habilidade passante demonstrou-se determinante para classificar o concreto em autoadensável. Dentre os cinco concretos que não foram classificados como autoadensável, três concretos não cumpriram o quesito de habilidade passante.

Em uma avaliação mais específica, associou-se os resultados de autoadensabilidade com as características das misturas dos concretos. Dessa forma, tentou-se apontar os prováveis motivos que uns concretos foram classificados como autoadensável e outros não. A Tabela 29, auxilia nessa discussão. 
Tabela 29 -Associação dos resultados de autoadensabilidade e as características das misturas dos concretos.

\begin{tabular}{|c|c|c|c|c|c|}
\hline \multirow[t]{2}{*}{ CONCRETO } & \multirow[t]{2}{*}{ CAA $^{*}$} & \multicolumn{3}{|c|}{ QUESITOS CAA } & \multirow[t]{2}{*}{ OBSERVAÇÕES } \\
\hline & & $\mathbf{C P}^{*}$ & $\mathrm{HP}^{*}$ & $\mathbf{R S}^{*}$ & \\
\hline $1 \mathrm{C}$ & & ---- & ---- & $\mathrm{X}$ & teor de SP insuficiente \\
\hline $2 \mathrm{C}$ & $\mathrm{X}$ & $\mathrm{X}$ & $\mathrm{X}$ & $\mathrm{X}$ & teor de SP adequado \\
\hline $3 \mathrm{C}$ & & $\mathrm{X}$ & & $\mathrm{X}$ & teor de SP insuficiente \\
\hline $4 \mathrm{C}$ & $\mathrm{X}$ & $\mathrm{X}$ & $\mathrm{X}$ & $\mathrm{X}$ & teor de SP adequado \\
\hline $5 \mathrm{C}$ & $\mathrm{X}$ & $\mathrm{X}$ & $\mathrm{X}$ & $\mathrm{X}$ & \\
\hline $6 \mathrm{C}$ & $\mathrm{X}$ & $\mathrm{X}$ & $\mathrm{X}$ & $\mathrm{X}$ & $\begin{array}{l}\text { aumento de SP melhorou habilidade passante } \\
\text { do concreto }\end{array}$ \\
\hline $7 \mathrm{C}$ & $\mathrm{X}$ & $\mathrm{X}$ & $\mathrm{X}$ & $\mathrm{X}$ & \\
\hline $8 \mathrm{C}$ & $\mathrm{X}$ & $\mathrm{X}$ & $\mathrm{X}$ & $\mathrm{X}$ & \\
\hline $9 \mathrm{C}$ & & $\mathrm{X}$ & & $\mathrm{X}$ & teor de SP insuficiente \\
\hline $10 \mathrm{C}$ & $\mathrm{X}$ & $\mathrm{X}$ & $\mathrm{X}$ & $\mathrm{X}$ & teor de SP adequado \\
\hline $11 \mathrm{C}$ & $\mathrm{X}$ & $\mathrm{X}$ & $\mathrm{X}$ & $\mathrm{X}$ & \\
\hline $12 \mathrm{C}$ & $\mathrm{X}$ & $\mathrm{X}$ & $\mathrm{X}$ & $\mathrm{X}$ & $\begin{array}{l}\text { aumento de SP melhorou habilidade passante } \\
\text { do concreto }\end{array}$ \\
\hline $13 \mathrm{C}$ & & ---- & ---- & $\mathrm{X}$ & teor de SP insuficiente \\
\hline $14 \mathrm{C}$ & $\mathrm{X}$ & $\mathrm{X}$ & $\mathrm{X}$ & $\mathrm{X}$ & teor de SP adequado \\
\hline $15 \mathrm{C}$ & $\mathrm{X}$ & $\mathrm{X}$ & $\mathrm{X}$ & $\mathrm{X}$ & \\
\hline $16 \mathrm{C}$ & $\mathrm{X}$ & $\mathrm{X}$ & $\mathrm{X}$ & ---- & \\
\hline $17 \mathrm{C}$ & & $\begin{array}{ll}--- \\
\end{array}$ & $\begin{array}{cc}--- \\
\end{array}$ & $\mathrm{X}$ & teor de SP insuficiente \\
\hline $18 \mathrm{C}$ & $\mathrm{X}$ & $\mathrm{X}$ & $\mathrm{X}$ & $\begin{array}{ll}--- \\
\end{array}$ & $\begin{array}{l}\text { aumento de SP comprometeu a estabilidade } \\
\text { do concreto }\end{array}$ \\
\hline \multicolumn{6}{|c|}{$\begin{array}{l}\mathrm{CA}^{*}=\text { classificado como concreto autoadensável } \\
\mathrm{CP}^{*}=\text { capacidade de preenchimento (quando atendido o espalhamento e a viscosidade pelo t500 ou funil V) } \\
\mathrm{HP}^{*}=\text { habilidade passante } \\
\mathrm{RS}^{*}=\text { resistência à segregação }\end{array}$} \\
\hline
\end{tabular}

Fonte: Próprio autor.

Nota-se, na Tabela 29, que no geral, em relação aos concretos com proporções iguais, mesma quantidade de materiais secos e de água, o aumento no teor de aditivo foi importante para enquadrar o concreto como autoadensável conforme a ABNT NBR 15823-1 (2010). Pode-se citar os seguintes exemplos: 1C e 2C, somente o 2C foi classificado como CAA; 3C e 4C, somente o 4C foi classificado como CAA; 9C e 10C, somente o 10C foi classificado como CAA; $13 \mathrm{C}$ e $14 \mathrm{C}$, somente o 14C foi classificado como CAA; 17C e 18C, somente $18 \mathrm{C}$ foi classificado como CAA. Cabe destacar o 18C, que o teor de aditivo empregado foi capaz de atender à autoadensabilidade exigida pela norma, porém comprometeu a estabilidade da mistura. Observa-se, também, que a substituição de fíler calcário mostrou-se importante para tornar o concreto como autoadensável. Nesse caso, tem-se o exemplo dos concretos $1 \mathrm{C}, 3 \mathrm{C}$ e 5C, que possuem relação água/sólidos igual a 0,40 e mesmo teor de aditivo superplastificante, no entanto se diferem quanto ao teor de substituição do cimento por fíler calcário. Dentre esses concretos, somente o $5 \mathrm{C}$ foi definido como autoadensável e, assim, pode-se dizer que a substituição de $30 \%$ de cimento por fíler calcário nesse concreto foi importante para conferir boas características de autoadensabilidade, corroborando as constatações observadas por Sahmaran et al. (2006) e Türkel e Kandemir (2010), os quais afirmam que o emprego de fíler 
calcário pode melhorar as propriedades de autoadensabilidade e de reologia do material cimentício.

A seguir, estão apresentadas as relações entre os ensaios, a saber: slump flow, funil V, T500, caixa L e caixa U. Para tanto, adotou-se uma padronização em todos os gráficos para facilitar a discussão dos resultados. Essa padronização consiste em apresentar os resultados dos concretos e das argamassas autoadensáveis com pontos verdes, enquanto os resultados dos concretos e das argamassas não autoadensáveis (concreto convencional - CCV) são apresentados com pontos de cor vermelha. É importante frisar que para o concreto classificado como autoadensável, a argamassa que o referenciou também foi considerada como autoadensável.

Na Figura 56, tem-se a relação dos resultados dos ensaios de Funil V e T500. Ambos resultam em valores de viscosidade plástica aparente, podendo esse resultado ser obtido por um dos dois ensaios para classificar o concreto quanto ao quesito de viscosidade (fluidez) de acordo com a norma ABNT NBR 15823 - 1 (2010). Observa-se, na Figura 56, que a relação dos resultados desses ensaios traduziu-se em uma regressão linear com coeficiente de determinação igual a 0,46; portanto, uma relação não adequada que desperta um maior cuidado na avaliação da viscosidade aparente do concreto.

Figura 56 - Regressão tipo linear entre os resultados de viscosidade plástica aparente dos concretos obtidos tanto pelo ensaio de funil $\mathrm{V}$ como também pelo ensaio de T500.

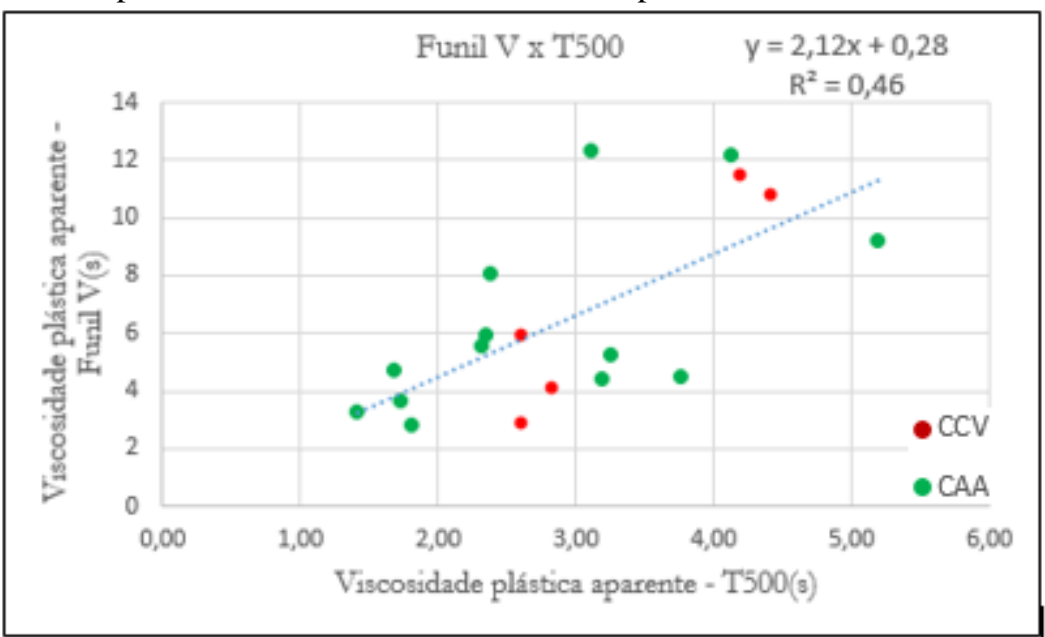

Fonte: Próprio autor.

Ensaios que avaliam habilidade passante, como, a caixa L e a caixa U apresentaram uma relação importante com o ensaio de slump-flow neste trabalho. Primeiro, tem-se, na Figura 57(a), uma regressão linear dos resultados da caixa L e de slump-flow, na qual consta uma equação com 
coeficiente de determinação igual a 0,80. Nota-se, também, que os concretos classificados como autoadensáveis apresentaram resultados no ensaio de caixa $L$ entre os valores de 0,6 e 1,0. Os resultados inferiores a 0,8 não atenderam à tolerância exigida por esse ensaio para cumprir o quesito de habilidade passante, no entanto esses concretos foram aprovados no quesito habilidade passante por meio dos critérios exigidos pelo ensaio de anel J. Essa divergência nos resultados desperta a importância de rever os critérios para o quesito de habilidade passante desses ensaios, bem como desperta a possibilidade de exigir os dois ensaios para avaliar esse quesito de autoadensabilidade ou adoção de somente um ensaio. Essa questão torna-se mais importante para apreciação quando se considera que o anel $\mathrm{J}$ brasileiro pode conferir um menor rigor na avaliação da habilidade passante do concreto, visto que esse anel possui barras verticais com diâmetros menores dos anéis $\mathrm{J}$ empregados pelos ensaios prescritos por normas europeias e pela norma dos Estados Unidos.

Quanto à relação dos resultados dos ensaios de caixa U e slump-flow, verifica-se, também, uma regressão linear conforme está apresentado na Figura57 (b), na qual consta uma equação com coeficiente de determinação igual ao encontrado na relação caixa L e slump-flow que foi 0,80 . Isso demonstra e reforça que o ensaio de slump-flow pode ser uma alternativa para prever habilidade passante do concreto.

Nota-se, na Figura 57(b), que para concretos autodensáveis com valores de espalhamento entre $650 \mathrm{~mm}$ e $750 \mathrm{~mm}$, seus resultados no ensaio de caixa $U$ se situaram no intervalo entre $0 \mathrm{~mm}$ e $50 \mathrm{~mm}$. De maneira mais geral, os concretos classificados como autoadensável, apresentaram resultados no ensaio de caixa $U$ no intervalo de $0 \mathrm{~mm}$ a $60 \mathrm{~mm}$. Diante disso, pelo presente estudo, sugere-se duas classes de classificação de autoadensabilidade, sendo um nível de resultados entre $0 \mathrm{~mm}$ e $30 \mathrm{~mm}$ e outro nível entre $30 \mathrm{~mm}$ e $60 \mathrm{~mm}$, visto que ainda esse ensaio não é normalizado e a tolerância de resultado mais difundida pelo meio técnico é o valor limite de $30 \mathrm{~mm}$, como visto na Tabela 8. Cabe destacar que esse ensaio foi considerado por Libre et al. (2012) como mais capaz do que o ensaio da caixa L para identificar alterações na composição do concreto com emprego de adições minerais e aditivos químicos. Isto reforça uma futura inclusão desse ensaio em normas vigentes. 
Figura 57 - (a) Regressão tipo linear entre os resultados de espalhamento e do ensaio de caixa dos concretos (b) Regressão tipo linear entre os resultados de espalhamento e resultados do ensaio de caixa U dos concretos.

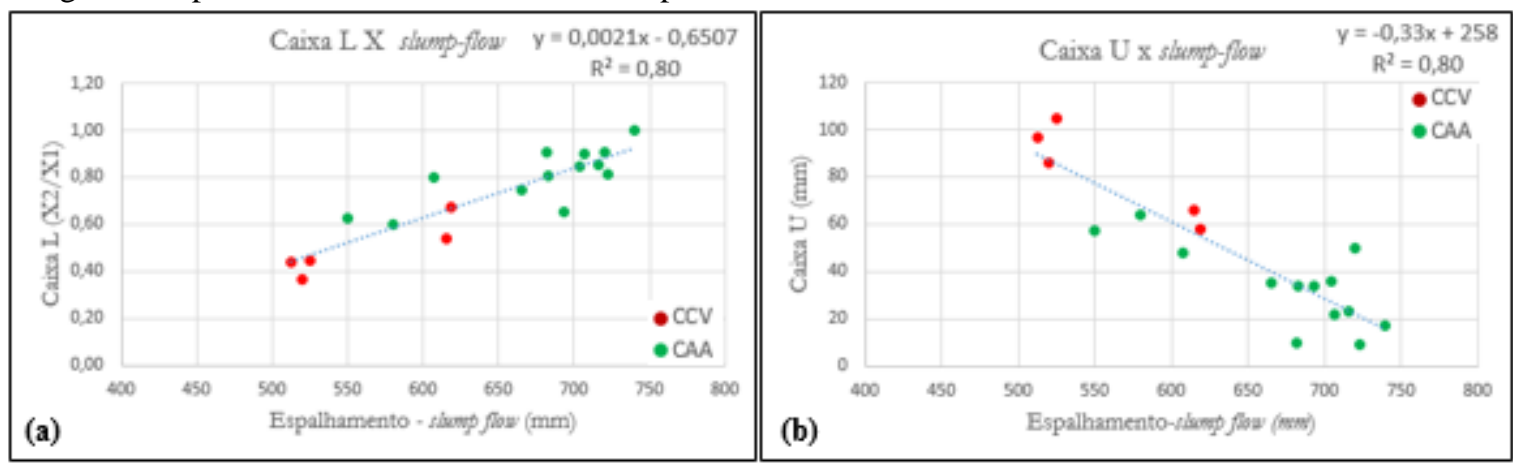

Fonte: Próprio autor.

Figura 58 - Aparência superficial dos concretos. (a) concreto 16C; (b) concreto 18C.

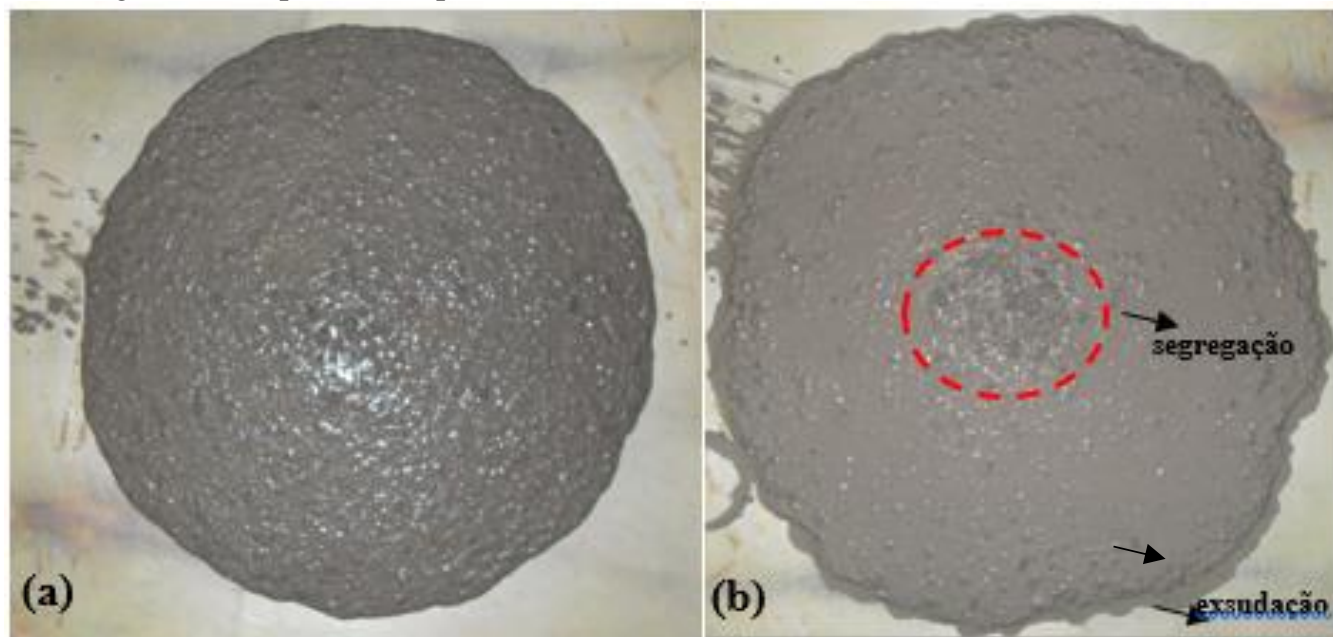

Fonte: Próprio autor.

Quanto à estabilidade do concreto, observou-se que os concretos 16C e 18C apresentaram resultados iguais a $21,31 \%$ e $34,26 \%$, respectivamente. Isso significa que esses concretos segregaram conforme definido pela ABNT NBR 15823-1 (2010). Entretanto, quando se faz uma avaliação por inspeção visual do estado fresco desses concretos, nota-se na Figura 58 (a) que o concreto 16C é um concreto coeso, ao contrário do concreto 18C, Figura 58(b), que apresenta ser um concreto que realmente segregou e exsudou. Diante disso, constata-se que a inspeção visual ainda é um instrumento importante para avaliar a estabilidade de qualquer material cimentício no estado fresco, assim como se desperta o questionamento frente o ensaio de coluna de segregação, no que tange à sua capacidade de classificar a estabilidade do concreto. 


\subsection{ANÁLISE DA AUTOADENSABILIDADE DAS ARGAMASSAS REFERÊNCIAS}

É importante ressaltar que as argamassas foram classificadas como autoadensável a partir da classificação da autoadensabilidade do concreto. Isso significa para o concreto classificado como autoadensável, a sua argamassa referência também foi classificada como autoadensável.

Dessa forma, nota-se na Figura 59 que as argamassas autoadensáveis responsáveis por referenciarem os concretos autoadensáveis apresentaram valores de área relativa de espalhamento no intervalo de 5 a 11,5 e valores de velocidade relativa de fluidez no intervalo próximo de $2 \mathrm{~s}^{-1}$ a $7 \mathrm{~s}^{-1}$. Esses valores coincidem em parte com os valores encontrados por Chai (1998), o qual sugere valores de área relativa de espalhamento maior e igual a 8 e valores de velocidade de relativa de fluidez entre $1 \mathrm{~s}^{-1}$ e $5 \mathrm{~s}^{-1}$. No entanto, os valores encontrados no presente estudo estão fora da região dos valores encontrados por Nepomuceno et al. (2014), que sugerem intervalos bem estreitos, como a área relativa de espalhamento entre 5,30 e 5,90 e velocidade relativa de fluidez entre $1,14 \mathrm{~s}^{-1}$ e $1,30 \mathrm{~s}^{-1}$.

Figura 59 - Relação dos resultados de velocidade relativa de fluidez-Rm(mini-funil) e Área relativa de espalhamento-Gc das argamassas.

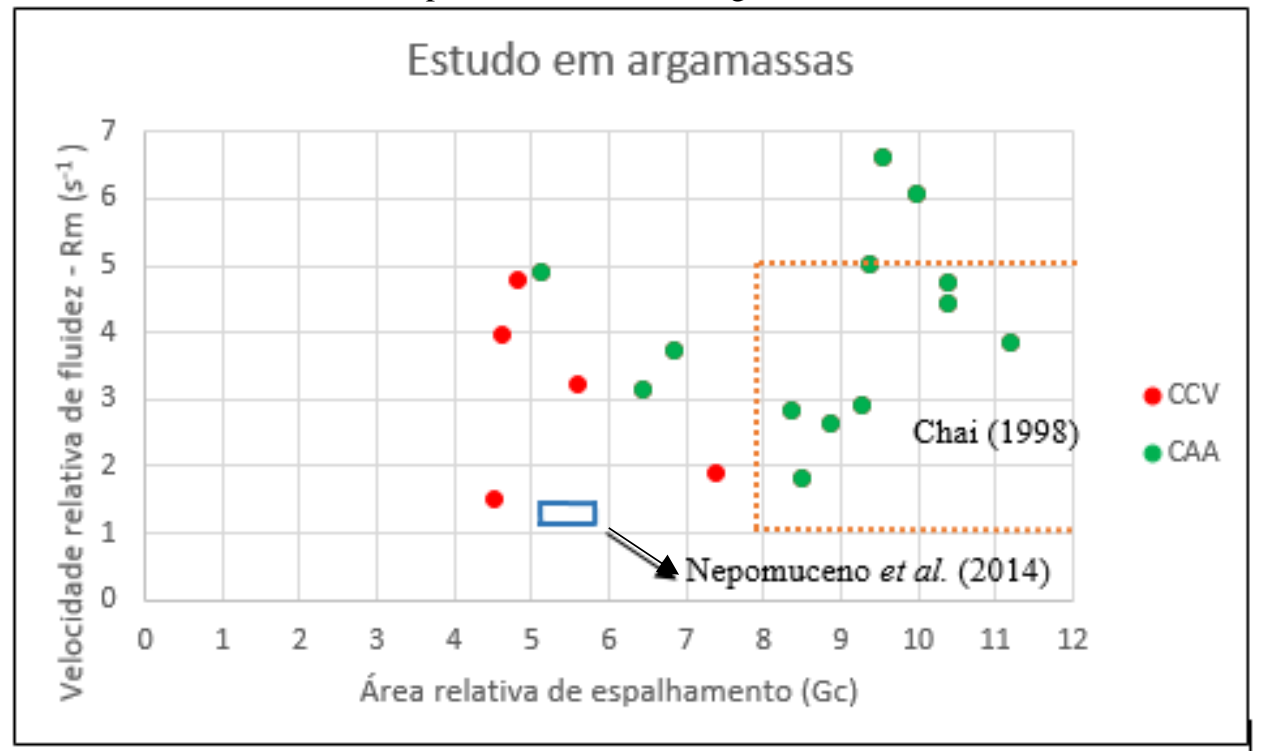

Fonte: Próprio autor.

O fato dos parâmetros de mistura das argamassas autoadensáveis desta tese possuírem valores semelhantes aos valores dos parâmetros de mistura empregados nas argamassas de Chai (1998), pode ser a explicação mais plausível para justificar a coincidência dos valores de autoadensabilidade das argamassas. Chai (1998) adotou, por exemplo, uma relação de volume de areia e volume de argamassa $(\mathrm{Vs} / \mathrm{Vm})$ maior que 0,45 para as misturas de relação 
água/aglomerante superior a 0,34 , portanto corroborando com o valor médio adotado nesta tese que foi 0,48. Entretanto, Nepomuceno et al. (2014) empregaram a relação Vs/Vm em torno de 0,40; a qual também foi empregada por Ouchi e Okamura (2003) e considerada por Chai (1998) uma relação muito baixa para um consumo de aglomerante recomendado pelo ACI. Quanto menor a relação de $\mathrm{Vs} / \mathrm{Vm}$, isso implica em um maior emprego de finos na mistura. A relação entre os volumes de finos e de areia (Vp/Vs) empregada por Nepomuceno et al. (2014) em suas argamassas autoadensáveis foi entre 0,60 e 0,80, enquanto que nesta tese empregou-se um valor em torno de 0,40. Essa diferença entre os valores empregados de $\mathrm{Vp} / \mathrm{Vs}$, pode explicar a disparidade dos valores de autoadensabilidade das argamassas desta pesquisa com os valores de autoadensabilidade das argamassas de Nepomuceno et al.(2014), conforme estão apresentados na Figura 59.

\subsection{ASSOCIAÇÃO DO COMPORTAMENTO DE AUTOADENSABILIDADE DAS ARGAMASSAS E DOS CONCRETOS}

Muitos estudos alcançaram boa relação entre os resultados de autoadensabilidade e reologia de argamassas e de concretos autoadensáveis (OZAWA et al., 1994; EDAMATSU et al., 1999; JIN, 2002; OLIVEIRA, 2013). Yahia et al. (1999) e Nagamoto et al. (1997) encontraram relações importantes entre resultados de espalhamento de argamassas e de concretos autoadensáveis, bem como entre resultados de fluidez. Jin (2002) afirma que esses resultados e outros tipos de relação entre argamassa e concreto não acostumam ser bem registrados para conhecimento de futuros pesquisadores, por isso se têm poucas referências de resultados.

Nesse sentido, na Figura 60, tem-se a relação dos resultados de espalhamento das argamassas e dos concretos como, também, a relação dos resultados de fluidez (Funil V x mini-funil V). A relação dos resultados de espalhamento, obteve-se uma regressão linear com equação de regressão e coeficiente de determinação que foi igual a 0,81, conforme está apresentada na Figura 60(a). Observa-se que o espalhamento das argamassas entre $320 \mathrm{~mm}$ e $350 \mathrm{~mm}$ pode alcançar concretos de espalhamento entre $600 \mathrm{~mm}$ e $740 \mathrm{~mm}$. Isso significa que a determinação do espalhamento da argamassa é importante para prever a capacidade de preenchimento do concreto autoadensável. 
Figura 60 - (a) Regressão linear entre os resultados de espalhamento (slump-flow) dos concretos e os resultados de espalhamento (mini-slump) das argamassas. (b) Regressão tipo exponencial entre os resultados de viscosidade aparente dos concretos por meio do ensaio de funil $\mathrm{V}$ e das argamassas referências por meio do ensaio de minifunil.

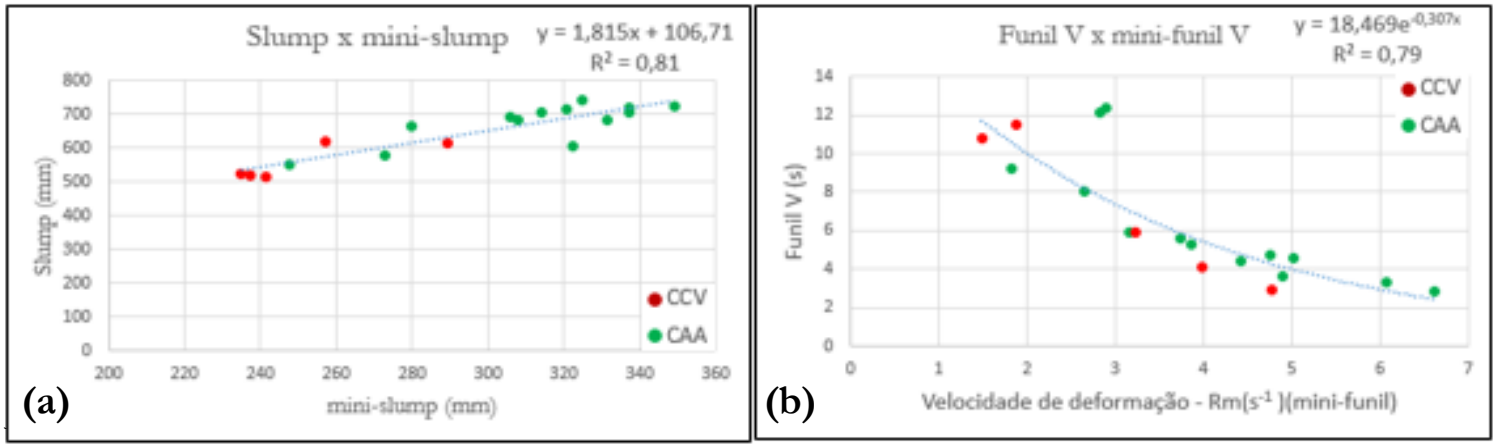

Fonte: Próprio autor.

Obteve-se, também, uma relação importante entre os ensaios de mini-funil V e funil V conforme está apresentada na Figura 60 (b). Nesse caso, foi obtida uma regressão tipo exponencial, na qual consta a equação de regressão e o coeficiente de determinação que foi igual a 0,79 . Notase que os valores de velocidade relativa de fluidez das argamassas entre o intervalo aproximado de $3 \mathrm{~s}^{-1}$ e $6 \mathrm{~s}^{-1}$ podem referenciar concretos autoadensáveis com fluidez entre o intervalo aproximado de $2 \mathrm{~s}$ e $12 \mathrm{~s}$. Isso comprova que o ensaio de mini-funil V, em argamassas, é importante no sentido de prever a viscosidade plástica aparente e habilidade de preenchimento do concreto.

Diante dos resultados, confirmou-se que existe uma forte relação das características no estado fresco das argamassas e dos concretos. Isso pode ser explicado pelo alto teor de argamassa na composição de um concreto com proporções comumente empregadas em um concreto autoadensável. Os concretos produzidos neste estudo tiveram um teor de argamassa de $72 \%$, em volume, portanto um alto teor de argamassa. Segundo Yahia et al. (1999), concretos autoadensáveis que possuem aproximadamente 30\% de agregado graúdo, em volume, são viáveis estudos nas argamassas que os compõem para obtenção de parâmetros estimados das propriedades no estado fresco do concreto.

Para finalizar, decidiu-se propor sugestões de classes para argamassas autoadensáveis com resultados obtidos pelos ensaios de mini-slump e mini-funil fazendo um paralelo com as classes de concretos autoadensáveis prescritas na norma ABNT NBR 15823-1 (2010). É importante essa proposta, visto que no Brasil ainda não há norma para classificar argamassas 
autoadensáveis, grautes ou “microconcreto". A seguir, na Tabela 30, está apresentada sugestões de classes para argamassas autoadensáveis.

Tabela 30 - Sugestões de classes de autoadensabilidade para argamassas.

Tabela de equivalência de classes de autoadensabilidade entre argamassas e concretos

\begin{tabular}{|c|c|c|c|c|c|}
\hline \multicolumn{3}{|c|}{ Argamassas autoadensáveis } & \multicolumn{3}{|c|}{ Concretos autoadensáveis } \\
\hline Ensaios & Classe & Tolerâncias & Ensaios & Classe & $\begin{array}{l}\text { Tolerâncias ABNT } \\
\text { NBR 15823-1(2010) }\end{array}$ \\
\hline \multirow{3}{*}{ mini-slump } & $\mathrm{mSF} 1$ & $245 \mathrm{~mm}$ a $305 \mathrm{~mm}$ & \multirow{3}{*}{ slump-flow } & SF1 & $550 \mathrm{~mm}$ a $650 \mathrm{~mm}$ \\
\hline & $\mathrm{mSF} 2$ & $315 \mathrm{~mm}$ a $355 \mathrm{~mm}$ & & SF2 & $660 \mathrm{~mm}$ a $750 \mathrm{~mm}$ \\
\hline & & & & SF3 & $760 \mathrm{~mm}$ a $850 \mathrm{~mm}$ \\
\hline \multirow{2}{*}{ mini-funil V } & mVF1 & $<4 s$ & \multirow{2}{*}{ funil V } & VF1 & $<9 \mathrm{~s}$ \\
\hline & mVF2 & $4 \mathrm{~s}$ a $8 \mathrm{~s}$ & & VF2 & $9 \mathrm{~s}$ a $25 \mathrm{~s}$ \\
\hline
\end{tabular}

Observa-se, na Tabela 30, que foi possível propor duas classes de espalhamento e duas classes de viscosidade plástica aparente tomando como referência os resultados das argamassas autoadensáveis desta tese.

Dessa forma, com relação ao espalhamento das argamassas, definiu-se que a classe mSF1 se refere as argamassas de espalhamento entre $245 \mathrm{~mm}$ e $305 \mathrm{~mm}$, as quais equivalem aos concretos classificados como SF1 de espalhalhamento entre $550 \mathrm{~mm}$ e $650 \mathrm{~mm}$. A classe mSF2 se refere as argamassas de espalhamento entre $315 \mathrm{~mm}$ a $355 \mathrm{~mm}$, as quais equivalem aos concretos classificados como SF2 de espalhamento entre $660 \mathrm{~mm}$ e $750 \mathrm{~mm}$.

Quanto a viscosidade plástica aparente, na Tabela 30, nota-se que a classe mVF1 se refere as argamassas com tempo de fluidez menor que $4 \mathrm{~s}$, as quais equivalem aos concretos classificados como VF1 com tempo de fluidez menor que 9s. A classe mVF2 se refere as argamassas com tempo de fluidez entre $4 \mathrm{~s}$ e $8 \mathrm{~s}$, as quais equivalem aos concretos classificados como VF1 com tempo de fluidez compreendido entre $9 \mathrm{~s}$ e $25 \mathrm{~s}$.

\subsection{REOLOGIA TEÓRICA DOS CONCRETOS AUTOADENSÁVEIS}

Como se sabe os parâmetros reológicos dos concretos foram estimados conforme as equações de Sedran e De Larrard (1999). Na Figura 15, estão apresentados os resultados desses parâmetros reológicos em molde de reografia (reograma), bem como estão apresentados faixas (domínios) de valores de parâmetros reológicos encontrados por outros pesquisadores. 
Nota-se, na Figura 61, que boa parte dos concretos classificados como autoadensável apresentou valores dos parâmetros reológicos no domínio referente aos valores encontrados por Zerbino et al.(2009), enquanto três concretos autoadensáveis ficaram fora desse domínio. Outros pesquisadores, tais como, Petit et al. (2007) e Heirman et al. (2006), também, encontraram valores dos parâmetros reológicos dos concretos autoadensáveis nesse domínio.

Além disso, na Figura 61, verifica-se que somente três concretos autoadensáveis apresentaram valores de parâmetros reológicos no domínio recomendado por Banfill (2006) e nenhum concreto apresentou valor no domínio recomendado por Wallevik (2006). Por fim, constata-se, no presente trabalho, que os valores estimados dos parâmetros reológicos dos concretos autoadensáveis são correlatos aos valores já encontrados por outros pesquisadores.

Figura 61 - Relação dos resultados dos parâmetros reológicos teórico dos concretos.

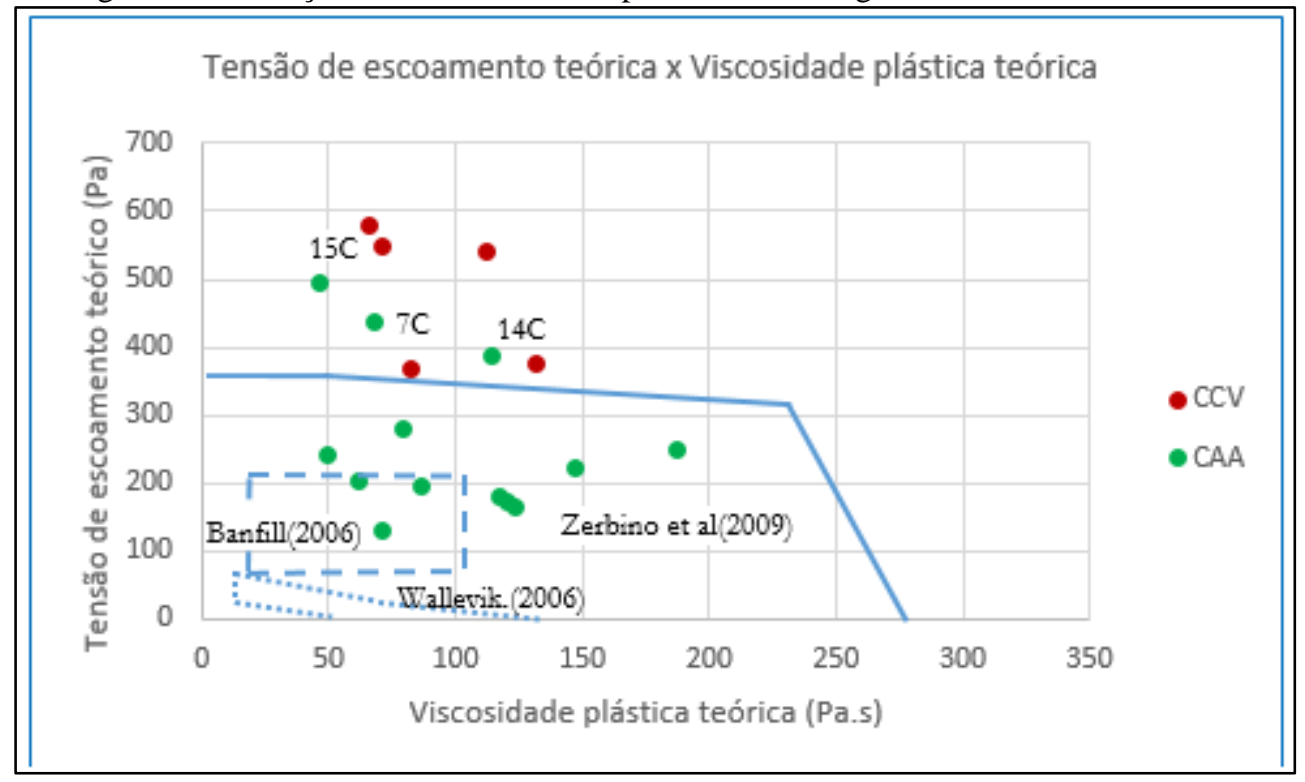

Fonte: Próprio autor.

\subsection{AVALIAÇÃO DA REOLOGIA DAS ARGAMASSAS REFERÊNCIAS}

Neste item, são apresentados os comportamentos dos resultados dos parâmetros reológicos das argamassas referências, tais como, viscosidade plástica de torque, tensão de escoamento de torque e histerese. Os resultados médios desses parâmetros reológicos estão apresentados no subitem 4.6.2, capítulo 4.

Inicialmente, na Figura 62, estão apresentados os resultados de viscosidade plástica de torque. Primeiramente, observa-se nitidamente uma tendência da viscosidade da argamassa diminuir 133 
com aumento de água na mistura. Esse comportamento é coerente, pois o aumento de água na mistura significa menor concentração de sólidos e atrito entre as partículas sólidas que, por sua vez, resulta em uma menor viscosidade. Nesse sentido, os resultados de viscosidade plástica de torque das argamassas para as relações água/sólidos 0,40, 0,45 e 0,50 estão compreendidos entre 0,95 mN.m.min e 1,77 mN.m.min; 0,45 mN.m.min e 0,90 mN.m.min e 0,25 mN.m.min e 0,53 mN.m.min, respectivamente. Esses valores coincidem com os resultados de viscosidade plástica de torque das argamassas autoadensáveis estudadas por Oliveira et. al (2013). Estes autores obtiveram resultados de viscosidade entre $0,38 \mathrm{mN} . \mathrm{m} . \mathrm{min}$ e 1,31 mN.m.min para argamassas com substituição de cimento por fíler calcário de até $40 \%$. Com relação a influência das variáveis tipo de aglomerante e teor de aditivo sobre a viscosidade das argamassas, não se notou um comportamento evidente.

Figura 62 - Comportamento dos valores médio de tensão de escoamento de torque das argamassas referencias.

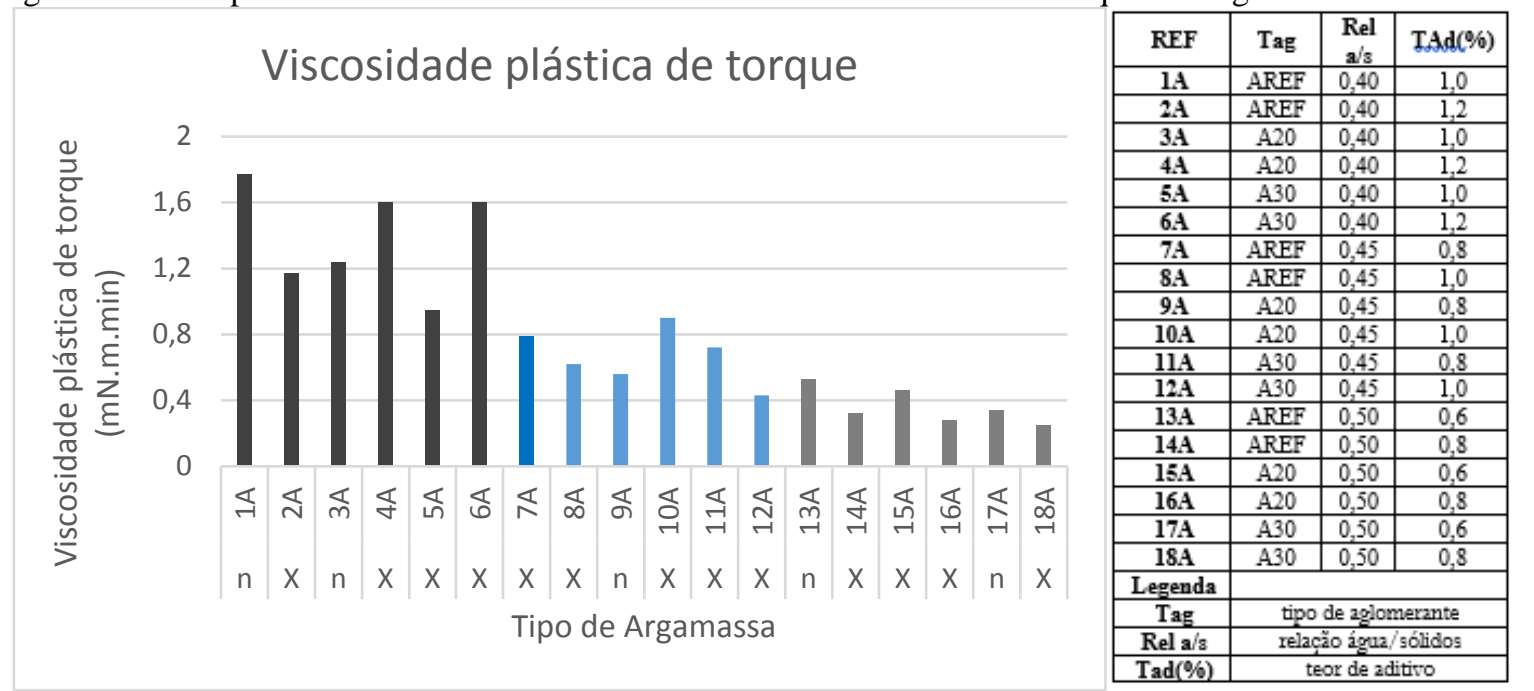

Fonte: Próprio autor.

Na Figura 63, estão apresentados os resultados de tensão de escoamento de torque. Nota-se que os resultados de tensão de escoamento de torque há diferenças entre as argamassas de diferentes relações água/sólidos. A par disso, as argamassas de relação água/sólidos igual a 0,40 possuem tensão de escoamento de torque no intervalo entre 2,66 mN.m e 5,27 mN.m, as argamassas de relação água/sólidos igual a 0,45 possuem valores entre $0,74 \mathrm{mN} . \mathrm{m}$ e 3,36 mN.m e, por fim, as argamassas de relação água/sólidos igual a 0,50 possuem tensão de escoamento de torque entre 2,46 mN.m e 11,34 mN.m. Esses valores, também, coincidem com os valores de tensão de escoamento de torque das argamassas autoadensáveis obtidos por Oliveira et al.(2013), os quais obtiveram valores entre 2,46 mN.m e $14,83 \mathrm{mN} . \mathrm{m}$. 
Quanto ao comportamento das argamassas frente aos resultados apresentados na Figura 63, observa-se uma leve diferença dos resultados de tensão de escoamento de torque entre as argamassas de relação água-sólidos iguais a 0,40 e 0,45, sendo que as argamassas de relação 0,40 possuem alguns valores superiores. Isso pode ser atríbuido pelo fato destas argamassas possuírem uma maior concentração de sólidos que, por sua vez, restringe um pouco o início do fluxo. Com relação as argamassas de relação água/sólidos igual a 0,50, nota-se, na Figura 63, uma oscilação de valores de tensão de escoamento de forma evidente, a ponto de se ter valores de tensão de escoamento iguais a 5,76 mN.m e 11,34 mN.m. Estes valores são maiores do que os valores obtidos para as argamassas de relação água/sólidos iguais a 0,40 e 0,45. A provável explicação desses maiores valores para as argamassas de relação água/sólidos 0,50, deve-se a maior velocidade de sedimentação das partículas sólidas dessas argamassas no recipiente de ensaio tornando a parte inferior do recipiente mais concentrada de sólidos e, com isso, exige-se mais esforço por parte do reômetro para iniciar o fluxo da argamassa (MENDES; BAUER, 2015).

Figura 63 - Comportamento dos valores médio de tensão de escoamento de torque das argamassas referencias.

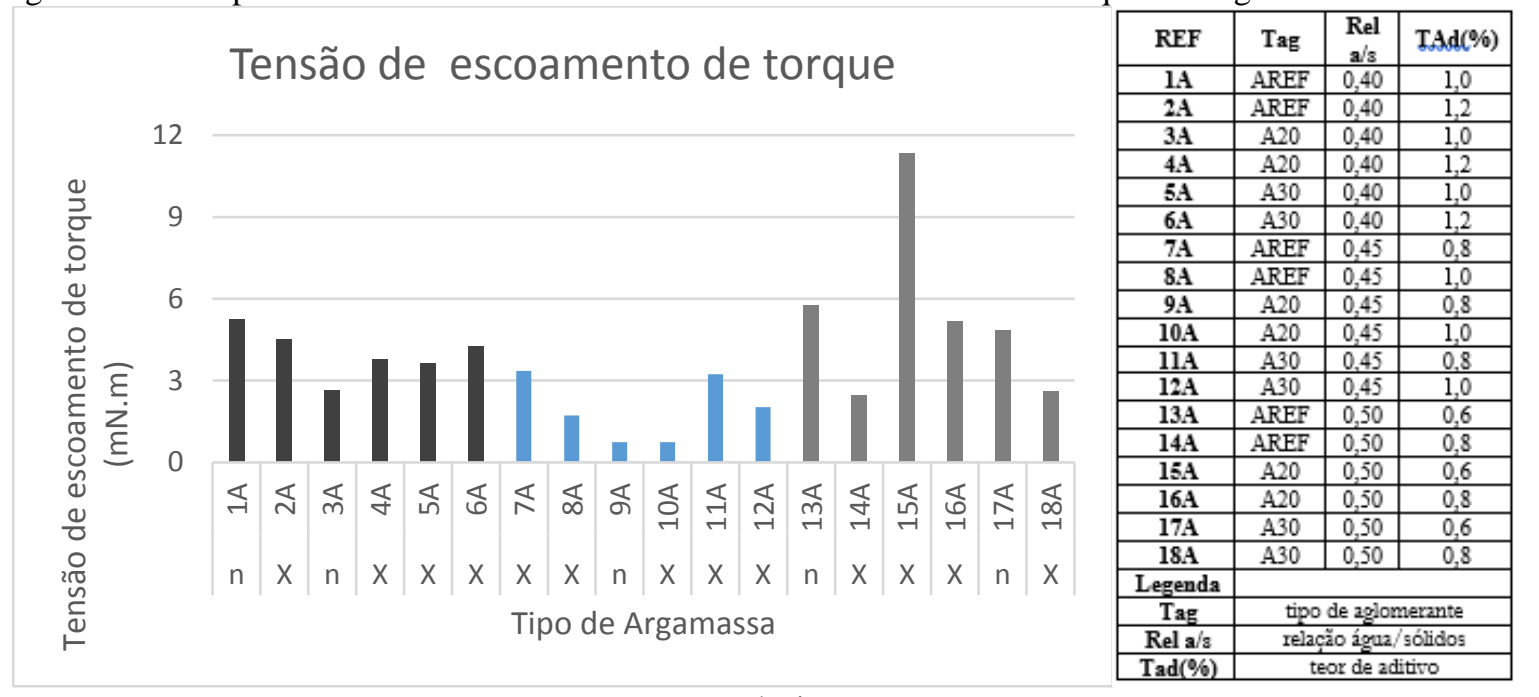

Fonte: Próprio autor.

Na Figura 65, estão apresentados os resultados de histerese advindos das curvas de fluxo das argamassas apresentadas no subitem 4.6.1. A histerese significa a energia demandada de cada argamassa para sofrer uma quebra estrutural das partículas sólidas sob ação de um cisalhamento. Cabe enfatizar que a histerese permite efetuar uma análise qualitativa do cisalhamento que, por sua vez, possibilita tirar conclusões quanto à estabilidade da estrutura do material (SUHR, 1991). 
Nesse sentido, na Figura 64, verifica-se diferenças nos resultados de histerese das argamassas de forma clara, quando se compara as argamassas de diferentes relações água/sólidos. As argamassas de relações água/sólidos 0,$40 ; 0,45$ e de 0,50 possuem resultados médios de histerese iguais 3938 mN.m.rpm, 2539 mN.m.rpm, 2039 mN.m.rpm, respectivamente. Isso significa que se demandou mais energia para quebra estrutural das argamassas de relação água/ sólidos igual 0,40 e menor energia para quebra estrutural das argamassas de relação água/sólidos igual a 0,50, portanto comprova no geral que a histerese tende de ser maior quando se tem uma maior concentração de sólidos no fluido (argamassa). Cabe destacar, que o resultado de histerese da argamassa 16A foi desconsiderado para o cálculo da média de histerese das argamassas de relação água/sólidos 0,50, devido este resultado ser bem divergente das demais argamassas. Este resultado divergente pode ser resultado de uma maior concentração de sólidos na região inferior do recipiente de ensaio que, por sua vez, comprometeu a descrição do seu comportamento reológico de fluxo conforme o mecanismo relatado por Mendes e Bauer (2015). Nota-se, na Figura 64, que as argamassas de relação água/sólidos igual a 0,45 apresentam uma menor diferença entre seus valores de histerese. Quanto a influência de outras variáveis, tais como, tipo de aglomerante e teor de aditvo, não se notou de maneira nítida uma tendência no comportamento dos resultados de histerese das argamassas.

Figura 64 - Valores médios de histerese das argamassas referencias.

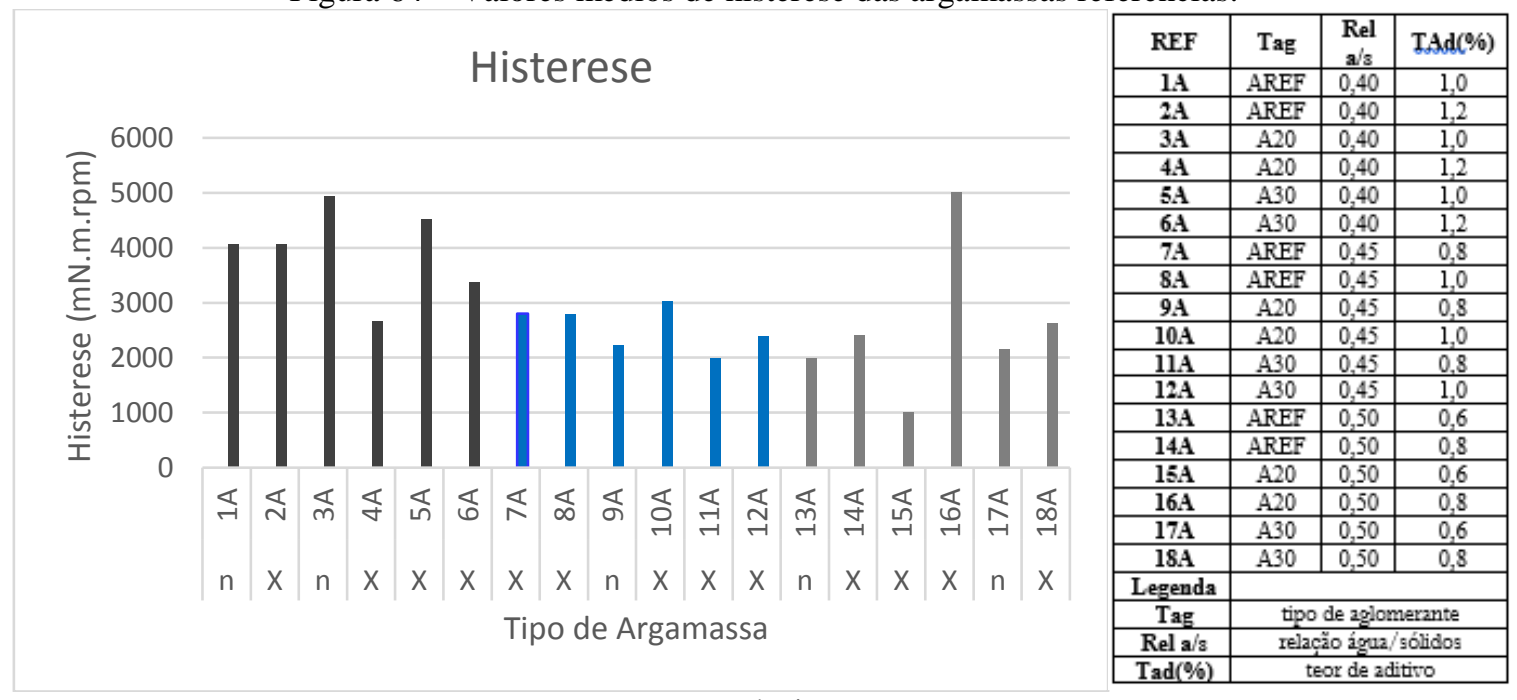

Fonte: Próprio autor.

A seguir, classificou-se a reologia das argamassas autoadensáveis de acordo com suas curvas de fluxo mais predominantes, seus parâmetros reológicos fundamentais e seus valores de histerese, com intuito de sugerir referências de características reológicas para futuros trabalhos 
relacionados com argamassas e concretos autoadensáveis. A seguir, no Quadro 01, as principais características reológicas das argamassas autoadensáveis desta tese.

Quadro 1 - As principais características reológicas das argamassas.

\begin{tabular}{|c|c|c|}
\hline \multicolumn{3}{|c|}{ Características reológicas das argamassas autoadensáveis } \\
\hline Relação a/s 0,40 & Relação a/s 0,45 & Relação a/s 0,50 \\
\hline 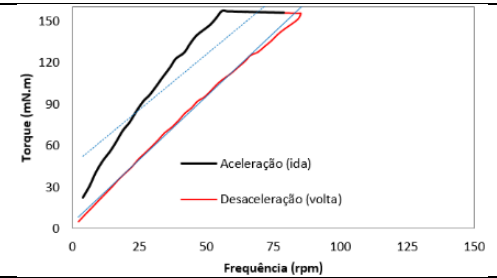 & 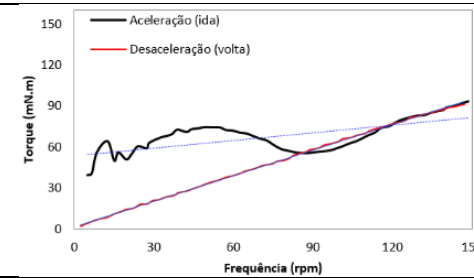 & 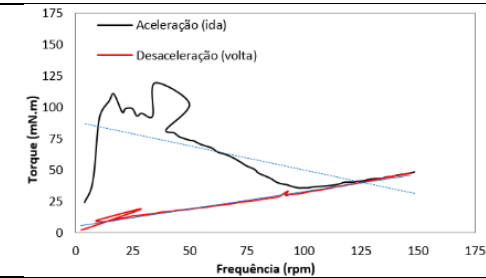 \\
\hline Viscosidade Plástica de Torque & Viscosidade Plástica de Torque & Viscosidade Plástica de Torque \\
\hline 0,95 mN.m.min a 1,60 mN.m.min & $0,43 \mathrm{mN} \cdot \mathrm{m} \cdot \mathrm{min}$ a $0,90 \mathrm{mN} \cdot \mathrm{m} \cdot \mathrm{min}$ & $0,25 \mathrm{mN} \cdot \mathrm{m} \cdot \mathrm{min}$ a $0,46 \mathrm{mN} \cdot \mathrm{m} \cdot \mathrm{min}$ \\
\hline Tensão de Escoamento de Torque & Tensão de Escoamento de Torque & Tensão de Escoamento de Torque \\
\hline $3,63 \mathrm{mN} . \mathrm{m}$ a $4,54 \mathrm{mN} . \mathrm{m}$ & $0,74 \mathrm{mN} . \mathrm{m}$ a $3,36 \mathrm{mN} . \mathrm{m}$ & 2,46 mN.m a $11,34 \mathrm{mN} . \mathrm{m}$ \\
\hline Histerese & Histerese & Histerese \\
\hline 2671 mN.m.rpm a 4523 mN.m.rpm & 1993 mN.m.rpm a 3025 mN.m.rpm & 1013 mN.m.rpm a 5012 mN.m.rpm \\
\hline
\end{tabular}

Fonte: Próprio autor.

Observa-se, no Quadro1, que as principais características reológicas das argamassas autoadensáveis estão separadas por grupos, em função da relação água/sólidos. Isso significa, que não se considerou diferenças de tipo de aglomerante e teor de aditivo empregado para classificação dessas argamassas.

Primeiramente, no Quadro 1, verifica-se que as argamassas autoadensáveis de relação água/sólidos igual a 0,40, possuem predominantemente curva de fluxo ascendente pseudoplástica com tensão de escoamento e curva de fluxo descendente tipo binghamiano. Em especial, na curva ascendente nota-se um alcance de torque de $150 \mathrm{mN} . \mathrm{m}$ antes de ser submetida uma taxa de cisalhamento de $150 \mathrm{rpm}$ na argamassa. Os seus valores de viscosidade plástica de torque estão entre 0,95 mN.m.min e 1,60 mN.m.min, portanto este intervalo é superior aos intervalos de viscosidade das argamassas autoadensáveis de relação água/sólidos iguais a 0,45 e 0,50 .Os seus valores de tensão de escoamento de torque estão entre 3,63 mN.m a 4,54 mN.m e os valores de histerese estão entre 2671 mN.m.rpm a 4523 mN.m.rpm.

Com relação as argamassas autoadensáveis de relação água/sólidos igual a 0,45, estas possuem predominantemente curva de fluxo ascendente pseudoplástica com tensão de escoamento e curva de fluxo descendente tipo binghamiano. Em especial, na curva ascendente nota-se uma tendência em seguir a mesma direção da curva descendente a partir da metade do fluxo. Isso 
significa que essas argamassas têm uma maior facilidade de ter um fluxo de comportamento constante com taxas de cisalhamento menores que $150 \mathrm{rpm}$. Os seus valores de viscosidade plástica de torque estão entre $0,43 \mathrm{mN} . \mathrm{m} . \mathrm{min}$ e $0,90 \mathrm{mN}$.m.min, portanto este intervalo é considerado intermediário quando comparado com os intervalos de viscosidade das argamassas autoadensáveis de relação água/sólidos iguais a 0,40 e 0,50. Os seus valores de tensão de escoamento de torque estão entre $0,74 \mathrm{mN} . \mathrm{m}$ e $3,36 \mathrm{mN}$.m e os valores de histerese estão entre 1993 mN.m.rpm a 3025 mN.m.rpm.

As argamassas autoadensáveis de relação água/sólidos igual a 0,50, possuem predominantemente curva de fluxo ascendente pseudoplástica com tensão de escoamento e curva de fluxo descendente tipo binghamiano. Em especial, na curva ascendente possui vários picos ou perturbações antes de alinhar a direção da curva descendente, a qual é linear. Os seus valores de viscosidade plástica de torque estão entre 0,25 mN.m.min e 0,46 mN.m.min, portanto este intervalo possuem valores menores quando comparados os valores dos intervalos das argamassas de relação água/sólidos iguais a 0,40 e 0,45. Os seus valores de tensão de escoamento de torque estão entre 2,46 mN.m a 11,34 mN.m e os valores de histerese estão entre 1013 mN.m.rpm a 5012 mN.m.rpm.

Diante do exposto, observou-se que a concentração de sólidos é determinante para influenciar nas propriedades reológicas de forma nítida. Além disso, notou-se que foi possível diferenciar as argamassas autoadensáveis de diferentes relações água-sólidos por meio dos intervalos de viscosidade plástica de torque, no entanto não foi possível diferenciá-las por meio dos parâmetros de tensão de escoamento de torque e de histerese. Esta impossibilidade, deve-se o fato das argamassas de relação água/sólidos igual a 0,50 terem alcançado picos de valores de tensão de escoamento e de histerese devido a instabilidade dessas misturas, a qual já foi relatada sua influencia na determinação desses parâmetros.

Por fim, cabe frisar que as argamassas autoadensáveis de relação água/sólidos igual a 0,45 demonstraram ser mais estáveis frente ao comportamento reológico quando submetidas a diferentes tipos de aglomerantes e teores de aditivo. Isso se explica diante das seguintes observações: a amplitude da diferença de histerese das argamassas foi menor, as curvas de fluxo ascendente tenderam para linearidade antes de uma taxa de 150rpm, os intervalos dos valores 
de tensão de escoamento e de viscosidade plástica foram bem estreitos e teve-se maior número de argamassas classificadas como autoadensável.

\subsection{COMPORTAMENTO REOLÓGICO DE ARGAMASSAS E DE CONCRETOS}

A partir dos resultados dos parâmetros reológicos das argamassas e dos concretos, buscou-se identificar alguma relação entre esses parâmetros, assim como relacioná-los com parâmetros de viscosidade aparente ou fluidez desses materiais. Primeiro, tem-se na Figura 65, a relação dos resultados de viscosidade plástica de torque com resultados de velocidade relativa de fluidez (mini-funil) que é um parâmetro de viscosidade aparente das argamassas referências. Observase uma regressão tipo exponencial, na qual consta uma equação com coeficiente de determinação igual a 0,78. Nota-se que os parâmetros de velocidade relativa de fluidez e viscosidade plástica de torque são grandezas que tendem ser inversas, ou seja, argamassas com baixas velocidades relativas de fluidez possuem maiores valores de viscosidade plástica de torque. No geral, na Figura 65, verifica-se que os valores de viscosidade plástica de torque das argamassas referencias de concretos autoadensáveis estão compreendidos no intervalo de 0,25 mN.m.min a 1,60 mN.m.min.

Figura 65 - Regressão tipo exponencial entre os resultados de velocidade relativa de fluidez-Rm e os resultados de viscosidade plástica de torque das argamassas.

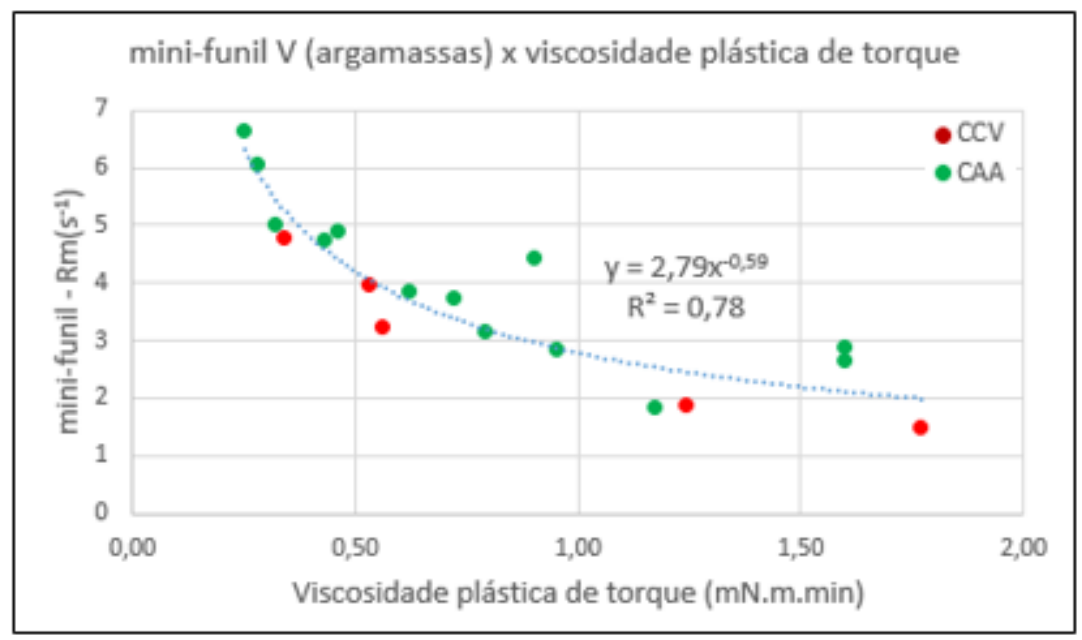

Fonte: Próprio autor.

Em seguida, na Figura 66, têm-se as relações dos valores de viscosidade plástica de torque das argamassas referências com os valores de viscosidade plástica aparente dos concretos obtidos por meio dos ensaios de funil V e de T500, respectivamente. Observa-se, na Figura 66(a), que a relação entre os resultados de viscosidade plástica aparente pelo ensaio de funil $\mathrm{V}$ e 
viscosidade plástica de torque, conferiu-se uma regressão linear com uma equação de coeficiente de determinação igual a 0,71 ; portanto uma relação importante que demonstra uma tendência razoavelmente definida. No entanto, na Figura 66 (b), os resultados de viscosidade plástica aparente, obtidos por meio do ensaio de T500, quando relacionados com os resultados de viscosidade plástica de torque não se obteve uma regressão linear relevante, visto que o coeficiente de determinação foi igual a 0,31. Isso significa, mais uma vez, que os valores gerados pelo ensaio de T500 não têm o mesmo grau de confiabilidade dos valores gerados pelo ensaio de funil V, assim constata-se que a capacidade do ensaio T500 em definir o quesito de habilidade de preenchimento ou viscosidade do concreto é ineficiente.

Figura 66 - (a) Regressão tipo linear entre os resultados de viscosidade plástica aparente dos concretos por meio do ensaio de funil V e resultados de viscosidade plástica de torque das argamassas. (b) Regressão tipo linear entre os resultados de viscosidade plástica aparente dos concretos por meio do ensaio T500 e resultados de viscosidade plástica de torque das argamassas.

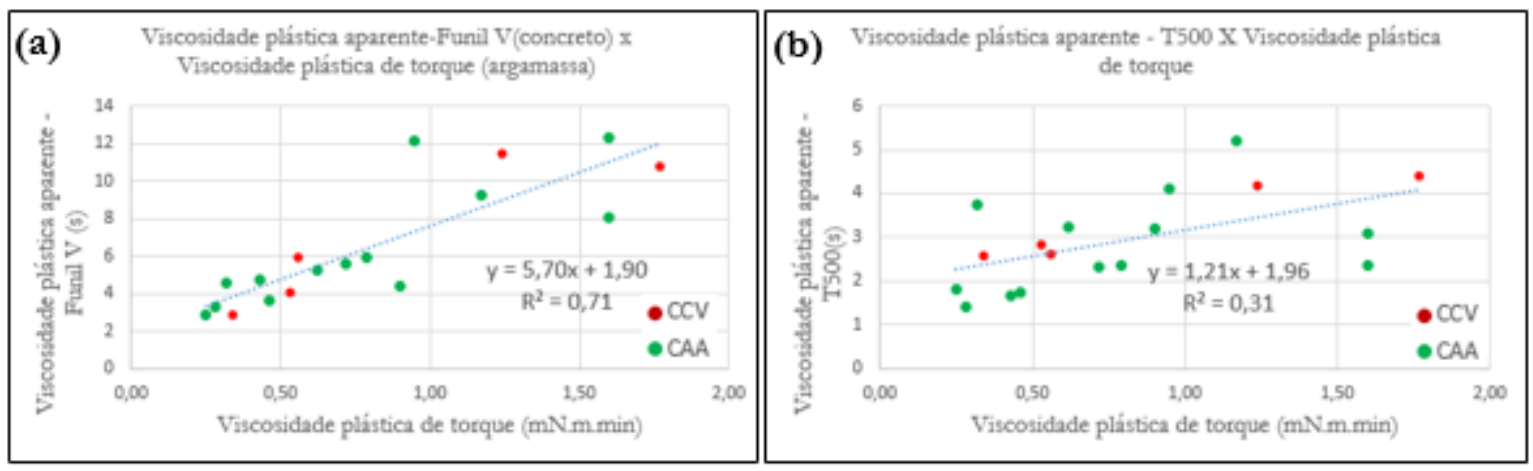

Fonte: Próprio autor.

\subsection{AVALIAÇÃO DO PARÂMETRO WFT}

Na Figura 67 estão apresentados os valores da espessura de água envolta das partículas sólidas da argamassa, conhecido como parâmetro WFT. Vale ressaltar, segundo Fung (2010), que o valor negativo desse parâmetro significa que a quantidade de água foi insuficiente na mistura cimentícia para propiciá-la uma trabalhabilidade adequada. Entretanto, o valor positivo significa a espessura de água envolta dos grãos da mistura que pode ser capaz de propiciar uma redução de atrito entre as partículas sólidas, assim contribuindo para uma melhor trabalhabilidade da matriz cimentícia no seu estado fresco. 
Figura 67 - Relação dos valores encontrados de WFT para as argamassas referências.

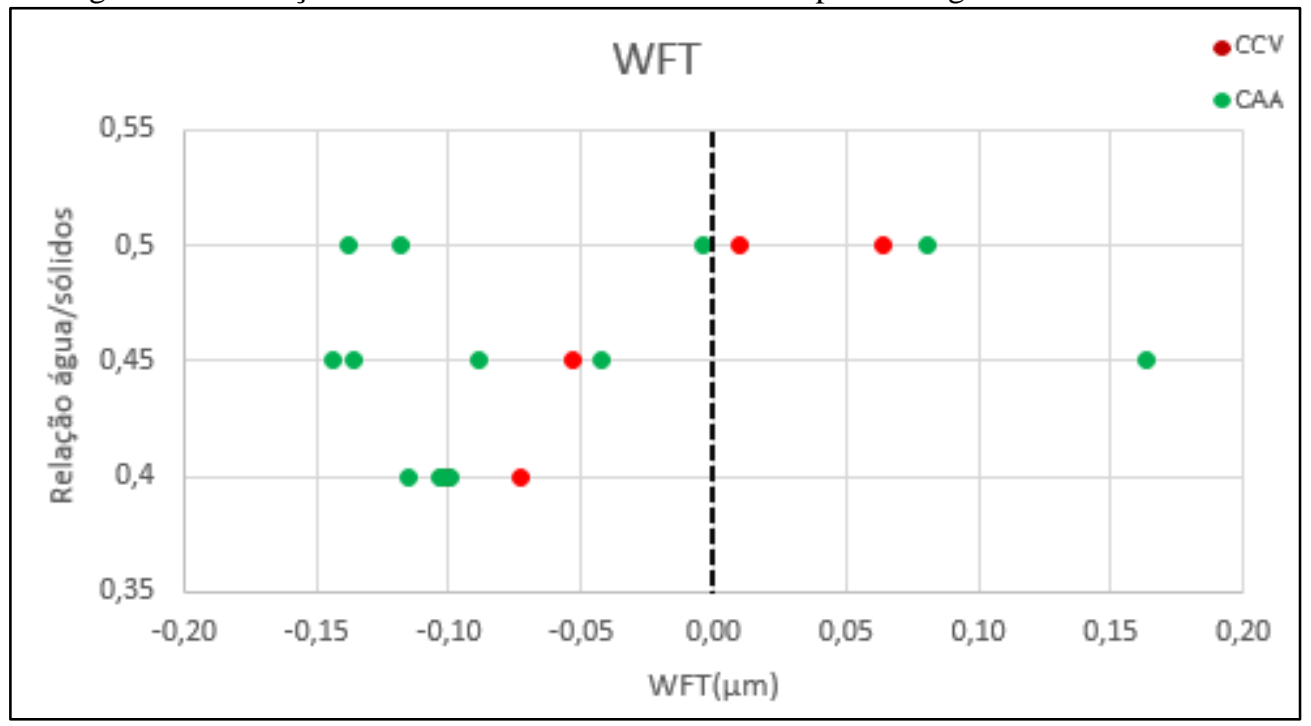

Fonte: Próprio autor.

Nota-se, na Figura 67, que dentre as argamassas autoadensáveis, a maioria teve o valor de WFT entre $-0,1500 \mu \mathrm{m}$ e $0,0000 \mu \mathrm{m}$ e somente duas argamassas apresentaram valores positivos de WFT iguais $0,0807 \mu \mathrm{m}$ e $0,1634 \mu \mathrm{m}$. Estes valores positivos de WFT se referem às argamassas 7A e 15A, respectivamente. É importante destacar que as argamassas não classificadas como autoadensáveis, tiveram seus valores de WFT dentro do intervalo dos valores obtidos pelas argamassas autoadensáveis.

Quando se verifica os resultados de WFT das argamassas em função da sua relação água/sólidos, observa-se, na Figura 67, que as argamassas de relação água/sólidos igual a 0,40 apresentaram seus valores em um intervalo bem estreito entre $-0,1155 \mu \mathrm{m}$ e $-0,0732 \mu \mathrm{m}$. As argamassas de relação água/sólidos igual 0,45 tiveram seus valores entre -0,1433 $\mu$ m e 0,1634 $\mu \mathrm{m}$. Por último, as argamassas de relação água/sólidos igual 0,50 apresentaram valores entre $0,1374 \mu \mathrm{m}$ e $0,0807 \mu \mathrm{m}$.

Diante dos resultados expostos, verifica-se que os resultados negativos de WFT para as argamassas autodensáveis não são coerentes com a definição do parâmetro de espessura de água envolta dos grãos, a qual define que o valor negativo de WFT significa que o material cimentício não teve água suficiente para atender um nível adequado de trabalhabilidade. Explicações para esses resultados adversos estão descritos em duas prováveis hipóteses, a seguir.

A primeira hipótese é o fato da pequena variação da densidade de empacotamento influenciar fortemente o valor do parâmetro de WFT, conforme constatado também por Fung (2010). 
Observa-se, na Tabela 26, que as argamassas de relação água/sólidos igual 0,50 com proporções e tipos de materiais sólidos iguais, sofreram pequena variação na densidade de empacotamento que, por sua vez, refletiu de forma acentuada nos seus valores de WFT. Por exemplo, as argamassas 17A e 18A possuem traços iguais, exceto no teor de aditivo, nota-se que o primeiro obteve uma densidade de empacotamento igual a 0,670 e o segundo 0,660, que resultaram em valores de WFT iguais a $0,0095 \mu \mathrm{m}$ e $-0,1374 \mu \mathrm{m}$, respectivamente. No mesmo sentido, têmse as argamassas 15A e 16A, que obtiveram resultados de densidade de empacotamento e do parâmetro WFT iguais 0,674 e $0,0807 \mu \mathrm{m}$ e 0,660 e -0,1185 $\mu \mathrm{m}$, respectivamente. Os valores negativos de WFT se referem às argamassas classificadas como autoadensável e com maiores teores de superplastificante. Essa variação da densidade de empacotamento reforça a dificuldade apontada por vários pesquisadores da importância de adotar um método de densidade de empacotamento que seja adequado para determinação do parâmetro WFT (WONG, 2007; FUNG, 2010). Esses pesquisadores afirmaram que a densidade por via seca não é recomendada pelo fato do efeito eletrostático das partículas sólidas, portanto eles têm usado por via úmida.

A densidade por via úmida foi adotada neste trabalho, no entanto tem demonstrado que para materiais cimentícios mais trabalháveis ou autoadensáveis não é tão adequado. Isso se deve a maior capacidade desses materiais perderem sua estabilidade no estado fresco durante o processo de determinação da densidade de empacotamento. As argamassas que possuem maior relação água/sólidos e maior teor de aditivo são mais suscetíveis para perderem estabilidade no estado fresco. A perda de estabilidade da mistura se resume na rápida sedimentação das partículas sólidas no recipiente do misturador, com isso a mistura torna-se heterogênea e a amostra retirada para a determinação da densidade de empacotamento pode possuir uma concentração reduzida de sólidos que, por sua vez, refletirá na obtenção do valor real da densidade de empacotamento da argamassa. Por outro lado, quando se considera as argamassas mais coesas e homogêneas, tais como as argamassas de relação água/sólidos igual 0,40; a determinação de suas densidades de empacotamento resulta na obtenção de valores bem próximos que refletem, também, na obtenção de valores bem próximos do parâmetro WFT.

A segunda hipótese consiste no fato do cálculo do parâmetro WFT não considerar o efeito do aditivo superplastificante de reduzir a quantidade de água na mistura, bem como o seu potencial de dispersar as partículas de cimento e promover uma adequada trabalhabilidade. $\mathrm{O}$ aditivo 
superplastificante empregado nas argamassas desta tese possui base química de policarboxilato de sódio, com potencial de redução de água na mistura de até $25 \%$. Isso significa que a água considerada para o cálculo do parâmetro WFT de cada argamassa pode ser insuficiente se tomada isoladamente para promover trabalhabilidade ou autoadensabilidade a argamassa. Diante disso, conclui-se que os valores negativos de WFT refletem as misturas sem o emprego do aditivo superplastificante.

$\mathrm{Na}$ tentativa de considerar o efeito do superplastificante para enquadrar as argamassas autoadensáveis na zona dos valores positivos de WFT, assim fazendo cumprir com a definição da espessura de água envolta dos grãos para promoção da autoadensabilidade, decidiu-se criar um parâmetro WFTeq que pudesse conferir um valor positivo. Esse parâmetro significaria o valor da espessura de água entre os grãos da mistura cimentícia para promover autoadensabilidade (trabalhabilidade) equivalente àquela alcançada pela argamassa com emprego de superplastificante com alto redutor de água. Para isso, primeiramente fez-se um levantamento de faixas de valores de WFT encontrados pelos principais pesquisadores que adotam esse parâmetro, com o intuito de propor uma equação que tivesse um valor médio capaz de somar com valor de WFT obtido, tornando aquele valor negativo de WFT em valor positivo e, assim, representando uma medida de espessura de água. Dentre as faixas encontradas de WFT, pode-se inicialmente citar a faixa entre $-0,1700 \mu \mathrm{m}$ e $0,4000 \mu \mathrm{m}$ encontrada por Kwan e $\mathrm{Li}$ (2012), a faixa entre $-0,1000 \mu \mathrm{m}$ e $0,5000 \mu \mathrm{m}$, por Kwan e Wong (2008), a faixa entre $0,1500 \mu \mathrm{m}$ e $0,2500 \mu \mathrm{m}$, por Fung (2010), e a faixa entre $-0,1500 \mu \mathrm{m}$ e 0,6000 $\mu \mathrm{m}$, por Li e Kwan (2013). Diante disso, constatou-se que o menor valor médio de WFT das faixas consideradas é em torno de $-0,1500 \mu \mathrm{m}$. Da presente tese, o menor valor é $-0,1433 \mu \mathrm{m}$. Por fim, definiu-se que o termo para somar com WFT deve ser igual a 0,1500. Dessa forma, obteve-se o WFTeq das argamassas desta pesquisa conforme a Equação 15, a seguir.

$$
\mathrm{WFTeq}=\mathrm{WFT}+0,1500
$$

Em que:

WFTeq= espessura de água equivalente, $\mu \mathrm{m}$;

WFT= espessura de água real, $\mu \mathrm{m}$. 
Na Tabela 31, estão apresentados os valores de espessura de água equivalente (WFTeq) entre os grãos das argamassas referências. Observa-se que o maior valor é $0,3134 \mu \mathrm{m}$ e o menor valor é $0,0126 \mu \mathrm{m}$.

Tabela 31 - Resultados e classificações de autoadensabilidade das argamassas referências.

\begin{tabular}{|c|c|c|c|c|c|c|c|}
\hline \multirow{2}{*}{$\begin{array}{l}\text { Ref. } \\
\text { Argamassa }\end{array}$} & \multirow{2}{*}{$\mathbf{A A A}$} & \multirow{2}{*}{$\begin{array}{l}\text { Ref. } \\
\text { Concreto }\end{array}$} & \multirow{2}{*}{$\begin{array}{c}\text { Tipo de } \\
\text { aglomerante }\end{array}$} & \multirow{2}{*}{$\begin{array}{c}\text { Relação } \\
\text { água/sólidos }\end{array}$} & \multirow{2}{*}{$\begin{array}{c}\text { Teor de } \\
\text { aditivo }(\%)\end{array}$} & \multicolumn{2}{|c|}{ WFTeq $=$ WFT $+0,150$} \\
\hline & & & & & & WFT & WFTeq \\
\hline $1 \mathrm{~A}$ & & $1 \mathrm{C}$ & REF & 0,40 & 1,0 & $-0,1006$ & 0,0494 \\
\hline $2 \mathrm{~A}$ & $\mathrm{X}$ & $2 \mathrm{C}$ & REF & 0,40 & 1,2 & $-0,0993$ & 0,0507 \\
\hline $3 \mathrm{~A}$ & & $3 \mathrm{C}$ & 20 & 0,40 & 1,0 & $-0,0732$ & 0,0768 \\
\hline $4 \mathrm{~A}$ & $\mathrm{X}$ & $4 \mathrm{C}$ & 20 & 0,40 & 1,2 & $-0,1027$ & 0,0473 \\
\hline $5 \mathrm{~A}$ & $\mathrm{X}$ & $5 \mathrm{C}$ & 30 & 0,40 & 1,0 & $-0,1035$ & 0,0465 \\
\hline $6 \mathrm{~A}$ & $\mathrm{X}$ & $6 \mathrm{C}$ & 30 & 0,40 & 1,2 & $-0,1155$ & 0,0345 \\
\hline $7 \mathrm{~A}$ & $\mathrm{X}$ & $7 \mathrm{C}$ & REF & 0,45 & 0,8 & 0,1634 & 0,3134 \\
\hline $8 \mathrm{~A}$ & $\mathrm{X}$ & $8 \mathrm{C}$ & REF & 0,45 & 1,0 & $-0,0425$ & 0,1075 \\
\hline $9 \mathrm{~A}$ & & $9 \mathrm{C}$ & 20 & 0,45 & 0,8 & $-0,0536$ & 0,0964 \\
\hline $10 \mathrm{~A}$ & $X$ & $10 \mathrm{C}$ & 20 & 0,45 & 1,0 & $-0,1357$ & 0,0143 \\
\hline $11 \mathrm{~A}$ & $\mathrm{X}$ & $11 \mathrm{C}$ & 30 & 0,45 & 0,8 & $-0,0890$ & 0,0610 \\
\hline $12 \mathrm{~A}$ & $X$ & $12 \mathrm{C}$ & 30 & 0,45 & 1,0 & $-0,1433$ & 0,0067 \\
\hline $13 \mathrm{~A}$ & & $13 \mathrm{C}$ & REF & 0,50 & 0,6 & 0,0643 & 0,2143 \\
\hline $14 \mathrm{~A}$ & $X$ & $14 \mathrm{C}$ & REF & 0,50 & 0,8 & $-0,0035$ & 0,1465 \\
\hline $15 \mathrm{~A}$ & $\mathrm{X}$ & $15 \mathrm{C}$ & 20 & 0,50 & 0,6 & 0,0807 & 0,2307 \\
\hline $16 \mathrm{~A}$ & $\mathrm{X}$ & $16 \mathrm{C}$ & 20 & 0,50 & 0,8 & $-0,1185$ & 0,0315 \\
\hline $17 \mathrm{~A}$ & & $17 \mathrm{C}$ & 30 & 0,50 & 0,6 & 0,0095 & 0,1595 \\
\hline $18 \mathrm{~A}$ & $\mathrm{X}$ & $18 \mathrm{C}$ & 30 & 0,50 & 0,8 & $-0,1374$ & 0,0126 \\
\hline
\end{tabular}

Fonte: Próprio autor.

A seguir, estão apresentadas as relações do parâmetro WFTeq com os valores dos resultados de espalhamento, tensão de escoamento e viscosidade das argamassas, bem como dos concretos que estas refereciam.

Inicialmente, na Figura 68, estão apresentadas as relações dos resultados de WFTeq com os resultados de espalhamento das argamassas e dos concretos. Observa-se, primeiramente, que essas relações tanto para as argamassas e quanto para os concretos seguem uma tendência linear decrescente na medida que o valor de WFTeq aumenta. Além disso, verificam-se tendências lineares bem semelhantes, que demonstram uma sintonia importante entre os valores de tensão de escoamento das argamassas e dos concretos. Isso comprova mais uma vez a relevância de se estudar argamassa do concreto autoadensável. Dentre as regressões lineares, a regressão linear referente aos valores de espalhamento do concreto possui um melhor ajuste a ponto de se ter um coeficiente de determinação igual a 0,76. 
Figura 68 - Relação dos resultados de WFTeq e de espalhamento das argamassas e dos concretos.
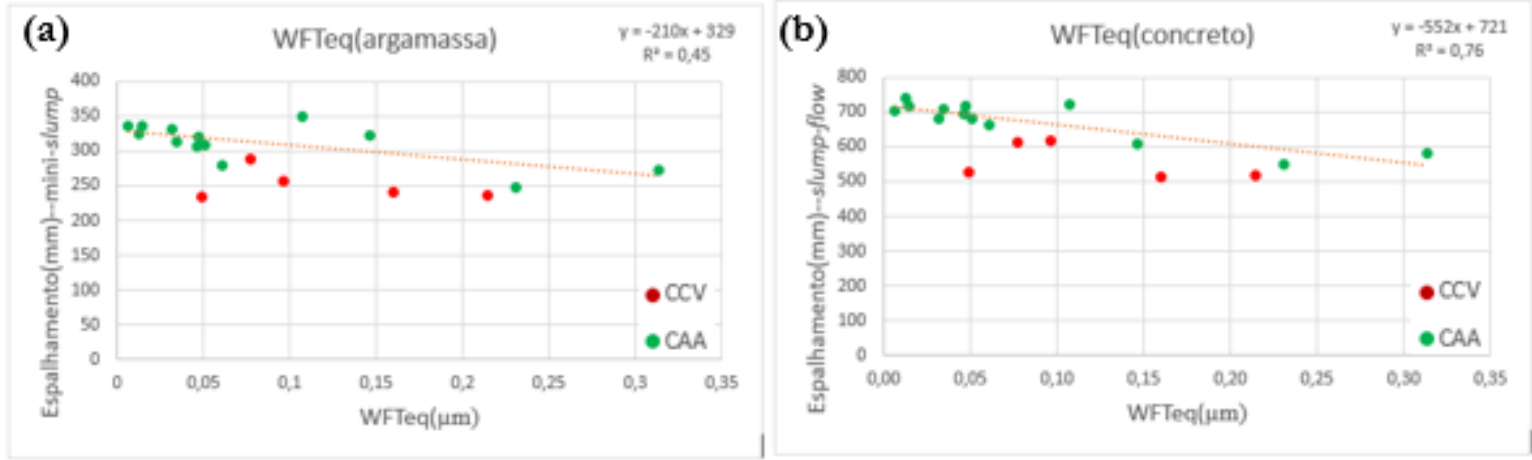

Fonte: Próprio autor.

Nota-se, na Figura 68, que a maioria das argamassas classificada como autoadensável possui valores de WFTeq entre $0,000 \mu \mathrm{m}$ e $0,0500 \mu \mathrm{m}$. Essa faixa de valores é considerada mais baixa comparada aos valores das demais argamassas. Isso se deve, principalmente, ao fato das argamassas autoadensáveis terem demonstrado uma densidade de empacotamento menor quando comparadas com as argamassas de mesmo traço, conforme a primeira hipótese citada acima, neste item. Menor densidade de empacotamento de uma argamassa significa que no seu sistema granular boa parte dos vazios está preenchido com água e, com isso, resta menos água para cobrir uma área especifica total dos sólidos para uma mistura homogênea. Isso resulta em uma espessura reduzida de água (WFTeq) para essas argamassas. Diante disso, constata-se que o efeito do aditivo superplastificante é mais importante do que o efeito da água para propiciar autoadensabilidade às misturas cimentícias, visto que o valor de WFTeq é baixo.

Verifica-se, na Figura 68, que conforme o WFTeq aumenta, o espalhamento tende a diminuir tanto nas argamassas como nos concretos. Esse comportamento pode ser explicado por meio de uma hipótese que faz interface com a primeira hipótese supracitada neste item. Nesse caso, observa-se que as misturas com maiores valores WFTeq têm mais água disponível e, somado com efeito do superplastificante, podem tornar mais sucetíveis para perder a estabilidade da mistura que, por sua vez, promoverá maior concentração de sólidos em determinadas regiões. Essas regiões há mais atrito entre os grãos, com isso comprometendo a trabalhabilidade do material cimentício. A maioria dessas argamassas, possui relação água/sólidos 0,50, portanto mais água.

Na Figura 69 estão apresentadas as relações entre os resultados de WFTeq e a tensão de escoamento das argamassas e dos concretos. Observa-se que os valores compreendidos de WFTeq entre $0,00 \mu \mathrm{m}$ e $0,05 \mu \mathrm{m}$ se referem em boa parte às argamassas autoadensáveis, as 
quais possuem tensão de escoamento de torque entre $0,74 \mathrm{mN} . \mathrm{m}$ e $6 \mathrm{mN}$.m. Com relação aos concretos autoadensáveis, o intervalo da tensão de escoamento teórica se situa entre 100 Pa e 300 Pa para a mesma faixa de WFTeq das argamassas autoadensáveis.

Figura 69 - Relação dos resultados de WFTeq e tensão de escoamento. (a) WFTeq e tensão de escoamento de torque (argamassas) (b) WFTeq e tensão de escoamento teórica.

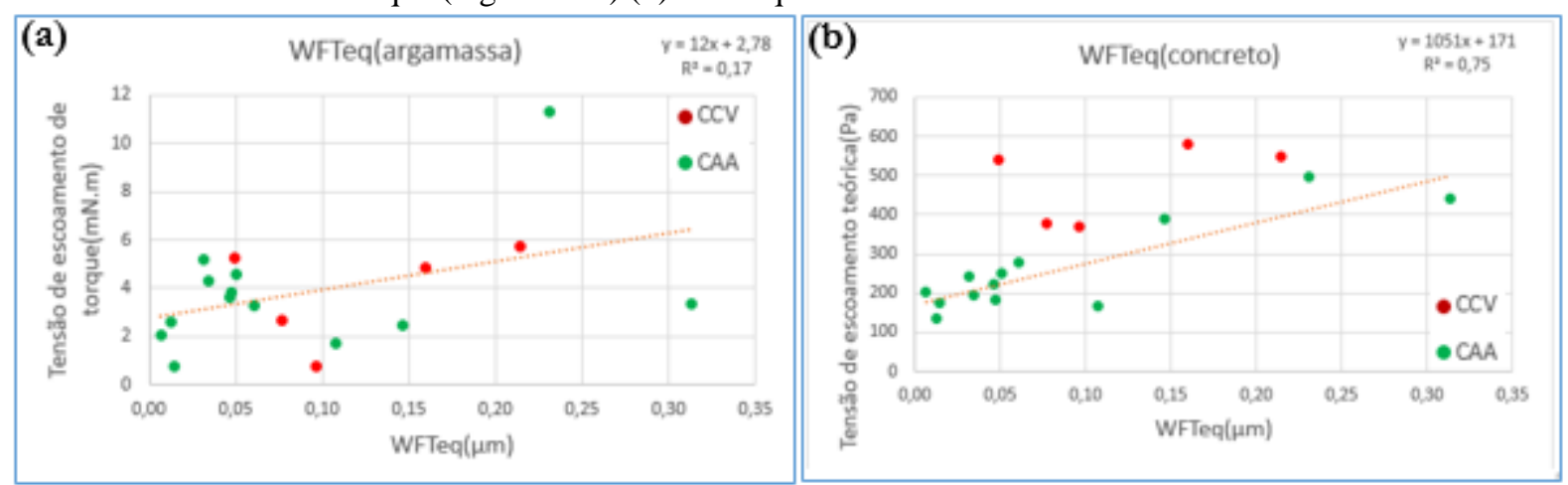

Fonte: Próprio autor.

Quanto aos comportamentos dessas relações, na Figura 69(a), verifica-se primeiramente que a relação dos resultados de WFTeq e tensão de escoamento de torque das argamassas é ruim, visto que o coeficiente de determinação da regressão linear é muito baixo igual a 0,17 . No entanto, quando se compara essa relação com a regressão linear entre os resultados de WFTeq e tensão de escoamento teórica do concreto, nota-se que ambas relações mostram ter uma tendência linear crescente e semelhantes. Isso significa, que a tensão de escoamento tende a crescer com aumento do WFTeq, sendo que a relação mais confiável é com resultados de tensão de escoamento do concreto pelo fato dessa relação ter conferido uma importante regressão linear, com coeficiente de determinação igual a 0,75 , conforme está apresentada na Figura 69(b). Esses comportamentos podem ser explicados de acordo com a provável hipótese que explica os comportamentos obtidos da relação de WFTeq das argamassas e dos resultados de espalhamento de argamassas e de concretos. Dessa forma, pode-se dizer que as argamassas referências com maiores valores de WFTeq sofreram uma sedimentação dos seus sólidos de forma rápida, os quais resultaram em uma maior concentração de sólidos no fundo do recipiente do reômetro e, com isso, demandou-se um maior esforço para iniciar os seus fluxos. 
Nota-se que as relações apresentadas do parâmetro WFTeq com os resultados de espalhamento e de tensão de escoamento foram contrários quando comparados com os resultados obtidos por Kwan e Wong (2008) e Fung (2010). Isso, mais uma vez, desperta sobre a importância de se estudar mais o parâmetro WFT frente aos materiais cimentícios autoadensáveis.

Por último, na Figura 70, estão apresentadas as relações dos resultados de WFTeq e de viscosidade das argamassas referências, bem como estão apresentadas as relações de WFTeq das argamassas com os resultados de viscosidade dos concretos que são referentes. Considerouse os resultados de viscosidade de diferentes meios de obtenção. Na, Figura 70 (a), tem-se a relação de WFTeq com os resultados de viscosidade plástica aparente das argamassas obtidos por meio do mini-funil. Na, Figura 70 (b), tem-se a relação de WFTeq com os resultados de viscosidade plástica aparente dos concretos por meio do funil V. Na, Figura 70 (c), tem-se a relação de WFTeq com os resultados de viscosidade plástica de torque das argamassas obtidos por meio de um reômetro. Por fim, na Figura 70 (d), tem-se a relação de WFTeq com os resultados de viscosidade plástica aparente das argamassas obtidos por meio do mini-funil.

Primeiramente, na Figura 70, observa-se uma nuvem de pontos para cada relação dos valores de WFTeq e valores de um determinado tipo de parâmetro de viscosidade da argamassa ou do concreto, sendo que, no geral, todas relações apresentam nuvens de pontos semelhantes. Nesse sentido, constata-se que a maioria das relações dos resultados das argamssas e dos concretos autoadensáveis possuem valores que estão compreendidos numa faixa de WFTeq entre 0,00 $\mu \mathrm{m}$ e $0,05 \mu \mathrm{m}$, e alguns bem próximos do valor $0,05 \mu \mathrm{m}$. Quando se excluem as relações dentro e próxima desta faixa, verifica-se que o comportamento das relações dos resultados das argamassas e dos concretos restantes pode tender para uma curva tipo potência ou exponencial. Os trabalhos dos pesquisadores Kwan e Wong (2008), Fung (2010) e Li e Kwan (2013) obtiveram curvas tipo exponencial para essas relações que envolvem resultados de viscosidade. 
Figura 70 - Relação dos resultados de WFTeq e viscosidade plástica. (a) WFTeq e viscosidade plástica aparente (mini-funil) (b) WFTeq e viscosidade plástica aparente (FunilV) (c) WFTeq e viscosidade plástica de torque (d) WFTeq e viscosidade plástica teórica.

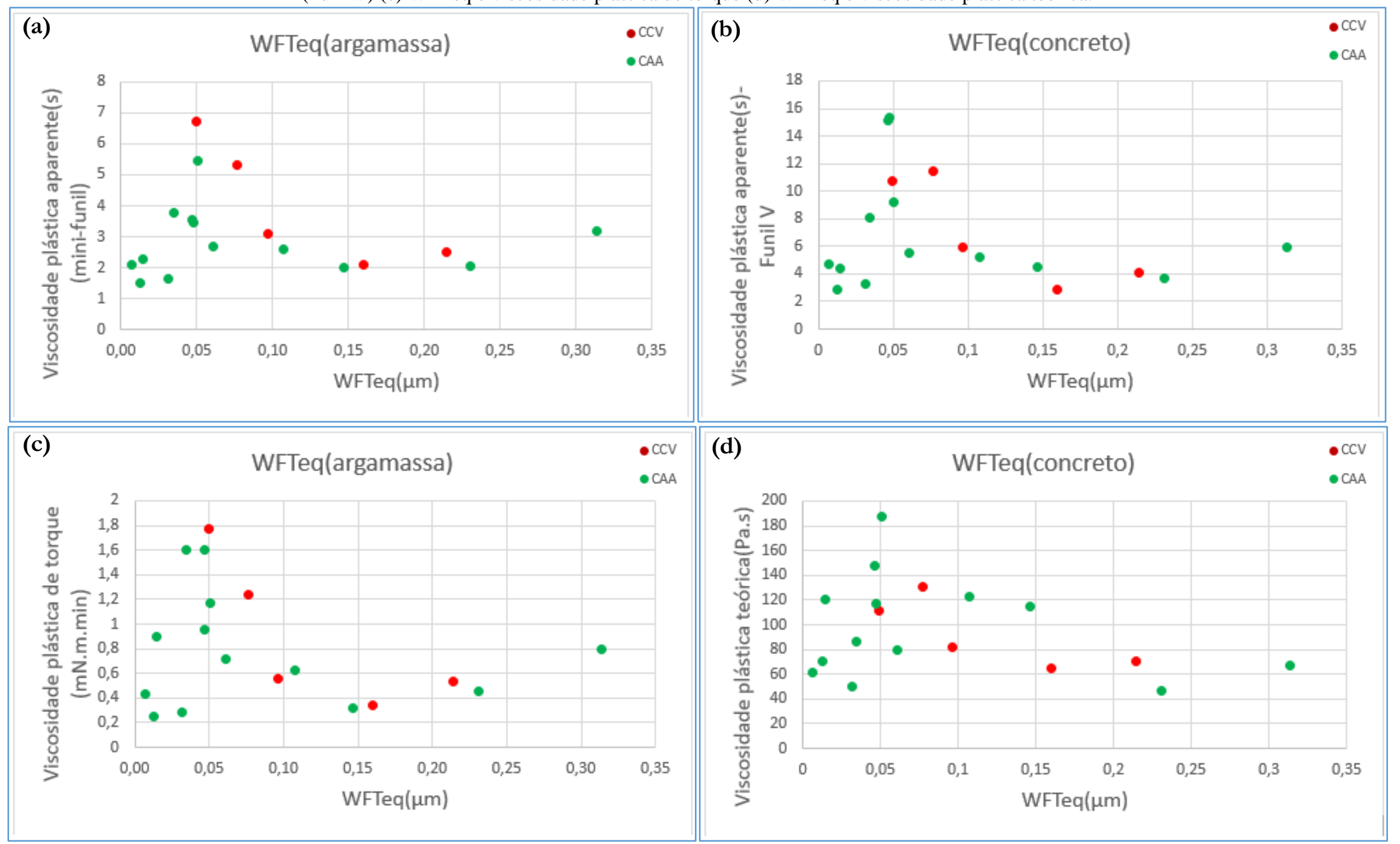

Fonte: Próprio autor. 
Por fim, os resultados referentes ao parâmetro WFT quando relacionados com os resultados de autoadensabilidade e de reologia das argamassas e dos concretos autoadensáveis não mostraram, na maioria dos casos, os mesmos comportamentos obtidos pelas argamassas convencionais estudadas por outros pesquisadores. Diante disso, constatou-se que o parâmetro WFT não pode governar os parâmetros de autoadensabilidade e de reologia dos materiais cimentícios autoadensáveis, entretanto indo contra a afirmação defendida pelos pesquisadores Kwan e Wong (2008) e Fung (2010). Estes pesquisadores defendem que o parametro WFT é capaz de governar as propriedades de trabalhabilidade e de reologia das pastas, argamassas e concretos. Para que essa afirmação seja válida para os materias cimentícios autoadensáveis, são necessários mais estudos, ou seja, é necessário propor um método de obtenção da densidade de empacotamento mais adequado, estudar rigorosamente o efeito combinado da água e superplastificante e incluir o efeito do aditivo superplastificante no cálculo do parâmetro WFT.

\subsection{AVALIAÇÃO DAS PROPRIEDADES MECÂNICAS DOS CONCRETOS}

Sabe-se pela presente pesquisa, que o foco principal foi o estudo das propriedades no estado fresco de argamassas e de concretos. Entretanto, considerou-se importante fazer uma sucinta avaliação das características mecânicas dos concretos autoadensáveis, visto que esses são mais argamassados que os concretos usuais e, por isso, são mais deformáveis também no estado endurecido. Além disso, despertou-se conhecer as características mecânicas do concreto com adição de fíler calcário motivado pelo momento atual que já se cogita o aumento da proporção de fíler inerte na composição dos tipos de cimento comercializado no Brasil, por razões de economia no custo de produção e de sustentabilidade no que se refere ao produto com menor energia incorporada. As propriedades mecânicas estudadas foram resistência à compressão e módulo de elasticidade do concreto.

\subsubsection{Resistência à Compressão}

Na Figura 71 estão apresentados os resultados médios aos 28 dias de Resistência à Compressão dos concretos na Tabela 27, item 4.8.1, e, no Apêndice F, estão apresentados os resultados individuais. 
Figura 71 - Resultados médios de resistência à compressão.

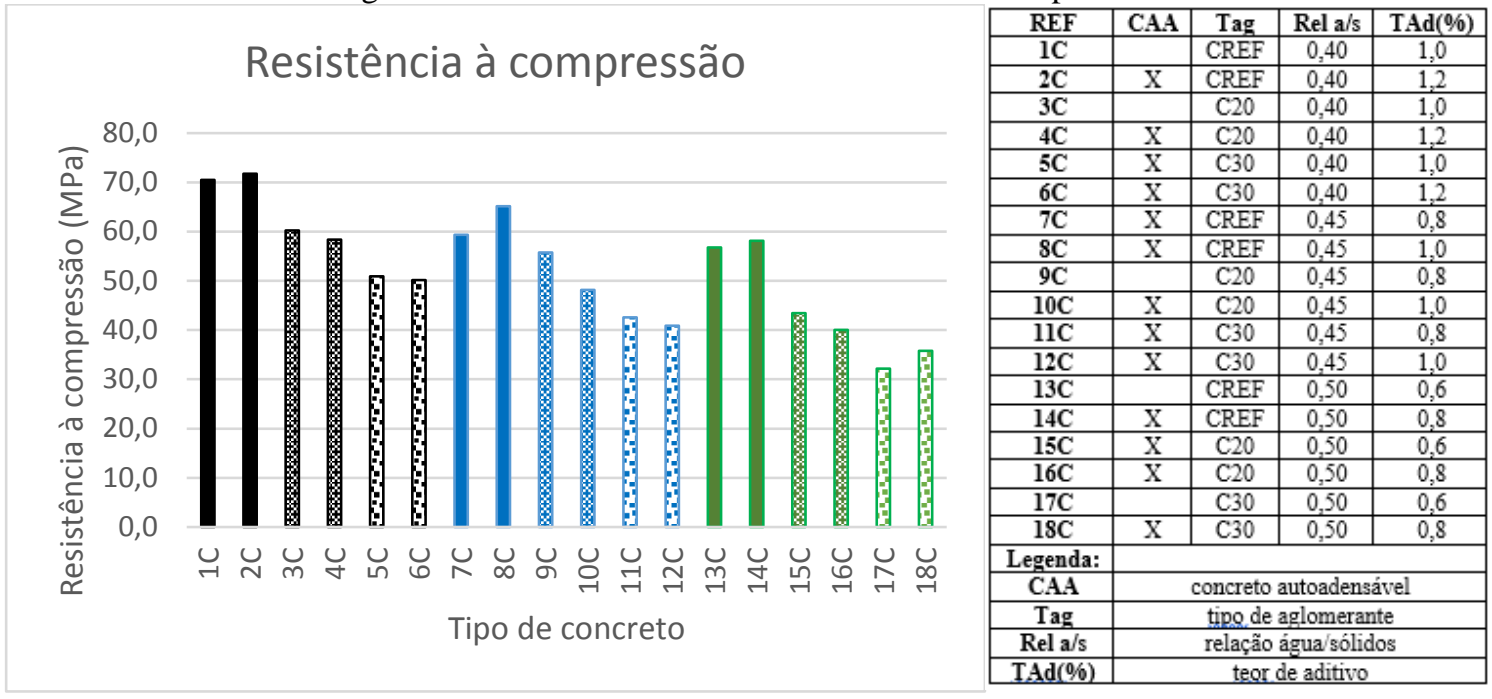

Fonte: Próprio autor.

Primeiramente, observa-se uma redução da resistência à compressão na medida que se aumenta o teor de substituição de cimento por fíler calcário. Nesse sentido, por exemplo, nota-se que os concretos referentes a relação água/sólidos igual a 0,40, os CREF, C20 e C30 apresentaram, aproximadamente, resultados médios de resistência à compressão iguais $70 \mathrm{MPa}, 60 \mathrm{MPa} \mathrm{e}$ 50MPa, respectivamente. Ou seja, com substituição de $20 \%$ de fíler calcário refletiu na redução da resistência à compressão em torno de 14\% e com 30\% de substituição reduziu em torno de $28 \%$ a resistência à compressão. Quanto aos concretos com relações água/sólidos iguais 0,45 e 0,50, a redução da resistência à compressão com substituição de fíler calcário foi para os primeiros $16 \%$ e $32 \%$ e para os segundos $27 \%$ e $40 \%$, respectivamente. Isso significa, que a substituição do cimento por filer calcário promoverá a redução da formação de C-S-H que, por sua vez, comprometerá a resistência à compressão do concreto. Esse efeito é mais intensificado para os concretos com maiores relações água/aglomerante devido a zona de interface entre o agregado graúdo e argamassa do concreto ser mais porosa e, com isso, menos resistente, conforme relatado por vários autores (METHA; MONTEIRO, 2014; NEVILLE, 1997; AITCIN, 2000).

Verifica-se, na Figura 71, que o aumento da relação água/sólidos (aumento da relação água/aglomerante) também refletiu para redução da resistência à compressão do concreto. Esse efeito é conhecido como à lei de Abrams, segundo a qual o aumento da relação água/aglomerante resulta em menor resistência à compressão. Conforme Mehta e 
Monteiro (2014), isto pode ser explicado como uma conseqüência natural do progressivo enfraquecimento da matriz (pasta hidratada), em virtude do aumento da porosidade gerada pelo aumento da relação a/ag.

Cabe destacar, que não se notou um comportamento nítido da influência do teor de aditivo superplastificante sobre a resistência à compressão do concreto, assim como não se notou diferença da resistência à compressão dos concretos autoadensáveis e dos concretos classificados como não autoadensáveis.

Com intuito de verificar se as variáveis envolvidas influenciaram de maneira significativa a resistência à compressão, realizou-se uma análise estatística de variância (ANOVA) que, por sua vez, os seus resultados encontram-se na Tabela 32 , onde os valores de "F calculados"( $\left.F_{\text {cal }}\right)$ foram comparados com os valores de "F tabelados" $\left(\mathrm{F}_{\mathrm{tab}}\right)$ para um nível de significância de 5\%. $\mathrm{O}$ valor de $\mathrm{F}_{\text {tab }}$ é igual a $\mathrm{F}_{\alpha}=0,05$ ( $v 1$, v2), obtido da Tabela A.1 do Anexo A, sendo v1 e $v 2$ os graus de liberdade do efeito avaliado e do resíduo, respectivamente. É importante frisar, que para ANOVA, considerou-se somente os concretos autoadensáveis com maiores teores de aditivo superplastificante, os quais possuem maior autoadensabilidade e são identificados com números pares (2C, 4C, 6C, 8C, 10C, 12C, 14C, 16C e 18C). Esse critério foi adotado no sentido de se ter uma condição fixa, que tornasse possível relacionar os concretos autoadensáveis diante de diferentes relações água/sólidos

A Tabela 32 apresenta os resultados da ANOVA realizado para os dados de resistência à compressão. A análise estatística mostrou que o modelo fatorial é significativo, a partir da

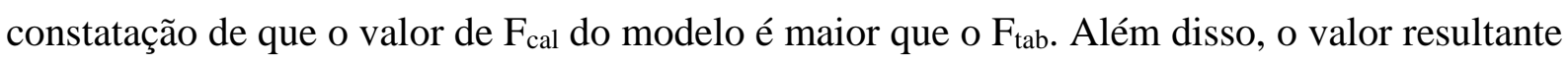
foi igual $\mathrm{R}^{2}$ mod foi 0,98 , bastante elevado. Isso significa, que $99 \%$ da variação total dos dados é explicada pelo modelo. 
Tabela 32 - Resultados da análise de variância (ANOVA) realizada com os dados de resistência à compressão, para as variáveis consideradas no modelo estatístico.

\begin{tabular}{|c|c|c|c|c|c|c|}
\hline Efeito & SQ & GL & MQ & Fcal & Ftab & Resultado \\
\hline Modelo & 3387,29 & 4 & 846,82 & 342 & 2,82 & significativo \\
\hline Erro (resíduo) & 54,40 & 22 & 2,47 & -- & -- & -- \\
\hline Total & 3441,69 & 26 & -- & -- & -- & -- \\
\hline Tipo de aglomerante & 2367,99 & 2 & 1184 & 478,79 & 3,44 & significativo \\
\hline Relação água/sólidos & 1019,30 & 2 & 509.65 & 206,09 & 3,44 & significativo \\
\hline Erro (resíduo) & 54 & 22 & 2,47 & -- & -- & -- \\
\hline \multicolumn{7}{|c|}{$\mathrm{R}_{\text {mod }}=0,99 \mathrm{R}^{2}$ mod $=0,98$} \\
\hline \multicolumn{7}{|l|}{ Onde: } \\
\hline \multicolumn{7}{|c|}{$\mathrm{SQ}=$ Soma dos quadrados; $\mathrm{GL}=$ Graus de liberdade; $\mathrm{MQ}=$ Média dos quadrados; } \\
\hline \multicolumn{7}{|c|}{$\mathrm{F}=$ Parâmetro de Fisher para o teste de significância dos efeitos; } \\
\hline \multicolumn{7}{|c|}{ Resultado = Resultado da análise, com a indicação se o efeito é significativo ou não; } \\
\hline \multicolumn{7}{|c|}{$\mathrm{R}_{\text {mod }}^{2}=$ Coeficiente de determinação do modelo e } \\
\hline \multicolumn{7}{|c|}{$\mathrm{R}_{\mathrm{mod}}=$ Coeficiente de correlação do modelo. } \\
\hline
\end{tabular}

Fonte: Próprio autor.

A análise de variância também mostrou que os efeitos individuais dos fatores principais analisados, ou seja, tipo de aglomerante e relação água/sólidos são estatisticamente significativos a um nível de confiança de 95\%. Isto confirma a influência de cada uma dessas variáveis independentes, quando tomadas isoladamente.

A variável mais influente na resistência à compressão foi o tipo de aglomerante e em segundo lugar apresentou-se a variável relação água/sólidos.

Por fim, realizou-se comparação múltipla de médias pelo método de Duncan, em virtude da influência das variáveis: tipo de aglomerante e relação água/sólidos. Os resultados destas análises são apresentados a seguir.

a) Efeito do tipo de aglomerante

Na Figura 72 está apresentado o resultado do agrupamento de médias, onde as linhas tracejadas verticais definem os grupos que diferem significativamente, na qual se constata que os três tipos de aglomerantes considerados neste estudo, produzem efeitos estatisticamente diferentes sobre a resistência à compressão. 
Figura 72 - Valores médios globais de resistência à compressão em função do tipo de aglomerante empregado nos concretos, com seus intervalos de confiança de $95 \%$ e seus desvios padrões. As linhas tracejadas verticais definem os grupos que diferem significamente.

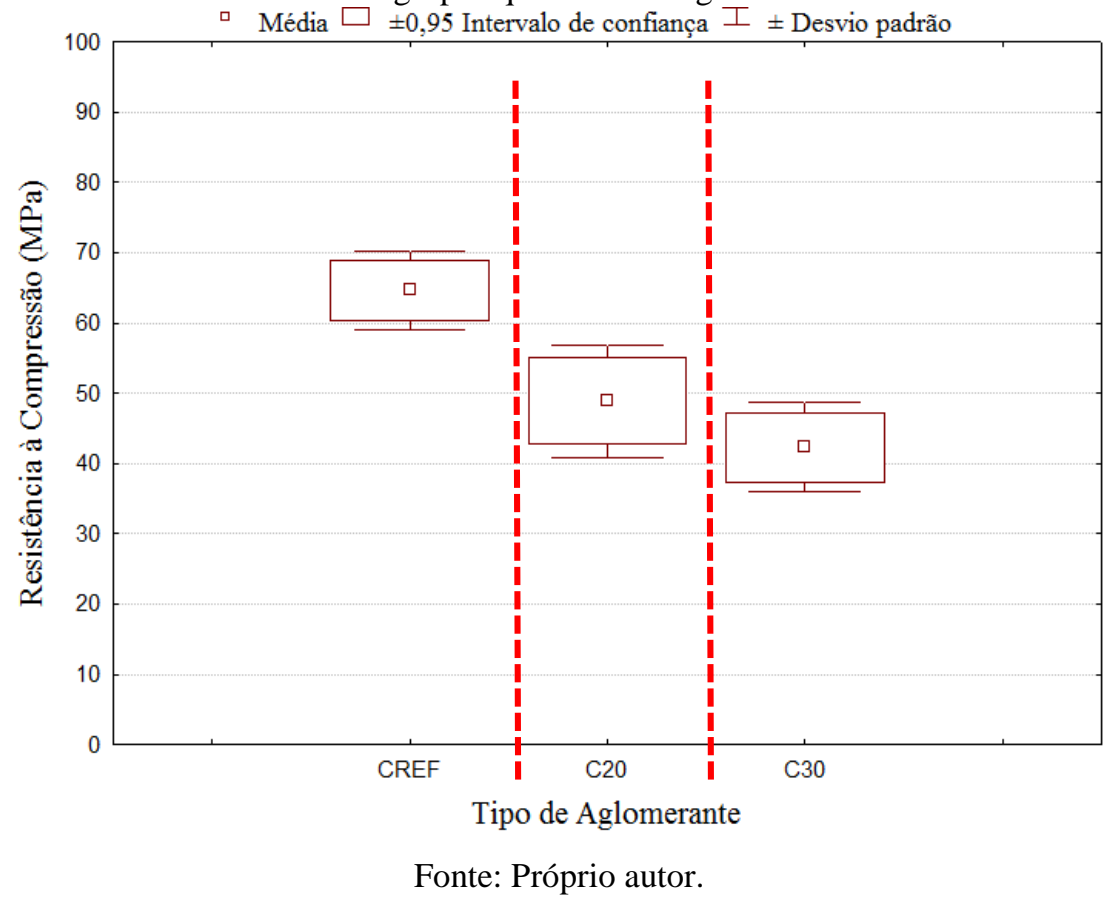

b) Efeito da relação água/sólidos

Na Figura 73 está apresentado o resultado do agrupamento de médias, onde as linhas tracejadas verticais definem os grupos que diferem significativamente, na qual se constata que as três relações água/sólidos considerados neste estudo, produzem efeitos estatisticamente diferentes sobre a resistência à compressão. 
Figura 73 - Valores médios globais de resistência à compressão em função da relação água/sólidos empregado nos concretos, com seus intervalos de confiança de $95 \%$ e seus desvios padrões. As linhas tracejadas verticais definem os grupos que diferem significamente.

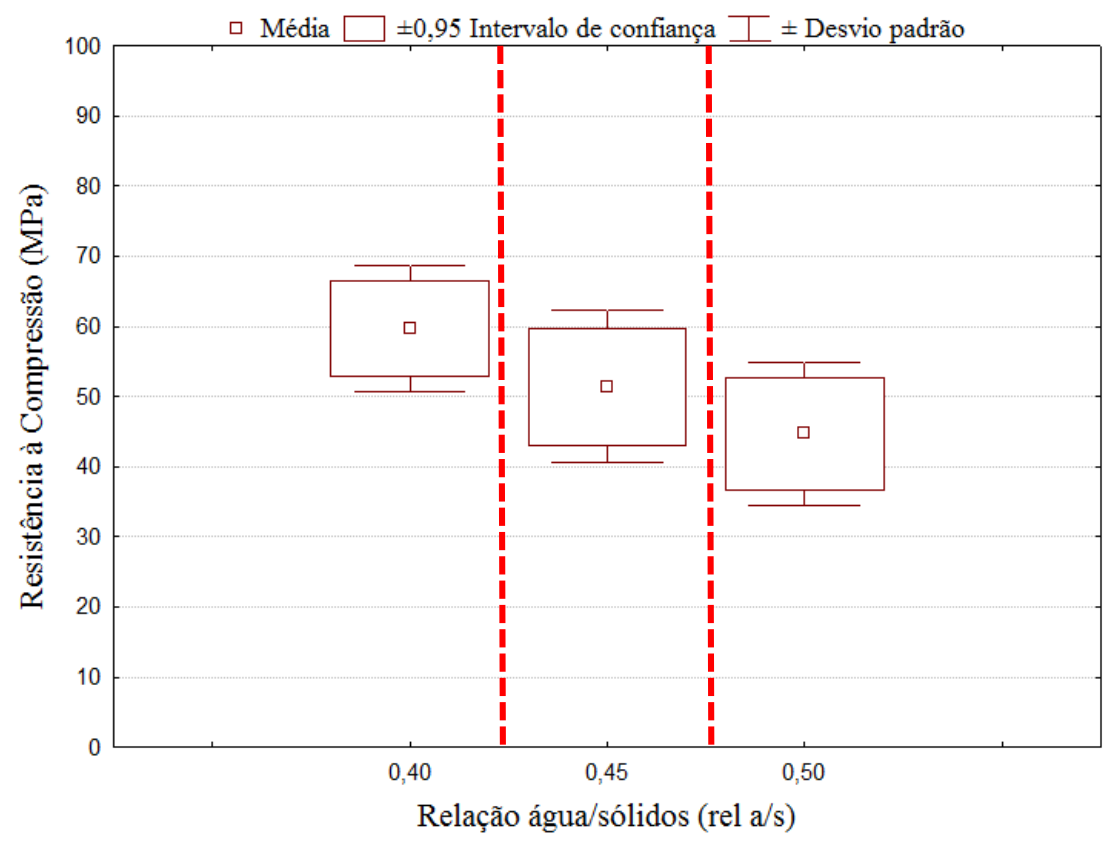

Fonte: Próprio autor.

\subsubsection{Módulo de elasticidade}

Na Figura 74 estão apresentados os resultados médios aos 28 dias de Módulo de Elasticidade apresentada na Tabela 28, item 4.8.2 e, no Apêndice F, estão apresentados os resultados individuais. Inicialmente, nota-se que a influência da substituição de cimento por fíler calcário sobre o Módulo de Elaticidade é quase imperceptível quando se compara essa inflûencia nos resultados de Resistência à Compressão. Verifica-se, também, que não há uma diferença nítida entre os resultados de módulo de elasticidade de concretos autoadensáveis e de concretos não adensáveis, bem como não há um comportamento evidente da influência do aumento do teor de aditivo superplastificante no módulo de elasticidade. 
Figura 74 - Resultados médios de módulo de elasticidade dos concretos.

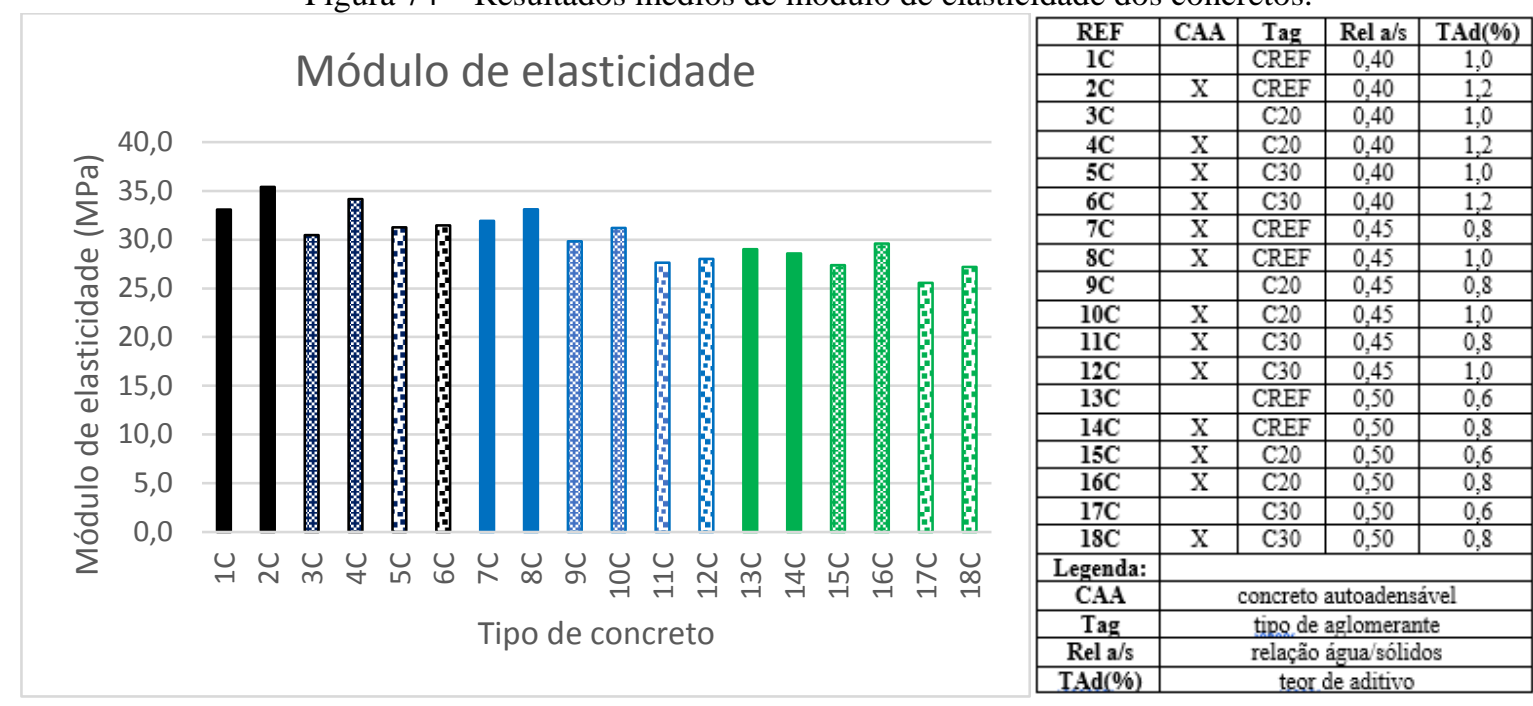

Fonte: Próprio autor.

Nota-se, na Figura 74, uma redução do módulo de elasticidade com aumento da relação água/sólidos (aumento da relação água/aglomerante). Os valores médios de módulo de elasticidade dos concretos CREF com diferentes relações água/sólidos iguais 0,40, 0,45 e 0,50 foram 34,25 GPa, 32,90 G e 28,80 GPa, respectivamente. Em termos percentuais, a diferença do primeiro com segundo foi de $4 \%$ e do primeiro com terceiro foi de $16 \%$. Os concretos C30 obtiveram também uma diferença entre os concretos de relação água/sólidos 0,40 e 0,50 igual a $16 \%$, enquanto os concretos C20 obtiveram uma diferença de $12 \%$. Observa-se que essa redução dos resultados mecânicos em função da relação água/sólidos dos concretos tem maior magnitude quando se trata dos resultados de resistência à compressão.

Com intuito de verificar se as variáveis envolvidas influenciaram de maneira significativa ao módulo de elasticidade, realizou-se uma análise estatística de variância (ANOVA) que, por sua vez, os seus resultados encontram-se na Tabela 33, onde os valores de " $F$ calculados" $\left(\mathrm{F}_{\text {cal }}\right)$ foram comparados com os valores de "F tabelados" $\left(\mathrm{F}_{\mathrm{tab}}\right)$ para um nível de significância de 5\%. $\mathrm{O}$ valor de $\mathrm{F}_{\text {tab }}$ é igual a $\mathrm{F}_{\alpha}=0,05(v 1, \mathrm{v} 2)$, obtido da Tabela A.1 do Anexo A, sendo $v 1$ e $v 2$ os graus de liberdade do efeito avaliado e do resíduo, respectivamente. É importante ressaltar, que para ANOVA, considerou-se somente os concretos autoadensáveis com maiores teores de aditivo superplastificante, os quais alcançaram maior autoadensabilidade e são identificados com números pares (2C, 4C, 6C, 8C, 10C, 12C, 14C, 16C e 18C). Esse critério foi adotado no 
sentido de se ter uma condição fixa, que tornasse possível relacionar os concretos autoadensáveis diante de diferentes relações água/sólidos

A Tabela 33 apresenta os resultados da ANOVA realizado para os dados de módulo de elasticidade. A análise estatística mostrou que o modelo fatorial é significativo, a partir da

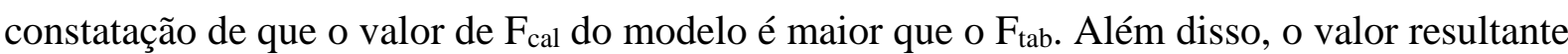
foi igual $\mathrm{R}^{2}$ mod foi 0,68 , um valor razoável. Isso significa, que $68 \%$ da variação total dos dados é explicada pelo modelo.

Tabela 33 - Resultados da análise de variância (ANOVA) realizada com os dados de módulo de elasticidade para as variáveis consideradas no modelo estatístico.

\begin{tabular}{|c|c|c|c|c|c|c|}
\hline Efeito & SQ & GL & MQ & Fcal & Ftab & Resultado \\
\hline Modelo & 133,53 & 4 & 33,38 & 11,59 & 2,82 & significativo \\
\hline Erro (resíduo) & 63,35 & 22 & 2,88 & -- & -- & -- \\
\hline Total & 196,88 & 26 & -- & -- & -- & -- \\
\hline Tipo de aglomerante (TAg) & 44,68 & 2 & 22,34 & 7,76 & 3,44 & significativo \\
\hline Relação água/sólidos (Rel a/s) & 88,86 & 2 & 44,43 & 15,43 & 3,44 & significativo \\
\hline Erro (resíduo) & 133,54 & 4 & & -- & -- & -- \\
\hline \multicolumn{7}{|c|}{$\mathrm{R}_{\text {mod }}=0,82 \mathrm{R}^{2}{ }_{\text {mod }}=0,68$} \\
\hline \multicolumn{7}{|l|}{ Onde: } \\
\hline \multicolumn{7}{|c|}{$\mathrm{SQ}=$ Soma dos quadrados $; \mathrm{GL}=$ Graus de liberdade $; \mathrm{MQ}=$ Média dos quadrados } \\
\hline \multicolumn{7}{|c|}{$\mathrm{F}=$ Parâmetro de Fisher para o teste de significância dos efeitos; } \\
\hline \multicolumn{7}{|c|}{ Resultado = Resultado da análise, com a indicação se o efeito é significativo ou não; } \\
\hline \multicolumn{7}{|c|}{$\mathrm{R}_{\text {mod }}^{2}=$ Coeficiente de determinação do modelo e } \\
\hline \multicolumn{7}{|c|}{$\mathrm{R}_{\mathrm{mod}}=$ Coeficiente de correlação do modelo. } \\
\hline
\end{tabular}

Fonte: Próprio autor.

A análise de variância também mostrou que os efeitos individuais dos fatores principais analisados, ou seja, tipo de aglomerante e relação água/sólidos são estatisticamente significativos a um nível de confiança de 95\%. Isto confirma a influência de cada uma dessas variáveis independentes, quando tomadas isoladamente.

A variável mais influente no módulo de elasticidade foi a relação água/sólidos e em segundo lugar apresentou-se a variável tipo de aglomerante.

Por fim, realizou-se comparação múltipla de médias pelo método de Duncan, em virtude da influência das variáveis: tipo de aglomerante e relação água/sólidos. Os resultados destas análises são apresentados a seguir. 
a) Efeito do tipo de aglomerante

Na Figura 75 está apresentado o resultado do agrupamento de médias, onde as linhas tracejadas verticais definem os grupos que diferem significativamente, na qual se constata que o concreto com substituição de $30 \%$ do cimento por fíler calcário, C30, produz efeito estatisticamente diferente sobre o módulo de elasticidade quando comparado com os concretos CREF e C20. Por fim, estes dois concretos produzem efeitos iguais estatisticamente sobre o módulo de elasticidade.

Figura 75 - Valores médios globais de módulo de elasticidade em função do tipo de aglomerante empregado nos concretos, com seus intervalos de confiança de $95 \%$ e seus desvios padrões. As linhas tracejadas verticais definem os grupos que diferem significamente.

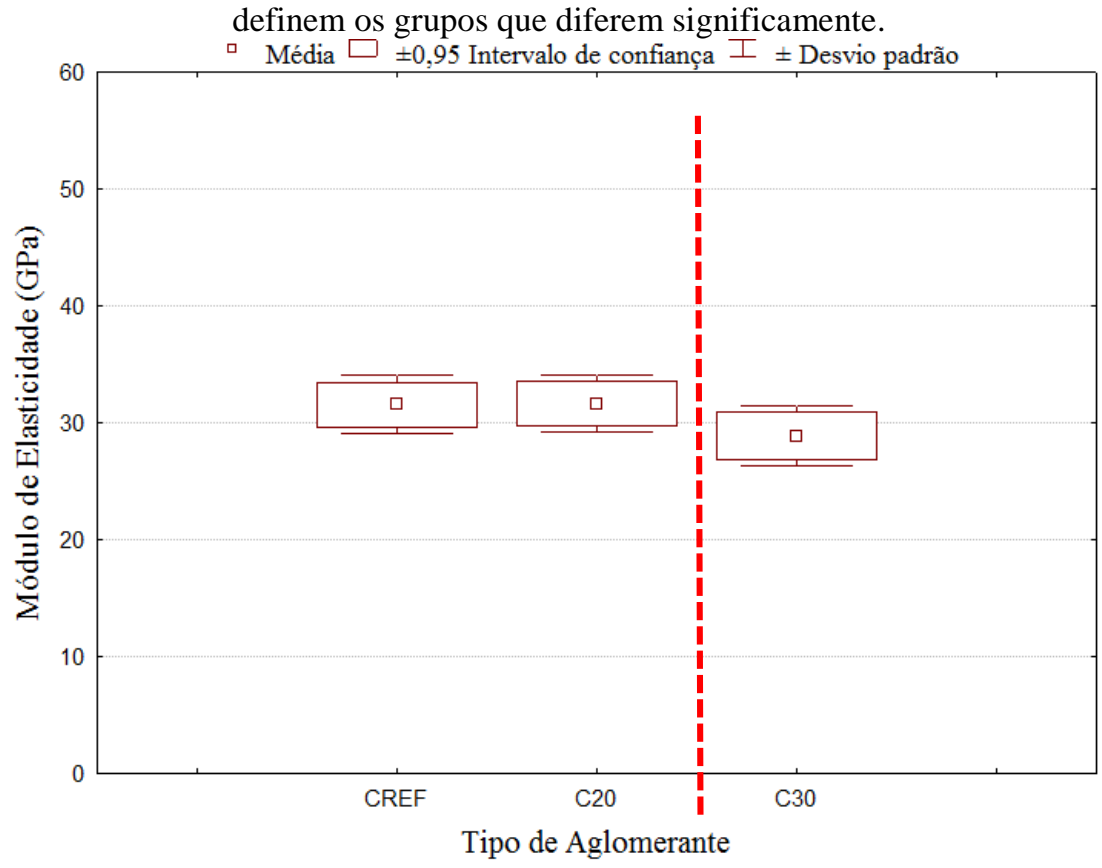

Fonte: Próprio autor.

b) Efeito da relação água/sólidos

Na Figura 76 está apresentado o resultado do agrupamento de médias, onde as linhas tracejadas verticais definem os grupos que diferem significativamente, na qual se constata que as três relações água/sólidos considerados neste estudo, produzem efeitos estatisticamente diferentes sobre o módulo de elasticidade. 
Figura 76 - Valores médios globais de módulo de elaticidade em função da relação água/sólidos empregado nos concretos, com seus intervalos de confiança de $95 \%$ e seus desvios padrões. As linhas tracejadas verticais definem os grupos que diferem significamente.

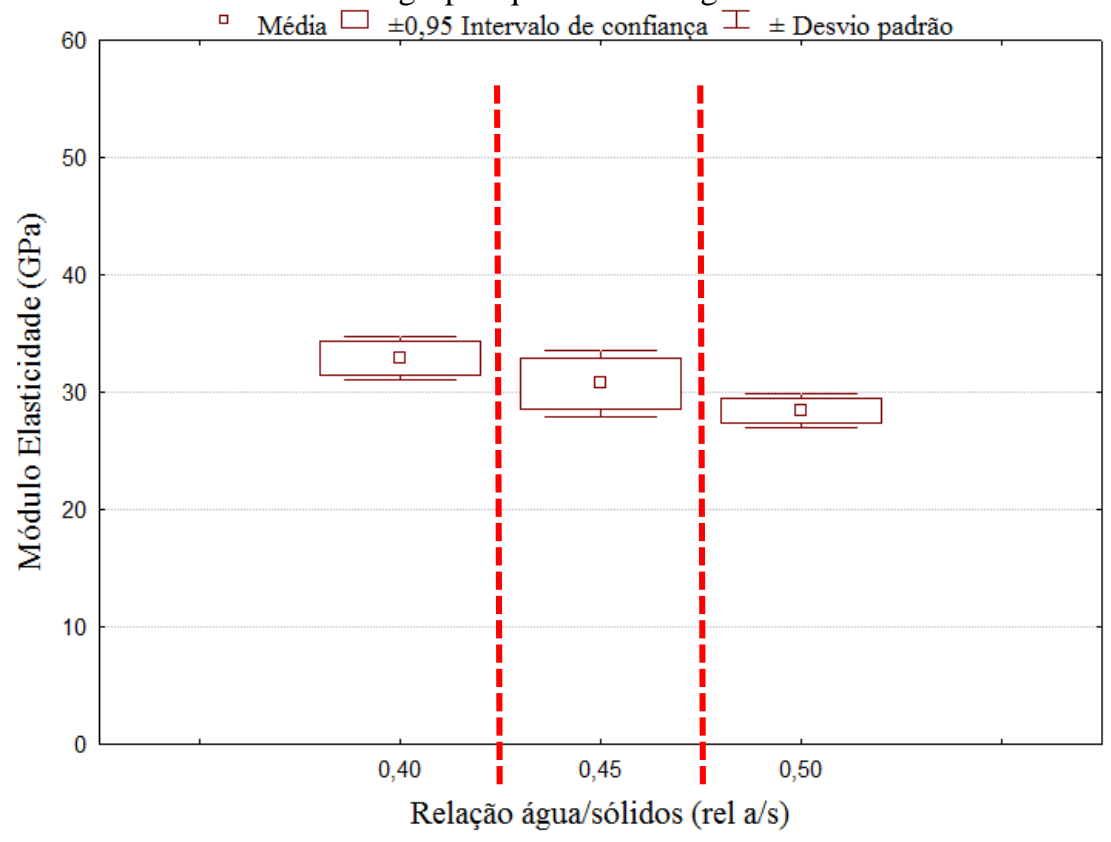

Fonte: Próprio autor. 


\section{CONCLUSÕES E SUGESTÕES PARA NOVAS PESQUISAS}

\subsection{CONCLUSÕES}

Com base no programa experimental desta pesquisa, são apresentadas, neste item, as principais conclusões obtidas.

- Pode-se afirmar que os estudos em argamassas foram capazes de referenciar os prováveis concretos autoadensáveis. Isso pode ser explicado pelo alto teor de argamassa na composição do concreto. Os concretos produzidos neste estudo tiveram um teor de argamassa de $72 \%$, em volume, portanto um alto teor de argamassa típico de um concreto autoadensável;

- Constatou-se que a substituição em parte do cimento por fíler calcário, influenciou de maneira significativa a autoadensabilidade da argamassa mesmo sendo com menor magnitude do que outras varáveis. Essa influência foi no sentido de melhorar as propriedades no estado fresco;

- No geral, observou-se que definir autoadensabilidade do concreto não transparece algo simples e resolvido do ponto de vista técnico e científico. Notou-se a falta de sintonia entre ensaios que avaliam o mesmo quesito de autoadensabilidade, bem como foi possível classificar um concreto como autoadensável sem cumprir com o quesito de resistência à segregação;

- Quanto a estabilidade do concreto, observou-se que os concretos 16C e 18C apresentaram resultados iguais a $21,31 \%$ e $34,26 \%$, respectivamente. Isso significa, que esses concretos segregaram conforme definido pela ABNT NBR 15823-1 (2010). Entretanto, quando se faz uma avaliação por inspeção visual do estado fresco desses concretos, nota-se na Figura 9 (a), que o concreto 16C é um concreto coeso, ao contrário, do concreto 18C, Figura 9 (b), que apresenta ser um concreto que realmente segregou e exsudou. Diante disso, constatase que a inspeção visual ainda é um instrumento importante para avaliar a estabilidade de qualquer material cimentício no estado fresco, assim como se desperta o questionamento frente o ensaio de coluna de segregação no que tange sua capacidade de classificar a estabilidade do concreto;

- Foi possível obter uma regressão tipo linear entre os resultados de espalhamento das argamassas por meio do ensaio de mini-slump e os resultados de espalhamento dos concretos por meio do ensaio de slump flow dos concretos. Foi possível, também, obter uma tendência 
entre os resultados do ensaio de funil $\mathrm{V}$ dos concretos e os resultados do ensaio de mini-funil V das argamassas. Nesse caso, obteve-se uma regressão tipo exponencial.

- Foi efetuada uma relação dos resultados de viscosidade plástica aparente gerados pelos ensaios de Funil V e de T500, na qual obteve-se uma regressão linear com coeficiente de determinação igual a 0,46. Diante disso, constatou-se que a relação não é apropriada, portanto sugere-se um cuidado maior na avaliação desse quesito para a classificação da autoadensabilidade do concreto;

- Não foi obtida uma importante relação dos resultados de viscosidade plástica aparente dos concretos, gerados por meio do ensaio T500, com os resultados de viscosidade plástica de torque das argamassas. Entretanto, obteve-se uma boa relação dos resultados de viscosidade plástica dos concretos gerados por meio do ensaio de funil $\mathrm{V}$ com os resultados de viscosidade de torque das argamassas. Dessa forma, constatou-se que os valores de viscosidade plástica aparente obtidos pelo ensaio de funil V são mais confiáveis do que os valores de viscosidade plástica aparente obtidos pelo ensaio T500;

- Com relação a avaliação da habilidade passante, notou-se que somente dez concretos foram classificados tanto pelo ensaio de anel J como, também, pelo ensaio de caixa L. Isso significa que não há uma sintonia importante entre os ensaios que avaliam habilidade passante. Além disso, observou-se que o quesito habilidade passante demonstrou ser determinante para classificar o concreto em autoadensável. Pode-se citar o exemplo dos cinco concretos que não foram classificados como autoadensável, dos quais três concretos não cumpriram com o quesito de habilidade passante;

- Os resultados de espalhamento do concreto apresentaram uma boa relação com os resultados dos ensaios de caixa L e de caixa U. Diante disso, pode-se dizer que é possível estimar habilidade passante dos concretos por meio do ensaio de espalhamento (slump flow);

- Com base nos resultados do ensaio de caixa U, sugere-se dois níveis de classificação de autoadensabilidade, sendo um nível de resultados em um intervalo de $0 \mathrm{~mm}$ até $30 \mathrm{~mm}$ e outro nível para resultados maiores que $30 \mathrm{~mm}$ até $60 \mathrm{~mm}$. Essa sugestão é importante para uma futura inclusão desse ensaio em normas vigentes. Libre et al (2012) detectou-se que o ensaio de caixa $U$ foi mais eficiente do que o ensaio de caixa $L$ para detectar alterações na composição do concreto; 
- Os parâmetros reológicos teóricos dos concretos autoadensáveis, estimados pelas equações de Sedran e De Larrard (1999), apresentaram valores dentro dos domínios propostos pelos pesquisadores que estudaram e estudam a tecnologia do concreto autoadensável.

- Com relação as argamassas de relação água/sólidos igual a 0,50, nota-se, na Figura 64, uma oscilação de valores de tensão de escoamento de forma evidente, a ponto de se ter valores de tensão de escoamento iguais a 5,76 mN.m e 11,34 mN.m. Estes valores chegam a ser maiores do que os valores obtidos para as argamassas de relação água/sólidos iguais a 0,40 e 0,45. A provável explicação desses maiores valores para as argamassas de relação água/sólidos 0,50, deve-se a maior velocidade de sedimentação das partículas sólidas dessas argamassas no recipiente de ensaio tornando a parte inferior deste mais concentrado de sólidos e, com isso, exige-se mais esforço por parte do reômetro para iniciar o fluxo da argamassa (MENDES; BAUER, 2015).

- Cabe frisar que as argamassas autoadensáveis de relação água/sólidos igual a 0,45 demonstraram ser mais estáveis frente ao comportamento reológico quando submetidas a diferentes tipos de aglomerantes e teores de aditivo. Isso se explica diante das seguintes observações: a amplitude da diferença de histerese das argamassas foi menor, as curvas de fluxo ascendente tenderam para linearidade antes de uma taxa de 150rpm, os intervalos dos valores de tensão de escoamento e de viscosidade plástica foram bem estreitos e teve-se maior número de argamassas classificadas como autoadensável.

- Os resultados referentes ao parâmetro WFT quando relacionados com os resultados de autoadensabilidade e de reologia das argamassas e dos concretos autoadensáveis não mostraram, na maioria dos casos, os mesmos comportamentos obtidos pelas argamassas convencionais estudadas por outros pesquisadores. Diante disso, constatou-se que o parâmetro WFT pode não governar os parâmetros de autoadensabilidade e de reologia dos materiais cimentícios autoadensáveis, entretanto indo contra afirmação defendida pelos pesquisadores Kwan e Wong (2008) e Fung (2010). Estes pesquisadores defendem que o parametro WFT é capaz de governar as propriedades de trabalhabilidade e de reologia das pastas, argamassas e concretos. Para que essa afirmação torne-se válida para os materias cimentícios autoadensáveis, são necessários mais estudos, tais como, propor um método de obtenção da densidade de empacotamento mais adequado, estudar rigorosamente o efeito combinado da água e superplastificante e incluir o efeito do aditivo superplastificante no cálculo do parâmetro WFT. 
- Com relação as propriedades mecânicas, constatou-se que a substituição do cimento por fíler calcário influencia tanto na resistência à compressão como também para o módulo de elasticidade.

\subsection{SUGESTÕES PARA NOVAS PESQUISAS}

A seguir, algumas sugestões para novas pesquisas.

- Identificar novos parâmetros de autoadensabilidade e de reologia de argamassas e de concretos com outros tipos de materiais empregados no Brasil, a fim de elaborar uma reografia (reograma) com concretos autoadensáveis produzidos em nosso país.

- Verificar a capacidade de outros tipos de ensaios para avaliar a estabilidade de argamassas e de concretos.

- Explorar o estudo do parâmetro WFT para argamassas e concretos autoadensáveis.

- Elaborar novas equações matemáticas para estimar os parâmetros reológicos do concreto autoadensável levando em consideração, também, parâmetros de autoadensabilidade que avaliam habilidade passante e de estabilidade do concreto e não somente parâmetros de habilidade de preenchimento e viscosidade.

- Explorar novos ensaios de avaliação qualitativa da resistência à segregação de argamassas e de concretos.

- Avaliar o efeito combinado do aditivo asuperlastificante com outros aditivos químicos frente a autoadensabilidade e reologia de materiais cimentícios. 


\section{REFERÊNCIAS}

ALENCAR, R. S. A. Dosagem do concreto auto-adensável: produção de pré-fabricados. 2008. 179 p. Dissertação (Mestrado em Engenharia Civil), Departamento de Engenharia de Construção Civil - Universidade de São Paulo, São Paulo, 2008.

ALLEN, T. Particle Size Measurement. ed. Chapman and Hall, 4ºed, 832p, London, 1990.

AMERICAN CONCRETE INSTITUTE. ACI 237R-07: Self-Consolidating Concrete, 2007.

ASSOCIAÇÃO BRASILEIRA DE NORMAS TECNICAS. NBR 15823-1: Concreto Autoadensável: Classificação, controle e aceitação no estado fresco. Rio de Janeiro, 2010.

ASSOCIAÇÃO BRASILEIRA DE NORMAS TECNICAS. NBR 15823-2: Concreto Autoadensável: Determinação do espalhamento e do tempo de escoamento - Método do cone de Abrams. Rio de Janeiro, 2010.

ASSOCIAÇÃO BRASILEIRA DE NORMAS TECNICAS. NBR 15823-3: Concreto AutoAdensável: Determinação da habilidade passante - Método do anel J. Rio de Janeiro, 2010.

ASSOCIAÇÃO BRASILEIRA DE NORMAS TECNICAS. NBR 15823-4: Concreto AutoAdensável: Determinação da habilidade passante - Método da caixa L. Rio de Janeiro, 2010. ASSOCIAÇÃO BRASILEIRA DE NORMAS TECNICAS. NBR 15823-5: Concreto AutoAdensável: Determinação da viscosidade -Método do funil V. Rio de Janeiro, 2010.

ASSOCIAÇÃO BRASILEIRA DE NORMAS TECNICAS. NBR 8522: Concreto Determinação do módulo estático de elasticidade à compressão. Rio de Janeiro, 2008.

ASSOCIAÇÃO BRASILEIRA DE NORMAS TÉCNICAS. NBR 10908: Aditivos para argamassa e concretos - Ensaios de uniformidade. Rio de Janeiro, 1990.

ASSOCIAÇÃO BRASILEIRA DE NORMAS TÉCNICAS. NBR 11768: Aditivos químicos para concreto de cimento Portland - Requisitos. Rio de Janeiro, 2011. 
ASSOCIAÇÃO BRASILEIRA DE NORMAS TÉCNICAS. NBR 5739: Concreto: Ensaio de Compressão de Corpo-de-Prova Cilíndrico. Rio de Janeiro, 1994.

ASSOCIAÇÃO BRASILEIRA DE NORMAS TÉCNICAS. NBR NM 248: Agregados Determinação da Composição Granulométrica. Rio de Janeiro, 2003.

ASTM INTERNATIONAL. C 1610: Static Segregation of Self- Consolidating Concrete Using Column Technique. EUA, 2010.

ASTM INTERNATIONAL. C 1611: Slump flow of Self-Consolidating Concrete. EUA, 2010. ASTM INTERNATIONAL. C 1621: Passing Ability of Self-Consolidating Concrete by JRING. EUA, 2009.

ASTM INTERNATIONAL. E 178: Standard Practice for Dealing With Outlying Observations, 2008 .

ATTIOGBE, E., SEE H., DACZKO, J., "Engineering properties of self-consolidating concrete", In: Proceedings of the First North American conference on the design and use of self-compacting concrete, Nov. 2002.

BANFILL, P. F. G, "Rheology of fresh cement and concrete", Rheology reviews, pp.61-130, 2006

BANFILL, P. F. G. Rheological methods for assessing the flow properties of mortar and related materials. In: Construction and Building Materials, v. 8, n.1, p. 43-49, 1994.

BAUER, E.; DESOUSA, J. G. G., GUIMARÃES, E. A.. Study of the laboratory vane test on mortars. In: Building and Environment. v. 42. p. 86-92, 2007.

BAUER, E.; SOUSA, J. G. G.; GUIMARÃES, E. A. Estudo da consistência de argamassas pelo método de penetração estática de cone. In: Simpósio Brasileiro de Tecnologia das Argamassas, 6., 2005, Florianópolis. Anais... Florianópolis: UFSC/ANTAC. 2005. p.371-378.

BENABED, B.; KADRI, E. H., AZZOUZ, L.; KENAI, S. Properties of self-compacting mortar made with various types of sand. In: Cement Concrete Composites, n.34, p.1167-1173, 2012. 
BIBM, CEMBUREAU, EFCA, EFNARC. The European Guidelines for Self-compacting Concrete. Specification, Production and Use, 2005.

BJÖRNSTRÖM, J; CHANDRA, S. Effect of superplasticizers on the rheological properties of cements. In: Materials and Structures, n.36, p. 685 - 692, 2003.

BOSILJKOV, V. B. SCC Mixes with poorly graded aggregate and high volume of limestone filler. In: Cement and Concrete Research, n.33, p. 1279 - 1286, 2003.

BOUKENDAKDJI, O.; KENAI, S.; KADRI, E. H.; ROUIS, F. Effect of slag on the rheology of fresh self-compacting concrete. In: Construction and Building Materials, n.23, p.25932598, 2009.

CALDARONE, M. A.; GRUBER, K. A.; BURG, R. G. High reactivity metakaolin: A new generation mineral admixture. In: Concrete International, n.11, p. 37-40, 1994.

CHAI, H. Design and Testing of Self-Compacting. 1998. 314p. Tese (Doutorado em Engenharia) - Departament of Civil, Environmental, University College London, Londres, 1998.

CHANDRA, S.; BJORNSTROM, J. Influence of cement and superplasticizers type and dosage on the fluidity of cement mortars-Part I. In: Cement and Concrete Research, n. 32, p. 16051611, 2002.

COLLEPARDI, M. Admixtures used to enhance placing characteristics of concrete. In: Cement Concrete Composites, n.20, p.103-112, 1998.

CONCRETE SOCIETY. Self-compacting concrete: a review. Technical Report, $n$. 62 , CCIP001, Camberley, 2005.

COUTO, P. B. Caracterização reológica de pastas de cimento Portland de alta resistência contendo diferentes tipos de polímeros superabsorventes pela técnica de reometria rotacional. Dissertação de Mestrado em Estruturas e Construção Civil, Departamento de Engenharia Civil e Ambiental, Universidade de Brasília, Brasília, DF, 212p, 2016. 
CUSSIGH, F., et al., "Project testing SCC-segregation test methods", In: Wallevik O, Nielsson I (eds) Self-compacting concrete, Third international RILEM symposium on self-compacting concrete, Reykjavik. RILEM Publications SARL, Bagneux, p 311, 2003.

De LARRARD, F., FERRARIS, C., F.,SEDRAN, T. Fresh concrete: A herschel Bulkley material, in Materials and structures, vol. 23, pp494-498, 1998.

DING, J.; LI, Z. Effects of metakaolin and silica fume on properties of concrete. In: ACI Materials Journal, v. 99, n. 4, p. 393 - 398, 2002.

DOMONE, P, Proportioning of self-compacting concrete - the UCL method, Department of Civil, Environmental and Geomatic Engineering, University College, London, pp.1-30, 2009.

DRANSFIELD, J. Admixtures for concrete, mortar and grout. In: NEWMAN e CHOO, B. S. (Ed). Advanced Concrete Technology: Constituent Materials, vol. 1, Elsevier, Oxford, 2003.

EDAMATSU, Y., NISHIDA N., OUCHI, M., "A rational mix-design method for selfcompacting concrete considering interaction between coarse aggregate and mortar particles", In: Proceedings of the first international RILEM symposium on self-compacting concrete, Stockholm, pp.309-320, 1999.

EFNARC, Specification and Guidelines for Self-Compacting Concrete, Ucrânia, 2005.32p.

EL-CHABIB, H., NEHDI, M., "Effect of mix design parameters on segregation of selfconsolidating concrete”, ACI Materials Journal, v.103, p. 393 - 398, 2006.

ESEN, Y., ORHAN, E., "Investigation of the effect on the physical and mechanical properties of the dosage of additive in self-consolidating concrete", Journal of Civil Engineering, v. 20, pp. 2849-2858, 2016.

FERRARIS, C., F. Measurementet of the Rheologic Properties of High Performance Concrete State of the Art Report. In: CJournal of Research of the National Institute of Standards and Technology, v.104, n.5, p. $462-478,1999$.

FEYS, D., SCHUTTER, G. D., "Changes in rheology of self-consolidating concrete induced by pumping", Materials and Structures, v. 49, pp. 4657-4677, 2016. 
FUNG, W. W. Role of water film thickness in rheology of mortar and concrete. Hong Kong. 201p. Tese (Doutorado) - Universidade de Hong Kong, 2010.

FUNG, W. W. Role of water film thickness in rheology of mortar and concrete. 201p., Tese de D. Sc. - Universidade de Hong Kong, Hong Kong, 2010.

GALLIAS, J. L.; KARA, R., BIGAS, J. P. The effect of fine mineral admixtures on water requirement of cement pastes. In: Cement and Concrete Research, n.30, p. 1543 - 1549, 2000.

GOLASZEWSKI, J., SIEDLARZ, A. K., CYGAN, G., DREWNIOK, M., "Mortar as a model to predict self-compacting concrete rheological properties as a function of time and temperature”, Construction and Building Materials, v. 124, pp. 1100-1108, 2016.

GOMES, P. C. C.; BARROS, A. R.. Métodos de Dosagem de Concreto Autoadensável. 1edição, pág 165, editora PINI, 2009.

GOMES, P.C.C. Optimization and characterization of high-strength self-compacting concrete, Tese de D. Sc - Universitat Politécnica de Catalunya, Barcelona, Espanha, 139p, 2002.

GROTH, P., NEMEGEER, D., "The use of steel fibres in self-compacting concrete", In: SKARENDAHL, A.; PETERSSON, Ö. (ed), Proc. 1st International RILEM Symposium on Self-Compacting Concrete, RILEM Publications S.A.R.L, Stockholm, Sweden, p. 497-508, 1999.

GROTH, P.; NEMEGEER, D. The use of steel fibres in self-compacting concrete. In: SKARENDAHL, A.; PETERSSON, Ö. (ed), Proc. $1^{\text {st }}$ International RILEM Symposium on Self-Compacting Concrete, RILEM Publications S.A.R.L, Stockholm, Sweden, p. 497-508, 1999.

GÜNEYISI, E., GESOGLU, M., ALGIN, Z., YAZICI, H.“Rheological and fresh properties of self-compacting concretes containing coarse and fine recycled concrete aggregates", Construction and Building Materials, v. 113, pp. 356-364, 2016.

HARTMANN, C.; JEKNAVORIAN, A.; SILVA, D.; BENINI, H. Aditivos Químicos para Concreto e Cimentos. In: ISAIA, G.C. (Ed.) Concreto: Ciência e Tecnologia. São Paulo : Ibracon, cap.10, vol 1, 2011, p. $347-380$. 
HASSAN, A. A. A.; LACHEMI, M.; HOSSAIN, K. M. A. Effect of metakaolin and silica fume on rheology of self-consolidating concrete. In: ACI Materials Journal, p. 657 - 663, 2012.

HEIRMAN, G., HENDRICKX, R., VANDEWALLE, L., VAN GEMERT, D., FEYS, D., De SHUTTER, G., DESMET, B., VANTOMME, J., "Integration approach of the Couette inverse problem of powder type sel-compacting concrete in a wipe-gap concentric cylinder rheometer Part II. Influence of mineral addition and chemical admixtures on the shear thickening flow behavior", Cement Concrete Research, v. 39, pp. 171-181, 2006.

HU, J., WANG, K.,"Effect of coarse aggregate characteristics on concrete rheology", Construction and Building Materials, v. 25, pp. 1196-1204, 2011.

IAM, S. G., SOKRAI, P., MAKUL, N., "Novel ternary blends of Type 1 Portland cement, residual rice husk ash, and limestone powder to improve the properties of self-compacting concrete", Construction and Building Materials, v. 125, pp. 1028-1034, 2016.

JACOBS, H., Design of SCC for durable concrete structures, 1999.

JAU, W. C., YANG, C. T.,"Development of a modified concrete rheometer to measure the rheological behavior of conventional and self-consolidating", Cement and Concrete Composites, v. 32, pp. 450-460, 2010.

JIN, J. Properties of mortar for self-compacting concrete. 2008. 398p. Tese (Doutorado em Engenharia) - Department of Civil and Environmental Engineering, Universidade of London, London, 2002.

JIN, J., DOMONE, P. L. J, "Relationships between the fresh properties of SCC and its mortar componente" In: SKARENDAHL, A.(Ed.), The 1st North American Conference on the design and use of self-consolidating concrete, p. 33 - 38, Chicago, 2002.

JIN, J., Properties of mortar for self-compacting concrete, 398p., Tese de D Sc., Department of Civil and Environmental Engineering, Universidade of London, London, 2002.

Journal of Rheology, v. 29, n. 3, p. 335-347. 1985. 
KASEMCHAISIRI, R; TANGERMSIRIKUL, S. Deformability prediction model for selfcompacting concrete. In: Magazine of Concrete Research, n.60, p. 93-108, 2008.

KHALEEL, O. R.; RAZAK, H. A. Mix design method for self compacting metakaolin concrete with diferente properties of coarse aggregate. In: Materials and Design, n.53, p.691-700, 2014.

KHAYAT, K. H. Workability, testing, and performance of self-consolidating concrete. In: ACI Materials Journal, n.96, p. 337-346, 1999.

KHAYAT, K., H., CORIC, M., S., LIOTTA, M.S. Influence of thixotropy on stability characteristics of cement grout and concretes, ACI Materials Journal, n. 99, pp. 234-241, 2002.

KIM, J. H.; NOEMI, N.; SHAH, S. P. Effect of powder materials on the rheology and formwork pressure of self-consolidating concrete. In: Cement and Concrete Composites, n.34, p. 746 $753,2012$.

KLEIN, N. S. Influência da substituição da areia natural pela areia de britagem no comportamento do concreto auto-adensável. Londrina, 2008. 155p. Dissertação (Mestrado) - Centro de Tecnologia e Urbanismo, Universidade Estadual de Londrina, Londrina, 2008.

KWAN, A. K. H, MCKINLEY. "Effects of limestone fines on water film thickness, paste film thickness and performance of mortar", Powder Technology, v. 261, p. 33-41, 2014.

KWAN, A. K. H, WONG, H. H. C., "Effects of packing density, excess water and solid surface area on flowability of cement paste", Advances in Cement Research, v.20, pp. 1-11, 2008.

KWAN, A. K. H., LI, L. G., "Combined effects of water film thickness and paste film thickness on rheology of mortar", Materials and Structures, v. 45, p. 1359-1374, 2012.

KWAN, A. K. H.; FUNG, W. W. S.; WONG, H. H. C. Water film thickness, flowability and rheology of cement - sand mortar. In: Advances in Cement Research. v. 22, 3-14, 2010.

KWAN, A. K. H; WONG, H. H. C. Effects of packing density, excess water and solid surface area on flowability of cement paste. In: Advances in Cement Research. v.20, p. 1-11, 2008. 
KWAN, A. K. H; WONG, H. H. C. Packing density of cementitious materials: part 1 measurement using a wet packing method. In: Materials and Structures. v.41, p. 689 - 701, 2008.

LACHEMI, M., HOSSAIN, K. M. A., PATEL, R., SHEHATA, M., BOUZOUBAA, N., "Influence of paste/mortar rheology on the flow characteristics of high-volume fly ash selfconsolidating concrete”, In: Magazine of Concrete Research, n.59, p. 517-528, 2007.

LI, L. G., KWAN, A. K. H. "Concrete mix design based on water film thickness and paste film thickness", Cement and Concrete Composites, v. 39, p. 33-42, 2013.

LIBRE, N. A.; KHOSHNAZAR, R.; MOHAMMAD, S., "Repeatability, responsiveness and relative cost analysis of SCC workability test methods", Materials and Structures, n.45, p. 1087-1100, 2012.

LIU, M., Wider Application of Additions in Self-Compacting Concrete, 367p., Tese de D. Sc Departament of Civil, Environmental and Geomatic Engineering, University College London, Londres, 2009.

LU, G.; WANG, K.; RUDOLPHI, T. J. Modeling rheological behavior of highly flowable mortar using concepts of particle and fluid mechanics. In: Cement and Concrete Composites, n.30, p. 1-12, 2008.

MADDURU, S. R. C., PALLAPOTHU, S. N. R. G., PANCHARATHI, R. K., GARJE, R. K., CHAKILAM, R."Effect of self curing chemicals in sel compacting mortars", Construction and Building Materials, v. 107, pp. 356-364, 2016.

MALHOTRA, V. M. Innovative applications of superplasticizers in concrete - A review. In: Mario Collepardi Symposium on Advances in Concrete Science and Technology. 1981.

MEHTA, P. K., MONTEIRO, J. P. M., Concreto: estrutura, propriedades e materiais. São Paulo: IBRACON, 2014.

MENDES, M. V. A. S., BAUER, E, “Avaliação da capacidade do parâmetro wft (water film thickness) contribuir para a obtenção do concreto autoadensável”, In: IV Congresso Ibero- 
americano sobre Betão Auto-compactável-BAC2015 - FEUP, Anais, Porto, Portugal, pp. 277 $287,2015$.

MENDES, M. V. A. S., BAUER, E. Avaliação da Reologia e da Trabalhabilidade das Argamassas Voltadas aos Concretos Autoadensáveis. In: XV Encontro Nacional de Tecnologia do Ambiente Construído, 6., 2014, Maceio. Anais... p.1-13.

MINDESS, S.; YOUNG, J. F.; DARWIN, D. Concrete. ed. $2^{\mathrm{a}}$ ed, Prentice Hall, p. 176-182, New Jersey, 2003.

NAGAMOTO, N.; OZAWA, K. Mixture proportions of self-compacting high performance concrete, in High performance concrete: Design and materials and advances in concrete technology, ACI SP-172, pp623-636, 1997.

NAJI, S., HWANG, S. D., KHAYAT, K. H., "Robustness of Self-Consolidating Concrete Incorporating Different Viscosity-Enhancing Admixtures”, ACI Materials Journal, v. 108, pp. 432-438, 2011.

NAWA, T.; IZUMI, T.; EDAMATSU, Y. State of the art reporto $n$ materials and design of self compacting concrete. In: International Workshop on SCC, p. 160-190, Japão, 1998.

NEHDI, M.; RAHMAN, M. A. Estimating rheological properties of cement pastes using various rheological models for different test geometry, gap and surface friction. In: Cement and Concrete Research, n.34, p. 1993 - 2007, 2004.

NEPOMUCENO, M., C., S., OLIVEIRA, L. A., LOPES, S., M., R., "Methodology for the mix design of self-compacting concrete using different mineral additions in binary blends of powders”, Construction and Building Materials, v.64, pp.82-94, 2014.

NGUYEN, N. Q.; BOGER, D. V. Direct yield stress measurement with the vane method.

NORMA EUROPEIA. EN 12350-10: Ensaio de escoamento na caixa L. Bruxelas, 2010.

NORMA EUROPEIA. EN 12350-12: Ensaio de espalhamento no anel J. Bruxelas, 2010.

NORMA EUROPEIA. EN 12350-8: Ensaio de espalhamento. Bruxelas, 2010. 
NORMA EUROPEIA. EN 12350-9: Ensaio de escoamento no funil V. Bruxelas, 2010.

NORMA EUROPEIA. EN 480-1: Aditivos para concretos, argamassas e grautes. Métodos de ensaio - Requisitos. Bruxelas, 1998.

NUNES, S., C., B. Performance-based design of self-compacting concreto (SCC): a contribution to enchance SCC mixtures robustness. 2008. 367p. Tese (Doutorado em Engenharia) - Faculdade de Engenharia, Universidade do Porto, Porto, Portugal, 2008.

NUNES, S., COUTINHO, J. S., FARIA, R., editores, Livro de comunicações do IV Congresso Ibero-americano sobre Betão Auto-compactável-BAC2015, FEUP, pp.1-628, Porto, 2015.

NÚÑEZ, E. B. B. Dosificación, Propiedades y Durabilidad en Hormigón Autocompactante para Edificación. 264p. Tese (Doutorado em Engenharia) - Escuela Técnica Superior de Ingenieros Caminos, Canales y Puertos, Universidad Politécnica de Madrid, Madrid, 2009.

NURUDDIN, M. F; DEMIE, S.; SHAFIQ, N. Effect of mix composition on workability and compressive strength of self-compacting geopolymer concrete. In: Can. J. Civ. Eng. n.38, p.1196-1203, 2011.

OKAMURA, H., OUCHI, M., "Self-compacting concrete", Journal of Advanced Concrete Technology, vol. 1, n. 1, pp. 5-15, 2003.

OKAMURA, H., OZAWA, K, "Mix design for self-compacting concrete", Concrete Library if Japonese Society of Civil Engineers, v.25, n.6, pp-107-120, 1995.

OKAMURA, H.; OUCHI, M. Self-compacting concrete. In: Journal of Advanced Concrete Technology, vol. 1, n. 1, p. 5-15, 2003.

OLIVEIRA, C., O. Análise das propriedades reológicas de materiais cimentícios associando o conceito de empacotamento de partículas. Dissertação de Mestrado - Faculdade de Engenharia - UNESP, Ilha Solteira-SP, pp.141, 2013.

OLIVEIRA, L., A., P., NEPOMUCENO, M., C., S., CARVALHO, J., C., M. Rheology of SelfCompacting Concrete Mortar Phase, In: Twin International Conferences $2^{\text {nd }}$ Civil Engineering, Covilha, Portugal, pp. 1-10, 2013. 
OUCHI, M. Self-compacting concrete: Development, applications and investigations. In: Nordic Concrete Research, n.23, pp.5, 1999.

OZAWA, K., SAKATA, N., OKAMURA, H., "Evaluation of self-compatibility of fresh concrete using the funnel test", In: Proc. of the Japan Society of Civil Engineers, vol. 23, n. 490, p. 71-80, 1994.

OZAWA, K.; SAKATA, N.; OKAMURA, H. Evaluation of self compactability of fresh concrete using the funnel test. Proc. of the Japan Society of Civil Engineers, vol. 23, n. 490, p. 71-80, 1995.

PAIVA, H. M. C. Caracterização reológica de argamassas. Dissertação de mestrado, Universidade de Aveiro, Aveiro, 98p, 2005.

PANDOLFELLI, V. C.; OLIVEIRA, I.R., STUDART, A. R., PILEGGI, R. G. Dispersão e Empacotamento de Partículas: princípios básicos e aplicações em processamento cerâmico. 2000, São Paulo: Fazendo Arte Editorial. 224.

PETERSSON, Ö., BILLBERG, P., VAN, B. K, “A model for self-compacting concrete”, In: BARTOS, P. J. M.; MARRS, D. L.; CLEAND, D. J.(eds), In: Proc. International RILEM Conference on Production Methods and Workability of Concrete, E \& FN, pp. 483-492, 1996.

PETIT, J. K., WIRQUIN, E., VANHOVE, Y., KHAYAT, K., "Yield stress and viscosity equations for mortars and self-consolidating concrete", Cement Concrete Research, v. 37, pp. 655-670, 2007.

POWERS, T.C., The Properties of Fresh Concrete, John Wiley \& Sons, New York, 1968.

REPETTE, Wellington Longuini .Concreto auto-adensável. In: Geraldo CechellaIsaia. (Org.). Concreto: Ciência e Tecnologia. 1ed. São Paulo: IBRACON, 2011, v. 2, p. 1769-1806.

RONCERO, J. GETTU, R. Aditivos superfluidificantes para hormigones de altas prestaciones. In: IV Simposio ANFAH - Especialidades Químicas para la Construcción. Madrid. 1998.

ROY, R. L., ROUSSEL, N., "The Marsh cone as a viscometer: Theoretical analysis and practical limits", Materials and Structures, n.38, p.25-30, 2005. 
SAHMARAN, M., CHRISTIANTO, H., YAMAN, I. O., "The effect of chemical admixtures and mineral additives on the properties of self-compacting mortars", Cement Concrete Research, n.28, pp. 432-440, 2006.

SAHMARAN, M., CHRISTIANTO, H., YAMAN, I. O., "The effect of chemical admixtures and mineral additives on the properties of self-compacting mortars", Cement Concrete Research, n.28, pp. 432-440, 2006.

SANTOS, C. C. N. Critérios de projetabilidade para as argamassas industrializadas de revestimento utilizando bomba de argamassa com eixo helicoidal. 2003. 130p. Dissertação (Mestrado) - Universidade de Brasília, Brasília, 2003.

SCHRAMM, G. Reologia e reometria: fundamentos teóricos e práticos. São Paulo: Artliber, p.234, 2006.

SCHWARTZENTRUBER, L. D., ROY, R. L., CORDIN, J, "Rheological behaviour of fresh cement pastes formulated from a Self-Compacting Concrete (SCC)", Cement and Concrete Research, n.36, pp.1203-1213, 2006.

SEDRAN, T., De LARRARD, F., "Optimization of self-compacting concrete thanks to packing model, In: Proceedings $1^{\text {st }}$ SCC Symp, CBI, RILEM PRO7, Suécia, 1999.

SHI, C., et al, "Design and application of self-compacting lightweight concrete", In: SCC2005China: $1^{\text {st }}$ international symposium on design, performance and use of self-consolidating concrete. RILEM Publications SARL, 2005.

SHI, C., WU, Z., LV, K., WU, L., “A review on mixture design methods for self-compacting concrete", Construction and Building Materials, v.84, pp.387-398, 2015.

SIEDLARZ, A. K., GOLASZEWSKI, J.,"Rheological properties of High Performance SelfCompacting Concrete: Effects of composition and time", Construction and Building Materials, v. 115, pp. 705-715, 2016.

SILVA, F. G. S. Estudo do Uso de Resíduo Catalítico do Refino de Petróleo na Construção Civil. Tese de Doutorado, Centro Interdisciplinar de Energia e Ambiente, Universidade Federal da Bahia , Salvador, BA, Brasília, DF, 217p, 2015. 
SILVA, P. Methods to Design Self-Compacting Concrete (SCC) - Evaluation of their TechnoEconomic Viability. Dissertação de Mestrado. Instituto Superior Tecnico, Universidade de Lisboa, Portugal, 2007, 207 p.

SONEBI, M.; LACHEMI, M.; HOSSAIN, K. M. A.. Optimisation of rheological parameters and mechanical properties of superplasticised cement grouts containing metakaolin and viscosity modifying admixture. In: Construction and Building Materials, n.38, p.126-138, 2013.

SOUSA, J. G. G. Contribuição ao Estudo das Propriedades das Argamassas de Revestimento no Estado Fresco. Tese de Doutorado, Publicação E.TD 010A/05, Departamento de Engenharia Civil e Ambiental, Universidade de Brasília, Brasília, DF, 233p, 2005.

SVAROVSKY, L., Powder Testing Guide: Methods of Measuring the Physical Properties of Bulk Powders, Elsevier Applied Science Publishers Ltd, England, 1987.

TATTERSALL, G. H. Workability and quality control of concrete, E \& FN Spon, London, 1991.

TÜRKEL, S., KANDEMIR, A, "Fresh and hardened properties of SCC made with different aggregate and mineral admixtures, Jornal of Materials in Civil Engineering, n.10, pp. 1025 $1031,2010$.

TUTIKIAN, B. F. Método para dosagem de concretos auto-adensáveis. Dissertação de Mestrado - Universidade Federal do Rio Grande do Sul, Porto Alegre, 2004. 148 p.

UYSAL, M. Self-compacting concrete incorporating filler additives: Performance at high temperatures. In: Construction and Building Materials, n.26, p.701-706, 2012.

VARHEN, C., DILONARDO, I., ROMANO, R. C. O., PILEGGI, R. G., FIGUEIREDO, A. D. F., "Effect of the substitution of cement by limestone filler on the rheological behaviour and shrinkage of microconcretes", Construction and Building Materials, v. 125, pp. 375-386, 2016.

VEJMELKOVÁ, E., KEPPERT, M., GRZESZCZYK，S., SKLINSKI，B，CERNY，R. Properties Of Self-Compacting Concrete Mixtures Containing Metakaolin And Blast Furnace Slag. In: Construction and Building Materials, v. 25, n. 4, p. 1325 - 1331, 2011. 
WALLEVIK, J. E. Relationship between the Bingham parameters and slump. In: Cement and Concrete Research, n.36, p. 1214 - 1221, 2006.

WALLEVIK, O. H. Description of fresh concrete properties by use of two-point workability test instrument, 1983. Dissertação (mestrado em Engenharia) -The Norwegian Institute of technology, Norway, 1983.

WALLEVIK, O. H., WALLEVIK, J. E. "Rheology as a tool in concrete science: The use of rheographs and workability boxes", Cement and Concrete Research, n.41, pp. 1279 - 1288, 2011.

WALLEVIK, O., KUBENS S., MÜLLER F., "Influence of cement-admixture interaction on the stability of production properties of SCC", In: Proceedings of the $5^{\text {th }}$ International RILEM symposium on self-compacting concrete, RILEM Publications SARL, p.211-216, 2007.

WALRAVEN, J. Self-compacting concrete: challenge for designer and researcher. Proceedings of the Second North American Conference on the design and Use of SelfConsolidation Concrete and Fourth International RILEM Symposium Self-Compacting Concrete, pp. 431-446, 2005.

WONG, H. H. Effects of water content, packing density and solid surface area on cement paste rheology. Hong Kong. 201p. Tese (Doutorado) - Universidade de Hong Kong, 2007.

YAHIA, A., TANIMURA, M., SHIMABUKURO, A., SHIMOYARNA, Y. Effect of rheological parameters on self-compactability of concrete containing various mineral admixtures, in Proceedings offirst international RILEM symposium on SCC, Stockholm, Sweden, pp523-535, 1999.

YAHIA, A.; TANIMURA, M. SHIMOYAMA, Y. Rheological properties of highly flowable mortar containing limestone filler-effect of powder content and w/c ratio. In: Cement and Concrete Research, n.35, p. 532-539, 2005.

ZERBINO, R., BARRAGAN, B., GARCIA, T., AGULLO, L., GETTU, R., "Workability tests and rheological parameters in self-compacting concrete”, Materials Structures, v. 42, pp. $947-$ 960, 2009. 
ANEXO A 
ANEXO A - Distribuição de Fischer.

Tabela 34 - Distribuição de Fischer - valores tabelados de Ftab, para $\alpha=0,05$.

\begin{tabular}{|c|c|c|c|c|c|c|c|c|c|c|c|c|c|c|c|c|c|c|c|}
\hline \multirow{2}{*}{$\mathrm{v}^{\circ}{ }^{\circ}$} & \multicolumn{19}{|c|}{ Grau de liberdade do numerador (fatores) v1 } \\
\hline & 1 & 2 & 3 & 4 & 5 & 6 & 7 & 8 & 9 & 10 & 12 & 15 & 20 & 25 & 30 & 40 & 60 & 120 & $\infty$ \\
\hline 1 & 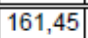 & 199,50 & 215,71 & 224,58 & 230,16 & 233,99 & 236,77 & 238,88 & 240,54 & 241,88 & 243,90 & 245,95 & 248,02 & 249,26 & 250,10 & 251,14 & 252,20 & 253,25 & 254,32 \\
\hline 2 & 18,51 & 19,00 & 19,16 & 19,25 & 19,30 & 19,33 & 19,35 & 19,37 & 19,38 & 19,40 & 19,41 & 19,43 & 19,45 & 19,46 & 19,46 & 19,47 & 19,48 & 19,49 & 19,50 \\
\hline 3 & 10,13 & 9,55 & 9,28 & 9,12 & 9,01 & 8,94 & 8,89 & 8,85 & 8,81 & 8,79 & 8,74 & 8,70 & 8,66 & 8,63 & 8,62 & 8,59 & 8,57 & 8,55 & 8,53 \\
\hline 4 & 7,71 & & 6 & & & & 6,09 & 04 & 6,00 & 5,96 & 5,91 & 5,86 & 5,80 & 5,77 & 5,75 & 5,72 & 5,69 & 5,66 & 5,63 \\
\hline 5 & 6,61 & 5,79 & 5,41 & 5,19 & 5,05 & 4,95 & 4,88 & 4,82 & 4,77 & 4,74 & 4,68 & 4,62 & 4,56 & 4,52 & 4,50 & 4,46 & 4,43 & 4,40 & 4,37 \\
\hline 6 & 5,99 & 5,14 & 4,76 & 4,53 & 4,39 & 4,28 & 4,21 & 4,15 & 4,10 & 4,06 & 4.00 & 3,94 & 3,87 & 3,83 & 3,81 & 3,77 & 3,74 & 3,70 & 3,67 \\
\hline 7 & 5,59 & 4,74 & 4,35 & 4,12 & 3,97 & 3,87 & 3,79 & 3,73 & 3,68 & 3,64 & 3,57 & 3,51 & 3,44 & 3,40 & 3,38 & 3,34 & 3,30 & 3,27 & 3,23 \\
\hline 8 & 5,32 & 4,46 & 4,07 & 3,84 & 3,69 & 3,58 & 3,50 & 3,44 & 3,39 & 3,35 & 3,28 & 3,22 & 3,15 & 3,11 & 3,08 & 3,04 & 3,01 & 2,97 & 2,93 \\
\hline 9 & 5,12 & & & & & & 3,29 & 3,23 & 3,18 & 3,14 & & 3,01 & 2,94 & 2,89 & 2,86 & 2,83 & 2,79 & 2,75 & 2,71 \\
\hline 10 & 4,96 & 4,10 & 3,71 & 3,48 & 3,33 & 3,22 & 3,14 & 3,07 & 3,02 & 2,98 & 2,91 & 2,85 & 2,77 & 2,73 & 2,70 & 2,66 & 2,62 & 2,58 & 2,54 \\
\hline 11 & & & & & & & & & & 2,85 & & 2 & 2,65 & 2,60 & 57 & & & 2,45 & 2,40 \\
\hline 12 & 4,75 & 3,89 & 3,49 & 3,26 & 3,11 & 3,00 & 2,91 & 2,85 & 2,80 & 2,75 & 2,69 & 2,62 & 2,54 & 2,50 & 2,47 & 2,43 & 2,38 & 2,34 & 2,30 \\
\hline 13 & 4,67 & 3,81 & & 3, & 3, & 2 & 2,83 & 2,77 & 2,71 & 2,67 & 2,60 & 2,53 & 2,46 & 2,41 & 2,38 & 2,34 & 2,30 & 2,25 & 2,21 \\
\hline 14 & 4,60 & & & & 96 & 2 & 2,76 & 2,70 & 2,65 & 2,60 & 2,53 & 2,46 & 2,39 & 2,34 & 2,31 & 2,27 & 2,22 & 2,18 & 2,13 \\
\hline 15 & 4,54 & 3,68 & 3,29 & 3,06 & 2,90 & 2,79 & 2,71 & 2,64 & 2,59 & 2,54 & 2,48 & 2,40 & 2,33 & 2,28 & 2,25 & 2,20 & 2,16 & 2,11 & 2,07 \\
\hline 16 & 4,49 & 3,63 & 3,24 & 3, & 2,85 & 2,74 & 2,66 & 2,59 & 2,54 & 2,49 & 2,42 & 2,35 & 2,28 & 2,23 & 2,19 & 2,15 & 2,11 & 2,06 & 2,01 \\
\hline 17 & 4,45 & 3,59 & & 2,96 & 2,81 & 2,70 & 2,61 & 2,55 & 2,49 & 2,45 & 2,38 & 2,31 & 2,23 & 2,18 & 2,15 & 2,10 & 2,06 & 2,01 & 1,96 \\
\hline 18 & 4,41 & 3,55 & 3,16 & 2,93 & 2,77 & 2,66 & 2,58 & 2,51 & 2,46 & 2,41 & 2,34 & 2,27 & 2,19 & 2,14 & 2,11 & 2,06 & 2,02 & 1,97 & 1,92 \\
\hline 19 & 4,3 & & & & & & & 2, & & & & 2, & 2,16 & 11 & 2,07 & 03 & 1,98 & 1,93 & 1,88 \\
\hline 20 & & & & & & & & & & & & & & & & & & & \\
\hline 21 & 4,32 & 3, & 3, & 2, & 2,68 & 2,57 & 2,49 & 2,42 & 2,37 & 2,32 & 2,25 & 2,18 & 2,10 & 2,05 & 2,01 & 1,96 & 1,92 & 1,87 & 1,81 \\
\hline 22 & 4,30 & & & & & & & & & 2,30 & 2,2 & & & 2,02 & & & & 84 & 1,78 \\
\hline 23 & 4,28 & 3,42 & 3,03 & 2,80 & 2,64 & 2,53 & 2,44 & 2,37 & 2,32 & 2,27 & 2,20 & 2,13 & 2,05 & 2,00 & 1,96 & 1,91 & 1,86 & 1,81 & 1,76 \\
\hline 24 & & & & & & & & & & & & & & & & & & & 1,73 \\
\hline 25 & 4,2 & & & & 2, & 2,49 & 2,40 & 2,34 & 2,28 & 2,24 & 2,1 & 2,09 & 2,01 & 1,96 & 1,92 & 37 & 1,82 & 1,77 & 1,71 \\
\hline 26 & 4,2 & 3,3 & & & & & & & & 2,22 & & 2,0 & 1,99 & 1,94 & & & 1,80 & 1,75 & 1,69 \\
\hline 27 & & & & & & & & & & 2,2 & & & & & & & & & 1,6 \\
\hline 28 & 4,20 & 3,34 & 2,95 & 2,7 & 2,56 & 2,45 & 2,36 & 2,29 & 2,24 & 2,19 & 2,12 & 2,04 & 1,96 & 1,91 & 1,8 & 32 & 1,77 & 1,71 & 1,65 \\
\hline 29 & & & & & & & & & & & & & & & & & 1,75 & & 1,64 \\
\hline 30 & 4,1 & 3,3 & 2,92 & 2, & & & & & & 2 & 2, & & & & & & 1,74 & & 1,62 \\
\hline 40 & 4,0 & 3,2 & 2,8 & & & & & 2, & 2 , & & & & & & & & & & 1,51 \\
\hline 60 & 4,00 & 3,15 & 2,76 & 2,53 & 2,37 & 2,25 & 2,17 & 2,10 & 2,04 & 1,99 & $\begin{array}{l}1,92 \\
\end{array}$ & 1,84 & 1,75 & 1,69 & 1,65 & 1,59 & 1,53 & 1,47 & 1,39 \\
\hline 120 & 3,92 & 3,07 & 2,68 & 2,45 & 2,29 & 2,18 & 2,09 & 2,02 & 1,96 & 1,91 & 1,83 & 1,75 & 1,66 & 1,60 & 1,55 & 1,50 & 1,43 & 1,35 & 1,25 \\
\hline$\infty$ & 3,84 & 3,00 & 2,60 & 2,37 & 2,21 & 2,10 & 2,01 & 1,94 & 1,88 & 1,83 & 1,75 & 1,67 & 1,57 & 1,51 & 1,46 & 1,39 & 1,32 & 1,22 & 1,00 \\
\hline
\end{tabular}




\section{APÊNDICES}




\section{APÊNDICE A - ESTUDO PILOTO}

O estudo piloto foi necessário para conhecer a interação dos materiais selecionados para produção de argamassas e de concretos na presente pesquisa. Nesse sentido, buscou-se obter parâmetros de mistura que conferissem homogeneidade e estabilidade aos materiais cimentícios supracitados, bem como testar alguns métodos de avaliação de autoadensabilidade e de reologia antes de empregá-los no Programa Experimental definitivo desta tese.

Inicialmente, foi realizado um estudo preliminar em concretos com intuito de buscar um concreto coeso. Em seguida, adotou-se a proporção de argamassa do concreto definido como coeso para iniciar os estudos em argamassas. Dentre as argamassas geradas, buscou-se identificar quais delas poderiam referenciar os concretos autoadensáveis, tomando como orientação os resultados de autoadensabilidade, reologia e espessura de filme de água dos grãos (WFT). Por fim, verificou-se a capacidade de referenciar das argamassas, tomadas como referencias de concretos autoadensáveis, por meio de ensaios que avaliam autoadensabilidade.

\section{A1 Estudo preliminar em concretos}

Os traços dos concretos foram definidos tomando os limites de proporção dos materiais para CAA, recomendado pelo American Concrete Institute (ACI). As proporções dos materiais sugeridas pelo ACI demonstram um menor consumo de cimento quando comparadas com as proporções sugeridas e adotadas pela RILEM. No Quadro 2, apresenta os limites das proporções dos materiais propostos pelo ACI. 
Quadro 2 - Proporções recomendadas para dosagem de CAA ACI 237R-07 (2007).

\begin{tabular}{|l|l|}
\hline \multicolumn{2}{|c|}{ Proporções de materiais recomendadas para produção de CAA } \\
\hline Volume absoluto de agregado graúdo & $28 \%$ a $32 \%$ \\
\hline Fração de pasta (calculado sobre o volume) & $34 \%$ a $40 \%$ \\
\hline Fração de argamassa(calculado sobre o volume) & $68 \%$ a $72 \%$ \\
\hline Consumo de cimento por $\mathrm{m}^{3}$ & $386 \mathrm{~kg} / \mathrm{m}^{3}$ a $475 \mathrm{~kg} / \mathrm{m}^{3}$ \\
\hline
\end{tabular}

Fonte: ACI 237R-07 (2007)

Para avaliação do estado fresco do concreto, tomou-se o ensaio de espalhamento e a inspeção visual para avaliar estabilidade. Quanto ao ensaio de espalhamento, adotou-se uma faixa de tolerância entre 600 mm e $800 \mathrm{~mm}$. Para avaliação da estabilidade, considerou-se a resistência à segregação e a exsudação do concreto. Nesse sentido, para avaliar a resistência à segregação, por inspeção visual, observou-se a existência de uma acentuada concentração de agregado graúdo na região central do concreto espalhado e, para avaliar a exsudação, verificou-se a existência de filme d'água ou anel de exsudação em sua periferia. Estas características no estado estado fresco confirmadas, definem um concreto não coeso. Na Tabela 35 estão apresentadas as principais características dos concretos produzidos, como as proporções dos materiais e o resultado de resistência à compressão aos 28 dias. De acordo com a Tabela 35, cabe enfatizar algumas características dos concretos:

- observa-se que o teor de substituição de areia artificial em substituição de areia rosa variou de $0 \%$ a $25 \%$;

- nota-se que o consumo de cimento foi em torno de $425 \mathrm{~kg} / \mathrm{m}^{3}$, a relação cimento/agregado foi de 1:4, assim configura-se um concreto de consumo intermediário;

- observa-se que os parâmetros, tais como, teor de argamassa, fração percentual de pasta, fração percentual de argamassa e volume percentual de agregado graúdo se mantiveram fixos;

- nota-se que o teor de argamassa manteve-se fixo em 61\%, o qual configura um concreto bem argamassado, típico de um CAA. Enquanto o concreto convencional o teor de argamassa gira em torno de $54 \%$. 
Tabela 35 - Principais características dos concretos estudados (estudo piloto).

\begin{tabular}{|c|c|c|c|c|}
\hline \multirow{4}{*}{ Especificações } & \multicolumn{4}{|c|}{ Tipo de Concreto } \\
\hline & $\mathrm{a} / \mathrm{s} \mathbf{0 , 4 5}$ & $\mathrm{a} / \mathrm{s} 0,45$ & a/s 0,45 & $\mathrm{a} / \mathrm{s} \mathbf{0 , 4 5}$ \\
\hline & & & & \\
\hline & $\begin{array}{l}\text { CAAREF } \\
\text { a/c } 0,50\end{array}$ & $\begin{array}{l}\text { CAA15 } \\
\text { a/c } 0,50\end{array}$ & $\begin{array}{l}\text { CAA20 } \\
\text { a/c } 0,50\end{array}$ & $\begin{array}{l}\text { CAA25 } \\
\text { a/c } 0,50\end{array}$ \\
\hline $\begin{array}{l}\text { Teor de subst. de areia artificial } \\
(\%)\end{array}$ & 0 & 15 & 20 & 25 \\
\hline Relação água/cimento & 0,5 & 0,5 & 0,5 & 0,5 \\
\hline Relação cimento/agregado & $1: 4$ & $1: 4$ & $1: 4$ & $1: 4$ \\
\hline $\begin{array}{l}\text { Traço em massa de cimento } \\
\text { (cimento : areia a : brita : água) }\end{array}$ & $\begin{array}{l}1: 0: 2,1: 1,8: 0 \\
5\end{array}$ & $\begin{array}{c}1: 0,30: 1,8: 1,8: 0 \\
5\end{array}$ & $\begin{array}{l}1: 0,42: 1,8: 0 \\
5\end{array}$ & $\begin{array}{c}1: 0,58: 1,58: 1,8: 0, \\
5\end{array}$ \\
\hline Consumo de cimento $\left(\mathrm{kg} / \mathrm{m}^{3}\right)$ & 422 & 425,5 & 425,4 & 427,3 \\
\hline Teor de argamassa (\%) & 61 & 61 & 61 & 61 \\
\hline $\begin{array}{l}\text { Fração percentual de pasta } \\
\text { (volume) }\end{array}$ & 38 & 38 & 38 & 38 \\
\hline $\begin{array}{l}\text { Fração percentual de argamassa } \\
\text { (volume) }\end{array}$ & 72 & 72 & 72 & 72 \\
\hline $\begin{array}{l}\text { Volume percentual de agregado } \\
\text { graúdo }\end{array}$ & 29 & 29 & 29 & 29 \\
\hline $\begin{array}{l}\text { Teor de aditivo em relação à massa } \\
\text { de cimento }(\%)\end{array}$ & 2 & 2 & 2 & 2 \\
\hline Slump flow $(\mathrm{mm})$ & 740 & 620 & 690 & 690 \\
\hline $\begin{array}{l}\text { Resistência à Compressão (28dias } \\
\text {-MPa) }\end{array}$ & 33,33 & 42,99 & 44,37 & 40,79 \\
\hline
\end{tabular}

Fonte: ACI 237R-07 (2007)

Na Figura 77 são apresentados os espalhamentos dos concretos estudados e, também, alguns aspectos relacionados à sua aparência. Nota-se que os concretos CAAREF e CAA15 sofreram exsudação e segregação, pois se observa uma concentração acentuada de agregado graúdo na região central do concreto espalhado e a existência de anel de exsudação na periferia do espalhamento. Esta instabilidade no estado fresco do concreto deve-se principalmente à insuficiência de finos. Por outro lado, os concretos CAA20 e CAA25 mostraram-se coesos, sendo o CAA20 mais coeso que o CAA25. 
Figura 77 - Aspecto visual do concreto após o espalhamento (estudo piloto).

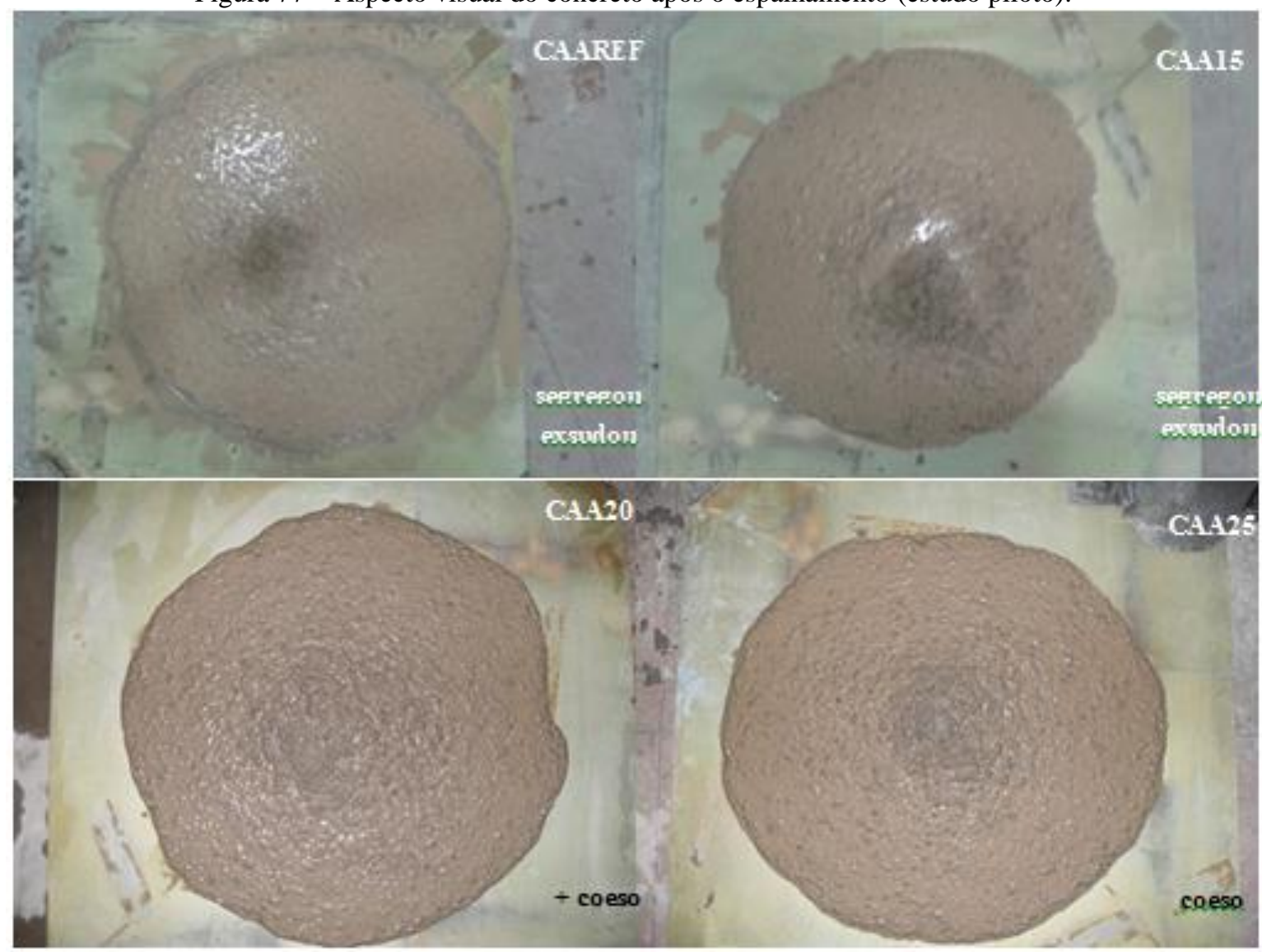

Fonte: Próprio autor.

Depois da constatação que o CAA20 mostrou-se mais coeso. Decidiu-se submetê-lo aos ensaios que avaliam a capacidade de preenchimento, tais como, o slump flow e funil $\mathrm{V}$, como também a capacidade de passagem por meio dos ensaios de Caixa L e Caixa U. Esses ensaios seguiram as recomendações da EFNARC (2005) e da ABNT NBR 15823 (2010). A seguir, na Tabela 36, os resultados do CAA20 frente aos ensaios que avaliam as habilidades de preenchimento e de passagem. Observa-se, no geral, que os resultados não estão de acordo com as tolerâncias. Cabe destacar com relação à capacidade de preenchimento e viscosidade, o tempo de escoamento no Funil V foi de 51 segundos, portanto muito além da tolerância máxima que é de 15 segundos. Isso significa que o concreto é mais viscoso, que pode ser explicado pelo alto teor de sólidos finos na mistura do concreto que, por sua vez, promove um maior atrito entre as partículas dificultando o fluxo.

Com relação a habilidade passante do concreto, observa-se que os resultados, também, não se enquadraram na tolerância apresentada na Tabela 36, tanto para o ensaio da Caixa L como para 
o ensaio da Caixa U. Esses resultados definem um concreto com baixa autoadensabilidade. Mais uma vez, pode-se dizer que o teor de sólidos finos dificultou o fluxo.

Tabela 36 - Resultados dos ensaios que avaliam as habilidades de preenchimento e passagem (estudo piloto).

\begin{tabular}{|c|c|c|c|c|}
\hline Propriedades & Ensaios & Parâmetros & Faixa & Resultados \\
\hline \multirow{2}{*}{$\begin{array}{ll}\text { Capacidade } & \text { de } \\
\text { preenchimento } & \end{array}$} & Slump Flow (mm) & Dfinal & 600 a $800 \mathrm{~mm}$ & 710 \\
\hline & Funil V(s) & $\mathrm{TV}$ & 6 a $15 \mathrm{~s}$ & 51 \\
\hline \multirow[t]{2}{*}{$\begin{array}{ll}\text { Capacidade } & \text { de } \\
\text { passagem } & \end{array}$} & Caixa L & $\begin{array}{l}\mathrm{RB}=\mathrm{H} 2 / \mathrm{H} 1 \text { (rel. de } \\
\text { bloqueio) }\end{array}$ & $\geq 0,80$ & 0,31 \\
\hline & Caixa U (mm) & R1-R2 & 0 a $30 \mathrm{~mm}$ & 145 \\
\hline
\end{tabular}

Fonte: Próprio autor.

\section{A2 Estudo preliminar em Argamassas}

Com intuito de identificar as prováveis argamassas que poderiam referenciar os concretos autoadensáveis. Os estudos em argamassas, tomou-se o teor de substituição de $20 \%$ de areia rosa pela areia artificial calcária como uma condição fixa, essa condição foi observada a mais propícia para se alcançar os concretos coesos no item A1. Dessa forma, as argamassas foram avaliadas frente aos ensaios de mini-slump, mini-funil $\mathrm{V}$ e vane test $\mathrm{e}$, também, submetidas à coleta de alguns parâmetros necessários para o cálculo da espessura de água média entre os grãos, representada pelo parâmetro WFT (water film thickness).

Na Figura 78 estão apresentadas as variáveis adotadas, as quais foram: relação água/sólidos (em volume) e o teor de superplastificante. Dessa forma, ensaiou-se nove pontos experimentais, os quais estão destacados de cor verde na Figura 78. Os demais pontos experimentais não foram considerados pelo fato de ter constatado, empíricamente, que as argamassas referentes a esses pontos não alcançariam uma autoadensabilidade e reologia desejada. 
Figura 78 - Planejamento experimental do estudo em argamassas de CAA (estudo piloto).

\section{A-20}

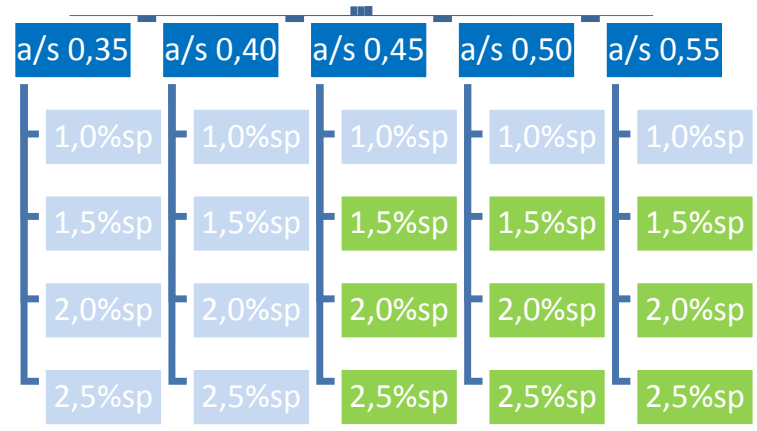

Fonte: Próprio autor.

Na Figura 79 estão apresentadas algumas etapas que foram efetuadas durante avaliação das argamassas no estado fresco.

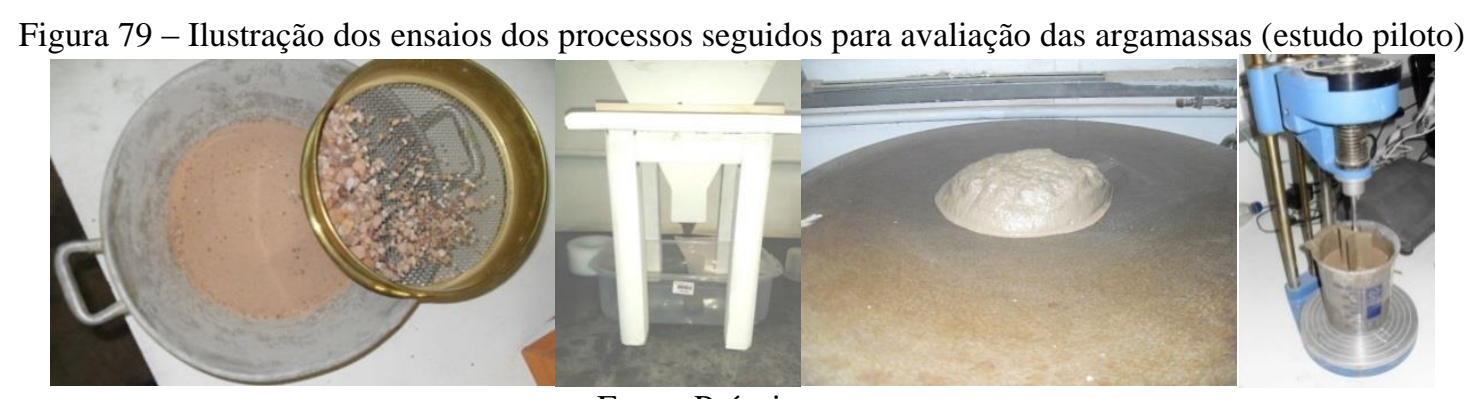

Fonte: Próprio autor.

\section{A3 Resultados das argamassas}

Na Tabela 37 estão apresentados os principais resultados de autoadensabilidade das argamassas relativos aos ensaios de mini-funil $\mathrm{V}$ e de mini-slump, bem como os resultados de reologia por meio do ensaio de vane test, do qual se obteve a tensão de escoamento. 
Tabela 37 - Resultados das argamassas frente aos ensaios que avaliam trabalhabilidade e tensão de escoamento (Vane test) (estudo piloto).

\begin{tabular}{|c|c|c|c|c|c|c|}
\hline \multirow[t]{2}{*}{ Situações* } & \multirow{2}{*}{$\begin{array}{l}\text { mini-Funil } \\
V \\
\text { (segundos) }\end{array}$} & \multirow{2}{*}{$\begin{array}{l}\text { mini-slump } \\
(\mathrm{mm}) \\
\text { (espa.-100) }\end{array}$} & \multicolumn{4}{|c|}{ Vane test } \\
\hline & & & mola & palheta & $\begin{array}{l}\text { ângulo } \\
\text { (graus) }\end{array}$ & $\begin{array}{c}\text { tensão } \\
(\mathrm{kPa})\end{array}$ \\
\hline $0,45 \mathrm{a} / \mathrm{s} \_1,5 \mathrm{sp}$ & não escoa & 0 & 4 & $50 \mathrm{mmx} 100 \mathrm{~mm}$ & 218 & 0,58 \\
\hline $0,45 \mathrm{a} / \mathrm{s} \_2,0 \mathrm{sp}$ & não escoa & 15,3 & 4 & $50 \mathrm{mmx} 100 \mathrm{~mm}$ & 209 & 0,56 \\
\hline $0,45 \mathrm{a} / \mathrm{s} \_2,5 \mathrm{sp}$ & não escoa & 159,7 & 4 & $50 \mathrm{mmx} 100 \mathrm{~mm}$ & 128 & 0,34 \\
\hline $0,50 \mathrm{a} / \mathrm{s} \_1,5 \mathrm{sp}$ & incompleto & 51,7 & 3 & $50 \mathrm{mmx} 100 \mathrm{~mm}$ & 143 & 0,52 \\
\hline $0,50 \mathrm{a} / \mathrm{s} \_2,0 \mathrm{sp}$ & incompleto & 186,0 & 3 & $45 \mathrm{mmx} 89 \mathrm{~mm}$ & 124 & 0,62 \\
\hline $0,50 \mathrm{a} / \mathrm{s} \_2,5 \mathrm{sp}$ & 9,12 & 202,3 & 4 & $50 \mathrm{mmx} 100 \mathrm{~mm}$ & 226 & 0,61 \\
\hline $0,55 \mathrm{a} / \mathrm{s} \_1,5 \mathrm{sp}$ & 22,41 & 191,2 & 4 & $50 \mathrm{mmx} 100 \mathrm{~mm}$ & 148 & 0,40 \\
\hline $0,55 \mathrm{a} / \mathrm{s} \_2,0 \mathrm{sp}$ & 4,21 & 210,0 & 4 & $50 \mathrm{~mm} \times 100 \mathrm{~mm}$ & 64 & 0,17 \\
\hline $0,55 \mathrm{a} / \mathrm{s} \_2,5 \mathrm{sp}$ & 4,57 & 162,8 & 4 & $50 \mathrm{~mm} \times 100 \mathrm{~mm}$ & 65 & 0,17 \\
\hline
\end{tabular}

Na Tabela 38 são apresentados os resultados de WFT e, também, os principais parâmetros necessários para o seu cálculo. É importante frisar, que as superfícies específicas das areias foram estimadas através da distribuição granulométrica a laser, sendo que para areia artificial obteve um valor igual $19,13 \mathrm{~cm}^{2} / \mathrm{g}$ e para areia rosa obteve um valor igual $11,54 \mathrm{~cm}^{2} / \mathrm{g}$. Com relação ao cimento CPV-ARI foi adotado o valor igual $5786,00 \mathrm{~cm}^{2} / \mathrm{g}$, conforme consta na Tabela 1.

Tabela 38 - Resultados das argamassas frente ao parâmetro WFT (estudo piloto).

\begin{tabular}{|c|c|c|c|c|}
\hline Situações* & $\begin{array}{l}\text { Densidade de } \\
\text { empacotamento } \\
(\Phi)\end{array}$ & $\begin{array}{l}\text { Índice de vazios } \\
\text { mínimo (umin) }\end{array}$ & $\begin{array}{l}\text { Água excedente } \\
\left(u^{\prime} w\right)\end{array}$ & $\begin{array}{l}\text { WFT } \\
\text { u',w }(\mu \mathrm{m})\end{array}$ \\
\hline $0,45 \mathrm{a} / \mathrm{s} \_1,5 \mathrm{sp}$ & 0,659 & 0,518 & 0,448 & $-0,431$ \\
\hline $0,45 \mathrm{a} / \mathrm{s} \_2,0 \mathrm{sp}$ & 0,669 & 0,494 & 0,448 & $-0,291$ \\
\hline $0,45 \mathrm{a} / \mathrm{s} \_2,5 \mathrm{sp}$ & 0,668 & 0,498 & 0,502 & 0,026 \\
\hline $0,50 \mathrm{a} / \mathrm{s} \_1,5 \mathrm{sp}$ & 0,653 & 0,531 & 0,502 & $-0,019$ \\
\hline $0,50 \mathrm{a} / \mathrm{s} \_2,0 \mathrm{sp}$ & 0,666 & 0,501 & 0,502 & 0,006 \\
\hline $0,50 \mathrm{a} / \mathrm{s} \_2,5 \mathrm{sp}$ & 0,651 & 0,536 & 0,555 & 0,122 \\
\hline $0,55 \mathrm{a} / \mathrm{s} \_1,5 \mathrm{sp}$ & 0,654 & 0,529 & 0,555 & 0,165 \\
\hline $0,55 \mathrm{a} / \mathrm{s} \_2,0 \mathrm{sp}$ & 0,641 & 0,561 & 0,555 & $-0,035$ \\
\hline $0,55 \mathrm{a} / \mathrm{s} \_2,5 \mathrm{sp}$ & 0,650 & 0,538 & 0,555 & 0,112 \\
\hline
\end{tabular}
Fonte: Próprio autor.

Inicialmente, pode-se destacar a regressão linear dos valores de espalhamento das argamassas em função do WFT, a qual obteve um coeficiente de determinação igual a 0,83 , conforme consta na Figura 80. 
Figura 80 - Correlação entre os resultados de espalhamento da argamassa versus os valores de WFT (estudo piloto).

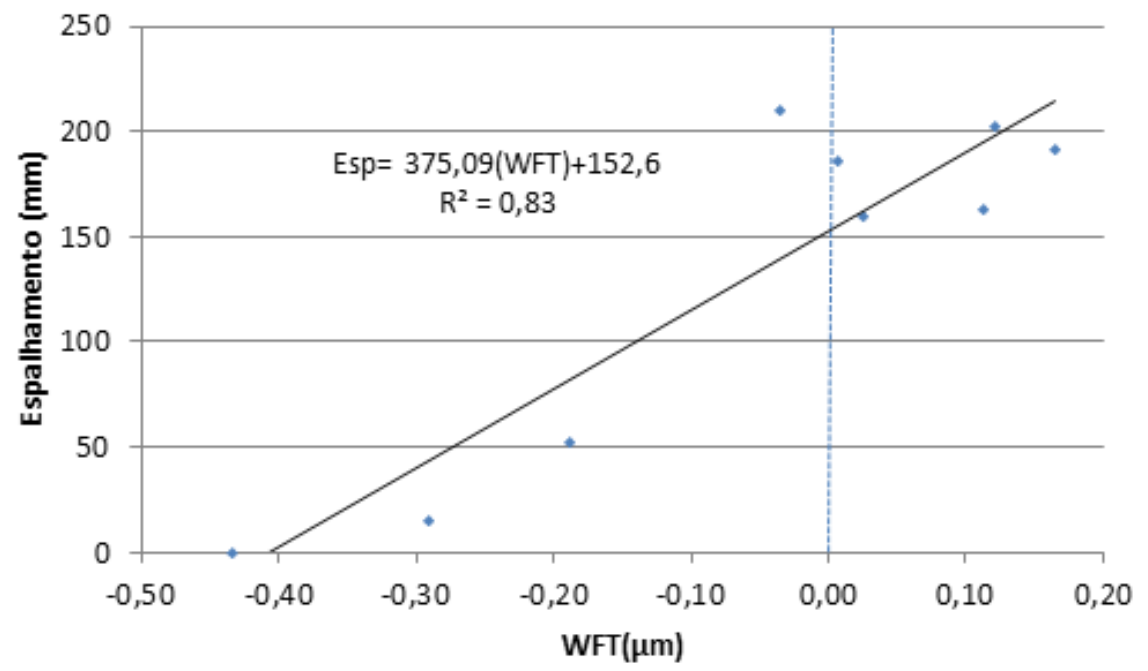

Fonte: Próprio autor.

Observa-se, na Figura 80, que as argamassas com valores maiores de WFT possuem maiores espalhamentos. Isso se deve ao aumento da espessura de água envolta dos sólidos que levou a uma redução de atrito entre as partículas sólidas conferindo um maior espalhamento na mistura. Com relação aos resultados do ensaio de mini-funil V, pode-se afirmar que os seus resultados não propiciaram um comportamento consistente. Diante disso, sugere-se mais pontos experimentais e maior repetibilidade desse ensaio para que se possa alcançar um comportamento palpável e conclusivo.

No que tange à relação dos valores de WFT com a tensão de escoamento. Verifica-se de forma evidente, na Figura 81, uma tendência de redução da tensão de escoamento com o aumento do valor WFT. Entretanto, observa-se que os valores circunscritos de vermelho distanciaram dessa tendência, os quais representam às argamassas de relação água/sólidos igual a 0,50. Uma explicação para esse fato pode ter sido a ocorrência de segregação e exsudação dessas argamassas que propiciaram o aumento de concentração de sólidos na parte inferior do recipiente do ensaio de Vane Test que, por sua vez, pode ter refletido no aumento dos resultados de tensão de escoamento.

Quanto às argamassas que estão representadas pelos pontos circunscritos de cor verde, pode-se notar que seus valores de tensão de escoamento são baixos. Isso se deve a característica fluída das argamassas que pode ter contribuído para reduzir a tensão de escoamento de forma acentuada tornando os pontos circunscritos de cor verde distantes da reta referência constante 
na Figura 81. Esta reta representa a tendência de reduzir a tensão de escoamento quando se aumenta o valor de WFT.

Com base nos resultados de mini-slump, mini-funil V, parâmetro WFT e tensão de escoamento das argamassas, decidiu-se alcançar os concretos que cumprissem com os requisitos de autoadensabilidade, visto que o concreto com relação água/sólidos igual a 0,45 e teor de aditivo superplastificante igual a 2\% não atendeu os requisitos. Para isso, buscou-se referencias de argamassas que, de maneira geral, apresentaram bons resultados de autoadensabilidade e de reologia. Além disso, buscou-se argamassas que tiveram valores de WFT mais próximos de zero com diferentes relações água/sólidos.

Figura 81 - Relação da tensão de escoamento com parâmetro WFT, seguido com a ilustração do aspecto visual das argamassas estudadas (estudo piloto).
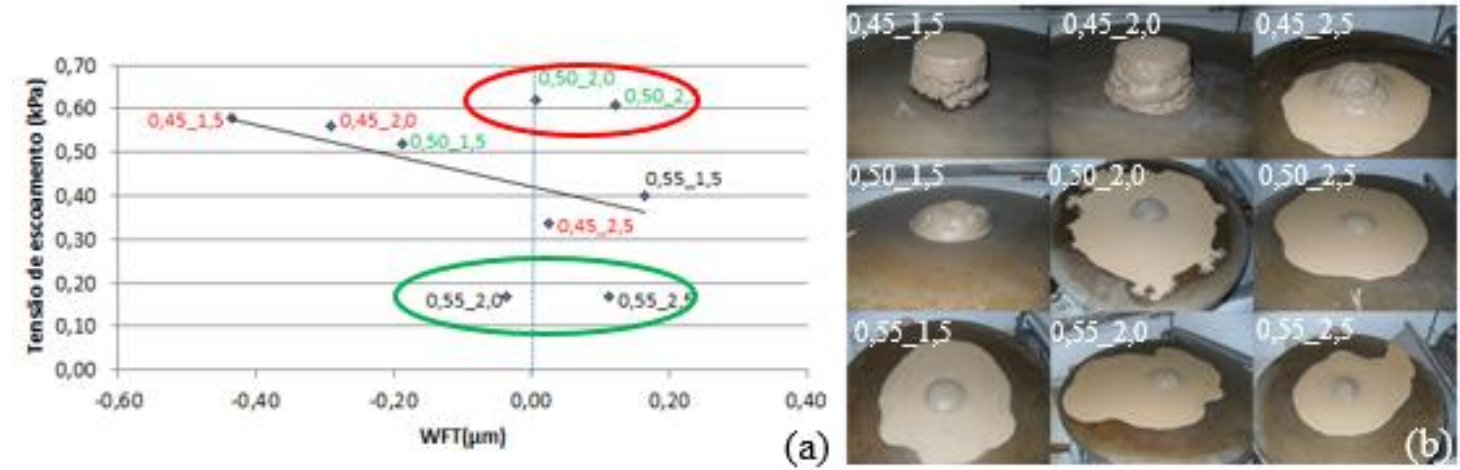

Fonte: Próprio autor.

Portanto, adotou-se as proporções das argamassas A0,50_2,0 e A0,55_2,0 para comporem os concretos, tendo em vista as tolerâncias prescritas pelo ACI 237R-07 (2007), no Quadro 2.

\section{A4 Resultados de autoadensabilidade dos concretos obtidos a partir de argamassas referências}

A seguir, na Tabela 39 e Figura 82 são apresentadas as principais características dos concretos produzidos por meio de referencias de proporções de argamassas selecionadas no item 3.2.3. 
Tabela 39 - Resultados dos concretos quanto aos ensaios de autoadensabilidade(estudo piloto).

\begin{tabular}{|c|c|c|c|c|c|}
\hline Propriedades & Ensaios & Parâmetros & Faixa & Resultados & \\
\hline & & & & C50_20 & C55_20 \\
\hline $\begin{array}{l}\text { Teor de areia artificial (\%) em } \\
\text { substituição da areia rosa }\end{array}$ & & & & 20 & 20 \\
\hline $\begin{array}{l}\text { Traço em massa de cimento } \\
\text { (cimento : areia a :areia b: } \\
\text { brita : água) }\end{array}$ & & & & $1: 1,58: 0,52: 1,80: 0,56$ & $\begin{array}{c}1: 1,58: 0,52: \\
1,80: 0,56\end{array}$ \\
\hline Consumo de cimento $\left(\mathrm{kg} / \mathrm{m}^{3}\right)$ & & & & 416 & 406 \\
\hline $\begin{array}{l}\text { Teor de argamassa } \\
(\%) \text { (massa) }\end{array}$ & & & & 67 & 67 \\
\hline $\begin{array}{l}\text { Teor de aditivo em relação à } \\
\text { massa de cimento }(\%)\end{array}$ & & & & 2,0 & 1,5 \\
\hline $\begin{array}{l}\text { Resistência à Compressão aos } \\
28 \text { dias }(\mathrm{MPa})\end{array}$ & & & & 60,4 & 29,8 \\
\hline \multirow[t]{2}{*}{ Capacidade de preenchimento } & $\begin{array}{l}\text { Slump } \\
\text { Flow } \\
(\mathrm{mm})\end{array}$ & Dfinal & $\begin{array}{l}600 \quad \mathrm{a} \\
800 \mathrm{~mm}\end{array}$ & 800 & 800 \\
\hline & $\begin{array}{l}\text { Funil } \\
\mathrm{V}(\mathrm{s})\end{array}$ & $\mathrm{Tv}$ & 6 a $15 \mathrm{~s}$ & 12,35 & 4,53 \\
\hline \multirow[t]{2}{*}{ Capacidade de passagem } & Caixa L & $\begin{array}{l}\mathrm{RB}=\mathrm{H} 2 / \mathrm{H} 1(\mathrm{rel} . \\
\text { de bloqueio) }\end{array}$ & $\geq 0,80$ & 0,99 & 0,98 \\
\hline & $\begin{array}{l}\text { Caixa } \\
\mathrm{U}(\mathrm{mm})\end{array}$ & R1-R2 & $\begin{array}{l}0 \quad \mathrm{a} \\
30 \mathrm{~mm}\end{array}$ & 5 & 5 \\
\hline
\end{tabular}

Fonte: Próprio autor.

Nota-se, na Tabela 39, que os concretos C0,50_2,0 e C0,55_2,0 cumpriram com os requisitos de capacidade de preenchimento e de habilidade passante. No entanto, quando se verifica a estabilidade do concreto no estado fresco, constata-se por meio de inspeção visual, que o C0,50_2,0 manteve-se coeso (conforme visto na Figura 77(a)), ao contrário do C0,55_2,0 que sofreu exsudação, conforme ilustra a Figura 77 (b). Portanto, pode-se afirmar que os estudos em argamassas foram capazes de referenciar os prováveis concretos autoadensáveis. Dessa forma, cabe enfatizar que a relação água/sólidos igual e próxima de 0,50, pode ser uma referência mais favorável para o alcance dos concretos autoadensáveis, desde que as características dos materiais e proporções sejam similares como adotadas neste estudo piloto. 
Figura 82 - Aspectos visuais dos concretos. (a) C0,50_20, (b) C0,55_2,0 (estudo piloto).
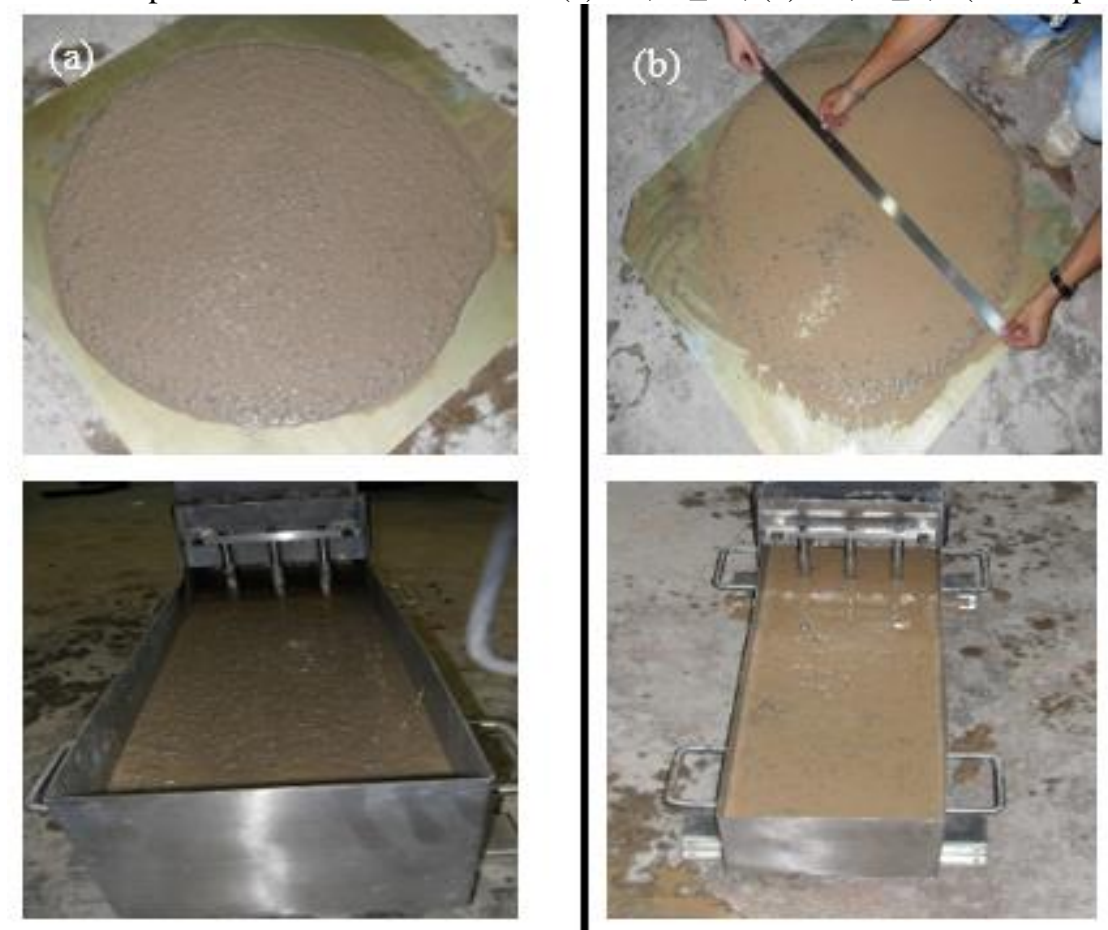

Fonte: Próprio autor.

\section{A5 Considerações gerais sobre o estudo piloto}

A seguir, as principais considerações sobre o estudo piloto que serviram para balizar e planejar o Programa Experimental da presente tese.

- Constatou-se que o teor de substituição de $20 \%$ da areia rosa pela areia artificial foi relevante para se obter um o concreto coeso;

- Foi possível obter uma regressão tipo linear entre os resultados de espalhamento de mini-slump e os resultados de WFT. Com isso, concluiu-se que quanto maior o valor de WFT, maior será a espessura de água envolta dos sólidos que, por sua vez, propicia uma redução de atrito entre as partículas sólidas conferindo um maior espalhamento na mistura;

- Foi possível, também, obter uma tendência entre os resultados de tensão de escoamento e os resultados de WFT. Isso significa que o aumento da espessura de água entre os grãos favorece o escoamento, podendo esse efeito ser explicado, também, pela redução de atrito entre as partículas sólidas;

- As relações obtidas, nesse estudo piloto, dos parâmetros de autoadensabidade e de reologia ( tensão de escoamento) com o parâmetro WFT, pode ser um indicativo que 
esse parâmetro realmente é capaz de governar as propriedades de trabalhabilidade e de reologia dos materiais cimentícios, conforme Kwan et al. (2010) já afirmaram. Para isso, deve-se fazer mais investigações para se ter uma confirmação mais consistente;

- Pode-se afirmar que os estudos em argamassas foram capazes de referenciar os prováveis concretos autoadensáveis;

- Constatou-se que a relação água/sólidos igual e próxima de 0,50, pode ser uma referencia mais favorável para o alcance de concretos autoadensáveis, desde que as características dos materiais e proporções sejam similares como adotadas nesse estudo. 


\section{APÊNDICE B - ANOVA - ESPALHAMENTO DA \\ ARGAMASSA (1'ETAPA)}

\section{B1 ANÁLISE DE VARIÂNCIA REFERENTE $O$ ESTUDO DA TRABALHABILIDADE DAS ARGAMASSAS COM ÊNFASE NA INFLUÊNCIA DO SUPERPLASTIFICANTE}

Sabe-se que a seleção do aditivo superplastificante a base de policarboxilato de sódio que melhor conferiu características de autoadensabilidade às argamassas, envolveu a determinação de resultados de espalhamento e de fluidez (viscosidade) por meio de ensaios de mini-slump e de mini-funil, respectivamente. Neste Apêndice, está apresentado a ANOVA referente os resultados de espalhamento e, no Apêndice C, está apresentado a ANOVA referente os resultados de fluidez.

\section{B11 Espalhamento (mini-slump)}

Com intuito de verificar se as variáveis envolvidas influenciaram de maneira significativa o espalhamento, realizou-se uma análise estatística de variância (ANOVA) que, por sua vez, os seus resultados encontram-se na Tabela 40, onde os valores de " $F$ calculados"( $\left.F_{\text {cal }}\right)$ foram comparados com os valores de " $\mathrm{F}$ tabelados" $\left(\mathrm{F}_{\text {tab }}\right)$ para um nível de significância de 5\%. O

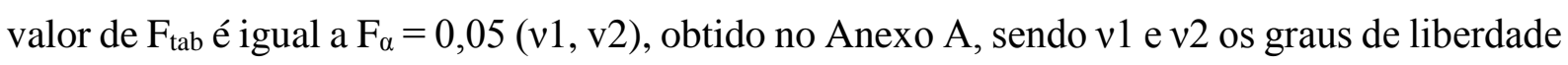
do efeito avaliado e do resíduo, respectivamente. É importante salientar, que nessa análise de variância foi adotado o modelo fatorial completo com quatro variáveis independentes e três níveis de variação. Essa análise foi importante, principalmente, para identificar a existência de interação entre os fatores (variáveis independentes) sobre a variável resposta espalhamento. Cabe destacar, também, que a variável teor de aditivo superplastificante, os níveis ou teores considerados foram $0,8 \% ; 1,0 \%$ e 1,2\% para ANOVA, pelo fato desses valores terem demonstrado ser os prováveis teores de saturação dos aditivos que propiciaram conferir maior espalhamento e fluidez as argamassas estudadas.

A Tabela 40 apresenta os resultados da ANOVA realizado para os dados de "espalhamento 100". Este parâmetro significa o ganho de espalhamento. A análise estatística mostrou que o modelo fatorial é significativo, a partir da constatação de que o valor de $\mathrm{F}_{\text {cal }}$ do modelo é maior 


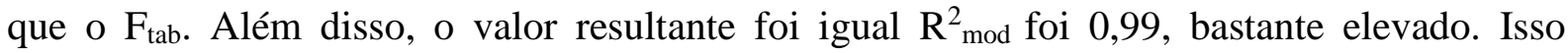
significa, que $99 \%$ da variação total dos dados é explicada pelo modelo.

Tabela 40 - Resultados da análise de variância (ANOVA) realizada com os dados de espalhamento (espalhamento-100), para as variáveis consideradas no modelo estatístico.

\begin{tabular}{|c|c|c|c|c|c|c|}
\hline Efeito & SQ & GL & MQ & Fcal & Ftab & Resultado \\
\hline Modelo & 2090210 & 80 & 26127,63 & 2849,54 & 1,00 & significativo \\
\hline Erro (resíduo) & 1485 & 162 & 9,17 & -- & -- & -- \\
\hline Total & 2091695 & 242 & -- & -- & -- & -- \\
\hline Tipo de aglomerante (TAg) & 6447 & 2 & 3224 & 351,6 & 3,63 & significativo \\
\hline Tipo de aditivo (TAd) & 1724021 & 2 & 862010 & 94012,8 & 3,63 & significativo \\
\hline Teor de aditivo (TA\%) & 205144 & 2 & 102572 & 11186,8 & 3,63 & significativo \\
\hline Tempo (t) & 26773 & 2 & 13387 & 1460,0 & 3,63 & significativo \\
\hline TAg $\mathrm{x}$ Tad & 11322 & 4 & 2830 & 308,7 & 3,01 & significativo \\
\hline TAg x TAd $\%$ & 3343 & 4 & 836 & 91,8 & 3,01 & significativo \\
\hline TAd $\times$ TAd $\%$ & 87801 & 4 & 21950 & 2393,9 & 3,01 & significativo \\
\hline TAg $\times \mathrm{t}$ & 520 & 4 & 130 & 14,2 & 3,01 & significativo \\
\hline TAd $\times \mathrm{t}$ & 5355 & 4 & 1339 & 146,0 & 3,01 & significativo \\
\hline TAd $\% \times \mathrm{t}$ & 844 & 4 & 211 & 23,0 & 3,01 & significativo \\
\hline TAg $\times$ TAd $\times$ TAd $\%$ & 5995 & 8 & 749 & 81,7 & 2,59 & significativo \\
\hline TAg $\times$ TAd $\times \mathrm{t}$ & 1299 & 8 & 162 & 17,7 & 2,59 & significativo \\
\hline TAg $\times$ TAd $\%$ x t & 1286 & 8 & 161 & 17,5 & 2,59 & significativo \\
\hline TAd $\mathrm{x}$ TAd $\%$ x t & 6637 & 8 & 830 & 90,5 & 2,59 & significativo \\
\hline TAg $\times$ TAd $\times$ TAd $\% \times$ t & 3422 & 8 & 214 & 23,3 & 2,59 & significativo \\
\hline Erro (resíduo) & 1485 & 16 & 9 & -- & -- & -- \\
\hline \multicolumn{7}{|c|}{$R_{\text {mod }}=0,99 R^{2}$ mod $=0,99$} \\
\hline \multicolumn{7}{|l|}{ Onde: } \\
\hline \multicolumn{7}{|c|}{$\mathrm{SQ}=$ Soma dos quadrados; $\mathrm{GL}=$ Graus de liberdade $; \mathrm{MQ}=$ Média dos quadrados; } \\
\hline \multicolumn{7}{|c|}{ F = Parâmetro de Fisher para o teste de significância dos efeitos; } \\
\hline \multicolumn{7}{|c|}{ Resultado = Resultado da análise, com a indicação se o efeito é significativo ou não; } \\
\hline \multicolumn{7}{|c|}{$\mathrm{R}_{\text {mod }}^{2}=$ Coeficiente de determinação do modelo e } \\
\hline \multicolumn{7}{|c|}{$\mathrm{R}_{\mathrm{mod}}=$ Coeficiente de correlação do modelo. } \\
\hline
\end{tabular}

Fonte: Próprio autor.

A análise de variância também mostrou que os efeitos individuais dos fatores principais analisados, ou seja, tipo de aglomerante, tipo de aditivo, teor de aditivo e tempo, são estatisticamente significativos a um nível de confiança de 95\%. Isto confirma a influência de cada uma dessas variáveis independentes, quando tomadas isoladamente.

A variável mais influente no espalhamento foi o tipo de aditivo, em segundo lugar apresentouse a variável teor de aditivo, em terceiro lugar a variável tempo e a menor influência foi exercida pelo variável tipo de aglomerante. 
Quanto às interações duplas, triplas e quadrúplas, observa-se a sinergia dos fatores para esses tipos de interação, evidenciada pelo resultado estatisticamente significativo, demonstrando que o efeito que uma variável exerce sobre o espalhamento depende das outras variáveis associadas a ela. Cabe destacar, a interação dupla entre os fatores tipo de aditivo e teor de aditivo, que demonstrou ser estatisticamente significativo numa intensidade bem superior quando comparada com outras interações. Isso se comprova, quando se compara o Fcal e Ftab e notase uma elevada diferença entre esses parâmetros.

Por fim, realizou-se comparação múltipla de médias pelo método de Duncan, em virtude da influência das variáveis: tipo de aglomerante, tipo de aditivo, teor de aditivo e tempo. Os resultados destas análises são apresentados a seguir.

\section{B111 Efeito do aglomerante}

Na Figura 83 está apresentado o resultado do agrupamento de médias, onde as linhas tracejadas verticais definem os grupos que diferem significativamente, na qual se constata que os três tipos de aglomerantes considerados neste estudo, produzem efeitos estatisticamente diferentes sobre o espalhamento. É importante frisar, que a variável tipo de aglomerante é estatisticamente significativo numa intensidade baixa. Isso se comprova quando se compara o Fcal e Ftab e notase uma pequena diferença, ao contrário das outras variáveis independentes significativas que a diferença desses parâmetros foi bem maior. Essa pequena intensidade justifica o fato das médias serem bem próximas, conforme pode ser visto na Figura 83. 
Figura 83 - Valores médios globais de espalhamento em função do tipo de aglomerante empregado nas argamassas, com seus intervalos de confiança de $95 \%$ e seus desvios padrões. As linhas tracejadas verticais definem os grupos que diferem significamente.

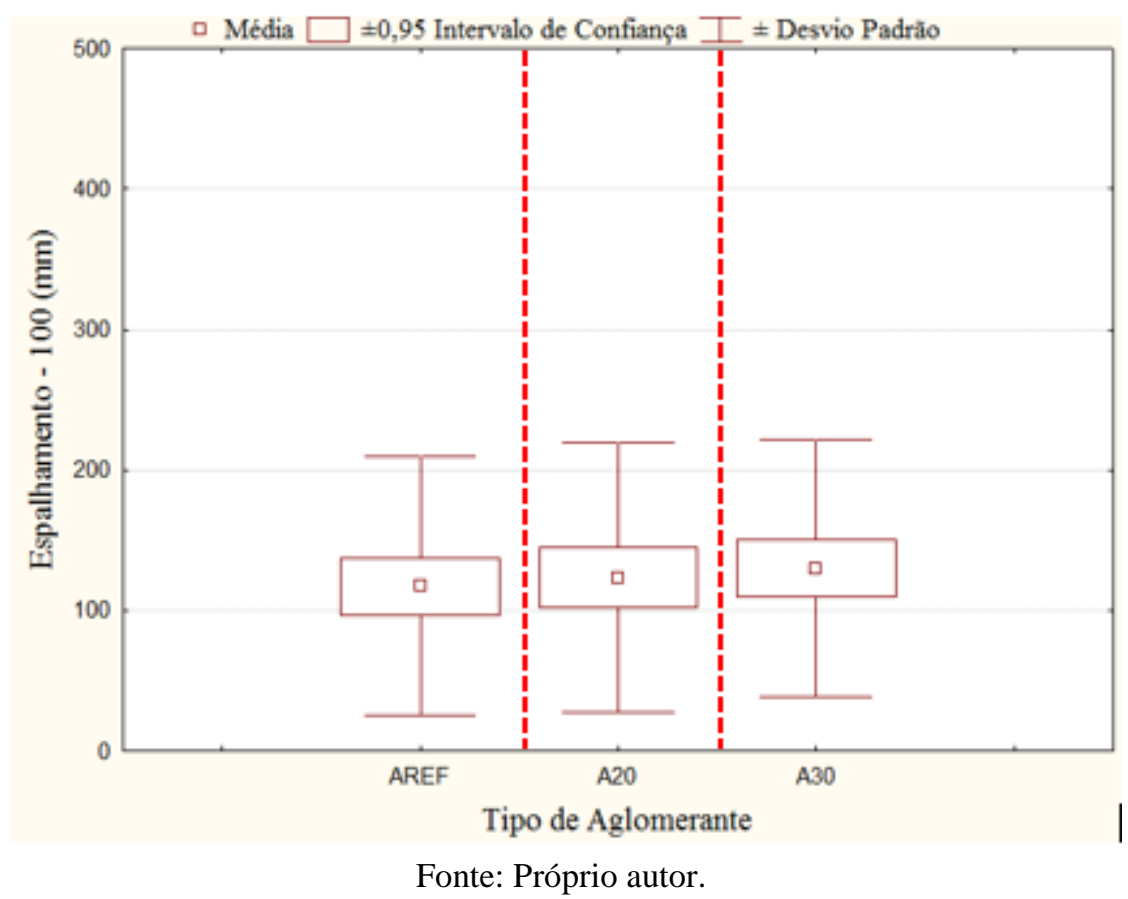

\section{B112 Efeito do tipo de aditivo}

Na Figura 84 são mostrados os valores médios globais de espalhamento para cada tipo de aditivo superplastificante, com seus intervalos de confiança de $95 \%$ e seus desvios padrões. As linhas tracejadas verticais definem os grupos que diferem significativamente, na qual se constata que os três tipos de aditivo superplastificante considerados neste estudo, produzem efeitos estatisticamente diferentes. 
Figura 84 - Valores médios globais de espalhamento em função do tipo de aditivo empregado nas argamassas, com seus intervalos de confiança de $95 \%$ e seus desvios padrões. As linhas tracejadas verticais definem os grupos que diferem significamente.

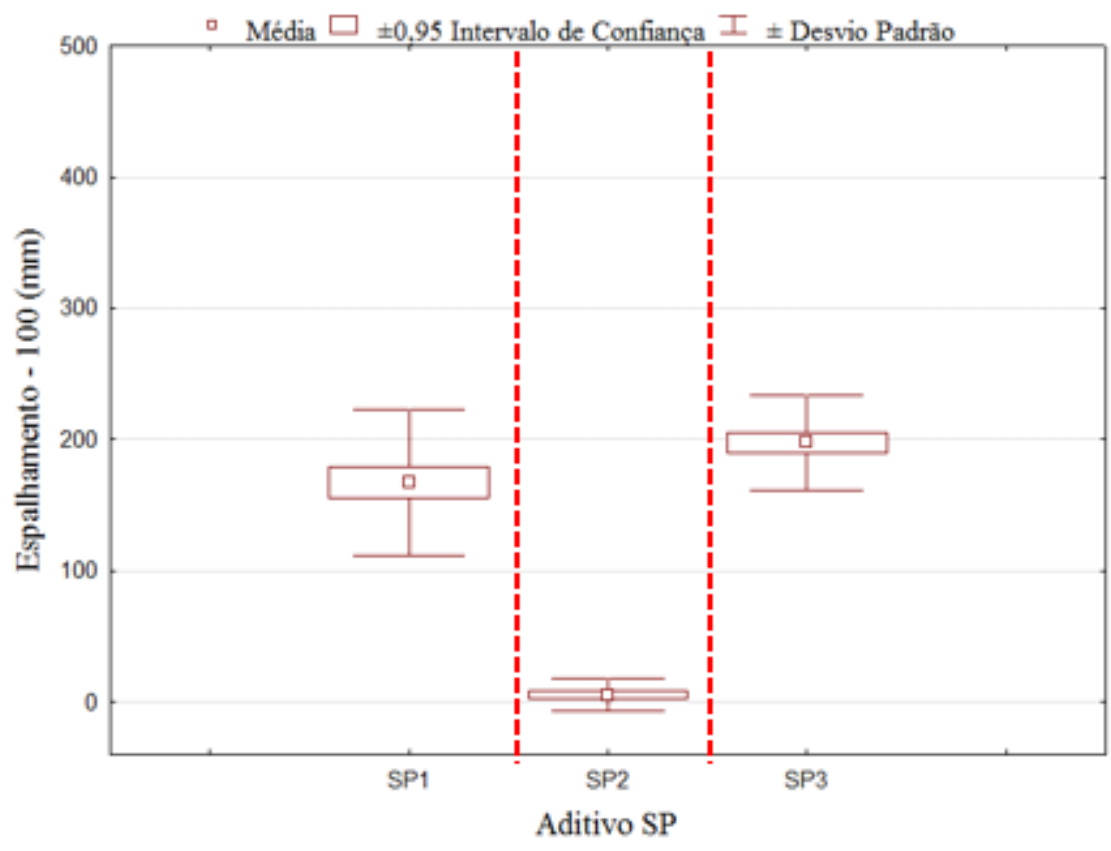

Fonte: Próprio autor.

\section{B113 Efeito do teor de aditivo}

Na Figura 85 são apresentados os valores médios globais de espalhamento para os teores de aditivo $0,8 \%, 1,0 \%$ e $1,2 \%$ com seus intervalos de confiança de $95 \%$ e seus desvios padrões. As linhas tracejadas verticais definem os grupos que diferem significativamente, na qual se constata que os três teores de aditivo considerados neste estudo, produzem efeitos estatisticamente diferentes.

Conforme a mesma, o teor de aditivo de $1 \%$ apresenta ser o ponto de saturação dos aditivos SP1 e SP3, visto que a partir desse teor se observa um patamar horizontal na maioria das curvas (azul e verde) referentes as argamassas com emprego desses aditivos. No entanto, para o aditivo SP2 não se verifica o mesmo comportamento, ou seja, não se nota o ponto de saturação. Diante disso, o fato do aditivo SP2 não ter apresentado o ponto de saturação no teor de $1 \%$, pode ter influenciado para que os teores $1,0 \%$ e $1,2 \%$ não fizessem parte do mesmo grupo, conforme está apresentado na Figura analisada. 
Figura 85 - Valores médios globais de espalhamento em função dos teores de aditivo empregado nas argamassas, com seus intervalos de confiança de $95 \%$ e seus desvios padrões. As linhas tracejadas verticais definem os grupos que diferem significamente.

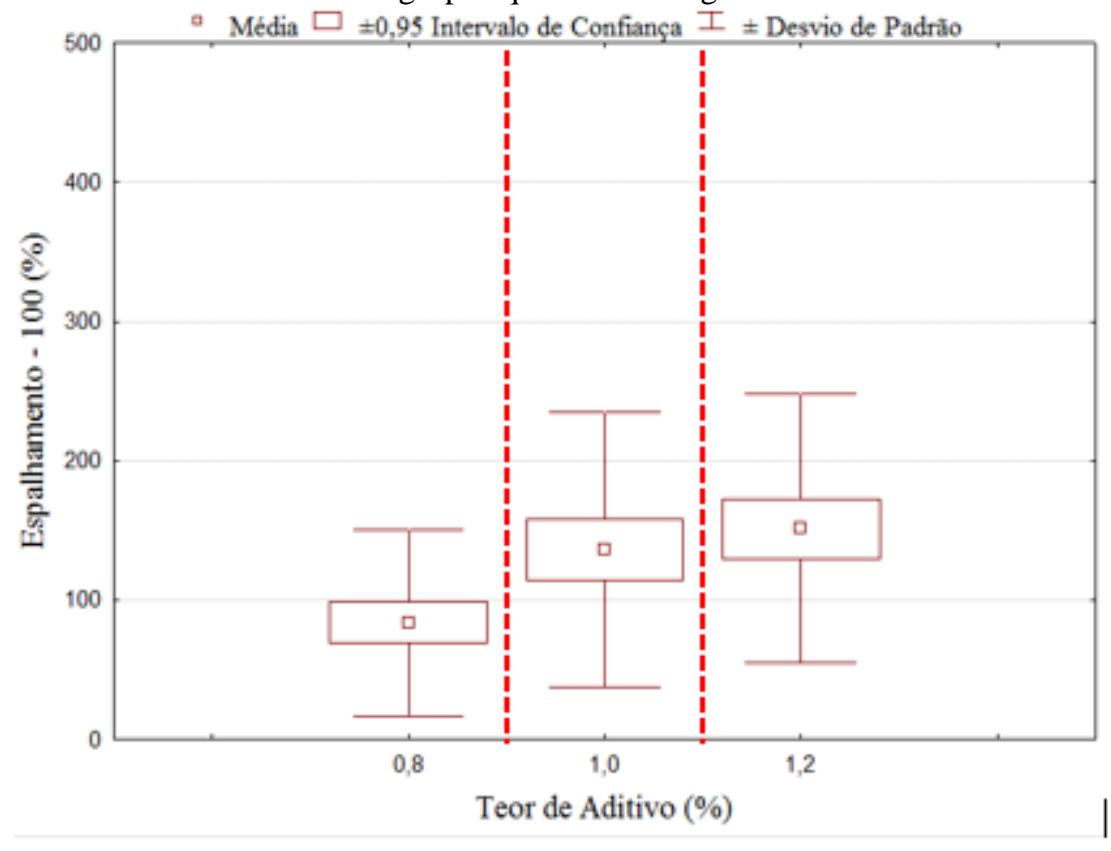

Fonte: Próprio autor.

\section{B114 Efeito do tempo}

Na Figura 86 são apresentados os valores médios globais de espalhamento para os tempos 30 min, 60 min e 90 min com seus intervalos de confiança de $95 \%$ e seus desvios padrões. As linhas tracejadas verticais definem os grupos que diferem significativamente, na qual se constata que os três tempos considerados neste estudo, produzem efeitos estatisticamente diferentes. 
Figura 86 - Valores médios globais de espalhamento em função dos tempos considerados para medir o espalhamento das argamassas, com seus intervalos de confiança de $95 \%$ e seus desvios padrões. As linhas tracejadas verticais definem os grupos que diferem significamente.

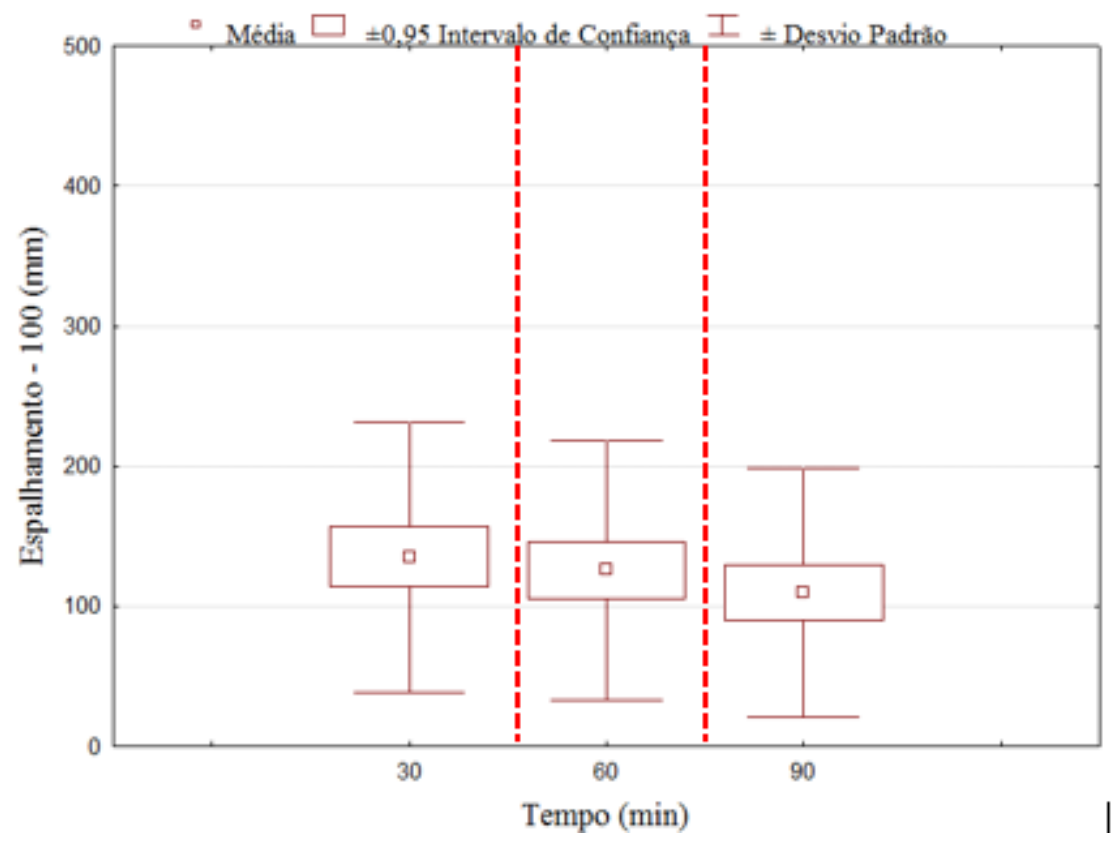

Fonte: Próprio autor. 


\section{APÊNDICE C - ANOVA: FLUIDEZ DA ARGAMASSA (1 ${ }^{\mathrm{a}}$ ETAPA)}

\section{C1 AVALIAÇÃO DA VISCOSIDADE (MINI-FUNIL)}

Com intuito de verificar se as variáveis envolvidas influenciaram de maneira significativa a fluidez, realizou-se uma análise estatística de variância (ANOVA) que, por sua vez, os seus resultados encontram-se na Tabela 41 , onde os valores de " $F$ calculados" $\left(F_{\text {cal }}\right)$ foram comparados com os valores de "F tabelados" ( $\mathrm{F}_{\text {tab }}$ para um nível de significância de 5\%. O valor de $\mathrm{F}_{\text {tab }}$ í igual a $\mathrm{F}_{\alpha}=0,05(\mathrm{v} 1, \mathrm{v} 2)$, obtido no Anexo $\mathrm{A}$, sendo $v 1$ e $v 2$ os graus de liberdade do efeito avaliado e do resíduo, respectivamente. É pertinente salientar, que nessa análise de variância foi adotado o modelo fatorial completo com quatro variáveis independentes e três níveis de variação. Essa análise foi importante, principalmente, para identificar a existência de interação entre os fatores (variáveis independentes) sobre a variável resposta fluidez. Cabe destacar, também, que a variável teor de aditivo superplastificante, considerou-se os níveis ou teores $0,8 \% ; 1,0 \%$ e 1,2\% para ANOVA, pelo fato desses valores terem demonstrado ser os prováveis teores de saturação dos aditivos que propiciaram conferir maior espalhamento e fluidez as argamassas estudadas.

A Tabela 41 apresenta os resultados da ANOVA realizado para os dados de fluidez. A análise estatística mostrou que o modelo fatorial é significativo, a partir da constatação de que o valor

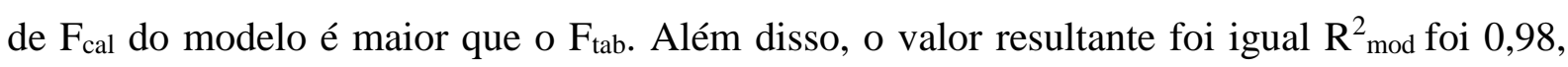
bastante elevado. Isso significa, que $98 \%$ da variação total dos dados é explicada pelo modelo. 
Tabela 41 - Resultados da análise de variância (ANOVA) realizada com os dados de fluidez, para as variáveis consideradas no modelo estatístico.

\begin{tabular}{|c|c|c|c|c|c|c|}
\hline Efeito & SQ & GL & MQ & Fcal & Ftab & Resultado \\
\hline Modelo & 6533414 & 80 & 81667,67 & 209,98 & 1,29 & significativo \\
\hline Erro (resíduo) & 63005 & 162 & 388,92 & -- & -- & -- \\
\hline Total & 6596419 & 242 & -- & -- & -- & -- \\
\hline Tipo de aglomerante (TAg) & 152928 & 2 & 76464 & 196,61 & 3,00 & significativo \\
\hline Tipo de aditivo (TAd) & 4141092 & 2 & 2070546 & 5323,84 & 3,00 & significativo \\
\hline Teor de aditivo (TA\%) & 744708 & 2 & 372354 & 957,41 & 3,00 & significativo \\
\hline Tempo (t) & 1023939 & 2 & 511969 & 1316,39 & 3,00 & significativo \\
\hline TAg $x$ TAd & 45154 & 4 & 11288 & 29,03 & 2,37 & significativo \\
\hline TAg $\times$ TAd $\%$ & 25908 & 4 & 6477 & 16,65 & 2,37 & significativo \\
\hline TAd $\times$ TAd $\%$ & 49936 & 4 & 12484 & 32,10 & 2,37 & significativo \\
\hline TAg $\times \mathrm{t}$ & 26349 & 4 & 6587 & 16,94 & 2,37 & significativo \\
\hline TAd $\mathrm{x} \mathrm{t}$ & 179241 & 4 & 44810 & 115,22 & 2,37 & significativo \\
\hline TAd $\%$ x t & 34186 & 4 & 8547 & 21,97 & 2,37 & significativo \\
\hline TAg x TAd $\times$ TAd $\%$ & 43812 & 8 & 5477 & 14,08 & 1,94 & significativo \\
\hline TAg x TAd $\times \mathrm{t}$ & 9666 & 8 & 1208 & 3,11 & 1,94 & significativo \\
\hline TAg $\times$ TAd $\%$ x t & 5812 & 8 & 726 & 1,87 & 1,94 & $\begin{array}{c}\text { não } \\
\text { significativo }\end{array}$ \\
\hline TAd $x$ TAd $\%$ x t & 16698 & 8 & 2087 & 5,37 & 1,94 & significativo \\
\hline TAg $\times$ TAd $\times$ TAd $\%$ x t & 33984 & 16 & 2124 & 5,46 & 1,65 & significativo \\
\hline Erro (resíduo) & 63005 & 162 & 389 & -- & -- & -- \\
\hline \multicolumn{7}{|c|}{$\mathbf{R}_{\text {mod }}=0,99 R^{2}$ mod $=0,98$} \\
\hline $\begin{array}{l}\text { Onde: } \\
\mathrm{SQ}=\text { Soma dos quadrados } ; \mathrm{GL}= \\
\mathrm{F}=\text { Parâmetro de Fisher para o t } \\
\text { Resultado = Resultado da análise } \\
\mathrm{R}^{2}{ }_{\text {mod }}=\text { Coeficiente de determina } \\
\mathrm{R}_{\text {mod }}=\text { Coeficiente de correlação }\end{array}$ & $\begin{array}{l}\text { dade; } M Q=1 \\
\text { ncia dos efeit } \\
\text { ão se o efeito } \\
\text { e }\end{array}$ & los qua & $\begin{array}{l}\text { s; } \\
\text { ão; }\end{array}$ & & & \\
\hline
\end{tabular}

Fonte: Próprio autor.

A análise de variância também mostrou que os efeitos individuais dos fatores principais analisados, ou seja, tipo de aglomerante, tipo de aditivo, teor de aditivo e tempo, são estatisticamente significativos a um nível de confiança de 95\%. Isto confirma a influência de cada uma dessas variáveis independentes, quando tomadas isoladamente.

A variável mais influente na fluidez foi o tipo de aditivo, em segundo lugar apresentou-se a variável tempo, em terceiro lugar a variável teor de aditivo e a menor influência foi exercida pelo variável tipo de aglomerante.

Quanto às interações duplas, triplas e quadrúplas, observa-se a sinergia dos fatores para esses tipos de interação, evidenciada pelo resultado estatisticamente significativo, demonstrando que 
o efeito que uma variável exerce sobre a fluidez depende das outras variáveis associadas a ela. Exceto a interação tripla TAg (tipo de aglomerante) x TAd\% (teor de aditivo) x tempo (t) que não se apresentou significativa. Dentre as interações que apresentaram significativas, a interação TAd (teor de aditivo) x tempo ( $\mathrm{t}$ ) apresentou-se ser mais influente, a qual se confirma na maior diferença proporcional entre os parâmetros Fcal e Ftab. É importante frisar, que a influência das interações sobre a variável dependente fluidez é menor na maioria dos casos ao se comparar com os efeitos individuais dos fatores. Mais uma vez, isso se comprova diante da maior diferença proporcional entre os parâmetros Fcal e Ftab.

Por último, realizou-se comparação múltipla de médias pelo método de Duncan, em virtude da influência das variáveis: tipo de aglomerante, tipo de aditivo, teor de aditivo e tempo. Os resultados destas análises são apresentados a seguir.

\section{C11 Efeito do aglomerante}

Na Figura 87 está apresentado o resultado do agrupamento de médias, onde as linhas tracejadas verticais definem os grupos que diferem significativamente, na qual se constata que os três tipos de aglomerantes considerados neste estudo, produzem efeitos estatisticamente diferentes sobre a fluidez. É importante frisar, que a variável tipo de aglomerante é estatisticamente significativo numa intensidade baixa. Isso se comprova pela pequena diferença entre os parâmetros Fcal e Ftab. Essa pequena intensidade justifica o fato das médias serem bem próximas entre AREF e A20, conforme pode ser visto na Figura abaixo. 
Figura 87 - Valores médios globais de fluidez em função do tipo de aglomerante, com seus intervalos de confiança de $95 \%$ e seus desvios padrões. As linhas tracejadas verticais definem os grupos que diferem significamente.

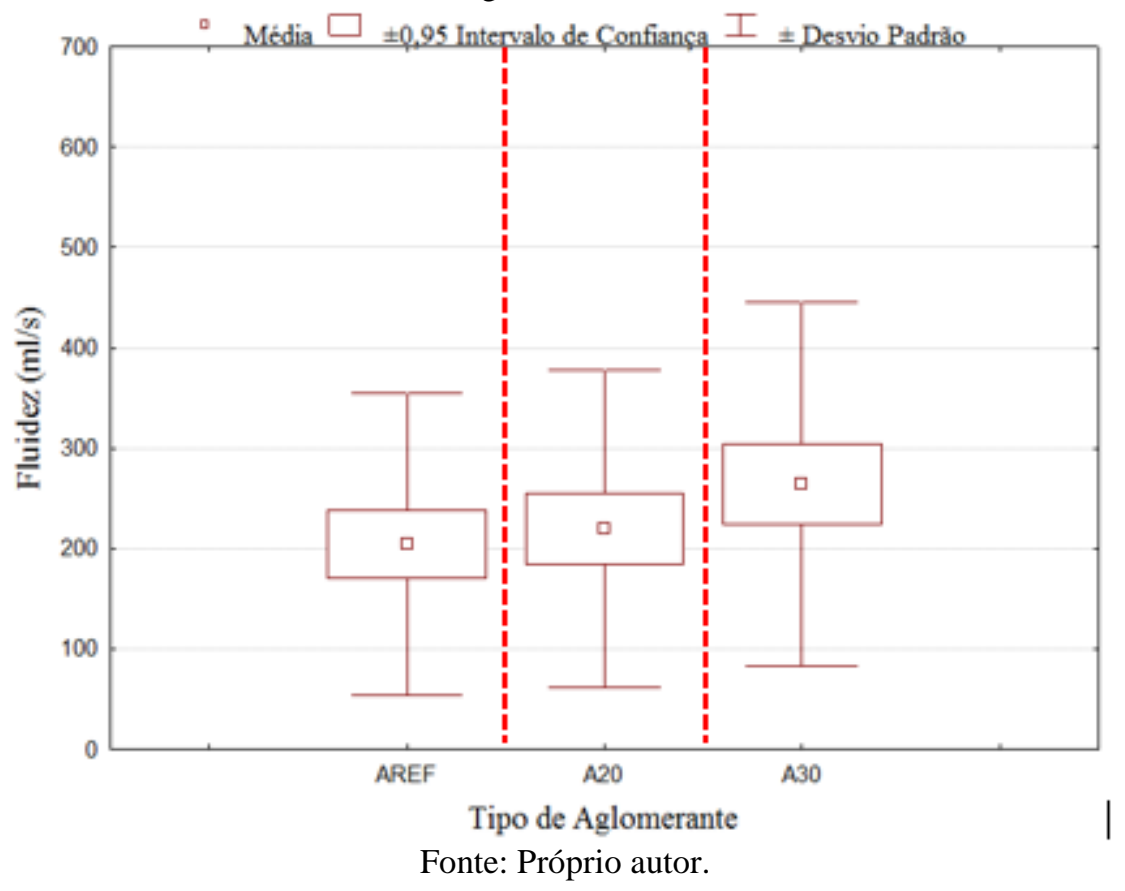

\section{C12 Efeito do tipo do aditivo}

Na Figura 88 são mostrados os valores médios globais de fluidez para cada tipo de aditivo superplastificante, com seus intervalos de confiança de $95 \%$ e seus desvios padrões. As linhas tracejadas verticais definem os grupos que diferem significativamente, na qual se constata que os três tipos de aditivo superplastificante considerados neste estudo, produzem efeitos estatisticamente diferentes. 
Figura 88 - Valores médios globais de fluidez em função do tipo de aditivo superplastificante, com seus intervalos de confiança de $95 \%$ e seus desvios padrões. As linhas tracejadas verticais definem os grupos que diferem significamente.

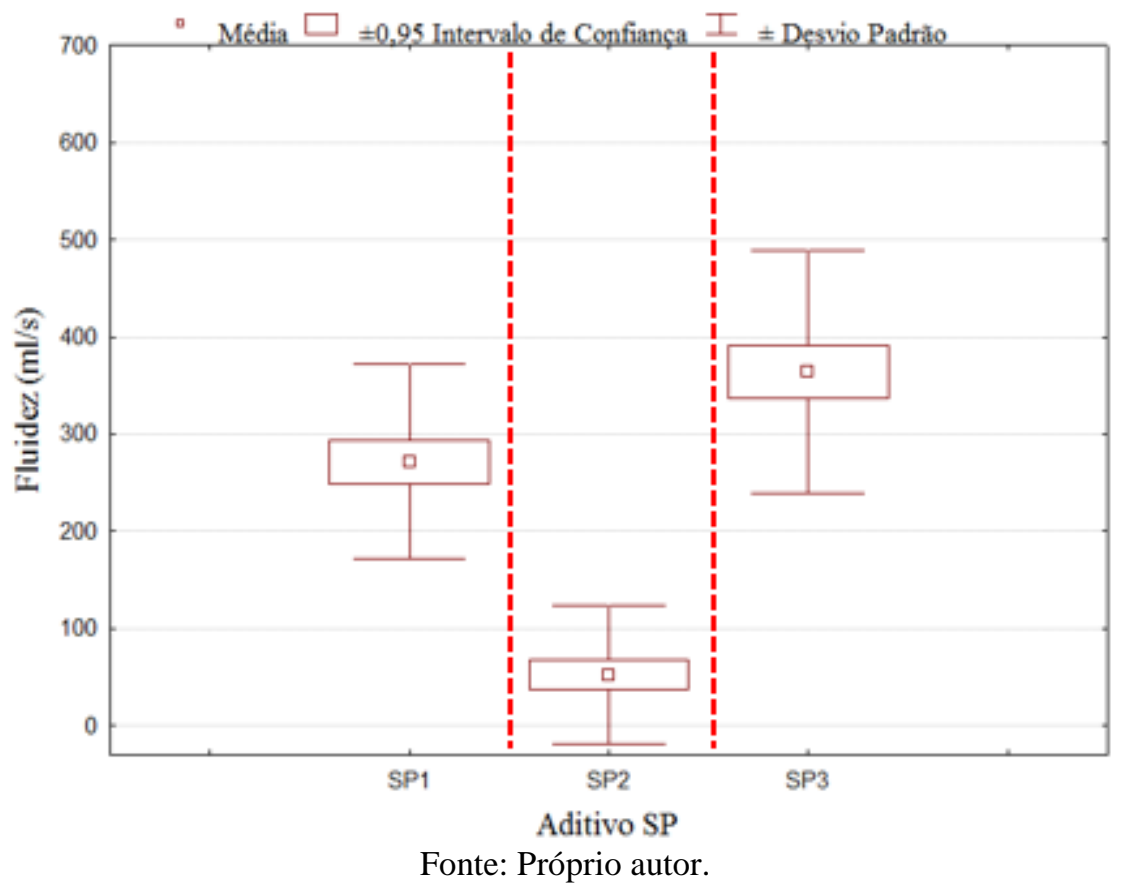

Verifica-se, na Figura 88, que o valor médio global de fluidez das argamassas com emprego do aditivo SP3 foi maior quando comparado com os valores médios de fluidez das argamassas com emprego dos aditivos SP2 e SP1.

\section{C13 Efeito teor do aditivo}

Na Figura 89 são apresentados os valores médios globais de espalhamento para os teores de aditivo $0,8 \%, 1,0 \%$ e $1,2 \%$ com seus intervalos de confiança de $95 \%$ e seus desvios padrões. As linhas tracejadas verticais definem os grupos que diferem significativamente, na qual se constata que os três teores de aditivo considerados neste estudo, produzem efeitos estatisticamente diferentes.

Observa-se, na Figura 49, capítulo 4, que o teor de aditivo de $1 \%$ apresenta ser, também, o ponto de saturação dos aditivos SP1 e SP3 diante do comportamento de fluidez das argamassas. Valores acima desse teor demonstraram ter uma tendência de patamar horizontal na maioria das curvas (azul e verde) referentes as argamassas com emprego desses aditivos. No entanto, para o aditivo SP2 não se verifica o mesmo comportamento, ou seja, não se nota o ponto de saturação. O fato do aditivo SP2 não ter apresentado o ponto de saturação no teor de $1 \%$, pode 
ter influenciado para que os teores $1,0 \%$ e 1,2\% não fizessem parte do mesmo grupo, conforme está apresentado na Figura 89.

Figura 89 - Valores médios globais de fluidez em função do teor do aditivo superplastificante, com seus intervalos de confiança de $95 \%$ e seus desvios padrões. As linhas tracejadas verticais definem os grupos que diferem significativamente.

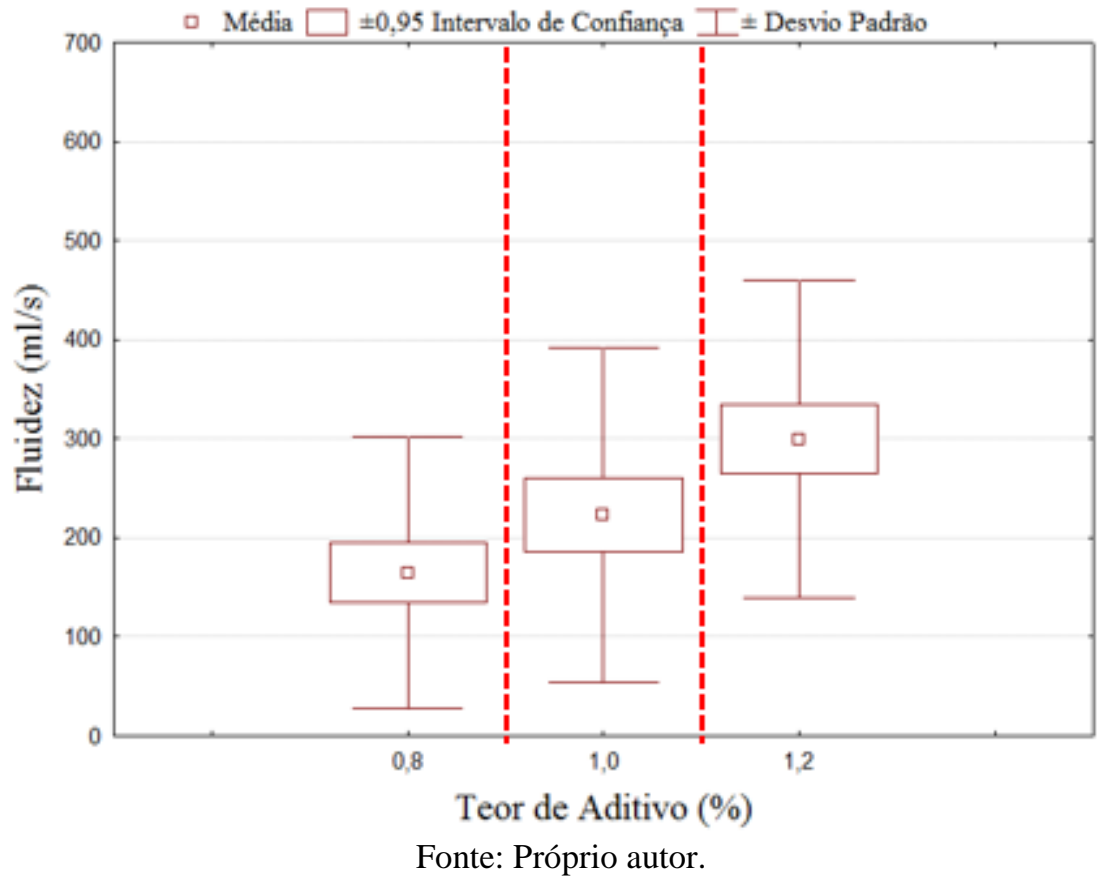

\section{C14 Efeito do tempo}

Na Figura 90 são apresentados os valores médios globais de espalhamento para os tempos 30 min, 60 min e 90 min com seus intervalos de confiança de $95 \%$ e seus desvios padrões. As linhas tracejadas verticais definem os grupos que diferem significativamente, na qual se constata que os três tempos considerados neste estudo, produzem efeitos estatisticamente diferentes. 
Figura 90 - Valores médios globais de fluidez em função da variável tempo, com seus intervalos de confiança de 95\% e seus desvios padrões. As linhas tracejadas verticais definem os grupos que diferem significativamente.

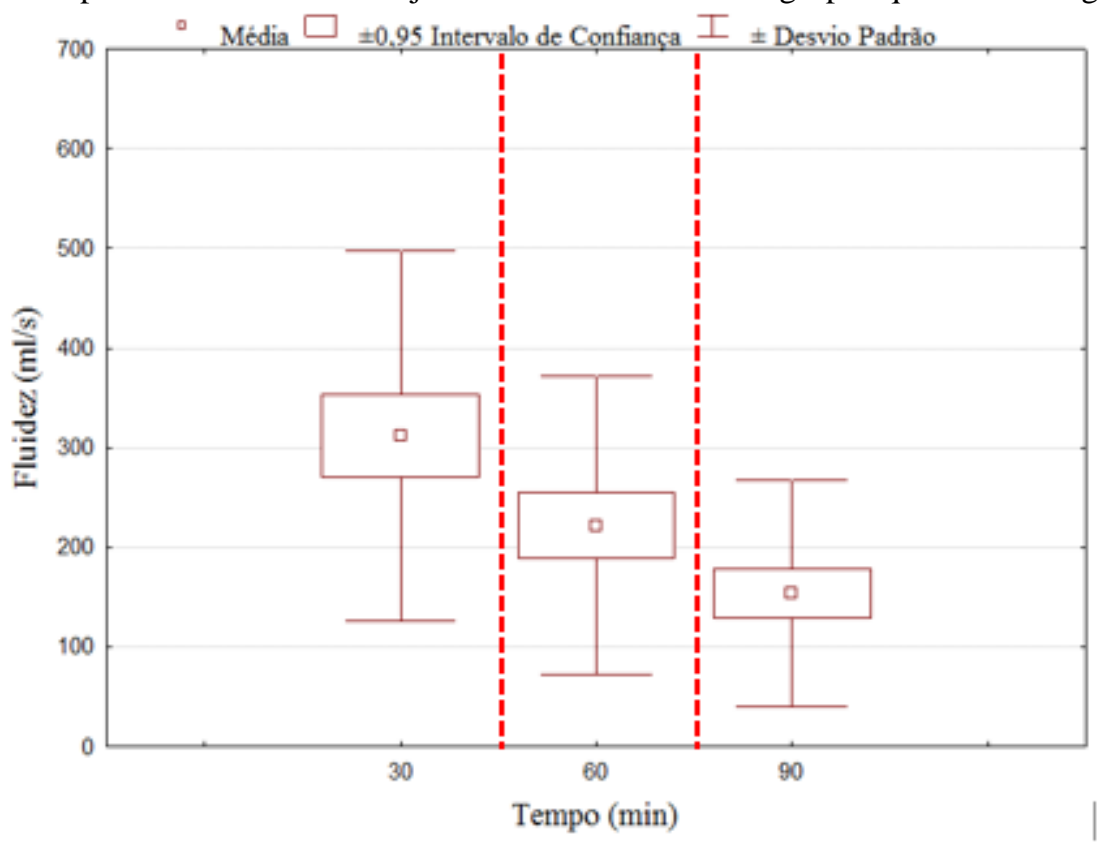

Fonte: Próprio autor. 


\section{APÊNDICE D - ANOVA: ESPALHAMENTO DA \\ ARGAMASSA (2 ETAPA)}

\section{D1 ANÁLISE DE VARIÂNCIA REFERENTE O ESTUDO DAS ARGAMASSAS PARA PRODUÇÃO DE CONCRETOS AUTOADENSÁVEIS}

No estudo anterior concluiu-se que o aditivo SP3 conferiu maior trabalhabilidade e às argamassas. Diante disso, adotou-se o aditivo superplastificante SP3 neste estudo e, também, no estudo em concretos. A seguir, estão apresentados a ANOVA dos resultados de espalhamento das argamassas com relações água/sólidos 0,40; 0,45 e 0,50 com emprego do aditivo SP3, com intuito de identificar as prováveis argamassas referências para produção de concretos autoadensáveis. No Apêndice E, estão apresentados a ANOVA referente os resultados de fluidez.

\section{D11 Espalhamento (mini-slump)}

A seguir são apresentados a ANOVA para os resultados de espalhamento das argamassas para cada relação água/sólidos, bem como comparação múltipla de médias pelo método de Duncan dos fatores que apresentaram ser significativas.

\section{D111 Relação água/sólidos 0,40 (slump-flow)}

Em seguida, faz-se uma abordagem estatística dos resultados de espalhamento das argamassas referentes a relação água/sólidos igual a 0,40, fundamentada na análise de variância (ANOVA) dos efeitos principais, conforme apresentada na Tabela 42. 
Tabela 42 - Resultados da análise de variância (ANOVA) realizada com os dados de espalhamento das argamassas de relação água/sólidos 0,40, para as variáveis consideradas no modelo estatístico.

\begin{tabular}{|c|c|c|c|c|c|c|}
\hline Efeito & SQ & GL & MQ & Fcal & Ftab & Resultado \\
\hline Modelo & 313860 & 6 & 52310 & 221,81 & 2,23 & significativo \\
\hline Erro (resíduo) & 17452 & 74 & 236 & -- & -- & -- \\
\hline Total & 331312 & 80 & -- & -- & -- & -- \\
\hline Tipo de aglomerante (TAg) & 11054 & 2 & 5527 & 23,44 & 3,13 & significativo \\
\hline Teor de aditivo (TA\%) & 285258 & 2 & 142629 & 604,78 & 3,13 & significativo \\
\hline Tempo (t) & 17549 & 2 & 8774 & 37,21 & 3,13 & significativo \\
\hline Erro (resíduo) & 17452 & 74 & 236 & -- & -- & -- \\
\hline \multicolumn{7}{|c|}{$\mathrm{R}_{\bmod }=0,97 \mathrm{R}^{2} \bmod =0,94$} \\
\hline \multicolumn{7}{|l|}{ Onde: } \\
\hline \multicolumn{7}{|c|}{$\mathrm{SQ}=$ Soma dos quadrados $; \mathrm{GL}=$ Graus de liberdade $; \mathrm{MQ}=$ Média dos quadrados; } \\
\hline \multicolumn{7}{|c|}{$\mathrm{F}=$ Parâmetro de Fisher para o teste de significância dos efeitos; } \\
\hline \multicolumn{7}{|c|}{ Resultado = Resultado da análise, com a indicação se o efeito é significativo ou não; } \\
\hline \multicolumn{7}{|c|}{$\mathrm{R}^{2}{ }_{\text {mod }}=$ Coeficiente de determinação do modelo e } \\
\hline \multicolumn{7}{|c|}{$\mathrm{R}_{\mathrm{mod}}=$ Coeficiente de correlação do modelo. } \\
\hline
\end{tabular}

Fonte: Próprio autor.

A análise estatística dos resultados mostrou que o modelo fatorial adotado é significativo em um valor de $\mathrm{R}^{2}$ mod igual a 0,94 . Constatou-se também, que os efeitos individuais dos fatores principais analisados: tipo de aglomerante, teor de aditivo e tempo, são estatisticamente significativos a um nível de confiança de 95\%, evidenciando a influência que cada uma das variáveis independentes exerce no espalhamento, quando tomada isoladamente.

Tomando-se como base a magnitude dos valores de Fcal, pode-se constatar que a variável mais influente no espalhamento foi teor de aditivo, seguida do tempo e tipo de aglomerante, nesta ordem.

Em virtude da influência das variáveis do modelo mostrar-se ser estatisticamente significativa, realizou-se a comparação múltipla de médias pelo método de Duncan. Os resultados destas análises estão expostos e discutidos a seguir.

a) Efeito do tipo de aglomerante

Na Figura 91 está apresentado o resultado do agrupamento de médias relativo as argamassas de relação água/sólidos igual 0,40 mediante o efeito do tipo de aglomerante, onde as linhas tracejadas verticais definem os grupos que diferem significativamente. Verifica-se que os aglomerantes A20 e A30 fazem parte de um grupo e AREF de outro grupo. Esses grupos produzem efeitos estatisticamente diferentes sobre a fluidez. Isso significa que a substituição 
de parte do cimento por fíler calcário foi capaz de promover um aumento do espalhamento de maneira significativa nas argamassas de relação água/sólidos 0,40, embora o efeito tipo de aglomerante seja estatisticamente significativo em uma baixa magnitude. Esta baixa magnitude se comprova pela pequena diferença entre os parâmetros Fcal e Ftab.

Figura 91 - Valores médios globais de espalhamento em função do tipo de aglomerante referentes as argamassas de relação água/sólidos 0,40 , com seus intervalos de confiança de $95 \%$ e seus desvios padrões. As linhas tracejadas verticais definem os grupos que diferem significativamente.

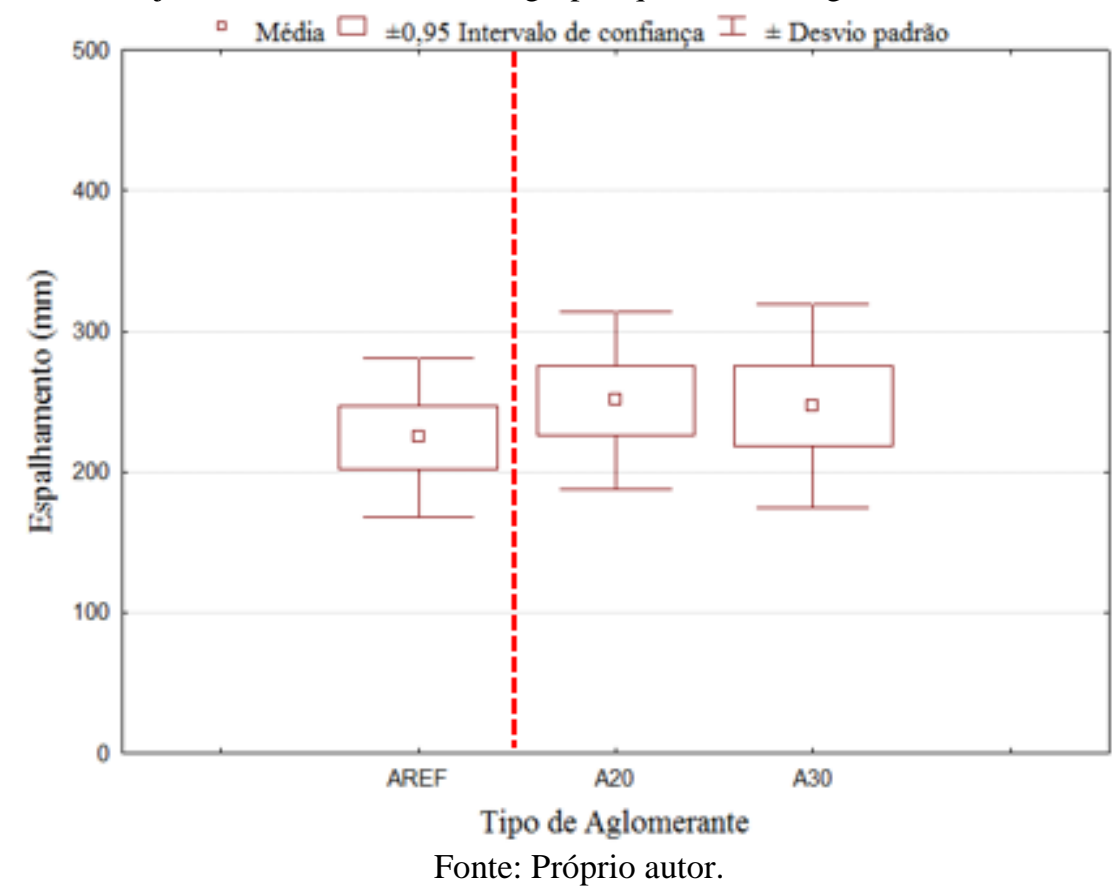

b) Efeito do teor de aditivo

Na Figura 92 são apresentados os valores médios globais de espalhamento para os teores de aditivo $0,8 \%, 1,0 \%$ e $1,2 \%$ com seus intervalos de confiança de $95 \%$ e seus desvios padrões. As linhas tracejadas verticais definem os grupos que diferem significativamente. Dessa forma, têm-se três teores de aditivo que produzem efeitos estatisticamente diferentes.

Observa-se que os teores de aditivo de $1 \%$ e de $1,2 \%$ possuem médias globais bem próximas, no entanto são diferentes estatisticamente. Vale ressaltar, que esse efeito é o mais influente sobre o espalhamento da argamassa. 
Figura 92 - Valores médios globais de espalhamento em função do teor do aditivo referentes as argamassas de relação água/sólidos 0,40, com seus intervalos de confiança de 95\% e seus desvios padrões. As linhas tracejadas verticais definem os grupos que diferem significativamente.

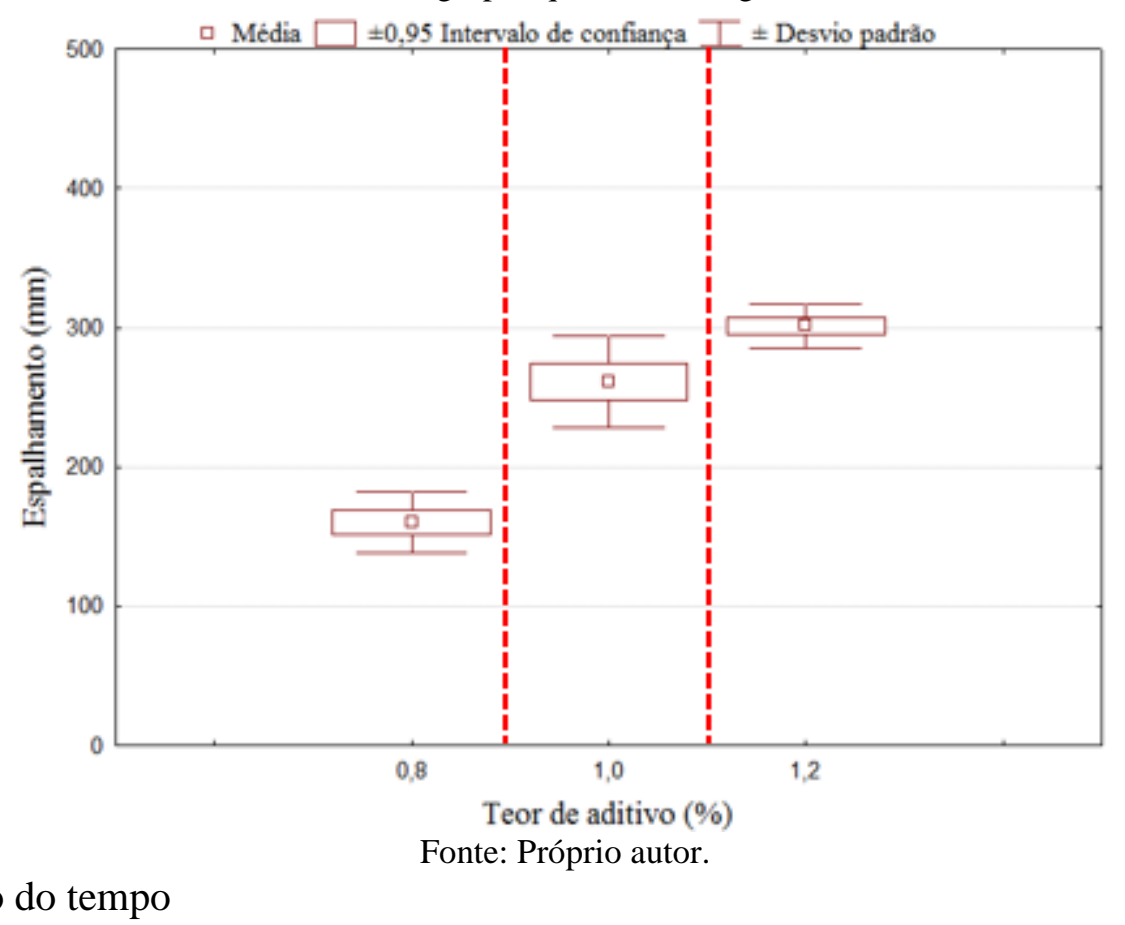

c) Efeito do tempo

Na Figura 93 são apresentados os valores médios globais de espalhamento para os tempos 30 min, 60 min e 90 min com seus intervalos de confiança de $95 \%$ e seus desvios padrões. As linhas tracejadas verticais definem os grupos que diferem significativamente, na qual se constata que os três tempos considerados neste estudo, produzem efeitos estatisticamente diferentes. Isso retrata, que a argamassa ou qualquer outro material cimentício reduz seu espalhamento com decorrer do tempo. 
Figura 93 - Valores médios globais de espalhamento em função do tempo referentes as argamassas de relação água/sólidos 0,40, com seus intervalos de confiança de $95 \%$ e seus desvios padrões. As linhas tracejadas verticais definem os grupos que diferem significativamente.

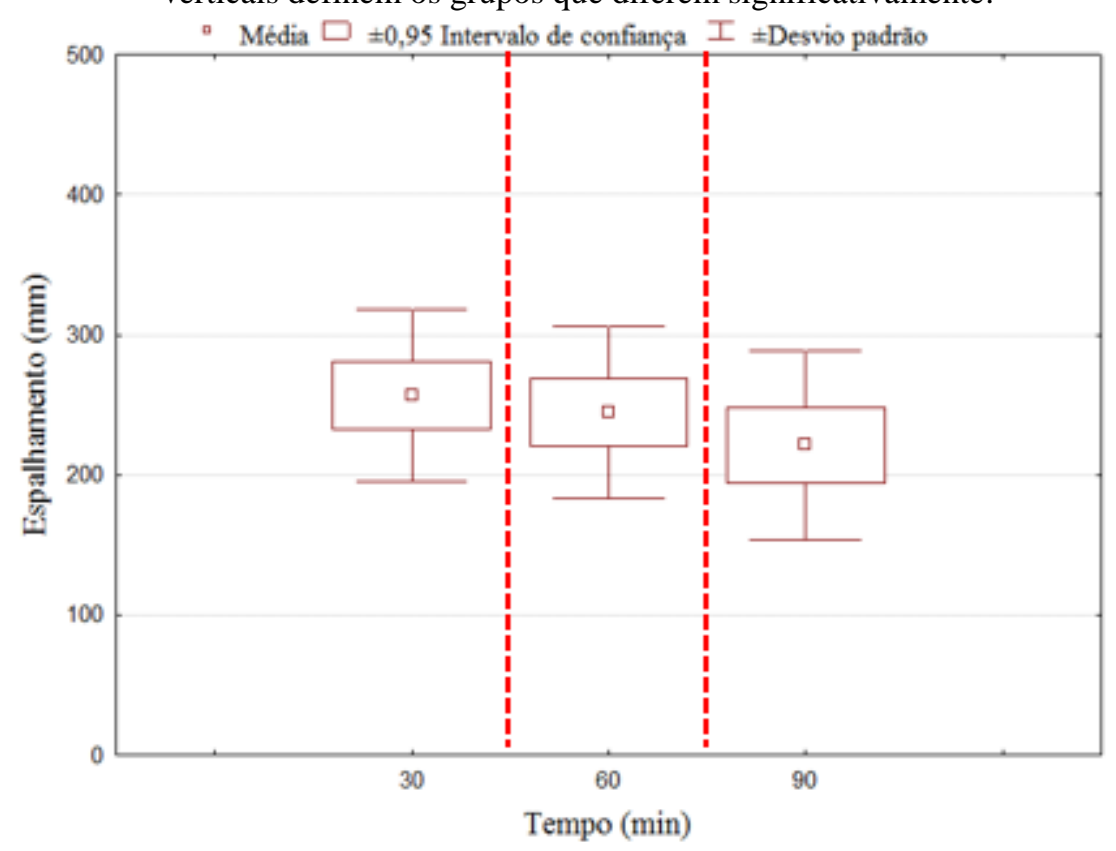

Fonte: Próprio autor.

\section{D112 Relação água/sólidos 0,45 (slump-flow)}

A seguir é apresentada uma abordagem estatística dos resultados de espalhamento das argamassas referentes a relação água/sólidos 0,45 , fundamentada na análise de variância (ANOVA) dos efeitos principais, conforme apresentado na Tabela 43.

Tabela 43 - Resultados da análise de variância (ANOVA) realizada com os dados de espalhamento das argamassas de relação água/sólidos 0,45 , para as variáveis consideradas no modelo estatístico.

\begin{tabular}{|c|c|c|c|c|c|c|}
\hline Efeito & SQ & GL & MQ & Fcal & Ftab & Resultado \\
\hline Modelo & 101722 & 6 & 16954 & 201,03 & 2,23 & significativo \\
\hline Erro (resíduo) & 6241 & 74 & 84 & -- & -- & -- \\
\hline Total & 107963 & 80 & -- & -- & -- & -- \\
\hline Tipo de aglomerante (TAg) & 831 & 2 & 416 & 4,93 & 3,13 & significativo \\
\hline Teor de aditivo (TA\%) & 84171 & 2 & 42085 & 499,03 & 3,13 & significativo \\
\hline Tempo (t) & 16720 & 2 & 8360 & 99,13 & 3,13 & significativo \\
\hline Erro (resíduo) & 6241 & 74 & 84 & -- & -- & -- \\
\hline \multicolumn{7}{|c|}{$\mathrm{R}_{\text {mod }}=0,99 \mathrm{R}^{2}{ }_{\text {mod }}=0,97$} \\
\hline \multicolumn{7}{|c|}{ Onde: } \\
\hline \multicolumn{7}{|c|}{$\mathrm{SQ}=$ Soma dos quadrados; $\mathrm{GL}=$ Graus de liberdade $; \mathrm{MQ}=$ Média dos quadrados; } \\
\hline \multicolumn{7}{|c|}{ F = Parâmetro de Fisher para o teste de significância dos efeitos; } \\
\hline \multicolumn{7}{|c|}{ Resultado = Resultado da análise, com a indicação se o efeito é significativo ou não; } \\
\hline \multicolumn{7}{|c|}{$\mathrm{R}_{\text {mod }}^{2}=$ Coeficiente de determinação do modelo e } \\
\hline \multicolumn{7}{|c|}{$\mathrm{R}_{\mathrm{mod}}=$ Coeficiente de correlação do modelo. } \\
\hline
\end{tabular}

Fonte: Próprio autor. 
A análise estatística dos resultados mostrou que o modelo fatorial adotado é significativo, resultando em um valor de $\mathrm{R}^{2}$ mod igual a 0,97 . A análise mostrou, também, que os efeitos individuais dos fatores principais analisados: teor de aditivo, tempo e tipo de aglomerante, são estatisticamente significativos a um nível de confiança de 95\%, evidenciando a influência que cada uma das variáveis independentes exerce no espalhamento, quando tomada isoladamente.

Ao analisar a magnitude dos valores de Fcal, constatou-se que a variável mais influente no espalhamento foi teor de aditivo, seguida do tempo e tipo de aglomerante, nesta ordem.

Em virtude da influência das variáveis do modelo mostrar-se ser estatisticamente significativa, realizou-se a comparação múltipla de médias pelo método de Duncan. Os resultados destas análises estão expostos e discutidos a seguir.

a) Efeito do tipo de aglomerante

Na Figura 94 está apresentado o resultado do agrupamento de médias relativo as argamassas de relação água/sólidos igual 0,45 mediante o efeito do tipo de aglomerante, onde as linhas tracejadas verticais definem os grupos que diferem significativamente. Verifica-se que os aglomerantes AREF e A30 fazem parte de um grupo e AREF de outro grupo. Vale lembrar, que esse efeito é influente sobre o espalhamento de forma bem ínfima como pode se observar nos valores de Fcal e Ftab, os quais são 4,93 e 3,13, respectivamente. Neste caso, pode-se dizer que essas argamassas aplicadas na construção civil submetem ao mesmo desempenho. 
Figura 94 - Valores médios globais de espalhamento em função do tipo de aglomerante referentes as argamassas de relação água/sólidos 0,45 , com seus intervalos de confiança de $95 \%$ e seus desvios padrões. Os grupos estão discriminados na figura.

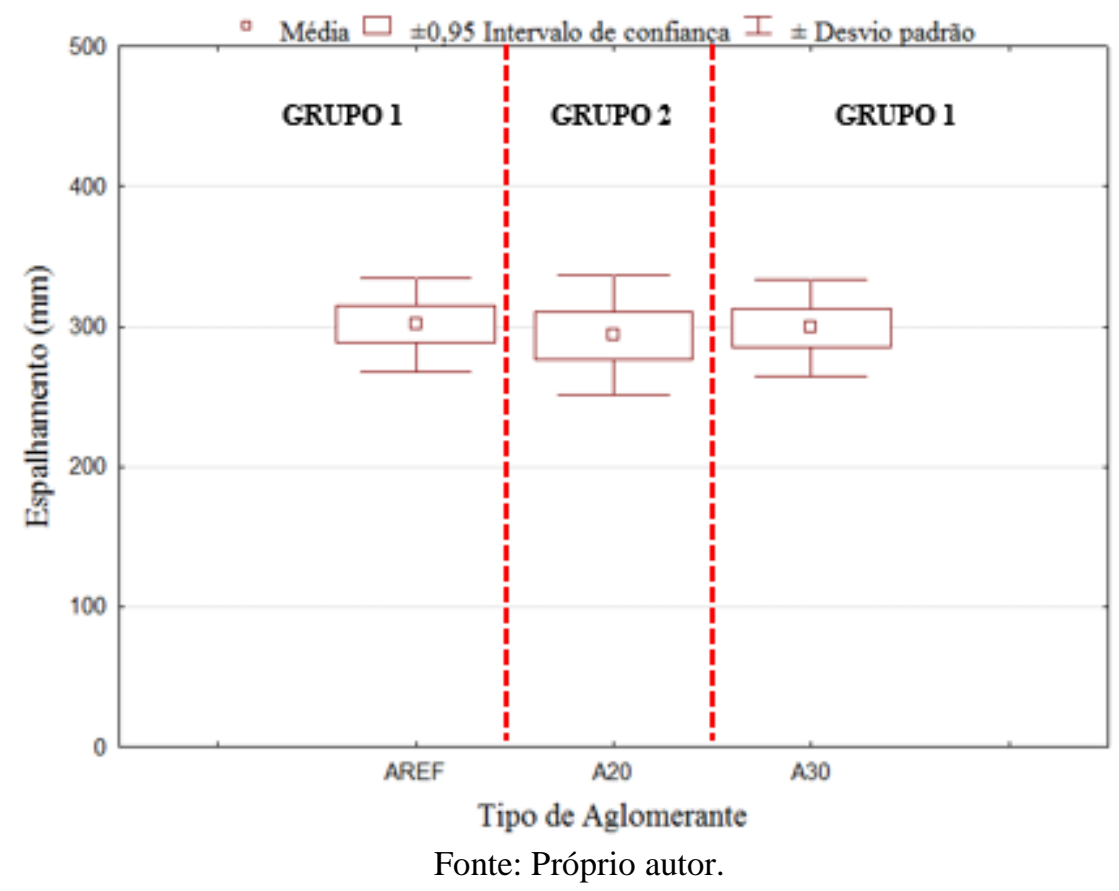

b) Efeito do teor do aditivo

Na Figura 95 são apresentados os valores médios globais de espalhamento para os teores de aditivo $0,8 \%, 1,0 \%$ e $1,2 \%$ com seus intervalos de confiança de $95 \%$ e seus desvios padrões. As linhas tracejadas verticais definem os grupos que diferem significativamente. Dessa forma, têm-se dois grupos que produzem efeitos estatisticamente diferentes.

Observa-se, na Figura 95, que os teores de aditivo de $1 \%$ e de $1,2 \%$ fazem parte do mesmo grupo. Isso valida a afirmação citada no item 4.2.1, onde se enfatiza que o teor de $1 \%$ de aditivo pode ser o ponto de saturação do aditivo para as argamassas de relação água/sólidos igual a 0,45. Cabe destacar, que o efeito do teor de aditivo é o mais influente sobre o espalhamento da argamassa. 
Figura 95 - Valores médios globais de espalhamento em função do teor do aditivo referentes as argamassas de relação água/sólidos 0,45, com seus intervalos de confiança de $95 \%$ e seus desvios padrões. As linhas tracejadas verticais definem os grupos que diferem significativamente.

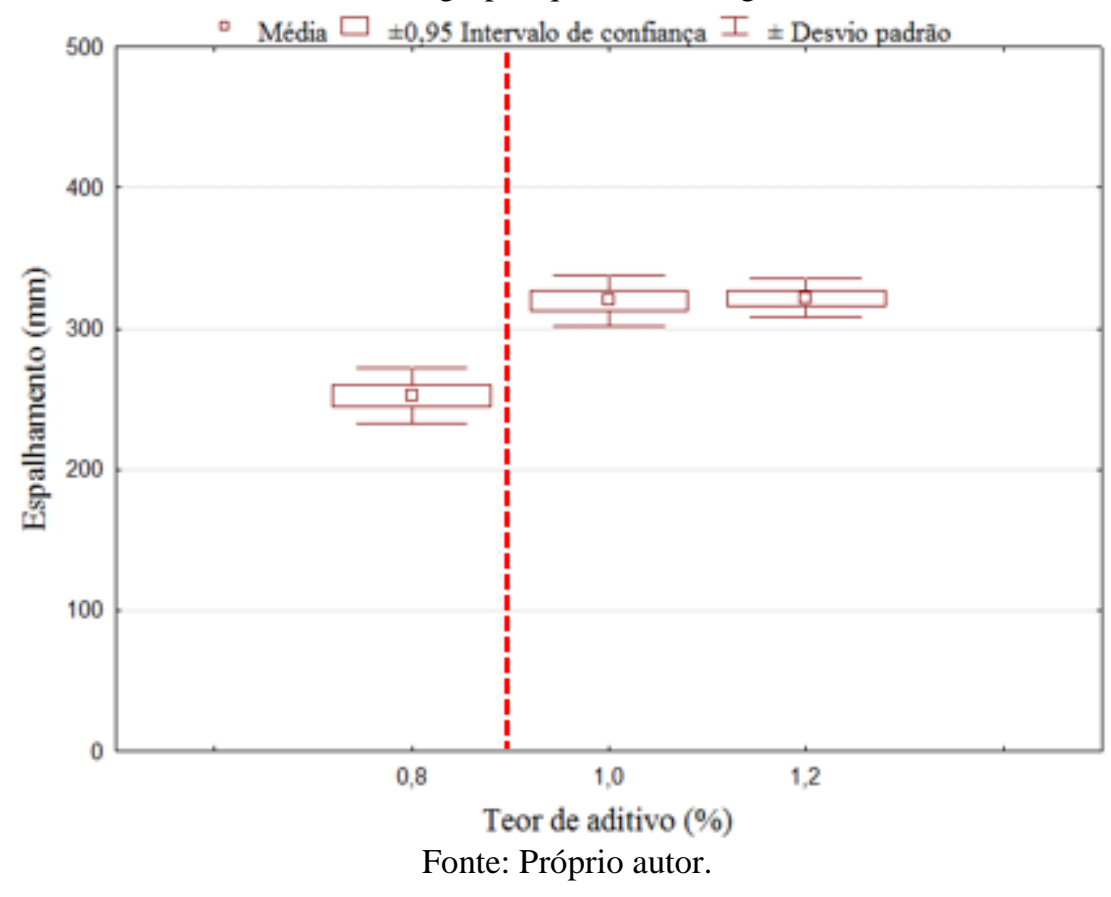

c) Efeito do tempo

Na Figura 96 são apresentados os valores médios globais de espalhamento para os tempos 30 min, 60 min e 90 min com seus intervalos de confiança de $95 \%$ e seus desvios padrões. As linhas tracejadas verticais definem os grupos que diferem significativamente, na qual se constata que os três tempos considerados neste estudo, produzem efeitos estatisticamente diferentes. Mais uma vez mostra que a argamassa ou qualquer outro material cimentício reduz seu espalhamento com decorrer do tempo. 
Figura 96 - Valores médios globais de espalhamento em função do teor do aditivo referentes as argamassas de relação água/sólidos 0,45, com seus intervalos de confiança de $95 \%$ e seus desvios padrões. As linhas tracejadas verticais definem os grupos que diferem significativamente.

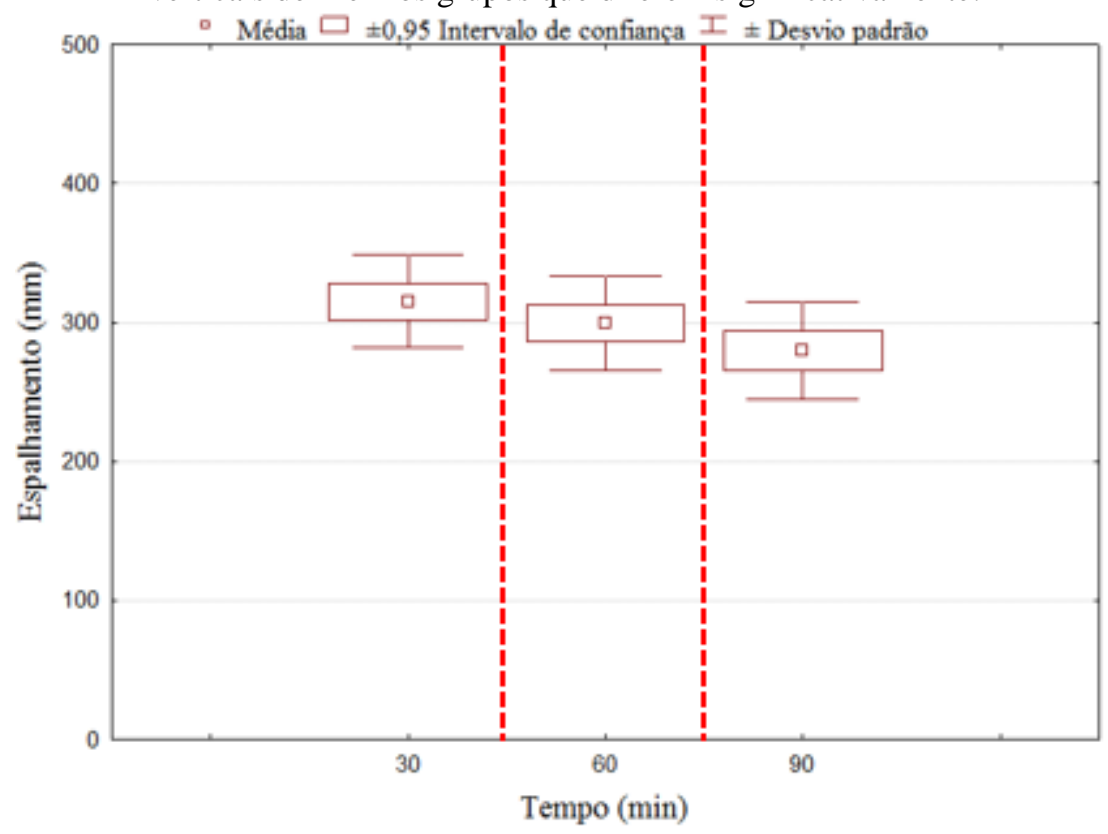

Fonte: Próprio autor.

\section{D113 Relação água/sólidos 0,50 (slump-flow)}

A seguir é apresentada uma abordagem estatística dos resultados de espalhamento das argamassas referentes a relação água/sólidos igual a 0,50, fundamentada na análise de variância (ANOVA) dos efeitos principais, conforme apresentado na Tabela 44.

Tabela 44 - Resultados da análise de variância (ANOVA) realizada com os dados de espalhamento das argamassas de relação água/sólidos 0,50, para as variáveis consideradas no modelo estatístico.

\begin{tabular}{|c|c|c|c|c|c|c|}
\hline Efeito & SQ & GL & MQ & Fcal & Ftab & Resultado \\
\hline Modelo & 101097 & 5 & 20219 & 380 & 2,42 & significativo \\
\hline Erro (resíduo) & 2556 & 48 & 53 & -- & -- & -- \\
\hline Total & 103653 & 53 & -- & -- & -- & -- \\
\hline Tipo de aglomerante (TAg) & 377 & 2 & 189 & 3,55 & 3,18 & significativo \\
\hline Teor de aditivo (TA\%) & 89630 & 1 & 89630 & 1683,48 & 4,05 & significativo \\
\hline Tempo (t) & 11090 & 2 & 5545 & 104,15 & 3,18 & significativo \\
\hline Erro (resíduo) & 2556 & 48 & 53 & -- & -- & -- \\
\hline \multicolumn{7}{|c|}{$\mathrm{R}_{\bmod }=0,99 \mathrm{R}^{2} \bmod =0,97$} \\
\hline \multicolumn{7}{|l|}{ Onde: } \\
\hline \multicolumn{7}{|c|}{$\mathrm{SQ}=$ Soma dos quadrados; GL = Graus de liberdade; $\mathrm{MQ}=$ Média dos quadrados; } \\
\hline \multicolumn{7}{|c|}{ F = Parâmetro de Fisher para o teste de significância dos efeitos; } \\
\hline \multicolumn{7}{|c|}{ Resultado = Resultado da análise, com a indicação se o efeito é significativo ou não; } \\
\hline \multicolumn{7}{|c|}{$\mathrm{R}^{2}{ }_{\text {mod }}=$ Coeficiente de determinação do modelo e } \\
\hline \multicolumn{7}{|c|}{$\mathrm{R}_{\text {mod }}=$ Coeficiente de correlação do modelo. } \\
\hline
\end{tabular}

Fonte: Próprio autor. 
A análise estatística dos resultados mostrou que o modelo fatorial adotado é significativo, resultando em um valor de $\mathrm{R}^{2}$ mod igual a 0,97 . A análise mostrou, também, que os efeitos individuais dos fatores principais analisados: tipo de aglomerante, teor de aditivo e tempo, são estatisticamente significativos a um nível de confiança de 95\%, evidenciando a influência que cada uma das variáveis independentes exerce no espalhamento, quando tomada isoladamente.

Tomando-se como base a magnitude dos valores de Fcal, pode-se constatar que a variável mais influente no espalhamento foi teor de aditivo, seguida do tempo e tipo de aglomerante, nesta ordem.

Em razão da influência das variáveis do modelo mostrar-se ser estatisticamente significativa, realizou-se a comparação múltipla de médias pelo método de Duncan. Os resultados destas análises estão expostos e discutidos a seguir.

a) Efeito do tipo de aglomerante

Na Figura 97 está apresentado o resultado do agrupamento de médias relativo as argamassas de relação água/sólidos igual 0,50 mediante o efeito do tipo de aglomerante, onde o diagrama apresentado na figura define os grupos que diferem significativamente. Nota-se que o tipo de aglomerante AREF faz parte do mesmo grupo do tipo de aglomerante A20 como, também, no grupo que consta A30. E os aglomerantes A20 e A30 são diferentes, ou seja, não pertencem ao mesmo grupo. Cabe destacar, que a variável tipo de aglomerante influencia em uma magnitude muito baixa sobre o espalhamento. Isso se justifica pela pequena diferença entre os parâmetros de Fcal e de Ftab, os quais possuem valores 3,55 e 3,18, respectivamente. Portanto, afirmar convictamente que substituir parte de cimento por fíler calcário influencia no espalhamento da argamassa, tem demonstrado até o momento, que essa afirmação pode ser precipitada. 
Figura 97 - Valores médios globais de espalhamento em função do tipo de aglomerante referentes as argamassas de relação água/sólidos 0,50, com seus intervalos de confiança de $95 \%$ e seus desvios padrões.

Os grupos estão discriminados de acordo com diagrama que consta na figura.

b) Efeito do teor de aditivo

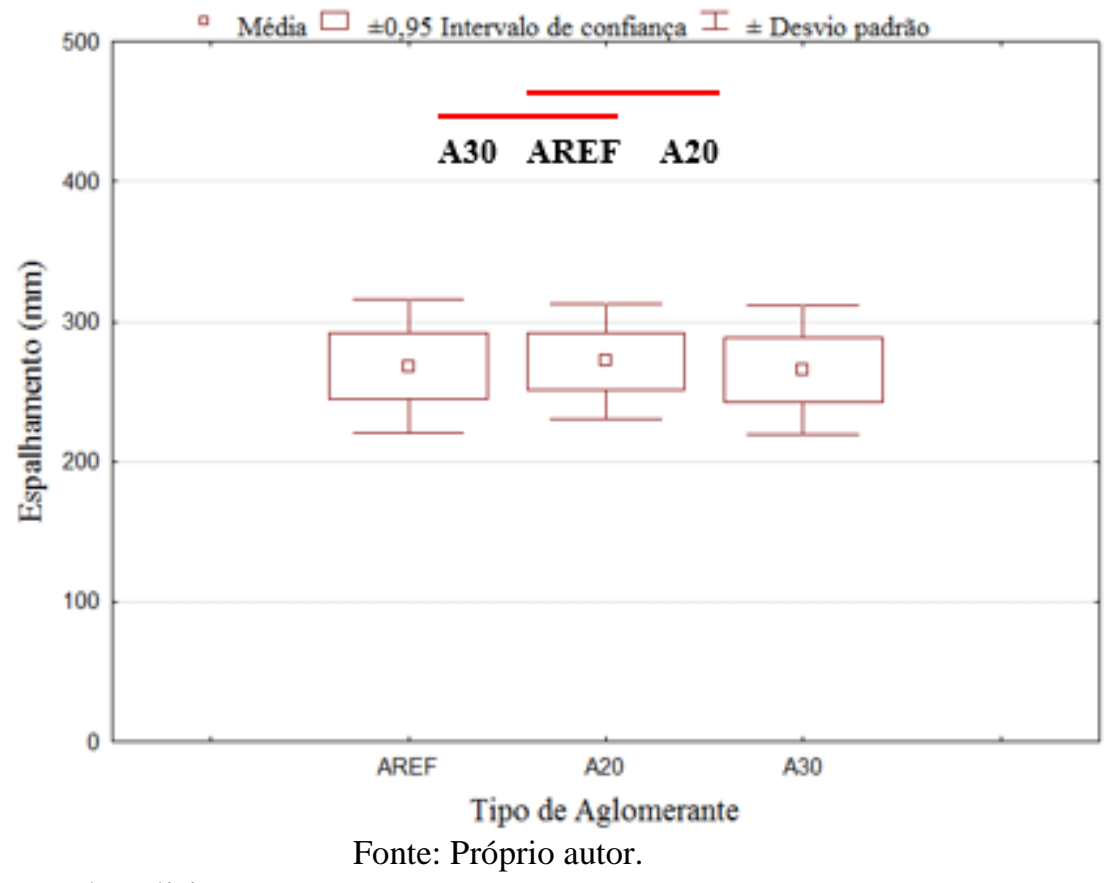

Na Figura 98 são apresentados os valores médios globais de espalhamento para os teores de aditivo $0,6 \%$ e $0,8 \%$ com seus intervalos de confiança de $95 \%$ e seus desvios padrões. Outros níveis de teores de aditivo foram desconsiderados pelo fato de não propiciarem uma argamassa coesa ou estável. As linhas tracejadas verticais definem os grupos que diferem significativamente. Dessa forma, têm-se dois grupos que produzem efeitos estatisticamente diferentes. Observa-se, na Figura 98, a forte influência do aumento do aditivo superplastificante nas argamassas de relação água/sólidos 0,50, quando se analisa a diferença das médias globais de espalhamento referentes aos teores $0,6 \%$ e $0,8 \%$, a qual foi próxima de $100 \mathrm{~mm}$. Isso pode justificar na prática a alta magnitude demonstrada estatisticamente para a variável teor de aditivo na capacidade de influenciar sobre o espalhamento da argamassa. 
Figura 98 - Valores médios globais de espalhamento em função do teor de aditivo referentes as argamassas de relação água/sólidos 0,50 , com seus intervalos de confiança de $95 \%$ e seus desvios padrões. As linhas tracejadas verticais definem os grupos que diferem significativamente.

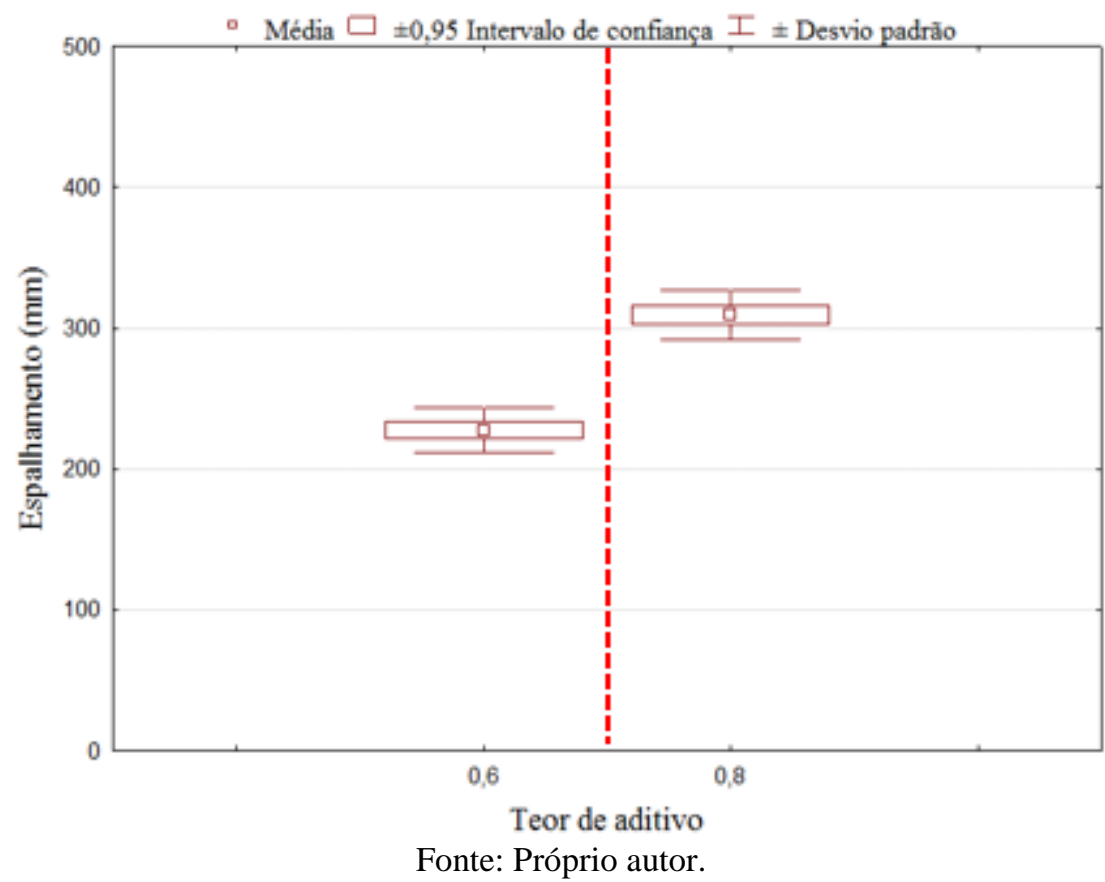

c) Efeito do tempo

Na Figura 99 estão disponibilizados os valores médios globais de espalhamento para os tempos 30 min, 60 min e 90 min com seus intervalos de confiança de $95 \%$ e seus desvios padrões, referentes as argamassas de relação água/sólidos igual a 0,50. As linhas tracejadas verticais definem os grupos que diferem significativamente, na qual se constata que os três tempos considerados neste estudo, produzem efeitos estatisticamente diferentes. Isso significa que a argamassa ou qualquer outro material cimentício reduz seu espalhamento com decorrer do tempo. 
Figura 99 - Valores médios globais de espalhamento em função do tempo referentes as argamassas de relação água/sólidos 0,50, com seus intervalos de confiança de $95 \%$ e seus desvios padrões. As linhas tracejadas verticais definem os grupos que diferem significativamente.

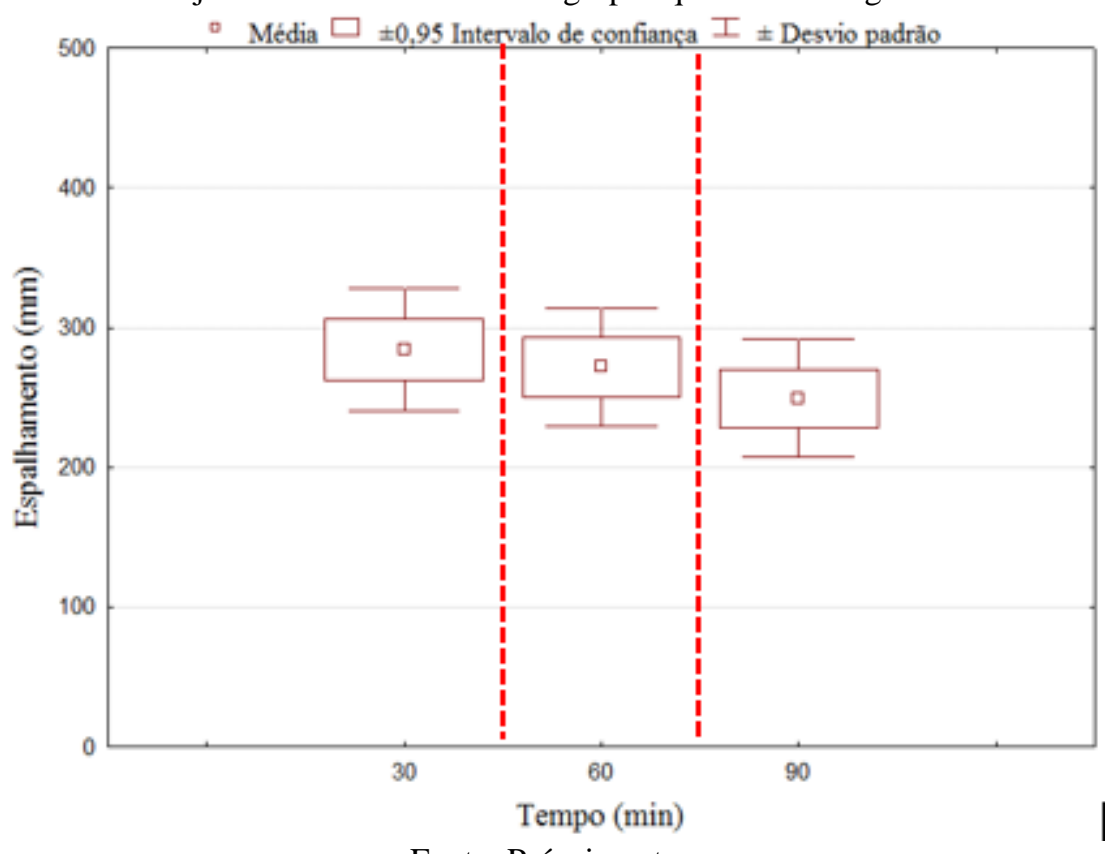

Fonte: Próprio autor. 


\section{APÊNDICE E - ANOVA: FLUIDEZ DA}

\section{ARGAMASSA (2'atAPA)}

\section{E1 AVALIAÇÃO DA VISCOSIDADE (MINI-FUNIL)}

A seguir, estão apresentados a ANOVA para os resultados de fluidez das argamassas para cada relação água/sólidos, bem como comparação múltipla de médias pelo método de Duncan dos fatores que apresentaram ser significativas.

\section{E11 Relação água/sólidos 0,40 (mini-funil)}

Em seguida, faz-se uma abordagem estatística dos resultados de fluidez das argamassas referentes a relação água/sólidos igual a 0,40, fundamentada na análise de variância (ANOVA) dos efeitos principais, conforme apresentada na Tabela 45.

Tabela 45 - Resultados da análise de variância (ANOVA) realizada com os dados de fluidez das argamassas de relação água/sólidos 0,40 , para as variáveis consideradas no modelo estatístico.

\begin{tabular}{|c|c|c|c|c|c|c|}
\hline Efeito & SQ & GL & MQ & Fcal & Ftab & Resultado \\
\hline Modelo & 475227 & 6 & 79204 & 72,98 & 2,23 & significativo \\
\hline Erro (resíduo) & 80314 & 74 & 1085 & -- & -- & -- \\
\hline Total & 555541 & 80 & -- & -- & -- & -- \\
\hline Tipo de aglomerante (TAg) & 50047 & 2 & 25024 & 23,07 & 3,13 & significativo \\
\hline Teor de aditivo (TA\%) & 205282 & 2 & 102641 & 94,57 & 3,13 & significativo \\
\hline Tempo (t) & 219899 & 2 & 109949 & 101,31 & 3,13 & significativo \\
\hline Erro (resíduo) & 80314 & 74 & 1085 & -- & -- & -- \\
\hline \multicolumn{7}{|c|}{$\mathrm{R}_{\bmod }=0,92 \mathrm{R}^{2} \bmod =0,84$} \\
\hline \multicolumn{7}{|l|}{ Onde: } \\
\hline \multicolumn{7}{|c|}{$\mathrm{SQ}=$ Soma dos quadrados; GL = Graus de liberdade; $\mathrm{MQ}=$ Média dos quadrados; } \\
\hline \multicolumn{7}{|c|}{ F = Parâmetro de Fisher para o teste de significância dos efeitos; } \\
\hline \multicolumn{7}{|c|}{ Resultado = Resultado da análise, com a indicação se o efeito é significativo ou não; } \\
\hline \multicolumn{7}{|c|}{$\mathrm{R}_{\text {mod }}^{2}=$ Coeficiente de determinação do modelo e } \\
\hline \multicolumn{7}{|c|}{$\mathrm{R}_{\mathrm{mod}}=$ Coeficiente de correlação do modelo. } \\
\hline
\end{tabular}

Fonte: Próprio autor.

A análise estatística dos resultados mostrou que o modelo fatorial adotado é significativo para um valor de $R^{2}$ mod igual a 0,84 . A análise mostrou, também, que os efeitos individuais dos fatores principais analisados: tipo de aglomerante, teor de aditivo e tempo, são estatisticamente significativos a um nível de confiança de 95\%, evidenciando a influência que cada uma das 
variáveis independentes exerce na fluidez (viscosidade plástica aparente), quando tomada isoladamente.

Tendo-se como parâmetro a magnitude dos valores de Fcal, pode-se constatar que a variável mais influente na fluidez foi tempo, seguida do teor de aditivo e tipo de aglomerante, nesta ordem.

Em virtude da influência das variáveis do modelo mostrar-se ser estatisticamente significativa, realizou-se a comparação múltipla de médias pelo método de Duncan. Os resultados destas análises estão expostos e discutidos a seguir.

a) Efeito do tipo de aglomerante

Na Figura 100, consta-se o resultado do agrupamento de médias, onde as linhas tracejadas verticais definem os grupos que diferem significativamente. Observa-se dois grupos, sendo um grupo se refere ao tipo de aglomerante AREF e outro grupo se refere aos aglomerantes A20 e A30. Dessa forma, pode-se afirmar que a substituição de parte do cimento por fíler calcário promove um aumento da fluidez nas argamassas de relação água/sólidos igual a 0,40. É importante frisar, que a variável tipo de aglomerante é estatisticamente significativo em uma baixa magnitude, ou seja, pouco influente sobre a fluidez. Isso se comprova pela pequena diferença entre os parâmetros Fcal e Ftab. 
Figura 100 - Valores médios globais de fluidez em função do tipo de aglomerante referentes as argamassas de relação água/sólidos 0,40, com seus intervalos de confiança de $95 \%$ e seus desvios padrões. As linhas tracejadas verticais definem os grupos que diferem significativamente.

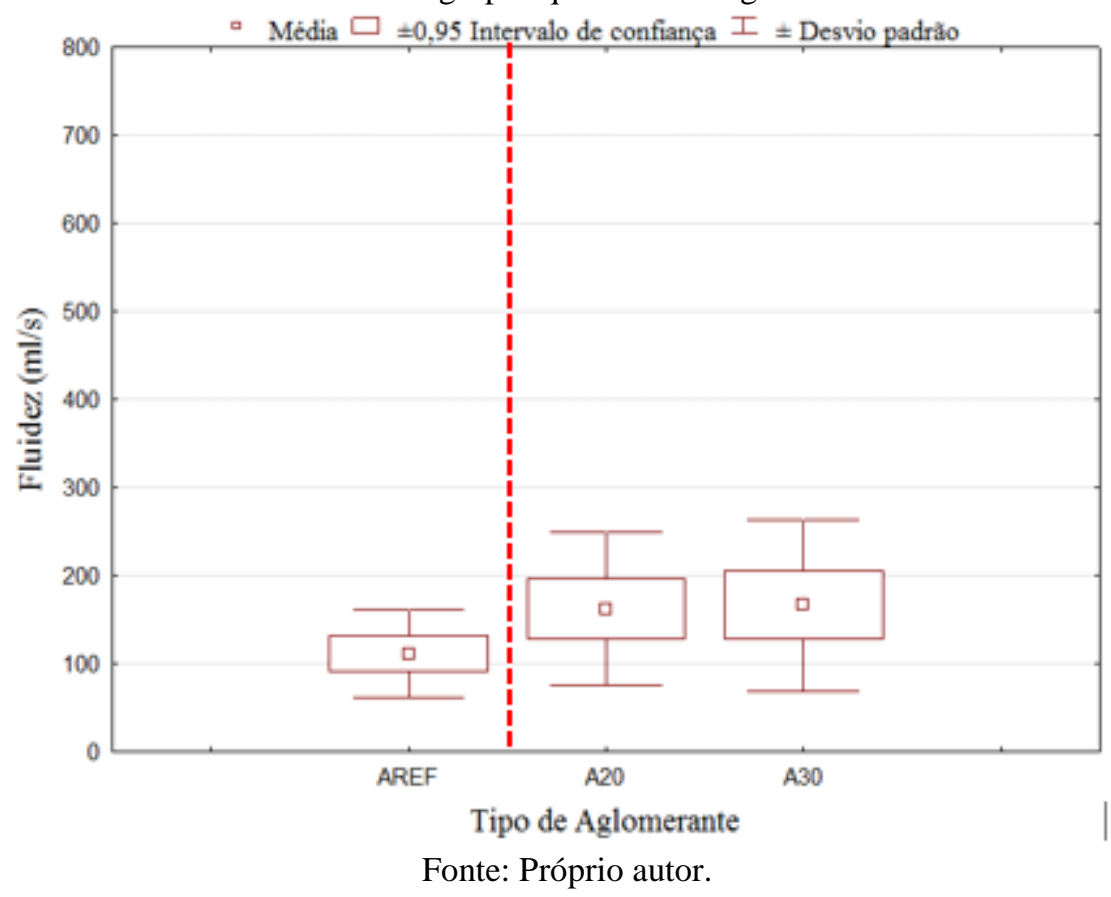

b) Efeito do teor de aditivo

Na Figura 101 está apresentado o resultado do agrupamento de médias, onde as linhas tracejadas verticais definem os grupos que diferem significativamente, na qual se constata que os três teores de aditivo, produzem efeitos estatisticamente diferentes sobre a fluidez. A diferença entre os parâmetros Fcal e Ftab dessa variável, retrata que o efeito do teor de aditivo é influente sobre a fluidez das argamassas próxima da magnitude da variável tempo. 
Figura 101 - Valores médios globais de fluidez em função do teor do aditivo referentes as argamassas de relação água/sólidos 0,40, com seus intervalos de confiança de $95 \%$ e seus desvios padrões. As linhas tracejadas verticais definem os grupos que diferem significativamente.

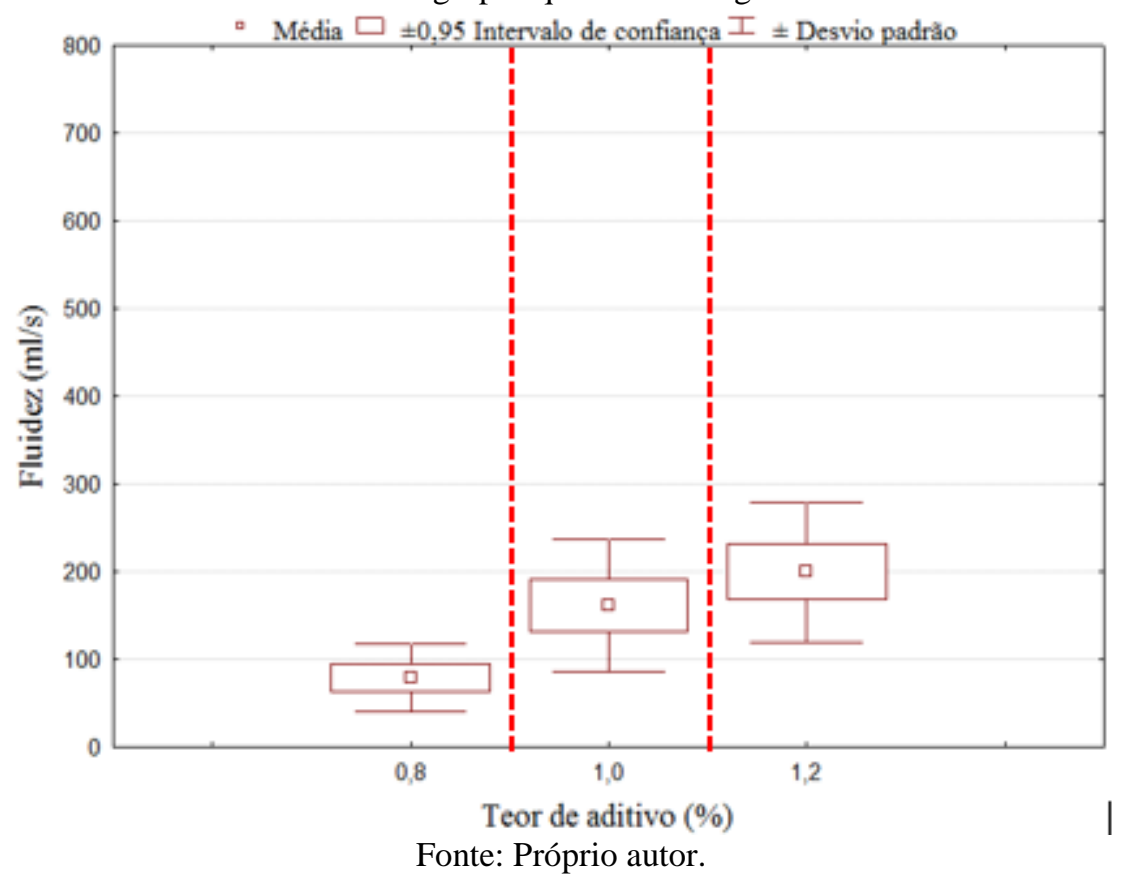

c) Efeito do tempo

A Figura 102 demonstra o resultado do agrupamento de médias, onde as linhas tracejadas verticais definem os grupos que diferem significativamente, na qual se constata que os três tempos considerados neste estudo, produzem efeitos estatisticamente diferentes sobre a fluidez. É importante frisar, que a variável tempo é influente com maior intensidade do que as demais variáveis. Isso se comprova pela maior diferença entre os seus parâmetros Fcal e Ftab. 
Figura 102 - Valores médios globais de fluidez em função do tempo referentes as argamassas de relação água/sólidos 0,40, com seus intervalos de confiança de $95 \%$ e seus desvios padrões. As linhas tracejadas verticais definem os grupos que diferem significativamente.

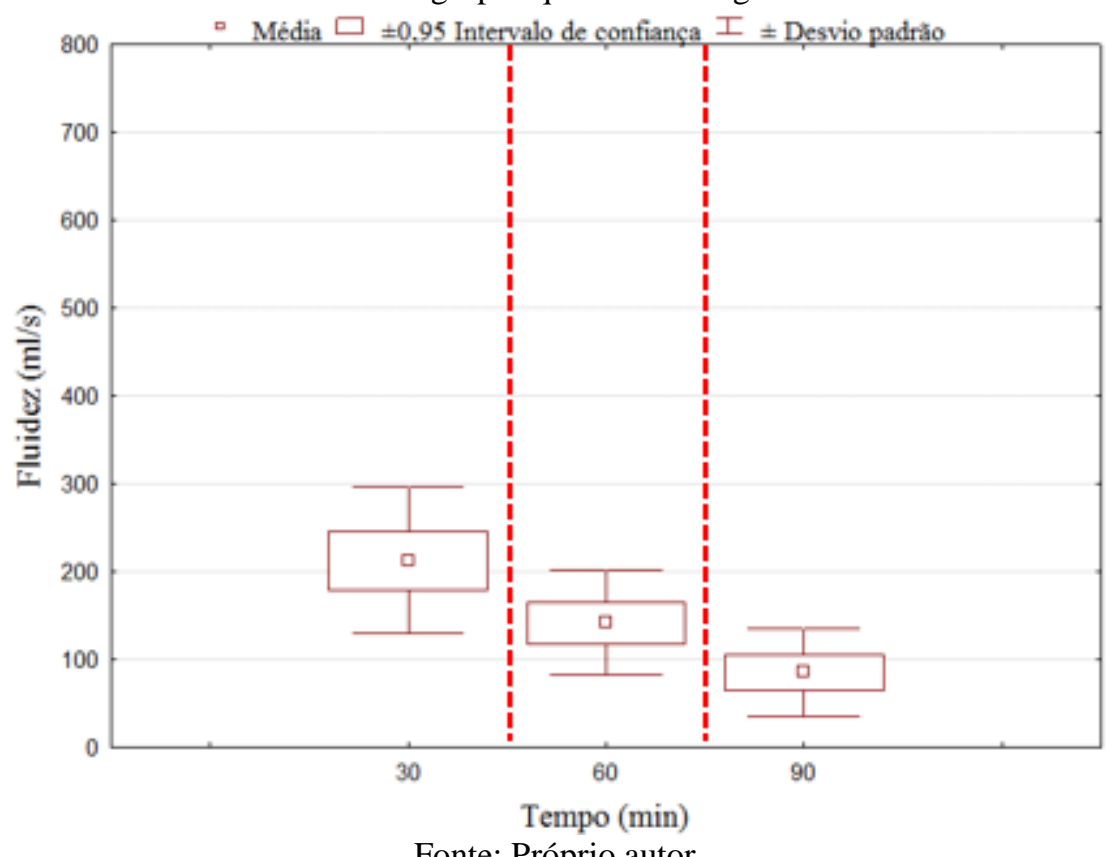

Fonte: Próprio autor.

\section{E12 Relação água/sólidos 0,45 (mini-funil)}

Em seguida, uma abordagem estatística dos resultados de fluidez das argamassas referentes a relação água/sólidos 0,45, fundamentada na análise de variância (ANOVA) dos efeitos principais, conforme apresentada na Tabela 46.

Tabela 46 - Resultados da análise de variância (ANOVA) realizada com os dados de fluidez das argamassas de relação água/sólidos 0,45, para as variáveis consideradas no modelo estatístico.

\begin{tabular}{|c|c|c|c|c|c|c|}
\hline Efeito & SQ & GL & MQ & Fcal & Ftab & Resultado \\
\hline Modelo & 1175918 & 6 & 195986 & 112,69 & 2,23 & significativo \\
\hline Erro (resíduo) & 128693 & 74 & 1739 & -- & -- & -- \\
\hline Total & 1304611 & 80 & -- & -- & -- & -- \\
\hline Tipo de aglomerante (TAg) & 45516 & 2 & 22758 & 13,09 & 3,13 & significativo \\
\hline Teor de aditivo (TA\%) & 401862 & 2 & 200931 & 115,54 & 3,13 & significativo \\
\hline Tempo (t) & 728541 & 2 & 364270 & 209,46 & 3,13 & significativo \\
\hline Erro (resíduo) & 128693 & 74 & 1739 & -- & -- & -- \\
\hline \multicolumn{7}{|c|}{$\mathbf{R}_{\text {mod }}=0,95 R^{2}$ mod $=0,89$} \\
\hline \multicolumn{7}{|l|}{ Onde: } \\
\hline \multicolumn{7}{|c|}{$\mathrm{SQ}=$ Soma dos quadrados; $\mathrm{GL}=$ Graus de liberdade; $\mathrm{MQ}=$ Média dos quadrados; } \\
\hline \multicolumn{7}{|c|}{ F = Parâmetro de Fisher para o teste de significância dos efeitos; } \\
\hline \multicolumn{7}{|c|}{ Resultado = Resultado da análise, com a indicação se o efeito é significativo ou não; } \\
\hline \multicolumn{7}{|c|}{$\mathrm{R}_{\text {mod }}^{2}=$ Coeficiente de determinação do modelo e } \\
\hline \multicolumn{7}{|c|}{$\mathrm{R}_{\mathrm{mod}}=$ Coeficiente de correlação do modelo. } \\
\hline
\end{tabular}

Fonte: Próprio autor. 
A análise estatística dos resultados mostrou que o modelo fatorial adotado é significativo, resultando em um valor de $\mathrm{R}^{2}$ mod igual a 0,89 . Observou-se, também, que os efeitos individuais dos fatores principais analisados: tipo de aglomerante, teor de aditivo e tempo, são estatisticamente significativos a um nível de confiança de 95\%, evidenciando a influência que cada uma das variáveis independentes exerce na fluidez (viscosidade plástica aparente), quando tomada isoladamente.

Com relação a magnitude dos valores de Fcal, constatatou-se que a variável mais influente na fluidez foi tempo, seguida do teor de aditivo e tipo de aglomerante, nesta ordem.

Em virtude da influência das variáveis do modelo mostrar-se ser estatisticamente significativa, realizou-se a comparação múltipla de médias pelo método de Duncan. Os resultados destas análises estão expostos e discutidos a seguir.

a) Efeito do tipo de aglomerante

Na Figura 103, encontra-se o resultado do agrupamento de médias, onde as linhas tracejadas verticais definem os grupos que diferem significativamente. Observa-se dois grupos, sendo um grupo se refere aos tipos de aglomerante AREF e A20 e outro grupo se refere ao aglomerante A30. Dessa forma, pode-se afirmar que a substituição de $30 \%$, em massa, da parte do cimento por fíler calcário promove um aumento da fluidez nas argamassas de relação água/sólidos igual a 0,45. Cabe destacar, que a variável tipo de aglomerante é estatisticamente significativo em uma baixa magnitude, ou seja, pouco influente sobre a fluidez. Isso se comprova pela pequena diferença entre os parâmetros Fcal e Ftab. 
Figura 103 - Valores médios globais de fluidez em função do tipo de aglomerante referentes as argamassas de relação água/sólidos 0,45, com seus intervalos de confiança de $95 \%$ e seus desvios padrões. As linhas tracejadas verticais definem os grupos que diferem significativamente.

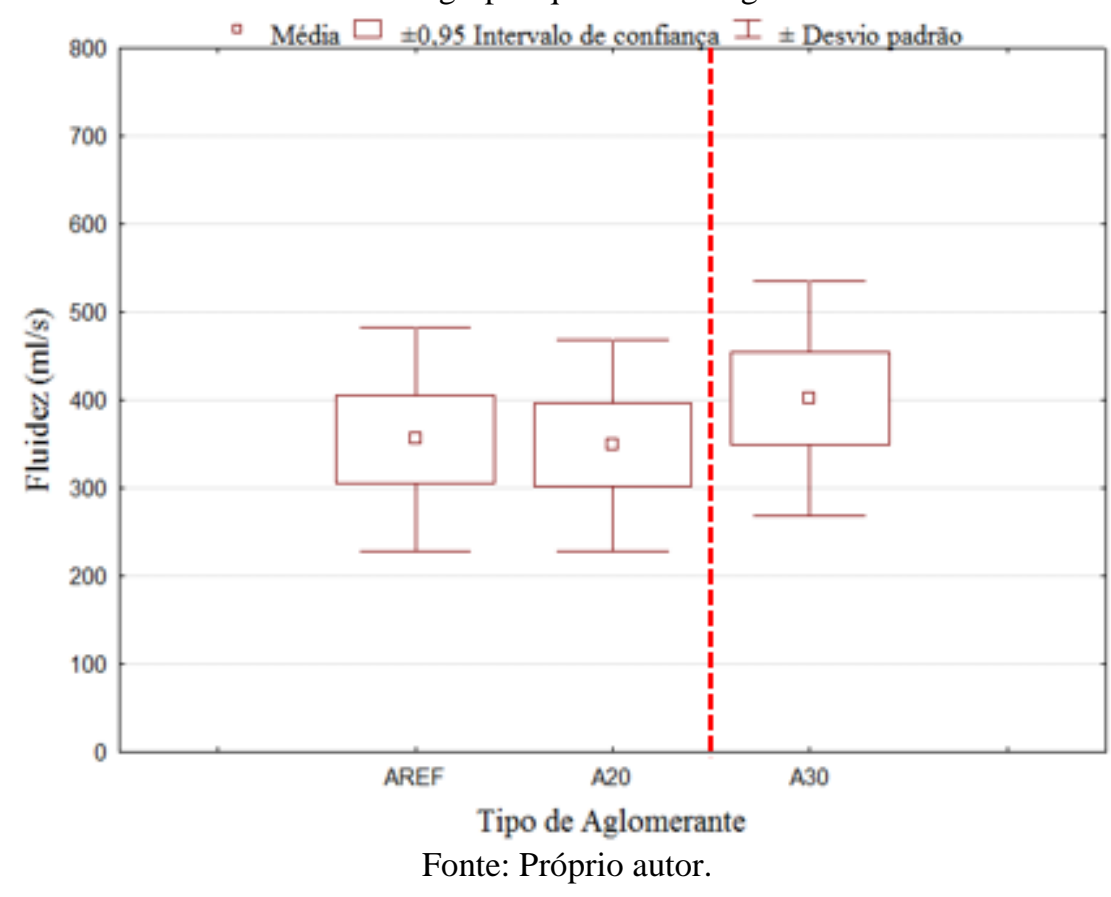

b) Efeito do teor de aditivo

Na Figura 104 está apresentado o resultado do agrupamento de médias, onde as linhas tracejadas verticais definem os grupos que diferem significativamente, na qual se constata que os três teores de aditivo, produzem efeitos estatisticamente diferentes sobre a fluidez. A variável teor de aditivo é o segundo mais influente sobre a fluidez das argamassas. Isso se confirma pela diferença dos seus parâmetros Fcal e Ftab ser a segunda maior. 
Figura 104 - Valores médios globais de fluidez em função do teor de aditivo referentes as argamassas de relação água/sólidos 0,45, com seus intervalos de confiança de $95 \%$ e seus desvios padrões. As linhas tracejadas verticais definem os grupos que diferem significativamente.

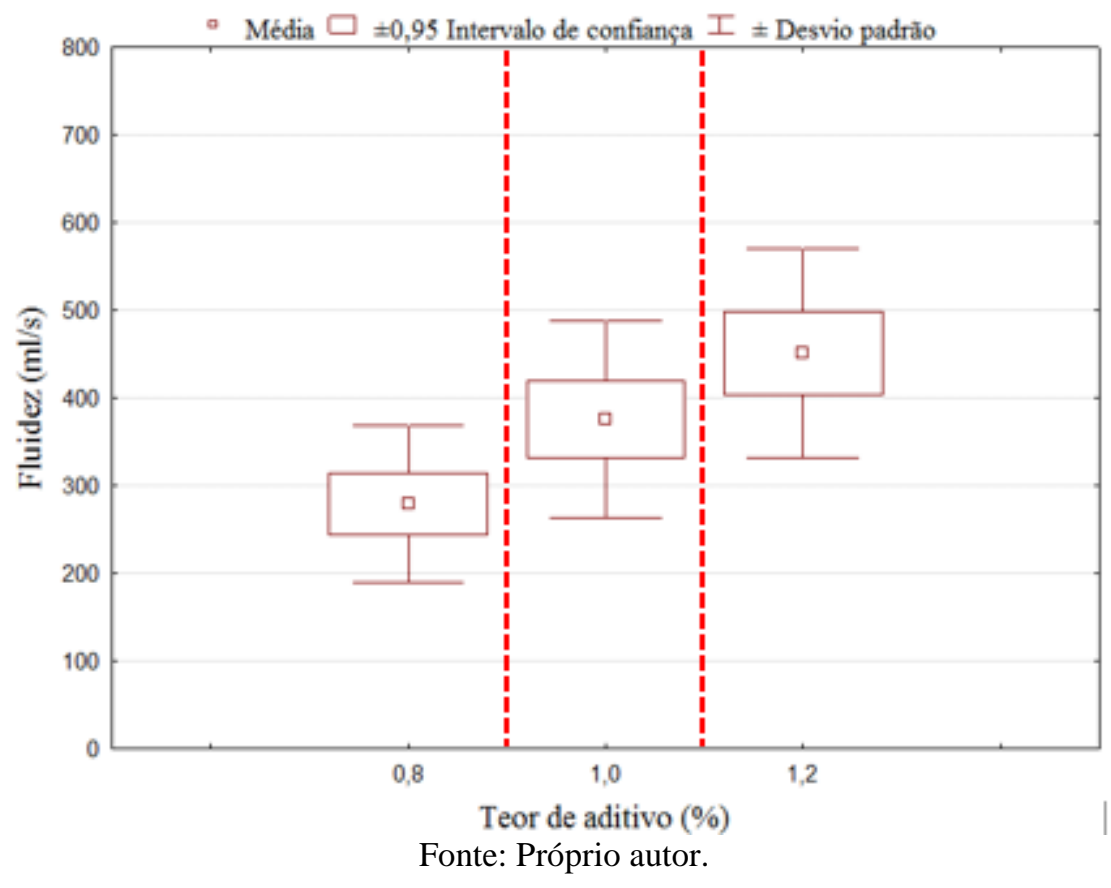

c) Efeito do tempo

A Figura 105 disponibiliza o resultado do agrupamento de médias, onde as linhas tracejadas verticais definem os grupos que diferem significativamente, na qual se constata que os três tempos considerados neste estudo, produzem efeitos estatisticamente diferentes sobre a fluidez. É notório, que a variável tempo é influente com maior intensidade do que as demais variáveis. Isso se comprova pela maior diferença entre os seus parâmetros Fcal e Ftab. 
Figura 105 - Valores médios globais de fluidez em função do tempo referentes as argamassas de relação água/sólidos 0,45, com seus intervalos de confiança de $95 \%$ e seus desvios padrões. As linhas tracejadas verticais definem os grupos que diferem significativamente.

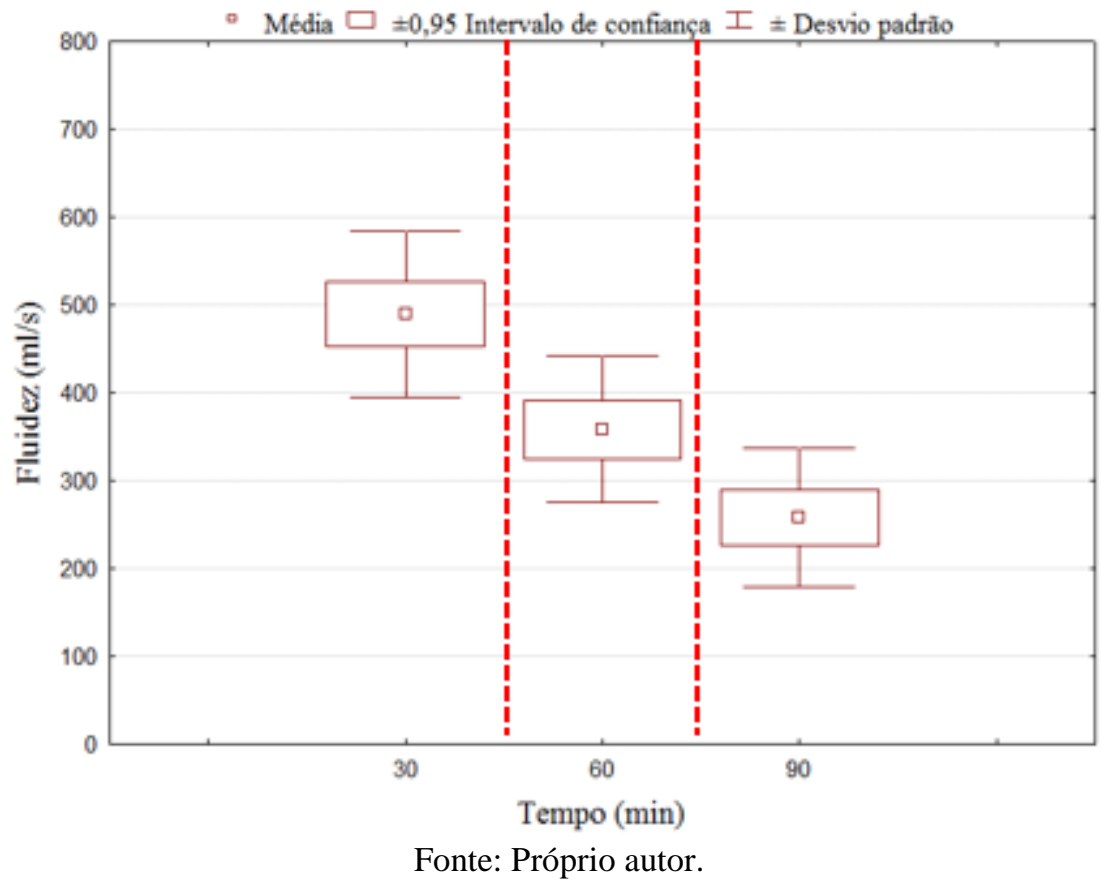

\section{E13 Relação água/sólidos 0,50 (mini-funil)}

Com relação aos resultados de fluidez das argamassas referentes a relação água/sólidos igual a 0,50, tem-se a análise de variância (ANOVA) dos efeitos principais, conforme apresentada na Tabela 47. 
Tabela 47 - Resultados da análise de variância (ANOVA) realizada com os dados de fluidez das argamassas de relação água/sólidos 0,50, para as variáveis consideradas no modelo estatístico.

\begin{tabular}{|c|c|c|c|c|c|c|}
\hline Efeito & SQ & GL & MQ & Fcal & Ftab & Resultado \\
\hline Modelo & 1097007 & 5 & 219401 & 75,71 & 2,42 & significativo \\
\hline Erro (resíduo) & 139098 & 48 & 2898 & -- & -- & -- \\
\hline Total & 1236105 & 53 & -- & -- & -- & -- \\
\hline Tipo de aglomerante (TAg) & 88578 & 2 & 44289 & 15,28 & 3,18 & significativo \\
\hline Teor de aditivo (TA\%) & 318574 & 1 & 318574 & 109,93 & 4,05 & significativo \\
\hline Tempo (t) & 689856 & 2 & 344928 & 119,02 & 3,18 & significativo \\
\hline Erro (resíduo) & 139098 & 48 & 2898 & -- & -- & -- \\
\hline \multicolumn{7}{|c|}{$\mathbf{R}_{\text {mod }}=0,94 R^{2}$ mod $=0,88$} \\
\hline \multicolumn{7}{|c|}{ Onde: } \\
\hline \multicolumn{7}{|c|}{$\mathrm{SQ}=$ Soma dos quadrados; $\mathrm{GL}=$ Graus de liberdade; $\mathrm{MQ}=$ Média dos quadrados; } \\
\hline \multicolumn{7}{|c|}{ F = Parâmetro de Fisher para o teste de significância dos efeitos; } \\
\hline \multicolumn{7}{|c|}{ Resultado = Resultado da análise, com a indicação se o efeito é significativo ou não; } \\
\hline \multicolumn{7}{|c|}{$\mathrm{R}_{\text {mod }}^{2}=$ Coeficiente de determinação do modelo e } \\
\hline \multicolumn{7}{|c|}{$\mathrm{R}_{\mathrm{mod}}=$ Coeficiente de correlação do modelo. } \\
\hline
\end{tabular}

Fonte: Próprio autor.

A análise estatística dos resultados mostrou que o modelo fatorial adotado é significativo, resultando em um valor de $\mathrm{R}^{2}$ mod igual a 0,88 . É notório que os efeitos individuais dos fatores principais analisados: tipo de aglomerante, teor de aditivo e tempo, são estatisticamente significativos a um nível de confiança de 95\%, evidenciando a influência que cada uma das variáveis independentes exerce na fluidez (viscosidade plástica aparente), quando tomada isoladamente.

Tomar como parâmetro a magnitude dos valores de Fcal, pode-se constatar que a variável mais influente na fluidez foi teor de aditivo, seguida do tempo e tipo de aglomerante, nesta ordem. Cabe destacar, que o Fcal $(109,93)$ referente a variável teor de aditivo é bem próxima do Fcal $(109,02)$ referente a variável tempo. Pode-se afirmar neste caso, que essas duas variáveis influenciam numa mesma intensidade frente a fluidez.

Em virtude da influência das variáveis do modelo mostrar-se ser estatisticamente significativa, realizou-se a comparação múltipla de médias pelo método de Duncan. Os resultados destas análises estão expostos e discutidos a seguir.

a) Efeito do tipo de aglomerante

Na Figura 106 está apresentado o resultado do agrupamento de médias, onde as linhas tracejadas verticais definem os grupos que diferem significativamente. Observa-se dois grupos, 
sendo um grupo se refere ao tipo de aglomerante AREF e outro grupo se refere aos aglomerantes A20 e A30. Essa configuração, também, foi obtida para as argamassas de relação água/sólidos igual a 0,40. Dessa forma, reforça a afirmação que a substituição de parte do cimento por fíler calcário promove um aumento da fluidez nas argamassas de relação água/sólidos igual a 0,40. É importante destacar, que a variável tipo de aglomerante é estatisticamente significativo em uma baixa magnitude, ou seja, pouco influente sobre a fluidez. Isso se comprova pela pequena diferença entre os parâmetros Fcal e Ftab.

Figura 106 - Valores médios globais de fluidez em função do tipo de aglomerante referentes as argamassas de relação água/sólidos 0,50, com seus intervalos de confiança de 95\% e seus desvios padrões. As linhas tracejadas verticais definem os grupos que diferem significativamente.

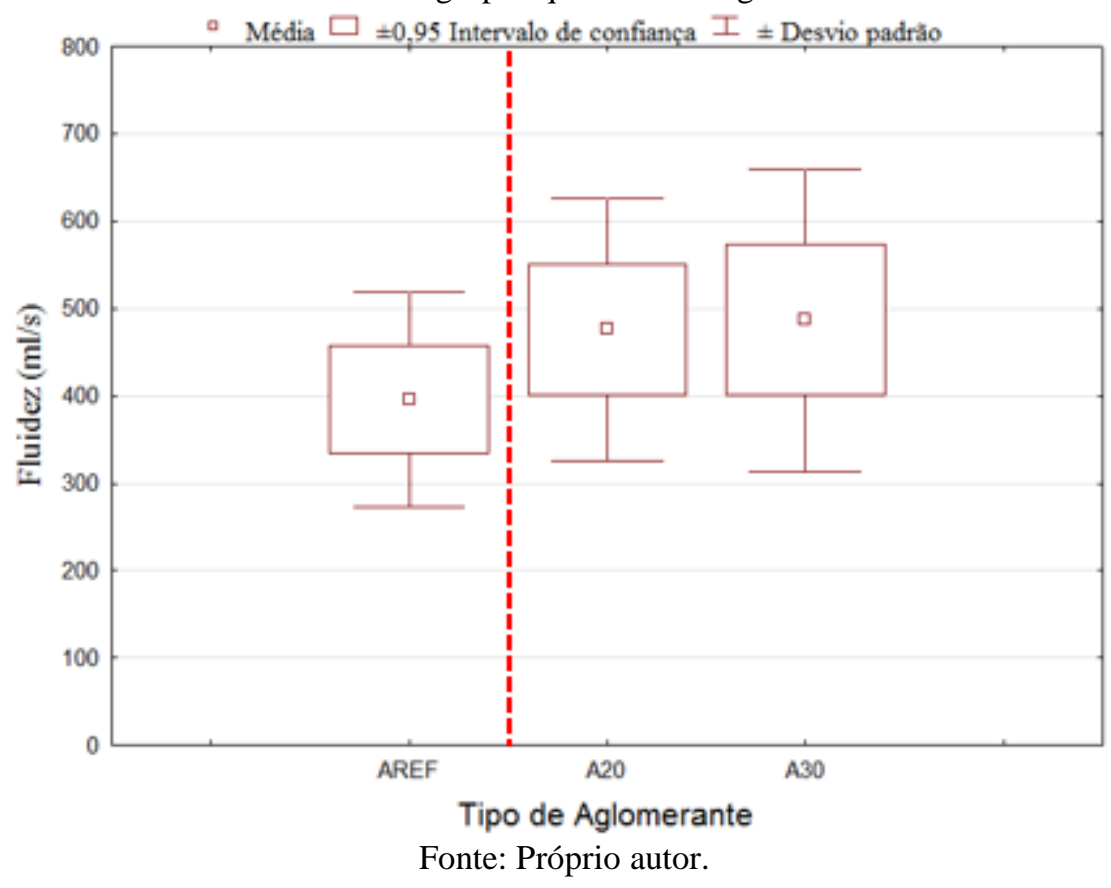

b) Efeito do teor de aditivo

Na Figura 107 destaca-se os valores médios globais de fluidez para os teores de aditivo 0,6\% e $0,8 \%$ com seus intervalos de confiança de $95 \%$ e seus desvios padrões. Outros níveis de teores de aditivo foram desconsiderados pelo fato de não propiciarem uma argamassa coesa ou estável. As linhas tracejadas verticais definem os grupos que diferem significativamente. Dessa forma, têm-se dois grupos que produzem efeitos estatisticamente diferentes sobre a fluidez. 
Figura 107 - Valores médios globais de fluidez em função do teor de aditivo referentes as argamassas de relação água/sólidos 0,50, com seus intervalos de confiança de $95 \%$ e seus desvios padrões. As linhas tracejadas verticais definem os grupos que diferem significativamente.

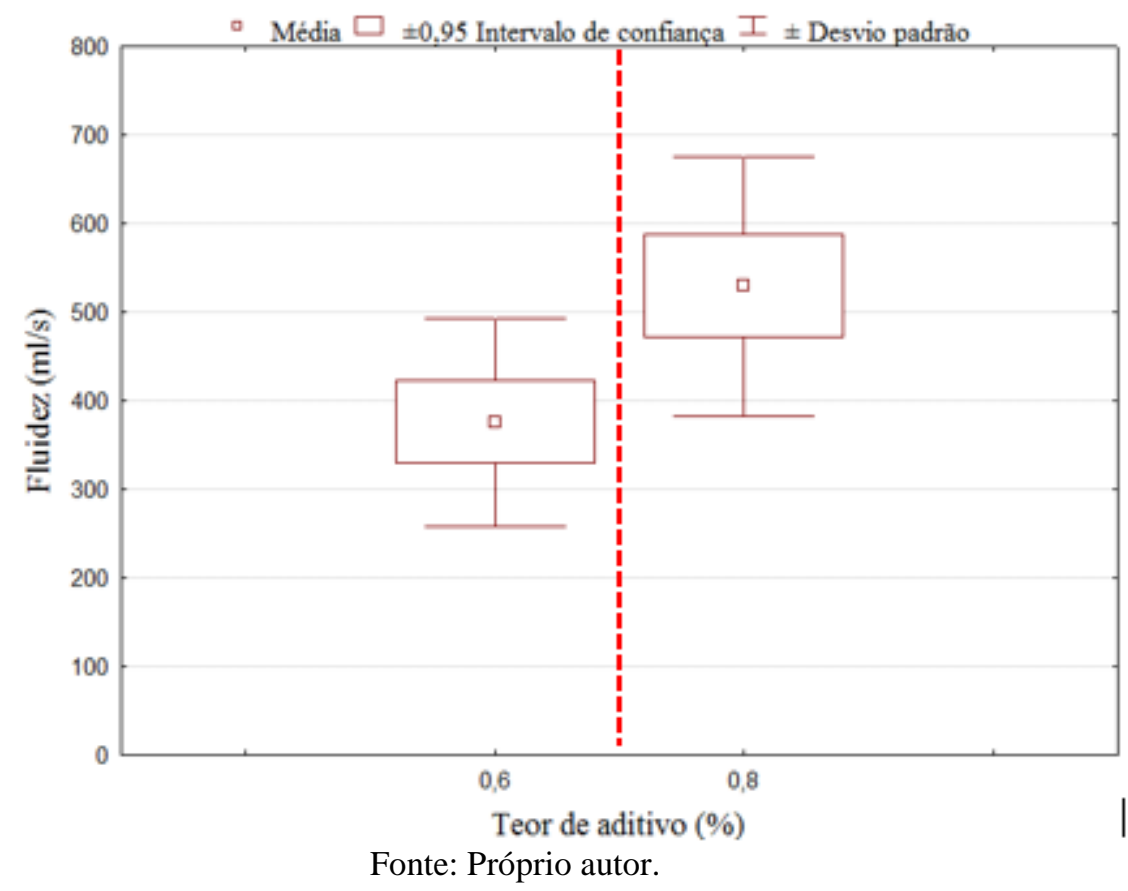

c) Efeito do tempo

Na Figura 108 está apresentado o resultado do agrupamento de médias, onde as linhas tracejadas verticais definem os grupos que diferem significativamente, na qual se constata que os três tempos, produzem efeitos estatisticamente diferentes sobre a fluidez. A diferença entre os parâmetros Fcal e Ftab dessa variável, retrata que o efeito do tempo é influente sobre a fluidez das argamassas bem próxima da magnitude da variável teor de aditivo. Por último, constata-se de forma bem nítida a perda de fluidez de 50\%, aproximadamente, das argamassas de relação água/sólidos igual a 0,50, quando se compara os valores médios globais de fluidez referentes aos tempos de $30 \mathrm{~min}$ e $90 \mathrm{~min}$. 
Figura 108 - Valores médios globais de fluidez em função do tempo referentes as argamassas de relação água/sólidos 0,50, com seus intervalos de confiança de $95 \%$ e seus desvios padrões. As linhas tracejadas verticais definem os grupos que diferem significativamente.

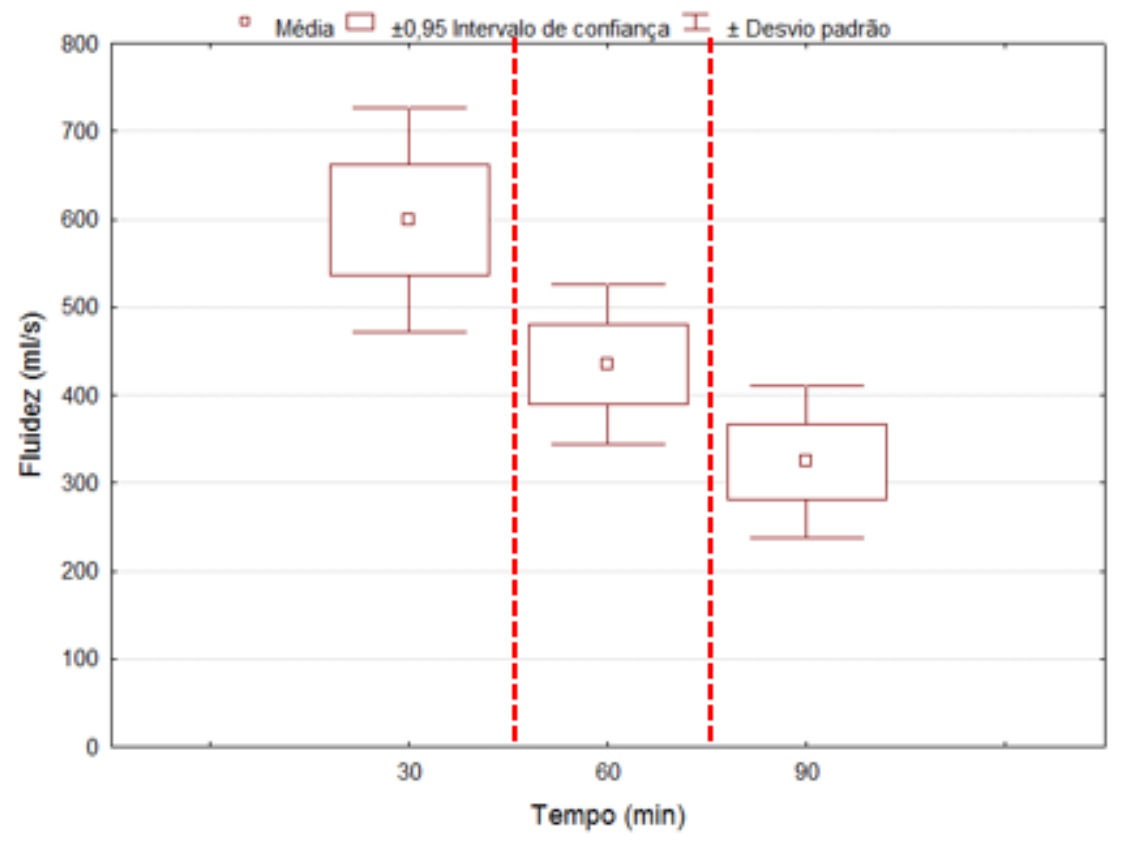

Fonte: Próprio autor. 


\section{APÊNDICE F - Resultados individuais de Resistência à Compressão e Módulo de Elasticidade}

\begin{tabular}{|c|c|c|c|c|c|c|c|}
\hline \multicolumn{8}{|c|}{ Resultados individuais } \\
\hline \multirow{3}{*}{\multicolumn{2}{|c|}{ CONCRETOS }} & \multirow{2}{*}{\multicolumn{3}{|c|}{$\frac{\text { RESISTÊNCIA À COMPRESSÃO }}{\text { (MPa) }}$}} & \multirow{2}{*}{\multicolumn{3}{|c|}{\begin{tabular}{|c|} 
MÓDULO DE ELASTICIDADE \\
(GPa) \\
\end{tabular}}} \\
\hline & & & & & & & \\
\hline & & 1 & 2 & 3 & 1 & 2 & 3 \\
\hline $1 \mathrm{C}$ & CREF40S10 & 69,0 & 69,7 & 72,8 & 33,4 & 34,4 & 31,4 \\
\hline $2 \mathrm{C}$ & CREF40S12 & 71,8 & 71,9 & 71,6 & 35,7 & 34,6 & 36,0 \\
\hline $3 C$ & C2040S10 & 58,8 & 60,6 & 61,3 & 31,6 & 31,1 & 28,7 \\
\hline $4 C$ & C2040S12 & 57,8 & 58,7 & 58,7 & 36,2 & 32,1 & 34,2 \\
\hline $5 C$ & C3040S10 & 50,1 & 50,4 & 52,2 & 31,0 & 31,4 & 31,5 \\
\hline $6 C$ & C3040S12 & 49,7 & 50,2 & 50,5 & 30,0 & 31,5 & 32,9 \\
\hline $7 C$ & CREF45S08 & 57,6 & 59,5 & 60,9 & 31,9 & 36,2 & 32,0 \\
\hline $8 C$ & CREF45S10 & 64,6 & 65,4 & 65,5 & 32,8 & 32,2 & 34,4 \\
\hline $9 \mathrm{C}$ & C20C45S08 & 55,6 & 55,7 & 55,9 & 29,2 & 30,1 & 30,2 \\
\hline $10 \mathrm{C}$ & C2045S10 & 47,4 & 48,4 & 48,6 & 29,3 & 33,0 & 31,4 \\
\hline $11 C$ & C3045S08 & 42,1 & 42,4 & 43,2 & 29,8 & 27,7 & 27,5 \\
\hline $12 \mathrm{C}$ & C3045S10 & 39,0 & 41,4 & 42,3 & 28,5 & 30,4 & 25,1 \\
\hline $13 C$ & CREF50S06 & 55,4 & 56,9 & 58,0 & 28,1 & 29,3 & 29,7 \\
\hline $14 C$ & CREF50S08 & 57,0 & 58,5 & 58,9 & 29,3 & 27,9 & 28,6 \\
\hline $15 \mathrm{C}$ & C2050S06 & 43,2 & 43,3 & 43,8 & 27,6 & 26,2 & 28,3 \\
\hline $16 C$ & C2050S08 & 39,9 & 40,1 & 40,1 & 30,3 & 29,3 & 29,2 \\
\hline $17 \mathrm{C}$ & C3050S06 & 31,7 & 32,0 & 32,9 & 24,8 & 26,2 & 25,7 \\
\hline $18 \mathrm{C}$ & C3050S08 & 35,7 & 35,8 & 35,9 & 27,2 & 28,8 & 25,5 \\
\hline
\end{tabular}

